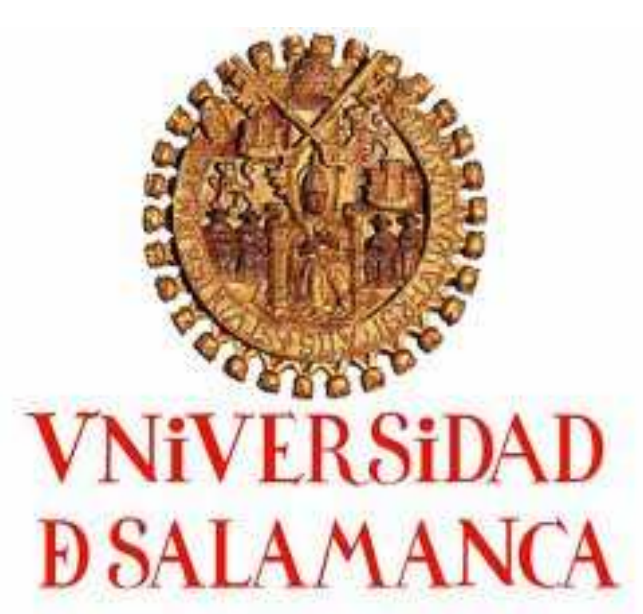

FACULTAD DE DERECHO

DEPARTAMENTO DE DERECHO PÚBLICO GENERAL

TESIS DOCTORAL

\title{
LA “SANTA CIUDADANÍA” DEL IMPERIO: CONFESIONALIDAD COMO FUENTE RESTRICTIVA DE DERECHOS EN BRASIL (1823-1831)
}

\author{
Autor: \\ JAIRDILSON DA PAZ SILVA \\ Directora de Tesis: \\ Prof . Dra. Ángela Figueruelo Burrieza
}

Salamanca - España 



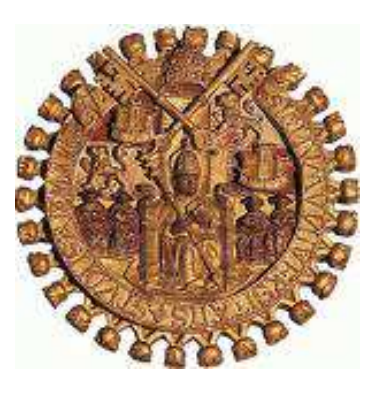

UNIVERSIDAD DE SALAMANCA

FACULTAD DE DERECHO

DEPARTAMENTO DE DERECHO PÚBLICO GENERAL

PROGRAMA DE DOCTORADO PASADO Y PRESENTE DE LOS

DERECHOS HUMANOS

LA “SANTA CIUDADANÍA” DEL IMPERIO:

CONFESIONALIDAD COMO FUENTE RESTRICTIVA DE

DERECHOS EN BRASIL (1823-1831)

JAIRDILSON DA PAZ SILVA 



\section{JAIRDILSON DA PAZ SILVA}

\section{La "santa ciudadanía" del imperio: confesionalidad como fuente restrictiva de derechos en Brasil (1823-1831)}

\begin{abstract}
Tesis presentada en el Departamento de Derecho Público General, Facultad de Derecho de la Universidad de Salamanca para la obtención de la mención de Doctorado conforme a los requisitos establecidos en el Real Decreto 1396/2007 de 29 de octubre, por el que se establece la ordinación de las enseñanzas universitarias oficiales

Director de la Tesis,

Prof ${ }^{a}$ Dra. Ángela Figueruelo Burrieza.
\end{abstract}

Fdo.: doctorando
Fdo.: directora de tesis 



\section{AGRADECIMIENTOS}

Desde aquí muestro un especial agradecimiento a la Secretaria de Educación del Estado de Bahía por haberme concedido un permiso para realizar mis estudios de Doctorado. Me gustaría agradecer al profesor Carlos Petit Calvo por lo mucho que me ha ayudado en mis estancias en España y como en Italia.

Un agradecimiento a los profesores y colegas del Grupo de Investigaciones INDUSAL, por el largo camino de aprendizaje y por las ayudas prestadas, además del fuerte vínculo de amistad: a Julio Sánchez, Izaskun Álvarez, Carlos Rojas y a José Gleenson.

Mi sincera gratitud a los amigos que siguieron conmigo este periplo de duro trabajo que me hizo privarme de su compañía muchas veces. Quería expresar mis agradecimientos a mi novia Allonah por haber soportado que nos quedáramos lejos para que yo terminase este trabajo.

A mi padre, a doña María, a mis hermanos, a Solangen, a mis tías Conce y Core también dedico estas líneas. Me gustaría agradecer a mis directoras por las ayudas concedidas y las comprensiones. Es importante recordar de mis colegas, un especial agradecimiento a ellos y a mis profesores, que mucho me ayudaron en este camino.

Doy gracias por el aprendizaje de la convivencia a los colegas profesores Odilon Góis, Vanessa Spinosa, Telma Gonçalves y todos aquellos que pasaron por mi vida en la magnífica ciudad de Salamanca. Mis agradecimientos, principalmente por el apoyo musical, a Jairo. Mi sincera gratitud a todo el personal de las distintas bibliotecas de la Universidad de Salamanca, por la pronta ayuda y la gran paciencia mostrada.

A mi vecina en Salamanca, doña Andrea, por el apoyo y "las patatas". Al casero Rafa que fue siempre muy atento y colaborador. Me gustaría agradecer también al profesor Dilton Araujo sus influencias positivas.

Un especial agradecimiento a mi Directora de Tesis Prof ${ }^{a}$. Dra. Ángela Figueruelo por las correcciones y todo el incentivo que me dio en el largo periplo de la redacción del texto, por el apoyo y por sus atenciones.

Ad Deum qui laetificat iuventutem mea 

(Frases)

"Caminho por uma rua que passa em muitos países; se não me veem, eu vejo, e saúdo os velhos amigos."

(Carlos Drummond de Andrada)

\section{SALAMANCA DORADA}

Cuando a la casa por la noche regresaba,

$Y$ un soplo de aire frío la faz me acariciaba,

Tenía la seguridad de solamente acompañado,

Con fantasías que en realidad se habían trasmutado.

Dorada, bella, tan hermosa... que en nueve

Tú nombre se escribe y en un aliento se vuelve.

Yo en diez y un tanto extremoso,

Cuanto te abandono, extranjero conviérteme lloroso.

Fábula de encanto, amor de mi alma,

Regreso y estoy contigo...

$Y$ en mi existir todo se amaina...

(Jairdilson da Paz Silva) 



\title{
RESUMEN
}

Los procesos constitucionales de España, Portugal y Brasil estuvieron bastante interconectados tras las revoluciones liberales de España, Oporto y el proceso de independencia de Brasil. La Constitución de Cádiz significó una bandera enarbolada en todas las revoluciones del periodo. En estos tres procesos constitucionales buscamos resaltar la relación entre la ciudadanía definida en los textos constitucionales estudiados y el establecimiento de la confesionalidad del Estado. Buscamos establecer la relación de como la declaración de Confesionalidad del Estado restringía la Ciudadanía. Esta misma relación será estudiada específicamente en la Constitución otorgada de 1824 de Brasil. Ahí se adoptó el principio general de concesión de ciudadanía a los "acatólicos", pero no se admitió el principio de la elegibilidad de éstos, principalmente en las leyes electorales del periodo. Los no católicos se quedaban alejados de una parte del proceso electoral, podían votar pero no ser elegidos para diputados u otros cargos públicos. La discusión iniciada en la Asamblea Constituyente sobre la atribución de la plenitud de los derechos políticos a los no católicos solamente se solucionó al final del siglo XIX con la Ley Saraiva, en donde se admitió el principio de la elegibilidad de los "acatólicos".

PALABRAS CLAVES: Constitucionalismo - Ciudadanía - Confesionalidad Sufragio - Brasil - Siglo XIX.

\begin{abstract}
Constitutional processes of Spain, Portugal and Brazil were quite interconnected after the liberal revolutions of Spain, Porto and the Brazilian independence process. The Constitution of Cadiz meant a white flag for all the revolutions of the period. In these three constitutional processes, we highlight the relationship between citizenship defined in the constitutional texts studied and the establishment of the confessional state. We seek to establish the relationship of how the declaration of a Confessional State restricted Citizenship. This same relationship will be studied specifically in the Constitution of 1824 in Brazil. This constitution adopted the general principle of granting citizenship to the "non-Catholics", but did not accept the principle of eligibility of these people, mainly in the electoral laws of the period. Non-Catholics stayed away from a part of the electoral process, they could vote but not be elected to public office or other deputies. The discussion started in the Constituent Assembly on the attribution of the fullness of political rights to Catholics was only to be solved at the end of the nineteenth century with the Saraiva Law, in which the principle of eligibility of "nonCatholics " was accepted.
\end{abstract}

KEY WORDS: Constitutionalism - Citizenship - Confessional - Suffrage Brazil - Century XIX. 


\section{RESUMO}

Os processos constitucionais de Espanha, Portugal e Brasil estiveram bastante interconectados depois das revoluciones liberais de Espanha, Porto e o processo de independência de Brasil. A Constituição de Cádiz significou uma bandeira em todas as revoluções do período. Nestes três processos constitucionais buscamos ressaltar a relação entre a cidadania definida nos textos constitucionais estudados e o estabelecimento da confesionalidade do Estado. Buscamos estabelecer a relação de como a declaração de confesionalidade do Estado restringia a Cidadania. Esta mesma relação será estudada especificamente na Constituição outorgada de 1824 de Brasil. Ali se adotou o principio general de concessão de cidadania aos "acatólicos", mas não se admitiu o principio da elegibilidade destes, principalmente nas leis eleitorais do período. Os nãos católicos ficavam assim alijados de uma parte do processo eleitoral, podiam votar, mas não ser eleitos para deputados ou outros cargos públicos. A discussão iniciada na Assembleia Constituinte sobre a atribuição da plenitude dos direitos políticos aos não católicos somente se solucionou ao final do século XIX com a Lei Saraiva, onde se admitiu o principio da elegibilidade dos "acatólicos".

PALAVRAS CHAVES: Constitucionalismo - Cidadania - Confesionalidade Sufrágio - Brasil - Século XIX. 


\section{SIGLAS UTILIZADAS}

DDAC Diario de las Discusiones y Actas de las Cortes.

ACC Actas de la Comisión de Constitución.

DCGECNP Diários das Cortes Geraes e Extraordinárias da Nação Portugueza.

AGCLIB Assembleia Geral Constituinte e Legislativo do Império do Brasil.

DAGCL Diários da Assembleia Geral Constituinte e Legislativa.

APBAC Annais do Parlamento Brasileiro - Assembleia Constituinte.

ASIB Annaes do Senado do Império do Brazil

ACD Anais da Câmara dos Deputados 



\section{SUMARIO}

1.0. El liberalismo en las Cortes de Cádiz .33

1.0.1. Etapas de una crisis dinástica: el Rey, la Nación y la Constitución 36

1.0.2. La Revolución Constitucional española. 49

1.0.3. Corrientes ideológicas presentes en Cádiz: de la ilustración al liberalismo. 66

1.1. La Revolución Liberal de 1820, España como epicentro 79

1.1.1. La Referencia Política que supuso la Constitución de Cádiz en las Revoluciones liberales: el mito del constitucionalismo español. 88

1.1.2. La Prensa y la Revolución: el periodismo en el Trienio Liberal tras el silencio del sexenio absolutista en España

1.2. La Revolución Liberal de Oporto de 1820: la extensión de la revuelta liberal 110

1.2.1. El texto doceañista y su influencia en la Revolución de Oporto........................ 116

1.2.2. Reflejos periodísticos en España de la Revolución portuguesa

\section{Capítulo II. PROCESOS CONSTITUCIONALES LUSO-BRASILEÑOS: DE UN IMPERIO CONFESIONAL A OTRO.} 135

2.1. De la Ilustración al liberalismo portugués 135

2.1.1. La Reforma Pombalina: la "Lei da Boa Razão" y los "Estatutos Novos da Universidade de Coimbra"

2.1.2. Proyecto para un "Novo Código" para Portugal ................................................ 148

2.1.3. La presencia francesa en Portugal y la "Súplica Constitucional" ..................... 153

2.2. La Constituyente luso-brasileña de 1821/1822.

2.2.1. Los diputados brasileños en la definición de la ciudadanía en las Constituyente de 1821/1822

2.3. El Estado confesional y la ciudadanía en el Imperio Luso-brasileño

2.4. El proceso de independencia: adhesión a las Cortes y el desencanto con el movimiento constitucional Luso-brasileño

2.4.1. La Cuestión brasileña en las Cortes de Lisboa: los artículos adicionales a la Constitución referentes al Gobierno de Brasil 
Capítulo III. CONSTITUCIONALISMO, CIUDADANÍA Y CONFESIONALIDAD DEL ESTADO: EL PROBLEMA DEL DERECHO AL SUFRAGIO.

3.1. El Liberalismo de la Restauración y el principio monárquico: la solución para un imperio, una constituyente y un emperador 239

3.2. La convocatoria de la Asamblea Constituyente 255

3.2.1. Comentarios al Proyecto Constitucional de 1823 271

3.3. Entrada en vigor de la Carta Constitucional de 1824 285

3.3.1. Ciudadanía, confesionalidad y derecho al sufragio en el texto constitucional brasileño de 1824 .

\section{CODA. EL PRINCIPIO DE LA ELEGIBILIDAD DE LOS ACATÓLICOS:}

LA SOLUCIÓN A LO LARGO DEL SIGLO XIX, HASTA LA VIGENCIA DE LA LEY SARAIVA EN 1881

A) Las instituciones confesionales luso-brasileñas.

B) El reconocimiento del Estado por la Santa Sede: Las Bulas Sollicita Catholicis y Praeclara Portugaliae

C) Los elementos confesionales en las elecciones y las leyes electorales del Imperio: el principio de la elegibilidad de los acatólicos en la Ley Saraiva 


\section{INTRODUCCIÓN}

Evocar un planteamiento sobre el concepto de ciudadanía confesional desde la perspectiva que nos proponemos ofrecer puede parecer algo superfluo, si no está bien enmarcado en una realidad concreta. Con este trabajo pretendemos abordar la construcción de la ciudadanía ${ }^{1}$ - de síntesis confesional, pero con un cierto matiz definido por la Constitución de 1824, brasileña, que estuvo en vigor durante casi todo el siglo XIX. También es un resultado de los acontecimientos cambiantes de todo el orden constituido, que marca indeleblemente el fin del Antiguo Régimen.

La Constitución de Cádiz será el reflejo de las ideas que Francia irradió tras la Revolución, a través de la presencia de las tropas napoleónicas en la Península Ibérica. Este hecho desencadenará toda una cuestión en torno al concepto de ciudadanía y de los derechos fundamentales. En este sentido, las preocupaciones gaditanas influirán no sólo en el mundo hispánico, sino también en Portugal y en Brasil; este último con el status posterior de reino unido a Portugal y el Algarve, y luego como imperio independiente, no abandonará las innovaciones de la Constitución de Cádiz, aunque, esas fueron matizadas por otras influencias, como sucedió con los dos primeros textos constitucionales franceses.

La Independencia de Brasil fue precedida y acelerada por el proceso desencadenado después de la revolución liberal portuguesa. Además, se encuentra en perfecta sintonía con los acontecimientos sucedidos en España en aquellos tiempos.

El abordaje de la ciudadanía, definida en la constitución imperial, desde la perspectiva de la confesionalidad, buscará establecer un panorama de esta realidad que apenas tangencia lo que fue iniciado en la Península Ibérica. Al mismo tiempo pretendemos comprender los factores que plasmaron los distintos conceptos de ciudadanía en esta Constitución de carácter marcadamente liberal, pero, con rasgos de conservadurismo en tantos aspectos. De este modo, traeremos a debate las formas en que eran excluidos del proceso político los que se incluían en la ciudadanía definida por el texto constitucional, pero mitigada por el elemento confesional.

Las medidas adoptadas dentro de la nueva experiencia parlamentaria emprendida en Cádiz influirán fuertemente en el mundo luso, dentro de una concepción liberal en el nuevo orden político-social. Algún elemento del trato constitucional dispensado al tema de la

\footnotetext{
1 “Citadinanza è una parola che da qualche tempo gode di una crescente fortuna non solo nel lessico filosófico e sociológico, ma anche nel dibattito politico e nella stampa quotidiana. Il sucesso della parola coincide con un processo di più o meno consapevole estensione del suo campo semantico: da espressione impiegata semplicemente per descrivere la posizione di un soggetto di fronte ad un determinato Stato (rispetto al quale si è appunto o cittadini o stranieri) cittadinanza tende a divenire un crocevia di suggestioni variegate e complesse che coinvolgono l'intero corredo dei suoi dirriti e dei suoi doveri". COSTA. P.: Civitas, storia della cittadinanza in Europa. 1. Dalla civiltà comunale al settecento, Editiori Laterza, Bari, 1999, p. VII.
} 
ciudadanía en el imperio hispánico y sus complicadas soluciones, pasará al Imperio portugués y más tarde al Imperio brasileño, pero, sufriendo una simbiosis con los elementos propios del sistema luso-brasileño.

Estos textos constitucionales serán la consecuencia del proceso histórico por el que pasaron los derechos fundamentales a lo largo de los siglos, destacadamente los procesos históricos que se harán presentes a finales del siglo XVIII e inicios del siglo XIX, como fueron la Independencia de las Trece Colonias Británicas y la Revolución Francesa.

A partir de un universo teórico plasmado en estos procesos revolucionarios se asentarán constitucionalmente los conceptos de soberanía y ciudadanía, cambiando todo el orden de Ancien Régime ${ }^{2}$. Desde Francia estas ideas influirán considerablemente en texto doceañista para entonces llegar al vintismo portugués y luego después a Brasil, gracias a su correspondiente recorrido histórico.

A lo largo de siglos de dominación portuguesa, según José Murilo de Carvalho, en Brasil se instaló una sociedad que residía en una unidad territorial, lingüística, cultural y religiosa. Pero, sobre todo, "uma população analfabeta, uma sociedade escravocrata, uma economia monocultora e latifundiária, um Estado absolutista. A época da independência, não havia cidadãos brasileiros, nem pátria brasileira" ${ }^{3}$. El mismo autor dirá que el elemento más negativo para la ciudadanía fue la esclavitud. No había un ambiente favorable al desarrollo de una ciudanía, o de una ciudadanía en los modelos que se teorizaban entonces ${ }^{4}$. A la vez, tampoco se podía decir, en cuanto la otra cara de la moneda social, que los terratenientes en Brasil fuesen considerados ciudadanos, puesto que, les faltaba un elemento primordial inherente al concepto de ciudadanía -el propio sentido de ésta, en las palabras de Murilo de Carvalho-, la igualdad de todos ante la ley ${ }^{5}$. Antes, eran potentados que detentaban un poder jurisdiccional en

\footnotetext{
2 "Viendo a unos conciudadanos tan divididos y tan retraídos en sí mismos, un poder real tan extenso y tan poderoso, se podría creer que el espíritu de independencia había desaparecido juntamente con las libertades públicas, y que todos los franceses se sometían igualmente a la sujeción. Pero no era así; aunque el gobierno dirigía por sí solo y absolutamente todos los asuntos comunes, todavía estaba muy lejos de ser el dueño de todos los individuos. Rodeada de tantas instituciones preparadas para el poder absoluto, la libertad seguía viviendo; pero era una especie singular de libertad, de la cual es difícil hoy en día hacerse una idea, y que es necesario examinar muy de cerca para poder comprender el bien y el mal que haya podido hacernos". TOCQUEVILLE, Alexis: El antiguo régimen y la revolución, Ediciones Guadarrama, Madrid, 1969, p. 151.

${ }^{3}$ MURILO DE CARVAlHO, J.: Cidadania no Brasil. O longo caminho, Civilização Brasileira, $9^{\text {a }}$ Edição, Rio de Janeiro, 2007, p. 18.

4 “Escravidão e grande propriedade não constituíam ambiente favorável à formação de futuros cidadãos. Os escravos não eram cidadãos, não tinham os direitos civis básicos à integridade física (podiam ser espancados), à liberdade e, em casos extremos, à própria vida, já que a lei os considerava propriedade do senhor, equiparandoos a animais. Entre escravos e senhores, existia uma população legalmente livre, mas a que faltavam quase todas as condições para o exercício dos direitos civis, sobretudo a educação. Ela dependia dos grandes proprietários para morar, trabalhar e defender-se contra o arbítrio do governo e de outros proprietários.” Idem, p. 21.

${ }^{5}$ Para saber más sobre la evolución de la ciudadanía brasileña, se puede leer más en: MURILO DE CARVALHO, J.: Desenvolvimiento de la ciudadanía en Brasil, Fideicomiso Historia de las Américas - Serie Ensayos, México, 1995.
} 
sus territorios, administraban ellos la justicia, pero ciudadanos no eran. Incluso en el periodo colonial la designación de naturales del reino ${ }^{6}$ en las Ordenaciones Filipinas tampoco dejaba margen para imaginar o formar un ciudadano. "Natural", en la época de la Ordenaciones Filipinas, era lo que hoy podríamos considerar como nacional. Eran vistos como naturales los nacionales del Reino de Portugal y/o los miembros de las otras partes del reino.

En la Ley de 16 de diciembre de $1815^{7}$, Brasil fue elevado a la categoría de Reino, y de inmediato sus habitantes, que satisfacían los requisitos de este mandamiento, eran considerados "naturales" del reino portugués, o mejor dicho, eran nacionales del Reino Unido de Portugal, Brasil y Algarves. Inmediatamente después de la independencia, en el año 1823, reunida la Asamblea Legislativa del Imperio, esta recepcionó una parte de la legislación del Imperio Portugués, también las normas emitidas por el regente D. Pedro y las Cortes portuguesas de 1820, a través de la Ley de 20 de octubre ${ }^{8}$.

Pero, las bases estructurales de la nueva nación serán proporcionadas por la Carta Otorgada de 24 de marzo de 1824, que será la Constitución Política del Imperio y que seguirá en vigor durante casi todo el siglo $\mathrm{XIX}^{9}$. En ella, se establece la forma de gobierno monárquico, hereditario, constitucional y representativo. Determinando, además, la religión oficial del Imperio, la Católica Apostólica Romana en el art. $5^{\circ}$, y se define a los miembros del cuerpo social del Estado ${ }^{10}$. Lo que las Ordenaciones prevén en términos de naturalidad, se prefigurará como ciudanía en el art. $6^{\circ}$, del Título II, de la Constitución imperial. En síntesis, la definición dada para los ciudadanos brasileños no era muy diferente de la recogida en las Ordenaciones Filipinas. El término "naturales del reino" aparece por vez primera en las Cortes de Thomar $(1581)^{11}$, donde, frente a la unión de las coronas ibéricas, se tomó la decisión de preservar las leyes propias y la identidad portuguesa frente a la española. Lo discutido en aquellas Cortes fue acatado por el monarca español y pasó a figurar en el Título LV del libro II de las Ordenaciones Filipinas.

\footnotetext{
${ }^{6}$ MENDES DE ALMEIDA, C.: Código Filipino ou Ordenação do Reino de Portugal, Rio de Janeiro, Tipografia do Instituto Filomático, 14 ${ }^{\mathrm{a}}$ Edição, 1870, p. 489.

${ }^{7}$ COLEÇAO DE LEIS DO IMPÉRIO

http://www2.camara.gov.br/atividade-legislativa/legislacao/publicacoes/doimperio/colecao1.html

${ }^{8}$ COLEÇAO DE LEIS DO IMPÉRIO

http://www2.camara.gov.br/atividade-legislativa/legislacao/publicacoes/doimperio/colecao1.html

De tal forma que el Código Filipino seguirá en vigor hasta el advenimiento del Código Civil brasilero de 1916, ya en el período republicano, por lo tanto.

${ }^{9}$ Para leer más sobre el tema: BONAVIDES, P. y ANDRADE, P.: Historia Constitucional do Brasil, Malheiros, $3^{\text {a }}$ Edição, Rio de Janeiro, 1991.

${ }^{10}$ CONSTITUIÇAO POLITICA DO IMPÉRIO DO BRASIL -, art.: $1^{\circ}, 2^{\circ}, 3^{\circ}$ y $5^{\circ}$. Por lo que se refiere a la nacionalidad, las disposiciones previstas en el Código Filipino, recepcionado por el Imperio, la Constitución Imperial revoca el Titulo LV, del Libro II, de este instituto legal.

11 “(...) se não se dessem a espanhóis, como ia acontecendo, os bens da coroa, as comendas, os ofícios e benefícios, mas sim aos naturais do reino.” RODRIGUES DE SOUZA, J.: Analise e Comentário da Constituição Política do Império do Brasil, São Luis do Maranhão, 1867, pp. 35 y 36.
} 
Formada la nación, la Constitución del Imperio en su art. $6^{\text {o12 }}$ definía la ciudadanía en términos prácticos, bajo el Título $2^{\circ}$, "De los ciudadanos brasileños". Pero, para la definición dada en el artículo sexto, la alusión al texto de las ordenaciones del reino sería insuficiente con el delineamiento dado en este sentido por los teóricos iluministas, consolidados en el proceso revolucionario francés, y observados en este proceso. Las Constituciones, primero la portuguesa y después la imperial brasileña, seguirán la estela de Cádiz para hacer la composición de su corpus jurídico, entretanto, con matices propios.

Los deseos de libertad, confusos en Brasil en el momento de la independencia, se nutren de los ideales liberales de la Revolución Francesa. El propio título Déclaration des droits de l'homme et du citoyen, traerá la dicotomía entre hombre-ciudadano, extremadamente contractualista, por lo que son derechos con doble titularidad. Sobre los derechos que se atribuían a uno y a otro, García Manrique defiende su opinión:

“(...) la mejor forma de entender la dicotomía hombre-ciudadano, es considerar que el hombre es un sujeto de naturaleza moral mientras que el ciudadano es un sujeto de naturaleza política. El hombre es el sujeto natural que existe con anterioridad a la celebración del contrato social (...). El ciudadano en cambio, es ese mismo hombre que ha firmado ya el contrato social (...), que pertenece a una comunidad política (la nación) y es titular de ciertos derechos políticos ${ }^{13}$."

Derechos estos, establecido por la ley, y que no son más que una abstracción como el hombre, sino una realidad en la sociedad. El concepto de ciudadano presente en la Constitución Imperial, no traerá este principio de universalidad, sino que intentará, sobre diversos puntos de referencia, delimitar quiénes son los ciudadanos, sujetos de derechos.

En la Constituyente de 1823 , el relator de la materia que atañe a la ciudadanía ${ }^{14}$, que prefiguraría en el proyecto constitucional abortado -Antônio Carlos ${ }^{15}$-, confiesa haber consultado el tema en diversos textos constitucionales de la época.

\footnotetext{
${ }^{12}$ Constituição do Império do Brasil, diz em seu Art. 6. "São Cidadãos Brazileiros: I. Os que no Brazil tiverem nascido, quer sejam ingenuos, ou libertos, ainda que o pai seja estrangeiro, uma vez que este não resida por serviço de sua Nação. II. Os filhos de pai Brazileiro, e Os illegitimos de mãi Brazileira, nascidos em paiz estrangeiro, que vierem estabelecer domicilio no Imperio. III. Os filhos de pai Brazileiro, que estivesse em paiz estrangeiro em sorviço do Imperio, embora elles não venham estabelecer domicilio no Brazil. IV. Todos os nascidos em Portugal, e suas Possessões, que sendo já residentes no Brazil na época, em que se proclamou a Independencia nas Provincias, onde habitavam, adheriram á esta expressa, ou tacitamente pela continuação da sua residencia. $V$. Os estrangeiros naturalisados, qualquer que seja a sua Religião. A Lei determinará as qualidades precisas, para se obter Carta de naturalisação”. Se puede encontrar em:

HTTPS://legislacao.planalto.gov.br//legisla//legislacaonsf/viwTodos

${ }^{13}$ GARCÍA MANRIQUE, R.: "Segunda Parte: Sentido y Contenido de la Declaración de 1789 y textos posteriores”, in G. M. PECES-BARBA, E. FERNÁNDEZ GARCÍA y R. DE ASÍS ROIG (dirección), Historia de los Derechos Fundamentales, (Tomo II: Siglo XVIII, Vol. III), Dykinson S. L., Madrid, 2001, p. 254.

14 (...) la constitución es la primera garantía de los derechos individuales. MIRANDA, Jorge: "Contributo para uma teoria da inconstitucionalidade", Revista da Faculdade de Direito da Universidade de Lisboa, suplemento, Dissertação de Alunos VII, (? de 1968), p. 33.
} 
En el contenido del art. $6^{\circ}$ de Constitución de 1824, hay una confusión entre los términos ciudadanos y nacionales; esta definición en parte siguió aquellas dadas por las constituciones que enumeramos precedentemente.

En cuanto al proceso de concesión de ciudadanía a la población negra y mulata, la Constitución Imperial brasileña será la más incluyente en el proceso de conceder la ciudadanía a estos grupos ${ }^{16}$. Mientras, la portuguesa de 1822 fue ampliamente incluyente en su definición de ciudadanía, en el art. 21.IV, los esclavos manumitidos sin reservas alcanzaban la ciudadanía plena $^{17}$. El art. 6.I traerá el término libertos, cualificando como ciudadanos a estos sujetos; ya en el art.94.II, son exceptuados en las elecciones para diputados, senadores y miembros de los consejos de Provincia, lo que da a entender que pueden votar en las Asambleas Parroquiales. En las discusiones planteadas en la Asamblea Constituyente de 1823 no se adoptaron criterios raciales para definir la ciudadanía, hecho este que pasó a la carta otorgada de $1824^{18}$. En Cádiz los criterios raciales sí fueron adoptados en una sociedad acostumbrada a lidiar con una división en castas. Los arts. 22 y 29 de la Constitución de Cádiz dirigidos a la población africana en los dominios españoles, les dificultaba la concesión del título de ciudadanía ${ }^{19}$. Siguiendo la línea de Berbel y Marquese, lo que extraemos es una definición de ciudadanía incluyente en la Constitución Portuguesa y en la Constitución Imperial brasileña -mientras ésta última

15 “(...) Principalmente as partes iniciais da Constituição da convenção, as partes dispositivas da Constituição de 1795 e alguma coisa da carta de Luis XVIII, de 1814”. Además, “(...) muitos pontos de semelhança com a Constituição espanhola" de 1812, conocida como la Constitución de Cádiz. Se puede leer más en el capítulo: O constitucionalismo no Brasil de Afronso Arinos. ARINOS DE MELO FRANCO, Afonso Arinos: Introdução à publicação comemorativa do sesquicentenário da independência do Brasil, Rio de Janeiro, Arquivo Nacional/Ministério da Justiça, 1972. Caio Prado Junior también dirá que “(...) ao elaborarem-no foram os constituintes brasileiros buscar seus modelos nas constituições da época, inglesa e francesa, nesta especialmente, e nos principais filósofos e políticos do contrato social de Rousseau". In ALECRIN, Otacílio: Idéias e instituições do Império, Instituto de Estudos Jurídicos, Rio de Janeiro, 1933, p. 46/7.

16 "De hecho, en el marco de las sociedades esclavistas americanas del paso del siglo XVIII al XIX, momento de cambio en las estructuras históricas del colonialismo y la esclavitud negra, la definición de ciudadanía plasmada en la Constitución brasileña fue, sin duda, la más incluyente para los descendentes de africanos. Según la carta otorgada por don Pedro I en 1824, los esclavos nacidos en Brasil - o sea, los no africanos - que fuesen manumitidos eran considerados ciudadanos brasileños, lo que les reservaba, en la letra de la ley, el pleno usufructo de los derechos civiles. Con relación a los derechos políticos, la Constitución brasileña siguió el criterio establecido por los revolucionarios franceses de distinguir a los ciudadanos pasivos, que apenas gozarían de los derechos civiles, de los ciudadanos activos, que participarían directamente en el juego electoral por cumplir determinadas condiciones del censo". BERBEL, Marcia Regina y MARQUESE, Rafael de Bivar: "Esclavitud, ciudadanía e ideología proesclavista en las Cortes de Lisboa y la Asamblea Constituyente de Río de Janeiro (1821-1824)", en M. CHUST y I. FRASQUET (eds.), Los colores de las independencias americanas. Liberalismo etnia y raza, CSIC: Colección América, Madrid, 2009, p.120.

${ }^{17}$ El art. 34 de la Constitución Portuguesa, que habla de los absolutamente inelegíveis, en su apartado VII, pondrá los libertos nacidos en país extranjero.

${ }^{18}$ Para saber más vea BERBEL, Márcia Regina y MARQUESE, Rafael de Bivar, op.cit., pp. 130-137.

19 “Los artículos se dirigían a la población de origen africano del Nuevo Mundo y adoptaban reglas bastantes rígidas para la concesión del título de ciudadano a los habitantes marcados por esta herencia, que prácticamente los excluían de la ciudadanía y el censo de población”. Ibídem, p. 122. 
diferenciaba entre criollos (esclavo nacido en Brasil) y africanos-, y la constitución gaditana que adopta rígidos criterios raciales de exclusión o de difícil acceso al título de ciudadano.

Otros tantos procesos de exclusión de participación activa o pasiva en los derechos de ciudadano se constatan en las tres constituciones mencionadas. Desde un completo silencio sobre la esclavitud, los indígenas y las mujeres, con excepción de la familia real, hasta los extranjeros naturalizados que en muchos artículos tienen una ciudadanía a medias en la Carta de 1824. También se verifican procesos de exclusiones de analfabetos, art.33.VI de la Constitución Portuguesa y art.25 VI de la Constitución de Cádiz.

La ciudadanía definida en la Constitución Imperial siguió la solución revolucionaria francesa, puesto que evitaba muchas espinas de la poliédrica sociedad brasileña de entonces. De tal forma que se optó por definir una ciudadanía dual, una activa y otra pasiva. Esta solución fue observada tanto en el proyecto de $1823^{20}$ como en la Carta Otorgada de 1824. La primera era atribuida a los que serían llamados a participar de la organización y funcionamiento del Estado. Los que no contaban con los atributos para que le fuesen concedidas aquellas prebendas eran considerados ciudadanos de segunda clase, con derechos civiles, pero, sin derechos políticos. Sin embargo, dentro de la plena ciudadanía ${ }^{21}$ había impedimentos o cortapisas a través de mecanismos censitarios, además del confesional para seleccionar a los que pretendían alcanzar a los cargos y puestos públicos elegibles. En el art. 90 (prevé que son los ciudadanos activos los que ocupen cargos públicos), art. 91 (determina quien tendrá voto en las elecciones primarias), art. 92 (fija los excluidos de votar en las Asambleas Parroquiales), art. 93 (dice que los impedidos de votar en las asambleas primarias de parroquia no pueden ser miembros, ni votar en el nombramiento de alguna autoridad electiva nacional, o local), y el art. 94 (establece que pueden ser electores y votar en las elecciones para diputados, por ejemplo, lo que tienen voto en las Asambleas Parroquiales, exceptuando a los que estén por debajo de determinada

\footnotetext{
${ }^{20}$ CONSTITUÇAO POLITICA DO IMPÉRIO DE 1824 - La dicotomía ciudadano activo y pasivo también estaba en el proyecto de Antonio Carlos, que estaba inspirado en el ideario francés. Se pretende esquivar una definición conflictiva, pasando por una solución diplomática, al sistematizar en el Cap. I, Titulo II, usando el epígrafe: "Dos Membros da Sociedade do Império do Brasil". Y, en el art. $1^{\circ}$ del Cap. V del proyecto, enunciaba: "São Brasileiros", al invés de "São Cidadãos brasileiros". El Titulo V, art. 122, entretanto, al tratar de las elecciones, concede voto, como en la carta otorgada, a los ciudadanos activos. Cualificaba estos con facultades de votar en las asambleas primarias y parroquias. Los brasileños ingenuos, los libertos nacidos en Brasil y los extranjeros naturalizados se exigió que estuviesen en el pleno ejercicio de los derechos políticos.

${ }^{21}$ DIARIOS DA ASSEMBLÉIA-GERAL CONSTITUINTE E LEGISLATIVA DO IMPERIO DO BRASIL (SESSAO DE 23.09.1823, pág. 90) - El diputado constituyente José Antônio da Silva Maya, al comentar el epígrafe "Membros da Sociedade do Império do Brasil”, referenda que la intensión del legislador no es hacer una diferenciación entre Brasileños y Ciudadanos Brasileños, sino de concebir "(...) somente a distinção entre cidadãos ativos y cidadãos passivos, como se vê no Capitulo 5 das Eleições (...)”. Corroboró en esta asertiva, en la misma sesión de las cortes constituyentes el diputado Luiz José de Carvalho e Mello, que " a intenção dos autores do projeto era falar em geral dos membros do Império com a qualidade de cidadãos, reservando-se para fazerem as exceções em seu lugar competente, acerca dos que são, por assim dizer, mais privilegiados”.
} 
renta, los condenados y los libertos - dando a entender que estos últimos pueden votar en las Asambleas Parroquiales) marcan esta ciudadanía bipolar, dentro de lo que define el art. $6^{\circ}$.

Sin embargo, las discusiones sobre el epígrafe del art. $5^{\circ}$ del proyecto constitucional de 1823, "São Brasileiros" 22 , no pasó sin que se suscitase un debate al respecto. Puesto que, en ese momento, todos tenían presente la idea de la solución francesa de división de la ciudadanía, donde por un lado se podría gozar de derechos civiles y por el otro se podría gozar de los derechos políticos. De esta forma, la simple concesión de la ciudadanía a todos los brasileños era algo impensable, puesto que era fruto de una sociedad poliédrica incorregible en esa época. Pero, a la vez, los debates y las soluciones vinculadas a las ideas liberales, no podrían deshacerse del término ciudadanía que causaba un cierto frenesí en esos momentos. Aunque fue debatida la enmienda propugnada por José Antonio da Silva Maya, esta pasó sin mayores problemas $^{23}$. De este modo, la Carta Otorgada de 1824 recogió en el epígrafe del art. $6^{\circ}$ la inscripción: "São Cidadãos Brasileiros”. Aún así, el término ciudadano empleado ahí, reafirmamos, solo quería aludir al conjunto de los individuos de la sociedad brasileña del Imperio de Brasil.

La frontera entre ciudadanos activos y pasivos venía marcada a lo largo de la Constitución del Imperio, además, en leyes extravagantes. El art. 45, por ejemplo, contiene los requisitos para ser elegido senador. El art. 75 contiene los requisitos de edad y exige un determinado peculio para ser consejero del Estado. $\mathrm{Y}$ en el art. 95 vienen enumerados los requisitos para ser elegido diputado. Los arts. 162 y 169 contemplan los requisitos para ser electo Juez de Paz y vereadores (una especie de diputados para las Cámaras Municipales).

El Decreto de 26 de marzo de 1824, que establece las reglas para las elecciones en el Imperio, en su art. $4^{\circ}$, fijará el número de electores por parroquias. Además, el art. $6^{\circ}$ del mismo decreto dirá quien tiene voto en las elecciones primarias, donde se incluye a los extranjeros

\footnotetext{
${ }^{22}$ DIARIOS DA ASSEMBLÉIA-GERAL CONSTITUINTE E LEGISLATIVA DO IMPERIO DO BRASIL (SESSAO DE 23.09.1823, págs. 90 y 110)La emenda al texto del proyecto constitucional de 1823, ofrecida por Manuel José de Sousa França, pretendía cambiar la expresión del epígrafe del art.5 ${ }^{\circ}$, para lo que figuraría posteriormente en el art. $6^{\circ}$ de la Carta Otorgada. El diputado Antonio de Rocha Franco rebate la enmienda diciendo que "(...) se não há distinção entre brasileiros e cidadãos brasileiros, e são uma mesma coisa, (...) a palavra cidadão é va, e sem sentido (...). (...) Os honrados membros que não distinguem entre brasileiros e cidadãos brasileiros, são os mesmos que distinguem entre cidadãos ativos e cidadãos passivos, e o que eles dizem cidadãos passivos é o mesmo que eu e outros chamamos simplesmente de brasileiros, vindo aqueles ilustres Membros a reconhecer, por um lado, a mesma distinção que por outro excluem, e não admitem. Mas, além de que a expressão cidadão passivo me parece pouco exata, por isso que os cidadãos que não tem o exercício dos direitos de sua cidade deixa de ser tal, entendo que para ser brasileiro basta só a naturalidade, ou a naturalização (...)". También el diputado por Pernambuco, Manoel Caetano de Almeida e Albuquerque, revolucionario de 1817 se opondrá a la emenda y la definición dada para una ciudadanía bifurcada.

${ }^{23}$ DIARIOS DA ASSEMBLÉIA-GERAL CONSTITUINTE E LEGISLATIVA DO IMPERIO DO BRASIL (SESSAO DE 25.09.1823, pág. 112)
} 
naturalizados. Así, en el art. $7^{\circ}$ y en sus apartados se enumeran a los excluidos de las Asambleas Parroquiales.

De tal forma que los ciudadanos pasivos, que gozan apenas de las garantías y de los derechos civiles están contemplados en el Título VIII de la Constitución. De esta forma, el art. 179 prevé la inviolabilidad de los derechos civiles y políticos (para quien los tenga) de los ciudadanos brasileños, garantizándoles la libertad, seguridad personal y la propiedad. Luego, este mismo artículo, en sus incisos, contiene determinadas contradicciones que influirán en lo que se entiende como ciudadano activo. Es el caso del inciso V, que prohíbe la persecución por motivos religiosos, nos obliga a pensar en la confesionalidad del Estado y en las exclusiones de la ciudadanía activa. Otro inciso genérico es el XIV, donde se prevé que todo ciudadano brasileño - aquí se entiende comprendidos también a los pasivos - puede ser admitido a cargos públicos, civiles y militares, sin otra distinción que el mérito y la capacidad personal. En esta misma línea, se prevé en el inciso XXXI la instrucción gratuita a todos los ciudadanos; aquí se entienden comprendidos los ciudadanos de forma global.

En el texto constitucional de Cádiz, en la portuguesa de 1822 y en la brasileña imperial, a primera vista, lo que aparece es la confesionalidad del Estado en la invocación de los respectivos preámbulos ${ }^{24}$. En el art. 12, establece la confesionalidad de la Nación española y prohíbe las demás ${ }^{25}$. Es confesional, pero sobre todo intolerante ${ }^{26}$. Este clavo absolutista en el ambiente liberal de la constitución de Cádiz marcará la tónica de la discrepancia que ofrece al art. 10 de la Declaración Francesa. ${ }^{27}$. Al fin y al cabo lo que querían los liberales era una supremacía de la autoridad civil ${ }^{28}$. Libertad civil no religiosa, era la tónica de Cádiz ${ }^{29}$. El art. 25

\footnotetext{
${ }^{24}$ Const. de Cádiz: "En el nombre de Dios, Padre, Hijo y Espíritu Santo autor y supremo legislador de la sociedad”;Const. Portuguesa: "Em nome da Santíssima e Indivisível Trindade”; Const. Imperial Brasileña: "Em nome da Satíssima Trindade”.

${ }^{25}$ El artículo 12 dirá: "La religión de la nación española es y será perpetuamente la católica, apostólica, romana, única verdadera. La Nación la protege por leyes sabias y justas y prohíbe el ejercicio de cualquiera otra". La propuesta inicial era de un texto más intolerante todavía: "La Religión de la Nación española es la católica, apostólica, romana, con exclusión de cualquier otra”; Actas de la Comisión de Constitución (1811-1813), ORTEGA SEGURA, Manuel, op.cit., pp. 25 y 85.

${ }^{26}$ Se puede saber más sobre la Constitución de Cádiz desde esta perspectiva con una lectura más completa desde la página 258 y ss., en: PORTILLO VALDÉS, J. M.: Revolución de nación. Orígenes de la cultura constitucional en España, 1780-1812, CEPC-BOE, Estudios Políticos, Madrid, 2000.

${ }^{27}$ En verdad, el consenso se da por aquellos dos sectores que discutían el tema en el ámbito del proyecto constitucional poseyeren en común un inconsciente fundado en el ámbito del catolicismo. El tema religioso "ha debido ocupar en la ley fundamental del Estado un lugar preeminente, cual corresponde a la grandeza y sublimidad del objeto"; ARGÜELLES, Agustín: Discurso preliminar a la constitución, Centro de Estudios Constitucionales, Madrid, 1989, p. 80.

${ }^{28}$ MIR Y NOGUERA, Juan: El triunfo social de la Iglesia católica (2 vols. del tomo I), Madrid, Imprenta de Jubera Hermanos, 1910, pp. 65 y ss, en M. ORTEGA SEGURA, op. cit., p. 25.

${ }^{29}$ Más en MARTÍNEZ SOSPEDRA, Manuel: La Constitución de 1812 y el primer liberalismo español, Cátedra Fadrique Furio Ceriol, Valencia, 1978, p. 378.
} 
de la Constitución Portuguesa establece la confesionalidad del Estado portugués, pero permite a los extranjeros el ejercicio particular de sus respectivos cultos. La Constitución del Imperio de Brasil en su art. 5 sigue la misma fórmula, admite una cierta libertad religiosa, pero con reservas; el culto será doméstico o particular, en casas para eso destinadas, sin forma exterior de Templo. A la vez que prohíbe persecuciones por motivos religiosos, art. 179, V.

Profesar otra religión, que no fuera la oficial del Estado, tenía efectos de impedir que se ejercieran algunos derechos de ciudadano como los reconocidos en los arts. 92, apartados IV y 95, apartado III $^{30}$. Además, los altos cargos públicos estaban obligados a jurar la religión católica $^{31}$. En Portugal pasaba lo mismo, pues todo el proceso electoral estaba relacionado con actos religiosos católicos. Mientras permitía a los extranjeros practicar sus religiones en suelo portugués, las exclusiones a los que profesaban otras religiones venían implícitas o explícitas en muchos artículos de la Constitución Portuguesa de 1822.

Desde el preámbulo del texto brasileño hasta fijarse en el art. $5^{\circ}$ la Religión Oficial del Estado no deja lugar a dudas que el Estado es confesional. Pero, luego las matizaciones que hacen algunos artículos nos llevan a pensar en una cierta tibieza al principio defendido por el art. $5^{\circ}$. Guilherme Pereira das Neves ${ }^{32}$, analizando a George C. A. Boehrer, gran brasilianista, concluye que el Brasil del siglo XIX era religiosa e intelectualmente un país pombalino, como una fórmula sintomática de la dinámica de la iglesia en este periodo y su situación. Así lo es porque el art. $6^{\circ}$, regulando quiénes son los ciudadanos brasileños, nos dice en el inciso V que también eran ciudadanos "Os estrangeiros naturalisados, qualquer que seja a sua Religião". También el art. 179.V. nos dice que "Ninguem póde ser perseguido por motivo de Religião, uma vez que respeite a do Estado, e não ofenda a Moral Publica". Ese principio, es, quizás, una reminiscencia del art. 10 de la Declaración Francesa, pero tomada en parte por la Carta Imperial. Así, se entablará en el Brasil del siglo XIX, pombalino, en las palabras de Boehrer, toda una discusión sobre los derechos políticos de los acatólicos. Porque muchos de los que se podrían considerar como ciudadanos activos, y por lo tanto con gozo de derechos políticos, no solamente civiles, eran acatólicos; así, restaba este escollo impeditivo que les negaba la ciudadanía plena.

\footnotetext{
${ }^{30} \mathrm{El}$ art. 95, IV excluye de votar a los religiosos de comunidades claustrales, ya el art. 95, III inhabilita para ser nombrado diputado no profesar la religión del Estado.

${ }^{31} \mathrm{El}$ art. 179, V, no obstante amonesta: "Ninguém pode ser perseguido por motivo de religião, uma vez que respeite a do Estado, e não ofenda a moral pública".

${ }^{32}$ PEREIRA DAS NEVES, G.: “A religiao do Império e a Igreja” en GRINBERG, K \& SALLES, R, (orgs.): $O$ Brasil Imperial. Volume I: 1808-1831, Civilização Brasileira, Rio de Janeiro, 2009, p. 377-428.
} 
Claramente la Carta Otorgada brasileña, en el art. 95, apartado III, decía que no podría ser elegido diputado "os que não professarem a religião oficial do Estado". Los que no profesasen la religión oficial eran denominados "acatólicos" en el debate parlamentario y en la prensa. Estaban vedados a determinados cargos públicos en función del juramento contenido en el art. $103^{33}$ de la Constitución. Así, las funciones de diputado, regente y emperador estaban prohibidas a los acatólicos. Tanto en razón del art. 95, III, como del juramento del 103. Y para el cargo de senador, el art. 45 no contiene ninguna referencia a la religión para poder ser elegido, pero, el juramento del Reglamento Interno del Senado preveía jurar por los Santos Evangelios desde que comenzó a funcionar en 1826.

El debate sobre la posibilidad de que los acatólicos ocupasen cargos públicos pasó por todo el siglo XIX, culminando con la Ley Saraiva ${ }^{34}$, la así llamada ley electoral de 1881. A través del art. $2^{\circ}$ de esta ley se permitía ser elector, y por lo tanto ser ciudadano activo, a todos los descritos en el art. $6^{\circ}$ de la Constitución, y particularmente en el apartado V, que hablaba de brasileros naturalizados, cualquiera que fuera su religión. El proyecto original de la ley preveía una citación expresa de los acatólicos en la vida política, pero en el texto final apenas se daba a entender transversalmente citando los artículos de la constitución que se referían a la ciudadanía $^{35}$. Sin embargo, dada la aprobación de la ley, distinta al proyecto original, muchos aspectos se quedaron en suspensión. Saldanha Marinho, en su intervención en el Parlamento, en la Sesión de 7 de noviembre de 1881, dirá: "Nao aceitaram o principio? Sujeitem-se às consequências" 36 . También Ruy Barbosa dirige una solicitud a la Comisión de Policía en este sentido, en la Sesión de la Cámara en 6 de Febrero de 1882.

El primer incidente concreto en este sentido pasó cuando un diputado acatólico Antônio Romualdo Monteiro Manso, del $9^{\circ}$ Distrito electoral de la Provincia de Minas Gerais fue electo

\footnotetext{
${ }^{33}$ CONSTITUÇAO POLITICA DO IMPERIO DO BRASIL - Art. 103. "Juro manter a Religião Catholica Apostolica Romana, a integridade, e indivisibilidade do Imperio; observar, e fazer observar a Constituição Politica da Nação Brazileira, e mais Leis do Imperio, e prover ao bem geral do Brazil, quanto em mim couber".

${ }^{34}$ COLLECÇAO DAS LEIS DO IMPÉRIO DO BRASIL - 1881, Parte I, Tomo XXVIII, Volume I (Actos do Poder Legislativo de 1881, Parte I). Art. $2^{\circ}$ : "É eleitor todo cidadão brazileiro, nos termos dos arts. $6^{\circ}, 91$ e 92 da Constituição do Império (...)”.

${ }^{35}$ Walter Costa Porto nos informa que: "O projeto de que resultaria a Lei Saraiva foi encaminhado pelo Governo, em abril de 1880, à Câmara e afirmava, expressamente, em seu artigo $2^{\circ}$, que seria eleitor "todo cidadão brasileiro, nato ou naturalizado, católico ou acatólico, ingênuo ou liberto”. E, adiante, quando falava dos elegíveis, no artigo $8^{\circ}$, dizia serem "aptos para os cargos de Senador, Deputado Geral, membros da Assembléia Legislativa Provincial, Vereador, Juiz de Paz e quaisquer outros criados por lei, todo cidadão compreendido no artigo 2․" COSTA PORTO, W.: "Católicos e acatólicos: o voto no Império", Revista LIBERDADE e CIDADANIA - Ano 2 - n. 5 - julho / setembro (2009) - www.flc.org.br p. 3.

${ }^{36}$ Uno de los elementos que se quedaron en suspensión fue el juramento que se mantenía en el Estatuto Interno del Senado del Imperio, confrontándose a La Ley Saraiva que permitía la elección de los acatólicos a la Cámara Alta del Imperio. "Veremos os acatólicos nesta Câmara não prestar juramento e não serão por isso repelidos". " $O$ Parlamento e a evolução nacional” - (1871-1888), Brasília: Senado Federal, 1979, 33 série, vol. 6, p. 160. In Idem, p. 4.
} 
para el puesto vacante del senador Resende Monteiro. En la Sesión de 6 de septiembre de 1888, en el momento de la toma del juramento previsto en el Estatuto Interno del Senado del Imperio, el senador electo declaró en el pleno que: "Não posso prestar o juramento porque é contra minhas convicções. ${ }^{, 37}$ Este hecho desencadenó el problema de la colisión con la Ley electoral en vigor, lo que provocó una inmediata discusión en el Senado Imperial y se decidió por reformar el artículo "hereje", y en la Sesión de $1^{\text {0 }}$ de noviembre, se decidió agregar un párrafo al mismo, dispensando al senador electo de jurar contra sus creencias y opiniones políticas. Muchos otros senadores, entendían que el propio artículo ya estaba tácitamente revocado por la Ley Saraiva, en virtud del principio de la jerarquía de las normas jurídicas.

Claro que todo eso es fruto de un proceso de discusión a lo largo del siglo XIX sobre la inclusión o no de los "acatólicos" como ciudadanos activos políticamente y no solamente con derechos civiles. La conformación de la ciudadanía en la aurora del Imperio Brasileño, como vimos, pasa por innumerables factores. Desde la fijación en el texto constitucional, donde confluyen muchas corrientes que influyen en el proceso de creación de las instituciones, hasta la creación de mecanismos de exclusiones, sobre todo la confesionalidad del Estado - se establece así una doble ciudadanía, evitando con eso las dicotomías inherentes de esta misma sociedad; se crea un medio término de ciudadanía también para satisfacer a la élite gobernante, por la presencia de extranjeros en el territorio nacional (entiéndase ingleses a estos extranjeros). Esta discusión perdurará a lo largo del siglo XIX, hasta la inclusión de los acatólicos con la votación de la Ley Saraiva en 1881, pero el texto final, como vimos, fue bastante distinto al proyecto original.

Como forma de obtener un recorte temporal que permita fundamentar este trabajo, utilizaremos el año 1823 como punto inicial porque fue en la Constituyente del mismo año donde se reflejó en Brasil lo ocurrido en la Península Ibérica. De este modo, la Revolución Liberal de Oporto de 1820, que desencadenó el proceso constitucional en Portugal, adoptó muchas de las innovaciones de la Constitución de Cádiz de 1812. También será el punto de partida que desencadenó la consolidación de la independencia de Brasil y a la vez una fuente de influencia para el proceso constitucional brasileño. Ello se explica porque, muchos de los diputados electos para la constituyente de 1821 en Portugal volverán y participarán como diputados electos de la constituyente de 1823 en Brasil. Esto enmarca uno de los innumerables factores que influyen en la independencia y el proceso constitucional en el Imperio.

\footnotetext{
${ }^{37}$ MAGALHAES JÚNIOR, R.: O Império em chinelos, Rio de Janeiro: Civilização Brasileira, 1957, p. 265.
} 
Por otra parte, marcamos como punto final la fecha de 1831 que, con la abdicación del emperador, pone fin a un periodo en el cual podemos verificar la institucionalización del Brasil independiente y las cuestiones que surgen con la efectiva aplicación de la Constitución y la consecuente relación del binomio ciudadanía/confesionalidad en los procesos electorales. Así mismo, otros acontecimientos importantes estarán integrados en este marco histórico. De esta forma, en 1826 el Parlamento del Imperio empieza sus trabajos, lo que presupone el pleno funcionamiento de las instituciones legislativas. Este mismo año, el 10 de abril, Portugal reconoce la independencia de Brasil, que desatará otros dos procesos de igual importancia para nuestra investigación. El 13 de enero de 1826, el Papa recibe al plenipotenciario brasileño en Roma, reconociendo días después los poderes del mismo y la existencia de un nuevo país, dictándose dos bulas papales, una el 15 de julio de 1826, Sollicita Catholicis, y la otra el 15 de mayo de 1827, Praeclara Portugaliae, donde reconoce en esta última los poderes de patrono semejantes a los concedidos a los reyes de Portugal, finalizando así el proceso de reconocimiento del Estado brasileño y la plena relación con la Santa Sede.

Dentro del marco histórico, previamente señalado, partiremos de la definición de ciudadanía recogida en la Constitución del Imperio de Brasil y su relación con la confesionalidad del Estado, tratando de buscar las influencias del liberalismo ibérico. Utilizaremos como fuentes primarias, además de los textos constitucionales, los debates parlamentarios, la obra doctrinal, las leyes electorales y haremos un sondeo de la prensa escrita en aquella época. También buscaremos constatar el alcance de la aplicación de las leyes electorales.

Aunque tengamos a Brasil como eje principal del estudio intentaremos comparar los textos constitucionales español, portugués y brasileño para poder analizar con detalle lo que dice la Constitución Imperial de Brasil sobre el tema ciudadanía/confesionalidad. Partiremos desde nuestro objeto general de estudio, esto es, el liberalismo ibérico, y la conformación de estos conceptos en los primeros textos constitucionales de España y Portugal, hasta llegar a Brasil y su texto constitucional.

También hemos creído necesario estudiar la aplicación del derecho a través de la práctica electoral. Para ello, utilizaremos no solamente las leyes electorales vigentes en aquel momento, sino que seguiremos el propio proceso electoral, a través de la ley electoral, e igualmente acudiremos a los debates parlamentarios de la época para tratar de reforzar la visión de la aplicación práctica del derecho electoral brasileño del periodo. 
El constitucionalismo brasileño del inicio del siglo XIX, estuvo influenciado en parte por el liberalismo ibérico de España y Portugal, si bien es cierto que, respecto a la formación de la ciudadanía, el texto constitucional sufrió influencias diversas, tanto por lo que se refiere al peso de la confesionalidad del Estado, como a la adopción del parámetro revolucionario francés de ciudadanía bipartida en ciudadanos activos y ciudadanos pasivos, a lo que hay que añadir la presencia política y económica en territorio brasileño de los británicos, reforzada por la ratificación de los Tratados de 1810, que supuso cierta tolerancia religiosa en el texto constitucional.

De esta forma, pretendemos conseguir una aportación realmente novedosa para la historiografía jurídica del período con el estudio de la ciudadanía en confrontación con la confesionalidad del Estado brasileño plasmada en su Constitución; consideramos que nos encontramos ante una faceta poco estudiada en la historiografía jurídica brasileña, porque los estudios existentes acerca del derecho de ciudadanía y su formación, no han sido realizados desde esta perspectiva confesional que se pretende abordar en la presente investigación.

Intentando cumplir con nuestro objetivo dividimos el trabajo en tres capítulos y una CODA al capítulo III. Dedicamos el primero a tratar del liberalismo ibérico y la conformación que tuvo en el escenario europeo. Este será un modelo para el liberalismo portugués que a su vez también servirá de paradigma al liberalismo brasileño. Por lo tanto, partiremos del modelo gaditano de constitución enarbolado en todas las revoluciones del periodo; 1820 fue el año revolucionario no solamente para España sino también para Portugal y una parte de Italia. Tanto el modelo de pronunciamiento militar, como vehículo para obtener a una revolución liberal efectiva y rápida, como la utilización de la Constitución de Cádiz para consolidar el gobierno formado en aquel proceso revolucionario, se pudo percibir en aquellos países en donde llegó la revolución liberal. Hasta en Brasil, después de la Revolución de Oporto, y en Portugal, se había jurado por un día la Constitución de Cádiz. El modelo revolucionario español, tributario de los procesos revolucionarios franceses, se extenderá por una buena parte de Europa, y la prensa española dará cuenta de que dicho modelo revolucionario era un modelo vencedor. Esto hará con que internamente el proceso revolucionario perdure, y lleve tres años para ser atacado por Francia con los Cien Mil Hijos de San Luis. Era un proceso, hasta entonces, de flujo y reflujo revolucionario en donde los procesos internos respaldaban a los procesos revolucionarios externos y viceversa. De modo que llegó a influir hasta en Brasil, de cara a su proceso de Independencia y su Asamblea Constituyente que dará un proyecto de constitución inspirado en el modelo gaditano. 
El capítulo II lo dedicamos a verificar la formación del liberalismo portugués y como este influenció en el liberalismo brasileño. Las reformas en el periodo del Marqués de Pombal, la "Ley da Boa Razão", la Reforma Universitaria y el Proyecto de Nuevo Código, todo esto conformará el ideario brasileño en el momento de la redacción del texto constitucional y durante todo el proceso de independencia. Ahí también buscamos retratar el momento de la independencia brasileña y como algunos marcos legales van a modelar tanto el confesionalismo como la ciudadanía. La ciudadanía tomará un camino más blando que Cádiz, y así como se hizo en Portugal se buscará fusionar la concepción de Nacionales y Ciudadanos. De tal modo que se evitase también "racializar" al tema de la ciudadanía. Los Tratados de 1810 con Inglaterra influirán tanto en Portugal como en Brasil, para que la tolerancia religiosa fuese adoptada. En Portugal apenas a los extranjeros, ya en Brasil se buscó que los nacionales también gozasen de este tipo de tolerancia.

En el capítulo tercero estará es la clave de la presente investigación. Allí pretendemos demostrar cómo se alcanza una ciudadanía confesional blanda en relación al texto de Cádiz. Pero, a la vez, buscaremos verificar que la confesionalidad del texto constitucional restringía la ciudadanía establecida en el propio texto constitucional. En el proyecto de Antonio Carlos, proyecto abortado con la propia Constituyente, se preveía que los "acatólicos" cristianos tuviesen todos los derechos, civiles y políticos. Los no católicos de las demás religiones apenas tenían previstos los derechos civiles. Este principio pasará en parte al texto constitucional otorgado de 1824, donde no se abandonaba del todo la tolerancia religiosa, pero se restringía con el establecimiento de la confesionalidad del Estado a los derechos de los no católicos. Este grupo recibe la ciudadanía con los correspondientes derechos civiles y con una parca participación en el proceso electoral. Como la constitución brasileña había adoptado el modelo revolucionario francés de división de la ciudadanía en Ciudadanos Activos y Ciudadanos Pasivos, esto hará que se fusionase también la concepción de nacional y ciudadano. Los "acatólicos" tenían los derechos de los ciudadanos pasivos, como derechos civiles, y por ello podían participar en el proceso electoral, pues participaban en las elecciones primarias como votantes, pero, no podían ser elegidos diputados generales. Esto era lo que preveía la constitución, que vetaba quienes no profesasen la religión del Estado acceder al cargo de diputado. Los demás cargos públicos estaban vetados por el juramento en mantener a la Religión Católica, previsto en el art. 103 de la Constitución del Imperio. Pero, veremos, que el principio de la elegibilidad de los "acatólicos" fue muy debatido en el parlamento y al final les fue negado este derecho. Sin embargo, permaneció en potencia dicho derecho, y no murió esta concepción de libertad religiosa. Aunque en el periodo que pretendemos estudiar, comprendido 
entre 1823, con la apertura de la Asamblea Constituyente y 1831, con la abdicación del Imperador y consecuentemente el final del Primer Imperio, apreciamos que la discusión y la propuesta de una libertad religiosa fue mucho más amplia que la verificada en Portugal y en España. Pero, eso no fue suficiente para constatar el establecimiento del principio de la elegibilidad católica. Con libertad religiosa, con derechos civiles y participación en el proceso electoral, los acatólicos veían restringidos sus derechos por la confesionalidad del Estado.

Finalmente, en el Capítulo IV redactaremos una CODA de la tesis. Terminamos nuestra investigación en el capítulo III, demostrando que los derechos políticos de los no católicos estaban restringidos por el establecimiento de la confesionalidad del Estado aunque se adoptase el principio de la libertad religiosa. Así pues, el principio de la elegibilidad de los acatólicos no será establecido en el periodo que nos propusimos analizar, 1823-1831. Sin embargo, la discusión para ampliar la libertad religiosa y la consecuente ampliación de los derechos políticos de los no católicos en el imperio se mantendrá a lo largo del siglo XIX. Pero esta discusión queda fuera del periodo que nos propusimos analizar; por ello establecemos una CODA que pretende aportar el cómo y donde el principio de la elegibilidad de no católicos fue establecido. Únicamente en 1881, cincuenta años después del final del Primer Imperio, es cuando el principio de la elegibilidad de los no católicos es reconocido por la Ley Saraiva. Esta ley permanece fuera del marco histórico de la tesis, pero, hemos querido dar cuenta de ella para informar que la discusión establecida a partir de 1823 tuvo un final exitoso, y el principio de la elegibilidad de los "acatólicos" fue adoptado, aunque mucho más tarde en el tiempo, pues se acercaba ya el final del siglo XIX. 



\section{Capítulo I}

\section{EL LIBERALISMO IBÉRICO Y SUS MATIZACIONES}

\subsection{El liberalismo en las Cortes de Cádiz}

Es con la Guerra de la Independencia, $1808-1814^{38}$, período éste que verá como las ideas liberales toman cuerpo y se fraguan en una constitución, cuando España se ve enfrentada a Francia a través de una guerra internacional, a la vez que enfrentada a sí misma en una guerra civil; la primera de la época contemporánea según Alberto Gil Novales ${ }^{39}$. Este enfrentamiento no es una ecuación simple, como cuando se enfrenta la libertad a la tiranía, el liberalismo al absolutismo, el tradicionalismo al reformismo. Es mucho más que eso y a veces algunos de estos elementos al mismo tiempo. El primer liberalismo español, en palabras de Roberto Breña, se constituyó con una amalgama de doctrinas y normas políticas que convivían al momento de la invasión napoleónica, y que en este contexto fueron recuperadas, repensadas y adaptadas en el período en que se delimitó lo que vendría a ser definido por liberalismo doceañista ${ }^{40}$. Sin embargo, al fin y al cabo, fraguaría en un cambio drástico, con una serie de disposiciones jurídicas, de la vida política y de la sociedad española. Era ya otra época, desde la Revolución Francesa de 1789, donde la transformación de la política y de la sociedad venían con reclamos de la tradición histórica, y no solamente del liberalismo - así también pasó en Portugal y en el Brasil ya independiente. Haciendo con que la ruptura tuviera visos de continuismo, lo que lleva a muchos autores a pensar si hubo realmente una ruptura tajante o un continuismo del status quo con el status ante, bajo otro ropaje, como es el caso de los autores Carlos Garriga y Marta Lorente $^{41}$. Sea como sea, son innegables la presencia de las ideas liberales en la Constitución gaditana; innegable también es el cambio que supuso al momento, y aún más, cuando ocurrió su repristinación en el Trienio Liberal, periodo este de gran interés para el desarrollo del trabajo que aquí nos proponemos realizar.

El 1808, coinciden los autores Hocquellet y Portillo Valdés, fue el año en el cual tuvieron lugar un horizonte de eventos, tanto en el propio seno de la monarquía española como

\footnotetext{
${ }^{38}$ Para saber más detalladamente sobre la Guerra de la Independencia contra las tropas napoleónicas, se puede leer en ESDRAILE, Charles: La Guerra de Independencia. Una nueva historia, Crítica Barcelona, Barcelona, 2004.

${ }^{39}$ GIL NOVALES, Alberto: El liberalismo temprano en un diccionario biográfico en BARREIRO FERNÁNDEZ, X. R. (coord.): O liberalismo nos seus contextos. Un estado da cuestión, Santiago de Compostela, USC, 2008, p. 12.

${ }^{40}$ BREÑA, Roberto: El primer liberalismo español y los procesos de emancipación de América, 1808-1824. Una revisión historiográfica del liberalismo hispánico, México D.F., El Colegio de México, 2006, p. 30.

${ }^{41}$ Para saber más sobre el continuismo en la Constitución de Cádiz, se recomienda leer GARRIGA, Carlos y LORENTE, Marta: Cádiz, 1812. La Constitución jurisdiccional, Madrid, CEPC, 2007.
} 
entorno a lo que ella representaba ${ }^{42}$. La Monarquía Compuesta ${ }^{43}$ iba a colapsarse, pues de una constelación se formarían muchas estrellas, algunas de ellas fugaces en cuanto instituciones políticas. Es una ruptura tajante con el viejo orden del régimen del inmenso imperio español. Sin embargo, a distinción de lo que pasó en Francia en 1789, España tendrá el impulso inicial con la crisis de la sucesión. El planteamiento sobre quien debía detentar la soberanía empezó no desde una revolución como sucedió en Francia, sino como consecuencia de la crisis sucesoria y de la invasión de las tropas napoleónicas ${ }^{44}$.

Intentando esbozar un cuadro de la crisis de 1808, Parra López, siguiendo las ideas de Portillo Valdés, afirma que esta crisis empieza por disputas dinásticas, y en seguida se transforma en crisis de independencia, para a continuación dar un giro en dirección a una crisis revolucionaria o constitucional. Solamente en este período, es cuando, según Portillo Valdés, los liberales ganan terreno, y el debate político se fija en el problema de la constitución de la monarquía ${ }^{45}$. De este escenario surgen dos posiciones enfrentadas al momento. Según Parra López la primera será defendida por los que se identificarán más tarde como "liberales", que defienden la convocatoria de Cortes por la Nación, pero no son reacios ni al rey ni a la confesionalidad del Estado. Sin embargo, este primer grupo defiende una amplia reforma en las leyes del reino. En torno al otro grupo, o postura, se reunían los absolutistas que propugnaban atenerse a la constitución o legislación histórica de la monarquía. Y para garantizar esto, defendían el establecimiento de un poder militar fuerte, justo para evitar que la crisis de soberanía se transformara en una crisis constitucional. Esta posición era defendida por

\footnotetext{
${ }^{42}$ Para ampliar el tema se puede leer a HOCQUELLET, Richard: El Rey y la nación. Monarquía tradicional y representación moderna en PORTILLO VALDÉS, J., VEIGA ALONSO, X. R. y BAZ VICENTE, Mª . (eds.): A Guerra da Independencia e o primeiro liberalismo en España e América, Publicacións da Cátedra Juana de Vega USC, Santiago de Compostela, 2009. También se puede complementar con PORTILLO VALDÉS, J.: Entre la monarquía y la nación: cortes y constitución en el espacio imperial español en PORTILLO VALDÉS, J., VEIGA ALONSO, X. R. y BAZ VICENTE, Ma . (eds.): A Guerra da Independencia e o primeiro liberalismo en España e América, Publicacións da Cátedra Juana de Vega - USC, Santiago de Compostela, 2009. También piensan así los profesores Manuel Chust y Ivana Frasquet en CHUST, M. Y FRASQUET, I. (eds.): La transcendencia del liberalismo doceañista en España y en América, Imprenta Romeu, S.L -Generalitat Valenciana - Biblioteca Valenciana, Colección Historia/Estudios, Valencia, 2004.

${ }^{43}$ Se puede saber más sobre el concepto de Monarquía Compuesta consultando a ARRIETA ALBERDI, Jon: "Entre Monarquía Compuesta y Estado de las Autonomías. Rasgos básicos de la experiencia histórica española en la formación de una estructura política plural", Ivs Fvgit, 16, 2009-2010, pp. 9-72 ISSN: 1132-8975, pp. 9 a 72 Disponible en ifc.dpz.es/recursos/publicaciones/32/06/02arrieta.pdf Consultado en 18/06/2012, 20:13h.

${ }^{44}$ HALPERIN DONGHI, Tulio: Crisis de la monarquía hispana y nacimiento del liberalismo en PORTILLO VALDÉS, J., VEIGA ALONSO, X. R. y BAZ VICENTE, Ma . (eds.): A Guerra da Independencia e o primeiro liberalismo en España e América, Publicacións da Cátedra Juana de Vega - USC, Santiago de Compostela, 2009, pp. 21 y ss.

${ }^{45}$ PORTILLO VALDÉS, J. M.: Entre la monarquía y la Nación: cortes y constitución en el espacio imperial español en PORTILLO VALDÉS, J., VEIGA ALONSO, X. R. y BAZ VICENTE, Ma. (eds.): A Guerra da Independencia e o primeiro liberalismo en España e América, Publicacións da Cátedra Juana de Vega - USC, Santiago de Compostela, 2009, pp. 133 y ss.
} 
generales como Palafox y La Romana ${ }^{46}$. Lo propugnado por los liberales sale victorioso y una nueva Constitución trae cambios considerables dentro de lo practicado hasta ese momento por la monarquía hispánica. De una posición inicial de una soberanía en depósito, mientras estaba ausente el rey ${ }^{47}$, se fija en el texto constitucional que el origen del poder ya no reside en el rey, sino en la Constitución, además de fijar los límites del poder real en el artículo $172^{48}$.

La formula hallada para hacer frente a la dominación extranjera y la abdicación ignominiosa de los monarcas borbones fue, según nos cuenta Manuel Chust, la encontrada por los intelectuales orgánicos del liberalismo, que rescataron una antigua fórmula suareciana, el pacto traslatii $^{49}$. Esta fue una justificativa teórica que logró el éxito de un gobierno revolucionario que refutaba las abdicaciones de los borbones en la persona de Napoleón Bonaparte y al propio gobierno de José Bonaparte. La fórmula del pacto traslatii sintetizaba que en la "ausencia del Monarca, la Soberanía regresaba al pueblo"50.

De tal forma fueron sensibles los cambios en este sentido, que Varela Suanzes-Carpegna llega a afirmar que los límites del poder real ya no estaban esparcidos en conceptos legales generales, y de forma imprecisa, como en "las leyes inmutables del reino", sino que pasan a ser delimitados y definidos en el texto constitucional. El poder constituyente está en la constitución, al monarca le queda relegado el poder constituido por esta ${ }^{51}$. De monarquía

${ }^{46}$ PARRA LÓPEZ, Emilio la: El Príncipe Inocente. La imagen de Fernando VII en 1808 en CHUST, M. Y
FRASQUET, I. (eds.): La trascendencia del liberalismo doceañista en España y en América, Imprenta Romeu, S.L
-Generalitat Valenciana - Biblioteca Valenciana, Colección Historia/Estudios, Valencia, 2004, p. 32 .
47 “Así desde la teoría liberal era la Nación quien reclamaba desde principios historicistas, iusnaturalistas,
contractuales o escolásticos suaresianos la asunción de la Soberanía por el 'pueblo`, dado que el Monarca estaba
'secuestrado`y, por lo tanto, 'ausente`. Si la soberanía volvía a la Nación, la representación de ésta la asumían las
Cortes. Aconteció que éstas también habían experimentado un cambio en la forma de representación, ya que ahora
era en los diputados donde residía la soberanía de la totalidad de esa Nación.” CHUST, M.: Rey, Soberanía y
Nación: las Cortes doceañistas hispanas, 1810-1814 en CHUST, M. y FRASQUET, I.: La transcendencia del
Liberalismo Doceañista en España y en América, Imprenta Romeu, S.L -Generalitat Valenciana - Biblioteca
Valenciana, Colección Historia/Estudios, Valencia, 2004, p. 52. ${ }^{48}$ PARRA LÓPEZ, Emilio la: op. cit., pp. 32.

${ }^{49}$ Además del ya cita profesor Manuel Chust, también se puede encontrar más explicaciones sobre aquella formula suaresiana en VARELA SUANZES-CAPEGNA, J.: La teoría del Estado en los orígenes del constitucionalismo hispanico (Las Cortes de Cádiz), Madrid, C.E.C, 1983, pp. 62 y ss.

${ }^{50}$ El profesor Manuel Chust formula algunas cuestiones para entender este momento de cambio drástico de la soberanía del rey a la Nación: "Majestad era ahora la Nación, ;compuesta por los representantes de ambos hemisferios! Pero ¿qué era la Nación para el 'imaginario colectivo?’ ¿Quiénes debían ser y mediante qué requisitos sus representantes? Es más, ¿a quién representaban? Y sobre todo, ¿en función de qué argumentos, justificaciones y teoría? Hábilmente los diputados liberales de ambas fracciones, la americana y la peninsular, manejaban mistificadoramente el concepto de Nación dotándolo con significado diferentes, en unas ocasiones apelando al Estado nación y, en otras, tan sólo al de Nación en su definición cultural." CHUST, M.: Rey, Soberanía y Nación..., op. cit. p. 55.

${ }^{51} \mathrm{El}$ autor, en otra obra suya, citada por él mismo, Du consensus populi à la volontè générale. La représentation du pouvoir chez les dirigeants patriotes pendant la Guerre d'Indepéndence, sobre la teorización sobre el rey: "en el imaginario político que sostiene esta construcción ideal remite a una metáfora familiar de la monarquía española, en la que el rey es identificado con la imagen de padre de la nación. La otra metáfora que también se empleó en el discurso patriótico es la orgánica, muy acorde también con la situación de 1808. Dado que en este 
absoluta pasamos a una monarquía constitucional ${ }^{52}$; la constitución y no el monarca pasa a ser el símbolo de unidad del Estado, y esta será la tónica del momento ${ }^{53}$.

\subsubsection{Etapas de una crisis dinástica: el Rey, la Nación y la Constitución}

Para una compresión sintetizada del periodo, Richard Hocquellet, nos trae una división muy atrayente de las etapas que conforman los acontecimientos acaecidos para llegar a la Constitución de Cádiz: en primer lugar busca delinear la figura del rey, que en el imaginario de la época era visto como el padre de la nación. En la segunda etapa, una nación que prescinde del rey para organizarse. En una tercera y última etapa, analiza el porqué, dentro del embate y de las soluciones posibles en la crisis, la posición, o vía liberal, defendida por algunos patriotas que acabó imponiéndose en el texto constitucional ${ }^{54}$. Esta división nos servirá de guía en una parte de nuestra exposición como forma de introducir los antecedentes de la Constitución gaditana.

Como ya veníamos diciendo, la crisis de la monarquía española será el desencadenante de un proceso muy complejo, que llega hasta Cádiz ${ }^{55}$. Entretanto no es el inicio de la crisis de la monarquía, sino, más bien, la consecuencia de una crisis que ya se arrastraba hacía ya un tiempo. Afirma el profesor Halperin Donghi, que en el vasto imperio español hacía mucho que era complicada la administración, dado que su dimensión abarcaba tres continentes, y cada vez se tornaba más difícil responder a las demandas de este vasto imperio ${ }^{56}$. Pero, para comprender los hechos desencadenantes nos fijamos en el propio año de 1808 y analizamos la figura de Fernando VII, "el deseado"; éste será el punto central en este recorrido histórico y que evoca elementos que matizarán el periplo de la Constitución de Cádiz: colabora indirectamente, a

caso al rey se lo representa como la cabeza del cuerpo constituido por el conjunto de sus súbditos, la acefalia evocaba a su vez la situación provocada por el rechazo de las abdicaciones. El reino, tal cual un cuerpo sin cabeza, se presentaba así como una aberración política que podía llevar a la monarquía, el peor de todos los males en la mentalidad de los responsables de la autoridad". HOCQUELLET, Richard: op. cit., pp. 56 y ss.

52 "Ausente de legitimidad divina, carente de referentes de soberanía, a no ser la que estaba construyendo el liberalismo hispano, éste recurrió a justificaciones escolásticas para solventar la sorpresiva coyuntura revolucionaria liberal. Una situación revolucionaria burguesa antifeudal que devenía en un desmoronamiento de la Monarquía en ambos hemisferios. Una coyuntura en donde las Juntas americanas también Soberanas y Gubernativas, se intitulaban "Defensoras de los Derechos de Fernando VII", como estrategia política y como fórmula reivindicativa de un reconocimiento y una legitimidad unívoca, la del Soberano." CHUST, M.: Rey, Soberanía y Nación..., op. cit., p. 55.

${ }^{53}$ VARELA SUANZES-CARPEGNA, J.V.: La teoría del Estado en los orígenes del constitucionalismo hispánico (las Cortes de Cádiz), Centro de Estudios Constitucionales, Madrid, 1983, pp. 416 y ss.

${ }^{54}$ HOCQUELLET, Richard: op. cit., pp. 56 y ss. En este artículo el autor divide los procesos que conformaron a la Constitución de Cádiz en tres etapas precisas.

${ }^{55}$ SOLÉ TURA, Jordi \& AJA, Eliseo: Constituciones y períodos constituyentes en España (1808-1936), Madrid,

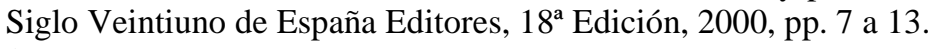

${ }^{56}$ Para saber más sobre el proceso de desintegración del Imperio español, se recomienda la lectura de HALPERIN DONGHI, T.: op. cit., pp. 21 a 51. 
través de su figura, para la promulgación del texto constitucional; la deroga prontamente en su retorno a España en 1814; la vuelve a jurar posteriormente en 1820 en el momento de su repristinación por la Proclama de Riego, con el consecuente establecimiento del período que quedó reconocido como el Trienio Liberal en España; al final, vuelve a derogarla con la ayuda de los Cien Mil Hijos de San Luis. Así que es una figura que subsiste tanto a etapas absolutistas como liberales llevadas a cabo en España.

El desencadenante de todo eso es el conocido Motín de Aranjuez; no fue ninguna sorpresa pues España estaba ya convulsionada según nos cuenta Charles Esdraile ${ }^{57}$. El motín tuvo lugar en el día 18 de marzo de 1808; esto fue debido a varios desencadenantes, entre los que destacan la derrota en la batalla de Trafalgar; el descontento de la nobleza; el deseo del príncipe de Asturias de gobernar; las desamortizaciones de los bienes de la Iglesia; la acción de los agentes de Napoleón en España; además de las intrigas de las Cortes, donde los aristócratas estaban recelosos del poder absoluto de Valido del Rey, Godoy; colmaba todo el resto al parece sus relaciones con la reina. De la reunión de todos estos elementos será el combustible para una crisis dinástica de grandes proporciones.

Entretanto, un poco antes, firmaron el Tratado de Fontainebleau Godoy y Napoleón; este contenía una cláusula secreta para invadir y dividir Portugal. Para ello se permitía la entrada de las tropas francesas en territorio español ${ }^{58}$. Sin embargo, las tropas francesas pasaron a ocupar áreas del territorio español que no estaba adscritas al Tratado. Estos hechos hicieron que la familia real se marchara a Aranjuez, donde podría llevar a cabo los planes de una posible huida hacia América, como ya había hecho María I de Portugal y su hijo, el príncipe regente, futuro rey Juan VI, que se marcharon hacia Brasil (hecho este que comentaremos más adelante), a la vista de la eminente llegada de las tropas francesas y a consecuencia del Tratado de Fontainebleau.

Con el Motín provocado por sus partidarios y el propio Fernando, allí donde se encontraba la familia real, hace que Carlos IV abdique en la persona del príncipe de Asturias, ahora proclamando Fernando VII. Como consecuencia del golpe de Estado, Godoy cae prisionero en manos de Fernando. Los ataques a los partidarios de Godoy eran frecuentes,

\footnotetext{
${ }^{57}$ ESDRAILE, Charles: op. cit., pp. 69 y ss.

58 "En pocas palabras, Portugal se dividía en tres partes: el norte se entregaba a los reyes de Etruria, el centro quedaba militarmente ocupado hasta el final de la guerra y posteriormente se dispondría según las circunstancias, y el sur se entregaba a Godoy, mientras que Napoleón se comprometía a garantizar los dominios de los Borbones españoles y a permitir que Carlos IV fuera nombrado «emperador de las dos Américas». También se acordó el asunto de cómo sería ocupado de hecho Portugal; el plan básico era que marcharían sobre Lisboa desde León veintiocho mil soldados franceses y trece mil españoles, mientras que otros dieciséis mil españoles cruzarían la frontera desde Galicia y Extremadura. Entre tanto, se reunirían en Bayona otros cuarenta mil soldados franceses para defenderse de las incursiones británicas, si bien se acordó que estas tropas no entrarían en España sin la aprobación previa de Madrid." Ibidem, pp. 37 y 38.
} 
mientras que el no reconocimiento explícito de los franceses a Fernando VII en cuanto Rey de España disgustaba de momento a sus seguidores. Esto llevó a creer que los franceses tenían otros planes para España. Relacionado con ello, tanto en Vitoria como en Madrid hubo conmociones. En la primera ciudad, se intentaba impedir que el rey Fernando se trasladase a la frontera francesa; y en Madrid, se protestaba por la abdicación de Carlos IV ${ }^{59}$. Así se encontraba España en los primeros días del gobierno de Fernando VII, antes de su abdicación conjunta con su padre en la persona de Napoleón, que a su vez trasladaría la corona a José $\mathrm{I}^{60}$.

Lo ocurrido en marzo de 1808 en Aranjuez proyectó la figura de Fernando VII en el imaginario colectivo. Gracias al mencionado motín, "el deseado" príncipe pasa a representar las virtudes de un soberano magnánimo, que se disponía a oír a los clamores de su pueblo y de esta forma concentraba en sí todas las esperanzas ${ }^{61}$. Pero, Fernando no fue capaz de comprender la complejidad de la situación del reino. Todo su objetivo se limitaba a eliminar a Godoy y hacerse con el trono. Mientras tanto, el estado del reino era de ocupación por las tropas francesas, con un ejercicio de un poder paralelo por parte del lugar teniente de Napoleón, el Gran Duque de Berg; que se aprovechó de la confusión para dictar órdenes en Madrid. Murat va a conseguir del propio Carlos IV una declaración de nulidad de su abdicación ${ }^{62}$. Pero, para ganarse la confianza de Napoleón, los dos reyes de España, como se declaraban en estos momentos, reconocían la tutela del Emperador de los Franceses ${ }^{63}$. Esta crisis sucesoria, de la que venimos hablando, será un punto débil y un flanco fácil para las investidas del "Corso" 64 .

\footnotetext{
${ }^{59}$ Ibidem, pp. 70.

60 "La España de 1808 sufrió un choque en el cual se mezclaron todos los elementos (...). Me refiero obviamente al cambio dinástico, a la formación de las Juntas Supremas, a la organización de un gobierno de resistencia y a la convocatoria de las Cortes de Cádiz que proclamaron la soberanía nacional. Pero también a la guerra y a su impacto en las poblaciones, así como a las insurrecciones en las colonias de América." HOCQUELLET, Richard: op. cit., pp. 55.

61 "Las aclamaciones de la muchedumbre en Aranjuez y sobre todo en Madrid, durante su entrada el 24 de marzo, tal y como las relató la Gazeta de Madrid, hicieron de Fernando un rey aureolado de una legitimidad directa que se adjunta a la legal debida a su posición dinástica." HOCQUELLET, Richard: op. cit., pp. 56. También confirma esta posición Emiliano La Parra López cuando dice: "En 1808 los españoles se forjaron una imagen extraordinariamente positiva de Fernando VII. El rey fue considerado la encarnación del Bien frente al Mal (sucesivamente, Godoy y Napoleón) y cuando se vio amenazada la independencia de España como consecuencia de la "traición" de Bayona, la nación se levantó en armas en su nombre. Cuantos siguieron esta dirección estaban convencidos de que la legitimidad de Fernando para ocupar el trono y el carácter católico de la nación española constituían la base de la monarquía que había que defender frente a la agresión del "tirano" Napoleón". PARRA LÓPEZ, Emilio la: op. cit., pp. 31.

${ }^{62}$ Se pueden seguir las comunicaciones epistolares entre Napoleón y Carlos IV, además de con Fernando VII, mantenidos entre marzo y mayo de 1808 en Juan Pérez de Guzmán y Gallo entre las páginas 195 y 270. " Después de la proclamación de Fernando VII las instrucciones de Napoleón fueron: á Bessières, en carta de 30 de marzo, que él no había reconocido, ni reconocería al Príncipe de Asturias, y que, por lo tanto, Carlos IV seguía siempre siendo el Rey de España; (...)." GUZMÁN Y GALLO, J. P.: El dos de mayo de 1808 en Madrid, Madrid, Estabelecimiento Tipográfico Sucesores de Rivadeneyra, Paseo de San Vicente n. 20, 1908 (ed. Facsimilar de Editorial Maxtor, 2008), p. 196.

63 "Desde que en Madrid se constituyeron los dos poderes rivales, el legítimo, representado en Fernando VII, y el intruso, en el Gran Duque de Berg, la escena multiplicó la esfera de su acción simultánea, siendo tan distinta la
} 
El paso siguiente de las abdicaciones en Bayona fue de un gran sentimiento de orfandad en España ${ }^{65}$. Hocquellet nos trae dos lecturas para este sentimiento y la posterior reacción de la nación. Una estaba presente en el imaginario político de la época, donde el rey era identificado, dentro de una metáfora familiar, como el padre de la nación. Otra metáfora muy explotada en los discursos patrióticos, y al gusto del momento, era la organicista. Algo un poco más racional que la primera metáfora. En esta posición el rey era la cabeza del cuerpo social, o conjunto de súbditos. Entre estas dos metáforas, la que mejor figurará en la bandera de la movilización de los españoles será la familiar, puesto que el miedo de orfandad y acefalia, se percibe en los discursos de rechazo al cambio dinástico ${ }^{66}$.

En estos momentos en que el enemigo es el francés vale la pena no buscar identificar la lucha por la independencia con ideas venidas del propio enemigo ${ }^{67}$, como nos aclara Portillo Valdés. Y en este sentido lleva a la afirmación de Hocquellet de que la metáfora familiar era más apropiada para rescatar una identidad de procedencia medieval, donde el vasallo debía obediencia al señor que proporciona la cohesión del conjunto y su protección, y a cambio el vasallo le debía fidelidad y defensa ${ }^{68}$. Ahí estaría la clave paradigmática del patriotismo español en la lucha contra los franceses; que a la vez evita evocar directamente a las ideas esparcidas

dirección del objetivo, que cada cual, por su parte, se proponía a realizar. Tan a ciegas caminaba el gobierno del nuevo monarca respecto a las intenciones del invasor extranjero, como Napoleón aparentaba estarlo de los propósitos de Fernando. Á éste, la conducta extraña é inexplicable del representante del Emperador, que tan súbito cambio habían hecho respecto á su persona desde el momento mismo de su exaltación al Trono, para cuya empresa había, al parecer, recibido el auxilio directo de su influjo, creaba una situación obscura y enigmática, difícil de descifrar. El César francés había experimentado, por su parte, una contrariedad visible de la realización improvisada de un hecho que no esperaba”. GUZMÁN Y GALLO, J. P.: op. cit., p. 195.

${ }^{64}$ PARRA LÓPEZ, E. La: op. cit., p.35 y ss.

${ }^{65}$ El profesor Richard Hocquellet crea una teoría muy interesante sobre el complejo de huérfano de los españoles, que tenía doble faceta: luto por la situación en que se encontraba la patria, a la vez que gozaban los españoles de una cierta libertad jamás vista antes. Esta teoría el autor desarrolla en El complejo de huérfano. Los españoles antes de la acefalia, citado en HOCQUELLET, Richard: op. cit., pp. 58.

${ }^{66}$ En este sentido, nos aclara Hocquellet, José I era visto como el usurpador de la posición de padre de que gozaba Fernando VII, que era el padre de la patria, y en eso se basaban los rebeldes, en el deber que tiene los hijos en luchar por su padre. Esta posición defiende Richard Hocquellet en su libro $\mathrm{Du}$ consensus populi à la volonté générale. La représentation du pouvoir chez les dirigeants patriotes pendant la Guerre d Independence, Mélange de la Casa Velázquez, 35-1, 2005, p. 79-78 mencionado en HOCQUELLET, R.: El rey y la nación..., op. cit., p. 57. Así mismo, la Gazeta de Oviedo del 02 de julio de 1808, donde se apoya Hocquellet sus ideas, trae en la respuesta al editor, en la página 70, lo siguiente: "No hallo rebeldía en donde no veo hijos, esclavos, vasallos y hombres en contradicción con su Padre, Señor y Rey: ó contra Dios que es todo esto respeto del hombre. Si el Francés es nuestro Padre: si es Señor de los Españoles: si es Rey de las Españas; y si es Dios de las Gentes, dígale a Vm. que somos completamente rebeldes; pero si no hay nada de esto, como no lo hay, ni lo puede haber, ríase Vm. en su mala barba y dígale: Que nadie pensó hasta ahora, que oponerse á los salteadores fuese rebeldía”.

67 "Y como nuestras leyes son viejas, nos venía a dar otras nuevas: ésta es la última tiranía y humillación que pueden sufrir los pueblos vencidos del conquistador. Pues ¡quál será la soberbia y vanidad de Napoleón, que se hace nuestro legislador antes de conquistarnos! Dígalo la nueva Constitución española, que nos regaló su sabiduría y beneficencia: monumento escandaloso de nuestra futura esclavitud." CAPMANY. Antonio: Centinela contra franceses, Por Martín Trullás Impresor, Madrid, 1808, p. 40.

68 "La mistificación de este pasado de origen medieval entroncaba, por otra parte, con un movimiento más global de afirmación de la identidad española que se reforzó a finales del siglo XVIII y después de la Revolución francesa". HOCQUELLET, R.: El rey y la nación..., op. cit., p. 57. 
por la Revolución Francesa por motivos obvios; aunque de fondo se las podemos encontrar en este momento $^{69}$. De esta mistificación resultará un hecho nuevo: donde antes solo ejercía la autoridad el soberano, ahora todo el cuerpo social la puede disfrutar. Antonio Capmany alude en sus escritos en la Centinela contra franceses, a la participación de todos en el poder, como participantes en el ejercicio de la autoridad ${ }^{70}$. También Manuel Quintana percibirá el sentimiento que los españoles nutrían hacía su rey en cuanto padre de la nación. Quintana publica un artículo, coetáneo de la obra de Capmany, intitulado "Reflexiones sobre el patriotismo", donde concluye que la palabra patria adviene de padre ${ }^{71}$. De esta forma, siguiendo la teoría de la orfandad de Hocquellet, podemos imaginar aquél sentimiento de que hablamos un poco antes y la consecuente mitificación de la figura de Fernando VII como padre de la nación.

De esta forma, pensando en la figura de Fernando VII y su presencia en el imaginario colectivo en la España de la Guerra de Independencia contra los franceses, pasamos a constatar como la nación intenta organizarse sin la presencia del rey. Richard Hocquellet destaca que la acefalia u orfandad fue la clave para que los patrióticos buscasen conservar la monarquía sin la presencia de Fernando. La solución fue la formación de Juntas gubernativas, que se identificaban con las localidades de los distintos reinos que conformaban la nación en una auténtica federación de la soberanía ${ }^{72}$. La formación de Juntas en las distintas localidades del reino fue una reacción a las abdicaciones de Bayona y una muestra del rechazo a las mismas ${ }^{73}$. De forma que la soberanía pasó a ser ejercida en la práctica por estas Juntas, que según Portillo Valdés, reclamaban, cada una de ellas, ser depositarias de la Soberanía de Fernando VII ${ }^{74}$; lo

\footnotetext{
69 "En medio a estos temores y anuncios que cercaban mi corazón sobresaltado, padecía yo el dolor y rabia de ver anunciados en carteles y en periódicos nuestros: Código Napoleón - Vida de Napoleón - Catecismo de Napoleón: traducido al castellano, y vendidas á la rebatiña. Horror y vergüenza de nuestra Nación!" CAPMANY. Antonio: op. cit., p. 33.

70 "Españoles de todos sexos, edades, estados y condiciones: con todos hablo." Ibidem, p. 14.

71 "La voz Patria tenia entre los antiguos una acepción mucho más estrecha que la que le han dado comúnmente los modernos. Con ella designamos nosotros el lugar de nacimiento de uno ó muchos individuos: ellos llaman Patria el estado ó sociedad á que pertenecían, y cuyas leyes les aseguraban la libertad y el bien estar. Su derivación misma, que parece venir de padre y de familia, nos manifiesta que esta palabra envolvía siempre relaciones de amor, de bien general y de orden." SEMANARIO PATRIÓTICO, n.III, 15 de septiembre de 1808, p. 47.

${ }^{72}$ Se puede leer más en VILLACAÑAS BERLANGA, J. L.: Una propuesta federal para la Constitución de Cádiz: el proyecto de Flórez Estrada en CHUST M. y FRASQUET, I. (eds.): op. cit., pp. 77 y ss. En este capítulo el autor hace referencia a la forma federal en que funcionaban las Juntas de las diferentes regiones de España en la época de la Guerra de Independencia. Además, después de la formación de la Junta Suprema, esta siguió contando con representantes de las Juntas Locales. Esta práctica federal se intentó posteriormente introducir en la Constitución, pero si éxito.

73 "El movimiento de creación de instituciones de emergencia para hacerse cargo de la situación en los ámbitos locales y regionales, las Juntas, fue caracterizado por los observadores contemporáneos como la revolución de las provincias". PORTILLO VALDÉS, J. M.: Entre la monarquía... op. cit., p. 134.

${ }^{74}$ Además de Chust y Frasquet, también hace referencia al principio suareciano del Tranlatio Imperii RIVERA GARCÍA, A.: El concepto de libertad en la época de las Cortes de Cádiz en CHUST M. y FRASQUET, I. (eds.): op. cit., p. 97.
} 
cual había llevado a la monarquía a alcanzar una apariencia verdaderamente federal ${ }^{75}$. El descalabro que representaban las abdicaciones de Bayona, hizo que se usase la fórmula del Translatio Imperii, que era una situación tal de interinidad que la soberanía no podía restar en el príncipe. Frente a esta situación se buscó amparo en las leyes de Partidas (legislación castellana tradicional), donde se encontró la fórmula que mantenía que sólo el pueblo podría ser el depositario de la soberanía acéfala, a través de las Juntas creadas para esta finalidad ${ }^{76}$. Sin embargo, sigue afirmando el mismo autor, que la llamada "revolución de las provincias" de modo alguno supuso una usurpación revolucionaria de la soberanía, o para romper con el status quo político de la monarquía. No fue una revolución al estilo francés. El proceso se fundamentó apenas en la fórmula, a la que ya aludimos antes, del "depósito de la soberanía" mientras estaba ausente el rey ${ }^{77}$. De todos modos, las Juntas de 1808 tuvieron una doble tarea, según Hocquellet: "asegurar la unidad del cuerpo político y responder de manera más eficaz a los problemas del momento". ${ }^{78}$

El universo de Juntas esparcidas por todo el territorio español (también del otro lado del Atlántico), se mostraba inviable en muchos aspectos. De hecho, se propugnó una formación de un gobierno conjunto de aquélla multiplicidad de juntas ${ }^{79}$; lo que se logró a finales de septiembre de 1808. La nueva, pasó a llamarse de Junta Central Suprema Gubernativa del Reino, que estuvo de inmediato bajo la presidencia de Floridablanca. Entretanto, en esta Junta Central, había un representante de cada una de las Juntas locales como ya aludimos antes. Al

\footnotetext{
${ }^{75}$ Ibidem, p. 135.

76 "Cuando en el verano de 1808 se trató de formar una de estas Juntas en la ciudad de México, su síndico Francisco Primo de Verdad y Ramos explicó con sobrada elocuencia la lógica legal y política que subyacía tras la formación de estos cuerpos. (...) El argumento central del síndico mexicano consistía en identificar a las instituciones centrales de gobierno (consejos, secretarías de Estado, audiencias y chancillerías) como elementos accesorios de la monarquía. Esenciales en ella eran únicamente el rey y los pueblos” Idem, p. 135. Portillo Valdés formula sus conclusiones con base en la Representación del Licenciado Primo de Verdad y Ramos, dirigida al virrey José de Iturrigaray sobre la legitimidad, utilidad y necesidad de la convocatoria para el establecimiento de una Junta de Gobierno Nacional del Reino de Nueva España. Septiembre 12, 1808, en Ernesto Lemoine, Carlos María de Bustamante y su "apologética historia" de la revolución de 1810, México DF, UNAM, 1984, pp. 9 y ss. También sobre este tema Varela Suanzes-Carpegna en un capítulo de su libro intitulado: La distinción entre titularidad y ejercicio de la soberanía, e muy esclarecedor. Este capítulo se encuentra en VARELA SUANZESCARPEGNA, J.: La teoría del Estado en los orígenes del constitucionalismo hispanico (Las Cortes de Cádiz), Madrid, C.E.C., 1983, pp. 275-300.

77 "La diferencia es obvia, pues se trataba más de una idea de custodia o guarda de la soberanía del monarca legítimo que de un proceso revolucionario de afirmación de la soberanía nacional, que no llegará a ser realidad sino en setiembre de 1810." PORTILLO VALDÉS, J. M.: Entre la monarquía... op. cit., p. 134.

${ }^{78}$ HOCQUELLET, R.: El rey y la nación..., op. cit., p. 59.

${ }^{79}$ El profesor Richard Hocquellet discurre de forma precisa sobre el significado político de las Juntas en España. Él dirá que la Institución de las Juntas se constituye en una práctica antigua en España, y funcionaba como comisiones con determinadas competencias transversales, pues en ella estaban responsables de la Administración Pública de todos los sectores. También servirá el término para designar a las Cortes que no están presididas personalmente por el rey. El Autor también nos habla de otra designación más genérica por el término Junta, cuando se refiere a distintos tipos de asambleas, siendo este sentido el más acertado para designar las Juntas en los movimientos patrióticos defendidas por los partidarios de Fernando VII. Ibidem, p. 59 y ss.
} 
avance de la guerra esta Junta Central se fue desplazando, siendo la Batalla de Bailén, en julio de 1808, un marco para estos desplazamientos. Ya en 1809, pasa de Aranjuez a Sevilla, y de ahí a Cádiz. Con el tiempo fue mostrándose ineficaz y fue perdiendo el crédito del público, hasta deshacerse ${ }^{80}$.

La forma de enfrentarse a una realidad donde el reino estaba acéfalo y el pueblo huérfano, fue el sistema juntista, que venía a cubrir ese vacío dejado por la ausencia regia ${ }^{81}$. Sin embargo, la soberanía que fue recuperada por las Juntas, es la misma del Rey prisionero en Bayona; y aquellas la ejercían bajo la legitimidad que tenían como defensoras de los derechos de Fernando VII. Así que, se declaraban detentadoras de la soberanía en depósito, aunque en la práctica la ejercían directamente ${ }^{82}$. Este hecho fue motivo de debate en el seno de estas mismas Juntas, generando los siguientes interrogantes: ¿cómo ejercer? y ¿cómo representar? la soberanía que tenían en depósito.

La solución para la dispersión de la soberanía, llega, como ya decimos arriba, con la creación de la Junta Central, que, como afirma Portillo Valdés, reunirá el universo federal de las Juntas. Hocquellet aporta una lectura también interesante a este hecho. Puesto que la Junta Central tenía un representante de cada Junta Local, que se parecía a la representación de los reinos que conformaban la soberanía de Fernando. Esta Junta Central cada vez va asumiendo la representación del propio Rey y con él se confunde. Intenta mostrar eso cuando, dice Manuel Chust, adopta el tratamiento de Majestad $^{83}$. De este modo el propio rey estaba respaldando las acciones de esta Junta Central ${ }^{84}$. Esta apropiación de la soberanía cada vez va a hacer con que

\footnotetext{
80 "Desde que fichara la Central al poeta Manuel José Quintana para su secretaría general, sus decretos más relevantes se acompañaron de elocuentes manifiestos, que pueden tomarse en conjunto como crónica de la revolución. Interesa reparar aquí en dos series de decretos de la central, porque marcarán muy de cerca el rumbo de la revolución en España. Por un lado, los que, comenzando el 22 de enero de 1809, se dirigieron expresamente a los "españoles americanos". Proclamaban estos decretos la consideración de las provincias americanas como partes integrantes y esenciales de la monarquía, y anunciaban que los americanos tendrían igual representación a los europeos en las futuras Cortes. Sin embargo, en la misma Central eran ya perfectamente perceptibles diferencias de fondo entre la consideración de unos y otros españoles. Ni las juntas americanas que se forman entre 1809 y 1810 fueron reconocidas por la Central, ni enviaron, por tanto, representantes a ella. La representación americana prevista para la Central se adjudicaba a las demarcaciones tradicionales y no a las juntas, representando obviamente un número bastante menor. En cualquier caso, ningún representante elegido en América llegó a tiempo antes de ser disuelta la Central. Además, la Central, al constituirse en septiembre de 1808 dio por bueno el acto de fuerza con que un comerciante vasco, Gabriel del Yermo, había liquidado la proyectada junta de México poco antes." PORTILLO VALDÉS, J. M.: Entre la monarquía... op. cit., p. 135.

${ }^{81}$ Sobre el sistema juntista se puede aprofundar más en TORRES DEL MORAL, A.: Constitucionalismo histórico español, Madrid, Atomo Ediciones, 1986, pp. 33 a 36.

${ }^{82}$ A esta ambigüedad nos llama la atención HOCQUELLET, R.: El rey y la nación..., op. cit., p. 59 y ss.

${ }^{83}$ DECRETO DE 25 DE SEPTIEMBRE DE 1810: "Las Cortes generales y extraordinarias declaran, á consecuencia del decreto de ayer 24 del corriente, que el tratamiento de las Cortes de la Nación debe ser y será de aquí en adelante de Magestad". Colección de los decretos y órdenes que han expedido las Cortes generales y extraordinarias desde su instalación en 24 de septiembre de 1810 hasta igual fecha de 1811, Imprenta Nacional, Madrid, 1813, Tomo I, pp. 3 y 4.

${ }^{84}$ CHUST, M.: Rey, Soberanía y Nación..., op. cit., p. 54.
} 
se distanciase la Junta Central del proyecto inicial del depósito; de tal forma fue así, que paso a paso muchos de los miembros de la Junta Central comenzaron a plantear que la legitimidad ultima y representativa de este nuevo sistema de gobierno recaía en los españoles. Aunque esta visión no era la única, puesto que, había muchas matizaciones en este campo ${ }^{85}$.

Con el traslado de la Junta Suprema Central Gubernativa del Reino para Sevilla, en 24 de septiembre de 1808, Floridablanca, el cansado político que sobrevivió a Carlos III y Carlos IV, viene a fallecer en diciembre del mismo año. Con la desaparición de Floridablanca se deja paso a que unas variadas tendencias político/ideológicas emergiesen a la superficie de la Junta Central. D. José Moniño, conde de Floridablanca, representante acabado de los hombres de la Ilustración, fue la persona a la cual se asignó la tarea de llevar a cabo la labor espinosa del gobierno de la Junta Central. Como dijo Fernando Jiménez de Gregorio, su época ya había pasado y representaba en aquél órgano gubernativo el moderantismo antirreformista ${ }^{86}$. Su prestigio y venerable ancianidad era una barrera para los que proponían una reforma más radical en las leyes fundamentales del reino. Además, se opuso enérgicamente a la convocatoria de Cortes y el establecimiento de una regencia. La creación de una regencia era algo previsto en las situaciones en que se encontraba el reino sin un rey, por la Ley de Partida, Titulo XV, Partida II $^{87}$. Jovellanos, otro político de la época, viene a representar así el término intermedio de las tendencias absolutista y reformadora. Sin embargo, esto no impidió a que Calvo de Rozas, representante de Zaragoza en la Junta Central, y un gran inspirador del bando reformista, hiciese salir a la luz su tendencia ultrarreformadora al presentar la propuesta de convocatoria de Cortes; lo que fue bien recibida por los radicales ${ }^{88}$. Con esta propuesta se

\footnotetext{
85 "Desde el punto de vista de los patriotas, las Cortes podían entenderse como la renovación del pacto que ligaba el reino a su rey - legítimo - , o como la reunión del reino en tiempo de peligro, y por lo tanto como un instrumento de cohesión para determinar los medios que se debían tomar. Esas diversas formas de entender el sentido de las Cortes se dejan ver en los textos del verano de 1808, que apelaban a ellas como el recurso el más pertinente en la situación que padecía la nación. Parece que el de Álvaro Flórez Estrada se refería a una verdadera asamblea nacional soberana, mientras que la Junta de Murcia se enmarca en la doctrina pactista. Otros mezclaban diferentes visiones debidas a la vez a l’air du temps, a la tradición y a la necesidad, llegando finalmente a inventar unas Cortes que jamás habían existido en la monarquía española.” HOCQUELLET, R.: El rey y la nación..., op. cit., p. 60 y 61 .

${ }^{86}$ Fernando Jiménez Gregorio hace una excelente digresión sobre las fuerzas políticas dentro de la Junta Central y como, con la consulta hecha a la luz de los decretos de consulta al país (22 de mayo y 08 de junio de 1809), se pronuncia autoridades y organismos de Murcia. Para un conocimiento más amplio se puede leer en JIMÉNEZ GREGORIO, F.: Murcia y los Decretos de 22 de mayo y 08 de junio de 1809: aportación a la historia política de la Guerra por nuestra Independencia de 1808, Publicación de la Universidad de Murcia, Murcia capital, 1946, pp. 869 y ss.

87 "Propuso Jovellanos tal solución para dar base legal al Gobierno de España. Su iniciativa fue deferentemente escuchada y aplazada su resolución. Representa Jovellanos en la Junta Central el prudente término medio entre las dos tendencias extremas: la absolutista y la reformadora. Al no secundar la propuesta de D. Gaspar Melchor, ninguno de los dos bandos en pugna, se perdió la gran ocasión de haber conducido aquella revolución política por los cauces de lo tradicional, que hincaba sus raíces en las más caras instituciones de nuestra Edad Media”. Ibidem, p. 870.

${ }^{88}$ Esta propuesta, fechada en Sevilla el 15 de abril, la publica FERNÁNDEZ MARTÍN en su Derecho parlamentario, tomo I; pp. 436 a 438. Sobre el señor CALVO DE ROZAS puede verse la obra de PEDRO T.ONGÁS, La representación aragonesa en la Junta Central Suprema apud JIMÉNEZ GREGORIO, F.: Murcia y
} 
alzaban los distintos grupos que componían la Central: los reformistas, que pretendían dar a la obra legislativa un aspecto constituyente, y los antirreformistas, que buscaban la manutención de las prerrogativas regias. Así que, en este contexto todos los partidos ya estaban en total discordia $^{89}$. De este modo, entra en escena una figura que busca prudentemente un término medio y una conciliación para que fueran posibles las reformas político-sociales para un país en guerra y acéfalo ${ }^{90}$.

La llegada del poeta Manuel José Quintana a la Junta Central, para la secretaría general, según nos cuenta Portillo Valdés y Jiménez Gregorio, dio una vida inusitada a las peticiones de los radicales. Sus decretos eran acompañados de elocuentes manifiestos, llenos de la liberalísima doctrina, que en su conjunto es casi una crónica de la revolución. El radicalismo de Quintana también fue combatido a través de emisión de opiniones por otros vocales de la Junta Central como Rivero, Bonifaz, Valdés y Palafox, utilizado los mismos instrumentos que usaba el primero. Pero también tiene el apoyo jacobino entusiasmado del vizconde de Quintanilla de estas nuevas ideas. Se mantiene Jovellanos, como ya habíamos señalado, en una posición equidistante de los dos partidos. Jovellanos defiende que las Cortes al ser reunidas ahora no tendrían la capacidad de reformar todos los fundamentos de las instituciones del reino, sino que esta tarea estaría reservada a otras Cortes reunidas en mejores tiempos de los que corren. Era una en el clavo y otra en la herradura, para no herir sensibilidades y avanzar con el proyecto de una Constitución ${ }^{91}$.

Lo cierto es que en el mes de mayo de 1809, los vocales de la Central se pelearon fuertemente sobre la oportunidad o no de convocar Cortes para el reino, y qué tipo de Cortes debían ser convocadas. Además, se discutía el origen del poder que estos vocales ejercían en la Junta Central. Unas figuras, entre los vocales, que querrían ir más allá de la mera recomposición política de la monarquía fueron, el ya mencionado Calvo de Rozas (Aragón), pero también, Martín de Garay (Extremadura) y Jovellanos (Asturias), que según Hocquellet,

los Decretos de 22 de mayo y 08 de junio de 1809: aportación a la historia política de la Guerra por nuestra Independencia de 1808, Publicación de la Universidad de Murcia, Murcia capital, 1946, p. 870.

${ }^{89}$ JIMÉNEZ GREGORIO, F.: op. cit., p. 871.

90 "Por fin, la nación española se va a juntar en Cortes. El Real decreto que las anuncia para el próximo agosto se lee ya con entusiasmo en todas partes (...). Al contemplar esta grande idea, mi corazón salta en el pecho de alegría, viendo acercarse el momento que tan ardientemente había deseado. Después de haber sido el primer a proponer a la Suprema Junta Gubernativa la necesidad de anunciar a la nación unas Cortes generales; después de haber procurado demostrar la justicia y utilidad de esta medida; después de haber promovido con el más puro celo los decretos que acordaron y fijaron su convocación, y de haber cooperado por espacio de ocho meses con todas las fuerzas de mi espíritu para el arreglo de su organización y la preparación de sus trabajos, ¿qué me quedaba que desear, sino de ver empezada esta tan gran obra?" Son las primeras palabras de JOVELLANOS: Memorias en defensa de la Junta Central apud MARTínEZ NOVAL, Bernardo: Jovellanos, (edición Facsímile, Orlando Moratinos Otero), Fundación Foro Jovellanos del Principado de Asturias, Cuadernos de Investigación, Monografías, Gijón, 2006, p. 89.

${ }^{91}$ Esta postura de Quintana y Jovellanos se puede encontrar en PORTILLO VALDÉS, J. M.: Entre la monarquía y la nación..., p. 135, en JIMÉNEZ GREGORIO, F.: op. cit., p. 871 y en HOCQUELLET, R.: op. cit., p. 62. 
eran buenos conocedores de los medios apropiados para formar una "opinión pública", en palabras del mismo autor. Y estos medios fueron proporcionados por la propia Junta Central, al proteger determinados periódicos que salieron a la luz en el verano de 1809, que pasaron a difundir ideas como "voluntad general", la "representación nacional", o la "soberanía proveniente del pueblo" o "ciudadanos". Tres periódicos, de acuerdo con Hocquellet, estuvieron presentes en la construcción de estas opiniones públicas: "El Semanario patriótico (mayo - agosto de 1809); El espectador sevillano (octubre - diciembre de 1809); y El voto de la nación española (diciembre de 1809 - enero de 1810)"92. Muchos de estos artículos fueron reproducidos en periódicos patrióticos Peninsulares y americanos, según nos cuenta el autor que venimos citando. Contrarios a todo esto estaban Rodrigo Riquelme, de un patriotismo neoescolástico, Francisco Palafox y su hermano José, más bien reaccionarios y partidarios de un gobierno aristocrático ${ }^{93}$. De este modo, se proporcionaron los medios para ganarse partidarios de una reforma completa de las leyes de la monarquía. Y en el otoño de 1809, en Sevilla, la Junta se sentía a gusto para emitir "apelaciones al pueblo con proclamas, largos preámbulos en los decretos y manifiestos impresos, difundidos en cientos de ejemplares"94.

El auge de toda esta preparación del terreno fue la emisión por la Junta Central de los decretos del 22 de mayo y del 8 de junio de 1809, que Hocquellet llama de "Consulta al país". Del universo de dictámenes, el decreto de 22 de mayo viene en realidad convocar a Cortes, pero ventilaba una consulta previa, con una serie de cuestiones a ser solucionadas con antelación:

\section{“RESPUESTA A LOS OCHO ARTÍCULOS DEL}

Decreto de la Suprema Junta Central, con fecha de 22 de mayo de 1809, entregada el día 24 de diciembre del mismo año.

Real Decreto de 22 de Mayo.

$1^{\text {o }}$ Medios y recursos para sostener la santa guerra actual.

$2^{\circ} \quad$ Medios de asegurar la observancia de las leyes fundamentales del reino.

$3^{\text {o }}$ Medios de mejorar nuestra legislación, desterrando los abusos introducidos y facilitando su perfección.

$5^{\circ}$ De las reformas necesarias en el sistema de instrucción y educación pública.

$6^{\circ} \quad$ Cómo arreglar y sostener un exército permanente en tiempo de paz y de guerra.

$7^{\circ} \quad$ Cómo idem de marina.

$8^{\circ}$ Qué parte deban tener las Américas en las juntas de Córtes"95.

\footnotetext{
${ }^{92}$ HOCQUELLET, R.: op. cit., p. 61.

${ }^{93}$ Estos últimos más bien seguidores del conde del Montijo, que había escrito la obra llamada Discurso sobre la autoridad de los Ricos Hombres, 1974, según nos cuenta Richard Hocquellet. Ibidem, p. 62 y ss.

${ }^{94}$ Idem, p. 62.

${ }^{95}$ DE VADILLO, J. M.: Escritos presentados al Gobierno español en el año de 1809, Imprenta del Estado-Mayor General, Cádiz, 1809, p. 47.
} 
Esta consulta o cuestionario fue remitida a todas las autoridades y personas de relieve de la España no invadida o refugiadas en las zonas libres. Así, como que de forma de nota inicial, precediendo al largo preámbulo del informe, el abogado de los Reales Consejos, trae la siguiente justificación para tal cuestionario: "Sumaria demonstración de la urgencia de reformar nuestros códigos, según lo ha exigido siempre en todos los pueblos para los suyos respectivos (en) la sucesión de los tiempos" $" 96$.

Fernando Jiménez de Gregorio, transcribe el mismo cuestionario presente en el Decreto de 22 de mayo de la siguiente forma:

“- Medios y recursos para sostener la Santa guerra en la que con la mayor justicia se halla empeñada la nación, hasta conseguir el glorioso fin que sé ha propuesto.

- Medios de asegurar la observancia de las leyes fundamentales del $\mathrm{R}^{\circ}$.

- Medios de mejorar nuestra legislación desterrando los abusos introducidos y facilitando su perfección.

- Recaudación, administración y distribución de las rentas del Estado.

- Reformas necesarias en los sistemas de Instrucción y educación pública.

- Modo de arreglar y sostener un ejército permanente en tiempo de paz y de guerra, conformándose con las obligaciones y rentas del Estado.

- Modos dé conservar la Marina, proporcionado a las mismas.

- Parte que deben tener las Américas en las Juntas de Cortes.

- $\quad 4^{\circ}$. Para reunir las luces necesarias a tan importantes discusiones, la Junta consultará a los Consejos, Juntas Superiores de las Provincias, Tribunales, Ayuntamientos, Cabildos, Obispos y Universidades, y oirá a los sabios y personas ilustradas". ${ }^{97}$

La consecuencia de este decreto, tal y como nos cuenta el propio Fernando Jiménez Gregorio, fue la emisión por parte de la Junta Central de otro decreto, el de 8 de junio de 1809 , en el cual nombró una comisión de Cortes, entre cuyas funciones estaba la de solicitar la información que requería el artículo $4^{\circ}$ (transcrito arriba). Así que, en el día 24 de junio la Comisión se dirigió a los organismos y personas referidas en el art. $4^{098}$. La contestación, según nos dice Hocquellet, "sobre la oportunidad de convocar las Cortes y sobre la forma que deberían tomar éstas, muestran una obvia mayoría favorable a una asamblea de tipo nacional moderno". De este modo, la proposición de una modernidad política se impone de cierta forma a la visión tradicional en lo que se refiere a la organización del poder, a la posición sobre la guerra y la acefalia del Estado ${ }^{99}$.

\footnotetext{
${ }^{96}$ Ibidem, p. 01.

${ }^{97}$ JIMÉNEZ GREGORIO, F.: op. cit., pp. 871 y 872.

${ }^{98}$ Idem, p. 872.

99 "Los promotores de esta modernidad política habían conseguido imponer un vocabulario nuevo y su enunciado en la mente de los patriotas que representaron sus informes. (...) La composición de las comisiones establecidas para preparar la convocatoria de dichas Cortes no deja lugar a dudas. De ellas forman parte las figuras más
} 
Una cuestión planteada por la Junta Central fue: ¿qué parte deben tener las Américas en las Juntas de Cortes? Los dignatarios y órganos públicos de Murcia, llamados a pronunciarse, emitieron opiniones en el sentido de que veían a los americanos como integrantes de la monarquía y, por tanto, con los mismos derechos que los peninsulares. ${ }^{100}$ Portillo Valdés nos aclara que la serie de decretos de la Junta Central, principalmente los que empiezan en 22 de enero de 1809, hacían referencia a los "españoles americanos"101. Estos decretos externalizaban la opinión de que las provincias americanas eran partes integrantes y esenciales de la monarquía, y para tanto deberían tener una representación paritaria con los peninsulares. Aunque en la práctica no era así. No hubo un reconocimiento de las Juntas formadas en América, entre 1808 y 1809, ni tubo en la Junta Central Representantes de aquellas Juntas americanas. En cuanto a la cuestión numérica, la Junta Central reconocía apenas las Juntas que estaban adscritas a las circunscripciones tradicionales, deslegitimando así a tantas otras Juntas formadas a lo largo y ancho del territorio americano ${ }^{102}$. Otros dos hechos se le pueden imputar a la Central como poco receptiva a la legitimación de las Juntas americanas. Según aquél mismo autor, los representantes de las Juntas americanas no llegaron a tiempo para participar en las decisiones de la Junta Central, mientras ésta seguía funcionando sin la presencia de los representantes americanos. Además, ésta fue disuelta antes de que llegaran aquellos; y organizada la Junta de México, fue eliminada por un acto de fuerza por Gabriel del Yermo, con el beneplácito de la Junta Central ${ }^{103}$.

Así pues, el contenido de los decretos emitidos por la Junta Central pretendía con claridad la formación de Cortes, en un claro traspaso de la crisis de sucesión a la crisis constitucional, hecho éste que va a ser concretado en el decreto de mayo de 1809, de convocatoria de Cortes constituyentes. También hubo en América, en casi todas las provincias

relevantes del patriotismo revolucionario: Agustín de Argüelles, Isidoro Antillón, Alberto Lista, Juan Nicasio Gallego... Después de un año y medio de ausencia del rey, el consenso acerca de la convocatoria de unas Cortes generales y extraordinarias encargadas de representar a la nación en lucha, sin que el propio rey la firmara, se impuso probando finalmente de esta manera que el reino tenía su independencia política. Y esto sin prejuiciar el resultado de las resoluciones que se tomarían en la asamblea". HOCQUELLET, R.: op. cit., p. 62.

100 JIMÉNEZ GREGORIO, F.: op. cit., pp. 873 y ss.

${ }^{101}$ PORTILLO VALDÉS, J. M.: op. cit., p. 136.

102 Sobre la crisis en América de la monarquía se puede leer más en CARMAGNANI, M.: América entre ilustración y liberalismo y en TERNAVASIO, M.: América y las crisis de la monarquía, ambos capitulo presentes en PORTILLO VALDÉS, J., VEIGA ALONSO, X. R. y BAZ VICENTE, Mª (eds.): A Guerra da Independencia e o primeiro liberalismo en España e América, Publicacións da Cátedra Juana de Vega - USC, Santiago de Compostela, 2009.

${ }^{103}$ Sobre la crisis en México y su liberalismo se puede leer BUVE, Raymond: La influencia doceañista en una provincia novohispana mayormente indígena: Tlaxcala, 1809-1824; también FRASQUET, Ivana: El liberalismo gaditano en el México independiente, 1821-1824; como también ORTIZ, J.: Fuerzas armadas y Liberalismo en México en una etapa revolucionaria: 1810-1821; y en SERRANO, J. A.: Liberalismo y contribuciones directas en México, 1810-1835; todos capítulos que se encuentra en CHUST, M. y FRASQUET, I.: La transcendencia del Liberalismo Doceañista en España y en América, Imprenta Romeu, S.L -Generalitat Valenciana - Biblioteca Valenciana, Colección Historia/Estudios, Valencia, 2004. 
que constituyeron Juntas, una derivación hacía procesos constitucionales a la vez que, en muchas provincias, se declaraba la independencia o dieron los primeros pasos en esta dirección ${ }^{104}$. Sin embargo, lo que se abstrae de este período es que tanto en la parte europea como en la americana, un nuevo sujeto singular, en las palabras de Portillo Valdés, se veía capacitado a asumir plenamente la soberanía y no actuar como mero depositario.

Con la desaparición de la Junta Central, se dejó paso a un Consejo de Regencia. Jovellanos al escribir Memorias en defensa de la Junta Central, dejaba traslucir que la composición de esta Regencia en nada reflejaba una victoria simple y directa de los partidarios de esta solución monárquica. Este expediente estaba mucho más acorde con los embates y los conflictos dentro de la ya disuelta Junta Central. Así que, con la acción militar en Andalucía lo que hizo José I fue trasladar a la cosmopolita ciudad de Cádiz a los elementos que formarían el crisol perfecto para las nuevas Cortes constituyentes. Allí tomaría forma, lo que vendría a ser conocido como el liberalismo gaditano. La ciudad pasaba por una efervescencia política muy grande, principalmente después del verano de $1810^{105}$.

En contra de todos los pronósticos, las Cortes, prometidas y convocadas por la Junta Central, lograron reunirse; aunque "ni el gobierno de la Regencia era partidario de ello, ni había posibilidad material de elegir a buena parte de los representantes" ${ }^{\text {106 }}$. Un impulso a la efectiva convocatoria fue la llegada de los diputados que estaban ya electos y la voluntad de la democrática Junta de Cádiz. Aunque persistía el problema de no verse formadas Las Cortes con todas las representaciones, puesto que, América aun no había enviado sus diputados. Hábilmente se pensó un sistema que solucionaría estas ausencias de principio, que fue el sistema de suplencia para las provincias ocupadas y de ultramar, consistiendo en la elección de personas naturales de las provincias, y que residiesen en Cádiz. Con todos los problemas que pudiese conllevar este tipo de representación, principalmente para América, fue un hallazgo que hizo posible las Cortes de Cádiz ${ }^{107}$. Esta decisión del Consejo de Regencia demuestra la

\footnotetext{
104 "En abril y diciembre de 1811 respectivamente se habían sancionado las constituciones de Cundinamarca Nueva Granada - y Venezuela, y en febrero, marzo y octubre del año siguiente lo fueron los documentos constitucionales de Quito, España y Chile. Contemporáneamente, desde mayo de 1810 las provincias del Río de la Plata funcionaban con normas provisorias que acabarán convirtiéndose en auténticas constituciones.” Ibem, p. 136. 105 “Los gaditanos naturales y forasteros iban a experimentar nuevas prácticas de lo político a partir de algunas realidades locales, tales como las tertulias, la prensa, o el capital intelectual y conceptual que llevaban con ellos los miembros de este grupo conformando en la Sevilla del año nueve". HOCQUELLET, R.: El rey y la nación..., op. cit., p. 63. Dos periódicos salidos a la fecha fueron el Consico y el Observador.

${ }^{106}$ PORTILLO VALDÉS, J. M.: Entre la monarquía y la nación..., op. cit., p. 136.

107 "Las negociaciones entre el Consejo de Regencia, los diputados electos y los refugiados de las provincias ocupadas con derecho a elegir diputado suplente se prolongaron durante casi tres meses. Pero al final, las peticiones y las presiones de la Junta de Cádiz lograron acabar con las últimas reservas de los regentes." HOCQUELLET, R.: El rey y la nación..., op. cit., p. 63 y 64. Así mismo, en las Actas del Consejo de Regencia, en la serie general, legajo 8 , según el mismo autor, nos trae una descripción de estos momentos cruciales.
} 
persistencia de los partidarios de la revolución liberal en no da marcha atrás en la convocatoria de Cortes.

Formadas Las Cortes, no se hizo esperar, los diputados Muñoz Torrero y Luján llevaron a cabo la aprobación del decreto que asumía plenamente la soberanía como algo propio de la nación ${ }^{108}$. Así que la nación prescindía del rey para organizarse, como venimos diciendo de acuerdo con la ruta que se marco para la soberanía dentro de la crisis de la monarquía española, según no cuenta Richard Hocquellet. Y como consecuencia de aquél acto, también Las Cortes restauran la monarquía en la persona de Fernando VII. Aquí, en el momento en que Las Cortes se reservaron las prerrogativas del Poder Legislativo, de acuerdo con Portillo Valdés, se produjo de verdad la revolución española; en la emblemática noche del día 24 de septiembre de $1810^{109}$.

\subsubsection{La Revolución Constitucional española}

Nada más asumir la soberanía de la nación, las Cortes, ahora denominadas Cortes Generales y Extraordinarias, en posesión de sus prerrogativas legislativas, hicieron salir a la luz innumerables decretos entre septiembre de 1810 y agosto de 1811, en donde se pasó a establecer las bases del proceso constituyente ${ }^{110}$. De esta forma se estableció la primacía de las Cortes en materia legislativa y en el sistema político, además, estas decretaron la igualdad de derechos entre españoles de uno y otro lado del atlántico ${ }^{111}$. También se decretó la libertad de imprenta y la abolición de los señoríos jurisdiccionales ${ }^{112}$. O sea, la revolución constitucional y liberal empezaba en este momento. Así que, la intensa vida política en Cádiz asentía con todos estos acontecimientos ${ }^{113}$.

\footnotetext{
${ }^{108}$ PORTILLO VALDÉS, R. M.: Entre la monarquía y la nación..., op. cit., p. 137.

109 DECRETO DE 24 DE SEPTIEMBRE DE 1810: "Los diputados que componen este Congreso, y que representan la Nación Española, se declaran legítimamente constituidos, en Cortes generales y extraordinarias, y que reside en ellas la soberanía nacional”. Colección de los decretos..., op. cit., p. 1.

${ }^{110}$ Para profundar en el tema, principalmente en la diferenciación entre Cortes Constituyentes, Cortes Ordinarias y Cortes de Revisión se aconseja leer VARELA SUANZES-CARPEGNA, J.: La teoría del Estado..., op. cit., pp. 303 y ss.

${ }^{111}$ Según nos cuenta Portillo Valdés, las Cortes evitaron acatar al pedido de los americanos en dos puntos, lo de equiparar la representación americana y europea, y de esperar a que llegara a los diputados de América para proceder a los trabajos constituyentes.

${ }^{112}$ Sobre estas permanencias de los poderes jurisdiccionales con la implantación de la Constitución de Cádiz se puede ampliar más los conocimientos con la lectura de ALONSO ROMERO, M. P.: Orden procesal y garantías entre Antiguo Régimen y constitucionalismo gaditano, CEPC, Madrid, 2008, pp. 275 a 315. También en esta línea de permanencias en la Constitución de Cádiz se pronuncian GARRIGA, C. y LORENTE, M.: op. cit., pp. 373 y ss.

${ }^{113}$ Eso nos deja percibir la lectura de los cinco tomos de TORRENO, Conde de: Historia del levantamiento, guerra y revolución de España, Imprenta de J. Martín Alegría, Callejón de San Marcos, n. 6, Madrid, 1848. Además de la lectura de los tomos I y II de ARGÜELLES, A.: Examen de la reforma constitucional que hicieron las Cortes generales y extraordinarias desde que se instalaron en la Isla de León el día 24 de septiembre de 1810 hasta que
} 
Con la afluencia de periódicos, decurrentes de la decretada libertad política de imprenta $^{114}$, las elecciones para diputado en Cádiz serán muy diferentes de las realizadas en las provincias libres de España. Mientras que en las provincias la elección iba a obedecer el patrón tradicional de elegir a los "mejores" dentro del cuerpo social, en Cádiz, en un ambiente más libre de determinadas trabas, se buscará elegir a los que mejor pudiesen defender al proyecto patentado por los liberales ${ }^{115}$. Como ya hicimos resaltar, en la mismísima sesión inaugural, y aunque dispusiesen de una minoría relativa de cuarenta por ciento en las Cortes, los liberales consiguieron aprobar el decreto que establecía la soberanía nacional ${ }^{116}$. De donde también se deduce el principio de la división de poderes.

De este modo, en el mes de noviembre empieza el proceso constitucional en las Cortes elegidas para este fin. No sería en teoría la primera Constitución de España, y los patriotas tenían conocimiento de ello. Richard Hocquellet nos habla que el Estatuto de Bayona, en vigor en la España josefina, traía ya algunos avances, tales como un cierto equilibrio de poderes y la mismísima representación de la nación ${ }^{117}$. Además, establecía determinados derechos del periodo napoleónico post-revolucionario. Lo que respecta a la confesionalidad era igual de intolerante que la Constitución que vendría a ser aprobada en el año de $1812^{118}$.

cerraron en Cádiz sus sesiones en 14 del propio mes de 1813, En la Imprenta de Carlos Wood e hijo, Poppin`s court, Fleet Street, Londres, 1835.

${ }^{114}$ DECRETO DE 10 DE NOVIEMBRE DE 1810: Art. I - “Todos los cuerpos y personas particulares, de cualquier condición o estado que sean, tienen libertad de escribir, imprimir y publicar sus ideas políticas sin necesidad de licencia, revisión o aprobación alguna anteriores a la publicación, baxo las restricciones y responsabilidades que se expresaran en el presente decreto". Art. VI - "Todo lo escrito en materia de religión quedan sujetos á la previa censura de los Ordinarios eclesiásticos, según lo establecido en el Concilio de Trento". Colección de los decretos..., op. cit., p. 13 y 14. Sin embargo, Richard Hocquellet matiza que la votación masiva de este decreto en la sesión del día 19 de octubre, hace ver que los distintos grupos que componían las Cortes tenían una clara idea de cambio de la monarquía, pero, a la vez reflejaba la composición heterogénea frente a los liberales, la introducción de la "cuestión religiosa, protección de la dignidad de los individuos, composición de la comisión de vigilancia de esta libertad". HOCQUELLET, R.: El rey y la nación..., op. cit., p. 65.

115 "Consiguieron su elección como diputados suplentes figuras emblemáticas de este grupo, como Isidoro Antillón, Agustín de Argüelles, Juan Nicasio Gallego, Evaristo Pérez de Castro (...). Pero, si por un lado podemos considerar que las circunstancias especiales del Cádiz de esta época explican el resultado de los votos y el triunfo del proceso revolucionario, debemos también, por otro lado, pensar de una manera más analítica el éxito de la alternativa liberal en el sentido de que no se resuelve simplemente en la aritmética de las urnas gaditanas." Idem, p. 65.

116 "No disponemos de las actas de esta primera sesión, así que al igual que los demás historiadores que se interesaron por este evento intenté comprender lo que allí pasó retomando las relaciones del voto de un decreto posterior que responde a la misma orientación política: el de la libertad de imprenta, votado en la sesión del 19 de octubre (1810)." Idem, p. 65.

${ }^{117}$ Para saber más sobre el Estatuto de Bayona, su estructura y características, se pude leer en FERNÁNDEZ SARASOLA, I.: La Constitución de Bayona (1808), Tomo I (Colección Las Constituciones Españolas - dirigida por Miguel Artola), Madrid, Iustel, 2007, pp. 53 y ss. También en VARELA SUANZES-CARPEGNA, J.: Constituciones y Leyes Fundamentales, Tomo I (Colección Leyes Políticas Españolas. 1808-1978, dirigida por el mismo autor), Madrid, Iustel, 2012, pp. 20, 151 y ss. Además, se puede complementar en TORRES DEL MORAL, A.: op. cit., pp. 28 yss.

${ }^{118}$ Hay que notar que en el Estatuto de Bayona, en el preámbulo la invocación del nombre de Dios todo poderoso era llamativo. $\mathrm{Y}$ en su el artículo primero se denota la confesionalidad del Estado, además de proclamar la total intolerancia religiosa: "La Religión Católica, Apostólica y Romana, en España y en todas las posesiones españolas, 
Con fecha 23 de diciembre de 1810 se formaría, por proceso electivo de los miembros, la Comisión que elaboraría la Constitución ${ }^{119}$. En esta Comisión se nota la presencia de individuos que habían actuado antes en la Comisión establecida por la Junta Central en $1809^{120}$. Aunque fuesen minoría en las Cortes, los liberales fueron imponiéndose principalmente con la pertinencia ideológica ${ }^{121}$. Puesto que la palabra libertad era utilizada en sus más variados sentidos, se trató de una polisemia que condujo al éxito. Libertad se confundía con liberar a la nación del invasor y con capacidad de goce de derechos, ambas serian condiciones previas para crear una ciudadanía moderna. Así que los avances lógicos de los liberales se encajaban con los patrióticos, al pretender liberar a la nación, como también con las ideas revolucionarias, vinculadas al ideario del liberalismo ${ }^{122}$. La definición de nación que se prefiguraría para la Constitución de 1812 estaba acorde con los acontecimientos del momento; puesto que, considerada como un cuerpo abstracto de individuos que serían vistos como iguales en derechos y libres para expresar sus opiniones, así como para desarrollar sus actividades públicas ${ }^{123}$. Además, se preveía la adopción de una ley única para todos que sirviera de defensa contra los excesos del poder frente a las libertades establecidas ${ }^{124}$.

Como ya habíamos comentado antes, lo primero que hicieron las Cortes reunidas fue asumir la soberanía como propia de la nación ${ }^{125}$. Y, además, reconocieron a Fernando VII como el legítimo monarca de España, por la nación soberana. El mismo decreto del día 24 de

será la religión del Rey y de la Nación, y no se permitirá ninguna otra”. ESTATUTO DE BAYONA. En esta cuestión se puede leer más en HOCQUELLET, R.: El rey y la nación..., op. cit., p. 66. Varela Suanzes-Carpegna trae una excelente exposición sobre las clasificaciones doctrinales de los diputados doceañistas: realistas, americanos y los liberales de la metrópoli, en VARELA SUANZES-CARPEGNA, J.: La teoría del Estado..., op. cit., pp. 5-51.

${ }^{119}$ Es interesante consultar a los proyectos presentados durante las Cortes de Cádiz y analizados por FERNÁNDEZ SARASOLA, I.: Proyectos constitucionales..., op. cit., pp. 133-365.

120 "Individuos que habían trabajado ya en 1809 en las comisiones establecidas por la Junta Central en el marco de la convocatoria a Cortes, tal como Argüelles o Ranz Romanillos (secretario de Hacienda de Godoy y que fue secretario de la asamblea de Bayona y que tradujo la Constitución, posteriormente se puso al servicio del bando patriótico, lo que fue aceptado por la Junta Central), e individuos que fueron los promotores de las primeras medidas revolucionarias, como Muñoz Torrero o Pérez de Castro". Idem, p. 66.

${ }^{121}$ Sobre la ideología liberal de proyección constitucional se puede leer más en MATTEUCCI, N.: op. cit., pp. 259 y ss.

122 "Se iba abriendo paso de este modo la revolución constitucional. La idea de una nación atlántica, el reconocimiento de la capacidad de la opinión pública para juzgar de la acción política, la delimitación de poderes, la supremacía de la nación y la concepción de ésta como reunión de vecinos padres de familia que no reconocen otra sumisión o vasallaje. Todo ello conformaba la base fundamental del programa que se contenía en los decretos elaborados por las Cortes antes de entrar en la discusión del proyecto constitucional." PORTILLO VALDÉS, J. M.: Entre la monarquía y la nación..., op. cit., p. 137.

${ }^{123}$ Se puede profundizar más sobre conceptos históricos, sociológicos y el racionalismo-normativo constitucional, en una visión amplia e introductoria sobre el tema en TOMÁS Y VALIENTE, F.: Constitución: Escritos de introducción histórica, Madrid, Marcial Pons Ediciones Jurídicas y Sociales, 1996, pp. 29 y ss.

${ }^{124}$ HOCQUELLET, R.: El rey y la nación..., op. cit., pp. 66 y 67.

${ }^{125}$ Un largo estudio sobre los problemas enfrentados por la toma de la soberanía, primero por las Juntas y luego por las Cortes Constituyentes son tratados por VARELA SUANZES-CARPEGNA. I.: La Teoría del Estado..., op. cit., pp. 50-213. Sobre el concepto moderno de soberanía se puede encontrar en FIORAVANTI, M.: Constituzione e popolo sovrano, Bologna, Società Editrice il Mulino, 1998, pp. 47-87. 
septiembre también divide los poderes. Las Cortes se hace llamar de Majestad, y a Fernando y al Poder judicial de altezas ambos. La nación era el único sujeto en plenas condiciones en estos momentos para gestionar la crisis. Así que es la revolución constitucional, pero, con evidentes matices ibéricos, como bien señala Portillo.

Lo curioso y novedoso del proceso constitucional euroamericano, que tendrá lugar en Cádiz, es el relieve que asume la nación como un baluarte de los derechos. Esta será la guardiana de derechos y libertades. Por lo tanto, empecemos por el artículo $4^{\circ}$ del texto gaditano, cuando proclama que "La nación está obligada a conservar y proteger por leyes sabias y justas la libertad civil, la propiedad y los demás derechos legítimos de todos los individuos que la componen". Este artículo, precedía por la orden a otro artículo que definía el objetivo del gobierno; en el texto definitivo se trasladó al Título III, "Del Gobierno". El artículo 13, ya en el texto definitivo de la constitución, decía: "El objetivo del Gobierno es la felicidad de la nación, puesto que el fin de toda sociedad no es otro que el bien estar de los individuos que la componen" ${ }^{126}$. Se decidió hacer el traslado porque se veía extraño al momento poner en el mismo fardel la definición de la nación a la vez que se definía el objetivo del gobierno. Principalmente que ya se había suprimido la última parte del artículo $3^{\circ}$ del proyecto, en donde decía: “(...) y de adoptar la forma de gobierno que más le convenga" ${ }^{127}$. Argüelles, en la misma sesión de Cortes, dirá que si no se hubiese suprimido la última parte del art. 3, la transición para el 4 sería más lógica, en concordancia con lo pronunciado por el diputado Aner. Pero, además, insistía en la conveniencia de aprobarse el futuro art. 13, por su importancia, y se decidiría en qué capítulo le ubicaría futuramente, y así fue. De acuerdo también estaba el diputado Espiga, pero, proponía alguna alteración más para seguir en la secuencia lógica del capítulo ${ }^{128}$. Espiga expone al reto novedoso de la Constitución, en donde la felicidad de la nación consistiría justo en el bien estar de sus individuos y éste en la conservación de sus derechos ${ }^{129}$. La lógica

\footnotetext{
${ }^{126}$ DIARIO DE LAS DISCUSIONES Y ACTAS DE LAS CORTES, Tomo VIII, Imprenta Real, Cádiz, 1811, p. 89.

${ }^{127}$ El diputado por el Principado de Cataluña, Felipe Aner de Esteve, en su intervención en la sesión de las Cortes, trae el siguiente parece a este respeto: "Este articulo vendrá bien cuando se hable del gobierno: aquí solo tratamos de la nación. Hemos dicho que la española es la reunión \&c. (Leyó los artículos 1, 2 y 3). Es visto que hasta aquí nada se dice de gobierno; y así no veo yo el mejor enlace entre este artículo y los tres que le anteceden. Si no se hubiera suprimido la ultima parte del artículo 3, la transición seria una tanto más exacta; pero habiéndose suprimido, soy de parecer que este artículo 4 se traslade al Capítulo III, en donde se habla de Gobierno, pues allí vendrá bien el expresar quál sea su objeto” DDAC, tomo VIII, p. 89.

128 "En lugar de objeto de gobierno, dígase el objeto de estas, á saber de las leyes fundamentales de que habla el artículo 3, y entonces será la transición más exacta.” DDAC, tomo VIII, p. 90. También en este sentido comenta PORTILLO VALDÉS, J. M.: Entre la monarquía y la nación..., op. cit., p. 143 y ss.

129 "No hay duda que en diciendo la felicidad de la nación se ha dicho todo; pero las partes que constituyen este ente moral son las que siendo felices hacen esta felicidad nacional. En el artículo 5 se trata de la conservación de los derechos; á saber: que la felicidad de la nación consiste en el bien estar de sus individuos, y este resulta de la conservación de sus derechos, creyendo que no estaría por demás esta explicación.” DDAC, tomo VIII, p. 90.
} 
impuesta en la comisión, según Portillo, era una relación clara entre forma de gobierno y salvaguarda de derechos, lo que al final se impuso ${ }^{130}$. Así que el diseño estructural de la Constitución se veía trastocado por la supresión de la parte final del artículo 3 del proyecto y la definición de los derechos y libertades en el sistema constitucional, según Argüelles ${ }^{131}$.

A diferencia de la Constitución de los franceses de 1791, la española de 1812 no trae una declaración de derechos en primer plano, sino que, solamente después de definir a la nación como soberana sobre todo lo demás, hace una frugal alusión a los derechos ${ }^{132}$. La declaración de derechos propiamente dicha, como dirá Portillo Valdés, se encuentra en primer lugar en el artículo 4 de la constitución en donde se encuentran "el sistema”, según lo define Argüelles y otros diputados. Después de eso viene la definición de poderes y el establecimiento y asignación de estos a los institutos que les corresponda. De modo que la nación y no una declaración de derechos se presentaba como superiores en el texto constitucional ${ }^{133}$. En segundo lugar, nos deparamos con el propio concepto de derechos y las correspondientes libertades ${ }^{134}$. De ahí que las libertades se encontrarán dispersas en el articulado del texto constitucional, puesto que, están recogidas mucho más como formalidades que como derechos subjetivos, que en este último caso se radicaría esencialmente en el individuo y transcendería a todo el ordenamiento jurídico ${ }^{135}$. O sea, la preferencia es clara en relación a la nación frente a los derechos individuales. Pues, al modo de declaración francesa se indicaría que aquellos derechos subjetivos no se doblegarían a los poderes constituidos. Del contrario, tratándolos como formalidades y sometidos a la nación, que está por encima de aquellos, les podía

\footnotetext{
${ }^{130}$ PORTILLO VALDÉS, J. M.: Entre la monarquía y la nación..., op. cit., p. 143.

131 "Ahora se ve quan difícil es hacer alteración en un sistema si no se toman en consideración todas las bases y principios que contiene. Se no se hubiese suprimido la parte que decía: y de adoptar la forma de gobierno que más le convenga, no tendrían lugar los justos reparos que ha expuesto el Sr. Aner; la transición del artículo 3 al 4 sería más lógica y qual debía ser." DDAC, tomo VIII, p. 90.

${ }^{132}$ Sobre el constitucionalismo gaditano y sus peculiaridades en relación al texto francés podemos encontrar ciertas explicaciones en SOLÉ TURA, Jordi \& AJA, Eliseo: op. cit., pp. 13 y ss. También en TORRES DEL MORAL, A.: op. cit., pp. 33 y ss. Además de VARELA SUANZES-CARPEGNA, J.: Constituciones y Leyes..., op. cit., pp. 25, 208 y ss.

${ }^{133}$ El diputado Antonio Oliveros así se pronuncia a ese respeto: "Las leyes fundamentales se establecen por la nación, y es bien claro que ésta no puede tener otro interés ni objeto que su felicidad; por las leyes fundamentales la nación forma el gobierno, y éste no puede tener otro interés que los de la nación. (...) Y por consiguiente aquella felicidad que consiste en el bien estar de los individuos que componen un estado, es efecto inmediato de las operaciones de gobierno". DDAC. Tomo VIII, p. 91.

${ }^{134}$ Para profundizar más en los valores y derechos fundamentales constitucionales, léase TOMÁS Y VALIENTE, F.: op. cit., pp. 43 y ss.

${ }^{135}$ Villanueva, diputado por Valencia, tenía un pensamiento similar a Oliveros: "El fin de toda sociedad política es el bien de los individuos que la componen, no sólo considerados en si mismos, sino en orden al bien público de la sociedad, y en orden a Dios. Me parece que esto se explicaría mejor diciendo: el fin de toda sociedad política es el bien de los individuos; porque el bien estar tiene un sentido aislado al individuo, sin los demás respectivos de que no pueden desentenderse como miembros de la sociedad." DDAC, tomo VIII, p. 91.
} 
garantizándolos, aunque también delimitarlos ${ }^{136}$. El diputado Muñoz Torrero, resumía todo sentenciando que "el orden de las ideas de este artículo (art. $4^{\circ}$ ) es muy sencillo. Se habla de la nación, y luego de las familias que la componen y se reúnen para su bien estar"137.

Así que los derechos subjetivos del individuo no se conciben como parte fundamental del sistema constitucional en el texto doceañista. Esta matización de la política constitucional en España no sólo se puede identificar como mero temor a que se tachara de copia del proceso revolucionario francés. Hay que pensar que una guerra, justo contra los franceses, y una crisis dinástica daban el contrapunto a esta decisión.

Entretanto, muchos ilustrados no dudaron en su momento de evocar como modelo a la primera constituyente francesa, pero, los textos liberales también buscaban alejar a este modelo de los descarríos que tomó este proceso en el terror jacobino y en el despotismo napoleónico ${ }^{138}$. Sin embargo, otro modelo constitucional también era conocido y manejado por los diputados; modelo este que traía una opción menos radical que el texto francés, el constitucionalismo norteamericano $^{139}$. En este sentido, hay claras evidencias de consulta a otros modelos constitucionales por la comisión de constitución ${ }^{140}$. En cuanto a la Declaración de Derechos, la comisión pareció mucho más propensa a hacerlo en las discusiones en las que se mantuvo, que pasarlas al proyecto final de la constitución ${ }^{141}$. Así que, como nos aclara Portillo, la duda en la Comisión era si primero deberían hacer una declaración de los derechos, o si sería mejor definir al sujeto de estos derechos, el individuo español.

La comisión discutió mucho sobre estos aspectos. En la Sesión del día 29 de marzo, el artículo $6^{\circ}$ ofrece un esbozo de proyecto definiendo a los derechos de los españoles, que serían:

\footnotetext{
${ }^{136}$ Estas ideas se pueden encontrar en PORTILLO VALDÉS, J. M.: Entre la monarquía y la nación..., op. cit., p. 143.

${ }^{137}$ DDAC, tomo VIII, p. 91 y 92.

138 “Empéñanse algunos en que la constitución española tiene mucho de la célebre que los franceses no supieron conservar. Otros pretenden que la nuestra sea original. Para que todos cotejen y se desengañen sale la presente traducción." Así se expresaba el traductor (Miguel de Burgos) en esta leyenda la filiación modélica de la Constitución de Cádiz hacia la francesa de 1791. La Constitución Francesa. Decretada por la Asamblea Nacional constituyente en los años de 1789, 1790 y 1791; aceptada por el rey en 14 de septiembre de 1791, Madrid, 1814.

139 “Como se ha hecho moda publicar voluminosos proyectos de Constitución, y todos suponen tan buena l de los Estados-Unidos de América, se reimprime en poco más de un pliego y al pié de la letra la que tradujo en Filadelfia, hace un año, el Dr. Villavicencio para Caracas, su patria; y a fin de aprovechar el papel, se agrega la Estadística de su población en tres censos, o decenios sucesivos a la independencia, para que cada uno calcule su punto favorito." Leyenda encontrada en la traducción de Villavicencio. Constitución de los Estados-Unidos de América, Cádiz, 1811. Citado en PORTILLO VALDÉS, J. M.: Entre la monarquía y la nación..., op. cit., p. 144. ${ }^{140}$ ACTAS DE LA COMISIÓN DE CONSTITUCIÓN, 1811. Así se desprende de la Sesión de 16 de marzo: "Reunida la Comisión se presentó el señor Romanillos con el proyecto de Constitución y el catálogo trabajado por él mismo de las leyes de diferentes Códigos nacionales que tratan de puntos constitucionales".

${ }^{141}$ ACC, 1811. Evidencia de esto es cuando se discute la definición de quiénes son españoles en la Sesión de 2 de abril de 1811, en donde se negociaba el lugar en la constitución para ubicar a este articulo, y la conveniencia de situarlo antes de lo que trata de los derechos.
} 
la seguridad, la libertad y la propiedad. Así que se discutió si era oportuno incluir la igualdad entre estos derechos. Pero, no se llegó a una conclusión en esta sesión, puesto que se tenía pensado redactar un artículo específico para la igualdad. En la Sesión del día 5 de abril, finalmente se acordó que la igualdad debía figurar entre los otros tres derechos enumerados antes, aunque se discutiera la definición que esta debería tener en el texto constitucional ${ }^{142}$. Al final se abrió un capitulo intitulado: "De los españoles, sus derechos y obligaciones", donde se definía al español en el art. $1^{\circ}$ y en el articulo $2^{\circ}$ a los derechos de estos. Así mismo los artículos que se siguen hacen una definición de uno de los cuatro derechos establecidos, a saber: "la libertad, la seguridad, la propiedad y la igualdad"143. Percibimos que aquí en este esbozo del Capítulo II de la constitución, la nación como protectora de los derechos de los españoles establecido en el artículo $5^{\circ}$, votado en la Sesión del día 29 de marzo ${ }^{144}$, no vuelve a aparecer en el esbozo trazado en la Sesión del día 10 de abril.

Entretanto, en el proyecto final, pasado a las Cortes hubo una remodelación completa en esta declaración de derechos. Así que en la Sesión del día 7 de agosto, la comisión decide reformular al artículo $5^{\circ}$, del Capítulo I, del Título I, dándole un aire más original y sencillo, en palabras de la comisión ${ }^{145}$. De este modo, el derecho de la igualdad se quedaría diluido u oblicuamente insinuado.

Según Portillo Valdés, ni siquiera eso pasó. En la Sesión del día 8 de agosto se volvió a hablar en las actas sobre los derechos de los españoles ${ }^{146}$. Al final, se quedó el texto presentado a las Cortes, que fue aprobado y que figura en el texto del art. 4 de la Constitución de 1812: "La Nación está obligada a conservar y proteger por leyes sabias y justas la libertad civil, la propiedad y los demás derechos legítimos de todos los individuos que la componen”. Esta fue la declaración de derechos considerada bastante frugal, en donde solamente se recogía la libertad civil y la propiedad como derechos de los españoles; los otros dos van a desaparecer del texto definitivo. Se volvía al proyecto original al someter los derechos a una tutela nacional, en

\footnotetext{
${ }^{142}$ ACC, Sesión de 5 de abril de 1811: "Se discutió largamente sobre la definición de la igualdad, y al fin se sentó y acordó la siguiente definición, aunque con la reserva de rectificarla si pareciere y se pudiere adoptar un concepto mejor: La igualdad consiste en que no haya diferencia alguna entre los individuos que componen la Nación en el uso y goce de sus derechos, ni en la distribución de premios y aplicación de castigos".

${ }^{143}$ ACC, Sesión de 10 de abril de 1811.

${ }^{144}$ ACC, Sesión de 29 de marzo de 1811: Art. 5. - "La Nación está obligada a proteger y conservar a sus individuos todos sus derechos".

${ }^{145}$ ACC, Sesión de 7 de agosto de 1811: "Se propusieron diferentes pensamientos dirigidos a dar otro aire a los artículos que tratan de los derechos de los españoles, por parecer a algunos de los señores de la Comisión que será más original y sencillo enunciar las cosas sin hacer la enumeración de los derechos. Y discutido largamente quedó aprobado, o acordado por la mayoría, que a continuación del artículo $5^{\circ}$. del capítulo $1^{\circ}$. del Título I se indicasen o expresasen las definiciones de los tres primeros derechos, y oblicuamente se insinuase el cuarto".

${ }^{146}$ ACC, Sesión de 8 de agosto de 1811: "Presentó la fracción el artículo en que se habla de los derechos, y quedó acordado en los términos que contiene la copia original que conserva el secretario de la Comisión y sirve para la revisión que se está haciendo del proyecto".
} 
lugar de singularizar los mismos derechos como algo propio de los individuos que componen la nación ${ }^{147}$. Así que, como no hay una declaración explícita y tasada de derechos conectando con los españoles que habían de gozarlos, se hace una referencia al "individuo", solamente en el art. 4 de la Constitución ( $5^{\circ}$ del proyecto), justamente en donde se especifica la nación española ${ }^{148}$.

Vista de esta forma a la Declaración de derechos en la Constitución de Cádiz, nos queda la pregunta del porqué del derrotero tomado por estos legisladores, tan diferente a lo que se podría esperar, una declaración a la francesa. O mejor dicho, en dónde los derechos subjetivos del individuo ocupen un eje central en el texto constitucional. No es que no hubiese discusiones en este sentido ${ }^{149}$, o que no se conociera aquella forma de vincular a los individuos los derechos subjetivos de estos ${ }^{150}$. En algo nos guía Portillo Valdés, al decirnos que la configuración de los derechos había sido concretada bajo la libertad nacional y no la individual. Los escritos de Argüelles y Flórez Estrada, dilucidan derechos tales como libertad, igualdad, seguridad y propiedad, lo hacen desde una lógica francesa, decretada en $1789^{151}$.

Entretanto, la superficialidad de los legisladores gaditanos a la hora de declarar los derechos de los españoles, no pasó desapercibida. En el libro Ligeras observaciones sobre el

\footnotetext{
${ }^{147}$ PORTILLO VALDÉS, J. M.: Entre la monarquía y la nación..., op. cit., p. 145.

148 "La idea cultural de 1812 respecto a derechos y libertades se mueve más hacia una compresión objetiva de control legislativo que hacia una posición central subjetiva que los situara por encima del ordenamiento y de poderes con capacidad de determinación sobre la libertad personal entendida así como derechos. (...) Resulta perfectamente coherente tanto con el desarrollo de una revolución nacional, como con la situación que la referencia a los derechos había finalmente encontrado bajo el árbol de la libertad nacional y no de la individual. " Ibidem, p. 146.

${ }^{149}$ En la Sesión de la Comisión del día 10 de abril de 1811, Torrero y Pérez de Castro presenta en el Capítulo II del proyecto, bajo el Titulo De los Españoles, sus Derechos y obligaciones, las siguientes definiciones para los derechos a ser recogidos en el texto constitucional: "Art. $3^{\circ}$ - La libertad consiste en poder hacer todo lo que no perjudica a la sociedad ni ofende a los derechos de otro. Art. $4^{\circ}$ - La seguridad consiste en ser cada individuo protegido por la fuerza pública contra la ofensa que se haga a su persona o a sus derechos. Art. $5^{\circ}$ - La propiedad es el derecho de gozar y disponer libremente de sus bienes y del fruto de su talento, de su trabajo y de su industria. Art. $6^{\circ}$ - La igualdad consiste en que no haya diferencia alguna entre los individuos que componen la Nación en el uso y goce de sus derechos.

${ }^{150}$ En textos liberales que antecedieron a la constitución aparecen tales derechos y sus definiciones, como los que aparecen en el Conde Toreno y Flórez Estrada. Este ultimo autor se refería a los derechos como "bienes que llamaré imprescindibles e inajenables, los reduciré a tres, a saber: la seguridad, la libertad y la igualdad de condiciones.” FLÓREZ ESTRADA, A.: Constitución para la nación española (1809), Madrid, 1958, p. 315. Además, Argüelles pensaba que "la Libertad, la igualdad y la propiedad, son derechos naturales que el hombre tiene en si mismo, que debe a Dios, y cuya conservación procura cuando se reúne a sus semejantes, o lo que es igual, cuando constituye las sociedades. Estos atributos preciosos dan al hombre: $1^{\circ}$ la libertad, o sea la facultad de hacer con seguridad cuanto le pareciere más acomodado a sus deseos, siempre que con ello no dañe a los demás hombres: $2^{\circ}$ la igualdad, o sea el derecho para ser protegido en sus medios, y en sus facultades, sin diferencia de unos hombres a otros, gozando de un misma consideración sin distinción alguna: y $3^{\circ}$ la propiedad, o la facultad exclusiva de disponer y gozar a nuestro arbitrio del producto de nuestro trabajo. (...) Seguridad, que es el convencimiento que tiene el hombre, de que nada podrá perturbarle en el disfrute de sus derechos". ARGÜELLES, J. C.: Reflexiones sociales o idea para la constitución española, que un patriota ofrece a los representantes de cortes, Imprenta de José Estévan, Valencia, 1811, pp. 7 y 8.

151 "El mismo proyecto de Flórez Estrada daba amplia entrada también estas deducciones, aunque remitidas a la última parte del mismo: libertad de imprenta y limitadamente religiosa, inviolabilidad del domicilio, garantías procesales, igualdad para acceso a los oficios y empleos, supresión de la nobleza, de los vínculos y mayorazgos.” PORTILLO VALDÉS, J. M.: Entre la monarquía y la nación..., op cit., p. 147.
} 
proyecto de la nueva constitución, Valentín de Foronda va a tejer críticas a una no declaración más amplia de derechos por la Cortes constituyentes ${ }^{152}$. Así que el legislador se mostraba mucho más preocupado, dada la crisis por la qué pasaba la nación, en definir al sujeto nacional antes que al sujeto individual, como ya lo decimos ${ }^{153}$.

Este aspecto constitucional gaditano en donde la nación se sobrepone como supraindividual no era para nada desconocido en la cultura liberal llevada a cabo en España del periodo. Tanto en las Actas de la Comisión de constitución como en los Diarios de Sesiones de las Cortes se percibe una tendencia en fraguar una idea ya preconcebida en este sentido. Muchos pensadores españoles emitieron opiniones en donde se podía sentir una exaltación a la sociedad/nación como superior y gestora de los derechos naturales, siendo para estos mismo pensadores, fuente para el derecho civil, positivado, pero incapaz de regir la vida en sociedad, sin una adecuación a la vida en conjunto, que sería mucho más provechosa. García Malo, en su obra La política natural, fue uno de los contribuyentes para este pensamiento, en donde los derechos naturales se curvan frente a las demandas del conjunto de la sociedad. Él va a afirmar que "el estado de la naturaleza, de que nos hablan los filósofos (...), es una verdadera quimera" $" 154$.

Así que, en esta obra, traen virtudes y derechos que en el futuro se recogerán en las Cortes de Cádiz. La propiedad, "que no es sino la facultad de gozar exclusivamente de las cosas

\footnotetext{
152 “ ¿Es posible que se hable con tanta ligereza de la libertad civil, de la propiedad, de estos sagrados y primitivos derechos que el Monarca del Universo concedió al hombre en sociedad? (...) Yo creía que debiera ser la base de la Constitución una explicación muy diminuta de los insinuados derechos, como que todas las leyes deben trotar de ellos; como que todas las providencias no son sino una aplicación de ellos, pues no se proponen otro objeto que su conservación, en la que pende la verdadera felicidad de las sociedades, como el sistema planetario en que no se interrumpan las leyes de la gravitación y atracción de los cuerpos.” FORONDA, V.: Ligeras observaciones sobre el proyecto de la nueva constitución, La Coruña, 1811 apud PORTILLO VALDÉS, J. M.: Entre la monarquía y la nación..., op. cit., p. 148.

${ }^{153}$ En realidad, el artículo cuarto de la Constitución doceañista no se preocupa tanto en decir los derechos de los españoles como de habilitar a la nación como guardiana de los mismos, como bien lo concluye José M. Portillo Valdés.

154 “Las leyes civiles pueden, pues, ser consideradas, bajo ciertos respectos, como leyes naturales. La única diferencia consiste en que las leyes que se llaman naturales por excelencia, están inmediatamente fundadas en nuestra naturaleza, y son necesarias a toda la especie, mientras que las leyes civiles, que se llaman también leyes positivas, son de la sociedad, y la aplicación de las leyes de nuestra naturaleza á circunstancias momentáneas. Las leyes naturales son eternas e invariables; pero su aplicación, hecha por la ley civil, debe variar con las circunstancias y necesidades de la sociedad. (...) Las leyes de las naciones, que constituyen lo que se llama el derecho de gentes, no son más que las leyes naturales aplicadas a las diferentes sociedades en que el género humano está dividido. (...) Así que no puede haber otros derechos legítimos que los que están fundados en la naturaleza, en la justicia, en la utilidad, en el interés verdadero de la sociedad (...). Esta no puede jamás perder el derecho de oponerse a lo que la desagrade, de revocar lo que la imprudencia le ha hecho conceder y de remediar el mal que su debilidad ha podido hacerle sufrir. Por otra parte, se sigue también que una acción aunque prohibida por la ley civil, puede ser justa, cuando es conforme la ley natural. Entonces, aunque justa es ilícita." GARCÍA Malo, Ignacio: La política natural o discurso sobre los verdaderos principios del gobierno (Imprenta de Mallorca-1810), Reimpresión por Martín Trullás, Manresa, 1820, pp. 21, 32, 33,37 y 38. Esta obra que el autor dedica a Quintana en una nota inicial, según Portillo Valdés, había sido una traducción hecha por Malo del Abade Thorel, y no en realidad un creación propia.
} 
que el talento, el trabajo y la industria proporcionan”. Ésta es inherente a la naturaleza humana en sus desigualdades, pero, "turbar a un hombre en su libertad y en su propiedad, es quitarle los medios de conservarse e impedirle de ser feliz". De este modo, para evitar que se turbe la libertad y la propiedad, hace falta "la justicia (que) es la virtud que mantiene los derechos de los hombres". Se debe añadir a todo esto, para un mejor funcionamiento del sistema la virtud, que "no puede ser sino lo que contribuye a la utilidad, a la felicidad, a la seguridad de la sociedad". El amor en la familia, entre los "conciudadanos", "el amor a la patria", todo esto fundado en la "justicia (que) es la verdadera base de todas las virtudes sociales"155. Mensajes muy acordes con el texto constitucional gaditano.

Estos fueron los conceptos que triunfaron en 1812. Derechos individuales bajo la protección de la nación y una frugal enumeración de los derechos de los ciudadanos. En las Actas de la Comisión de constitución afloraban otros derechos diferentes a los dos que se quedaron fijados en el artículo $4^{\circ}$ del texto constitucional ( $5^{\circ}$ del proyecto): libertad civil y propiedad. Extrañaba a algunos diputados de la Cortes de Cádiz, la ausencia de un derecho en aquél artículo, el derecho a la igualdad. El diputado Ortiz, en la Sesión del día 30 de agosto de 1811, dirá: "yo encuentro que falta una expresión en este artículo”. Al diputado le parecía que después de expresar la "libertad civil" debería hacerse referencia a la "igualdad legal", "porque siendo uno de los derechos primitivos de los ciudadanos, debe haber igualdad legal: eso es un hecho; delante de la ley todos son iguales". Prometida de ser mencionada (la igualdad) oblicuamente por la Comisión de constitución en el proyecto, otro diputado, Muñoz Torrero, ponía una pala de cal al asunto al decir que "no se ha puesto la igualdad, porque ésta en realidad no es un derecho, sino un modo de gozar de los derechos"156. Así que la nación era el garante de todo esto, no hacía falta mencionar a todos los derechos, puesto que se deducía del texto constitucional, que estaba lleno de "virtud" y "amor a la patria". Con esta garantía, el articulo $4^{\circ}$ finalizaba: "y los demás derechos legítimos de todos los individuos que la componen (la nación)".

Entretanto, la igualdad como derecho, que advenía de la división de los poderes, como enseñaban los catecismos políticos de la época, no fuera olvidada, y se decía que "todos los hombres son iguales ante la ley". Pero este mismo catecismo, encontrado en las Lecciones políticas para el uso de la juventud española, escritas por el cura del Sagrario de Sevilla, Manuel López Cepero, advertía contra la mala interpretación de la libertad, puesto que, aunque no se pudiese conservar la felicidad pública en su ausencia, "así también ella puede destruir en

155 Ibidem, pp. 39, 42, 43, 44. También se puede encontrar comentario semejante, al analizar dicha obra, en PORTILLO VALDÉS, J. M.: Entre la monarquía y la nación..., p. 150.

${ }^{156}$ DDAC, tomo VIII, pp. 92 y 93. 
un momento a la sociedad misma, y reducirla a un caos horroroso de confusión, y de desorden, si se equivoca su idea verdadera". En la lección VI de este catecismo se tratará exclusivamente de la igualdad. De forma que, para este catecismo, "la ley es la expresión de la voluntad general" y por lo tanto "tiene el mismo empeño en proteger a la virtud que en perseguir el vicio: de consiguiente, ante la ley somos todos iguales".

“H (hijo). - ¿Y por qué me dixo V. que mientras la igualdad se conserve será feliz la sociedad?

$P$ (padre). - Porque como la ley es igual para todos, mientras ella esté en vigor, han de ser los hombres forzosamente iguales, de manera que la subordinación a las leyes y a la imparcial aplicación de estas es lo que produce la verdadera igualdad. $H$. - Y ¿por qué me dixo $V$. que la igualdad mal entendida podía destruir la sociedad?

P. - Porque la sociedad no puede subsistir sin orden, y este exige ciertas consideraciones respeto de muchos de los ciudadanos, sin los quales todo sería confusión y desorden." 157

La igualdad tenía un valor que no era solamente, como dijo Muñoz Torrero, una condición para gozarse de los demás derechos. Esta, según vimos en el catecismo, garantizaba la equidad, la distribución de la justicia, la paz social y la felicidad de todos. Por lo tanto habría que hacer buen uso y buena interpretación de ésta. Aunque nos parece algo paradójico. Como explica Portillo Valdés, analizado estos mismos catecismos, dirá que "el mensaje más habitual se podría sintetizar en la aparente paradoja de que la desigualdad corría pareja y era condición de la igualdad"158. En una sociedad acostumbrada a lidiar con las desigualdades del antiguo régimen, la introducción de este principio, aun más, sugerido por un cura, debía ser tomado con cautela. Pero, podía ser un medio para alcanzar, no por la ambición, pero, ciertamente por el trabajo, la fortuna, aunque era algo de lo más remoto en esa época.

Al igual que el cura sevillano, el Semanario Patriótico, del día 22 de junio de 1809, con ideas más liberales, pero desalentadoras, emite sus opiniones en la conclusión del discurso sobre la libertad e igualdad:

"La absoluta inutilidad de estos esfuerzos por igualarse los hombres, tantas veces repetidos, y tantas abandonados con aumento de enormes males, es lo que da tregua de siglos enteros á la guerra nunca apagada entre la clase que nada tiene, y la que goza de todo. (...) Sabed que en vano apetecéis esa igualdad que pide vuestro corazón de tiempo en tiempo (...). No es el amor a la igualdad el que os arrebata; es la misma ambición que aborrecéis en los que más pueden. Queréis mandar como los que mandan, queréis dominar como lo que dominan, queréis

\footnotetext{
${ }^{157}$ LÓPEZ CEPERO, M.: Lecciones políticas para el uso de la juventud española, Tercera Edición, Imprenta de Villalpando, Madrid, 1814, pp. 34 - 37.

${ }^{158}$ Esta discusión sobre la inserción de la igualdad entre los derechos individuales se puede encontrar en PORTILLO, VALDÉS, J. M.: Entre la monarquía y la nación..., op. cit., p. 151.
} 
tener esclavos como los que subyugan. (...) El solo apoyo de las riquezas es muy débil cuando han producido ya la nulidad e indolencia. No contempléis su aparente gloria para abatiros: la patria no debe esperar otra cosa para igualaros con ellos que servicios iguales a los que en otro tiempo los elevaron. Empero sí, contentos con vuestro destino, sabéis apreciar los bienes de la pobreza honrada, quedaos enhorabuena en las clases inferiores que no por serlo son más infelices. ¿Tenéis brazos? La patria respetará los frutos de vuestra industria con igual miramiento que los tesoros de su primer magistrado. ¿Tenéis honor? Vuestro carácter será invulnerable contra los tiros del poder y el influjo de las riquezas. ¿Tenéis hogar? Tan sagrado será ante las leyes como los umbrales de los palacios. Ah! Si existe una patria en la nación en que vivís, si el suelo en que los vio nacer no es una habitación de carceleros y esclavos, iguales seréis todos ante el tribunal de la patria, ya se trate de premiar meritos, ya de imponer castigo (...).","159

De este modo, la igualdad debía caminar en el estricto molde propuesto en este discurso. Para Portillo, reflejaba, en este discurso, no la ambición sino el trabajo, la propiedad y el derecho, puesto que estos últimos estarían amparados por la libertad. Esta era una propuesta de igualdad que no huyera al control, permaneciendo bajo determinados parámetros. Era una igualdad que proporcionaban medios, como oportunidad, pero ayudaba mucho más a los que tenían los medios como la propiedad. Así que la igualdad no era usada como un término absoluto, podía comportar desigualdades, como se verá a lo largo del texto gaditano, cuando se refiere a la atribución y concesión de la ciudadanía, por ejemplo.

De todo esto abstraemos que la discusión para una efectiva declaración de derechos de los españoles era lo que menos importaba en las Cortes de Cádiz. La nación era lo más importante en este periodo, y "la dimensión realmente interesante para los derechos de los individuos españoles no era la individual sino la de miembro de una comunidad nacional" ${ }^{\text {160 }}$. Prueba de esto son las discusiones llevadas a cabo por los diputados Villanueva y Terrero en las Cortes. Refiriéndose al artículo quinto del proyecto, Villanueva opina que "donde se dice proteger... la libertad civil... interpondría yo la religión, el orden público, la libertad \&c.” Y aclara el mismo diputado, dentro de lo propuesto por Portillo, a un concepto de nación supraindividual: "porque los individuos de la nación no deben considerarse solamente con respeto a sí mismos, sino con respeto a la religión que profesa y protege el Estado, y al orden que deben subsistir en la sociedad." Mientras que el diputado Torrero irrumpe en apoyo a las ideas del colega, radicalizándolas: "que se añada al artículo: y a la santa religión que profesa. La rasen: aquí se hace una enumeración de los derechos que la nación está obligada a

\footnotetext{
${ }^{159}$ SEMANARIO PATRIÓTICO, 22 de junio de 1809, pp. 124, 125, 127 y 128.

${ }^{160}$ PORTILLO VALDÉS, J. M.: Entre la monarquía y la nación..., op. cit., p. 152.
} 
conservar, y el primero y principal es la religión". ${ }^{161}$ Otro diputado entra en el debate para apoyar a estas adiciones al artículo. Simón López propondrá que:

"El principal deber a que está obligada la nación es el de defender a la religión católica, apostólica, romana. Así me parece que sería oportuno decirse de esta manera: la nación está obligada a proteger por leyes sabias y justas la religión católica apostólica, romana y sus ministros”. 162

También otro diputado, José Salas, dirá que lo mejor sería una redacción en donde se expresase que "la nación quiere, y manda que se conserve y proteja a la religión católica"163. El conde de Toreno advierte a los colegas diputados que estas adiciones se pueden contemplar en el artículo 13 del proyecto y 12 de la constitución, en donde se trata de la religión ${ }^{164}$. Pero fue el abogado de los Reales Consejos y diputado por Burgos, Gutiérrez de la Huerta, quien puso fin a la pretensión de meter en el artículo la referencia a la religión en donde se pretendía tratar de los derechos y libertades de los españoles, con el siguiente argumento:

"La adición que se pretende en mi concepto varía la esencia del artículo, porque si se dixera que la nación estaba obligada a proteger los derechos \&c., poniéndose entre ellos la religión, estableceríamos por dogma la tolerancia. Los Estados-Unidos de América tienen establecido y jurado proteger la religión de todos los individuos de aquél estado, de modo que allí existen todas las religiones libremente, y pueden ser del mismo modo exercidas... Si V.M. sentara esta palabra religión envuelta con los demás derechos de los individuos, daríamos lugar a que tuviéramos por tolerantes, y á que se dixese que V.M. sancionaba, y no impedía el culto que cada uno quisiese seguir; lo qual es absolutamente contrario al dogma que establece la constitución, de que no debe haber más religión que la católica, apostólica, romana. No confundamos las ideas: es menester que V.M. haga entender a la nación y á todo el mundo que la religión católica, apostólica, romana es la única que profesa, y la qual protegerá con exclusión de otra qualquiera, y que ninguno podrá atentar contra ella sin que la fuerza pública no le escarmiente. Esto ha dicho la comisión en quatro palabras en el artículo 13: V.M. hará en él las adiciones que quiera; pero no en este lugar; pues, como he dicho, seria esto dar una idea de que se establece el tolerantismo."165

Pronunciándose de esta forma el referido diputado blindaba la intolerancia religiosa en el texto doceañista contra futuras interpretaciones "perniciosas", porque no era el caso de desinformación y si de una opción explícita por ésta. El principio de tutela de los derechos individuales por la nación parecía que estaba ya consagrado, pero añadir a la religión en el artículo $5^{\circ}$ de proyecto supondría una tolerancia religiosa indeseable para los diputados.

\footnotetext{
${ }^{161}$ Esta y las demás citas de este párrafo se encuentran en el DDAC, tomo VIII, pp. 92 y93.

${ }^{162}$ DDAC, tomo VIII, p. 94.

${ }^{163}$ Idem.

${ }^{164}$ Sobre la relación entre Estado e Iglesia en este período véase en TOMÁS Y VALIENTE, F.: op. cit., pp. 115 y ss. Además se puede complementar en SÁNCHEZ AGESTA, L.: Los principios cristianos del orden político, Madrid, Instituto de Estudios Politicos, 1962, pp. 35 y ss.

${ }^{165}$ DDAC, tomo VIII, p. 96.
} 
Esta tutela nacional a los derechos individuales hizo con que Lord Holland se mostrase decepcionado con el resultado del texto gaditano en las cartas que escribió. Este había acompañado con interés al proyecto de Constitución española y ansiaba encontrar en éste las libertades y derechos, pero como atributos individuales y no tutelados por la nación. Para Lord Holland, lo que Cádiz expresaba no eran más que principios de filosofía política, bajo la dirección de la nación. El constitucionalismo para este era mucho más como garantía de libertades y derechos que la afirmación del sujeto nacional ${ }^{166}$.

En el texto constitucional, artículo $1^{\circ}$, queda patentado el principio de la superioridad de la nación sobre el individuo: "La nación española es la reunión de todos los españoles de ambos hemisferios". La nación se asienta en la comunidad de éstos. En primer lugar se establece esta posición supraindividual de la nación, para luego después determinar quiénes serían estos individuos, los españoles. Lo que se hizo en el capítulo II del título I, artículo $5^{\circ}$ de la constitución: "Son españoles: Primero. Todos los hombres libres nacidos y avecindados en los dominios de las Españas, y los hijos de éstos. Segundo. Los extranjeros que hayan obtenido de las Cortes carta de naturaleza. Tercero. Los que sin ella lleven diez años de vecindad, ganada según la ley en cualquier pueblo de la Monarquía. Cuarto. Los libertos desde que adquieran la libertad en las Españas”.

Así que, los esclavos, aunque nacidos en los dominios de la corona no eran considerados ciudadanos, tampoco el género femenino, como se desprende del texto constitucional. Los libertos podrían recibir la ciudadanía si se hiciesen libres en las Españas y además demostrasen una vecindad que sería difícil de comprobar dado a la situación de cautividad. Estos temas suscitarán grandes debates entre los diputados en Cádiz en la Sesión de 31 de agosto de 1811.

El primero que se manifestó sobre el asunto fue Francisco Javier Borrull, secretario del Santo Oficio y diputado por Valencia. Este veía un problema conceder a los africanos la ciudadanía, puesto que a los demás extranjeros, hombres libres, se les pedían además diez años de vecindad. Así lo es, explica el diputado, "para que se conozca su amor a la nación y firme deseo de sujetarse a sus leyes". Pero pondera el diputado, "y por lo mismo no puede servir a un africano el acaso de lograr libertad en España; siendo así que son por naturaleza inconstantes; que tal vez habrá llegado pocos meses antes, y que no puede saberse en debida forma su constante animo y voluntad de sujetarse á nuestras leyes”. Al que contesta el diputado Jaime

\footnotetext{
166 “LLos procesos se hacen públicamente?, ¿los presos son juzgados sin dilación y cada uno tiene no solamente derechos, pero el medio cierto de aprovecharse de ello para ser juzgado si está acusado?, ¿para no pagar más que su porción?, ¿para apelar contra toda opresión de los magistrados, etc.? Tiene, sí, la ventaja de saber por ciertas frases y discursos que tales abusos son concebidos en las Cortes, pero del modo de evitarlos o de vindicarse de ellos no sabe ni se aprovecha más el individuo oprimido sea grande, sea general, sea ganadero que en tiempo de Godoy." Cartas de Lord Holland a persona desconocida apud PORTILLO VALDÉS, J. M.: Entre la monarquía y la nación..., op. cit., p. 154.
} 
Creus que añadiendo "libertos nacidos en España"167 quitaría todos los problemas de encima sobre esta cuestión espinosa.

Sobre esta cuestión Juan Gallego, diputado suplente por Zamora, opina que el punto central es la vecindad, y no mirar se ha nacido dentro o fuera de España dicho esclavo. Y añade:

"La qualidad de liberto es un nacimiento interpretativo; pues un esclavo en el momento que adquiere su libertad nace civilmente; y no bastando para los demás el nacimiento sino que han de tener también la vecindad, del mismo modo el liberto a quien se le supone nacido civilmente debe tener esta calidad."168

José Miguel Guridi Alcocer, diputado por Tlaxcala, considerado un liberal avanzado contrarrestaría estas prevenciones contra los africanos. Este, acostumbrado a ver de cerca la esclavitud, sabía que un esclavo no se liberaba de un día para la noche, además, por ser en sí mismo una "mercancía" muy valiosa. Cuanto llegaban a conseguir la manumisión "se supone haber adquirido los usos y costumbres de la nación a cuyos territorios ha venido, trayéndolo con violencia la nación misma". Por este último hecho, el diputado creía que sería "muy justo que ella le dé una patria adoptiva en su nacimiento civil cuando la despojó de la natural.""169

Otro diputado, un suplente americano, Blas Ostolaza, nacido en Perú (Trujillo), conocía el valor de la libertad, no sólo porque fue confesor del rey cautivo en Valençay, o por haber sido apresado por los franceses, sino porque pasó buena parte de su vida en Perú, y a suponer, conocía de cerca también la situación de la esclavitud. Este sugiere que el párrafo debe ser aprobado tal cual fue presentado, a la razón de que "el objetivo de la comisión es favorecer a la libertad". Pero, para el catedrático de la Universidad de San Marcos, el diputado Vicente Morales Duarez, también nacido en Perú (Lima), la cuestión estaba en que se entendiese la voluntad de la comisión como identificando a los libertos como nacidos en España y no a los africanos traídos en cautividad: "no se trata del africano, es decir del negro, sino de los hijos de estos, los quales han nacido en el suelo español, en su religión, con sus costumbres, y que no puede equivocarse con los extrageros."

Argüelles, siendo un tanto conciliador y concordando en parte con Gallego, dirá que realmente nacían civilmente los esclavos manumitidos en el día de su libertad, pero que sería indiferente: "aquí se prescindía de que se eran esclavos o hijos de esclavos, porque al cabo se ha tratado de aliviar la suerte infeliz de unos desdichados que no han tenido culpa de su

\footnotetext{
${ }^{167}$ Todas las citas de este párrafo se puede encontrar en DDAC, tomo VIII, pp. 101 y 102.

${ }^{168}$ DDAC, tomo VIII, p. 102.

${ }^{169}$ Idem, p. 102

${ }^{170}$ Todas las citas de este párrafo se encuentran en Idem, p. 102.
} 
desgracia"171. Además, añade el diputado, el numero de los libertos no son tantos y quien concede la carta de manumisión son las Cortes, de modo que se puede evaluar a quien se la concede, así que no veía problema de que en el acto mismo de la libertad el manumitido fuese considerado español.

Al final de tantas discusiones, el párrafo terminó por aprobarse tal y como fue presentado por la comisión; solamente hubo un cambio a propuesta del diputado por Lugo, José Ramón Becerra, de que se substituyese la expresión en España por en las Españas ${ }^{172}$. De este modo, sería poco probable que los libertos se librasen de la necesidad de probar su vecindad para conseguir la condición de español. Y al nacido en África, su condición de acceder a la ciudadanía se ponía en numerus clausus en la constitución ${ }^{173}$.

Venimos hablando de los derechos atribuidos a los españoles, y la definición de estos como sujetos de derechos bajo la protección de la nación. Si los derechos era algo sucinto, los deberes no lo eran. En la lectura del artículo sexto y demás artículos que componen al Capítulo intitulado "De los españoles", verificamos la fijación de unas virtudes sociales que ya aludimos cuando citamos a García Malo y su libro La Política natural. Estos sujetos nacionales deberían tener como virtud fundamental "el amor de la patria", y como principales obligaciones "ser justos y benéficos". Estas virtudes debían servir en el momento como un baluarte para lucha y conservación de la nación y para distanciarse moralmente de los pérfidos invasores, como dejó claro el diputado Terrero, al decir que un francés, aunque viviese diez años en territorio español no se le concedería la vecindad. El mismo diputado al considerar el artículo séptimo del proyecto y sexto de la constitución, en la Sesión del día 2 de septiembre de 1811, dijo que veía indecoroso tener que fijar por ley un sentimiento tan natural e inherente al hombre como el "amor por la patria", a que los filósofos llaman de innatas o casi innatas predisposiciones. Y añade: "Los irracionales, si pudiesen expresar sus afectos, nos reprenderían viendo que necesitamos poner por ley este sentimiento tan natural"174.

Tanto Villanueva como Capmany apoyan a Terrero en que este sentimiento fuera tan omnipresente que era innecesario y hasta ofensivo a los españoles fijarlo como una obligación legal. Pero, Anér les recuerda que no todos españoles se acordaron del "amor a la patria" y "han

\footnotetext{
${ }^{171}$ Ibidem, pp. 102 y 103.

${ }^{172}$ Ibidem, p. 103.

${ }^{173}$ Sobre esta discusión parlamentar y a cerca de la condición del liberto africano o descendente de éste, trata también PORTILLO VALDÉS, J. M.: Entre la monarquía y la nación..., op. cit., pp. 154 y ss. También CHUST, M. \& FRASQUET, I.: Problemática del liberalismo: la etnia y la raza en las independencias en Iberoamérica en CHUST, M. \& FRASQUET, I. (eds.): Los colores de las independencias iberoamericanas, liberalismo, etnia y raza, Consejo Superior de Investigaciones Científicas, Madrid, 2009, pp. 9 y ss.

${ }^{174}$ DDAC, tomo VIII, p. 107.
} 
abrazado el partido de nuestros enemigos"175. También obedecer a las leyes y respetar a las autoridades establecidas, contribuir con los gastos del Estado, y defender la patria con armas cuando sea llamado por la ley, comprendía el rol de deberes de los españoles para con la nación, era el vínculo indisoluble. En estos momentos de guerra y peligro de la nación, estos sentimientos debían ser rememorados y obligados por la ley, esto vinculaba el español a la nación y lo habilitaba como bastión contra los invasores franceses.

Sin embargo, estos deberes, no pasaron sin causar preocupación en algunos diputados, como a Pedro Inguanzo ${ }^{176}$ que veía la doctrina del artículo $7^{\circ}$ del proyecto como verdadera, pero adecuada a un catecismo político, no a un texto constitucional. Y agrega que esta imposición legal de "amor a la patria" podría tener mayor transcendencia de lo que se imagina,

"puede rozarse con la doctrina de aquellos filósofos que piensan que la sociedad puede existir sin religión, y que la potestad civil es suficiente para todo lo que conviene. Esto es falsísimo como todos conocen: es preciso confesar que la sociedad y la potestad que rige en ella necesita del socorro de la religión, que es la que manda en el corazón del hombre, y le inspira y ordena las virtudes más importantes á la sociedad, como el amor a la patria" 177 .

Estas doctrinas filosóficas, a que se refiere Inguanzo, según nos cuenta Portillo Valdés, harán posible una interpretación republicana que viniese a establecer otros tipos de vinculaciones entre los españoles con la monarquía o la religión. El diputado se preocupaba así con futuras lecturas que desencaminasen los fundamentos que se habían puesto en Cádiz ${ }^{178}$.

Hasta este punto hicimos una reconstitución de los hechos que precedieron a la Constitución gaditana y apreciamos en su articulado las ideas claves para la definición de la ciudadanía y las bases para el establecimiento de la confesionalidad del Estado. Esto, lo hemos hecho para comprendernos mejor los procesos constitucionales que se desarrollarán en Portugal y principalmente en Brasil en la década de los años veinte del siglo XIX. Pero nos resta ver aún las corrientes ideológicas que venimos haciendo referencias y que permearon al texto doceañista. Intentaremos, con cierta brevedad, a partir del siguiente epígrafe, trazar unas líneas en este sentido.

\footnotetext{
175 Ibidem, p. 108.

${ }^{176}$ Pedro Inguanzo y Rivero (1764-1836), diputado por el Principado de Asturias, y de un genuino pensamiento conservador de principios tradicionales.

${ }^{177}$ Ibidem, p. 109.

${ }^{178}$ PORTILLO VALDÉS, J. M.: Entre la monarquía y la nación..., op. cit., p. 155 y 156.
} 


\subsubsection{Corrientes ideológicas presentes en Cádiz: de la ilustración al liberalismo}

A finales del siglo XVIII, llegaron a España los mensajes claros de cómo debía ser la Revolución Constitucional y lo que esta representaría para los pueblos ${ }^{179}$. Tres documentos fueron claves para ello: la Declaración de Derechos de Virginia de $1776^{180}$, la Constitución del Estado de Massachusetts de $1780^{181}$ y la Declaración de Derechos del Hombre y del Ciudadano de $1789^{182}$.

Los textos citados traían claramente la necesidad de unos principios constitucionales ${ }^{183}$ perfectamente delimitados por la ley, de tal modo que pudieron proporcionar seguridad a los derechos individuales y una deseada división de poderes, para evitar así la tiranía y asegurar a dichos derechos ${ }^{184}$. En suma: "la Constitución en realidad eran los derechos de los individuos, mientras que la separación de poderes era la forma más conveniente de gobierno para asegurar su garantía" 185 . Además de todo, la Déclaration des Droits de l'homme et du Citoyen de $1793^{186}$, trae en el artículo segundo una clara enumeración de los derechos: "Estos derechos son la igualdad, la libertad, la seguridad, la propiedad", lo que coincide en parte con los derechos que encontraremos algo después en los escritos de Valentín de Foronda. Así, volvemos a reafirmar que la declaración de derechos era la garantía contra el arbitrio del poder, y la separación de éste era la seguridad y la garantía de los mismos; "para defender y asegurar sus antiguos derechos y libertades", dirá el documento de los Lores ingleses ${ }^{187}$. La seña para llegar a esto vino del Bill of Rights inglés de 1689, manifestando que este será el instrumento que

\footnotetext{
${ }^{179}$ Sobre la ilustración liberal en el constitucionalismo del siglo XVIII, además de los proyectos constitucionales ya en la etapa juntista se puede ampliar más en este sentido en FERNÁNDEZ SARASOLA, I.: Proyectos constitucionales en España (1786-1824), Madrid, C.E.P.C, 2004, pp. 3-92.

${ }^{180}$ DECLARACIÓN DE DERECHOS DE VIRGINIA, 1776: Art. 1 - "Que todos los hombres son, por naturaleza, igualmente libres e independientes, y que tienen ciertos derechos inherentes de los que, cuando se organizan en sociedad, no pueden ellos ni su posteridad ser despojados ni privados por ninguna especie de contrato, a saber: el goce de la vida y de la libertad, con los medios de adquirir y poseer la propiedad y perseguir y obtener la felicidad y la seguridad".

${ }^{181}$ CONSTITUCIÓN DEL ESTADO DE MASSACHUSETTS, 1780: "El objeto de la creación, mantenimiento y administración del Gobierno es asegurarla existencia de la sociedad, protegerla y proporcionar a los individuos que la componen la facultad de disfrutar, con seguridad y tranquilidad, sus derechos naturales y las bendiciones de la vida; y cuando no se alcanzan estos grandes propósitos el pueblo tiene derecho a cambiar el gobierno y a tomar las medidas necesarias para su seguridad, prosperidad y felicidad".

${ }^{182}$ DECLARACIÓN DE DERECHOS DEL HOMBRE Y EL CIUDADANO, 1789: "Artículo 16.- Toda sociedad en la cual no esté establecida la garantía de los derechos, ni determinada la separación de los poderes, carece de Constitución.

${ }^{183}$ Maurizio Fioravanti aclara más sobre el constitucionalismo moderno en FIORAVANTI, M.: Constitución. De la Antigüedad a nuestros días, Madrid, Editora Trotta, 2001, pp. 71-146.

${ }^{184}$ Sobre el constitucionalismo y sus definiciones tipológicas, y las herencias del constitucionalismo medieval y el desarrollo del Estado absoluto, se puede leer más en MATTEUCCI, Nicola: Organización del Poder y Libertad. Historia del constitucionalismo moderno (presentación de Bartolomé Clavero), Madrid, Editora Trotta, 1998, pp. 23-43.

${ }^{185}$ PORTILLO VALDÉS, J. M.: Entre la monarquía y la nación..., op. cit., p. 138.

${ }^{186}$ Sobre el constitucionalismo francés se puede profundar más en MATTEUCCI, N.: op. cit., pp. 259 y ss.

${ }^{187}$ Preámbulo de la Bill of Rights inglesa de 1688.
} 
“impedirá, en lo sucesivo, la violación de los derechos y libertades antes enumerados, así como cualquier otro ataque contra la religión, derechos y libertades" ${ }^{\prime 188}$.

En aquellos instrumentos estaba la voluntad, presente en las revoluciones del mundo contemporáneo contra el despotismo, de fijar claramente los derechos y de imponer fuertemente, a través de un gobierno que fuese conveniente, la manutención de los mismos. Pero, algo mucho más elemental, "el quásar" de todo esto era el reconocimiento del individuo como tal. Este elemento sería la pieza fundamental en todo este proceso, de modo que influiría en la concepción misma de la sociedad moderna. A partir de la declaración de que este individuo era amo y señor de su conciencia y de su cuerpo, estarían sentadas las bases para la consecución de los demás derechos que les son inherentes ${ }^{189}$. Entretanto, no hay que pensar que el sujeto individual de derechos, presente en las sociedades euroamericanas de finales del siglo XVIII y principios del siglo XIX comprendía a la universalidad de la sociedad. Lejos de eso. Este sujeto debía traer determinadas características, implícitas o explícitas a la época, tales como la raza, el sexo, cultura y condición social, además de ciertas características religiosas. Era el hombre blanco de cultura cristiana europea, matizado en la sociedad católica o protestante, quien era digno de estos derechos. Tampoco, aunque se encajase en el término "hombre", de la declaración francesa, ostentando apenas la suficiente condición humana, era bastante para ser poseedor de derechos civiles y políticos. Es en este preciso momento, además, que el término ciudadano servirá de motivo de exclusión. Puesto que la Constitución Francesa de $1791^{190}$ traerá el concepto de la double citoyenneté, en donde unos gozarían de derechos políticos y otros de apenas derechos civiles (esto lo comentaremos en los capítulos siguientes de este trabajo). Así que, ni las expresiones "the good people of Virginia" o "we the people of Massachusetts", tampoco la "Nation française" correspondían a la totalidad de la sociedad" ${ }^{191}$. Más bien se identificaban con los individuos relacionados a la cultura cristiana y europea. Y era

\footnotetext{
${ }^{188}$ Parte final de la Bill of Rights inglesa de 1688. Sobre las guerras civiles en Inglaterra y el régimen parlamentario después de la Gloriosa Revolución se puede leer más en MATTEUCCI, N.: op. cit., pp. 79-161.

189 "De ahí se deducirían otros principios, igualmente interesantes y transcendentes: que la soberanía de uno sobre sí mismo implicaba también la colectiva de la sociedad, que quien es dueño de su persona puede desarrollar la conciencia religiosa y política que desee, que puede así mismo poseer absolutamente otras cosas, que siendo cualquiera soberano de sí mismo se establecía una igualdad jurídica. De aquí se deducía ya un torrente de medidas político constitucionales que caracterizan a estas revoluciones: supresión de los privilegios y obligación recíproca e igual respecto de la ley, libertad de pensamiento y emisión del mismo, libertad política de los ciudadanos, derecho de propiedad, garantías procesales.” Idem, p. 138.

${ }^{190}$ En el Titulo III, Cap. I, Sección II, en los artículos $2^{\circ}$ y $5^{\circ}$ de la Constitución francesa de 1791, viene definiendo al ciudadano activo: Art. $2^{\circ}$ - Para ser ciudadano activo es necesario... Art. $5^{\circ}$ - Están excluidos del exercício de los derechos de ciudadanos activos... Constitución Francesa (por D. Miguel de Burgos), Decretada por la Asamblea Constituyente en los años de 1789, 1790 y 1791; Aceptada por el rey en 14 de setiembre de 1791, Madrid, 1814, pp. 21 y 22.

${ }^{191}$ Para saber más sobre el constitucionalismo americano se puede buscar más información en MATTEUCCI, N.: op. cit., pp. 161-217. Además de APARISI MIRALLES, A.: La Revolución Norteamericana. Aproximación a sus orígenes ideológicas, Madrid, BOE/CEC, 1995, pp. 247 y ss.
} 
precisamente a estos a quienes se dirigían dichas constituciones y declaraciones de derechos ${ }^{192}$. Al final, las nociones de "pueblo" y "nación" se tornaron una realidad muy excluyente, y a las cuales se asociaban a las concepciones mismas de individuo y derechos ${ }^{193}$.

Muchas de estas ideas llegaron a España a través de los autores ilustrados, que o bien traducirán al castellano obras de otros países o bien con base en estas redactarán sus propios escritos sobre el asunto ${ }^{194}$. Un ejemplo de esto es el pensamiento del napolitano Gaetano Filangieri, que ya estaba bastante difundido entre los ilustrados españoles, así como entre los intelectuales europeos y americanos en general. En la Scienza della legislazione, traducida a principios de los años ochenta del siglo XVIII al castellano por Victorián de Villava, Filangieri proponía una revisión de los postulados de la obra de filosofía política muy apreciada por los ilustrado de entonces, L'Esprit des lois de Montesquieu ${ }^{195}$. Filangieri y Montesquieu, por supuesto no fueron coetáneos, pero las ideas del Barón alcanzaron al famoso jurista de la corte de Carlos III de Borbón. El jurista napolitano era un admirador del constitucionalismo de Norteamérica. Este creía que aquél era un modelo de palanca para una amplia reforma legislativa para poder ir corrigiendo la política de las monarquías europeas, proceso este gradual sin los traumas de las revoluciones, como pudo ser la francesa; aunque éste muriese de tuberculosis un año antes de la Revolución Francesa, a la edad de 35 años ${ }^{196}$. Filangieri proponía que se reconociera y salvaguardase a los derechos, que se distinguiera a los poderes e instituciones, que se hiciera una reforma legislativa en asuntos esenciales de comercio, guerra,

\footnotetext{
192 Sobre los principios constitucionales, la relación entre el individuo y el Estado, se puede saber más en CLAVERO, B.: Happy Constitution. Cultura y lengua constitucionales, Valladolid, Editora Trotta, 1997, pp. 1129.

${ }^{193}$ Idem, p. 139 y ss. Los citados textos constitucionales corresponden a los tres modelos constitucionales que nos informa MATTEUCCI, N.: op. cit., pp. 285 y ss. Además, los modelos constitucionales incidentes en el constitucionalismo del siglo XIX, descritos por Fioravanti como los modelos: historicista, individualista y estatalista, se puede encontrar en FIORAVANTI, Maurizio: Los Derechos Fundamentales. Apuntes de la historia de las constituciones, Valladolid, Editora Trotta, 1996, pp. 25-46.

${ }^{194}$ Sobre la ilustración en España se puede leer más en MARTÍNEZ NEIRA, M.: La ilustración (jurídica) española en PECES-BARBA MARTÍNEZ, G., FERNÁNDEZ GARCÍA, E. \& DE ASÍS ROIG, R. (dirs.): Historia de los Derechos Fundamentales, Tomo II: Siglo XVIII, Volumen I, Madrid, Jacaryan S.A., 2001, pp. 381 y ss. Además de GONZÁLEZ ALONZO, B.: Las raíces ilustradas del ideario administrativo del moderantismo español en CAPPELINI, P. (et ali): De la Ilustración al Liberalismo. Symposium en honor al profesor Paolo Grossi, Madrid, Centro de Estudios Constitucionales, 1995, pp. 197-298.

${ }^{195}$ Aquí tomamos nota y seguimos a Portillo Valdés, en cuanto a la traducción de Victorián de Villava, aunque la traducción a la que tuvimos acceso fue la de Jaime Rubio, abogado de los Reales Consejos, edición de 1822. Sobre la traducción de Victorián de Villava de las obras de Gaetano Filangieri, escribió Jesús Astigarra Goenaga: Victorián de Villava, traductor de Gaetano Filangieri, Cuadernos Aragoneses de Economía, Año 1997, Vol. 7 , Numero 1, ISSN 0211-0865, pp. 171-186. Este autor analiza la primera traducción parcial al castellano de la obra de Filangieri, donde, Villava atribuía un contenido doctrinal a un liberalismo afín al fisiócrata. Aquí también se analiza la introducción de las ideas económicas de Filangieri en España, que formaba parte de un programa más amplio de traducciones de textos extranjeros, configurando la ilustración de la época.

196 "Si se hubiera demostrado solamente á los soberanos que la Legislación merecía una reforma, sin duda si hubiera adelantado mucho para la felicidad de los pueblos." FILANGIERI, G.: Ciencia de la Legislación, (Traducción Jaime Rubio, abogado de los Reales Consejos), Tercera Edición, Tomo I, Imprenta de Nuñez, Madrid, 1822, p. IV.
} 
justicia y educación ${ }^{197}$. Además de todo, en el tomo X de la traducción al castellano, teje todo un tratado sobre la religión, que comentaremos en el capítulo siguiente.

El traductor pionero de Filangieri, pretendía suministrar las ideas para una reforma de la monarquía, pues así se trataba de evitar el terror jacobino de 1792. Villava, escribió su obra, Apuntes para una reforma de España sin perjuicio de la monarquía ni de la religión (1797), como una alternativa de reformas que permitieran conservar lo esencial de la monarquía a la vez que satisfacía a las aspiraciones de reformas políticas, de moda en este período. Villava, nos cuenta Portillo Valdés, no fue el único autor en las últimas dos décadas del siglo XVIII en plantear reformas en la monarquía en una especie de revolución feliz y pacífica, lejos del terror jacobino. Y dentro de un proyecto amplio en la Cátedra de Huesca, Villava y otros autores, buscaban alcanzar una constitución a través del estudio de la economía política ${ }^{198}$. De este modo, traduce a otro autor italiano, catedrático ordinario de Filosofía Moral de la Universidad de Nápoles y posteriormente catedrático extraordinario y regio de la Cátedra de Economía y Comercio, Antonio Genovesi, que escribió Lezione di Commercio ${ }^{199}$. Otra obra que también buscaba esclarecer al público español fue: Lecciones de economía civil (1779), que trae una inusitada propuesta de "felicidad pública"200. Nos dirá Valdés que, "la creación en la década siguiente de la primera cátedra de economía política en Zaragoza, regentada por Lorenzo Normante, y su difusión en la Academia de Jurisprudencia de Salamanca por Ramón Salas, son indicativos del interés que le prestaban los intelectuales españoles de los años ochenta y noventa" ${ }^{201}$. Así que estas obras conformaron el ideario de la ilustración española a finales del

\footnotetext{
197 "Si para Montesquieu a mediados de siglo el modelo había sido la constitución inglesa, para Filangieri en los años ochenta lo era la constitución de Pennsylvania. Alcanzar ese estadio de desarrollo político sin pasar por el trastorno de una revolución violenta era lo que denominó una 'revolución pacífica .” PORTILLO VALDÉS, J. M.: Entre la monarquía y la nación..., op. cit., p. 131.

${ }^{198}$ En el discurso preliminar de la obra el traductor, trae la siguiente justificativa: "Con el fin único que me he propuesto en la traducción de la Obra, ha sido en concurrir en cuanto pueda a la instrucción de mis nacionales en materia de Economía Política". GENOVESI, A.: Lecciones de comercio, ó bien de economía civil, (Traducido por Victorian de Villava, Colegial del Mayor de San Vicente Mártir de la Universidad de Huesca, y Catedrático de Código de la misma), Tomo I, Por Joachín Ibarra, Impreso de Camara de S.M., Madrid, 1785, p. XIX.

${ }^{199}$ Villava resume así la obra de Antonio Genovesi: "Introduce en su Obra generalizando con admirable perspicacia, hasta subir al descubrimiento del natural principio, origen y manantial de los varios ramos, que abraza la política económica, á saber es, la natural formación y constitución de la sociedad de los hombres, á fin de constituir cada sociedad un estado á parte, ó como él dice, un cuerpo político. Es admirable la sagacidad con que descubre y desentraña todas y cada una de las causas naturales y principios, que llevan los hombres por si mismos á esa sociedad y unión de cuerpo, y también todo lo que naturalmente concurre para modificar diversamente tales sociedades". Ibidem, p. VI.

${ }^{200}$ Tanto los comentarios sobre las traducciones de Victorián de Villava como los de Bernardo Danvila se puede encontrar en PORTILLO VALDÉS, J. M.: Entre la monarquía y la nación..., pp. 131 y 132.

${ }^{201}$ Ibidem, p. 132. También se puede leer sobre el trato que estos temas tuvo en las universidades en PESET, Mariano: Universidad y liberalismo en España y América Latina, pp. 17-48; además se puede buscar más informaciones en ROBLEDO, Ricardo: Tradición e Ilustración en la Universidad de Salamanca: sobre los orígenes intelectuales de los primeros liberales, pp. 49-80; tanto un capitulo como el otro se encuentra en ROBLEDO, R.: Orígenes del Liberalismo..., op. cit.
} 
siglo XVIII, lo que reflejará en las proposiciones liberales dentro de las Cortes constituyentes establecidas en la ciudad de Cádiz.

La optimización en cuestiones administrativas y de gobierno, lleva a diversos pensadores de la España de finales del siglo XVIII a interesarse por economía política, con el fin último, como ya lo decimos, de buscar la felicidad pública ${ }^{202}$. Entre los autores que escribieron sobre el asunto está Valentín de Foronda. En las Cartas sobre los asuntos más exquisitos de la economía política, Foronda trae una serie de consejos de cómo lidiar con asuntos tales como comercio, fiscalidad, el tráfico colonial o el fomento de la agricultura. Estas cartas están dirigidas a un amigo, pero su objetivo primordial es el Rey Carlos IV, que había comenzado su reinado en $1788^{203}$. Así que, para Foronda existían ciertos pilares sólidos para una sociedad: los derechos de propiedad, libertad y seguridad (que) serían los tres manantiales de la felicidad de todos los Estados. Porque del contrario, sigue Foronda, observando la faz de la tierra y las sociedades, no se veía más que una nube de leyes atroces, una masa impenetrable de leyes sumarias, un grupo formidable de ordenanzas disparatadas para el fomento de las artes, de la industria y del comercio, y un tropel de políticos económicos, afanados en fundir y refundir reglamentos, sin poder conseguir sus loables intensiones, y todo porque se separan de los tres sagrados principios que dexo insinuados.

Así pensaba Foronda en la primera edición de sus cartas. Sin embargo, en la edición tercera de 1821, a los tres manantiales de felicidad, el autor añade un más, la igualdad. Y en esta edición define a estos cuatro pilares de la felicidad ${ }^{204}$. Además, sigue el autor hablando que en la base de estos principios estarían los aciertos de los gobiernos, ellos son los elementos de las leyes, y que el "Monarca de la naturaleza” escribió sobre los hombres, sobre sus órganos y entendimientos. De forma que no ha escrito sobre "débiles pergaminos", tales principios. Y que por lo tanto no podrían ser despreciados por las supersticiones o la tiranía.

202 ALMENAR, Salvador: Economía política y liberalismo en España. De Jovellanos a la Gloriosa en ROBLEDO, R.: Orígenes del Liberalismo..., op. cit., 81 y ss.

203 "Lo primero que aconsejo a Vmd. es que reconcentre toda su atención para penetrarse de la verdad más importante, qual es que los derechos de propiedad, libertad y seguridad son los tres manantiales de la felicidad de todos los Estados. No lo dude Vmd. dulce amigo, estos tres principios son en toda clase de gobiernos lo que las palancas en la mecánica, ó lo que las leyes de la atracción, descubiertas por el gran Neuton, en la astronomía”. FORONDA, Valentín de: Cartas sobre los asuntos más exquisitos de la economía-política y sobre las leyes criminales, Tomo I, En la Imprenta de Manuel González, Madrid, 1789, p. 5 y 6.

204 "Por derecho de propiedad entiendo aquella prerrogativa concedida al hombre por el Autor de la naturaleza, de ser dueño de su persona, de su industria, de sus talentos, de los frutos que logre por sus tareas. Por el derecho de libertad entiendo la facultad de usar como uno quiera de los bienes adquiridos, y de hacer todo aquello que no vulnere la propiedad, la libertad, la seguridad é igualdad de los demás hombres. Por el derecho de seguridad entiendo que no puede haber fuerza ninguna que me oprima por ningún título, y que jamás puedo ser víctima del capricho ó del rencor del que gobierna. Por el derecho de igualdad entiendo que deben repartirse entre todos los ciudadanos tanto las ventajas como los gravámenes." FORONDA, V.: Cartas sobre los asuntos más exquisitos de la economía-política y sobre las leyes criminales, Tomo I, Tercera Edición (Ediciones anteriores, 1789 y 1794), Imprenta de Ramón Domingo, Pamplona, 1821, pp. 6 y 7. 
También Manuel de Aguirre, que escribió Cartas y discursos del Militar Ingenuo, estaba conectado con estas nuevas ideas y pensamientos de la ilustración. Admirador, como Filangieri, del constitucionalismo norteamericano, y además, proponía un complejo conjunto de propuestas de reforma legislativa, para una mejor ordenación territorial, de la propia religión, del estatuto de la propiedad o mismo de la fiscalidad. Estas reformas, según la visión de Aguirre, solamente serían factibles por medio de una constitución ${ }^{205}$.

Este ambiente ilustrado pudo desarrollarse en el reinado de Carlos IV y de su Valido, Godoy. Fue una relación de acuerdo a los intereses dinásticos, así que el trato con el gobierno y la monarquía fue siempre pendular. Y según la opinión de Valdés, fue este ambiente a veces propicio el que allanó el camino de los ilustrados para propagar sus ideas, aunque la revolución jacobina de 1792 estuviese aún presente en la memoria de todos; por tanto, estas ideas podrían ser tachadas de subversivas e incoherentes con la monarquía ${ }^{206}$. De acuerdo al momento, el movimiento ilustrado pudo, acorde con la política editorial, publicar obras que buscasen promover la reforma del sistema de gobierno monárquico. Aunque se buscó impedir tales publicaciones, salieron a la luz textos sobre regalismo, o mismo los que podrían ser tachados de subversivos, pudieron, circular en forma de manuscritos, o fueron publicados en el extranjero $^{207}$.

El movimiento ilustrado intensificó sus actividades bajo el gobierno de Godoy, que como vimos soplaba en favor o en contra de este movimiento de acuerdo a sus intereses, pero nunca lo proscribió en absoluto. Quizás porque los pensadores de la ilustración española estaban de acuerdo con dos presupuestos básicos: aportar bases legislativas para alejar al despotismo, a la vez que con estas reformas evitarían la revolución radical, puesto que, estaba presente en las mentes de todos en aquellos momento, como ya lo dijimos, las acciones de los jacobinos en Francia. Por este justo motivo, Valentín de Foronda propugnaba, como vimos, un sistema de seguridad jurídica, en donde derechos basilares para la estabilidad de la sociedad, como propiedad, seguridad, libertad e igualdad, no deberían de faltar en la organización de la monarquía. De esta forma se conectaría el gobierno con la sociedad, alejándole de la tiranía y de la decadencia por las malas prácticas legislativas. Pero, Portillo opina que estas ideas no van a tener cabida hasta el desarrollo de la crisis dinástica que se produjo a principios del siglo XIX

\footnotetext{
${ }^{205}$ PORTILLO, VALDÉS, J. M.: Entre la monarquía y la nación..., op. cit., pp. 132 y ss.

${ }^{206}$ Idem, p. 132. Además, Portillo Valdés, citando a Emilio la Parra, va a decir que la imagen simple y estereotipada de Manuel Godoy estaría muy lejos de la realidad, habiendo muchas etapas, favorables o menos favorables, de acuerdo a los intereses del Valido y del monarca.

207 "León de Arroyal, José Marchena, Victorián de Villava, Miguel Rubín de Celis, Alejandro Malaspina, Francisco Cabarrús, entre otros escribieron en los años noventa textos de distinto tipo - cartas, memoriales, libros - en los que el denominador común es la propuesta de la necesidad de la constitución como contenedor de las reformas que la monarquía precisaba." Ibidem, p. 133.
} 
en España, la cual ya comentamos. Pero, cuando se presentó la oportunidad, estas ideas confluirán hacía el texto de la Constitución de 1812.

El liberalismo doceañista, dirá Veiga Alonso, resultó de un crisol de conceptos y lenguajes que vienen de la ilustración y del iusracionalismo europeo, procedentes de autores como Locke, Montesquieu, Sièyes, Rousseau etc. Pero, todo este crisol de corrientes ideológicas y doctrinas estarán matizadas por las experiencias constitucionales llevadas a cabo en Norteamérica y en Francia. Los diputados y muchos pensadores de la ilustración española entran en contacto con estos preceptos constitucionales e ideas. Sin embargo, debemos añadir a lo antes señalado el momento histórico por el que pasaba España, huérfana y en guerra contra el invasor francés. Y no hay que olvidar las prácticas revolucionarias que se llevaron a cabo en este período que desembocó en una toma de la soberanía por la nación y las matizaciones a ésta, como previamente hemos expuesto: la nación como un sujeto supraindividual y intolerante religiosamente. Debemos destacar también en este texto constitucional una rígida división de poderes, en donde un legislativo unicameral asume relevancia frente a una monarquía limitada en sus poderes. Por estas y otras particularidades el texto gaditano pudo adaptarse al momento en que fuera hecho, alejándose en muchos aspectos del texto que la inspiró: la Carta francesa de $1791^{208}$.

Para allá de la afirmación de Artola en su libro Los afrancesados, que la ilustración no dejo huella en España, lo expuesto en las líneas precedentes deja entrever que la ilustración no solo tocó tierra en España como reverberó en los escritos de muchos pensadores españoles, aunque quepan matizaciones en esta afirmación.

La ilustración, para John Gilissen, fue el momento en que la Europa era francesa por la cultura, artes, letras y filosofía. Fue el siglo XVIII llamado el "Siglo de las Luces" (Aufklárung). Así que los escritores de este período infundieron su influencia en los pensadores tanto del siglo XIX como del XX. Ideas como soberanía de la nación, la separación de poderes, la preponderancia de la ley, la legalidad de las infracciones y de las penas, los derechos del hombre, los derechos naturales y subjetivos inalienables, van a corporificarse en el siglo XVIII. Estas ideas serán la expresión, para Gilissen, del liberalismo naciente y dominarán la concepción misma del derecho y del Estado ${ }^{209}$. Dirá el mismo autor que se debe al

\footnotetext{
208 VEIGA ALONSO, X. R.: As familias políticas no liberalismo decimonónico español, 1808-1868 en BARREIRO FERNÁNDEZ, X. R.: O liberalismo nos seus contextos. Um estado da cuestión, Publicacións da Cátedra Juana de Vega, Santiago de Compostela, 2008, p. 144 y SS.

209 “O Bill of Rigths em Inglaterra em 1689, as constituições dos Estados americanos em 1776-1777, a constituição federal dos Estados Unidos em 1787, a Declaração francesa dos Direitos do Homem e as constituições da época da Revolução (1791, 1793, 1795), actos legislativos ainda hoje em vigor directa ou indirectamente, transpuseram estas idéias políticas e filosóficas para a realidade jurídica. Entre os numerosos pensadores que contribuíram para a
} 
jusnaturalismo la autoridad atribuida a la autonomía de la voluntad, pues de ahí viene el concepto de laicización del derecho, su concepción racional y universal. Así que para los jusnaturalistas es el derecho que rige la sociedad civil, desvinculado de la religión. Francisco Suárez, defendía que el libre arbitrio era el fundamento de las relaciones contractuales y la regla del pacta sunt servanda, la base de todo derecho natural. Grocio desarrollará aún más esta regla, ampliándola y aplicándola no solamente en las relaciones entre individuos como en las relaciones entre naciones. Es el naciente derecho de las gentes basado en el respecto a los tratados. La voluntad es soberana, afirma Gilissen. Pufendorf afirma que el hombre es la fuente de la autoridad y del derecho. Estas ideas se cuajaran en el siglo XVIII en un sistema general de filosofía política y social, aún más para los fisiócratas. El contrato social de Rousseau se funda en la autonomía absoluta de la voluntad del individuo. "Está aquí toda la autonomía individual originaria que la Revolución Francesa retomará y consagrará en las leyes de su período intermedio $^{210}$.

Para Gilissen, los juristas del siglo XVIII no acompañan la evolución de la teoría sobre la autonomía del individuo de los filósofos, que solo fue desarrollada por aquéllos en el siglo XIX; precisamente fueron los juristas de la Escuela Exegética. Es en este momento que las leyes van a beneficiarse de las concepciones políticas y económicas, y en donde nociones tales como individualismo y liberalismo tendrán cabida. "Las fórmulas laissez faire, laissez passer y la ley de la oferta y procura reposan esencialmente sobre la libertad contractual" ${ }^{211}$. Esta era, para Gilissen, la regla de oro de la libertad absoluta de la convención entre las partes.

A este respeto, Cloude Morange nos trae una serie de cuestiones sobre como estas ideas permearon el ambiente ilustrado español y posteriormente al pensamiento liberal doceañista. Él se pregunta: "A qué nos referimos al hablar de Ilustración: Montesquieu, a Rousseau, a Locke, a Smith, a Kant o a Condorcet? ¿O, mucho más imprecisamente, a un conjunto de ideas y actitudes vitales: la razón y la experiencia contra la autoridad y la tradición; el espíritu crítico contra las supersticiones; las tolerancias contra el fanatismo; la fe en el progreso, etc., esto es, un denominador común entre un haz de corrientes a menudo contradictorias?” Además, como bien pontea Roberto Breña ${ }^{212}$, en el ámbito del crisol de ideas interrelacionadas entre sí en las Cortes Constituyentes de Cádiz, Morange vuelve a cuestionarse: "En cuanto al liberalismo, si lo

eclosão das idéias novas, quatro pelo menos exerceram uma influência duradoura sobre o direito dos séculos XIX e XX: Locke, Montesquieu, Rousseau e Beccaria.” GILISSEN, John: Introdução histórica ao Direito, $6^{\circ}$ Ediçao, Fundaçao Calouste Gulbenkian, Serviços de Eduaçao e Bolsas, Lisboa, 2011, p. 336 y 337.

${ }^{210}$ Ibidem, pp. 736 y ss.

${ }^{211}$ Ibidem, p. 738.

${ }^{212}$ BREÑA, R.: El primer liberalismo español y los procesos de emancipación de América, 1808-1824 (Una revisión historiográfica del liberalismo hispánico), El Colegio de México, México D.F, 2006, p. 176 y ss. 
consideramos también como un impreciso corpus de ideas generosas, una aspiración a más libertad, más civilización, etc., ¿es compatible esta afirmación con la que lo presenta como una ruptura con el Antiguo Régimen?", o mismo "siendo la ilustración una cultura más que una ideología, y la revolución liberal ante todo un proceso político, ¿no estamos comparando dos realidades heterogéneas?" 213 También alerta el mismo autor para que no se confunda liberalismo económico con liberalismo político.

Así que hay varias cuestiones sobre la ilustración y el liberalismo que se cultivará en España del siglo XVIII e inicios del siglo XIX. Roberto Breña analizado a Morange nos dice que este autor se cuestiona sobre la supuesta continuidad entre la Ilustración y el liberalismo, pero, deja trasparecer que hay claras persistencias de temas y palabras de la Ilustración en el primer liberalismo español ${ }^{214}$. Además, el propio Morange carga contra la idea de un preliberalismo en España, que sería fruto de una idea de linealidad temporal de la historia, en donde habría "una especie de armonioso crescendo hacia una meta predeterminada"215. Así que para este autor, aunque el liberalismo no hubiese nacido adulto en España, este tuvo que ir conformándose sobre la marcha de los acontecimientos de 1808, y en medio a múltiples contradicciones $^{216}$. De este modo, hay que matizar al liberalismo hispánico en su ambiente y en el momento que tuvo preponderancia histórica ${ }^{217}$. En este sentido, el profesor Breña buscó hacer una discusión historiográfica sobre la continuidad o discontinuidad entre la Ilustración y el liberalismo en España ${ }^{218}$.

Dentro de esta discusión historiográfica, Maravall es uno de los que aboga por una pretensa continuidad entre una y otra corriente ideológica. Pues este autor llega a afirmar que en el ambiente ilustrado en el reinado de Carlos III, existían autores para los cuales la libertad se constituía como algo primordial, originario y amplio, mientras que la propia autoridad del

\footnotetext{
${ }^{213}$ MORANGE, Cloude: Sobre la filiación Ilustración-Liberalismo (preguntas para un debate) en ROBLEDO, CASTELLS y ROMEO (eds.): Orígenes del liberalismo. Universidad, política y economía, Ediciones de la Universidad de Salamanca/Junta de Castilla y León, Salamanca, 2003, p. 248

${ }^{214}$ BREÑA, R.: op. cit., p. 177.

${ }^{215}$ MORANGE, C.: op. cit., p. 249.

216 "La 'revolución` no fue ni el producto mecánico de un agotamiento de la sociedad estamental ni la consecuencia de los acontecimientos internacionales. Fue las dos cosas a un tiempo. Tan erróneo sería considerarla como la conclusión esperada y preparada de un proceso secular, como creer que el choque de la invasión engendró de repente en los españoles una conciencia revolucionaria y el brusco deseo de crear un nuevo ordenamiento institucional. Pero, eso sí, 1808 creó una dinámica de imprevistas consecuencias.” Ibidem, p. 252.

${ }^{217}$ El tema de la soberanía popular parece una barrera insuperable entre liberales e ilustrados, pero no quiere decir que algunos ilustrados no la defendiesen, aunque sus posturas fuesen minoritaria en esta corriente ideológica. Autor como Foronda, Cabarrús, Arroyal, Cañuelo, Quintana e Ibáñez de la Rentería defendieron la postura de una soberanía nacional y de una constitución en el sentido moderno del término. VARELA SUANZES-CARPEGNA, J.: La Constitución de Cádiz y el liberalismo español del siglo XIX, Revista de las Cortes Generales, núm. 10, enero-abril de 1987, p. 47.

${ }^{218}$ BREÑA, R.: op. cit., p. 175 a 189.
} 
monarca se reducía a algo secundario, derivado y parcial. Estas propuestas radicales contradicen al pensamiento de algunos autores de que en España imperó solamente el moderantismo ${ }^{219}$. Además, este mismo autor irá atribuir al despotismo ilustrado como una ideología de acción que tenía cabida en el cambio de la estructura de la sociedad ${ }^{220}$.

Otro autor que refuerza la idea de que hay una relación secuencial entre ilustración y liberalismo es Elorza. Este autor además atribuí a los ilustrados españoles la insignia de primer liberalismo, y ver como indiscutible la relación de continuidad entre una y otra corriente ideológica $^{221}$. Contrariamente a Maravall y Elorza, Dufour veía irreconciliable la relación entre ilustrados y liberales ${ }^{222}$. En donde los primeros, por su visión elitista buscaban un gobierno fundado en una minoría, mientras que para los segundos el gobierno debería ser la expresión de la voluntad nacional. Pero, este antagonismo tiene matices. Observa Dufour que estas dos corrientes ideológicas se mostraban indisociables se orientada desde la óptica de los conservadores, sobre todo de los eclesiásticos ${ }^{223}$. Además, este autor ver puntos en común defendidos por ilustrados y liberales, tales como: la disolución del Tribunal del santo oficio, la libertad de imprenta, desamortizaciones etc.

Cuanto al tema de la soberanía popular, Dufour veía un punto de alejamiento entre una y otra corriente; pues, para los liberales esta era lo que fundamentaba la igualdad entre los hombres, mientras que para los ilustrados, de concepción elitista, no veía con buenos ojos a este principio $^{224}$. Sin embargo, no quiere decir que muchos de los autores ilustrados españoles no defendiesen este principio en sus escritos ${ }^{225}$. Así que no resulta tan maniquea las dos corrientes en si tratando de la soberanía nacional ${ }^{226}$. También le parece a Sarrailh que la continuidad es

\footnotetext{
${ }^{219}$ Se puede encontrar esta afirmación en MARAVALL, J. A.: La fórmula política del despotismo ilustrado en IGLESIAS, C. (ed.): Estudios de la historia del pensamiento español, siglo. XVIII, Mondadori, Madrid, 1991, pp. 61 a 81. También comenta este asunto, bajo las afirmaciones de Maravall, BREÑA, R.: op. cit., p. 177.

${ }^{220}$ MARAVALL, J. A.: op. cit., p. 450.

${ }^{221}$ ELORZA, A.: La formación del liberalismo en España en VALLESPÍN, F. (ed.): Historia de la Teoría Política, III, Alianza Editorial, Madrid, 1995, p. 405.

${ }^{222}$ Roberto Breña es de opinión que "los trabajos de Maravall y de Elorza muestran que en el siglo XVIII hubo propuestas sociopolíticas que fueron más allá de los esquemas ideológicos de la Ilustración”. BREÑA, R.: op. cit., p. 180.

${ }^{223}$ DUFOUR, G.: De la Ilustración al Liberalismo en ALBEROLA Y LA PARRA (eds.): La ilustración española, Instituto Juan Gil-Albert/Diputación Provincial de Alicante, Alicante, 1986, p. 366 y ss.

224 "El principio doctrinal de la soberanía nacional implica la diferencia más notable entre la Ilustración y el liberalismo: para la primera, el poder real era el centro y origen de todas las decisiones reformadoras; para el segundo, las decisiones políticas importantes debían emanar de las Cortes, cuyos diputados representaban a la Nación; en la cual, tal como lo estipularía la constitución gaditana en su artículo tercero, residía esencialmente la soberanía. Esta diferencia, fundamental sin duda, no impide encontrar una relación directa entre los dos procesos (...).” BREÑA, R.: op. cit., p. 181.

${ }^{225}$ DUFOUR, G.: op. cit., p. 381 y ss.

${ }^{226}$ Autores como Antonio Morales veía una distinguible continuidad entre ilustrados y liberales, aunque pudiese significar un impedimento el hecho de que para los ilustrados tenían al monarca como una pieza fundamental en este giro político. MORALES MOYA, A.: Jovellanos: Ilustración y liberalismo, 1759-1812 en MARCO, J. M.
} 
flagrante entre ilustrados y liberales. Pero, el momento histórico no fue favorable a los ilustrados reformistas, puesto que, el advenimiento de la Revolución Francesa representó un golpe en seco para las ideas más innovadoras del momento ${ }^{227}$.

Para Roberto Breña, las coincidencias programáticas son concordantes entre una y otra corriente política. Principalmente a lo que toca a críticas a la nobleza y al clero. También, afirma el autor, en las propuestas económicas y educativas, en sus diversas formas, se aprecian estas coincidencias. Sin embargo, sigue matizando el mismo autor que el término “continuismo" acepta gradaciones, y que un aspecto fundamental de la ilustración a ser tomado en cuenta es que se extiende en el tiempo, sufriendo mutaciones, pero se mantiene identificable a través de su carácter cultural e intelectual. Además, el autor hace notar que la revolución liberal peninsular, contrariamente al movimiento ilustrado, es un proceso político que tiene un marco fijo temporal. Así que este continuismo entre una y otra corriente política debería ser tomado con cautela ${ }^{228}$.

Un elemento que calibrará la ilustración y posteriormente al liberalismo doceañista para autores como Maravall, Breña y Portillo Valdés, será el fuerte poder estatalizado que detenía la Iglesia en la península. Este hecho, para Maravall, fue el freno de la ilustración española, puesto que, la monarquía fue incapaz de limitar al poder de la nobleza y del clero, a la vez que también lo fue al no impulsar una burguesía que hiciese frente a estos poderes ${ }^{229}$. Para Breña, el conjunto de elementos de poder que detenía la Iglesia servirá de herramientas en la lucha contra la Ilustración a su tiempo, y también contra el liberalismo ${ }^{230}$.

Portillo Valdés, dentro de la discusión historiográfica en la que estamos, se posiciona como favorable a la tesis de un continuismo entre ilustración e iluminismo, pero, la reformulación de la idea monárquica a finales del siglo XVIII influyo directamente en los procesos revolucionarios y sobre el liberalismo gaditano. Sin embargo, elementos contractualistas y de derecho natural fueron asimilados por el liberalismo en su vertiente más moderada. Además, para este autor, cualquier reforma de la monarquía debía pasar por el filtro

(coord.): Genealogía del liberalismo español (1759-1931), FAES, Madrid, 1998, p. 60 y ss. También Martínez Sospedra afirma que si hay algo fuera de cualquier duda es de la profunda continuidad existente entre liberalismo e ilustración. Además, añade que grande parte del bagaje intelectual del liberalismo estaba estrechamente ligada a los ilustrados reformadores de Carlos III y los diputados liberales de Cádiz. MARTÍNEZ SOSPEDRA, M.: La constitución española de 1812 (El constitucionalismo liberal a principios del siglo XIX), Facultad de Derecho, Valencia, 1978, p. 20 y ss.

${ }^{227}$ SARRAILH, J.: La España ilustrada en la segunda mitad del siglo XVIII, Fondo de Cultura Económica, México D.F., 1981, p. 710 y ss.

${ }^{228}$ BREÑA, R.: op. cit., p. 182 y 183.

${ }^{229}$ MARAVALL, J. A.: La fórmula política..., op. cit., p. 488.

${ }^{230}$ BREÑA, R.: op. cit., p. 185. 
religioso, dado que era el vínculo poderoso y efectivo para frenar a la vez el despotismo como la anarquía ${ }^{231}$.

En esta discusión historiográfica, llegamos a la conclusión, juntamente con Roberto Breña, que sí hubo permanencias en el campo político-social, pero con "connotaciones, énfasis y alcances distintos" ${ }^{232}$. Además, hay que resaltar que en el ámbito de la historia de los lenguajes políticos, hablar de continuismo necesitaría verificar, según Breña, los contextos pragmáticos de enunciación o la forma como se procesan los discursos públicos, puesto que, la constatación de usos de términos y expresiones no presupondría de per si un continuismo o coincidencia. Es así porque "existen transformaciones en los usos públicos del lenguaje. (Y) sólo analizando estos usos podremos detectar los desplazamientos en el conjunto de los presupuestos implícitos, dicho en otras palabras, en las alteraciones e las problemáticas subyacentes",233.

De este modo, tanto la ilustración como el liberalismo tuvieron que convivir con influjos teóricos de diversos matices. La neoescolástica y el pactismo, además de un historicismo frecuente que pretendía buscar en el pasado de la nación formulas para solucionar la crisis dinástica y política de la monarquía. La noción de constitución histórica fue uno de los temas más debatidos en las Cortes de Cádiz. Sumada a todo eso, como ya hicimos referencia, el poeta Quintana crea en el discurso, lo que luego se fraguará en el texto constitucional, una patria absorbente, una nación por encima de todo, y que al final sería el sujeto de derechos y la garante y reguladora de los derechos individuales. El iusnaturalismo, representado por Vattel $^{234}$, Grocio $^{235}$, Pufendorf ${ }^{236}$ entre otros, que había sido introducido en los planes de estudios de las universidades españolas en la segunda mitad del siglo XVIII, será un propulsor de interrogantes sobre determinados aspectos políticos de la monarquía, aunque no fuese de per si contradictorio con el absolutismo monárquico. Así que los aspectos "revolucionarios" del derecho natural

\footnotetext{
${ }^{231}$ PORTILLO VALDÉS, J. M.: Revolución de nación. Orígenes de la cultura constitucional en España, 17801812, BOE/CEPC, Madrid, 2000, p. 145 y ss. Así que, para Portillo Valdés, no se puede comprender bien la fijación de la nación como sujeto de derechos en Cádiz, si no se toma en consideración el carácter profundamente religioso y antipolítico de la monarquía hispánica. Para Portillo, aunque haya matizaciones sobre el continuismo entre las dos corrientes políticas, los liberales van a aplicar en el plano constitucional lo que no pudo hacer los ilustrados. Ibidem, pp. 146, 154 y ss.

${ }^{232}$ BREÑA, R.: op. cit., p. 189.

${ }^{233}$ Idem.

${ }^{234}$ VATTEL, Emmerich: El derecho de gentes, o principios de la ley natural, aplicadas a la conducta, y a los negocios de las naciones y de los soberanos (Traducida por Manuel Maria Pascual Hernández), Tomo I, Imprenta de D. Leon Amarita, Madrid, 1834, pp. 5 y ss. La traducción española que tuvimos acceso está compuesta de tres tomos.

${ }^{235}$ GROCIO, Hugo: Derecho de la guerra y de la paz, Reus, Madrid, 1925, IV volúmenes.

${ }^{236}$ PUFENDORF, Samuel: Droit de la nature et gens ou système général des principes les plus importants de la morale, de la jurisprudence..., Jean Nours, Londres, 1760, III volumes.
} 
presentes en sus premisas, según Breña, no eran a primera vista revolucionarios, sino que el peligro estaba en las conclusiones que se podía extraer de estas mismas premisas respeto al absolutismo monárquico. También, no olvidemos de los reaccionarios absolutistas, tradicionalistas, en palabras de Roberto Breña, que van a jugar un importante papel en las Cortes de Cádiz y en el propio derrumbe del edificio gaditano con el Manifiesto de los Persas presentado a Fernando VII en su retorno del cautiverio en Francia. Los afrancesados, van a ser un medio termino entre el tradicionalismo y el reformismo, que colaboraron con el gobierno de José Bonaparte, y por lo tanto, será la diana tanto para liberales como para absolutistas. Aunque estos compartían muchos de los supuestos doctrinales y políticos de los liberales. Todas estas corrientes estuvieron presentes de una u otra forma en el proceso constitucional gaditano ${ }^{237}$.

${ }^{237}$ Para más informaciones sobre estas corrientes ideológicas y sus relaciones con el proceso de construcción del edificio constitucional gaditano véase BREÑA, R.: op. cit., pp. 192 a 251. 


\subsection{La Revolución Liberal de 1820. España como epicentro}

Después del denominado periodo napoleónico, Europa se vio inmersa en ciclos que configuraron los procesos revolucionarios liberales en la primera mitad del siglo XIX. Al ser vencido Napoleón por las potencias europeas, las fronteras y los gobiernos retornaron a la situación anterior a la Revolución Francesa, de modo que Fernando VII volvió a España en calidad de monarca absoluto, como ya lo habíamos comentado ${ }^{238}$. Pese a que las Cortes habían decidido no reconocerle hasta que jurase la Constitución, este encontró apoyos en fuerzas diversas que lo condujeron al poder, asumiéndolo de forma absoluta. Fernando VII ${ }^{239}$ tachó de ilegítima la tarea de las Cortes de Cádiz y restableció los valores del Antiguo Régimen persiguiendo a los liberales; aunque algunos oficiales de ideología liberal intentaron obligar al monarca con las fuerzas de las armas a asumir los contenidos de la Constitución de 1812. Desde 1814 se sucedieron pronunciamientos de facciones del ejército que intentaban forzar el cambio de orientación del gobierno, pero todos los realizados hasta 1819 acabaron fracasando ${ }^{240}$.

Napoleón intentó jugar con la figura de Fernando hasta el último momento de liberarlo definitivamente de su lujoso cautiverio en el Château de Tayllerand, en Valençay, donde le acompañaba su tío don Antonio y su hermano Carlos. Las felicitaciones dirigidas a Napoleón y a José Bonaparte convencieron a Napoleón de que Fernando era un cínico, pero aún así impuso condiciones para devolverle el trono español. Condiciones estas decantadas en un Tratado que fue firmado por Fernando y llevado al conocimiento de las Cortes en España por el Duque San Carlos y José Palafox para obtener su ratificación. El caso es que Fernando se aliaría con Napoleón de buen grado para derrotar a los liberales. El ministro de Estado, José Lujando, informó a Henry Wellesley de que aquel Tratado era letra muerta, mientras que la regencia había declarado que serían nulos los actos de rey prisionero, mientras se encontrase en aquella situación $^{241}$.

Había todo un ambiente, principalmente en el ejército, de apoyo a la causa de Fernando VII en alejar a los liberales de poder. Dentro de la ideología liberal que permeaba la lógica del trienio, el militar era un sujeto ajeno a la sociedad y que no era acorde con los principios de la libertad. Así que, el ejército debía estar compuesto por un cuerpo de ciudadanos que tenían más aspiraciones en este sentido. En consecuencia, el ideal liberal era una milicia ciudadana. Por

\footnotetext{
${ }^{238}$ Para mayor información sobre la presencia francesa en territorio español y la Guerra de la Independencia se puede consultar a ESDAILE, Charles.: La Guerra de la Independencia. Una nueva historia, Barcelona, Crítica Barcelona, 2004, p. 18 y ss.

${ }^{239}$ GONZÁLEZ DURO, Enrique.: Fernando VII. El rey felón, Salamanca, Oberon, 2006, p. 36 y ss.

${ }^{240}$ ENCISO RECIO, Luis Miguel.: La opinión española y la independencia hispanoamericana 1819-1820, Gráfica Andrés Martín S.A., Valladolid, 1967, p. 540.

${ }^{241}$ Un contenido más amplio se puede consultar a ENCISO RECIO, Luis Miguel.: op. cit. pp. 539-566.
} 
otro lado, también estaba la negativa de los liberales en admitir las pretensiones del cuerpo de oficiales, y eso generaba situaciones de descontento. Así, dirá Esdaile, “en enero de 1814, cuando San Carlos y Palafox llegaron a Madrid hallaron una situación que parecía ofrecer a Fernando amplias esperanzas de derribar la Constitución” ${ }^{\text {242 }}$ de 1812. Había, además de todo, una situación de insatisfacción tanto en el pueblo como en el ejército con las acciones del gobierno liberal. Dada la situación San Carlos volvió a Francia con la proposición de un golpe, pese a que en este momento Napoleón se había convencido de liberar a Fernando, aunque sin conseguir que fructificasen las condiciones impuestas para ello. De esta forma Fernando VII es entronizado como monarca absoluto de España. A través del Decreto de 4 de mayo de 1814 se restablecía la monarquía absoluta y en el día 10 del mismo mes y año disolvía las Cortes ${ }^{243}$, dando inicio al sexenio absolutista.

Según Luis Miguel Enciso Recio a tres cuestiones básicas se reducía la política del sexenio absolutista: la personalidad y el pensamiento político del Rey Deseado, las características del régimen por él instruido y los problemas que hubo que afrontar ${ }^{244}$. En realidad, dirá el mismo autor, el rey no fue un gobernante digno de los tiempos y de los problemas que ese tiempo le planteó, ya que tenía frente a sí varias soluciones posibles en 1814 . Siendo que en paralelo a aquéllas cuestiones del sexenio fernandino otros tres problemas emergen: el orden público, la restauración económica y cultural y el conflicto del régimen con el liberalismo.

Tanto las alteraciones del orden público como la situación en que el país se encontraba después de la Guerra de la Independencia ${ }^{245}$, los problemas que tenía que enfrentar con las amenazas secesionistas del Ultramar y los reflejos de una gran depresión económica del occidente que se prologó hasta mitad del siglo XIX, ponía de rodillas al gobierno fernandino ${ }^{246}$. El panorama general era desolador.

\footnotetext{
${ }^{242}$ ENCISO RECIO, Luis Miguel.: op. cit. p. 553.

${ }^{243}$ DECRETO DE 04 DE MAYO DE 1814: “ (...) Declaro que mi Real ánimo es no solamente no jurar ni acceder a dicha Constitución ni a Decreto alguno de las Cortes generales y extraordinarias y de las ordinarias actualmente abiertas, a saber, los que sean depresivos de los derechos y prerrogativas de mi Soberanía establecidas por la Constitución las leyes en que largo tiempo la Nación ha vivido, sino el de declarar aquella Constitución y tales decretos nulos, de ningún valor ni efecto, ahora ni en tiempo alguno, como si no hubiera pasado jamás tales actos y se quitaran de en medio del tiempo, y sin obligación en mis pueblos y súbditos de cualquier clase de condición a cumplirlos ni a guardarlos." Se puede acceder al texto en: http://usuarios.multimania.es/historiahispana/txix.htm\# DECRETO DE FERNANDO VII (MAYO1814) Acceso en: 20/09/2011.

${ }^{244}$ ENCISO RECIO, Luis Miguel.: op. cit.

${ }^{245}$ Sobre la Guerra de Independencia se puede leer más en ESDAILE, Charles: op. cit.

${ }^{246}$ Se puede buscar más información sobre la situación del sexenio fernandino en Luis Miguel Enciso recio. Íbidem, pp. 24-25.
} 
La recaída de España en el absolutismo de 1814, con la vuelta de Fernando VII ${ }^{247}$, debió de representar para los espíritus superficiales de España una forma de rechazar de plano las experiencias revolucionarias de la época. Ninguno de los problemas nacionales se había resuelto con la emanación de los decretos del 4 de mayo, incluso muchos se habían agravado ${ }^{248}$. Así, desde 1814 hasta 1820 se suceden los pronunciamientos, las conjuraciones que pretenden un restablecimiento de la Constitución, siendo consecuentemente sofocados por el gobierno absolutista de Fernando VII ${ }^{249}$.

De esta forma el día primero del mes de enero de 1820 el teniente Coronel Don Rafael del Riego proclamó en Cabezas de San Juan (Sevilla) la Constitución de Cádiz; éste podría haber sido uno más de los pronunciamientos que habían marcado el sexenio absolutista fernandino, pero el hecho citado tuvo un carácter decisivo en el cambio del régimen ${ }^{250}$. Las tropas, que se concentraban en torno a Cádiz destinadas a embarcar hacía América, y descontentas con ello, se rebelaron; fue un gesto de gran repercusión, tanto en la América Española como en el mundo. Este acto fue visto no solamente como restauración de la Constitución de Cádiz, sino de todo el movimiento ilustrado que en ella había encontrado expresión. Para propalar el movimiento, Riego, desplaza a sus tropas, que desde el 27 de enero hasta el 13 de marzo de 1820 le lleva por Vejer, Algeciras, Málaga, Antequera, proclamando la Constitución; de este modo, hasta el propio Fernando VII había ya aceptado la Constitución. Aunque haya fracasado, de por sí, el movimiento de Cádiz, Riego se convirtió en el principal instigador del pronunciamiento liberal; había todo un clima liberal en la burguesía mercantil de Cádiz proporcionando de este modo un catalizador de las siguientes insurrecciones. El ejército encargado por el Gobierno para combatir a Riego, prefirió proclamar la Constitución en Ocaña,

\footnotetext{
247 "En los casi seis años transcurridos desde el día de su tumultuoso ascenso al trono, España había cambiado de modo inconmensurable. En lugar de la monarquía absoluta y la estricta censura de 1808, España tenía ahora una Constitución y una prensa floreciente; además habían desaparecido su sistema feudal, sus privilegios forales, sus consejos municipales hereditarios, sus aduanas interiores y los arcaicos sistemas de conscripción y recaudación de impuestos. Todos los españoles eran iguales ante la ley, y excepto en materia de religión, libres, si bien incluso en este aspecto se había producido un gran cambio, al experimentar la Iglesia una disminución enorme de su poder y su riqueza. Todo esto no resultaba necesariamente detestable para Fernando, que en su fuero interno recibía con satisfacción el modo en que de forma repentina se habían alcanzado ciertos objetivos que su padre y su abuelo no lograron durante cincuenta años, si bien al mismo tiempo estaba claro que difícilmente sería él mismo restaurado en toda la plenitud de sus poderes. Siendo el rey deseado un defensor rígido y sin tapujos de las prerrogativas regias, y la Constitución un documento indudablemente ofensivo hasta para los príncipes más moderados - incluso algunos liberales reconocían que trataba al monarca como a un peligroso animal salvaje -, el conflicto entre Fernando y el régimen patriota era inevitable. Sólo quedaba pendiente, pues, saber si el rey encabezaría o no el ataque contra el nuevo orden". ESDAILE, Charles: op. cit. pp. 539-540.

${ }^{248}$ JOVER ZAMORA, J.M.; GÓMEZ-FERRER, G. y FUSI AIZPÚRUA, J. P.: España: sociedad, política y civilización (siglos XIX-XX), Barcelona, Areté, 2001, pp. 45-57.

${ }^{249}$ Cfr. También las opiniones de Quiera ver más en GIL NOVALES, A.: El trienio liberal, Madrid, Siglo Veintiuno Editores, 1989.

${ }^{250}$ Ídem, pp. 3-5
} 
por lo que Fernando VII hubo de consentir. Juró la Constitución a la fuerza y se convirtió en el primer monarca constitucional de la Europa del siglo $\mathrm{XIX}^{251}$.

Al parecer, el pronunciamiento de Riego no era algo aislado y sin apoyo. Ya desde 1817 se urdían conspiraciones para sustituir el sistema de gobierno absoluto de entonces. Todo indica una presencia de conspiraciones de los masones, que conlleva la adhesión de jóvenes oficiales, subalternos, comerciantes, profesionales liberales; hechos que van a radicalizar las posiciones.

Luis Miguel Enciso Recio, citando a F. Suárez, dirá que todo en la Revolución de 1820 fue mediocre ${ }^{252}$. Esta mediocridad fue reflejada tanto en el campo militar como en lo que fue el movimiento de por sí.

También en la Corte la reacción fue mediocre. Se intentó hacer una política de concesiones, se intentó crear una Junta de Reformas de criterios moderados. Así lo es el decreto de 3 de marzo, donde el rey se proponía paliar los problemas de la nación y hacer una consulta a los cuerpos del Estado ${ }^{253}$. En este sentido, desfalcando a las filas realistas, La Bisbal, traicionando la causa debilita la posición de los absolutistas. Acto seguido, el día 6 el Rey, presionado por sus consejeros, decide convocar Cortes al modo tradicional. Pero el constitucionalismo era una posición más fuerte en aquel momento. El día 7 del mismo mes, en una reacción vacilante, fragmentada y oportunista el Rey declara en un Decreto que, de acuerdo a la voluntad del general del pueblo, ha decidido jurar la Constitución, así como crear una Junta Provisoria Consultiva en Madrid encargada de tomar las medidas oportunas para volver a un régimen liberal. La Junta asumió todos los poderes y el Rey, de su parte, firmó todo lo que le presentaba la Junta. Sucede, en cambio que esta Junta guardaba pocas similitudes en relación a su homóloga de 1808, dado que, en el orden temporal, la primera se fundamentaba en la soberanía popular y la segunda nacía de la mera delegación del poder real, con un carácter apenas consultivo $^{254}$. Fernando VII se ve obligado a prometer jurar la constitución, al parecer llevado a “error" por una consulta hecha al general Ballesteros sobre la situación del levante liberal ${ }^{255}$.

\footnotetext{
${ }^{251}$ JOVER ZAMORA, J.M.; GÓMEZ-FERRER, G. y FUSI AIZPÚRUA, J. P.: op. cit.

${ }^{252}$ ENCISO RECIO, Luis Miguel. Op. cit. pp. 125.

253 Ídem, pp. 126-127

${ }^{254}$ Se puede profundizar más en: JOVER ZAMORA, J.M.; GÓMEZ-FERRER, G. y FUSI AIZPÚRUA, J. P.: op. cit. p. 58.

255 "Fernando VII, que había incurrido en el error de consultar al general Ballesteros, tuvo la impresión - falsa, según parece - , de que el pueblo y, sobre todo, la guarnición, estaban con la causa revolucionaria, y en la noche de 6 y 7 prometió jurar la Constitución. Después de ello, la entrada de Freyre en Cádiz vino a ser un golpe de efecto sin consecuencias. El 9 de marzo una comisión arrancó de D. Fernando importantes concesiones. Ese mismo día el Rey se avino a jurar la Constitución y publicó el famoso documento en que se decía: 'Cuando yo meditaba (...) las variaciones de nuestro régimen fundamental (...) me habéis hecho entender vuestro anhelo de que se restableciese la Constitución (...) He oído vuestro votos, y, cual tierno padre, he condescendido ‘.” Ídem, pp. 126.
} 
El asentamiento liberal no fue tomado como algo negativo, ni por los estamentos clericales ni por la sociedad en su conjunto. Solo meses después, por haber tomado iniciativas radicales por parte del régimen es cuando el clero $^{256}$ y una parte de la sociedad pasaron a ver de forma negativa dicho movimiento ${ }^{257}$.

En este sentido la Revolución Liberal de $1820^{258}$ iba a tener dos consecuencias principales en el terreno político: la instauración del liberalismo y la promoción al mando de agentes de poco relieve. A todo eso se debe añadir un espíritu romántico, que se expresa en las vestimentas, los símbolos y en las canciones patrióticas. En cuanto a la aceptación de este nuevo régimen liberal por las clases populares, en opinión de Suárez, dicha orden no se produjo por el simple hecho de que se pasara a una confesión liberal todo el pueblo, sino por el apoyo dado por el rey al haber jurado la Constitución. Pero, era de esperar que el liberalismo ganara para sí gran parte de los sectores de las clases medias ya que su identificación era mayor con este sector $^{259}$. Por todo ello, el nuevo régimen tenía muchos puntos débiles que servirán para explicar en parte su fracaso futuro ${ }^{260}$.

En el ámbito de la Revolución liberal se planteaba una reforma política. Desde el inicio el carácter restaurador del doceañismo fue preponderante. En los meses de marzo y abril de 1820 se apreció que la revolución sería una marcha atrás en dirección a la primera experiencia liberal $^{261}$. Así, en la Junta Provisional se dejó libre el camino para los doceañistas, tanto para el Tribunal Supremo como para el Consejo de Estado, así como para la administración en general.

Las reformas fueron la tónica de la Junta y del Gobierno. Se restableció la libertad de imprenta y la abolición del Santo Oficio, de acuerdo con el pensamiento gaditano. Hubo

\footnotetext{
${ }^{256}$ MONTOLÍO HERNÁNDEZ, R.: La reforma de la dotación de culto en el Trienio Liberal (1820-1823). Toledo, Espacio, Tiempo y Forma, Serie V, Historia Contemporánea. 14,2001, págs. 33-54

257 "Pese al lógico recelo que podría suscitar el recuerdo de la política religiosa de las Cortes extraordinarias y ordinarias, la jerarquía y el clero mantuvieron una actitud prudente. Y la conducta del Papa, concretada en un breve del 30 de abril, vino a reforzar esta postura. Salvo incidentes aislados, los primeros meses del trienio trascurrieron tranquilos. Las tensiones entre la Iglesia y el régimen liberal hicieron aparición en mayo, y luego se ahondarían de forma dramática". ENCISO RECIO, Luis Miguel. Op. cit. pp. 127.

258 "La Constitució de Cadis va estar en vigor, teòricament, en tres ocasions distintes. La primera va ser entre 1812 i 1814, des que es va promulgar fins que Ferran VII va tornar a l'absolutisme; la segona, entre 1820 i 1823, en l'anomenat trienni constitucional; la tercera i última, després de la revolució de le estiu de 1836 - equívocament identificada amb el motí de La Granja -, mentre els vencedors s'apressaven a redactar-ne una de nova, ja que eren conscients que la de 1812 era inviable i que calia reformar-la para que se acomodase a nuestro estado actual y al de la Europa”. ARNABAT MATA, R.: La revolución de 1820 i el Trienni Liberal a Catalunya, Vic, Eumo Editorial, 2001. p. 11.

259 Ídem, p. 128-129.

260 "He aquí algunos: la anarquía, el carácter de restauración del doceañismo que tuvo la revolución, la falta de líderes, el predominio de los intereses de grupo sobre otros nacionales, el 'Politicismo` a ultranza de los revolucionarios, la malversación administrativa, el favoritismo y, sobre todo, las presiones a que se vio sometida la autoridad gubernamental por parte de otros tres poderes establecidos: las sociedades secretas, las sociedades patrióticas y el ejército. A todo ello habría que añadir el tinte federal de la revolución.” Ídem, p. 130.

${ }^{261}$ Se puede saber más en: ARNABAT MATA, R.: op. cit.
} 
eliminación de los privilegios y de la incorporación de señoríos a la Corona. Las Cortes se convocaron con carácter de ordinarias y de este modo se arrimaba a la idea asamblearia de Cádiz. Ya en abril, se permite el retorno de los afrancesados, lo que hace que se rompa la política restauradora. Aunque estas medidas fueron atenuadas enseguida. Los peligros a ser evitados eran una revolución fuera de control y una indeseada reacción absolutista ${ }^{262}$.

En realidad todos estos acontecimientos y alzada del ideario liberal están dentro del contexto denominado por el historiador Eric Hobsbawm como La Era de las Revoluciones, que comprende la segunda mitad del siglo XVIII y primera mitad del siglo XIX ${ }^{263}$. Unas revoluciones de carácter político, económico, social y cultural que se expanden a toda Europa amenazando al Antiguo Régimen, donde una nueva sociedad burguesa, capitalista e industrial, intenta suplantar a la antigua sociedad señorial. En España, como hemos mencionado antes, estos cambios estuvieron motivados por la pérdida de las colonias americanas, la bancarrota de la hacienda pública, la Guerra de la Independencia, y añadido a todo ello la crisis del sistema señorial. El proceso revolucionario liberal en España es algo dilatado en el tiempo y alcanza casi la totalidad de la primera mitad del siglo XIX, alternando revoluciones y contrarrevoluciones. El denominado Trienio Liberal (1820-1823) está inserto en este ciclo revolucionario que marca el proceso agónico del Antiguo Régimen en este periodo ${ }^{264}$. Durante el Trienio Liberal la realidad de España será contrastada con las teorías constitucionales tan propaladas a la época; será el momento de sentir el liberalismo en su real alcance para solucionar los problemas y las expectativas de la sociedad en aquél momento ${ }^{265}$.

Como ya se ha sido dicho antes, la Junta nacida de la delegación del poder real va a tomar una serie de medidas con la intención de poner en el orden del día los preceptos fomentados y aceptados por las Cortes de Cádiz, como la libertad de imprenta y la supresión de la Inquisición. También el restablecimiento de los ayuntamientos constitucionales y la forma administrativa del sistema provincial. El monarca es impelido a formar gobierno. Gobierno que se llegó a denominar y conocer como Gobierno de los Presidiarios. Porque sus miembros estuvieron perseguidos antes por sus ideas liberales. A mayor abundamiento se obligó a

\footnotetext{
${ }^{262}$ También se puede leer más en JOVER ZAMORA, J.M.; GÓMEZ-FERRER, G. y FUSI AIZPÚRUA, J. P. op. cit. pp. 57-63.

${ }^{263}$ Hobsbawm, E. J.: La era de la revolución: 1789-1848, Barcelona, Crítica, 2011, pp. 183 y ss.

${ }^{264}$ ARNABAT MATA, R.: op. cit. pp. 17-20.

265 "En estos tres y pico de años suceden unas cosas, de las que los españoles son a la vez espectadores y protagonistas, sin cuya recta comprensión toda la historia posterior del siglo XIX y aun del XX es difícilmente inteligible". GIL NOVALES, A.: Las sociedades patrióticas (1820-1823). Vol. I, Madrid, Tecnos, 1975, p. 5.
} 
convocar Cortes en julio de $1820^{266}$. Este período es un hiato de las etapas absolutistas, con dificultades para implementarse e insostenible a la larga como veremos a continuación.

La grandeza del Trienio Liberal, no solo se halla en el restablecimiento puro y simple de las ideas, preceptos y de la Constitución doceañista, sino que también lleva a cabo la labor de complementar dicha experiencia liberal anterior. El romanticismo de la época fue llevado a la cumbre desarrollando una gran actividad política, formando núcleos de sociedades patrióticas, con actuaciones paralela a las Cortes oficiales y de naturaleza izquierdista. Así de cierta manera se experimentaba una relativa euforia con la vuelta del régimen liberal, donde se exaltaba la libertad en todas sus acepciones, tales como: someter al rey al sistema constitucional; dar relevancia a la autoridad civil frente a la eclesiástica; destruir las instituciones forales y promover una verdadera unidad político-administrativa. Pero, al ser contrarrestada por las fuerzas contrarrevolucionarias no fue nada pacifica la implantación de estas reformas.

La coincidencia de intereses verificada en el primer sexenio por parte de la burguesía y el campesinado fueron disgregados completamente en el Trienio Liberal, como afirma Fontana $^{267}$. Ya Artola dirá que la revolución liberal inclina el carácter del movimiento a favor de la consolidación de la nueva propiedad, abstracción hecha de los intereses del campesinado. Pero, esto no es suficiente y el campesinado se impacienta en relación a los cambios de la política fiscal en el trienio, pues aunque pareciera ser un indicativo favorable, a la larga el plano inmediato es una carga indeseable ${ }^{268}$.

El descontento del campesinado será catalizado y conducido por la resistencia absolutista a través de la guerrilla. Este elemento que fue crucial para minar el establecimiento del poder francés y fue el fundamento para la independencia, ahora estaba siendo utilizado del mismo modo contra el establecimiento de un Estado liberal ${ }^{269}$. Y el divorcio entre la burguesía y el campesinado no dejaba un escenario liberal nada prometedor.

Lo que pasa es que la experiencia liberal experimentada en Cádiz no se quedará estática e inmutable a lo largo de los años; nuevos matices tiñen de nuevos colores al nuevo liberalismo,

\footnotetext{
${ }^{266}$ JOVER ZAMORA, J.M.; GÓMEZ-FERRER, G. y FUSI AIZPÚRUA, J. P.: op. cit. p. 58.

267 "El mismo Fontana, que enfrentándose con la interpretación catastrófica de los hechos - tradicionalmente empleada para explicar los problemas y el fracaso final del trienio - rompe una lanza a favor de la audacia y el acierto de la política de desarrollo llevada a cabo durante el mismo, llega a una conclusión irrefragable: El régimen constitucional no acertó a formular una política campesina adecuada, tal vez porque se veía obligado a respetar los intereses de los grandes propietarios señoriales que formaban en sus filas.” JOVER ZAMORA, J.M.; GÓMEZFERRER, G. y FUSI AIZPÚRUA, J. P.: op. cit. pp. 58 y ss.

268 Ídem, pp. 59 y ss.

269 "Las tensiones y las debilidades internas del constitucionalismo doceañista, la disociación entre burguesía y campesinado, así como la revuelta de este último, sometieron a dura prueba, durante el trienio, la viabilidad de ese nuevo Estado basado en lo político en la Constitución de Cádiz; y en lo económico en unas normas de liberalización que intentaban articular un mercado nacional e impulsar la modernización físcal”. Ídem, pp. 59.
} 
que bien se podría llamar de veinteañista. El liberalismo español no se caracteriza por una doctrina original y autóctona, puesto que es tributario de los franceses - sean doctrinarios o democráticos - además del radicalismo ingles de Jeremy Bentham, aunque en menor escala. Con todo eso, no será una mera reproducción, como decimos antes, ya que el liberalismo español se nutre de un sistema histórico de referencia, haciendo una constante apelación a una constitución histórica, y se vale de los pronunciamientos para sacar adelante la revolución ${ }^{270}$. Por lo tanto tiene rasgos específicos que lo hacen adaptarse a las situaciones locales; cuestión diferente será si este régimen implantado conseguirá llevar a cabo reformas que conlleve a su institucionalización abarcando ampliamente las demandas de distintos sectores de la sociedad, conflictuosa al momento. Hay que resaltar que los liberales de los años veinte son los mismos que estuvieron presentes en Cádiz y en la Guerra de Independencia, sin embargo, este grupo no es homogéneo, ya que está compuesto por liberales moderados y liberales radicales que formarán parte del gobierno del trienio, pero es cierto que los dos son procedentes del doceañismo gaditano ${ }^{271}$. Estas dos corrientes, que formarán la elite dirigente, estarán permeadas de un romanticismo, donde los sentimientos se desbordan frente a la razón. Así, las posiciones radicales se pronuncian al margen del bando al que pertenezcan: absolutistas ó liberales.

El lado moderado de los liberales estaba provisto de hombres experimentados, que habían vivido en el exilio o sufrido represalias, y que sabían que tal y como fue concebida la Constitución del doce no sería viable su implantación sin antes hacer unas adecuaciones, compatibilizando la libertad y el orden. Pragmáticamente intentaron llevar a cabo estas mudanzas $^{272}$. En su gobierno, que va hasta el año 22, intentaron introducir dichas reformas en la Constitución, y además, pensaron en crear un Cámara Alta y dar una mayor fuerza al poder ejecutivo, porque quizás veían en su horizonte la Carta Francesa de 1814. De esta forma pretendían un entendimiento con el monarca y la cooptación del ala progresista de los partidarios del absolutismo. El fracaso no se debió solamente al radicalismo absolutista, sino también al liberal. También contribuyó a ello la rigidez técnica para la reforma de la

\footnotetext{
${ }^{270}$ Un desarrollo más amplio se puede consultar en SÁNCHEZ HITA, B.: José Joaquín de Clararrosa y su Diario Gaditano (1820-1822). Ilustración, Periodismo y Revolución en el Trienio Liberal, Cádiz, Centro de Estudios Constitucionales, 2009, JOVER ZAMORA, J.M.; GÓMEZ-FERRER, G. y FUSI AIZPÚRUA, J. P.: op. cit. Además de RUIZ JIMÉNEZ, M.: El liberalismo exaltado. La confederación de comuneros españoles durante el Trienio Liberal, Madrid, Editorial Fundamentos, 2007.

271 "El radical está enraizado en el espíritu gaditano, encuentra sus bases sociales - cada vez en mayor medida - en las capas populares urbanas; tiene un carácter exaltado y posee una orientación democrática. El moderado, heredero también del doceañismo, se muestra, sin embargo, más propicio al entendimiento con las elites establecidas, en busca de soluciones viables; será un sector menos democrático que, en los años treinta, pactará con la nobleza y optará por el doctrinarismo". JOVER ZAMORA, J.M.; GÓMEZ-FERRER, G. y FUSI AIZPÚRUA, J. P.: op. cit. p. 60.

${ }^{272}$ ARNABAT MATA, R. op. cit., pp. 173-208.
} 
constitución, lo que llevaba a pensar en una nueva Carta Magna, que será decantada en los años $\operatorname{treinta}^{273}$.

Por otra parte estaban los liberales radicales que también preconizaban cambios, pero éstos deberían estar fundamentados en el constitucionalismo gaditano. Por sus ideas más castizas, si se puede decir de esta manera, lograban apoyos en muchas provincias, donde su lastre eran los oficiales del ejército, la milicia nacional, y ciertos sectores de las capas populares urbanas que afectados por las medidas de los liberales se alejaban de aquellos.

En el trienio el liberalismo se asentó en un trípode: el teórico, donde encuentra en los intelectuales su base social, además de los profesionales liberales; el práctico, donde actuaba directamente, a través de las medidas económicas legisladas, favoreciendo a los comerciantes, propietarios, negociantes etc. ${ }^{274}$; y por fin el clima romántico que impregnaba la sociedad, callando en las masas ajenas al doctrinarismo liberal, pero que se beneficiaban de las medidas del régimen ${ }^{275}$. Era este mismo espíritu romántico que relacionaba a los afrancesados, ideológicamente más próximo de los liberales moderados, con su pasado colaboracionista con la presencia francesa, a auténticos traidores de la patria. Alejándolos de todo el proceso de liberalización de la nación y de sus instituciones.

Las contestaciones al gobierno de los moderados fueron muy amplias y se llevaban a cabo tanto por los radicales absolutistas como por los exaltados liberales en el transcurso de estos gobiernos moderados, que van de marzo de 1821 a julio de 1822; las tensiones entre las facciones convirtieron a este gobierno en una institución inoperante ${ }^{276}$. En ese mismo mes de julio del año 22 los enfrentamientos entre la Guardia Real y la milicia, los primeros comandados por aristócratas leales al rey y los segundos apoyados por las Cortes y el Ayuntamiento de Madrid, hacen que los milicianos derroten a la Guardia Real y a consecuencia de esto un nuevo gobierno sea formado con el bando de los liberales exaltados. Este gobierno radicaliza el proceso de "liberalización" de la nación, lo que lleva al rey a huir hacia Sevilla. En

\footnotetext{
${ }^{273}$ BROSETA, S.: El trienio liberal, 1820-1823: la situación revolucionaria burguesa antifeudal en la ciudad de Valencia, en CHUST, M.: (ed.) De la cuestión señorial a la cuestión social, Valencia, Editora PUV, 2002, pp. 113122. Además se complementa con JOVER ZAMORA, J.M.; GÓMEZ-FERRER, G. y FUSI AIZPÚRUA, J. P.: op. cit. p. 60.

274 "La obra de gobierno llevada a cabo por los constitucionalistas durante el trienio tiene un sentido claro: restablecer la situación anterior a 1814 prosiguiendo la revolución liberal entonces iniciada, tratando de dar solución a unos problemas nuevos o a aquéllos mismos que ahora se habían agudizado. El problema campesino, en su triple vertiente: estructura de la propiedad, régimen jurídico y situación de la tierra en cuanto a su rendimiento y comercialización; la actitud que debía seguirse con la Iglesia, el problema pendiente de la Hacienda y las nuevas medidas que exigía un Ejército necesitado de una reordenación, serán los primeros problemas a que tiene que hacer frente el gobierno liberal”. Ídem, p. 61 y ss.

275 Ídem, pp. 61 y ss.

${ }^{276}$ ARNABAT MATA, R. op. cit., pp. 209-248.
} 
respuesta las Cortes lo deponen temporalmente y nombran una Regencia en su lugar. El día 7 de abril de 1823, los Cien Mil Hijos de San Luis penetran en España, desde Francia, sin encontrar resistencia, pero no son considerados invasores, sino libertadores del monarca cautivo en Sevilla, restableciendo así el gobierno absolutista ${ }^{277}$.

Si la Revolución Liberal de 1820 tuvo sus contradicciones internas y luego caminó hacia el fracaso del gobierno liberal a la hora de mantenerse en el poder, los ecos de esta revolución traspasaron las fronteras llegando a muchas zonas de Europa. Llegaron tanto al vecino Portugal, como al lejano y recién independiente Imperio de Brasil, que son los países que más nos interesan en este trabajo, como también llegaron a otras regiones europeas, como Nápoles y a Turín $^{278}$ por ejemplo.

\subsubsection{La referencia política que supuso la Constitución de Cádiz en las Revoluciones liberales: el mito del constitucionalismo español.}

Símbolo de resistencia frente a la dominación extrajera y proclamación de la libertad fundada en las ideas liberales, Cádiz fue el faro que emitía luz en las tinieblas del absolutismo y en la dominación extranjera, no solamente en Portugal, Brasil, Italia o Grecia en particular, donde se la veía de esta manera, como también en Rusia, Francia, Inglaterra y Escandinavia, aunque vista bajo otros aspectos ${ }^{279}$. Fue la mecha encendida que alumbraba a las aspiraciones de los liberales por toda Europa y calentaba al sueño de librarse de la dominación extranjera. En España, precursora, se buscaba expulsar a los franceses, en Portugal a los ingleses, en Italia a los austríacos y en Grecia a los turcos.

En muchos aspectos la Guerra de la Independencia librada en España contra los franceses se vio confrontados dos mundos en una misma nación: la España de la calle, la real, dicha hoy en día sociológica, y la España oficialista ${ }^{280}$. La primera hizo sentir el repudio que la dominación extranjera causaba y la situación de sometimiento humillante en que se encontraba la nación; la segunda sorprendentemente fue colaboracionista y muchas veces íntimamente ligada con las fuerzas invasoras; corrobora con esta idea la llegada de los "Cien mil hijos de San Luis" para poner fin al Trienio Liberal con el aval del rey Fernando VII. El paso dado hacía la legalidad en Cádiz recuperaba las fuerzas de la patria, prohibía que la nación fuera objeto o

\footnotetext{
${ }^{277}$ En el mismo sentido puede verse lo que dice GONZÁLEZ DURO, Enrique. Op. cit., pp. 279-318; JOVER ZAMORA, J.M.; GÓMEZ-FERRER, G. y FUSI AIZPÚRUA, J. P.: op. cit. pp. 64 y 65; ARNABAT MATA, R. op. cit., pp. 249-328.

${ }^{278}$ GIL NOVALES, A. op. cit., pp. 22- 24.

${ }^{279}$ Se puede buscar más información en ESCUDERO, José Antonio (Dir.): Constitución de 1812, Cortes y Constitución de Cádiz 200 años, Madrid, Editora Espasa, Tomo III, 2011.

${ }^{280}$ La Guerra de la Independencia de 1808 librada contra los franceses por España es tratada en sus detalles por ESDAILE, Charles: op. cit., pp. 31 y ss.
} 
mercancía puesta a venta por los monarcas ${ }^{281}$; además de todo, tomaba para sí en depósito la soberanía que al rey se le escapaba, puesto que estaba hecho "prisionero" en Bayona.

En este escenario el horizonte de eventos de una España sublevada contra la dominación francesa, una España anti-napoleónica frente a la España oficialista trazada en Bayona, fue la Constitución de 1812 española que serviría de modelo a toda Europa que querría sublevarse contra el Ancién Regime, sin entretanto abrazar completa y directamente las libertades de la Revolución Francesa impuestas por Napoleón a punta de bayoneta ${ }^{282}$.

La Constitución gaditana representará en las revoluciones liberales, principalmente en Italia, la opción radical para los liberales frente a las ofertas de Francia para que se adoptase la Charte de 1814, que más bien era la opción de los monárquicos legitimistas partidarios de una constitución otorgada. Este modelo llega a ser propuesto por Francia a Nápoles para evitar la invasión austriaca. El texto de Cádiz era visto como excesivamente radical, donde se vislumbraba a los textos franceses seguidos de 1791,1793 y 1795 , que al fin y al cabo se inspiraba ${ }^{283}$.

En Francia, como nos apunta Bruno Aguilera, la noticia de la Constitución de Cádiz dará lugar a dos tipos de reacciones al momento de su proclamación. Por un lado estaban los que deploraban aquél modelo constitucional, como el ministro de Asuntos Exteriores de Luis XVIII, Chateaubriand ${ }^{284}$, o autores como De Bonald y De Maistre. Chateaubriand definía a las Cortes de Cádiz como mera imitación de las asambleas revolucionarias francesas y además la criticaba por sus excesos liberales. Entre los defectos enumerados por el ministro francés estaba el restringido poder atribuido al rey; el falso principio de la soberanía popular, puesto que, ésta estaría depositada únicamente en Dios y en los espíritus geniales, por delegación del propio Dios. También el ministro francés veía a España caminar hacía una Republica aplicando este texto deplorable - en sus palabras. Así de plano, rechazaba Chabeaubriand la implementación

\footnotetext{
${ }^{281}$ De este sentimiento anti-francés trata AGUILERA, Bruno: Influencia de la Constitución de Cádiz en Francia en ESCUDERO, José Antonio (Dir.): op. cit., pp. 499 y ss.

282 "La excepción sin duda la constituye Francia, donde, por razones obvias, la Constitución gaditana es totalmente ignorada en los últimos años del régimen napoleónico, que coinciden con el primer periodo de su vigencia, entre 1812 y 1814. Aunque el carácter de texto constitucional aprobado como reacción frente a la ocupación napoleónica justifica que la Constitución de 1812 sea traducida al francés, lengua divulgativa por excelencia en la Europa del momento, desde el año 1814". Ídem, pp. 500 y ss.

${ }^{283}$ Se observa esta tentativa de sustituir al texto gaditano por la Carta francesa de 1814 en FERRANDO, Juan: op. cit., pp. 97 y ss. Y se puede complementar en AGUILERA, Bruno: op. cit., pp. 499 y ss.

${ }^{284}$ François-René de Chateaubriand (1764-1848), un aristócrata nacido en la Bretaña, que inicialmente se simpatiza con las ideas de la Revolución francesa, pero tras la Restauración, y por su defensa de la monarquía legitimista y firme partidario del restablecimiento de la dinastía borbónica, fue nombrado por Luis XVIII en 1815 par de Francia y Ministro de Estado, aunque al criticar al rey en 1820 cae en desgracia, momento en que inicia la etapa alta de su carrera política. Pero retorna como embajador en 1821 y en 1822 es nombrado ministro de asuntos exteriores. Ya como plenipotenciario en 1822 en el Congreso de Verona logra aprobar la intervención en España para acabar con el Trienio Liberal. Chateaubriand consideraba la Charte de 1814 una constitución libre, contrario de la radical gaditana. CHATAUBRIAND, François-René: La monarchie selon la Charte, Paris, Imprimerie de Le Normant, 1816, p. 17.
} 
de la Constitución gaditana, puesto que confrontaba con la legitimidad de derechos, convirtiendo al monarca en un delegado que le faltaba el derecho de veto. También aquellos autores citados antes, fervorosos defensores del derecho divino de los monarcas, no aceptaban la posición iusracionalista de la soberanía $\operatorname{popular}^{285}$.

Del lado contrario de los reaccionarios estaban los ya case extintos liberales radicales que sobraron al atardecer del Imperio napoleónico. Estos sí, veían a la Constitución de 1812 como una llama que brujuleaba testimonial a lo ocurrido en la Francia revolucionaria de 1789. De esta forma un diputado llamado Grégoire afirmaba que España, con lo pasado en Cádiz, recuperaba sus energías tras una guerra infamante. Y este mismo diputado veía al principio de la soberanía como una señal representativa de los antiguos hechos revolucionarios de antaño en Francia $^{286}$. Como se puede ver el texto gaditano produjo en Francia a la altura un frenesí que causaba reacciones en contra y a favor del texto doceañista. Unos criticaban su bajo contenido de principios esenciales del liberalismo, como la libertad de prensa o la de conciencia, atribuyendo a esto el éxito reaccionario de Fernando VII; otros la alababan por ser un reflejo de los viejos tiempos de la Francia Revolucionaria.

Pese a estas reacciones en Francia a la altura de la promulgación en España de la Constitución de 1812, el efecto mayor que esta Constitución causará será durante su repristinación en el Trienio Liberal. En este período los pensadores franceses se interesarán mucho más por el texto doceañista. Pasó de esta forma porque en aquél momento la repercusión de la carta española en Europa fue muy grande, se tornó el faro del liberalismo de los 800. Esta, la constitución, se transformó de este modo, en la sustituta del texto francés de 1791. Cádiz era ahora el prototipo del liberalismo a ser enarbolado como estandarte de todas las revoluciones, como matiza Boris Mirkine-Guetzévitch, principalmente la tratada en este trabajo, cuál sea, la de Oporto ${ }^{287}$. Además, será el pronunciamiento de $1820^{288}$, ya comentado más arriba, que consigue reponer el texto gaditano y lo proyecta como opción para los programas constitucionales del liberalismo europeo ${ }^{289}$.

\footnotetext{
${ }^{285}$ AGUILERA, Bruno: op. cit., pp. 500 y ss.

${ }^{286}$ Ídem, p. 501 y ss.

${ }^{287}$ MIRKINE-GUETZÉVICH, B.: La constitution espagnole de 1812 et les débuts du libéralisme européen : esquisse d histoire constitutionnelle comparée en Introduction à l'étude du droit comparé : recueil d'Études en l’honneur d`Edouard Lambert, Paris, Librairie Générale de Droit et de Jurisprudence, Troisième partie, Le droit comparé comme science juridique moderne, 1938, pp. 211 y 215.

288 "La reacción europea ante el triunfo de los liberales españoles fue relativamente moderada. (...) Aunque las cortes europeas no simpatizaban con la España constitucional, no llegaron a reflejar intenciones manifiestamente hostiles en las primeras comunicaciones que dirigen al primer Gobierno constitucional español. Lo que resulta hasta cierto punto sorprendente, si tenemos en cuenta que Metternich consideraba más peligrosa la revolución española de 1820 que la francesa de 1789 ya que a su modo de ver esta había sido local, mientras que aquella tenía una dimensión europea." AGUILERA, Bruno: op. cit., p. 502.

${ }^{289}$ Ídem, pp. 501 y ss.
} 
El movimiento reaccionario llevado a cabo por la Santa Alianza en Europa y que tenía a la cabeza al príncipe de Metternich sería contrarrestado por lo sucedido en España con el pronunciamiento de Riego. Era la opción surgida para ser usado como estandarte en toda la Europa revolucionaria. La fórmula aplicada en España, de pronunciamiento militar, era defendida por los progresistas europeos como el único camino a ser trillado por una minoría ilustrada hacía la libertad política. Era así, porque el pueblo no estaba apto a exigir estas mismas libertades ${ }^{290}$.

Tanto Fernández Sarasola ${ }^{291}$ como Bruno Aguilera afirman que este modelo de pronunciamiento militar español será seguido por los pronunciamientos en Nápoles, Oporto, Turín y Milán, hasta los decembristas rusos, que en San Petersburgo se sublevaron contra el Zar en 1825, quienes también utilizarán este modelo de pronunciamiento. Ni siquiera Francia, un ambiente en que la Charte de 1814 era vista como la antípoda de la carta gaditana, escapó de los pronunciamientos. También ahí los liberales conspiraban contra los borbones, y ejemplo de esto fue un pronunciamiento en Francia, la insurreccional de los 4 sargentos de La Rochelle. Pero, a la vez, desata una ola de diatribas al texto doceañista en Francia, dedicándole duras críticas. Entre estos críticos estaban Alfhonse Beauchamp ${ }^{292}$, quien publicó en 1822 una obra donde se comentaba el Trienio Liberal español. Otro crítico fue, el suizo alemán Karl Ludwig von Haller ${ }^{293}$, donde en un opúsculo, traducido al francés no economiza munición contra el texto gaditano.

En Francia, entre el radicalismo de la Constitución de 1791 y el modelo de otorga constitucional de la Charte Octroyée, los moderados preferirán al modelo liberal español representado en el texto doceañista. Aunque muy criticada, la Carta de Cádiz, en muchos aspectos, por lo general era bien vista por aquél sector liberal en el país galo. De esta forma llevó a Benjamin Constant ${ }^{294}$ a desaprobar el exagerado envío de los "Cien Mil Hijos de San

\footnotetext{
${ }^{290}$ MIRKINE-GUETZÉVICH, B.: op. cit., pp. 216-217.

${ }^{291}$ FERNÁNDEZ SARASOLA, Ignacio: La Constitución de Cádiz, origen, contenido y proyección internacional, Madrid, Centro de Estudios Políticos y Constitucionales, 2011, pp. 283 y ss.

${ }^{292}$ Alphonse Beauchamp “(...) calificaba la Constitución de Cádiz de triste ensayo, de carta falaz y de código de anarquía y despotismo. La considera, sobre todo, impracticable e ilegítima por haber sido redactada por unas Cortes que no habían sido convocadas con arreglo a las reglas de la monarquía." AGUILERA, Bruno: op. cit., p. 503. También se puede consultar en BEAUCHAMP, Alphonse de: De la révolution de l'Espagne et de sa crise actuelle, Paris, Ponthieu, 1822, pp. 76-77.

${ }^{293}$ HALLER, Karl Ludwig von: De la constitution des cortès d’Espagne, París, Nicolle, 1820. También tuvimos acceso a la edición española en donde se pretendía con dicha publicación alzar la causa de Fernando VII, donde el traductor decía ser una amante de su rey, HALLER, Karl Ludwig von: Analisis de la Constitución española, Madrid, Imprenta de D. José de Collada, 1823.

${ }^{294}$ Henry-Benjamin Constant de Rebecque (1767-1830) nacido en Suiza, Lausane, de familia hugonote, partió a Francia evitando las guerras religiosas. Constant consiguió convencer a Napoleón, en el gobierno de los Cien Días a aprobar el Acta Adicional de 1815, siendo el uno de los autores. Será un feroz crítico de la Restauración francesa. Defendía el Estado de Derecho y las libertades civiles en el período anterior al triunfo de la llamada Monarquía de
} 
Luis" en 1823 para interrumpir el período liberal español y proscribir a la Constitución de 1812 gaditana, como también llevó a François Pierre Guillaume Guizot ${ }^{295}$ a decir que aquél modelo constitucional implantado en España con la Revolución de 1820 fue muy respetuoso con la monarquía y mucho más pacífico que otros procesos revolucionarios del mismo carácter, como fue el caso de los ingleses ${ }^{296}$.

El texto repristinado de Cádiz, tras el pronunciamiento militar de Riego, era visto por Constant y por Guizot, dentro de la concepción liberal doctrinaria, como inaplicable tal cual se empleó en $1812^{297}$, por lo tanto, mejorable en muchos aspectos. Pero no la rechazaban de todo. Así fue, que el propio Guizot llega a ridiculizar las críticas que hizo von Haller a la Constitución de Cádiz ${ }^{298}$. Las ideas que, tanto la implantación de un gobierno liberal en España, como el mito que Cádiz propala por toda Europa - en un período de vigilancia de la Santa Alianza, celosa por consolidar las restauraciones monárquicas llevadas a cabo por esta y la manutención del status quo -, conduce a las potencias que componían la Santa Alianza, caso de Austria, Francia, Prusia y Rusia, a ver como inadecuado, en esos tiempo que corrían, la adopción de este texto "sedicioso" 299 . Estas potencias exhortan a los liberales españoles a cambiar la constitución de Cádiz dejándola más acorde con lo que se preveía en la Charte Octoyée. Incluso será la excusa o el leit motiv de la intervención militar austriaca en Nápoles y en el Piamonte ${ }^{300}$.

Por tanto, los liberales moderados franceses aceptaban el texto doceañista con cautelas, pero no lo desechaban. Lo que se buscaba, o se temía, era no repetir el vertiginoso periodo revolucionario francés. De este modo, un monocameralismo era mal visto en Francia, dado que no existía un órgano que ocupase el intersticio entre el ejecutivo y la Asamblea Legislativa popular. De ahí que pretenda Constant defender un pouvoir neutre o mismo Destutt de Tracy a

\footnotetext{
Julio, pero se muere en 1830 bajo este nuevo régimen. Era un extenuado defensor de un modelo liberal de Estado, criticaba tanto la monarquía absoluta como el republicanismo extremo.

${ }^{295}$ François Pierre Guillaume Guizot (1787-1874), nacido en Nimes de familia burguesa protestante. Su familia padeció a la etapa del Terror en Francia, donde su padre fue guillotinado. Luego después se va a Ginebra y recibe una educación calvinista. Vuelve posteriormente a Paris donde, en la Sorbona, será catedrático de historia general del Ministerio del Interior y en la segunda Restauración será nombrado Ministro de Justicia. Guizót se convirtió en líder del pequeño grupo de un partido llamados Doctrinarios, que defendía a la vez la Charte y la Corona, pero pensaba este en un monarquismo intermedio, moderado, a caballo entre la monarquía absoluta y el gobierno del pueblo. Así, defendía un sufragio censitario y de los principios constitucionales.

${ }^{296}$ Se puede profundar en esta cuestión tanto en la lectura de AGUILERA, Bruno: op. cit., pp. 504 y ss, como también y de forma más amplia en FERNÁNDEZ SARASOLA, Ignacio: op. cit., pp. 285 y ss.

${ }^{297}$ Ídem, 288 y ss.

${ }^{298}$ Guizot denomina de "laberinto de la estupidez humana" las críticas que hace Von Haller al texto gaditano. HALLER, Ludwig von: De la Constitution des Cortès de l'Espagne, Paris, Librairie grecque-latine-allemande, 1820. $C r f$ AGUILERA, B: op. cit. nota 36.

${ }^{299}$ AGUILERA, Bruno: op. cit., pp. 504 y ss.

${ }^{300}$ FERRANDO, Juan: op. cit., pp. 103 y ss.
} 
escudar el pouvoir conservateur (Estas propuestas serán acogidas en la Carta Otorgada de Brasil de 1824 y posteriormente en la Portuguesa de 1826, como debatiremos en los capítulos siguientes). A la división dura de los tres poderes existentes en Cádiz no les gustan a los liberales doctrinarios, y para contrarrestar a este modelo propugnan la creación de un senado, integrado por nobles y notables que actuaría como contrapeso, frenando los excesos de los representantes del pueblo ${ }^{301}$.

Pero es un hecho, que solamente se llamó a la atención en Francia para el texto doceañista después del éxito que este tuvo en los diversos procesos revolucionarios esparcidos por Europa, cada uno se identificaba a su manera con la Carta española, principalmente con el tema de la independencia frente a la tiranía de potencias extranjeras, que de una forma o de otra dominaban determinadas zonas de Europa, como ya enunciamos al inicio de este capítulo.

El texto gaditano hizo que en Francia se analizasen de forma detenida los aspectos principales de esta carta constitucional, destacando los aspectos positivos y negativos de la misma, desde la lógica teórica y las percepciones inherentes al caso francés. Uno de estos teóricos fue Jean Denis de Lanjuinais ${ }^{302}$, quien en un esfuerzo analítico, reduce la Constitución de Cádiz a 120 artículos, esenciales en su opinión para tornarla operativa ${ }^{303}$. Sin embargo, no fue solamente este crítico que veía al texto gaditano posibilidades de aplicación con ciertas mudanzas. El eclesiástico Dominique Dufour de Pradt y el político Jean Marie Duvergier de Hauranne $^{304}$ afirmaban que el mayor defecto de aquél texto constitucional estaría en la disminución o incluso en la eliminación del poder real, con lo que se hacía alusión a la detestada en su momento, como fue la Constitución de 1791 francesa $^{305}$.

La atracción que produce Cádiz en Europa, sobre todo en Francia, región que venimos tratando, se diluye con la Revolución que tuvo lugar en Francia en 1830. Los efectos se apreciaron tanto en Bélgica -que se independentiza de los Países Bajos y se dota de una Constitución, la de 1831, muy inspirada en los criterios del liberalismo doctrinario- como en

\footnotetext{
${ }^{301}$ AGUILERA, Bruno: op. cit., pp. 504 y ss. También se puede acompañar en FERNÁNDEZ SARASOLA, Ignacio: op. cit., pp. 271 y ss.

302 Jean-Denis de Lanjuinais (1753-1827), abogado, designado al Parlamento de Bretaña y profesor de Derecho eclesiástico en la Facultad de Derecho de Rennes. Fue un diputado moderado en la Convención de 1792, también durante la reacción Termidoriana de 1795. Tuvo siempre una actitud independiente y permaneció firme defensor de la Monarquía Constitucional.

${ }^{303}$ AGUILERA, Bruno: op. cit., p. 505.

${ }^{304}$ Dominique Georges-Frédéric Dufour de Pradt escribió sobre la situación española tras el pronunciamiento de Riego, intitulada De la révolution actuelle de l'Espagne, et de ses suites. Jean Marie Duvergier de Hauranne, era un arduo crítico de la monarquía absoluta y defendía los principios constitucionales en un sentido moderado. Escribió una obra donde criticaba la represión llevada a cabo por Fernando VII tras la intervención francesa para interrumpir el Trienio Liberal en 1823, intitulada Coup d'oeil sur l'Espagne.

${ }^{305}$ Ídem, pp. 506 y ss.
} 
Inglaterra, que se vio forzada a realizar una reforma electoral de 1832, como también en España con la nueva Constitución de 1837, inspirada en la Belga de 1831. Esto representó un alejamiento de lo que representaba Cádiz en su totalidad, optando de esta forma por un modelo, aunque inspirado en el esquema formal gaditano, más acorde con el liberalismo doctrinario ${ }^{306}$.

La repercusión que tiene la Revolución en España y la adopción de la Constitución de 1812 también atraerá la atención de Gran Bretaña. No solamente de políticos sino de teóricos interesados en el asunto. Estas repercusiones se aprecian principalmente en la prensa ${ }^{307}$, pero no solamente ahí, pues también vieron la luz algunas obras que trataban detenidamente al texto doceañista.

La Constitución de Cádiz no era una ilustre desconocida en Gran Bretaña; ésta, según nos señala Fernández Sarasola, había sido traducida al inglés un año después de proclamada en España y nuevamente fue llevada al conocimiento de los ingleses en el año de 1820. Nos informa, además, este mismo autor que las críticas al texto doceañista se ordenaban en cuatro grandes frentes en Gran Bretaña: el posicionamiento monárquico-constitucional que se decantaba en la Quarterly Review $^{308}$, el posicionamiento monárquico-parlamentarista de la Edinburgh Review ${ }^{309}$, el positivismo utilitarista de Jeremy Bentham en la Westminster Review y el posicionamiento del liberalismo radical inglés.

En dos momentos claves para el texto español los periódicos británicos se manifestaron con vehemencia sobre el asunto: en 1814 la Carta fue abolida por Fernando VII al regresar al poder, y de nuevo en 1823 cuando las tropas francesas restablecieron el absolutismo monárquico en España ${ }^{310}$. De este modo, las críticas al texto gaditano en la prensa británica estaban relacionadas directamente a su filiación política.

Otrosí, dentro de una interpretación monárquico-constitucional, la Quarterly Review no economizará ataques al texto gaditano en los puntos que consideraba defectuosos en aquélla carta. Entre estos puntos están: el parlamento unicameral; la no existencia de un veto absoluto

\footnotetext{
${ }^{306}$ Se puede leer más en FERNÁNDEZ SARASOLA, Ignacio: op. cit., p. 288.

${ }^{307}$ Sobre el tratamiento en la prensa Gran Bretaña dado al texto gaditano, sobre todo los periódicos y periodistas españoles ahí residentes, se puede encontrar en MORENO ALONSO, Manuel: Blanco White y la Constitución de 1812 en Inglaterra en ESCUDERO, José Antonio (Dir.):op. cit., pp. 515-523.

${ }^{308}$ Quarterly Review era un periódico oficial del partido ingles tories fundado en 1809 por John Murray.

${ }^{309}$ Edinburgh Review, tuvo su primer número impreso en 1755. Era un diario vinculado al partido whig. En este periódico, en 1813 sale muchos artículos en secuencia de Martínez Marina, como el Ensayo histórico-crítico y la Teoría de las Cortes. Eso se debe en gran medida a "José María Blanco White (que) es un punto de referencia obligado durante la primera experiencia histórica del constitucionalismo en España. Su caso es, además, de una gran originalidad, por haber asistido desde Inglaterra, de manera bien crítica y obsesiva, a todo el proceso del constitucional español. A él se debió hasta la difusión en Inglaterra de la Teoría de las Cortes de Martínez Marina, cuando el texto tan solo había corrido de manera profusa en copias manuscritas." MORENO ALONSO, Manuel: op. cit., p. 515.

${ }^{310}$ FERNÁNDEZ SARASOLA, Ignacio: op. cit., pp. 273 y ss.
} 
del rey, y la sujeción de este al Consejo de Estado - órgano este, elegido por las Cortes, en lo que se le veía débil por este motivo ${ }^{311}$. No solamente estos puntos llamaban a la atención del autor del artículo publicado en aquél periódico, sino también la aparente imitación de la Constitución de 1791 francesa, donde se establecía una democracia, vista por el periódico como nociva. Otra gran mancha de la Constitución española era la intangible intolerancia religiosa ${ }^{312}$. Además de todo, las críticas de este periódico se dirigían también contra el propalado historicismo reformador de la Constitución de Cádiz, puesto que, según se decía, la filosofía francesa mal se disfrazaba en el texto constitucional ${ }^{313}$.

José María Blanco White, manteniendo el mismo tono de critica de su periódico El Español ${ }^{314}$, cuando escribió en el numero XXIX de la Quarterly Review, tacha al unicameralismo, al principio de la soberanía nacional ${ }^{315}$, la falsedad del nacionalismo, como un mero disfraz de las doctrinas francesas. Además, justifica que la admisión de la confesionalidad, sólo era un artificio para que el texto constitucional tuviese aceptación, y la intención de aquéllos constituyentes no era otra que caminar en dirección a una republica.

En contrapartida, y tendiendo a una visión un poco más positiva que el periódico tory, el diario whig, la Edinburgh Review, desde su visión monárquica parlamentaria, no dejaba de reconocer que en el texto gaditano al monarca se le reservaban prerrogativas substanciales ${ }^{316}$. Además de todo, se apreciaba la limitación del poder de veto del monarca como algo positivo. En el volumen XXXVII, número 75, de febrero de 1823, se defendía la adopción de ciertos principios contenidos en la carta española como algo imprescindible para el éxito de la revolución española; principios como: la soberanía nacional, el reconocimiento de derechos subjetivos y la supremacía de las Cortes de Cádiz ${ }^{317}$.

Contrariamente a lo que se pueda pensar, la Edinburgh Review no ponía al texto español en la categoría de intachable. En aquellos puntos en que la constitución chocaba con lo que era la lógica británica, el diario no dudaba en hacer críticas. Entre estas está el unicameralismo,

\footnotetext{
${ }^{311}$ Quarterly Review, vol. XXVIII, octubre-enero 1822-1823, pp. 548, 555 y 556, citada por Ignacio Fernández Sarasola, Ídem, p. 273.

312 Ídem, pp. 547, 548 y 551.

${ }^{313}$ En la página 546 del volumen de la Quarterly Review, anteriormente citado, va a criticar lo que el aquél periódico llama de vía incorrecta tomada por los constituyentes gaditanos, introduciendo a la constitución novedades poco saludable, en vez de construir un constitución con base en las antiguas leyes fundamentales del reino de Castilla, como también de Aragón.

${ }^{314}$ MORENO ALONSO, Manuel: op. cit., pp. 516 y ss.

${ }^{315}$ El principio de la soberanía nacional era visto por Blanco White, en el número XXIX, abril-julio de 1823, como una de las drogas venenosas francesas. FERNÁNDEZ SARASOLA, Ignacio: op. cit., p. 274.

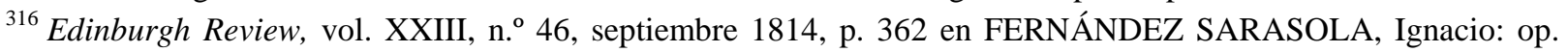
cit., p. 275.

${ }^{317}$ Edinburgh Review, vol. XXXVII, n. ${ }^{\text { }}$ 75, febrero de 1823, p. 242 en FERNÁNDEZ SARASOLA, Ignacio: op. cit., p. 274.
} 
puesto que era una forma excluyente para las clases privilegiadas de la sociedad. Claramente antagónica a la existencia de la Cámara de los Lores del Parlamento británico. De ahí que se dijese que el Consejo de Estado no era nada más que un embrión de la Cámara Alta, pero que resultaba insuficiente ${ }^{318}$. Por lo que se refiere a la incompatibilidad de los cargos de diputados y ministro, la Edinburgh Review clasificaba de error fatal, mostrando que era imprescindible para la tranquilidad de un Estado que el gobierno se administre por personas que tengan en alguna medida la confianza, y en todo caso el respeto, el cuerpo de la Nación ${ }^{319}$. Justificando como ejemplo, claro está, el modelo británico. Era así porque los principios de la doctrina francesa ${ }^{320}$ que se dejaba entrever en el texto gaditano no agradaban mucho a estos monárquicos parlamentaristas.

Lord Holland, uno de los críticos de Cádiz, se fijaba sobre todo en la afirmación de ser Cádiz una constitución histórica, y en la forma que la libertad de prensa era tratada en el texto constitucional; además de hacer ciertas observaciones sobre Las Cortes. Este autor veía como algo erróneo el modo en que aquéllas se organizaron. Como los demás que seguían la corriente monárquico-parlamentaristas rechazaban el parlamento unicameral, el sistema electoral indirecto, la imposibilidad de los diputados electos de concurrir a un segundo mandato. También criticaba el hecho del texto gaditano de no haber asimilado al modelo británico de monarquía parlamentaria. Crítica esta que coincidía no solamente con el partido tory, sino también, con la visión defendida por la Edinburgh Review ${ }^{321}$. Aparte de estas diatribas al texto doceañista, Lord Holland decía que el resto de la Constitución debía ser enmendado, aunque esta padecía de un mal mayor, el obstáculo de la irreformabilidad por ocho años previsto en el artículo 375 de la constitución. También Lord Wellington era partidario de muchas de las críticas profesadas por Lord Holland, aunque pertenecían a partidos diversos ${ }^{322}$.

El publicista británico, Jeremy Bentham, creador de la corriente del positivismo utilitarista, veía con buenos ojos a la Constitución de Cádiz, principalmente a lo que se refería a

\footnotetext{
${ }^{318}$ En el número 46, del volumen XXIII, de septiembre de 1814, en la página 363, anteriormente citado, el artículo de la Edinburgh Review, se hacían estas consideraciones.

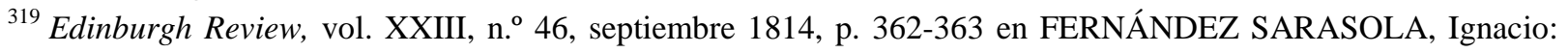
op. cit., pp. 275 y 276.

320 “(...) No acudía al modelo al modelo de checks and balances de Locke, Hume, Blackstone o Bolingbroke, sino al sistema de gobierno real, una Monarquía Parlamentaria que habían modelado las convenciones constitucionales. Estas mismas ideas fueron expuestas por dos británicos que se habían implicado, directa o indirectamente, en la política española: Lord Holland y el duque de Wellington. Respecto del primero, ya hemos visto hasta qué punto sus observaciones sobre las Cortes, la Constitución histórica y la libertad de imprenta fueron influyentes en España a través de algunos de sus más íntimos amigos, como Jovellanos, Blanco White, Argüelles o Quintana." FERNÁNDEZ SARASOLA, Ignacio: op. cit., p. 276.

${ }^{321}$ Para saber más se puede leer en MORENO ALONSO, Manuel: op. cit., pp. 518 y ss. Además, se puede complementar con FERNÁNDEZ SARASOLA, Ignacio: op. cit., pp. 277 y ss.

${ }^{322}$ Lord Wellington era del partido Tory y Lord Holland era del partido Whig.
} 
los aspectos genéricos, pero, también veía unos cuantos defectos en este texto constitucional ${ }^{323}$. Aunque, distintamente de la visión que externalizaban tanto tories como whigs, Bentham prefería a la Constitución de 1812 a la británica, cuando decía: ¡Pueblo de Europa! Si ha dado gracias al Altísimo por haber puesto ante tus ojos el Código Constitucional español, da también gracias por no haber puesto ante ti la visión del código inglés ${ }^{324}$.

En este sentido, Bentham miraba hacia el texto gaditano entusiasmado, en lo que se refiere a la tutela de los derechos subjetivos dirigidos por una concepción finalista de la nación, descrita en los artículos 4 y 13:

Art. 4. La nación está obligada a conservar y proteger por leyes sabias y justas la libertad civil, la propiedad y los demás derechos legítimos de todos los individuos que la componen;

Art. 13. El objeto del gobierno es la felicidad de la nación, puesto que el fin de toda sociedad política no es otro que el bienestar de los individuos que la componen ${ }^{325}$.

A diferencia de la crítica realizada por los tories y whigs, Bentham se resistía a admitir que los modelos y estándares del parlamentarismo ingles fueran adecuados para el caso español, de tal forma que no manifiesta agrado por el sistema de checks and balances, ya desde su obra intitulada A Fragment on Government, de 1776. Así pues, él ve con buenos ojos el unicameralismo prescrito en la Constitución de 1812. No solamente eso, sino que también va a elogiar cuanto el principio consagrado en el texto doceañista de la responsabilidad de las autoridades públicas, incluido el rey ${ }^{326}$. Bentham cuando hace críticas al texto gaditano, no lo hace con el objetivo de rechazar dicha ley fundamental o negar su aplicación, sino al contrario, él veía su posible aplicabilidad, pero consideraba que muchos de sus artículos debían ser retirados o modificados. En esta línea llega a amonestar tanto a Portugal como a Nápoles por no seguir determinados principios fijados en Cádiz. Hace también, el publicista inglés, una dura crítica al tratamiento dado a las colonias de ultramar y la poca representatividad dada a su población $^{327}$.

\footnotetext{
323 "La Constitución de 1812 hubo de someterse a la crítica todavía más severa, si cabe, de Jeremy Bentham, a la sazón relacionado con España a través del Conde de Toreno y de José Joaquín de Mora, editor del periódico El Constitucional. Bentham representaba la crítica radical a la Constitución gaditana. A tales efecto, el brillante filósofo rechazaba sin paliativos la comparación con el sistema británico, que él consideraba lleno de tachas, y proponía, por el contrario utilizar el sistema norteamericano como referente.” FERNÁNDEZ SARASOLA, Ignacio: op. cit., p. 278.

${ }^{324}$ Jeremy Bentham comentando a la política española en 1820 en Ídem, p. 279.

${ }^{325}$ CONSTITUCIÓN ESPAÑOLA DE 1812, Artículos 4 y 13.

${ }^{326}$ Muchas de estas críticas Jeremy Bentham aparecen en el artículo que escribe intitulado Emancipation Spanish (1820) citadas en FERNÁNDEZ SARASOLA, Ignacio: op. cit., pp. 279 y ss.

327 "Por lo que respecta a la regulación constitucional de los órganos del Estado, la crítica de Bentham se alejaba radicalmente de la vertida por la Edinburgh Review: los puntos oscuros de la Constitución de Cádiz residían en determinados aspectos que debilitaban a las Cortes respecto del Ejecutivo". Ídem, pp. 279 y 280.
} 
Otras críticas al texto español eran emanadas de la pluma de Bentham, principalmente en relación con el ministerio y en relación al ejecutivo, a algunos dispositivos constitucionales sobre la organización del parlamento, como la no reelegibilidad de los diputados, el reducido número de sesiones ${ }^{328}$ y la incompatibilidad de los cargos; esta ultima opinión coincidía con la que defendían los tories en la Quarterly Review. En cuanto a lo que se refiere a la opinión pública, el publicista inglés tenía una opinión bastante particular, que correspondía adecuadamente con su ideado Tribunal de la Opinión Pública, donde Bentham defendía el papel de la prensa, no solo en el ámbito informativo, sino también de control de los desmanes del ejecutivo, aún más en el caso de Cádiz, donde las Cortes se reunían por un reducido periodo, apenas tres meses ${ }^{329}$.

Pero, el defecto mayor para Bentham de la Constitución de 1812 estaba justo en el artículo 375:

Art. 375. Hasta pasados ocho años después de hallarse puesta en práctica la Constitución en todas sus partes, no se podrá proponer alteración, adición ni reforma en ninguno de sus artículos ${ }^{330}$.

Esta barrera erguida por el legislador crea un problema serio en los planteamientos de Jeremy Bentham, puesto que, si no se puede cambiar al texto, y aquel ve en esto muchos defectos cambiables, la aplicabilidad y proselitismo del texto constitucional quedan vulnerados. Muchas de estas críticas se plasmaron en la revista creada por Bentham, la Westminster Review ${ }^{331}$.

Y por fin, las críticas de la corriente del liberalismo radical inglés dirigidas a la Constitución de Cádiz. Estas últimas críticas fueron más condescendientes al texto español. Un amigo de Bentham, que encarnaba bien esta corriente, era Edward Blaquiere, un animado

\footnotetext{
328 "Precisamente su rechazo siempre al breve plazo de reunión parlamentaria hizo que vertiera una importante crítica a la restricción de las libertades de imprenta y reunión que realizaron las Cortes de 1820. En un escrito dirigido a los españoles (on the liberty of the Press and Public Discussion, 1820) Bentham señaló que, al limitar esos derechos, la Nación no podía defenderse de los ataques del Ejecutivo cuando las Cortes se hallasen disueltas. La crítica de Bentham correspondía con su idea de Tribunal de la Opinión Pública, como control social: la libertad de imprenta no debía servir sólo para instruir, sino también como medio de resistencia frente a los abusos de poder. Por tal circunstancia, al limitar este derecho las Cortes acababan por poner en peligro la propia Constitución. Sin embargo, es obvio que a la crítica de Bentham no podía subyacer un ataque al legicentrismo a partir de postulados iusnaturalistas. Como es de sobra sabido, Bentham se había esforzado en derribar la concepción iusnaturalista de los derechos subjetivos. Pero ello no le impedía considerar que el legislador debía aprobar una serie de securities que garantizasen los derechos individuales”. Ídem, pp. 280 y 281.

${ }^{329}$ Estas y otras de las ideas antes descritas serán defendidas por Bentham en su obra On the liberty of press and public discusión (1820); también en la obra intitulada Trois essais sur la politique de l'Espagne (1820) y en la Rid yourselves of Ultramaria (1820) discutidas y citadas por Ignacio Fernández Sarasola en Ídem, pp. 280 y ss.

${ }^{330}$ CONSTITUCIÓN ESPAÑOLA DE 1812, Artículo 375.

${ }^{331}$ The Westminster Review, abril de 1824, p. 290. Esta revista trajo publicados artículos de muchos personajes famosos de la época sobre el asunto, como Lord Byron, Coleridge, Stuart Mill y Carlyle. Nombres españoles también aparecen en la revista, siendo destacable el de Alcalá Galiano, quien escribió un artículo criticando a la Constitución doceañista en la línea benthamita. Alcalá Galiano escribe su artículo en el volumen VI de la revista, mayo-julio, 1826. La citación de esta revista la hace FERNÁNDEZ SARASOLA, Ignacio: op. cit., p. 281.
} 
defensor del texto gaditano y un entusiasta de las revoluciones inspiradas en aquél texto. Blaquiere defendía casi todo en el texto gaditano, hasta la barrera de ocho años impuesta por el legislador para proceder a cambios en el texto constitucional, este artículo criticado por Bentham, era visto por Blaquiere como un ejemplo de prudencia y sabiduría ${ }^{332}$. De esta manera, las críticas suavizadas al texto constitucional por el radicalismo inglés se contraponían a los demás detractores británicos del texto gaditano.

Hasta ahora hemos venido destacando los debates en el campo teórico del texto doceañista y el impacto que esto tuvo en los países precursores de modelos constitucionales, cuáles sean, Francia e Inglaterra, que por su parte servirán también de ejemplo a seguir por otros países. Pasaremos en seguida a destacar los reflejos en la prensa española de la aceptación del texto constitucional de 1812 por parte de los revolucionarios de países como Portugal, por ejemplo; que además pone en práctica el ideario gaditano. Pero antes veremos el impacto de la prensa en la absorción y esparcimiento de este ideario revolucionario liberal gaditano.

\subsubsection{La Prensa y la Revolución: el periodismo en el Trienio Liberal tras el silencio del sexenio absolutista en España.}

Durante el Trienio Liberal la prensa será un vehículo de propaganda política e ideológica, tanto para los liberales de varios matices como para los absolutistas ${ }^{333}$. Pero, este ambiente de libertad de publicación ya se había experimentado en Cádiz en el momento de la Guerras de la Independencia, lo que va a motivar el Decreto de 1810, que declaraba la libertad de imprenta; y en definitiva, la Libertad de Expresión será reconocida por la Constitución de 1812, prevaleciendo hasta la disolución de las Cortes por Fernando VII y la consecuente derogación de la Constitución. Entonces prevalecerá un largo "silencio" que durará hasta 1820; este silencio fue roto con el Pronunciamiento de Riego y la consecuente repristinación de la Constitución gaditana. En el Trienio Liberal se vivirá una nueva fase de la libertad de imprenta, donde los distintos colores ideológicos se batirán a través de escritos para todos los gustos.

La publicación de periódicos en España tuvo varios contratiempos, pues desde el final del siglo XVIII hasta el Trienio Liberal hubo momentos de expansión y de contracción. El Decreto de 1791 fue uno de aquéllos momentos donde se formaron barreras en contra de la actividad periodística, aunque ésta se recuperó luego en seguida. Sin embargo, en 1804, una Real Orden de 28 de abril limita la estampa de nuevos periódicos, y esto marca otro revés para

\footnotetext{
${ }^{332}$ La obra donde Edward Blaquiere decanta sus paciones por el texto gaditano fue intitulada An historical review of the Spanish Revolutión (1822) citada y comentada por Ignacio Fernández Sarasola en Ídem, p. 282.

333 "La prensa es convertí, durant el Trienni, en un dels principals mitjans de propaganda política i ideológica, de manera que a Catalunya al llarg d aquests anys es publicaren quarenta-tres periòdics, tot i que de durada molt diversa. La majoria, un 40\%, d'orientació constitucional, un 28\% dorientació liberal exaltada, un $18 \%$ d`orientació liberal moderada i un 13\% de reialistes.” ARNABAT MATA, Ramón: op. cit. p. 148.
} 
la prensa. Una otra adversidad fue creada por la Real Orden de 11 de abril de 1805, dada en Aranjuez, donde se preveía la vigilancia de los periódicos existentes por el Juzgado Especial de Imprenta, creado por esta misma Real Orden. Este órgano podía actuar de forma independiente del Consejo de Castilla, como de cualquier otro tribunal del reino ${ }^{334}$.

Otros hechos históricos van marcar el paso de la actividad periodística al inicio del siglo XIX. La presencia de las tropas napoleónicas y las inestabilidades políticas del momento van a favorecer una afluencia de una prensa bajo distintos tonos políticos y formatos. Fernando VII va a suprimir el Juzgado Especial de Imprenta creado por la Real Orden de 1805, en 27 de marzo de 1808. Lo que hace que el Consejo de Castilla asuma otra vez sus antiguas competencias en esta materia. Todo este frenesí literario, crea en la práctica ${ }^{335}$, llevada por la inestabilidad que sufría la nación española, una cierta libertad de imprenta. En realidad era el embrión de una futura proclamación de la Libertad de Expresión que va a ser vivida en su momento bajo los gobiernos liberales ${ }^{336}$.

La consecuencia de esta experimentada Libertad de Imprenta, tanto en los momentos inmediatamente anteriores a Cádiz, caso de la Guerra de Independencia ${ }^{337}$, como también en el período en que estuvo en vigor la Constitución de 1812, hace que se consolide un cierto público ávido consumidor de informaciones, y además, la costumbre de acceder a los periódicos entra en el vivir cotidiano de las ciudades. Toda una cultura de discutir este tipo de literatura se forma en los cafés, tertulias y círculos sociales. Esta demanda hará que muchos periódicos nunca desaparezcan y muchas veces se adapten a las nuevas realidades para la prensa ${ }^{338}$. Siendo

\footnotetext{
${ }^{334}$ SÁNCHEZ HITA, Beatriz: op. cit., pp. 69 y ss.

335 "La Libertad política de la imprenta, que existía de hecho desde el comienzo mismo de la insurrección, fue decretada por las Cortes el 10 de noviembre de 1810. Su importancia táctica fue claramente sentida por los antirreformistas, que no desperdician siempre a salir en defensa de este Paladín de la libertad, antemural del despotismo y vehículo de las luces. Fieles al optimismo racionalista que heredaran de los ilustrados, creen que la razón, debidamente ilustrada, puede conocer la verdad y triunfar del error. La libertad de imprenta es para ellos un medio de ilustración, de educación, que difundirá el espíritu público y formará la opinión pública, cuyo fiel barómetro será al mismo tiempo. Es significativo que el artículo relativo a la libertad de imprenta (el 371) está colocado en la Constitución en el capítulo dedicado a la instrucción pública. Es indispensable para el progreso de las luces, del que se derivarán todos los demás progresos o adelantamientos (he encontrado siempre la palabra progreso con su correspondiente complemento - progreso de las luces, progreso de la civilización, progreso de las ciencias, etc)." SEOANE CRUZ, María: El primer lenguaje constitucional español (Las Cortes de Cádiz), Madrid, Editorial Moneda y Crédito, 1968, pp. 140, 141 y 142.

${ }^{336}$ SÁNCHEZ HITA, Beatriz: pp. 70 y ss.

${ }^{337}$ SÁNCHEZ HITA, Beatriz: La prensa y la imprenta en el Cádiz de la Guerra de la Independencia (1808-1814) en MORTARI FERNÁNDEZ, Manuel \& MARTÍN MORENO, Ana (coord.): Prensa y Libertad de Imprenta. Los periódicos en el Cádiz de las Cortes, Cádiz, Galería GH40, 2010, pp. 57 y ss.

338 "En este sentido el caso más significativo de adecuación a la nueva realidad es el del Diario Mercantil de Cádiz, que tras muchos intentos consiguió editar a partir de 1802 uno de los más prolijos periodistas gaditanos: el barón de la Bruère. Desde 1804 Bruère también editará como suplemento el Correo de las Damas o Poliantea Instructiva, Curiosa y Agradable de Literatura, Ciencias y Artes, que continuaría saliendo hasta 1808. Desde marzo o abril de ese año sólo permanecerá en la palestra el Diario Mercantil, en el que los contenidos políticos, así como la literatura de talante patriótico iban a ganar espacio a los asuntos económicos; este impreso será igualmente uno de
} 
demasiado decir que con toda esta demanda, el aflujo de periódicos no solamente se debían a factores ideológicos, sino también a los de carácter económico, puesto que se torna un producto de consumo ${ }^{339}$.

La efusiva libertad de imprenta vivida bajo el Decreto de 1810 durará pocos años, dando paso a un sexenio silencioso bajo la batuta absolutista de Fernando VII, liberado el 24 de marzo de 1814 por el Tratado de Valençay. Ya en España, el Cardenal de Borbón, en el día 16 de abril presenta al rey la Constitución de 1812 para ser jurada por este, condición sine qua non para que se suspendiese la nulidad de sus actos, decretada el 1 de enero de 1811 por las Cortes mientras durase su cautiverio ${ }^{340}$. Recibía en Valencia con una mano la Constitución para jurarla y con la otra el Manifiesto de los Persas, de las manos del diputado absolutista Mozo de Rosales, que estaba firmado por 69 diputados de la misma corriente ideológica que Mozo para que el rey anulase la Constitución de Cádiz y todo lo que hubiese sido decretado por las Cortes hasta entonces. El rey deseado sigue a rajatabla lo que pedían los diputados absolutistas. Con el Decreto de 4 de mayo de 1814, que sólo se dará a conocer una semana después, destruye al régimen liberal, disuelve Las Cortes y anula la Constitución de $1812^{341}$. Consecuentemente acaba con la libertad que la imprenta gozaba hasta la fecha.

El fin de la Libertad de Imprenta era ya una muerte anunciada ${ }^{342}$. Algunos liberales desconfiaban o ya estaban seguros de las pretensiones del rey. Pero, ni todo periodista liberal estaba tan consciente de esta realidad, como Bartolomé José Gallardo de la Abeja Madrileña. La profesora María Cruz Seoane afirma que algunos periódicos de cuño liberal aún seguirán emitiendo sus números hasta el 11 de mayo de 1814, fecha en que se da a conocer el Decreto firmado una semana antes. Según Carlos Seco, España se acostó liberal y se levantó absolutista $^{343}$. Sin embargo, el estupor no era privilegio solo de los periodistas, pues las propias

\footnotetext{
los que mayor duración presente, pues continuará editándose ininterrumpidamente hasta 15 de marzo de 1814, aunque volverá a reaparecer más adelante.” Ídem, p. 70.

339 Ídem p. 81.

${ }^{340}$ CRUZ SEOANE, María: Oratoria y periodismo en la España del Siglo XIX, Valencia, Editorial Castalia, 1977, pp. 113 y ss.

${ }^{341}$ SÁNCHEZ HITA, Beatriz: op. cit. pp. 78 y ss.

342 "Las intenciones de Fernando no eran secretas para nadie. El Procurador General y la Atalaya, sintiendo próximo el triunfo se hacen más atrevidos y agresivos. Bartolomé José Gallardo, previendo lo que iba a ocurrir, dejó de publicar el 7 de mayo la Abeja Madrileña, despidiéndose de sus lectores con un gracioso suelto de transparentes alusiones: Los redactores de este periódico están imposibilitados de proseguir su publicación porque se encuentran atacados de un cierto aire seco que sopla de Levante, viéndose precisado a mudar de aires y tomar aguas termales... Porque el último mono se ahoga y más vale un me largo a tiempo que un ciento todo va ahora bien y cepos quedo. La Atalaya le dedicó un epitafio el día 9 que terminaba amenazadoramente: Procúrate enmendar, liberal fuerte / mira que ya cercana está tu muerte." CRUZ SEOANE, María: Oratoria y periodismo en la España del Siglo XIX, op. cit., p. 113.
}

${ }^{343}$ Ídem, p. 114. 
Cortes tuvieron una sesión ordinaria el día 10 de mayo y trataron de asuntos relativos al día siguiente, un día antes de su disolución ${ }^{344}$.

La prensa absolutista, encabezada principalmente por El Procurador General y por La Atalaya de la Mancha, cargaba contra los liberales, pidiendo un ejemplar castigo y dura persecución para estos. También desde los púlpitos se clamaba contra los liberales, como lo hacen los predicadores Manrique y García Bermejo ${ }^{345}$. La Inquisición resucitada cobra nuevas víctimas y se ceba con periódicos de inclinaciones liberales, publicados entre 1808 y 1814. La lectura y posesión de aquéllos periódicos y folletos estaban terminantemente prohibidas bajo pena de excomunión mayor y multa de 200 ducados $^{346}$. Esto todo contrariaba a las promesas hechas por el Decreto de 4 de mayo, que preveía una justa libertad de comunicación por medio de la imprenta sus ideas y pensamientos, aunque preveía un pero: debían estar dentro de aquellos límites que la sana razón soberana e independiente prescribe a todos para que no degenere en licencia ${ }^{347}$, devaneos y locuras. Es dentro de esta baliza que se pasó a prohibir a la manifestación de ideas que pusiesen en jeque la causa del Trono y del Altar. Lo que hace que se prohíba enseguida toda clase de periódicos. Esto demuestra un gran temor a los liberales. Por el Decreto de 25 de marzo de $1815^{348}$ solamente se deja publicar a la Gaceta y al Diario de Madrid.

Con la persecución que se llevó a cabo de afrancesados y liberales no restó mucha gente para dar continuidad a la actividad periodística, ni siquiera para contestar al nuevo régimen. Sin embargo, pese al decreto de 1815 y la prohibición que éste traía, salvo honrosas excepciones, y antes de la fiebre literaria del Trienio Liberal, fueron autorizados otros cuatro periódicos:

\footnotetext{
344 "En el silencio de la noche, las tropas del general Eguía, nombrado en secreto capitán general de Castilla la Nueva, irrumpieron en las casas de los regentes Agar y Ciscar, de los ministros y de los diputados más destacados de las Cortes ordinarias y extraordinarias y de otras personalidades liberales y los apresaron. Al día siguiente se hizo público el decreto de 4 de mayo y se declararon disueltas las Cortes. En los días posteriores continuaron las detenciones. Las promesas contenidas en el decreto de 4 de mayo de dar un gobierno moderado con Cortes y libertad de imprenta, eran desmentidas por los hechos de atroz persecución e injusticia. La prensa y la oratoria liberal enmudecieron. Sólo se oía la palabra de los absolutistas que ejercitaban a la persecución y a la violencia." Ídem p. 114.

${ }^{345}$ CRUZ SEOANE COUCEIRO, María: Libertad de imprenta: de vehículo de las luces a derecho del hombre en MORTARI FERNÁNDEZ, Manuel \& MARTÍN MORENO, Ana (coord.): Prensa y Libertad de Imprenta. Los periódicos en el Cádiz de las Cortes, Cádiz, Galería GH40, 2010, pp. 17 y ss.

${ }^{346}$ Se puede leer más en SÁNCHEZ HITA, Beatriz: op. cit., pp. 79 y ss. Además de CRUZ SEOANE, María: Oratoria y periodismo en la España del Siglo XIX, op. cit., pp. 115 y ss.

347347 CRUZ SEOANE COUCEIRO, María: Libertad de imprenta: de vehículo de las luces a derecho del hombre en MORTARI FERNÁNDEZ, Manuel \& MARTÍN MORENO, Ana (coord.): op. cit., pp. 53 y ss.

${ }^{348}$ DECRETO de 25 de marzo de 1815: "Habiendo visto con desagrado mío el menoscabo del prudente uso que debe hacer de la imprenta, que en vez de emplearla en asuntos que sirvan a la sana ilustración del público o a entretenerlo honestamente, se la emplea en desahogos y contestaciones personales, que no sólo ofenden a los sujetos contra los que se dirigen, sino a la dignidad y decoro de una nación circunspecta a quien convidan con su lectura; y bien convencido por mí mismo de que los escritos que particularmente adolecen de este vicio son los llamados periódicos y algunos folletos provocados por ellos, he venido en prohibir todos los que de esta especie se den a la luz dentro y fuera de la Corte; y es mi voluntad que sólo se publiquen la Gaceta y el Diario de Madrid".
} 
Almacén de Frutos Literarios, que funcionó de 1818 a 1819, que contenía una colección de documentos inéditos; La Minerva o El Revisor General, que empieza sus tirajes en 1817, con artículos científicos, históricos, poesías y de críticas literarias; la Miscelánea de Comercio, Artes y Literatura de Javier de Burgos ${ }^{349}$ y la Crónica Científica y Literaria de José Joaquín de Mora en $1819^{350}$. Siguiendo los vientos del momento, estas dos últimas publicaciones en el Trienio liberal van a trasmutar su contenido y orientación, de literario y científico en político, más al gusto del público de la ocasión. Aunque son permitidos aquellos periódicos, que subsistieron frente al Decreto de 1815, no trataban a lo más mínimo los asuntos políticos. Del romanticismo español que Mora exprimía en el cuaderno de la Crónica, juntamente con Alcalá Galiano, con el triunfo del liberalismo, este periódico pasa a llamarse El Constitucional, que será el propagador de las ideas liberales, abandonando su primera vocación, más inocente para Fernando VII ${ }^{351}$.

Después del silencio impuesto a la prensa con la derogación de la Constitución de 1812, volverá ésta a ser aplicada en 1820 con el pronunciamiento de Riego y con ello vuelve la libertad de prensa ${ }^{352}$. La prensa del Trienio Liberal se asemeja a estrellas fugaces; empieza con una vida intensa y luego se desvanece con el retorno del absolutismo. La efeméride marcó la vida de muchos de los periódicos surgidos en el periodo. Nos cuenta María Cruz Seoane que fue un fenómeno tan llamativo la fugacidad de muchos de estos periódicos que salió uno, llamado La Periodicomanía, con el exclusivo propósito de noticiar el nacimiento y muerte de los periódicos y burlarse de ellos. Los periódicos pasan de la fase absolutista con temas despolitizados a la fase liberal con una politización total de los mismos ${ }^{353}$.

\footnotetext{
${ }^{349}$ Se puede profundar más con MORÁN ORTI, Manuel: La Miscelánea de Javier de Burgos: la Prensa en el debate ideológico del Trienio Liberal, Madrid, Artes Liberales, Serie Trivium $\mathrm{N}^{\mathrm{o}} 15,2^{\mathrm{a}}$ Edición renovada, Ediciones UEM-CEES, 1996.

350 "Burgos, afrancesado, aunque condenado a destierro, vivió en Madrid eludiendo su proscripción con el consentimiento del rey. Mora, de inteligencia clara y vasta instrucción a las que sabía dar un aire ligero, había sido llevado a Francia como prisionero durante la guerra de la Independencia y no había tenido ocasión de mostrar sus simpatías liberales, por lo que pudo regresar una vez liberado.” CRUZ SEOANE, María: Oratoria y periodismo en la España del Siglo XIX, op. cit., p. 117.

${ }^{351}$ SÁNCHEZ HITA, Beatriz: La prensa y la imprenta en el Cádiz de la Guerra de la Independencia (1808-1814) en MORTARI FERNÁNDEZ, Manuel \& MARTÍN MORENO, Ana (coord.): op. cit., pp. 75 y ss.

352 "Poco tiempo después del grito de Riego, una vez que Fernando VII juraba la Constitución el 10 de marzo de 1820, la legislación sobre la imprenta decretada en la Guerra de Independencia sería restablecida. El 22 se hizo la convocatoria de Cortes, que se reunieron el 26 de junio de 1820, aunque sus sesiones se iniciaron el 9 de julio. Pronto se instaló la Junta Suprema de Censura, que había sido suprimida el 4 de mayo de 1814; y con igual celeridad, a la vista de los defectos de la ley de 1810, se procedió a la reelaboración sobre ésta y el decreto de 1813 de una nueva ley que fue aprobada por las Cortes el 22 de octubre de 1820. El articulado será ahora mucho más extenso que el de la etapa de la Guerra de la Independencia, y denota un claro intento por especificar los tipos de delitos en los que escritores y editores incurrían y las penas que en cada caso debían aplicarse; al tiempo que se indicaba el modo en que cada caso debían aplicarse; al tiempo que se indicaba el modo en que se debía proceder para denunciar cualquier tipo de escrito." SÁNCHEZ HITA, Beatriz: José Joaquín de Clararrosa y su Diario Gaditano (1820-1822). Ilustración, Periodismo y revolución en el Trienio Liberal, op. cit., p. 81.

${ }^{353}$ CRUZ SEOANE, María: Oratoria y periodismo en la España del Siglo XIX, op. cit., p. 119.
} 
Como ya fuera señalado antes, con el regreso del régimen constitucional se buscó también restablecer la ley de 1810 que reglamentaba la Libertad de Imprenta; y de pronto, junto con éste, surge la Junta Suprema de Censura que había sido suprimida con el decreto de 4 de mayo de 1814. Pero, tanto aquélla ley como el decreto que la reglaba, el de 1813, no convenían ya al momento vivido en el Trienio Liberal, así que se pasó a elaborar una nueva ley de Imprenta, aprobada por las Cortes en 22 de octubre de 1820. Mucho más detallada que la anterior, buscando clausular los tipos de delitos incurridos por los periodistas o por cualquier tipo de escritos. De esta forma se buscó dotar a la administración de órganos que controlasen o reglamentasen a la prensa. Lo que llama la atención fue la creación de un jurado, encargado de determinar si era causa de responsabilidad el escrito denunciado. Si se encontrase culpa, se establecía una multa o simplemente el denunciado era llamado a declarar frente los jueces electos para juzgar al pleito. En una instancia superior se encontraba el Juez de Primera instancia, que evaluaría la pena aplicada si no se estaba en desacuerdo con esta. Y en este caso se elegía otro jurado para volver a apreciar al pleito. Sin embargo, esto está muy de acuerdo con las propuestas de un Tribunal para la prensa de Jeremy Bentham, comentado anteriormente. De este modo, se crea el órgano de la Junta de Protección de la Libertad de Imprenta, que cuidaría de dicha libertad, siendo nombrada cada dos años y teniendo un carácter consultivo ${ }^{354}$.

La politización de algunos periódicos preexistentes al Trienio Liberal será total, como ya señalamos antes. Tanto la Crónica Científica y Literaria, que a partir del día 13 de marzo se convertirá en el Constitucional, liberal hasta la raíz, como también la Miscelánea de Comercio, Artes y Literatura que en el día 10 de marzo se transformó en Miscelánea de Comercio, Política y Literatura, sufrirán una conversión no solamente de cuño ideológico, sino también, según nos dice la profesora Cruz Seoane, citando a Alcalá Galiano, de cuño también económico; era una forma de aprovechar el "hambre" del momento y vender más, una cuestión también de supervivencia ${ }^{355}$. Pero, no serán solamente periódicos ya existentes en el sexenio absolutista los que confluirán con las corrientes liberales, sino que también aparecen innumerables periódicos nuevos, en una verdadera "periodicomanía"356.

\footnotetext{
${ }^{354}$ Más detalles sobre los órganos creados por la Ley de 22 de octubre de 1820, consultar a SÁNCHEZ HITA, Beatriz: José Joaquín de Clararrosa y su Diario Gaditano (1820-1822). Ilustración, Periodismo y revolución en el Trienio Liberal, op. cit., pp. 82 y ss.

355 Ídem, p. 120.

356 "Inmediatamente comienzan a salir periódicos nuevos. A primeros de junio de 1820, menos de tres meses después de proclamada la Constitución, en el gabinete de lectura del café de Levante, según El Conservador del día 3 de dicho mes se hallaban a disposición del público los periódicos que salen de mejor aprecio en la Corte; además de la Gaceta, el Diario, la Miscelánea, y el Constitucional, que existían ya antes del triunfo de la revolución, enumera los siguientes: La Ley, el Publicista, El Correo Universal de Política y Literatura, La Colmena, La Minerva Nacional, El Paladium Constitucional o Diario Patriótico de las Sociedades de San Sebastián y Fonda de Malta, Ciudadanos Celosos o Sociedad de San Sebastián, Aurora de España, El
} 
Como ya lo dijimos y volvemos a repetir, esta fiebre periodística no pasó para nada desapercibida y se tornó asunto clave para la propia prensa del Trienio. Es el caso del anteriormente citado Periodicomanía, como también lo de la Carta III del Pobrecito Holgazán de Miñano, que lamenta la quiebra del monopolio que detentaban, desde el Decreto de 1815, la Gaceta y el Diario $^{357}$ :

Ahora todo es baraúnda, y confusión, y gritos, y alborotos por estas calles; cada día sale un periódico nuevo con diferente título, y no parece sino que no tenían bastante con los antiguos. El que antes quería saber noticias de todo el mundo, ¿tenía más que leer la Gaceta? Y el que gustaba de divertirse un rato por las mañanas ¿tenía más que coger el Diario, que siempre es muy chistoso y satírico? Sobre que la gente con nada está contenta. Allí se trataba de todo con suma ligereza y donaire; ¿qué tendría nadie que decir de aquellos solemnes cultos y novenas, misiones que la Archicofradía primitiva de tal, incorporada con la esclavitud de tal, y la Hermandad de cual dedica, ofrece y consagra en su devota capilla o cosa semejante?

También en La Colmena de 17 de mayo se llamaba la atención por el torbellino de nuevos periódicos y sus consecuencias benéficas para la economía ${ }^{358}$ :

La Constitución ha despertado a la industria. La mendicidad se disminuye. Una multitud de ciegos que vivían a expensas de la caridad cristiana hallan ya su alimento en el trabajo que les proporciona la venta de papeles públicos. Las prensas han recibido operarios que ocupan sus brazos antes ociosos. Los molinos de papel se aumentarán. Los almacenistas de este ramo y los vendedores, libreros y encuadernadores verán circular el dinero. Los repartidores de los periódicos, los que los venden y los que ponen los carteles en las esquinas, todos ganan para subsistir. Los escritores públicos no puede decirse con seguridad que gozarán la misma suerte; pero el que no pueda recoger el fruto de su trabajo porque le llame Dios por otro camino más oculto buscará distinto modo de vivir que no llame tanto la expectación pública. Y la cuenta de correos se engrosará considerablemente y surtirá para la mayoría de caminos y puentes, establecimiento de postas y demás fines de su instituto en beneficio de la nación. Todos estos bienes son hijos legítimos de un solo artículo de la Constitución.

De esta forma percibimos como la profusión de periódicos fue intensa en el Trienio Liberal, de modo que todos los grupos políticos e ideologías sentían que podían expresarse de esta forma. Sin embargo, en los primeros momentos del período liberal, los absolutistas no se atrevían, como nos explica Seoane, a publicar materias defendiendo al régimen pasado ${ }^{359}$. Entretanto, esa prodigalidad periodística del Trienio guardaba ciertos espejismos con lo ocurrido en el curso de la Guerra de Independencia. Nos Cuenta Sánchez Hita que el formato

Conservador, El Vigilante, El Sol, El Universal Observador, Biblioteca Económica o Anales de Agricultura, Artes y Comercio, Periodicomanía, además de las publicaciones que hoy no incluiríamos entre los periódicos como Correspondencia entre Dos Amigos de la Libertad y Cartas del Pobrecito Holgazán." Ídem p. 120.

${ }^{357}$ Carta III del Pobrecito Holgazán en Ídem, p. 121.

${ }^{358}$ La Colmena de 17 de mayo en Ídem, p. 121.

${ }^{359}$ Ídem, pp. 124 y ss. 
periodístico verificado en los años liberales será muy parecido con los del período de la Guerra contra los franceses. Lo que diferencia un poco es que los del Trienio son mucho más politizados que los de antes; además, los títulos de estos periódicos estaban muy relacionados con la ideología a que pertenecían y defendían ${ }^{360}$.

De tal forma era así, que se puede hacer una clasificación de acuerdo a la función ideológica de cada periódico. Gil Novales impondrá una clasificación a la historiografía relacionada con el periodismo, que se queda así: un grupo de periódicos afrancesados; un grupo liberal moderados; una prensa anillera (de la Sociedad del Anillo) y otra absolutista ${ }^{361}$.

Esta profusión de periódicos va a buscar, principalmente en los grupos que compartían sus ideologías, pero no solamente, una fuente de financiación, como nos cuenta Seoane ${ }^{362}$. Lo que muchos no van a lograr será esta ansiada financiación. Aunque, en algunos casos no era necesario comprarlos, porque en algunos sitios se podían leer pagando una módica cuantía; es el caso de los gabinetes de lectura.

Así, el llamado grupo de los afrancesados estará compuesto por los que fueron obligados a emigrar con el restablecimiento del absolutismo en 1814. Rehabilitados políticamente tras el pronunciamiento de Riego, estos estarán empeñados en hacer una contrarrevolución, propensos a un despotismo ilustrado; al fin y al cabo aceptan la constitución, pero con reticencias. Dentro de este grupo de prensa afrancesada estaba el Universal Observador Español, recortando su nombre a únicamente Universal en 13 de julio de 1820, unos meses después de comenzar a funcionar el 12 de mayo ${ }^{363}$. Estaba dirigido por Manuel Narganes, y lo mejor de todo, estaba financiado por el gobierno, lo que le va a garantizar una larga supervivencia más o menos cómoda, sin percances, en un mar de periódicos “natimuertos" 364 . Otro periódico cofrade de este será el Censor. Este salía cada sábado, empezando el día 5 de agosto de 1820 y feneciendo el 13 de julio de 1822, y estaba dirigido por León Amarita. En cuanto a su postura política, que es lo que nos interesa aquí, era muy partidario del sistema constitucional, y buscaba defenderlo tanto de las confabulaciones del servilismo como de los extremistas liberales. No queriendo

\footnotetext{
360 SÁNCHEZ HITA, Beatriz: José Joaquín de Clararrosa y su Diario Gaditano (1820-1822). Ilustración, Periodismo y Revolución en el Trienio Liberal, pp. 85 y ss.

${ }^{361}$ GIL NOVALES, Alberto: Las Sociedades Patrióticas (1820-1823), Tomo II, Madrid, Tecnos, 1975, pp. 984 y SS.

${ }^{362}$ CRUZ SEOANE, María: Oratoria y periodismo en la España del Siglo XIX, op. cit., pp. 122 y ss.

${ }^{363}$ Se puede complementar leendo a ÁLVAREZ JUNCO, José \& DE LA FUENTE MONGE, Gregorio: Las consecuencias prácticas de la libertad de imprenta en MORTARI FERNÁNDEZ, Manuel \& MARTÍN MORENO, Ana (coord.): op. cit., pp. 95 y ss.

${ }^{364}$ Véase más en CRUZ SEOANE, María: Oratoria y periodismo en la España del Siglo XIX, op. cit., pp. 130 y ss. También en SÁNCHEZ HITA, Beatriz: José Joaquín de Clararrosa y su Diario Gaditano (1820-1822). Ilustración, Periodismo y Revolución en el Trienio Liberal, pp. 86 y ss.
} 
decir con esto que no trajera una lectura crítica de la propia Constitución, a lo que llamaba sus imperfecciones $^{365}$. También la Miscelánea, que compartía el editor Javier de Burgos con El Imparcial, se encuadraba en este grupo. Este último periódico saldrá a la luz en el día 10 de septiembre de 1821 y continuará hasta junio de 1822. Además, igual que el Universal, El Imparcial contaba con un patrono que le financiase, lo que le garantizaba en parte su supervivencia.

Del grupo de los liberales, los llamados moderados en la época, están muy vinculados a las oligarquías ciudadanas, a las clases medias y burguesas. Así que buscaban la consolidación de la libertad, a la burguesa, pero también era favorable a la manutención del orden. Según Gil Novales, no les costó mucho desvincularse de este régimen constitucional cuando este estaba en su ocaso. Aunque la profesora Beatriz Sánchez Hita afirma que, por traer en sus títulos el lugar en que estaban editados, denota una cierta vinculación y hasta financiación del gobierno. De este modo, tenemos El Espectador, que empieza en Madrid en el día 15 de abril de 1821 y deja de salir a partir del día 31 de marzo de 1823. Lo dirigía Evaristo de San Miguel, que lo definía como liberal exaltado ${ }^{366}$ y partidario de la restauración absolutista. Aunque, ya había empezado a salir desde 1820 los periódicos de esta corriente liberal. A estos se suman los comuneros, salidos a partir de $1821^{367}$. Dentro de la impronta doctrinal de cada periódico de este grupo llamado de exaltados en la época, se dividía en otros dos subgrupos, los batalladores y los satíricos. En el primer grupo estaba: El conservador, que se estampó en Madrid del 27 de marzo al 30 de septiembre de 1820, escrito por antiguos redactores de El Conciso y El Tribuno; el Eco de Padilla, editado también en Madrid, del 1 de agosto a 31 de diciembre de 1821, con filiación comunera y dirigido por José Joaquín de Mora. El según subgrupo estaba formado por: El Zurriago, editado en Madrid del 18 de septiembre de 1821 hasta el fenecimiento del régimen

\footnotetext{
${ }^{365}$ Sobre el periódico El Censor se puede profundizar más tanto en CRUZ SEOANE, María: Oratoria y periodismo en la España del Siglo XIX, op. cit., pp. 132, como en SÁNCHEZ HITA, Beatriz: José Joaquín de Clararrosa y su Diario Gaditano (1820-1822). Ilustración, Periodismo y Revolución en el Trienio Liberal, pp. 85 y ss.

${ }^{366}$ María Cruz Seoane hace una conceptualización de lo que era, para los periódicos de la época, "moderación” y “exaltación”. CRUZ SEOANE, María: Oratoria y periodismo en la España del Siglo XIX, op. cit., pp. 127 y ss.

${ }^{367}$ Los Comuneros son fruto de "cuando se produce una crisis en el seno de la masonería de la que se separa este grupo caracterizado por pretender llevar a cabo todas las reformas previstas y defender las soberanía nacional. El mayor porcentaje de éstos aparece sobre todo en Cádiz y San Fernando, Madrid, Murcia, La Coruña, Santiago, Granada y Sevilla, aunque también pueden encontrarse en otros puntos de la Península. En unos y en otros se muestra desde el principio el convencimiento de que había que llevar a la práctica todo lo dispuesto según la Constitución, para conseguir mantener la libertad que ésta otorgaba a los ciudadanos. Dentro de este grupo, en el que se encuadran la mayoría de los títulos más señeros de la prensa del Trienio Liberal, habría que distinguir entre aquellos en los que prima la impronta doctrinal y esos otros periódicos batalladores y satíricos". SÁNCHEZ HITA, Beatriz: José Joaquín de Clararrosa y su Diario Gaditano (1820-1822). Ilustración, Periodismo y Revolución en el Trienio Liberal, pp. 88 y 89.
} 
constitucional, estaba redactado por Félix Mejía y Benigno Morales ${ }^{368}$; La Tercerola, impreso en Madrid entre 1821 y 1822, que en su primer número sale como el Zurriago intermedio, lo que molestó a los partidarios de El Zurriago, pero, al final Félix Mejía termina por hacerse cargo también de la dirección de este ultimo ${ }^{369}$.

En el grupo de los conservadores o absolutistas aparecen: El Procurador del Rey, vehiculado en Madrid entre el 22 de mayo de 1822 y el 26 de noviembre de 1823 y el Restaurador, impreso entre 1 de julio hasta 31 de diciembre de 1824. Además están muchos periódicos provinciales, como el sevillano El Amante de la Religión, teniendo poco tiraje pero que estuvo vivo entre 1820 y $1823^{370}$.

De este modo, la oleada abundante de periódicos durante la vigencia de la Libertad de Imprenta sirvió tanto a un bando como a otro para defender sus ideologías. El sistema constitucional recibió un apoyo substancial en estas filas, pero, también se dejó paso a que el bando servilista defendiera por su parte el retorno del absolutismo.

Así, en lo que atañe a nuestro tema, que trataremos en seguida, la proyección que tuvieron los acontecimientos en Oporto, causó impacto en la prensa española, que pasó a noticiar la implantación del régimen liberal constitucional en aquél reino. Tal fue la militancia de la prensa exaltada en este asunto, que causó temor en muchos sectores de la sociedad, llevando a la prensa moderada a contrarrestar a la prensa exaltada, a veces utilizando las mismas armas que aquélla ${ }^{371}$. Para los ministerios, el temor que causaban los zurriaguistas va a transfigurarse en un edicto de la prensa oficial. En el día 15 de agosto de 1821, salió publicada en el Diario de Madrid una Real Orden prohibiendo todo comentario sobre lo sucedido en Nápoles, con la excusa de que provocaba las agitaciones populares ${ }^{372}$.

A modo de cumplir con nuestro objetivo buscaremos principalmente en cuatro periódicos, cuáles son, el Miscelánea, el Mercurio de España, El Censor y El Constitucional noticias sobre Oporto. Será así porque verificamos coincidencias en estos periódicos al traer noticias de esta revolución, dado eran periódicos liberales. Como también para poder dar manejabilidad al tema frente al mar de periódicos salidos en esa época. Por otra parte, no

\footnotetext{
${ }^{368}$ Un estudio más detenido de El Zurriago fue hecho por ZAVALA, Iris María: Románticos y Socialistas. Prensa española del XIX, Madrid, Siglo XXI de España Editores S.A, 1972, pp. 9-38.

369 SÁNCHEZ HITA, Beatriz: José Joaquín de Clararrosa y su Diario Gaditano (1820-1822). Ilustración, Periodismo y Revolución en el Trienio Liberal, p. 90.

370 Ídem, pp. 90 y ss.

371 "En respuesta, los moderados lanzaban canciones análogas esperanzados en contrarrestar el efecto de la punzante crítica zurriaguista. El Látigo Liberal oponía el suyo moderado: El Pueblo son, Que ama al Señor, Llama al Zurriago mal escritor, Porque predica la desunión, Que es de la patria la destrucción: Trágala, trágala tú, pendatón, Trágala, trágala, la moderación." ZAVALA, Iris María: op. cit., p. 24.

372 Ídem, p. 24.
} 
buscamos relacionar las noticias de los periódicos liberales con los periódicos llamados servilistas, o de tendencia conservadora. Dado que este primer abordaje del asunto y el poco tiempo para abarcar todo el universo periodístico no nos permitiría hacer un trabajo definitivo en esta dirección, ya que aquí no es este el objetivo principal. De modo que buscamos noticias sobre la revolución enunciada y pasamos a identificarlas apenas en los meses que se seguían a la revolución. Así, la Revolución portuguesa tuvo aquí cobertura hasta final de diciembre de 1820 en los cuatro periódicos enunciados previamente. Pero, antes de abordar a los periódicos y las noticias sobre la Revolución portuguesa, trataremos de unos antecedentes de esta misma revolución para mejor comprensión de lo opinado por aquellos periódicos. 


\section{2.- La Revolución Liberal de Oporto de 1820: la extensión de la revuelta liberal}

Los sucesos acaecidos en España y los éxitos alcanzados por los liberales en la Revolución de 1820 llegaron a Portugal, principalmente a través de una sociedad secreta llamada $O$ Sinedrio, fundada en 1818 con una doble pretensión: una de ellas era vigilar la situación española y la otra era penetrar en el ejército ${ }^{373}$. Pero, algunos antecedentes históricos marcaron esa postura portuguesa.

A finales de 1807 Godoy firmó con Francia el Tratado de Fontainebleau, como ya señalamos. Entre sus artículos, se contenía el permiso para que tropas francesas atravesasen el territorio español para así tomar Portugal. Si bien éste fue el pretexto sobre el que giró la causa de la negociación, el resto de las cláusulas obligan a pensar que las pretensiones de Napoleón iban más allá, por lo menos, hasta el otro lado del Atlántico, es decir, planeaba hacerse con el control de los vastos imperios coloniales de los que tanto la Monarquía española como la portuguesa eran poseedoras ${ }^{374}$.

De esta forma, todo estaba dispuesto para que a principios de año se iniciara la gran crisis de 1808. Los acontecimientos se sucedieron con inusitada rapidez ${ }^{375}$. El tiempo que se cuenta entre el motín de Aranjuez y las abdicaciones de Bayona apenas sobrepasa un mes, periodo suficiente para que el estado de cosas cambiase. Mientras que los franceses pasaban a ser enemigos y eran vencidos en Bailén, Napoleón designaba para el trono español a su hermano José a la vez que otorgaba el Estatuto de Bayona. En lo que respecta a Portugal, el otro año $8^{376}$, la Corte lusa consiguió eludir al ejército de Junot gracias a la marina británica que la escoltó hasta Brasil.

Al otro lado del Océano, las naves que arribaron con la Corte de los Bragança a los puertos de Salvador de Bahía y de Río de Janeiro en 1808, también llevaron consigo la idea de un nuevo Imperio. Los gobiernos portugueses, ya desde el siglo XVI, habían contemplado la posibilidad de fundar en otro lugar un Estado fuerte, lejos de la amenaza anexionista de la Monarquía hispana y más rico que el territorio peninsular. Brasil, 'la única colonia portuguesa

\footnotetext{
373 "Triunfante al otro lado de la frontera el movimiento de Riego, los promotores de la libertad y del restablecimiento económico y nacional de Portugal, Manuel Fernándes Tomás, José Ferreira Borges y José da Silva Carvalho, fundadores del Sinedrín, provocan el pronunciamiento militar del Campo de Santo Ovidio, en Oporto, el 24 de agosto de 1820, de donde la Revolución se extenderá a Lisboa". GIL NOVALES, A. op. cit., p. 23.

${ }^{374}$ CHUST, Manuel: “Un bienio trascendental: 1808-1810”, en M.CHUST (coord.), 1808. La eclosión juntera en el mundo hispano, México D.F., FCE y Colmex: Fideicomiso Historia de las Américas. Serie Estudios, 2007, pp. 18 y 19 .

375 Ibídem, p. 21

${ }^{376}$ Véase mejor el trazado de este evento en SÁNCHEZ GÓMEZ, Julio: “El otro año 8”, en F. J. MARRONI DE ABREU (ed.), Las invasiones napoleónicas y el mundo iberoamericano, Salamanca, Fundación Cultural Hispanobrasileña, 2008, pp. 105-122.
} 
social y económicamente susceptible de algún desarrollo, ${ }^{377}$, representaba todas las características imprescindibles para albergar aquel proyecto.

Las primeras medidas tomadas por el gabinete del, por entonces, príncipe-regente D. Juan fueron encaminadas al progreso económico de la recién estrenada metrópoli ${ }^{378}$, en paralelo se veía la creciente influencia de Gran Bretaña sobre aquel reino. Lo que no impidió el desarrollo de una política definitoria propia, caracterizada por el expansionismo en el Nuevo Mundo, aprovechando que las repercusiones del colapso de la Monarquía española en América, más duras que en la portuguesa ${ }^{379}$, abrían paso a todo un mundo repleto de oportunidades y de peligros al mismo tiempo. Por eso, no fue extraño que en 1815 el Congreso de Viena ratificase la elevación de Brasil a la categoría de reino, reconociendo de iure lo que venía siendo de facto.

Pero el espejismo de unidad que se desprende de esta elevación de Brasil a reino, escondía la presencia de un regionalismo arraigado. Cuando en marzo de 1817 estalló la revolución pernambucana, después de casi 10 años de la estancia de la Corte en Brasil, los revoltosos manifestaban ideales preeminentemente republicanos y 'uma noção, apenas aparentemente confusa, de federalismo, ${ }^{380}$, en todo caso se percibía ya un sentimiento mayor de 'brasilidad' ${ }^{381}$. Aunque a los pocos años del aplastamiento de la rebelión, la amenaza al gobierno del príncipe-regente provenía, esta vez, desde la península. El triunfo de la revolución de Oporto de 1820, contagio de lo sucedido en España, convocó Cortes y obligó a D. Joao VI a regresar a Lisboa.

Esta revolución burguesa (burguesía mercantil) emanaba de los resentimientos de las consecuencias de las invasiones napoleónicas, de la huida de la familia real (o mejor dicho, del Estado portugués) hacia Brasil; del dominio británico (Lord Beresford); y de la apertura de los puertos de Brasil a las naciones amigas (entiéndase Gran Bretaña). Todas estas situaciones, principalmente la larga estadía de la familia real en Río de Janeiro, causaban una distorsión en el Pacto Colonial, invirtiendo los papeles de Brasil y Portugal. El imperio colonial portugués pasa a ser administrado desde Río de Janeiro por D. Joao VI, haciendo que Portugal perdiese

\footnotetext{
377 VICENTE, António Pedro: "El príncipe regente en Brasil, causas y consecuencias de una decisión estratégica", en F. J. MARRONI DE ABREU (ed.), op. cit., p. 83.

${ }^{378}$ Para un análisis más detenido sobre estas disposiciones, véase PEREIRA DAS NEVES, Guilherme: "Del Imperio Luso-brasileño al Imperio del Brasil (1789-1822)", en A. ANNINO y F. X. GUERRA (coords.), Inventando la nación. Iberoamérica, siglo XIX, México, FCE, 2003, pp. 242 y ss.

379 McFARLANE, Anthony: "Independências americanas na era das revoluções: conexões, contextos, comparações", en J. MALERBA (org.), A independência brasileira. Novas dimensões, Rio de Janeiro, Editora FGV, 2006, p. 394.

${ }^{380}$ SILVA, Luiz Geraldo: "Pernambucanos, sois portugueses", Almanack Braziliense, $\mathrm{n}^{\circ} 1$ (maio de 2005), p. 77.

${ }^{381}$ MURILO DE CARVALHO, José: “Brasil. Naciones imaginadas”, en A. ANNINO y F. X. GUERRA (coords.), op. cit., p. 502.
} 
sus privilegios en el monopolio comercial, dejando de recibir las rentas de las colonias. Eso causaba todo un descontento en las élites de Portugal. El ejército portugués estaba bajo el mando de Lord Beresford y consecuentemente de los británicos. Así, la revuelta militar empezó en la ciudad de Oporto, los constitucionalistas no encontraron resistencia y otras ciudades fueron uniéndose al movimiento, como fue el caso de Lisboa, donde también hubo sublevaciones de las tropas constitucionalistas que tomaron el poder el 15 de septiembre de 1820. Trece días después las autoridades de Oporto y Lisboa se juntaron para formar la Junta Provisional del Supremo Gobierno del Reino. Con amplia adhesión de la sociedad, de inmediato surgieron unas demandas perentorias: se exigía el retorno de la Corte a Portugal, para restaurar la dignidad metropolitana; el establecimiento de una monarquía constitucional; y la restauración del exclusivismo comercial con Brasil. De pronto la Junta gubernamental que ejercía de hecho la regencia de Portugal y estaba encabezada por Lord Beresford fue sustituida por la Junta Provisional que luego convocó cortes generales extraordinarias y constituyentes ${ }^{382}$.

Este estallido revolucionario en Oporto traía consigo una ebullición político-social y económica muy fuerte, como ya se ha dicho, por el hecho de que la monarquía se encontraba en Brasil por el momento y Portugal pasaba por una situación sui generis, colonia de su antigua colonia, ahora transformada en metrópoli, además de la presencia británica que trasformaba a Portugal en una especie de protectorado. Una de las medidas llevada a cabo por el prínciperegente D. Joao fue la llamada apertura de los puertos a las naciones amigas, en 1808, seguida por un tratado comercial de los más humillantes de la historia portuguesa con Gran Bretaña, que destrozó la economía de Portugal $^{383}$. Así como la española, la revolución liberal portuguesa, tampoco carece de problemas internos. El radicalismo, propalado por Fernandes Tomás, suscitó una fuerte reacción conservadora o francamente reaccionaria, principalmente con el advenimiento de la independencia de Brasil en $1822^{384}$.

Pues bien, las noticias de que en el Trienio Liberal español la Constitución gaditana había vuelto a estar vigente de pleno derecho, constituyó un incentivo de inmediato para los constitucionalistas portugueses, donde los liberales se sublevaron en el mes de agosto de 1820, pocos meses después de la revolución española ${ }^{385}$. De esta forma, en la secuencia del

\footnotetext{
382 Para saber más detalles se puede leer en: BIRMINGHAM, David: Historia de Portugal, Cambridge, Cambridge University Press, 1995.

${ }^{383}$ OLIVEIRA MARQUES, A. H.: Historia de Portugal II, Mexico D.F., Fondo de Cultura Económica, 1983, p. 11.

${ }^{384}$ GIL NOVALES, A. op. cit., p. 23.

${ }^{385}$ Antonio Manuel Hespanha dirá que lo más importante en estos dos procesos era analizar los datos coyunturales y menos las coincidencias de fechas, más que causas, consecuencias: "Tais como o sentimento anti-inglês, a criação de um espaço público de discussão política e a difusão nele das idéias reformistas e constitucionalistas, a timidez (ou refluxo) do reformismo (indecisões quanto à prometida reforma dos forais, abandono de projeto de
} 
movimiento militar - así como en el caso español - y apoyado por la burguesía ilustrada portuguesa, es proclamada una Junta de Gobierno en la ciudad de Oporto, que se quedó encargada de convocar Cortes para elaborar una constitución, y manteniendo algún continuismo entre la constitución liberal y el Antiguo Régimen, afirma Antonio Manuel Hespanha, como la manutención de la religión y la dinastía, además de buscar solucionar los problemas del país.

Frente a estos acontecimientos, los gobernadores de Lisboa intentaron convocar Cortes a la antigua usanza, las Cortes del Reino, a través de la Proclamación de $1^{\circ}$ de septiembre de 1820. Pero, tanto la Junta de Oporto como el Gobierno de Lisboa terminaron por presión de las tropas revolucionarias y accedieron a que una nueva Constitución fuera aprobada en Cortes constituyentes convocadas para ello. En octubre, se juró la Constitución futura del Reino ${ }^{386}$.

De esta forma se prepararon las elecciones que tuvieron lugar en diciembre de 1820 , pero en las otras partes del imperio se prolongó hasta inicios de 1822. Ya el 14 de enero tuvo lugar una reunión preparatoria de Las Cortes. D. Joao VI, en Brasil en este momento, se vio obligado a aceptar la idea de una Constitución para el Reino, y en el Decreto de 24 de febrero de 1821, dirá:

"Havendo eu dado todas as providencias para ligar a constituição que se está fazendo em Lisboa como o que é conveniente ao Brazil, e tendo chegado ao Meu conhecimento que o maior bem que posso fazer aos Meus povos é desde já approvar essa mesma Constituição, e sendo todos os meus cuidados, como é bem constante, procurar-lhes todo o descanço, e felicidade: Hei por bem desde já approvar a Constrição, que alli se está fazendo e recebel-a no Meu Reino do Brazil, e no mais domínio da coroa. Os Meus Ministros e Secretarios de Estado a quem este vai dirigido o façam assim constar expedindo aos Tribunaes, e Capitães Geraes as ordens competentes. Palacio do Rio de Janeiro em 24 de Fevereiro de $1821 " 387$

Al contrario que Fernando VII, D. Joao VI tomó medidas para no quedarse fuera de este proceso; buscó enviar a su hijo hacia Portugal, para colaborar en la consolidación de la Constitución, convocó a la corte de Río a los representantes de las Cámaras municipales, jueces

reforma “do Código”), etc.”. HESPANHA, A. M.: Guiando a mao invisível, direito, Estado e lei no liberalismo mmonárquico português, Coimbra, Almedina, 2004, p. 61.

386 “A intervenção da Casa dos Vinte e Quatro e do Juiz do Povo de Lisboa (como representantes da parte mais democrática das antigas instituições representativas) reclamam eleições directas (25.10.1820), no que são apoiadas pelas tropas da guarnição de Lisboa. O governo acede (Instruções de 31.10), estabelecendo um sistema de eleições indirectas, em que votavam os chefes de família, com exclusão dos clérigos regulares, dos incapazes naturais ou legítimos e dos “criados de servir" (que não fossem chefes de família). Os eleitores de segundo grau deviam ter conhecimentos científicos e meios de sustento, firmeza de carácter, respeitar a religião e amar a pátria. Porém, um pronunciamento militar ("Martinhada", de 11.11.1820), obriga à adopção de um sistema de sufrágio, como o da Constituição de Cádiz, que é, de facto, finalmente adoptado (art. 27 a 103; instruções de 22. 11)”. HESPANHA, A. M. op. cit., p. 62.

${ }^{387}$ Decreto de 24 de Fevereiro de 1821.

http://www2.camara.gov.br/atividade-legislativa/legislacao/publicacoes/ doimperio Acceso en 23/09/11. 
letrados, tanto de Brasil como de Cabo Verde para adaptar la Constitución a todos los dominios del imperio. En este ínterin la propia Constitución de Cádiz, que serviría de modelo a la nueva Constitución, seria jurada, aunque por presión popular, sin ninguna modificación, en 21 de abril de 1821. El Rey la promulga provisionalmente en Brasil:

"Havendo tornado em consideração o termo de juramento que os eleitores paroquiais desta comarca, a instancias e declaração unânime do povo dela, prestaram à constituição espanhola, e que fizeram subir a minha real presença (...) sou servido ordenar que de hoje em diante se fique estrita e liberalmente observando neste reino do Brasil a mencionada constituição espanhola ate o momento em que se ache inteira e definitivamente estabelecida a constituição deliberada e decidida pelas cortes de Lisboa"388

Pero, la vigencia de la Constitución de Cádiz solo duró un día, puesto que, luego al día siguiente el rey se retractó atribuyendo a informaciones malintencionadas la toma de esta decisión:

“(...) Esta representação era mandada fazer por homens mal intencionados e que queriam a anarquia, e vendo que o meu povo Se conserva, como eu lhe agradeço, fiel ao juramento que eu com ele, de comum acordo, prestámos na praça do Rocio no dia 26 de Fevereiro do presente ano (...)". 389

Hubo una larga discusión en el momento sobre si realmente el nuevo proyecto constitucional reflejaría el continuismo o encarnaría las innovaciones liberales, principalmente en el Proyecto de Bases de Constitución presentado a 9 de marzo de 1821. Pondera Antonio Manuel Hespanha que el argumento usado de la continuidad conllevó una relectura de la tradición, introducida con la pretensión de legitimar los cambios, pero que mal conseguía disimular las novedades. Pero, es verdad que continuismos en la primera constitución liberal de preceptos del Antiguo Régimen también existirían. Ya en el segundo proyecto constitucional de 25 de junio de 1821 se dio comienzo a los trabajos para la futura Constitución de $1822^{390}$, que en muchos aspectos era un espejismo de la de Cádiz, es verdad que con menos artículos y con una declaración de derechos al inicio, y sin las complicadas soluciones electorales de Cádiz ${ }^{391}$.

Tanto en Portugal como en España, las ideas enciclopedistas y liberales, desde el final del siglo XVIII echaron raíces en la sociedad gracias a las reformas de la enseñanza emprendida por el marqués de Pombal en Portugal, dando lugar a los estrageirados, principalmente Luís Verney, en el Verdadeiro Método de Estudo de 1747; y en España las reformas en este sentido

\footnotetext{
${ }^{388}$ HESPANHA, A. M. op. cit., p. 62.

${ }^{389}$ HESPANHA, A. M. op. cit., p. 63.

${ }^{390}$ SUANZES-CARPEGNA, J. V.: O constitucionalismo espanhol e português durante a primeira metade do século XIX (um estudo comparado), Historia Constitucional, n. 11, 2010. http://www.historiaconstitucional.com, pp. 237-274.

${ }^{391}$ HESPANHA, A. M. op. cit., pp. 77 y ss.
} 
fueron llevadas a cabo por Campomanes y Olavide. Pero, igual que sucedió en España el verdadero triunfo de las ideas liberales estuvo ligado a dos factores: la Guerra de la Independencia y en contra de la presencia extranjera. La única diferencia respeto a España era que Portugal luchaba contra la dominación inglesa ${ }^{392}$.

Igual que se había manifestado Argüelles, el presidente al presentar el proyecto, dijo que no era la intención de estas Cortes perderse "en el laberinto de las teorías de los publicistas modernos" sino que las bases de la nueva constitución estarían en el antiguo Derecho Público de Portugal. El historicismo nacionalista era el opio doctrinal importante en el liberalismo vintista $^{393}$, así como el doceañista, distante por lo tanto de la actitud antihistoricista de los franceses de 1789, principalmente Sièyes ${ }^{394}$.

Muchos personajes del vintismo, egresados de Coimbra, traían los aires de las ideas del liberalismo que no solamente se respiraba en España y en Portugal, sino también en Nápoles y en Turín, este último un año más tarde. Sin embargo, en el léxico esgrimido en el vintismo portugués la palabra revolución no constó; pues ahí se decía que este movimiento sería una obra de regeneración nacional. Fátima Bonifácio dirá que en Portugal no se decía que se iba a revolucionar a la patria existente e inaugurar una nueva patria, dado que este designio fundacional estuvo ausente en el discurso vintista. Se hablaba sí de una pretendida restauración de una tradición democrática de Portugal, consumida por el absolutismo. Así, divididos entre ruptura y conservación (o restauración en el léxico vintista) se evoca una ambigüedad que sería desde el inicio su característica fundamental. De esta forma, el liberalismo portugués apenas toca a la "feudalidad" del país pero no la destruye, fruto de aquella ambigüedad. El radicalismo portugués, fundador de una tradición democrática o radical de hecho, como lo exigido en la "Martinhada" de 11 de noviembre - movimiento contrarrevolucionario -, que exhortaba a la Junta Provisional del Supremo Gobierno del Reino que las futuras Cortes no debían ser menos liberales de lo que habían sido las de Cádiz de 1812, nos deja pensando qué difícil sería, así como lo fue en Cádiz, romper con el pasado y reformular un futuro donde se inaugurarían todas las formulaciones liberales. Así de liberal, así de conservadora fue la Constitución de $1822^{395}$.

\footnotetext{
${ }^{392}$ VARELA SUANZES-CARPEGNA, J.: El constitucionalismo español y portugués durante la primera mitad del siglo XIX (un estudio comparado) en ÁLVAREZ CUARTERO, I. y SÁNCHEZ GÓMEZ, J. (Eds.): Visiones y revisiones de la independencia americana. La independencia de América: la Constitución de Cádiz y las constituciones iberoamericanas, Salamanca, Ediciones Universidad de Salamanca, 2007, pp. 25 y ss.

${ }^{393}$ Se puede complementar el estudio y el abordaje del Vintismo portugués con BONIFÁCIO, M. F.: $O$ vintismo como matriz do radicalismo português en ÁLVAREZ CUARTERO, I. y SÁNCHEZ GÓMEZ, J. (Eds.): Visiones y revisiones de la independencia americana. La independencia de América: la Constitución de Cádiz y las constituciones iberoamericanas, Salamanca, Ediciones Universidad de Salamanca, 2007, pp. 71-86.

${ }^{394}$ Para ampliar conocimientos se aconseja consultar a VARELA SUANZES-CARPEGNA, J. op. cit. pp. 13-52.

${ }^{395}$ Un contenido más amplio en BONIFÁCIO, M. F. op. cit. pp. 77-83.
} 
En esta Constitución, Portugal retomaba la discusión francesa sobre el principio de la soberanía nacional y el principio de la soberanía regia, desde el punto en que había parado. El Vintismo viene a representar aquél primer principio y el absolutismo el segundo, y a medio camino entre los dos estaba - como en la Restauración Francesa de 1814 - el "cartismo", una vía intermedia que admitía ambas soberanías. El Vintismo, como bien sentencia Fátima Bonifácio, “a pesar da obra de ruptura que na prática realizou, nunca se assumiu como revolucionário, buscando na mistificação de um passado medieval democrático um precedente para a sua própria legitimação". ${ }^{396}$ De este modo, al otro lado de la frontera un modelo constitucional era muy seductor a los intereses lusos de libertad y garantías.

\subsection{1.- El texto doceañista y su influencia en la Revolución de Oporto.}

Como ya habíamos señalado antes, la situación en Portugal era algo peculiar y un poco distinta de lo que pasaba en otras partes del mundo donde el contagio de la revolución liberal española llegó; la Península italiana, por ejemplo. El rey D. Joao VI estaba en Brasil, y había dejado atrás un reino que se sentía abandonado y bajo la fuerte influencia, tanto política como económica, de Inglaterra. Lord Beresford hacía que Portugal fuera en la práctica una dependencia de Gran Bretaña y a la vez una colonia de su propia colonia, Brasil ${ }^{397}$. Puesto que el último albergaba no solamente a la familia real, sino al propio Estado Portugués que se había trasladado allí a raíz de la invasión de Portugal por tropas francesas. Este caudal de insatisfacciones y el pronunciamiento militar llevado a cabo por Riego en España ${ }^{398}$, además de la ausencia de Lord Beresford que había ido a Brasil, incentivó que en el día 24 de agosto de 1820 , se produjese un pronunciamiento militar, en la ciudad de Oporto, que traería todo un cambio en el orden político encaminado en dirección a un gobierno constitucional y liberal ${ }^{399}$.

Posteriormente los revolucionarios crearon la Junta Provisional del Gobierno Supremo del Reino, teniendo por función gobernar a Portugal y elaborar una Constitución para el reino. No tardó mucho en contagiar a Lisboa, y ésta el 15 de septiembre del mismo año se unía al movimiento, como ya señalamos. Algunos días después, en Alcobaça, se realizó la fusión entre los gobiernos establecidos tras la revolución en Oporto y Lisboa. De esta fusión se crearon dos órganos: la Junta Provisional de Gobierno Supremo del Reino, encargada de los asuntos

\footnotetext{
396 Ídem, p. 83.

${ }^{397}$ Para un conocimiento más completo se puede consultar a MENDONÇA, Manuela: Influência da Constituição espanhola de 1812 na portuguesa de 1822 en ESCUDERO, José Antonio (Dir.): op. cit., pp. 481 y ss.

${ }^{398}$ Sobre lo que representa la Constitución de Cádiz es interesante consultar a PORTILLO VALDÉS, José María: Revolución y Nación. Orígenes de la cultura constitucional en España, 1780-1812, Madrid, Centro de Estudios Políticos y Constitucionales, 2000.

${ }^{399}$ HESPANHA, A. M.: Guiando a mão invisível, direito, Estado e lei no liberalismo monárquico português, Coimbra, Almedina, 2004, pp. 61, 62 y ss.
} 
administrativos, y la Junta Provisional Preparatoria de las Cortes, encargada de promover los debates constitucionales ${ }^{400}$. Cuando regresó Beresford de Brasil el 12 de octubre, fijados en la promesa de expulsión de los ingleses, le impiden desembarcar en Portugal. Los más radicales exigían la entrada en vigor de inmediato de la Constitución de Cádiz ${ }^{401}$. Pero ganará la corriente que propugnaba hacer una Constitución nueva para Portugal, siguiendo el modelo español, inclusive en la convocatoria de las elecciones.

Así, en el día 26 de enero de 1821, las Cortes Extraordinarias y Constituyentes de la Nación Portuguesa escogieron una Regencia y cinco secretarios de Estado, que serían los responsables del Reino hasta el regreso del Rey desde Brasil. A aquélla institución le incumbía la elaboración de una Constitución para el reino, por lo que se procedió a emitir, un poco más tarde, precisamente el 9 de marzo de 1821, las Bases de la Constitución Política de la Monarquía Portuguesa ${ }^{402}$.

El Rey se encontraba en Río de Janeiro, y no parecía dispuesto a volver al reino. El Conde de Palmela, simpatizante de la causa liberal, llega a reunirse con el Rey alertándole de los peligros de no aceptar un texto constitucional en Portugal, además de los peligros de las ideas liberales para contagiar a su querido idilio tropical. Como si fuera una profecía de Palmela, en febrero, Bahía se adhirió oficialmente a las Cortes de Lisboa. En Río de Janeiro, la División Auxiliar Portuguesa exigió del Rey que éste sancionase la Constitución que estaba siendo elaborada en Lisboa y que la aplicase también en Brasil. D. Joao, inmerso en dudas sobre la situación, cesa al gobierno formado en Lisboa y nombra en su lugar una Junta Gubernativa. Tal era la presión que en el día 7 de marzo de 1821 el Rey anunció su regreso a Portugal. Sin embargo, inteligentemente dejó a su hijo como Príncipe Regente del Reino de Brasil. D. Joao llega a Lisboa en abril, en el día 26 y luego es instado a irse al Palacio de las Necesidades, sede de las Cortes, para jurar otra vez las Bases de la Constitución ${ }^{403}$.

Como podemos ver, Portugal padecía de más o menos los mismos males que la Península italiana. La incómoda presencia inglesa, aliada a la situación de colonia de hecho de Brasil. Así, los liberales en Portugal veían al modelo español como la solución para estos males. Pero, como habíamos resaltado, solamente en un primer momento se juró a la Constitución de Cádiz como tal, en su totalidad, entretanto después se buscó hacer un texto propio para

\footnotetext{
${ }^{400}$ MENDONÇA, Manuela: op. cit., p. 484 y ss.

${ }^{401}$ Jorge Miranda nos habla que la Constitución de Cádiz llegó a ser puesta en vigor en Brasil por el Decreto de 21 de abril de 1820, pero luego al día siguiente fue revocada. MIRANDA, Jorge: O constitucionalismo liberal lusobrasileiro, Lisboa, Comissão Nacional para as Comemorações dos Descobrimentos Portugueses, 2000, p. 14.

402 Ídem, pp. 18 y ss. Además se debe consultar a MENDONÇA, Manuela: op. cit., p. 485 y 486.

403 Ídem, pp. 486 y ss. Antônio Manuel Hespanha hace un análisis muy detenido de estos hechos históricos, HESPANHA, A. M.: op. cit., p. 62 y ss.
} 
Portugal. Así que no se puede decir, como afirmamos siguiendo a Ferrando Badía, que en Portugal hubo una proclama constitucional, como si se puede afirmar en el caso de Nápoles y Turín, que también adoptaron la Constitución de Cádiz ${ }^{404}$.

Hasta ahora hemos hecho una recapitulación de los hechos, ya abordada en los epígrafes anteriores con más detenimiento, pero nos parecía necesario para afrontar la cuestión portuguesa, que tiene sus matices propios, y que además fue, de todos los procesos revolucionarios inspirados a raíz de lo pasado en España, lo que hizo una constitución propia, y no solamente adoptó en su totalidad el texto gaditano, como se hizo en Nápoles o Turín. De ahora en adelante pasaremos a las cuestiones de orden práctico, pero también al abordaje teórico, en lo que atañe a construir una Constitución nueva para Portugal, pero siguiendo casi estrictamente el modelo doceañista.

Las tres corrientes que veremos presentes en el texto vintista portugués serán la escolástica, la revolucionaria francesa y la británica. El profesor Ignacio Fernández Sarasola nos muestra como estas corrientes van a fundamentar el pensamiento de los diputados de las Cortes Constituyentes y a la vez van a hacer que se agrupen con una u otra de estas corrientes. Los diputados monárquico-tradicionalistas se identificaban con la escolástica, ya que los provenientes de Brasil combinaban la escolástica con las ideologías de Locke y Rousseau; los moderados se identificaban con el modelo británico; los liberales formados en Portugal estaban más inclinados al modelo convencional francés, con una cierta tendencia radical y al modelo gaditano, algo más gradualista ${ }^{405}$. Joaquín Varela Suazes-Carpegna ve además que estas agrupaciones de diputados en determinadas corrientes ideológicas son algo muy parecido a lo que pasó en las Cortes Constituyentes gaditanas ${ }^{406}$.

Como habíamos señalado al inicio de este epígrafe, realizamos una pequeña introducción de los hechos históricos, aunque ya se había hecho antes en los epígrafes precedentes. Así fue porque la similitud del caso español con el portugués se hace notar, dado que en uno y otro país, tras la invasión francesa, con las abdicaciones de Bayona y la huída de la Corte real portuguesa hacía Brasil se creó un vacío institucional en aquellas naciones que permitió una convocatoria de Cortes Constituyentes y la consecuente elaboración de un texto

\footnotetext{
${ }^{404}$ Sobre el esparcimiento de la revolución liberal en España a otras partes de Europa, principalmente, Nápoles, Turín y Oporto y la aceptación del modelo constitucional gaditano, hay una tesina reciente hecha en la Universidad de Messina y Milán: SILVA, Jairdilson da Paz: La stampa e la rivoluzione. Il movimenti liberali del 1820 (Napoli, Porto e Torino) e il riferimento a questi movimenti sui giornali spagnoli, Iscritto presso la Biblioteca della Facoltà di Scienze Politiche, Università degli Studi di Messina e Università degli Studi de Milano, Coll.: SD.EMD. XI.1 (Collezione), INV.: TSI 352 (Inventario), Anno: 2012 - Messina/Italia, pp. 20 y ss.

${ }^{405}$ FERNÁNDEZ SARASOLA, Ignacio: op. cit., p. 292.

${ }^{406}$ VARELA SUAZES-CARPEGNA, Joaquín: La teoría del Estado en los orígenes del constitucionalismo hispano (las Cortes de Cádiz), Madrid, CEPC, 2008.
} 
constitucional, apelativamente historicista ${ }^{407}$. La toma del modelo gaditano, no solo se dio por aquellos aspectos, sino que también se hizo por la proximidad geográfica y por el indudable valor simbólico que representaba Cádiz a la altura, no sólo en Portugal, sino también en buena parte de Europa, como vimos previamente. Era difícil en aquel momento a Portugal desvincularse del mito gaditano. Después de todo, constituyeron un punto de convergencia los conocimientos intercambiados entre los liberales en el exilio de ambos países ${ }^{408}$. De ahí que un diputado, Soares Franco, llegara a decir que “Espanha acaba de dar a Europa um exemplo (...). Daqui em diante será nossa aliada natural; habitantes da mesma península, penetrados pelos mesmos princípios ${ }^{409}$.

De esta manera se produjo la simbiosis de tres elementos combinados entre sí: el modelo gaditano, la inspiración radical de la Constitución Francesa de 1791 y las doctrinas de Jeremy Bentham, que llegaron de las manos del propio publicista inglés a través de misivas enviadas a las Cortes Generales Extraordinarias y Constituyentes portuguesas. Estas funcionaron desde enero de 1821 a septiembre de $1822^{410}$.

El texto español fue siempre un gran referente a la hora de debatir en el Parlamento el articulado del texto portugués. Pero, se propugnaba que el texto portugués no fuera una mera imitación del texto gaditano, y el carácter sagrado y mítico que éste representaba era rechazado por algunos diputados. Tal fue el caso del diputado Fernández Thomaz que se quejó diciendo en la sesión del día 13 de febrero de la Asamblea Constituyente, que el texto español no era un evangelio a ser seguido ciegamente ${ }^{411}$.

Sin embargo, comparando los textos de la Constitución de Cádiz y de la portuguesa de 1822, Jorge Miranda nos da el siguiente cuadro comparativo: en la Constitución de Cádiz habían preceptos sobre derechos $\left(\operatorname{art.} 4^{\circ}\right.$ ) y sobre deberes (art. $6^{\circ}$ a $8^{\circ}$ ), pero no había un título autónomo como en la Constitución portuguesa; la forma de gobierno era la de una monarquía moderada en España (art. 14\%) y para Portugal, una monarquía constitucional hereditaria (art. $29^{\circ}$ ); el poder ejecutivo en Cádiz correspondia al rey solamente (art. $16^{\circ}$ ), en Portugal el rey lo

\footnotetext{
${ }^{407}$ Antônio Manuel Hespanha dirá que se hizo uso, en el momento de la elaboración del texto constitucional portugués, de un lenguaje político-constitucional, en el que muchas palabras recibieron una nueva carga semántica, a veces cambiando levemente el significado anterior, y otras veces innovando. El apelo historicista de la Asamblea Constituyente portuguesa, hizo que el profesor Hespanha se preguntara si realmente lo que hubo fue una constitución o una regeneración. HESPANHA, A. M.: op. cit., p. 79 y ss.

${ }^{408}$ FERNÁNDEZ SARASOLA, Ignacio: op. cit., pp. 293 y ss.

${ }^{409}$ DIARIOS DAS CORTES GERAES E EXTRAORDINARIAS DA NAÇAO PORTUGUEZA, Sessao n. ${ }^{\circ}$, de 27 de janeiro de 1821, Imprensa Nacional, Lisboa, 1821-1822, pp. 5 y 6.

${ }^{410}$ MIRANDA, Jorge: Manual de Direito Constitucional, Vol. I, Coimbra, Editora Coimbra, 1988, p. 230. Se puede ver también del mismo autor: O constitucionalismo liberal luso-brasileiro, op. cit., pp. 10 y ss.

${ }^{411}$ DIARIOS DAS CORTES GERAES E EXTRAORDINARIAS DA NAÇAO PORTUGUEZA, Sessão de 13 de fevereiro de 1821. Diário, n. ${ }^{\circ} 14$, de 14 de fevereiro de 1821.
} 
co-dividía con los Secretarios de Estado ( $\operatorname{art.} 30^{\circ}$ ); el sufragio para las elecciones de las Cortes era universal, pero indirecto en España (arts. $35^{\circ}$ y ss), y en Portugal se marcaban algunas incapacidades para participar del pleito (art. 33º, y era más directo el proceso electoral en Portugal (arts. $37^{\circ}$ y ss); en Cádiz se prohibió la reelección de los diputados (art. $110^{\circ}$ ), pero no en la constitución portuguesa (art. $36^{\circ}$ ); la libertad de imprenta tiene más garantías en el texto gaditano (arts. $131^{\circ}, \mathrm{n} .24,371^{\circ}$ ) que en el portugués (art. $7^{\circ}$ y $8^{\circ}$ ); la Constitución de 1812 admite dos devoluciones de la ley para efectos de veto por el rey (art. 148 ${ }^{\circ}$ ), en Portugal apenas una $\left(\operatorname{art} .110^{\circ}\right)$; en el texto doceañista no hay representación paritaria de las provincias de Europa y del Ultramar en el Consejo de Estado (art. $232^{\circ}$ ), contrariamente a lo que sucede en el texto portugués (art. 162); y por fin la Constitución de Cádiz tiene 383 artículos mientras que la portuguesa tiene apenas $240 \operatorname{artículos}^{412}$. Estas son, en líneas generales, algunas de las diferencias que se aprecian al comparar el texto de una y otra constitución.

Además de aquellos cambios, el profesor Fernández Sarasola, señala otros matices en los artículos apuntados por Jorge Miranda. De hecho, como dijo Miranda, el Poder Ejecutivo estaba dividido entre el rey y sus ministros, pero es verdad que la monarquía lusa también partía de la declaración de soberanía nacional así como la española. También las facultades de las Cortes eran iguales en ambos países y hubo discusión, igual que en España, sobre la adopción o no de un bicameralismo; esto provocó grandes debates al respecto en uno y otro país ibérico. En cuanto a los órganos del Estado se reconocieron, igual que en Cádiz, la Regencia, la Diputación Permanente y el Consejo de Estado; aunque, como ya señalamos antes, éste no tenía una composición estamental. A lo que atañe al procedimiento legislativo, la definición de ley figuraba en el texto portugués (art. 104), y la iniciativa legislativa era prerrogativa de los ministros y no del rey (art. 105) ${ }^{413}$. Así se matizan unas y otras diferencias entre los textos constitucionales.

También destacan aquellos autores que la Constitución portuguesa innova en relación a la de Cádiz con la dedicación del Título I a los Derechos y Deberes individuales de los Portugueses. Esto está muy de acuerdo con las Declaraciones de Derechos francesas, según Jorge Miranda ${ }^{414}$. Además de esto se establecía la titularidad universal de alguno de los derechos, como la libertad de expresión defendida en el artículo $7^{\circ}$. Sin embargo, también recogía un principio iusnaturalista, que consideraba a la propiedad como un derecho sagrado e

\footnotetext{
${ }^{412}$ MIRANDA, Jorge: O constitucionalismo liberal luso-brasileiro, op. cit., pp. 14 y 15.

${ }^{413}$ FERNÁNDEZ SARASOLA, I.: op. cit., p. 296. Véase también a MENDONÇA, M.: op. cit., p. 487. Vale la pena también completar con la lectura de MIRANDA, Jorge: O constitucionalismo liberal luso-brasileiro, op. cit., p. 15.

414 Ídem, p. 16 y ss.
} 
inviolable. Otra discusión importante donde se prefirió seguir a Cádiz fue justamente en lo referente al concepto de ciudadano como diferente al concepto de nacional ${ }^{415}$.

De esta manera, se va percibiendo en el texto tanto la influencia constitucional francesa como la influencia gaditana, tanto en lo que se refiere a la clasificación de los títulos como de los órganos constitucionales, ya que la referencia en el texto constitucional de aquéllos viene acompañada de la función que estos desempeñan.

Por lo que se refiere a la declaración de la confesionalidad del Estado se puede ver en el texto portugués una mayor tolerancia, que además de la influencia del artículo $10^{\circ}$ de la declaración francesa, advenía también, opino, de la fuerte presencia política y económica que tenía Inglaterra en Portugal en esos momentos ${ }^{416}$. Así que la fórmula portuguesa, definida en el artículo 25, era declaración de la confesionalidad, mientras que admitía el ejercicio de los demás cultos ${ }^{417}$. Sin embargo, la propia declaración de confesionalidad no fue superada sin antes provocar discusiones acaloradas sobre el tema. El diputado Pinto de Magalhaes, en la Sesión de 23 de julio de $1821^{418}$, dirá que no se debía dejar este tema a cargo del texto constitucional, puesto que más bien se trataba de un catecismo moral de cada uno, aunque siendo España un espejo, se evitó la intolerancia gaditana, dado que en España el texto constitucional al reconocer la confesionalidad del Estado tuvo una mejor aceptación. Tanto en España como en Portugal la confesionalidad mitigaba el ejercicio de la libertad de imprenta ${ }^{419}$, que tenía un incansable defensor y "missivista" de aquéllos parlamentos. Se trataba de Jeremy Bentham $^{420}$.

Otro aspecto importante que la Constitución portuguesa de 1822 recoge es la vinculación de la alfabetización con el goce de los derechos políticos. Los artículos 237 y el 238, mandaban enseñar a los niños de ambos sexos a leer, escribir y contar, además del catecismo de las obligaciones religiosas y civiles. También mandaba establecer la enseñanza de las ciencias y de las artes. De hecho, como ya dijimos, se buscaba vincular el goce de los

\footnotetext{
${ }^{415}$ FERNÁNDEZ SARASOLA, I.: op. cit., p. 297 y ss.

416 Véase un artículo reciente de SILVA, Jairdilson da Paz: Procesos constitucionales en Iberoamérica. Las exclusiones en Cádiz (1812), Portugal (1822) y Brasil (1824), Revista Ecléctica, Editor Associació d'Estudis Culturals. Universitat de València, ISSN-e 2254-0113, No 1, 2012, pp. 92-101. (In línea) http://revistaeclectica.org/ Accedido en 02.07.2012.

417 Ídem, p. 296.

${ }^{418}$ DIARIOS DAS CORTES GERAES E EXTRAORDINARIAS DA NAÇAO PORTUGUEZA, Sessão de 23 de julio de 1821. Diário, n. ${ }^{\circ} 134$, p. 1624.

${ }^{419}$ DIARIOS DAS CORTES GERAES E EXTRAORDINARIAS DA NAÇAO PORTUGUEZA, Diário de Sessão, n. ${ }^{\circ}$ 66, de 30 de abril de 1821, pp. 714 y ss. Y Diário de Sessão, n. ${ }^{\circ}$ 88, de 25 de maio de 1821, pp. 1014 y ss, tratan del Proyecto de ley acerca de la Libertad de Imprenta.

${ }^{420}$ Véase un extracto de las obras de Jeremy Bentham traducidas al español FERRER Y VALLS, Francisco: Principios de Legislación y de codificación..., Tomos I y II, Imprenta de D. Tomas y Jordan, Madrid, 1834.
} 
derechos políticos a la obtención de habilidades literarias; esto era una condición resolutiva insertada en el sufragio, donde se buscaba un incentivo a la educación. El art. 33, VI dice que dejan de tener derecho al voto las personas que en el futuro, y al llegar a la edad de 25 años cumplidos, no superen leer y escribir ${ }^{421}$. Estando este artículo directamente vinculado a los que tenían 17 años en el momento en que la Constitución fuera publicada.

Como ya habíamos destacado al inicio de este capítulo, Jeremy Bentham, al igual que hizo con las Cortes en España, envió muchas cartas a las Cortes portuguesas, principalmente alertando sobre determinados preceptos que contenía la Constitución de Cádiz que él no veía con buenos ojos ${ }^{422}$. Muchas de estas recomendaciones fueron acatadas por las Cortes Constituyentes, pero no todas ellas, y muchos de los artículos y preceptos del texto doceañista que Bentham veía con muchos fallos se mantuvieron en la Constitución de 1822 portuguesa $^{423}$.

De hecho, las Cortes portuguesas acataron las advertencias de que debían identificar los nacionales como ciudadanos (art. 21); la intensa regulación de la libertad de imprenta y expresión (art. 7); el establecimiento de garantías jurisdiccionales expresas (art.8); y eliminaron la imposibilidad de reelección de los diputados (art. 36) ${ }^{424}$. Pero en tantos otros aspectos los diputados no siguieron las recomendaciones hechas por Bentham, tales como que las sesiones del parlamento no fuesen solo de tres meses (art. 83); las incompatibilidades entre el cargo de diputado y ministro (art. 99); la intangibilidad temporal absoluta (art. 28), aunque la Constitución portuguesa marcaba un plazo de 4 años para proceder a reformas, algo menos que la española ${ }^{425}$ que señalaba un plazo de 8 años; de este modo se siguió en parte lo propuesto por Bentham. Otro punto de desagrado para Bentham fue la introducción de un Título en la Constitución donde se recogían los Derechos y Deberes ${ }^{426}$.

Como pudimos constatar hubo una gran influencia del texto doceañista en la Constitución de 1822 portuguesa, pero se llevó a cabo también una gran reelaboración de algunos preceptos y de muchos artículos, para adaptar las especificidades del reino y para evitar muchas de las críticas dirigidas al texto gaditano.

\footnotetext{
${ }^{421}$ MIRANDA, Jorge: O constitucionalismo liberal luso-brasileiro, op. cit., p. 17.

422 Ídem, p. 18.

${ }^{423}$ FERNÁNDEZ SARASOLA, I.: op. cit., pp. 297 y ss.

${ }^{424}$ MENDONÇA, Manuela: op. cit., p. 493 y ss.

425 Ídem, p. 495 yss.

${ }^{426}$ HESPANHA, A. M.: op. cit., pp. 80 y ss. Además se puede consultar FERNÁNDEZ SARASOLA, I.: op. cit., p. 298.
} 


\subsection{2.- Reflejos periodísticos en España de la Revolución portuguesa ${ }^{427}$}

El periódico liberal moderado y trisemanal Miscelánea, como ya dijimos antes, entró en la ruta de la politización que contaminó a todos los periódicos después que entró en vigor el sistema constitucional en España. La Revolución que tuvo lugar en Portugal, en la ciudad de Oporto en 24 de agosto de 1820, descrita ya en epígrafes anteriores, será noticiada por este periódico en el día $1^{\circ}$ de septiembre de 1820 , en el número 185 :

"Ha llegado un extraordinario con noticias de haberse manifestado en Portugal una insurrección a favor del régimen constitucional. Oporto parece ser el centro de este movimiento, que se extiende hasta las fronteras de Galicia, y aún à todo el reino. Mañana daremos los pormenores que podamos recoger sobre este importante suceso. Algunas cartas de Lisboa dicen también que ha habido una sublevación de la Bahía de Todos los Santos, hecha con mucho orden y concierto ${ }^{428}$.

Como se había prometido, al día siguiente, un sábado, el número 186, en primera página, llamó la atención del articulista el silencio sobre la Revolución. Hasta el día 26 de agosto, según el Miscelánea, las gacetas portuguesas nada emiten sobre este suceso. Sin más novedad que este extrañamiento, también habló del regreso a Portugal de Lord Beresford, condecorado por el Rey y con poderes ampliados, como ya lo dijimos en este capítulo:

"Cartas de Lisboa del 19 anuncian que el mariscal Beresford había salido del Brasil para Inglaterra, y que en breve llegaría á Portugal, condecorado con la dignidad de generalísimo de este reyno y del Brasil, y el título del duque de Portugal y de los Algarbes. Una fragata inglesa estaba desembarcando millón y medio de cruzados para repartir entre las tropas portuguesas que se hallaron en la jornada de Vitoria en junio de 1813. Las Gazetas de Lisboa que llegan hasta 26 de agosto nada hablan de revolución. ¿Se querrá aquel gobierno el mismo silencio que guardó Madrid en enero y febrero? ¿Si estará limitado el movimiento insurreccional á la provincia de Entre Duero y Miño? Los correos de las fronteras deben traernos en breve noticias positivas ${ }^{\text {"429 }}$.

Otra nota, pero esta vez de menor tamaño, publicada en el día 22 de septiembre, un viernes, del número 206, ubicada al final de la página 4, en el canto derecho, daba cuenta de la adhesión de la guarnición de Lisboa al movimiento revolucionario empezado en el Oporto:

\footnotetext{
${ }^{427}$ Sobre este tema véase el artículo de SILVA, Jairdilson da Paz: "El flujo y reflujo revolucionario en la prensa española del trienio liberal: Nápoles, Oporto y Turín”, Hib - Revista de Historia Iberoamericana, DOI: 10.3232/RHI.2012.V.5..N1.03, ISNN: 1989-2616, Semestral, Año 2012, Vol. 5, Núm. 1. pp. 56-93. http://revistahistoria.universia.net/pdfs_revistas/articulo_170_1340980145796.pdf ISSN 1989-2616. Accedido en 07.05 .2012 .

${ }^{428}$ MISCELÁNEA DE COMÉRCIO, POLÍTICA Y LITERATURA, $\mathrm{n}^{\circ} 185$, viernes $1^{\circ}$ de septiembre de $1820,2^{\mathrm{a}}$ página.

${ }^{429}$ MISCELÁNEA DE COMÉRCIO, POLÍTICA Y LITERATURA, nº 186 , viernes 02 de septiembre de $1820,1^{\text {a }}$ página.
} 
"Acabamos de saber que en la tarde del día 15 del corriente, la guarnición de Lisboa, en unión con el pueblo, se declaró por el régimen constitucional. Creóse una junta provisional, la que inmediatamente expresos al gobierno de Oporto, y demás puntos del reino, mandando cesar las hostilidades. Todo se verificó con mucho orden y entusiasmo; en la noche hubo iluminación general. Mañana daremos los pormenores de este suceso" 430 .

En el día siguiente, como una vez más se había prometido, el número 207, en la portada, trae una materia completa sobre lo ocurrido en Lisboa el pasado día 15, conforme lo descrito en la Gaceta de Lisboa. Consonante a lo enunciado en el número anterior del periódico, la guarnición de Lisboa se había adherido al movimiento revolucionario de Oporto. La propia Gaceta de Lisboa en el día 16 de septiembre trae lo que fuera anunciado en el día anterior: “Lisboa 15 de septiembre, ¡Viva el rey D. Juan VI! ;Viva la dinastía de la casa real de Braganza! ;Viva nuestra Santa Religión! ;Vivan las cortes, que han de hacer nuestra nueva constitución!’ El periódico describe todo una escena de fiesta y alegría, con adhesión tanto del pueblo como de las armadas. Se habla de la lealtad y de la libertad portuguesa, de la generación de la patria y de la recuperación de la antigua gloria perdida: "se consiguió una justa y moderada libertad en este día, dos veces memorables, por ser el de nuestra restauración y sacudimiento de un pérfido yugo extranjero, y al mismo tiempo de una regeneración, que nos hace dignos de la sociedad de las naciones europeas, y de nuestra antigua é inmarcesible gloria”. En medio a una euforia de clamores a la libertad y triunfos revolucionarios, el articulista de la Gaceta de Lisboa, transcrito por el editor del Miscelánea, deja escapar los fines de esta revolución:

"Nuestra unión, nuestro amor al orden, las virtudes sociales del ilustre pueblo portugués, todo se dirigirá constantemente á un mismo fin, á la prosperidad de la nación. Nuestras cortes serán dignas del siglo en que existimos, buscamos los medios de consolidar nuestra existencia política, y harán que solo la ley se ejecute y obedezca".

En el número 213 del Miscelánea, la portada trae un enfoque peculiar de lo sucedido en Cádiz y en Portugal. Como este periódico liberal buscaba noticiar el impacto de lo sucedido en el comercio. En el día 29 de septiembre, enfoca como los reflejos de las revoluciones repercutían en el comercio entre España y Portugal:

"Las noticias de la epidemia en Cádiz y sus inmediaciones, y de los movimientos en Portugal, han hecho bajar la seda conchal desde 67 á 60 rs. libra, baja que no es posible preveer hasta dónde llegará, si continua aquéllas causas. El curso del comercio de este ramo por aquéllos puntos producirá enormes perjuicios

${ }^{430}$ MISCELÁNEA DE COMERCIO, POLÍTICA Y LITERATURA, nº 186, viernes 22 de septiembre de 1820, página 4. 
a este país, que para evitarse tales oscilaciones, debería proporcionarse salida por Alicante, Cartagena, o cualquier otro de sus puertos" $" 431$.

Lisboa se adhiere a la causa revolucionaria iniciada en Oporto y forma una Junta Interina de Gobierno, como ya lo comentamos en este capítulo, e inicia un acercamiento con la Junta Suprema de Gobierno formada en Oporto. La noticia de este acercamiento es trasmitida en el Miscelánea del sábado 7 de octubre, en su número 221. La noticia viene en la segunda página:

"Con fecha de 27 de septiembre ha dirigido desde Alcobaza la junta suprema de Portugal á la interina de Lisboa el papel siguiente.

Illmos. y Excmos. señores: la junta provisional del supremo gobierno del reino, deseando conciliar los intereses de la causa pública y el bien del estado, con todas las circunstancias particulares que le han parecido dignas de su atención, da al mismo tiempo á la junta interina establecida en Lisboa, al pueblo de esta gran capital y á la nación entera, una prueba nada equivoca de sus puros y desinteresados sentimientos; después de una madura reflexión juzgó conveniente reunir así todos los miembros del gobierno interino, componiendo uno solo cuerpo, dividido en las dos sesiones que explicaremos $" 432$.

Con esta actitud, las juntas formadas en Oporto y Lisboa buscaron disipar toda desconfianza sobre sus verdaderas intenciones, que dice no son otras que "la salvación de nuestra querida patria y su futura felicidad". Pero, como enunciado antes el gobierno será dividido en dos sesiones:

“(...) se reduce a que la una continuará, llamándose junta provisional del gobierno supremo del reino, la cual tendrá privativamente á su cargo la administración pública en todos sus ramos; y la otra se llamará junta provisional preparatoria de cortes, cuyo objeto será preparar y disponer con brevedad posible todo lo que se juzgue necesario para la más pronta convocación de las cortes, y para la regularidad y buen orden de su celebración. Esta última sesión se subdividirá en otras dos; la primera se ocupará de todo lo relativo a la convocación de las cortes, y la segunda de cuanto pueda servir de ilustración á las materias, que en ellas deben discutirse. ${ }^{433}$,"

La junta de Lisboa recibe con entusiasmo y cortesía la iniciativa de la junta de Oporto, manifestando en la Gaceta del día 28 de Lisboa esta cordialidad efusiva y la fusión de los gobiernos.

También en el número 228, de 14 de octubre, un sábado, se retransmite lo noticiado por la Gaceta de Lisboa del día 12 del corriente mes. En ese número, en la portada, como primera noticia, llama a la atención de una proclama publicada en Lisboa dejando traslucir la

\footnotetext{
${ }^{431}$ MISCELÁNEA DE COMERCIO, POLÍTICA Y LITERATURA, $\mathrm{n}^{\circ}$ 213, viernes 29 de septiembre de 1820, portada.

${ }_{432}$ MISCELÁNEA DE COMERCIO, POLÍTICA Y LITERATURA, nº 221, sábado, 07 de octubre de 1820, $2^{\mathrm{a}}$ página.

${ }^{433}{ }^{4} d e m, 2^{\mathrm{a}}$ página.
} 
satisfacción de la junta provisional de Oporto en unirse a la junta interina formada en Lisboa, "para trabajar en común acuerdo por el bien de la patria"434. Hablase de donativos para el funcionamiento del aparato estatal y de una colaboración de distintas facciones para el funcionamiento del gobierno constitucional. Además, y a la raíz de estos acontecimientos, es noticia la no intensión del Zar Alejandro, tras la revolución política en España, en no intervenir en los asuntos internos de este país.

En el periódico del día 18 de noviembre, aparece un manifiesto publicado por el Gobierno Supremo del reino, para la convocatoria de Las Cortes. Esto va a desatar una serie de discusiones, principalmente acerca de si se debía seguir el proceso establecido en la Constitución de Cádiz o no ${ }^{435}$.

Como ya habíamos abordado antes, Lord Beresford, al regresar de Brasil para Inglaterra y pasando por Portugal fue impedido de desembarcar en Lisboa por los revolucionarios. El Miscelánea del día 19 de noviembre, en la portada, noticia que "tres oficiales ingleses, que a pesar de la prohibición del Gobierno salieron de Lisboa, y pasaron a bordo del Vengador, donde se hallaba el mariscal Beresford, han sido despedidos del servicio, y recibiendo orden de salir inmediatamente de Portugal". Además de esta noticia, el manifiesto de la Junta de Gobierno ocupa casi toda la portada y la segunda página del periódico de este día. Este manifiesto exhorta a los portugueses a vigilar sobre la manutención del régimen actual y a votar a los candidatos que estén propensos a mantener este conquistado sistema. Parece ser una contra-reacción a una insidiosa investida de los absolutistas, puesto que critican también el sistema electoral. A lo que la Junta les responde:

"Se habla después de la forma de las elecciones, cosa que ya es inútil conocer, puesto que á poco de publicarse este manifiesto, se ha adoptado la constitución española que prescribe otro método de elección. Por último hace extensivas sus disposiciones a las islas adyacentes, al Brasil y a las demás posesiones de Ultramar (...). ${ }^{436, "}$

En este manifiesto se amonesta a los portugueses ya que es la primera vez en siglos que pueden elegir a sus representantes, que personalizan realmente a la voluntad general:

“¡Portugueses! ;Vigilancia, cautela y circunspección! No rompamos unos hierros, para entregarnos á los de los partidos y facciones. Se profana la santa libertad, cuando se deposita sus votos en otra urna, que en el seno de la patria. Considerad, considerad desde ahora hasta el último momento de las elecciones,

\footnotetext{
${ }^{434}$ MISCELÁNEA DE COMERCIO, POLÍTICA Y LITERATURA, no 228, sábado, 14 de octubre de 1820, portada. ${ }^{435}$ MISCELÁNEA DE COMERCIO, POLÍTICA Y LITERATURA, $\mathrm{n}^{\circ}$ 263, sábado 18 de noviembre de 1820, portada y $2^{\mathrm{a}}$ página.

${ }^{436}$ MISCELÁNEA DE COMERCIO, POLÍTICA Y LITERATURA, n 264, domingo 19 de septiembre de 1820, portada y $2^{\mathrm{a}}$ página.
} 
que vais a entregar vuestros bienes, vuestras libertades, vuestras personas, y todas las relaciones que os son más caras y os lo serán hasta la más remota posteridad, en las manos de vuestros diputados. Sean estos los patriarcas de la nación, los fundadores de la patria, y los apoyos del estado. Considerad y elegid. Lisboa, en el palacio del gobierno á 31 de octubre" ${ }^{437}$.

Dentro de esta discusión, si se debía seguir o no lo establecido en Cádiz, el número 267 del Miscelánea, que salió en un sábado de 22 de noviembre, trae una pronunciación dicha del pueblo y del ejército, y dirigida al general en jefe Gaspar Teixeira de Magalhaes y Cerda, donde veía conveniente la adopción del sistema electivo de Cádiz, además de adoptar directamente a la Constitución española:

"Viendo el pueblo de esta capital que la junta preparatoria de cortes no accedió en toda su extensión á la justa petición que lo hizo el juez del pueblo de Lisboa, á nombre del mismo, en unión con el ejercito, exponiendo ser la voluntad general, y de absoluta necesidad para el bien de la nación, que los diputados á cortes fuesen elegidos según el método, y con las mismos circunstancias prescripta en la constitución española, se llenó de indignación, y juzgó ofendidos sus derechos; y queriendo tanto el pueblo como el ejercito evitar que aquél acto de la junta preparatoria de cortes vaya adelante, en perjuicio de la nación, recurre por lo tanto á $V$. E. como general comandante en jefe de la fuerza armada del norte y sur de Portugal, para se digne tomar en consideración lo expuesto, y en su consecuencia se sirva reunir el ejercito, y haga proclamar la constitución española, la cual modificada por las cortes, convocadas en los términos que ella prescribe, se adopte, y se apropie a los usos, costumbres y terrenos de Portugal, sin que en ello se altere ni su sentido, ni las ideas liberales que contiene" 438 .

El resultado de esta petición, como nos aclara el editor del Miscelánea era jurar la Constitución española y adoptar su sistema electoral para elegir a los diputados de las tan ansiadas Cortes. Además "el gobierno se ocupa en hacer expedir a las provincias los artículos de la Constitución española, que reglan las elecciones de Diputados en Cortes, y se trabaja con mucha actividad en promover con la celeridad posible la deseada instalación del Congreso Nacional" $" 439$.

Aventando un antiguo fantasma que siempre rondó al imaginario portugués, el Miscelánea del día 26 de noviembre, a la raíz de un artículo publicado en el número 44 del mismo periódico, se preguntaba si, Portugal en la situación en que se encontraba en aquellos momentos, de abandono por parte del rey, debía o no unirse a España. Unirse o mantenerse separados para siempre. El articulista afirma que la unión estaría en manos de alguna potencia extranjera y la separación en manos del Congreso a ser convocado. Todo esto a raíz de la

\footnotetext{
${ }^{437}$ Ídem, página $2^{\mathrm{a}}$.

${ }^{438}$ MISCELÁNEA DE COMÉRCIO, POLÍTICA Y LITERATURA, nº 267, miércoles, 22 de noviembre de 1820 , portada.

${ }^{439}$ Ídem, $1^{a}$ página.
} 
semejanza que existía entre las dos naciones con la adopción de la Constitución española como modelo. El articulista defendiendo una posición de los ejércitos del norte, refiriéndose a esta posible unión dirá: "queremos ser portugueses, y queremos que también lo sean nuestros descendientes". De esta forma, los jefes de los cuerpos de los ejércitos del norte firman en el Palacio de las Necesidades, en el día 17 de noviembre unas propuestas decantadas en tres artículos:

"Articulo $1^{\circ}$. El estado actual de la capital y la opinión pública exigen que entre novamente en el gobierno los diputados que hicieron su dimisión, pues que á ella no concurrió el ejercito, y que este junto con la nación reconoció aquél gobierno hasta la instalación de las cortes.

$2^{\circ}$. Que las elecciones para diputados en cortes se hagan por el mismo sistema prescrito en la constitución española, por ser así la opinión general de la nación y del ejército, único motivo que dio lugar a la parada general de 11 de noviembre.

$3^{\circ}$. Que todo lo demás que se determina en la constitución española no pueda ponerse en práctica, en tanto que no se reúna el congreso, y se adopte la base de ella, y con las alteraciones que crea convenientes, sin que sean igualmente liberales $" 440$.

También sobre las elecciones el artículo del día 13 de diciembre del periódico que venimos mencionando, trae una crítica salida en un periódico lusitano en el día 6 de diciembre. La crítica está dirigida a la forma de cómo se eligen los diputados de determinadas capas de la sociedad, principalmente al elemento eclesiástico: "No dudamos, que si nuestros compatriotas siguen estos consejos, nos darán un concilio en lugar de un congreso nacional, y que las nuevas Cortes se diferenciaran muy poco de las antiguas" ${ }^{441}$. La queja también va dirigida a la forma como se aplica la Constitución española, que en su art. 46 manda que las Juntas Electorales de parroquias sean presididas por la autoridad política de cada una de las parroquias; pero, en Portugal sucedía justo al contrario, porque eran presididas por los desembargadores, excluyendo a los jueces y ministros de barrios y enviándolos fuera de sus términos y distritos.

A continuación, el Senado de la Cámara de Lisboa emitió una proclama donde saludó al pueblo de Lisboa, al que denominó como "ilustre, civilizado y constante pueblo de la capital del reino-unido", donde dijo, además, ser el "vuestro único representante" de ellos, aludiendo a la ausencia del Rey y de las Cortes establecidos en Río de Janeiro. Utilizó un lenguaje poético para referirse a la Revolución de Oporto, cuando dice: "resonó junto a las márgenes del Duero la voz del ciudadano libre, que el eco repitió á un mismo tiempo en las extremidades del reino,

\footnotetext{
${ }^{440}$ MISCELÁNEA DE COMERCIO, POLÍTICA Y LITERATURA, $\mathrm{n}^{\circ}$ 271, domingo, 26 de noviembre de 1820 , portada y $2^{\mathrm{a}}$ página.

${ }^{441}$ MISCELÁNEA DE COMERCIO, POLÍTICA Y LITERATURA, n 288 , miércoles, 13 de diciembre de 1820 , portada y $2^{\mathrm{a}}$ página.
} 
y desde aquél momento se oyó en todas las bocas constitución, constitución"; para luego enseguida denominar de ciudadanos al pueblo que tenía derecho a elegir a sus compromisarios, en las palabras de la proclama. Esgrime dicha proclama un tono elogioso a los ciudadanos llamándoles de "honrados, inteligentes, amigos de la patria, prudentes y celosos del bien público"; volvió además a convocar a los "compatriotas portugueses, vamos a completar nuestra bien principiada obra; esta es la intención y deliberada voluntad de nuestro amable Rey" y concluye, "nada quiere que no sea su mayor felicidad". Esta proclama del Senado de la Cámara, según el Miscelánea está fechada en el día 13 de diciembre en Lisboa, y el periódico salió el día 20 de diciembre en el número 295, un miércoles. Finalizó la dicha proclama, que enalteció a la revolución liberal y al régimen constitucional, pidiendo la convocación de Cortes:

“Completemos por la reunión de las cortes la obra de nuestra constitución; aseguremos por ella la exacta observancia de la santa religión de nuestros padres, la augusta dinastía de nuestros reyes, y nuestros imprescriptibles derechos de ciudadanos libres, y pueda entretanto decir el pueblo portugués a una sola voz: Somos felices, viva a la religión católica romana, viva el rey y su real dinastía, viva la constitución, viva los portugueses ${ }^{422, .}$

Según nos cuenta el articulista del Miscelánea, esta proclama fue publicada con todos los honores y magnificencias, precediendo a la publicación con todas las músicas de los regimientos de la guarnición. El Senado mandó iluminar a todos los edificios de su administración en las noches de los día 10, 17 y 24. Y exhortó a los ciudadanos a seguir este ejemplo, iluminando también sus casas. Además, el Gobierno Supremo ordenó a la Junta de Censura que declarasen a todos los redactores de periódicos "o papeles" como siendo responsables directos ante la Justicia de los ataques perpetrados por personas anónimas contra los particulares, publicados por aquéllos en sus periódicos.

Se vuelve a hablar de las elecciones para Diputados, y reproduciendo una nota del día 16 de diciembre de la Gaceta de Lisboa, en la $2^{\mathrm{a}}$ página del Miscelánea, en una pequeña nota, se elogia el buen paso de las elecciones y el contentamiento de todos con el resultado que dio a conocer a los Diputados de la provincia de Lisboa ${ }^{443}$.

Intentando tomar partido de la situación, el rey D. Joao VI, que estaba en Brasil en aquellos momentos revolucionarios envió unos despachos a Lisboa con este sentido. La Gaceta de Lisboa notició el hecho, lo que será reproducido por el Miscelánea del día 27 de diciembre: "El sábado 16 del corriente á las ocho y media de la noche, llegó a este puerto el bergantín

\footnotetext{
${ }^{442}$ MISCELÁNEA DE COMERCIO, POLÍTICA Y LITERATURA, $\mathrm{n}^{\circ}$ 295, viernes 20 de diciembre de 1820, final de la página 2 y página 3.

${ }^{443}$ MISCELÁNEA DE COMERCIO, POLÍTICA Y LITERATURA, $\mathrm{n}^{\circ} 299$, domingo, 24 de diciembre de 1820, $2^{\mathrm{a}}$ página.
} 
Providencia, que habiendo salido de la barra de Lisboa el 5 de septiembre, y llegado al Río de Janeiro el 17 de octubre, salió de aquél puerto en 29 del mismo mes con despachos" ${ }^{\text {"44 }}$. El contenido de estos despachos está dirigidos a precisar que el Rey se enteró de lo pasado en Oporto, y que la revolución estaba concentrada apenas en la Provincia del Miño. Mandó el Rey aplicar una amnistía general. A la vez que mandó convocar las Cortes generales por los gobernadores del reino, y extrañaba que se hubiesen convocado elecciones si el concurso de su real persona, tachándolas de ilegítimas. Además, mandó que lo que decidieran las Cortes se le enviase para la sanción real.

"Según las noticias que vamos recibiendo de todas las partes, las elecciones parroquiales se han celebrado con la mayor tranquilidad y acierto. Sabemos que en Oporto, en donde se resonó el primer grito de libertad, reina aun aquel fuego sagrado y el entusiasmo con que los intrépidos y valientes la proclamaron, lo cual ha producido una excelente elección. El señor obispo de aquélla diócesis fue el primer que se presentó con toda pompa con su lista de compromisarios al acto de las elecciones $" 445$.

Otro gran periódico de la época, el Mercurio de España, uno de los más longevos periódicos españoles que desapareció solamente en los años 30 del siglo XIX, notició los hechos pasados en Portugal. En el formato de revista, estaba dedicado a un público intelectual, y sus artículos era una gran referencia en la época.

En el fascículo de noviembre de 1820, el Mercurio de España daba cuenta de los sucesos acaecidos en Portugal. En la página 225, dentro del título dedicado a la Gran Bretaña, hablaba esta revista sobre el impacto que tuvieron estas noticias en el Reino Unido. Al articulista le llamaba la atención que el Gabinete inglés guardase silencio notable sobre los asuntos de Portugal. Hablaba el mismo, en tono elogioso, sobre cómo este Gabinete manejaba situaciones semejantes para sacar provecho de los mismos, y destacaba que era un ejemplo a ser seguido: "! Prudencia digna de imitarse si se busca la propia utilidad, y se creer que cada nación puede ser feliz de distinta manera! ",446

En el título que hablaba de Portugal, en la página 226 y 227, poco más que una página y media, se trataba de los sucesos en Portugal. Se marcaba como más notable lo ocurrido el día 11 de noviembre. De forma distinta a lo que hizo el Miscelánea que venía acompañando los hechos paso a paso, El Mercurio de España hacía un resumen de los hechos. Enunciaba que el día 31 de octubre se convocaban Cortes y que el día 11 de noviembre, la reunión del ejercito

\footnotetext{
${ }^{444}$ MISCELÁNEA DE COMERCIO, POLÍTICA Y LITERATURA, nº 302, miércoles, 27 de diciembre de 1820, $2^{\mathrm{a}}$ página.

445 Ídem, $2^{\text {a }}$ página.

${ }^{446}$ MERCURIO DE ESPAÑA, noviembre, página 225.
} 
nombraba al mariscal de campo Gaspar Teixeira de Magalhaes y Lacerda, a lo ya citado por el Miscelánea, comandante de los ejércitos del norte, pasando a ser comandante general de los ejércitos del norte y del sur. Este se apoderó de los principales puntos de Lisboa y estacionó sus tropas en la Plaza del Roció; a continuación fueron al palacio del gobierno y formaron una Junta Militar con la asistencia del Juez del pueblo y escribanos, y además invitó a la Plaza a los comandantes de la Guarnición de Lisboa. Esta Junta decidió:

"I ${ }^{o}$. Jurar la Constitución española sin perjuicio de que las cortes la modifiquen, y que la elección de los diputados se haga en la manera en que ella se prescribe: $2^{\circ}$. Nombrar cuatro miembros más para la junta provisoria del supremo gobierno: $3^{\circ}$. Separar las secretarías del reino y de la Hacienda; $4^{o}$. Y conferir el mando de todo el ejército al mariscal comandante del ejército del norte" ${ }^{447}$.

A este acto, la revista, comentando sobre su impresión por haber leído a los periódicos portugueses dice que a primera vista hubo indignación y se consideró un atentado esta iniciativa de la Junta Militar, sobre todo por haber sido sorprendidos, pero, luego la impresión era de que no les disgustaba la idea, y que estaban felices con el resultado. Ya que había sido acertado adoptar una Constitución ya vigente para luego poder ser modificada por las Cortes. Terminaba la revista el artículo con una fórmula salomónica, sin optar entre los que alabaron o vituperaron tales actos.

Otro gran periódico del periodo liberal que publicará lo ocurrido en Portugal será $E l$ Censor. Periódico templado y bastante preciso que traía al público artículos extensos de cuño político. Su nombre se deja a la tentativa de freno de los excesos del Gobierno, como también a otros periódicos por sus excesos, destacadamente El Zurriago. Era acérrimo enemigo de El Universal. Este periódico afrancesado al que muchos acusaban de ser financiado por los franceses, era muy respetado a la época.

En el número $1^{\circ}$ del día 16 de septiembre de 1820, El Censor traía un artículo completo sobre la Revolución Portuguesa. El artículo va desde la página 34 a la página 45. En estas once páginas el articulista hace un largo elogio al valor portugués, vinculándolo al propio valor español, además de llamar la atención sobre la no manifestación del Gabinete inglés sobre esta revolución liberal. Deduciendo que Gran Bretaña no haría nada para impedir que Portugal siguiese a su ejemplo de nación constitucional. Y para eso citaba el ejemplo de Sicilia en 1811, que recibió el apoyo de Inglaterra para la implantación de su Constitución ${ }^{448}$.

\footnotetext{
${ }^{447}$ Ídem, página 226.

${ }^{448}$ EL CENSOR, no. 1, 16 de septiembre de 1820, pp. 34-45.
} 
El Constitucional en el día 6 de septiembre, en su número 486, entre las páginas 3 y 4 trae impresas las proclamas hechas en Oporto, con la revolución liberal ${ }^{449}$. En el número 514, del día 4 de octubre traía en la portada una materia sobre el impacto y la receptividad que tuvo la Revolución de Portugal en Inglaterra. En Londres, el 13 de septiembre, el Morning Chronicle, transcrito por El Constitucional, afirmaba: "La Revolución de Portugal no nos admira: ya la habíamos vaticinado algún tiempo hace, y aún hubiéramos creído que si hubiera anticipado á Nápoles, porque sabíamos lo que pasaba en aquél país. Este reyno (Portugal) estaba convertido en colonia, y el Brasil era la metrópoli; el orgullo del pueblo padecía, y no podía llevar a bien el estado de envilecimiento en que se hallaba" ${ }^{450}$. Hablaba de un Portugal maltratado por ausencia de la Corte y la presencia extranjera.

En El Constitucional del día 5 de octubre, número 515, se da gran relevancia a la Revolución portuguesa cuando le atribuye toda la portada, la segunda página y una parte de la tercera página de este cuaderno. Dicho periódico reproduce un manifiesto publicado por un periódico portugués homónimo al español. Este manifiesto es "una respuesta de los oficiales de Oporto á los Gobernadores de Lisboa, con motivo de las proclamas que estos habían circulado cuando vieron acercarse la tormenta de la insurrección ${ }^{\star 451}$. El periódico español justificó la publicación de unos fragmentos principales del manifiesto para complacer y llamar la atención de los amigos de la libertad. Los oficiales dan una respuesta contundente a los gobernadores de Lisboa cuando dicen: “Acabemos de una vez, señores proclamadores: nuestra regeneración, si no está terminada, está decidida" ${ }^{452}$. Además el manifiesto dice que la historia de Portugal siempre está indexada a la española, puesto que, en la historia de la península Portugal sigue siempre la suerte de España, citando a los romanos, a los godos, a los árabes y a los franceses.

En el número 521, del día 11 de octubre, un miércoles, en la segunda página, canto derecho inferior, se noticia que:

"los liberales ingleses favorecen decididamente la Revolución de Portugal, y creen obrar en bien de los intereses de la Gran Bretaña. Esta ganará más en el desarrollo de la industria portuguesa que en el monopolio de un pueblo arruinado. Juan Bautista Say acaba de demostrar en su excelente carta á Mr. Malthus que un pueblo no puede ser útil al comercio de otro sino en razón de la abundancia de sus propios productos si no produce ó no si trabaja objetos de cambio con que adquirir

\footnotetext{
${ }^{449}$ El CONSTITUCIONAL: CRÓNICA CIENTÍFICA, LITERARIA Y POLÍTICA, n. 486, Madrid, miércoles, 6 de septiembre de 1820 , pp. 3 y 4.

${ }^{450}$ El CONSTITUCIONAL: CRÓNICA CIENTÍFICA, LITERARIA Y POLÍTICA, n. 486, Madrid, miércoles, 4 de octubre de 1820 , portada.

${ }^{451}$ El CONSTITUCIONAL: CRÓNICA CIENTÍFICA, LITERARIA Y POLÍTICA, n. 515, Madrid, jueves, 5 de octubre de 1820 , portada.

${ }^{452}$ Ídem, p. 3.
} 
los artículos de que carece, tendrá que vivir sin ellos. ¡Cuán productivo no sería el Portugal si reviviera alli la industria al abrigo de la libertad!”

Las noticias y la posibilidad de contagio de la Revolución portuguesa en Brasil son trasmitidas en Londres en el 2 de octubre. El Constitucional reproduce la noticia en los siguientes términos:

"Las cartas de Río de Janeiro con fecha de $1^{\circ}$ de agosto indican los temores que allí reinaban de ver una revolución por el estilo de la de Portugal. De Bahía, Pernambuco y otros puntos septentrionales del Brasil se han recibido otras cartas de comerciantes que se explican en los mismos términos. Uno de estos comerciantes dice que convendría tener en aquellos mares una escuadra inglesa, á fin de proteger en caso de necesario á los individuos de esta nación. ${ }^{453}$,"

También en la segunda página, este mismo número de El Constitucional notició la llegada del mariscal Beresford, que venía de Río de Janeiro en el navío inglés Vengador, de 80 cañones, y que nada sabía de lo sucedido en Portugal. Este que impedido de desembarcar y el gobierno revolucionario le mandó una diputación para hacerle entender que no le convenía desembarcar en este momento porque su persona podría correr riegos de vida.

A continuación de los hechos relacionados con Lord Beresford, El Constitucional de 4 de noviembre, un sábado, relata lo publicado en Lisboa 18 de octubre. Se publicó en la capital portuguesa el Real Despacho donde se elevaba al mariscal Lord Beresford "al eminente puesto de mariscal general cerca de su Real persona, y lo hace señor absoluto y despótico de todo cuanto tiene relación con lo militar" ${ }^{\text {,454 }}$. El articulista lisboeta afirmó que este Real Decreto sólo viene a corroborar con lo sucedido el 24 de agosto, y así se tiene más razón y motivo para tanto: "un jefe extranjero hecho Rey militar, no puede haber mayor desgracia" 455 . Además dio cuenta del envió de dinero a Lisboa desde Río de Janeiro, cuestión que les parece un milagro, puesto que eso nunca había sucedido, y venía en buena hora para auxilio de la causa.

Del mismo modo, el periódico sigue noticiando lo de Lord Beresford y su impacto en la opinión pública en Portugal. El Constitucional resolvió publicar el Real Decreto en su totalidad donde se concedían las dignidades de Jefe Militar Supremo de Portugal a este lord. Pero, además el periódico resaltaba la fuerza del pueblo en no sucumbir a la tiranía de dos o tres $\operatorname{personas}^{456}$.

\footnotetext{
${ }^{453}$ El CONSTITUCIONAL: CRÓNICA CIENTÍFICA, LITERARIA Y POLÍTICA, n. 528, Madrid, miércoles, 18 de octubre de 1820 , p. portada.

${ }^{454}$ El CONSTITUCIONAL: CRÓNICA CIENTÍFICA, LITERARIA Y POLÍTICA, n. 545, Madrid, sábado, 04 de noviembre de 1820, p. 04.

${ }^{455}$ Ídem, p. 04.

${ }^{456}$ El CONSTITUCIONAL: CRÓNICA CIENTÍFICA, LITERARIA Y POLÍTICA, n. 548, Madrid, martes, 07 de noviembre de 1820 , p. 1 y 2.
} 
Un jueves, 7 de diciembre, el número 578 de El Constitucional da cuenta de un banquete celebrado en Londres el 2 de octubre de 1820 en honor a los héroes de las revoluciones de España, Nápoles y Portugal. El banquete tuvo lugar en la fonda de la Corona y el Ancla. Presidió la mesa de este banquete el mayor general Sir Robert Wilson y había 500 invitados. Se hicieron muchas alabanzas a estas revoluciones, como pendones de la libertad, cantaron himno de los marsellesa "allons enfans de la patrie" 457 y otras canciones análogas a la causa de la libertad. La noticia ocupó prácticamente toda la extensión de las cuatro páginas del periódico, y además se prometía en una nota seguir con el artículo. Como consecuencia de lo prometido, al día siguiente, en el número 579, siguió noticiando sobre lo ocurrido en el banquete en Londres que conmemoraba las revoluciones liberales ${ }^{458}$.

Un extracto de una carta particular, que salió publicada en París el día 12 de diciembre, fue publicado en El Constitucional el 23 de diciembre. La carta hablaba de las relaciones entre el Congreso de Troppau y Portugal, y de la poca atención dispensada por el primero al segundo. Además daba cuenta de las hazañas de los embajadores portugueses en la capital parisina y de sus maniobras diplomáticas pintorescas ${ }^{459}$.

En cierto modo, tanto la Revolución portuguesa como la española no incomodaron tanto a la Santa Alianza como hicieron las de Italia. Por lo tanto serán las que más tiempo duren bajo el régimen liberal establecido por dichas revoluciones. Los periódicos liberales españoles publicaron con gran detalle lo acaecido en Portugal, pero no con tanto ardor como lo sucedido en Nápoles, principalmente por encontrarse aquel reino bajo la amenaza de invasión por Austria respaldada por la Santa Alianza.

\footnotetext{
${ }^{457}$ El CONSTITUCIONAL: CRÓNICA CIENTÍFICA, LITERARIA Y POLÍTICA, n. 578, Madrid, jueves, 07 de diciembre de 1820, p. 1-4.

${ }^{458}$ El CONSTITUCIONAL: CRÓNICA CIENTÍFICA, LITERARIA Y POLÍTICA, n. 579, Madrid, viernes, 08 de diciembre de 1820 , p. 2 y 3.

${ }^{459}$ El CONSTITUCIONAL: CRÓNICA CIENTÍFICA, LITERARIA Y POLÍTICA, n. 548, Madrid, sábado, 23 de diciembre de 1820 , p. 2 y 3.
} 


\section{Capítulo II}

\section{PROCESOS CONSTITUCIONALES LUSO-BRASILEÑOS: DE UN IMPERIO CONFESIONAL A OTRO}

\section{1.- De la Ilustración al liberalismo portugués}

Bastante sintonizados en la Península, Portugal, al igual que España, ha visto una afluencia de ideas y escritores iluminados por la razón de la época. Se propugnaba en Portugal la renovación de las ciencias jurídicas a partir de la segunda mitad del siglo XIX, eso para estar de acuerdo con los contenidos normativos inmersos en el momento histórico. Por lo tanto, Portugal necesitaba caminar con algunas de las ideas iluministas que ya estaban circulando hacía mucho tiempo al otro lado de los pirineos. Sin embargo los tintes iluministas que matizan y aclaran las ideas en la Península Ibérica recobran matices que les van a caracterizar en relación a otras regiones que aceptarán al iluminismo tanto en las teorías políticas como en el campo jurídico o en la propia enseñanza. Se puede afirmar que el iluminismo portugués, a semejanza del español, revela una clara influencia italiana ${ }^{460}$, según nos cuenta Almeida Costa $^{461}$. Esta semejanza se refleja en los escritos de Verney ${ }^{462}$, en especial el 'Verdadeiro Método de Estudar ${ }^{463}$, en donde se nota la influencia de Muratori ${ }^{464}$.

\footnotetext{
${ }^{460}$ Para mejor profundización de esta cuestión véase VARGUES, Isabel Nobre: “Liberalismo e Independencia. Os exiliados Italianos em Portugal (1820-1850)”, Revista Portuguesa de História/Universidade de Coimbra, Tomo XXXI, Vol. 2 (1996), pp. 412-426.

${ }^{461}$ ALMEIDA COSTA, M. J.: História do Direito Português, 4ª Edição Revisada e Actualizada (Colabora Rui Manuel de Figueiredo Marcos), Edição Almedina, Coimbra, 2010, p. 53.

${ }^{462}$ Para mejor profundizar en las ideas de Verney, consultar a CABARAL DE MONCADA, L.: Um "Iluminista" portugués do século XVIII: Luís António Verney e Italia e Portogallo nel Settecento, in "Est. De Hist. do Dir.", cit., vol. III, Coimbra, 1950, respectivamente, pp. 1 y ss, pp. 153 y ss. Conceitos e funçao da jurisprudencia segundo Verney, in "Boletim do Ministerio da Justiça", cit., $\mathrm{n}^{\circ}$ 14, pp. 5 y ss. GALVAO TELLES, I.: Verney e o Iluminismo italiano, in "Revista da Faculdade de Direito da Univ. de Lisboa, cit., vol. VII, pp. 196 y ss. ANDRADE, A. A.: Vernei e a cultura do seu tempo, Coimbra, 1966. GAMA CAETANO, F.: Nótula sobre Verney, Coimbra, 1985. El "Frade Barbadiño", como se le llamaban a Verney, fue un crítico acérrimo de la universidad portuguesa de entonces, pero también en lo que concierne a la legislación, a la práctica jurídicocientífica y a la propia enseñanza del derecho como tal. Lo que verá concretado sus criticas un cuarto de siglo después con la reforma pombalina.

463 Aquí conseguimos la versión castellana: VERNEY, Luis Antonio: Verdadero Método de Estudiar para ser útil a la República, y a la Iglesia, proporcionado al estilo, y necesidades de Portugal, (Traducido al Castellano por Don Joseph Maymó y Ribes, abogado de los Reales Consejos), Tomo I y II, Imprenta de Joachin Ibarra, Madrid, 1760. Se puede ver a PESET, José Luís: La influencia del Barbadiño en los saberes filosóficos españoles, in Bracara Augusta, Vol. XXVIII, Braga, 1974, pp. 223 y ss. PESET, J.L. y LAFUENTE, A.: Ciencia e Historia de la Ciencia en la España ilustrada, in Boletin de la Real Academia de la Historia, Tomo CLXXVIII (Cuaderno II), Madrid, 1981, pp. 267 y ss. En la realidad, la primera impresión del libro de Verney se dá en Napoles y luego después en Valencia, España. Almeida Costa nos indica que las Cartas de mayor interés en la obra de Verney son las XIII y XV, en donde se ocupa de la jurisprudencia civil y de la jurisprudencia canónica.

${ }^{464}$ Sobre Muratori y su influencia en Portugal se puede consultar a PATTARO, E.: Il pensiero giuridico di L. A. Muratori tra metodología e política, Milano, 1974. Se destacan las obras del doctor en derecho por la Universidad de Módena, Luis Antonio Muratori: Defectos de la jurisprudencia, (Traducido al Castellano por Vicente Maria de Tercilla - Abogado de los Reales Consejos), Imprenta de la viuda de D. Joachin Ibarra, Madrid, 1794. Fuerza de la Humana Fantasia, (traducido al Castellano por Vicente Maria de Tercilla), Imprenta de D. Manuel Martín, Madrid, 1777. La filosofía moral declarada y propuesta a la juventud, (Traducido por Antonio Moreno Morales),
} 
Así que, las orientaciones filosóficas y jurídicas que figuraban en el resto de Europa van a situar las ideas y el pensamiento en el Portugal de los setecientos. Como ejemplo tenemos a la Escuela Racionalista del Derecho Natural ${ }^{465}$, que se desarrolla mayormente en Holanda, Inglaterra y Alemania, así como también la Escuela Española de Derecho Natural, identificada con la Segunda Escolástica ${ }^{466}$. Nos aclara tanto Almeida Costa como Paulo Merêa que lo que se conoce por el sistema del Derecho Natural mucho se debe a Grocio ${ }^{467}$. Y muy acorde con este también está Hobbes, Locke, Pufendorf, Thomasius y Wolff. Será Pufendorf quien pondrá de relieve la sistematización del derecho natural como también representará la transición del iusnaturalismo grociano al iluminismo del setecientos. De este modo el derecho natural se va desmarcando de los presupuestos metafísico-religiosos, en donde se resalta el racionalismo en último análisis. Las ciencias jurídicas positivas serán, de este modo, deudoras de este derecho natural racionalista ${ }^{468}$.

Coeva de la Escuela del Derecho Natural, y con algunos elementos que se tocan entre sí, puesto que también nace en Alemania, está el “usus modernus pandectarum” "469 , que se trata de una nueva metodología de estudios y aplicación práctica del derecho romano. Será esta Escuela de los Comentadores la que dará paso al surgimiento de la Escuela Histórica, en una evolución que se reflejará en Portugal de 1747 a $1820^{470}$, y en donde veremos las referencias historicistas hechas tanto en la Constitución de Cádiz como en su tributaria, la Constitución portuguesa de

Tomos I y II, Tercera Edición, Por Benito Cano, Impresor en esta Corte, Madrid, 1790. La pública felicidad objeto de los buenos príncipes, (Traducion al Castellano), Imprenta Real, Madrid, 1790. Reflexiones sobre el buen gusto de las ciencias, (traducido por D. Juan Sempere - Abogado de los Reales Consejos), Imprenta de D. Antonio de Sancha, 1782.

${ }^{465}$ FIGUEIREDO MARCOS, R. M.: O jusracionalismo setecentista em Portugal, in Direito Natural e Política, vol. I, Coimbra 2005, pp. 179 y ss.

${ }^{466}$ Erik Wolf, Hans Welzel, Franz Wieacher y Hans Thieme son autores que sustentaban la idea de que el jusracionalismo laico del siglo XVIII estaba afiliado al derecho natural de raíz religiosa de la Escolástica medieval, aunque no sea del todo cierto. Pero se atribuye a esta escuela el papel de formación del derecho venidero. Otro autor que está considerado como fundador del jusnaturalismo moderno es Hugo Grócio, que publicó el Mare Liberum (1609) y al De iure belli ac pacis (1623). Grócio va a estar manifiestamente influenciado por la Segunda Escolástica, pero, va a representar un puente entre concepciones teológicas y filosóficas a las concepciones jusnaturalista racionalista. Para Hugo Grócio es importante consultar FEENSTRA, R.: Ius commune et droit comparé chez Grotius - Nouvelles remarques sur les sources citées dans ses ouvrages juridiques, à propos d'une réimpression du 'De iure belli ac pacis', in Revista Internacional de Direito Comparado, cit., Vol. III, pp. 7 y ss. (Republicada in "Miscellanea Domenico Maffei dedicata", cit., Vol. III, pp. 513 y ss.). TODESCAN, F.: Le redici teologiche del iusnaturalismo laico, vol. I - Il problema della secolarizzazione nel pensiero giuridico di Ugo Grocio, Milano, 1983, Vol. II - Il problema della secolarizzazione nel pensiero di Jean Domat, Milano, 1987 , Vol. III - Il problema della secolarizzazione nel pensiero de Samuel Pufendorf, Milano, 2001. Se puede consultar además a MERÊA, P.: Escolástica e Jusnaturalismo, cit., in Boletim da Faculdade de Direito, Coimbra, vol. XIX p. 289. Además de ALMEIDA COSTA, M. J.: op. cit., pp. 387 y ss.

${ }^{467}$ GROCIO, H.: Derecho de la guerra y de la paz, Reus, Vol. IV, Madrid, 1925.

${ }^{468}$ ALMEIDA COSTA, M. J.: op. cit., pp. 388 y 389.

${ }^{469}$ Sobre este asunto consultar a WIEACKER, I.: Historia do Direito Privado Moderno, cit., pp. 238 y ss, 340 y ss. También em COING, H.: Bartolus und der usus modernus Pandectarum in Deutschland, in Bartolo da Sassoferrato - Studi e documenti per il IV centenario, cit. Vol. I., pp. 23 y ss.

${ }^{470}$ MONCADA, C.: in Estudo de História do Direito, cit., vol. I, nota 1 de la p. 91. 
1822. Lo importante de esto es que no hay que confundir las dos escuelas del pensamiento jurídico, aunque guarde íntima relación, como ya se ha mencionado, con la Escuela del Derecho Natural. La distinción entre las dos está en que la "usus modernus" se trata de una orientación teórico-práctica, en donde la vida en concreto tiene mayor relieve. Puesto que buscaba en el estudio del sistema del Corpus Iuris Civilis abstraer de este derecho obsoleto normas aplicables en los tiempos que corren. Por otro lado, la Escuela del Derecho Natural se aproximaba mucho más a una escuela filosófica y de jurisprudencia teorética. Aunque, en el derecho portugués esta distinción no estaba bien marcada, sino al contrario, se encontraban bastante relacionadas entre $\mathrm{Si}^{471}$.

En esta evolución de Portugal en la modernización del pensamiento jurídico y político, influirá mucho el Iluminismo. En el reinado de D. José I, y en el gobierno de su valido el Marqués de Pombal, es cuando se aprecia nítidamente esta corriente filosófica es aplicada en la práctica. El siglo de las luces llega a Portugal. Ilustración que los alemanes denominaban “Aufklärung", los franceses de "Philosophie des Lumières", estas luces se referían a la luz de la razón, en donde sus cultivadores serían "iluminados" por la razón propia. Aunque para Portugal represente en la práctica la segunda mitad del siglo XVIII, estas ideas perviven para el resto de Europa por todo aquél siglo. El Antropocentrismo, basado en las concepciones griegas, será el elemento que contrarrestará, desde el Renacimiento Cultural del siglo XVI, al teocentrismo del periodo medieval. Esta misma concepción sitúa al hombre, aun no desprendido de sus ideas transcendentales, como bien comenta Moncada, como señor pleno de sus destinos ${ }^{472}$. En donde la razón y el racionalismo procedente de aquella, pasa por una hipertrofia, agrandase ${ }^{473}$, en donde todo está vinculado a la naturaleza, y la validez de las cosas se puede medir a través de la razón misma de los individuos. De este modo lo que interesa para aquella medida es la razón subjetiva y crítica, que estará capacitada para explicar y comprender el universo de las cosas.

En lo que concierne a la filosofía jurídica y política, el Iluminismo marcará nuevas posiciones teóricas impresas por un individualismo-liberal que va a fundamentar la propia comprensión del Derecho y del Estado. Los derechos serán los "primitivos", en el sentido de los primeros, originarios y naturales del propio individuo. Esto afianza con las ideas ya fomentadas tanto por el Renacimiento, en primer plano, como por las concepciones iusnaturalistas a

\footnotetext{
${ }^{471}$ Se puede extraer más información sobre estas escuelas y sus influencias en Portugal con la lectura de VIEIRA CURA, A. A.: Transmissao da propriedade e aquisiçao de outros direitos reais (algumas consideraçoes sobre a história do sistema do título e do modo), in Estudos em homenagem ao Prof. Dr. Raúl Ventura, vol. I, cit., pp. 373 y ss.

${ }^{472}$ MONCADA, L. C.: Estudo de História do Direito, cit., vol. III, p. 3.

${ }^{473}$ ALMEIDA COSTA, M. J.: op. cit., p. 394.
} 
posteriori $^{474}$. Aunque dicho de esta forma nos puede parecer a primera vista que fue un movimiento filosófico plano en todos sus cuadrantes, nada más lejos de la realidad. No estuvo tan homogéneo en los países por donde extendió sus raíces. Así que en donde surge, Holanda e Inglaterra, pasando a Francia luego después, tendrá características bastante distintas, hasta en Italia, en donde se producirá el modelo para los países marcadamente católicos y que será más o menos aceptado por España y Portugal, aunque permaneciendo Francia como un faro al que estos países no dejarán de mirar. Los destacados de este movimiento en Francia, serán los conocidos enciclopedistas Montesquieu, Voltaire, Rousseau, Diderot, D`Alembert, entre otros. Ya en Alemania, la corriente que se hizo fuerte fue la literaria del Clasicismo, en donde nombres como Lessing, Herder, Goethe, Schiller se destacan. Del lado de la filosofía jurídica y de la política la influencia del iusracionalismo se hace presente en Alemania, con nombres ya mencionados, como Pufendorf, Thomasius y Wolff ${ }^{475}$. De un modo en general, y principalmente en los países que aquí nos interesa, que son España y Portugal, hubo una mayor influencia del racionalismo y de la filosofía moderna, que va a producir una mayor renovación de la actividad científica, innovaciones en la enseñanza, o sea, mejoras pedagógicas, y una cierta difusión del espíritu laico, como también va a reflejar en una reforma de las instituciones sociales y políticas. Aunque ya hicimos referencias a las matizaciones ibéricas, este reformismo no tendrá la misma profundización que tuvo en Francia, principalmente en el carácter revolucionario, anti-histórico o laicista.

También otra corriente filosófica derivada del Iluminismo aportó en Portugal, lo que se quedó conocido como el Humanitarismo ${ }^{476}$. Esta corriente estuvo mucho más vinculada al

\footnotetext{
${ }^{474}$ PLANAS, J. A.: Fundación historicista de los derechos humanos, in GÓMEZ SÁNCHEZ, Y. y ESCUDERO, J. A. (coord.): Pasado, presente y futuro de los derechos humanos, México, 2004, pp. 61 a 67 y ss.

${ }^{475}$ Zília Osório de Castro resalta que los conocimientos y debates acerca del concepto de leyes fundamentales estarán muy acordes con la enseñanza de juristas alemanes, como Samuel Pufendorf (1632-1694), que fue introducido en el ámbito académico con la versión francesa de Jean Barbeyrac (Ámsterdam, 1712), así como Christian Wolff (1679-1754), conocido en el ámbito de la teoría política del iluminismo. En cuanto a las discusiones sobre las libertades de la nación, eran conocidos el suizo Jean-Jacques Burlamaqui (1694-1748) y Emmerich de Vattel (1714-1767). En el orden, estos autores aportan las obras: PUFENDORF, Samuel: De officio hominis e Civis Juxta Legem Naturalem Libri duo, Impresis Gul. Thurlbourn, Londres, 1737. Esta obra de Pufendorf será la referencia de otra producida por BARBEYRAC, Jean: An Historical and Critical Account of the Science of Morality, Printed for J. Walthoe et alli, London, 1729. WOLFF, Christina von: Logic, or rational thoughts on the powers of the human understanding, Nachdruk der Ausgabe, London, 1770. BURLAMAQUI, Jean-Jacques: Elementos del derecho natural, Imprenta y Libreria de Sanz, Granada, 1838. Y VATTEL, Emmerich: El derecho de gentes, o principios de la ley natural, (Tomos I y II), Imprenta de D. Leon Amarita, Madrid, 1834. También de este autor: VATTEL, Emmerich: Le droit de la guerre ou príncipes de la loir naturell..., Aux depens de la Compagnie, Amsterdam et Leide, 1758. Y también VATTEL, Emmerich: Le droit des gens, ou principes de la loi naturell appliqués a la conduite et aux affaires des Nations et des souverains, Chez Janet et Cotell, Libraires, Paris, 1820.

${ }^{476}$ En esta corriente va a destacar nombres como el de Montesquieu y Voltaire, en Francia, pero también del conocido Beccaria y el de no tan conocido Filangieri (a su tiempo si fue muy conocido y llegó a ser criticado a posteriori por Benjamin Constant) en Italia. Sobre Beccaria se puede ampliar más en la consulta de PISAPIA, G. D.: Presentazione dalla opera de Beccaria, Dei delitti e delle pene, (Reimpresión), Milano, 1973. También en
} 
derecho penal, y las vamos a percibir a través de la lectura de los textos constitucionales aquí abordados, no solamente el texto portugués, sino también en el texto español y posteriormente el texto brasileño. Esta corriente se desdoblará en dos aspectos básicos: desvincular el derecho penal de los presupuestos religiosos, marcándole dentro del contrato social, en una tutela de valores vinculados con el interés de la colectividad, en una externalización de valores, pero dentro del derecho y del marco del Estado. El otro aspecto será la idea de la necesidad y utilidad común, que delimitarían al derecho penal, poniéndose en posición diametralmente opuesta a la ética religiosa. La ley moral, para Cesare Beccaria, aunque es el paradigma de la ley positiva, se constituye como marco y límite de cualquiera criminalización de los actos ${ }^{477}$. Así que las acciones preventivas del derecho penal que preconizaba Beccaria, debían estar en el marco de la justicia y dentro del respeto a la dignidad de la persona humana ${ }^{478}$; además, se debía observar una cierta proporcionalidad entre la pena y la gravedad del delito, pero exigiendo una abolición de la penas corporales infamantes.

Todas estas ideas van a permear a las reformas hechas por Pombal, las conocidas “Reformas Pombalinas" ${ }^{479}$. Uno de los elementos que va a incidir en estas reformas serán los cambios que demandaba la universidad portuguesa. Hacía ya mucho tiempo que la decadencia

PISANI, M.: Attualità di Cesare Beccaria, Milano, 1998. Para Portugal, en temas relacionados, se puede leer a BRAGA DA CRUZ, G.: O movimiento abolicionista e a aboliçao da pena de norte em Portugal (Resenha histórica), Lisboa, 1967, pp. 29 y ss. Como también se puede consultar MANUPELLA, G.: Cesare Beccaria (17381794) - Panorama Bibliográfico, in Boletim da Faculdade de Direito, vol. XXXIX, p. 107 y ss. También la traducción para el portugués de BECCARIA, C.: Dos delitos e das penas, Lisboa, 1998. En la versión Italiana, impresa en París, BECCARIA, C.: Dei delliti e delle pene (Nuova Edizione Corretta e Accresciutta) in Parigi, 1786. También tuvimos acceso a una versión española traducida del italiano por D. Juan Antonio de las Casas, Tratado de los delitos y de las penas, 1774. En cuanto a Filangieri, ya habíamos hecho referencias a este jurisconsulto filósofo y a su obra Scienza della Legislazione en el capítulo I de este trabajo, pero, vale la pena consultar a ABADIA, J. L.: El eco de Filangieri en España, in Anuario de Historia del Derecho Español, tomo LIV, p. 477 y ss.

${ }^{477}$ También en este aspecto suscitará críticas a Cesare Beccaria, aún hoy en día, como las hechas por LAURA MASINI, G.S.: Gerdil, una censura al Dei delliti e delle pene, in Diritto romano attuale. Storia, método, cultura nella scienza giuridica, vol. 17, Napoli, 2007, pp. 81 y ss.

478 "Questi sono frutti, che si debbono alla luce di questo secolo. Ma pochissimi hanno esaminata e combattuta la crudeltà delle pene, e lìrregolarità delle procedure criminali, parte di legislazione così principale, e così trascurata in quasi tutta l'Europa; pochissimi, rimontando a principi generali, annientarano gli errori accumulati di più secoli, frenando almeno, con quellla sola forza che hanno le vertià conosciute, il troppo libero corso della mal diretta potenza, che ha datto fin`ora, un lungo ed autorizzato esempio di fredda atrocità. Eppure $i$ gemiti dei deboli, sacrificati alla crudele ignoranza ed alla ricca indolenza; i barbari tormenti con prodiga e inutile serverità multipicati, per delitti o non provati o chimerici; la squallidezza e gli orrori di una prigione, aumentati da più crudele cranefice dei miseri, l'incertezza, dovevano scuotere quella sorta di magistrati che guidano le opinioni delle menti umane." BECCARIA, C.: Dei delliti e delle pene (Nuova Edizione Corretta e Accresciutta) in Parigi, 1786, p.3. También tuvimos acceso a una versión española traducida del italiano por D. Juan Antonio de las Casas, Tratado de los delitos y de las penas, 1774.

${ }^{479}$ Sobre esta reforma, se puede consultar a BRADAO, M. y LOPES DE ALMEIDA, M.: A Universidade de Coimbra. Esboço da sua história, Coimbra, 1937, parte II. LOPES ALMEIDA, M.: A Universidade de 1580 a 1937, p. 63. ANTUNES, J.: Notas sobre o sentido ideológico da reforma pombalina. A propósito de alguns documentos da Imprensa da Universidade, in O Marquês de Pombal e o seu tempo, (Numero especial da Revista de Historia das Ideias), tomo II, Coimbra, 1982/1983, pp. 143 y ss. También se puede consultar a FIGUEIREDO MARCOS, R. M.: A legislação Pombalina. Alguns aspectos fundamentais, 2ª Edição, Coimbra, 2007. 
de la enseñanza en Portugal era notable, y era denunciada constantemente por Verney (el Frade Barbadiño). Es evidente que no fue de inmediato cuando estas críticas surtieran efecto, pero, en 1770 una Junta de Providencias Literarias fue creada para examinar las causas de la decadencia universitaria, y además, buscar las soluciones a estos problemas ${ }^{480}$.

Sin embargo, no todas las ideas preconizadas por el grupo de los “extrajerados" a constar en la Reforma del Marqués, puesto que su Despotismo Ilustrado ha filtrado a muchas de ellas ${ }^{482}$. Algunas de las reformas que emprendió el Marqués no tendrán mucho calado en la sociedad portuguesa de entonces, pero otras, principalmente en el ámbito de las ciencias jurídicas, volcadas a la interpretación, integración y aplicación de las normas, tendrán mayor impacto. Sin embargo, lo que más nos interesa serán los cambios tendentes a la formación de los juristas, entrando ahí la "Lei da Boa Razão" ${ }^{483}$ de 1769 y la reforma de la Universidad llevada a cabo por los “Estatutos Novos” de 1772. Estos dos últimos elementos de la Reforma Pombalina nos son más apreciados porque influyeron en la formación de los juristas y consecuentemente en el pensamiento jurídico de la época en que se formarán las Cortes Constituyentes de 1821 en Portugal y de 1823 en Brasil. Resultando que muchos de los diputados de Brasil elegidos para las Cortes de Lisboa regresaran y serán nuevamente elegidos para formar parte de las Cortes de Río de Janeiro por el hecho de que Brasil hubiese proclamando su independencia de Portugal $^{484}$. Pero, lo común es que estos diputados habían estudiado en la Universidad de Coimbra bajo los “Estatutos Novos" decretados por Pombal.

\footnotetext{
${ }^{480}$ El resultado de esta investigación fue llevado a cabo por la Junta de Providencias Literarias y saldrá reunido en un Compendio Histórico. Que luego también se reflejará en los Estatutos Nuevos de la Universidad de Coimbra, que saldrá a la luz en 1772.

${ }^{481}$ Sobre este grupo de pensadores que influenciados por pensadores de la renovación europea, y que trajeron a Portugal estas vivencias, se puede ampliar los conocimientos en la lectura de BORGES DE MACEDO, J.: "Estrangeirados", um conceito a rever, in Brancara Augusta, 2a Ediçao, Lisboa, 1979, vol. XXVIII, pp.179 y ss.

${ }^{482}$ Fue Verney, según nos cuenta Mário Julio de Almeida Costa, quien introducirá, a mediados del siglo XVIII, en Portugal un sistema de ideas con formulaciones más polémicas orientadas al iusnaturalismo, en un uso más moderno, dentro del pensamiento iluminista y de directrices humanitarias. Las Reformas del Marqués de Pombal estará direccionada a tres sectores: de la legislación, aunque puntuales; a la actividad científico-práctica de los juristas y de la enseñanza del derecho. ALMEIDA COSTA, M. J.: op. cit., p. 399. También aclara sobre el tema FIGUEIREDO MARCOS, R. M.: A legislación pompalina. Algunos aspectos fundamentales, op. cit., pp. 11 y ss.

${ }^{483}$ La "Lei da Boa Razao" fue promulgada en 18 de agosto de 1769 (fue así llamada por hacer insistentemente referencias a la "Buena Razón"), y fue el más importante documento legislativo portugués de la era pombalina, y es el texto legal que caracteriza la ideas del Marqués de Pombal, en relación a la posición del Estado frente a la aplicación del Derecho. La ley trata de los procesos judiciales y preveía una penalización para los abogados que se valieran de interpretaciones maledicentes y engañosas en los procesos judiciales. Estas informaciones están disponibles en un texto del Prof. Antonio Carlos, pero se encuentran en el Archivo Virtual de la Facultad de Derecho de la Universidad Nueva de Lisboa: http://www.fd.unl.pt/ConteudosAreasDetalhe.asp?ID=40\&Titulo=Biblioteca Accedido en el 25/02/2012.

${ }^{484}$ Acerca de los diputados brasileños que participaron de las Cortes Constituyentes de Lisboa véase el trabajo extenso y bien documentado de BERBEL, Márcia Regina: A naçao como artefato. Deputados do Brasil nas cortes portuguesa 1821-1822, HUCITEC/Fapesp, São Paulo, 1999, pp. 31 y ss. También la obra de CARVALHO, Manuel Emílio Gomes de: Os deputados brasileiros nas Cortes Gerais de 1821, Edições do Senado Federal Vol. 12 (Introdução de Pedro Calmon), Brasilia 2003, pp. 77 y ss. Además se debe complementar con la lectura de
} 


\subsubsection{La Reforma Pombalina: la “Lei da Boa Razão” y los “Estatutos Novos da Universidade de Coimbra”.}

La "Lei da Boa Razão" tendrá por objetivo solucionar las irregularidades en materia de los "assentos" $" 485$, lo que concierne a la utilización del derecho subsidiario, como también fijar parámetros precisos sobre la validez de las costumbres y enunciación en los procesos, y como el intérprete del derecho debía valerse de ellos para rellenar las lagunas existentes en el derecho $^{486}$. Esta ley contiene un preámbulo en donde el Rey D. José I emplea muchos verbos imperativos (faço, quero, mando) y de catorce párrafos con órdenes específicas para el fiel cumplimento de su contenido.

"Parágrafo 1- Proíbe decisão judicial contra direito expresso, à época, as ordenações e as leis destes meus reinos..."

Parágrafo 4- Dá aos Assentos da Casa da Suplicação a autoridade máxima na interpretação do direito, enquanto jurisprudência, antecipação da súmula vinculante.

Parágrafo 5- Eleva os Assentos a categoria de leis, enquanto fonte normativa.

Parágrafo 6- Obriga ao juízes recorrerem aos Assentos.

Parágrafo 7- Penaliza os advogados que se valem de interpretações enganosas maldosas e recursos meramente protelatórios.

Parágrafo 8- Confere competência máxima à Casa da Suplicação em Lisboa...

Parágrafo 9- Define o que é boa razão...

Parágrafo 10- Reforça as leis do reino com repulsa ao Direito Romano (Corpus Juris

Civilis, de Justiniano).

Parágrafo 11- Confirma o rei como fonte interpretativa mais graduada.

Parágrafo 12- Proíbe o Direito Canônico no Tribunais Civis.

Parágrafo13- Proíbe o uso das glosas Medievais de Accursio e Bartholo.

NEVES, Lúcia M. B. Pereira das: Corcundas e constitucionais. A cultura política da independencia (1820-1822), Editora Revan/Faperj, Rio de Janeiro, 2003, pp. 255 y ss.

${ }^{485}$ Los "assentos" de la "Casa da Suplicação", órgano que funcionaba como Corte Superior en Portugal, eran escritos en el llamado "Livro da Relação" que poseía un carácter fuertemente vinculador, puesto que los jueces o los "desembargadores" (jueces colegiados de las altas cortes) que decidiesen en disconformidad con aquellos preceptos podrían ser suspendidos, como preveía las "Ordenações Manuelinas" en su libro V. Para más información en este sentido se puede consultar ROSAS, Roberto: Jurisprudência. Uniformização. Súmula. in Direito Processual (inovações e perspectivas): estudos em homenagem ao Ministro Sálvio de Figueiredo Teixeira, Editora Saraiva, São Paulo, 2003, p. 388. Também em um artigo de FERREIRA NETO, O. S.: Os Assentos no Direito Português e as Súmulas no Direito Brasileiro: efetividade, segurança e imobilidade, disponible en la dirección: www.estig.ipbeja.pt/ ac direito/osly.pdf Accedido en 25/02/2013. Aclara también la consulta em CORRÊA TELLES, J. H.: Commentario Critico á Lei da Boa Razão, em data de 18 de Agosto de 1769, Lisboa, 1824 ( $2^{a}$ Edição, Lisboa 1845).

${ }^{486}$ Se complementa con la lectura de ALMEIDA COSTA, M. J.: op. cit., p. 401 y ss. Además de la lectura de la página 334 y siguientes sobre los “assentos", las páginas 348 y ss., sobre la utilización de los derechos subsidiarios y las páginas 337 y ss., sobre la validez de las costumbres en juicio. En cuanto a las fuentes del derecho, las inmediatas y subsidiarias se puede leer en las páginas 342 y ss. 


\section{Parágrafo 14- Manda observação dos costumes, definindo como condição de validade que tenham mais de cem anos. " 487}

Tres años después de entrar en vigor la referida ley los "Estatutos Novos da Universidade de Coimbra" 488 van a aclarar algunos de los aspectos de la misma, según nos explica Almeida $\operatorname{Costa}^{489}$.

Estos Nuevos Estatutos de la universidad serán el resultado, en gran medida, de las propuestas hechas por la Junta de Providencia Literaria ${ }^{490}$. Estas reformas tendrán un fuerte impacto en los cursos jurídicos, como ya habíamos referido, como creación de una cátedra de derecho natural y de las gentes; además, manda que se enseñe el derecho autóctono y se valore la historia de éste. Ya la enseñanza del derecho romano se ve sometida a la tutela del "usus modernus pandectarum". El método "sintético-demostrativo-compendiario" 491 sustituye al “analítico" en muchas de las asignaturas del curso ${ }^{492}$, a excepción de dos, en donde se

${ }^{487}$ La ley así sintéticamente resumida se encuentra en un texto del Prof. Antonio Carlos, pero se encuentra en el Archivo Virtual de la Facultad de Derecho de la Universidad Nueva de Lisboa: http://www.fd.unl.pt/ConteudosAreasDetalhe.asp?ID=40\&Titulo=Biblioteca Accedido en el 26/02/2012.

${ }^{488}$ Estos Estatutos fueron aprobados por la Ley de 28 de agosto de 1772. El libro II que se refiere a la Facultad de Leyes y a la Facultad de Cánones tuvo como principal autor a Joao Pereira Ramos de Azeredo Coutinho. Para ampliar los conocimientos se puede leer más en CALMON, P.: A reforma da Universidade e os dois brasileiros que a planejaram, in TORGAL, L. R. y VARGUES, I.: O Marquês de Pombal e o seu tempo (número especial da Revista de História das Ideias), Tomo II, Universidade de Coimbra, 1983, p. 93 y ss.

${ }^{489}$ ALMEIDA COSTA, M. J.: op. cit., p. 401 y ss.

${ }^{490}$ Dicha Junta será establecida por la Carta de Ley de 23 de diciembre de 1770 contenida en los Estatutos da Universidade de Coimbra, Livro II - Cursos Jurídicos das Faculdades de Cânones e Leis, Lisboa (Na Regia Officina Typografica - Por ordem de Sua Magestade), Anno de 1773. En el Título I, de este Estatuto, que trata de la Preparación para los cursos jurídicos, y su Capítulo I, en donde trata de la edad que deben tener los estudiantes que quisieren matricularse en cada una de las Facultades Jurídicas. Ahí trae la siguiente constatación en la página 253: "Constumam muitos Pais participar os estudos dos filhos, que destinam para a profissão do Direito, não consentido que Elles se detenham nas Escolas menores pelo tempo, que lhe he necessário, para nellas poderem bem aprender as Letras humanas, e as Disciplinas Filosóficas: Pondo tão somente todo o seu desvelo, em que Elles se habilitem com a maior brevidade possível para poderem matricular-se em Direito, com o ambicioso fim de se graduarem mais cedo; para pretenderem os empregos, e Lugares de Letras antes de terem idade, que para eles prescrevem as Ordenações dos Meus Reinos; para entrarem logo a ocupallos em fraude das Leis; e para terem depois mais tempo para subirem aos Lugares Superiores, e poderem disfrutallos por maior numero de annos."

491 “23 - (...) Que depois de aprendidas as principais regras, e preceitos da jurisprudência pelo direto caminho Syntetico-Demostrativo-Compendiario; e de formado um bom systema de todo Corpo da Jurisprudencia, que cada um professar, por benefício da melhor digestão, e ordem, e da deducçao, e connexao de todas as matérias dela; se ensine também por algum tempo a jurisprudência pelo Methodo Analytico: Para que os estudantes não só conheçam a natureza, effeitos, e vantagens desde Methodo; mas também aprendam o verdadeiro uso, e pratica delle; e saibam entender, e explicar as Leis na Theorica o que de muito the há de servir depois em todas as occupações, e exercícios da Jurisprudencia assim Acadêmicos, como forenses. 24 - Ouvirao pois também os Juristas as Liçoes Analyticas, e de haverem por meio delle formado Systema da Jurisprudencia Civil." Estatutos da Universidade de Coimbra, op. cit., (Liv. II, Tít. II, Cap. 23 y 24), p. 306.

${ }^{492}$ Para el Derecho Canónico se utilizará el Método Analítico (Titulo IX, Cap. I); para las lecciones de derecho canónico se utilizará el método sintético (Titulo VIII, Cap. I); para los principios del derecho público se utilizará lecciones sintética del derecho y de las decretaes (Titulo VIII, Cap. III); para las explicaciones del derecho público se utiliza al método sintético (Titulo VIII, Cap. IV); para las decretaaes se utilizará al método sintético (Titulo VIII, Cap. VI); para el derecho de las decretaes se utilizará el método sintético (Titulo VIII, Cap. VI). Estatutos da Universidade de Coimbra, livro II, op. cit., (Sumário). 
continuaría bajo la justificativa de emplearse el ejercicio de la exégesis de los textos legales ${ }^{493}$. Pues el objetivo en estas dos cátedras era el aprendizaje de la interpretación y ejecución de las leyes.

Así que esta reforma en la enseñanza, como nos cuenta Torgal y Vargues, será una reacción no solamente a la decadencia incontestable de la universidad, como también, una respuesta estatal para crear una enseñanza oficial, contraponiéndose al esquema de enseñanza libre llevado a cabo principalmente por los jesuitas, que el Marqués trata de expulsar de todos los dominios de la corona portuguesa en $1759^{494}$. Y para paliar el vacío dejado por aquella expulsión, en la Carta de Ley de 6 de noviembre de 1772, el Valido de D. José I busca imprimir un carácter universalista de la enseñanza pública, ya que ésta estaría destinada "ao maior número de povos e de habitantes deles, que a possibilidade pudesse permitir" ${ }^{\prime 495}$. Pero lo que de esta reforma nos interesa será la que ha sido llevada a cabo en las universidades, o en los Estudios Mayores, como se solían llamar. En 1759, juntamente con la expulsión de la Compañía de Jesús, el Valido va a extinguir la Universidad Jesuítica de Évora, y buscará alejar toda su influencia en la Universidad de Coimbra, con los Nuevos Estatutos de $1772^{496}$.

Entretanto, con la muerte del rey y la subida al trono por Dña. María I en 1777, el Valido cae en desgracia y también toda su reforma, satirizada por un conocido poema atribuido a Francisco Melo Franco, “O Reino da Estupidez", que en su primer Canto ironiza sobre la reforma en los siguientes términos:

\footnotetext{
${ }^{493}$ Estos cambios los traen los Estatutos da Universidade de Coimbra, Livro II - Cursos Jurídicos das Faculdades de Cânones e Leis, Lisboa (Na Regia Officina Typografica - Por ordem de Sua Majestade), Anno de 1773. Además de MERÊA, P.: Lance de Olhos sobre o Ensino do Direito desde 1772 até 1804 in Estudos da História do Ensino Jurídico em Portugal (1772-1902), Lisboa, 2005, pp. 357 y ss. También lo comenta ALMEIDA COSTA, M. J.: op. cit., p. 55 y ss. Se puede complementar más con la lectura de TORGAL, L. R. y VARGUES, I. N.: A Revolução de 1820 e a instrução pública, Paisagem Editora, Porto, 1984, pp. 19 y ss.

${ }^{494}$ Con esto se crea el puesto de Director General de los Estudios, que tenía por función organizar y coordinar la enseñanza en las Escuelas de Estudios Menores. Alvará de 28 de Junho de 1759, Collecção de Legislação Portuguesa pelo desembargador Antônio Delgado da Silva, 1750-1762, Lisboa, 1830, pp. 673-678. Estos poderes serán transferidos en 1771 a la Real Mesa Censoria, que era el órgano centralista en materia cultural, esto se dará por el Alvará de 4 de Junho de 1771, Colecção de Legislação, op. cit., 1763-1774, Lisboa 1829, pp. 540-541. Posteriormente se buscará establecer una red de escuelas de primeras letras, pero también de gramática latina, griego, retórica y filosofía. La enseñanza privada y el preceptorado estaban mantenidos pero se debía buscar una habilitación para ejercer el magisterio con la realización de exámenes y consecuente aprobación de la Mesa Censoria, eso se dará por la Lei de 6 de Novembro de 1772, Colecção de Legislação op. cit., 1763-1774, pp. 612615". También por Carta de Ley, el Marqués de Pombal buscó estatuir un "Subsidio Literario", que consistía en un impuesto nacional que buscaba sufragar los costes de la enseñanza pública.

${ }^{495}$ Lei de 6 de Novembro de 1772, Colecção de Legislação, op. cit., 1763-1774, p. 613.

${ }^{496}$ Después de elaborados los Nuevos Estatutos, el propio Marqués de Pombal, en la calidad de "Visitador" va a entregarlos en la Universidad en Coimbra. Se puede leer más en TORGAL, L. R. y VARGUES, I. N.: op. cit., pp. 22 y ss. Además se puede ampliar los conocimientos sobre la ideología de esta reforma en ANTUNES, J.: Notas sobre o sentido ideológico da Reforma Pombalina. A propósito de alguns documentos da imprensa da Universidade de Coimbra, «Revista de História das Idéias», vol. IV, tomo. II, Coimbra, 1982, pp. 143 ss.
} 
"Não canto aquelle Heróe Pio, e Valente

Que depois de ter visto a cara Patria

A cinzas reduzida, e campo vasto,

Mil p rigos contrastando o clima busca,

Aonde com os seus ditoso seja.

A molle estupidez cantar pretendo,

Que distante da Europa desterrada

Na Lusitania vem fundar seu Reino.

Dicta-me, oh musa, que eu não posso tanto,

Os nobres feitos, e diversos casos,

Que a esta grande empresa acompanhárao,

Hum feio monstro de cruel figura,

Desgrenhados cabelos, olhos vesgos,

Disforme ventre, circular semblante

Da lúgubre caverna, aonde jazia,

Bocejando sahio, e longo tempo

Nas vizinhas montanhas separando,

Estas vozes soltou de magoa cheia (...)" ${ }^{497}$.

Pero, también con relación a la reforma que emprendió Pombal, y sus impactos en el campo jurídico, se busca una profundización de los estudios de la historia del derecho de Portugal. Y por lo tanto se lleva a cabo la ejecución de unos programas en donde el profesor debía resaltar la Historia de las leyes, usos, y costumbres de la Nación Portuguesa. Además, se debía abordar una Historia de la Jurisprudencia Theoretica, o Ciencia de las Leyes de Portugal. Y a modo de conclusión se debía también estudiar, igualmente, la Historia de la Jurisprudencia Práctica, o el Ejercicio de las Leyes, de manera que se pudiese actuar en los "Auditorios, Relaciones y Tribunales del Reino" ${ }^{498}$. De este modo surge la necesidad de redactar un compendio para la asignatura de Historia del Derecho, como determina el párrafo 9, del

\footnotetext{
${ }^{497}$ MELO FRANCO, F.: O Reino da Estupidez, Officina de A. Bobèe, Paris, 1818, pp. 1 y 2. También tuvimos acceso a una edición facsímile manuscrita digitalizada por la Biblioteca Digital de Patrimonio Iberoamericano, pero de esta vez atribuída tanto a Francisco de Melo Franco como a José Bonifacio de Andrada e Silva: MELO FRANCO, F. y ANDRADA E SILVA, J. B.: O Reino da Estupidez. Poema Heroi-cómico, el original perteneciente a la Biblioteca Nacional, Río de Janeiro, Secção de Manuscritos.

${ }^{498}$ Véase el Estatuto da Universidade de Coimbra, op. cit., Livro II, titulo 3, cap. 9, parágrafos 1 e 2, pp. 357 e 358. "1- Ensinados os princípios da Historia do Direito Romano, passará o professor à História do Direito Portuguez. Nella se fará também cargo das referido das três partes, que explicou na de Direito Romano: Começando pela História das Leis, Usus, e Costumes Legítimos da Nação Portugueza: Passando depois à História da Jurisprudencia Theoretica, ou da Sciencia das Leis de Portugal: E concluindo com a História da Jursiprudencia Prática, ou do Exercício das Leis; e do modo de obrar e expedir as causas, e negócios nos Auditórios, Relações, e Tribunais destes Reinos. 2- Na Primeira parte dará a conhecer o modo, e a forma da legislação destes Reinos; as fontes; as origens; e os progressos das Leis (...)”.
} 
Capítulo IX, del Título III" ${ }^{499}$. De esta necesidad surge el "Historiae Iuris Civilis Lusitani Liber Singularis" de Pascoal José de Mello Freire dos Reis en $1788^{500}$, con incentivo de la Academia Real de Ciencias. Así que este compendio fue aprobado oficialmente para ser empleado en la enseñanza de la Historia del Derecho ${ }^{501}$.

Como ya fuera mencionado antes, la formación de la Junta de Providencia literaria va a investigar las causas de la decadencia de la Universidad de Coimbra. El resultado de esta investigación será un "Compêndio Histórico da Universidade de Coimbra” de 1771, y en donde claramente, desde el nombramiento de la Junta por el rey, el chivo expiatorio ya está señalado - los jesuitas ${ }^{502}$; y por ello serán expulsados, como forma de purgar a la universidad y al reino de este mal, como ya tuvimos ocasión de explicar. Sin embargo, este compendio será la base para los Nuevos Estatutos de la universidad. Pero, como también tuvimos ocasión de decir, el propio Verney ya alertaba de tal decadencia antes incluso de haber empezado la purga por el Marqués.

El referido Compendio identificará las deficiencias universitarias con mucha precisión y dará a los futuros estatutos medios para paliarlos ${ }^{503}$. Entre las deficiencias apuntadas por el Compendio está la preferencia que se venía dando a la enseñanza del derecho canónico, y está

\footnotetext{
499 "E porque entre os muitos Systemas, Compendios, e Summas da Historia do Direito Romano, não ha algum, que seja accommodado para o uso das Lições desta Cadeira; não só por não haver alguma, em que se ache escrita a Historiado Direito Portuguez; mas também porque igualmente não há algum, que compreenda todos três objetos próprios, e isseparáveis da dita Historia que versam sobre elas: Será o Professor obrigado a formar um Compendio Elementar da dita Historia do Direito, e de todas as suas partes, próprio, e accommodado para as Lições annuaes desta Cadeira: Formando-o com todas as circunstancias, e qualidades, que devem concorrer em semelhantes compêndios: E aplicando-se para a composição delles com muito fervor, atividade, e diligencia, para poder ordenallo com a maior brevidade possível". Estatutos da Universidade de Coimbra, op. cit., Livro II, Titulo III, Cap. 9, parágrafo 14, p. 364.

${ }^{500}$ MELLO FREIRE, Pascoal José: Institutiones iuris civilis lusitani, Coimbra, 1789 (trad. Miguel Pinto de Menezes [rev. A. M. Hespanha], in Boletim do Ministério da Justiça, 161 [1966], 94) p. 1 - "§ I - Sendo todo o direito, usado por qualquer nação, público ou particular, facilmente todos entendem que é igual a distinção no Direito Civil Português. Ocupar-nos-emos tanto de um como de doutro, mas cumpre-nos tratar, primeiro, do público, que é, sem dúvida, a espécie de direito mais nobre e excelente".

${ }^{501}$ Esta Reforma universitaria va a reflejar, mucho más que la Lei da Boa Razao, las corrientes ideológicas doctrinarias europeas tanto del siglo XVII como del siglo XVIII. ALMEIDA COSTA, M. J.: op. cit., p. 407. Acorde con esto también está España como bien ilustra ALVAREZ DE MORALES, A.: La Reforma de la enseñanza en España y Portugal en la Ilustración: semejanzas y diferencias in Universidades: História. Memória. Perspectivas, vol. I, p. 225.

${ }^{502}$ Parte I, Preludio I - "Já nao há por felicidade nossa neste presente tempo que possa duvidar com alguma aparência de razão, de que todos os estragos, no moral, e no Físico desta Monarquía se viram no meio dellas amontoados pelos longos períodos dos últimos dous Séculos, foram horrorosos effeitos das façanhosas atrocidades dos denominados jesuitas." Compêndio Histórico da Universidade de Coimbra, (Na Regia Officina Typografica - Por ordem de Sua Majestade), Lisboa, 1771, p. 1.

${ }^{503}$ El Compêndio Histórico da Universidade de Coimbra de 1771, apunta los errores en la universidad en la siguiente estructura: está dividido en dos partes, siendo que en la primera están cuatro preludios y la segunda parte está dividido en tres capítulos. Principalmente en el capítulo II y en su apéndice están apuntadas como los jesuitas han corrompido e imposibilitado los estudios de la jurisprudencia canónica y civil, principalmente por haber inducido una propaganda de la moral aristotélica. Ya los Estatutos Novos da Universidade divide los cursos jurídicos en dos facultades: Leyes y de Cánones. Pero todo condensado en el Libro II de los Estatutos, siendo este libro divididos en catorce títulos.
} 
también, el casi completo desconocimiento del derecho de Portugal, el excesivo uso y abuso del método de Bartolo, además de una utilización exagerada de la "opinio communis". Era completo el descrédito por el derecho natural y también por la historia del derecho ${ }^{504}$. De este modo se buscará introducir nuevas cátedras para adecuar la universidad a las nuevas corrientes del derecho. Las nuevas cátedras serán las de derecho natural, en un sentido más amplio, el derecho público universal, el derecho de las gentes y de historia del derecho y de las instituciones portuguesas, como ya tuvimos ocasión de comentar ${ }^{505}$. Estos cambios afectarán a la Facultad de Leyes. Ya para la Facultad de Cánones, continuará a enseñar, a menoscabo de toda la crítica sobre el estudio y aplicación del derecho romano, al "Corpus Iuris Civilis”, que contiene el Digesto, y al "Corpus Iuris Canonici" 506.

En la práctica la ordenación de las cátedras fue minuciosa, imponiendo el Estatuto los profesores de la escuela de jurisprudencia. Y lo que respecta a los de derecho romano y canónico, debían sustituir al ultrapasado y tradicional método escolástico o bartolista por directrices histórico-críticas o “cujacianas" 507 . Entretanto, la "Lei da Boa Razão" mantenía al derecho romano a título subsidiario, mientras que consagraba también los principios de la corriente del “usus modernus pandectarum”. Y para llevar esto a cabo el Estatuto mandaba que los profesores enseñasen solamente la jurisprudencia a través de Compendios elaborados por los mismos, de forma breve, que fuesen claros y bien ordenados. Estos, debían contener las reglas principales, las bases de la doctrina, las excepciones principales y de mayor uso en el

\footnotetext{
${ }^{504}$ Estatutos Novos da Universidade de Coimbra, 1772, op. cit., pp. 253 y ss. También ampliar más sobre las deficiencias de la universidad en ALMEIDA COSTA, M. J.: op.cit, pp. 408 y ss. También del mismo autor, ALMEIDA COSTA, M. J.: Leis, Cânones, Direito (faculdades de), in Diccionario de Historia de Portugal, vol. II, pp. 680 y ss. Además de MERÊA, P.: Lance de olhos..., op. cit., pp. 187 y ss.

505 "É na doutrina produzida no ámbito desta última disciplina que se formam as categorias como que o direito público irá lidar até bem depois da revolução liberal. De facto, o compêndio do austríaco Carlo António Matini, que veicula as posições do jusnaturalismo holando-alemao (Grócio, Punfendorf, Wolff, Thomasius, etc), mantevese em uso nas cadeira de direito público durante mais de três quartos de século. Daí que as bases filosóficas do iluminismo contratualista se tenham adaptado basicamente à teoria política do primeiro liberalismo, da qual apenas destoava o método metafísico e dedutivista do jusracionalismo". HESPANHA, A. M.: Guiando a mao..., op. cit., pp. 33 y 34. Se puede consultar a MARTINI, Caroli Antonii: De lege naturali, Confluentiae - Sumitibus J. C. Huber, Viena, 1781.

${ }^{506}$ El profesor Mario Julio Almeida Costa complementa sobre esta permanencia del derecho romano en los cambios propuestos, porque se veía a esta parte del derecho romano desde un punto de vista distinto del resto, y por eso queda incluida en la enseñanza. ALMEIDA COSTA, M. J.: op. cit., pp. 409 y ss. Además se puede constatar, al instituir la enseñanza de la asignatura de la Historia del Derecho y de la Instituciones Portuguesas, un abordaje precursor, para el profesor Jorge Miranda, de la enseñanza del derecho constitucional, ya antes de la Revolución liberal de 1820, que implantará lo que sería más una concepción moderna de constitución en Portugal. MIRANDA, J.: O ensino do Direito Constitucional moderno, in Revista da Faculdade de Direito da Universidade de Lisboa, Lisboa, 1998, vol. XXXIX, nº 2, pp. 851 y ss.

507 “A Lei também enfraquecia fortemente a relevância das fontes doutrinais, não apenas ao reafirmar que os direitos romano e canónico - o que, nesta altura, queria sobretudo dizer, a doutrina romano-canonística - apenas vigoravam na falta de lei do reino (o direito canónico era, pura e simplesmente, excluído como fonte de direito dos tribunais seculares), mas também ao negar valor vinculativo à Glosa de Acúrcio e aos Comentários de Bártolo (párf. 13), obras que direta ou indiretamente, tinham condicionado toda a doutrina anterior." HESPANHA, A. M.: Guiando a mão..., op. cit., p. 32.
} 
derecho. Debían ocuparse sobre todo de la Jurisprudencia didáctica y contener muy pocas polémicas para no mezclar el derecho cierto con el incierto. Las lecciones se debían pasar una y otra vez, así como los libros de estudios de la doctrina para ser fijados en la memoria ${ }^{508}$.

Del balance de la reforma pombalina se puede decir, apoyado por Almeida Costa, como una sincronización con la Europa moderna, principalmente a lo que se refiere a los cursos jurídicos. Pese a haber estado lejos de lo pretendido en la organización teórica de los reformadores, ha de hacerse notar al balance de la gestión al frente del gobierno de la Universidad de Coimbra del Rector Francisco de Lemos ${ }^{509}$, que ofrece a la Reina María I una "Relação Geral do Estado da Universidade" ${ }^{510}$ - 1777. Este recuento va a exponer lo alcanzado con la aplicación de los Estatutos. Sin embargo, hubo detractores de esta reforma, entre ellos, los más destacados fueron Antonio Ribeiro de Souza ${ }^{511}$, docente de Cánones, y Ricardo Raimundo Nogueira, docente de Leyes, de la Universidad de Coimbra. Los Estatutos del Marqués pervivirán hasta los idos de 1836, y pese a las críticas hechas a este, no sufrió grandes transformaciones. Apenas merecen ser resaltados los escasos cambios sufridos en el siglo XIX, en lo que respeta a la selección de los docentes, regulada por el Alvará de 1 de diciembre de 1804, y lo que concierne a los planes de estudios, modificados por el Alvará de 16 de enero de 1805. Con los cambios de este último instrumento legal el derecho portugués pasó a contar con dos cátedras en donde se aplicaba el método sintético y una cátedra en donde se aplicaba al método analítico. También se creó una cátedra independiente de práctica judicial y se fijaron dos cátedras de derecho natural; cabe resaltar que una de estas tiene la especificidad de dedicarse a los estudios autónomos del derecho público universal y de gentes. Siendo estas

\footnotetext{
${ }^{508}$ Estatutos da Universidade de Coimbra, Livro II, (Titulo III, Cap. I, paragrafo 20), op. cit., pp. 304 y 305.

${ }^{509}$ Francisco de Lemos de Faria Pereira Coutinho (1735-1822), nace en la casa de Marapicu, "freguesia" de Santo António de Jacotinga, término de la ciudad de Rio de Janeiro, a 5 de abril de 1735, fallece en Coimbra a 16 de abril de 1822. Era hijo de Manuel Pereira Ramos de Lemos e Faria, de familia ilustre, será rector de la Universidad de Coimbra en el periodo de 1770-1779 y 1779-1821. Y permanece como obispo titular de Coimbra hasta 1822. Sobre la biblioteca que llegó a tener se puede consultar en RODRIGUES, M. A.: Inventário da Livraria de D. Francisco de Lemos in Boletim do Arquivo da Universidade de Coimbra, vol. XIII e XIV, Coimbra, 1993/1994, pp. 5 y ss. También del mismo autor se puede consultar sobre el rectorado de Francisco de Lemos em RODRIGUES, M. A.: D. Francisco de Lemos Faria Pereira Coutinho, bispo de Coimbra e reformador-reitor da Universidade in A Universidade de Coimbra. Figuras e factos da sua história, vol. I,

510 "Primeira Parte da Legislação Literária, que respeita a instrução dos alunos. Ideia geral do que se fez nela. Esta parte foi a que se completaram nos Três tomos dos Estatutos já publicados. Nelles se reduziram todas as Sciencias aos seus verdadeiros princípios, de que estavam apartadas. Introduziu-se nos Cursos Scientificos das Faculdades Theológicas, e Jurídicas, Novas Disciplinas, que se não ensinavam na Universidade com grande detrimento das Letras, e do aproveitamento da mocidade estudioza”. LEMOS, F.: Relaçao Geral do Estado da Universidade (1777), II Centenário da Reforma Pombalina, Universidade de Coimbra, Coimbra, 1980, p. 10.

${ }^{511}$ Sobre las criticas de Antonio Ribeiro de Souza a las Reformas del Marqués de Pombal, se puede aprender más con la lectura de BRAGA, T.: Historia da Universidade de Coimbra, tomo III, (1700-1800), Lisboa, 1898 , p. 571. También es posible consultar a ROCHA PEREIRA, M. H.: Ecos da Reforma Pombalina na Poesia Setecentista in Bracara Augusta, vol. XXVIII, Braga, 1974, p. 313 y ss. Además de PEREIRA, J. E.: Antonio Ribeiro dos Santos e a Reforma Pombalina da Universidade in Universidade: História. Memória. Perspectivas, (Actas do Congresso de Historia da Universidade) - vol. I, Coimbra, 1991, pp. 215 y ss.
} 
signaturas comunes tanto para la Facultad de Cánones como para la de Leyes ${ }^{512}$. Estos cambios van a mejorar, a contrario sensus, la enseñanza tanto del derecho romano como del canónico. Pero, el edificio de la Reforma Pombalina se mantiene más o menos intacto durante todo el primer cuartel del siglo XIX.

\subsubsection{Proyecto para un “Novo Código” para Portugal.}

Hubo en este periodo una profusión de grandes autores ilustrados, entre los que destaca el ya nombrado Pascoal de Mello Freire dos Reis ${ }^{513}$, reconocido como el padre de la historia del derecho portugués. Este autor muy próximo a la corriente filosófica del "usus modernus" estaba muy conectado con las corrientes del pensamiento jurídico de la época en el resto de Europa, escribió cuatro libros sobre la historia del derecho portugués ${ }^{514}$. Además de su ya nombrado "Institutiones iuris civilis lusitani”, va a escribir también "Dissertação Histórico-Jurídica sobre os Direitos e Jurisdição do Grão- Prior do Crato, e o Seu Provisor" ${ }^{515}$. Fue encargado por la reina María I en 1783 para que elaborara un Nuevo Código para Portugal, tarea que la reina había legado antes a una junta que debía refundir las leyes del reino en un nuevo código, pero, la tentativa se quedó frustrada. Mello Freire va a escribir los Códigos de derecho público y de derecho penal. Fallece sin ver sus obras publicadas ${ }^{516}$. Solo en 1823 su sobrino publica el Código de Derecho Penal. También debe a su sobrino la publicación póstuma del ya

${ }^{512}$ Para mayores detalles se puede consultar a ALMEIDA COSTA, M. J.: Historia do Dir... op. cit., pp. 413,414 y ss. También se puede consultar a MERÊA, P.: O ensino do direito em Portugal de 1805 a 1836, in Jurisconsultos Portugueses do Século XIX (Direc. e colaboração de LOUREIRO, José Pinto), vol. I, Lisboa, 1947, pp. 149 y ss.

513 “Sabio publicista português, Vicario General del Crato, consejero del Supremo Consejo del Rey de Portugal y del Supremo Tribunal de Justicia, nació en 1738 en el lugar de Anciao. El Marqués de Pombal, tras sus reformas en la Universidad le nombró para desempeñar la cátedra de derecho portugués recientemente establecida, se tornó un famoso jurisconsulto de reconocido prestigio por casi toda Europa”. Diccionario Histórico o Biografia Universal Compendiada, Tomo IX, Librería de los Editores (Antonio y Francisco Oliva), Barcelona, 1833, p. 279.

${ }^{514}$ Se debe consultar también a REIS MARQUES, M.: Elementos para uma aproximação do estudo do "usus modernus pandectarum" em Portugal, in Boletim da Faculdade de Direito, vol. LVIII, Coimbra, p. 801 y ss.

${ }^{515}$ Esta obra póstuma se publicará por su sobrino Francisco Freire de Mello; MELLO FREIRE, P. J.: Dissertação Histórico-Jurídica sobre os Direitos e Jurisdição do Grão- Prior do Crato, e o Seu Provisor, (Primeira Edição), Imprensa Regia, Lisboa, 1809. Se puede consultar también BANHA DE ANDRADE, A. A.: A Reforma Pombalina dos Estudos Secundários (1759-1771), (constribuiçao para a historia da pedagogia de Portugal), Acta Universitatis Conimbrigensis, Vol. 1 (A Reforma), $1^{\text {a }}$ Parte, Coimbra, 1981, p. 526 y ss. El texto del Proyecto de Constitución de 1823, fue elaborado sobretodo por Ricardo Raimundo Nogueira, y lo publicó Paulo Merêia en el Boletim da Faculdade de Direito, XXIII, Editado en Coimbra, p. 196, citado por SUANZES-CARPEGNA, J. V.: "El constitucionalismo español y português durante la primera mitad del siglo XIX in SÁNCHEZ GÓMEZ, J. y ÁLVAREZ CUARTERO, I. (Eds.): Visiones y Revisiones de la Independencia Americana. La independencia de América: La Constitución de Cádiz y las constituciones iberoamericanas, Actas del Congreso, Ediciones Universidad de Salamanca, 2007, p. 49.

${ }^{516}$ Mello Freire va a influir enormemente en los juristas portugueses. Le comparan a grandes reformadores como Montesquieu, Voltaire, Beccaria o a Thomasius: JESCHECK, H. H.: Principes et solutions de la politique criminelle dans la reforme allemande ete portugaise, in Estudos in memoriam do Prof. Dr. José Beleza dos Santos, vol. I, Coimbra, 1966, pp. 436 y ss. Un jurista que sofre influencia de Mello Freire será Manuel de Almeida e Souza de Lobao. Este escribe Notas de Uso prático e Críticas. Adiçoes, Illustraçoes e Remissoes à imitação das de Miller a Struvio (Sobre todos os títulos e parágrafos do livro segundo das instituições do direito civil lusitano do doutor Pascoal José de Mello Freire), Parte II, Imprensa Nacional, Lisboa, 1963. 
mencionado "Dissertação Histórico-Jurídica sobre os Direitos e Jurisdição do Grão- Prior do Crato, e o Seu Provisor", y también el "Alegato Jurídico sobre los testamentos de los melancólicos". Había hecho previamente un gran servicio a la legislación portuguesa ${ }^{517}$, escribiendo para el uso de la universidad sus famosas "Instituciones del derecho público privado y criminal de Portugal", y una "Historia del derecho civil de Portugal" ${ }^{18}$. En esta última obra el autor retrocede hasta la conquista de España por los romanos y hace un gran recorrido histórico por la legislación portuguesa ${ }^{519}$.

Otro gran jurisconsulto de la época fue Ricardo Raimundo Nogueira ${ }^{520}$. José Agostinho de Macedo le va a atribuir un "Elogio Histórico" 521 . El proprio Nogueira escribió la obra "A História do Direito Pátrio", dedicado al quinto año del curso jurídico de la Universidad de Coimbra, para el año académico de 1795/1796 ${ }^{522}$. También le siguen otros como Francisco Coelho de Sousa e Sampaio, que así como Nogueira era profesor en la facultad de leyes, en la Cátedra de Historia del Derecho Romano y Patrio, además de "Desembargador da Relação do

517 "Quanto ao problema básico do direito de punir, Mello Freire, sob influência manifesta do pensamento da época, deriva-o da ideia de contrao ou pacto social. Neste contexto, sequaz de Grócio e Wolff, afasta a vingança do conceito de sanção jurídico-penal e afirma que a pena tem de ser imposta por uma entidade superior, consistindo, pois, no mal físico aplicado, por causa do mal moral, por aquele que tem o direito de obrigar (Institutiones Iuris Criminalis, Tít. I, parágrafos XI e XII). Relativamente aos fins das penas, Mello Freire poe de lado qualquer unilateralidade doutrinal e atribui-lhes um tríplice objetivo: a segurança do lesado, a emenda do lesante, e o exemplo dos outros (Institutiones Iuris Criminalis, tít. I, parágrafo XIII).” ALMEIDA COSTA, M. J.: op. cit., p. 416.

${ }^{518}$ Nos informa Almeida Costa que los varios compendios escritos por Mello Freire recibieron aprobación para las cátedras correspondientes. Las Institutiones a través del Aviso Regio de 7 de mayo de 1805 y se mantuvo por varios años. Pero, la vinculación de Mello Freire con el Despotismo Ilustrado del Marqués de Pombal hizo con que sus obras acabasen por ser puestas en el Index Librorum Prohibitorum, en 7 de enero de 1836. Sus obras escritas en latin son: Historiae Iuris Civilis Lusitani Liber Singularis, Lisboa, 1788; Institutiones Iuris Civilis Lusitani, cum Publici tum Privati, Lisboa, 1789/1793 (liv. I - 1789; liv. II y III - 1791; liv. IV - 1793); Institutiones Iuris Criminalis Lusitani, Lisboa, 1794. ALMEIDA COSTA, M. J.: op. cit., p. 415.

${ }^{519}$ Diccionario Histórico o Biografía Universal Compendiada, Tomo IX, Librería de los Editores (Antonio y Francisco Oliva), Barcelona, 1833, p. 280.

${ }^{520}$ Ricardo Raymundo Nogueira (1746-1827), nació en el Oporto en 31 de agosto de 1746. Profesor, jurista y político, se licenció en la Facultad de Leyes en 1765, ejerciendo la abogacía en Oporto hasta noviembre de 1772, fecha en que es llamado a la Universidad de Coimbra para hacer parte del cuerpo docente en la reformada Facultad de Leyes, en donde permanecerá hasta su jubilación, en 1802. Falleció en Lisboa, en 7 de mayo de 1827. Docente de la Facultad de Leyes, fue designado, en enero de 1790 para regir la primera cátedra de Instituta y, en abril de 1795, fue nombrado para la regencia de cátedra de Derecho Portugués. Véase más en CARIDADE DE FREITAS, P.: Um testemunho na transição para o século XIX. Ricardo Raimundo Nogueira (Análise histórico-jurídica), Ed. Almedina, Coimbra, 2005. También a FEIO, F. M. B.: Memorias históricas e descritivas acerca da Biblioteca da Universidade de Coimbra, e mais estabelecimentos anexos. Coimbra: Imprensa da Universidade, 1857.

521 "Eis aqui o que o Foro Portuguez viu reunido em Ricardo Raymundo Nogueira. Elle me dizia que no filosofo jurisconsulto Samuel Puffendorf se achava tudo; e que para a Jurisprudência universal, para os ofícios do homem, e do Cidadão nada mais era preciso; a este grande tesouro aqui adquirido ajuntava o tesouro do direito pátrio, que posto que, até aquele tempo, e antes dos escritos do Dr. Pascoal José de Mello, parecesse um corpo informe, e rude, e indigesta móle, sabia muito bem Ricardo Raymundo Nogueira separar nele as luz das trevas e deo exercício pratico e seus vastos conhecimentos (...)" MACEDO, J. A.: Elogio Histórico do Ilustrissimo e Excelentissimo Ricardo Raimundo Nogueira, Conselheiro D`Estado, Impressao Regia, Lisboa, 1827, p.11.

522 "O gosto pelos monumentos histórico-jurídicos, nascido na Alemanha e propagado de lá até nós, tem já produzido preciosisimos trabalhos, entre os quais avultam os Portugaliae Munumenta Historica, publicado pela Academia Real de Sciencias de Lisboa, sob a direção do nosso primeiro historiador - Sr. Alexandre Herculano Carvalho.” NOGUEIRA, R. R.: Prelecções sobre a História do Direito Pátrio, Imprensa da Universidade, Coimbra, 1866, p. 1 (advertências). 
Porto”. Escribirá este mismo autor unas "Prelecções do Direito Patrio Público, e Particular", que dedica al D. Juan, Príncipe de Brasil. Cuentan estas Prelecções, en palabras del mismo autor, de una primera parte, en donde se trata de las nociones preliminares del derecho portugués, que tiene por objeto los diversos códigos de la nación. Sus fuentes, así como las causas que le llevaron a las recopilaciones, y su autoridad, la autoridad de la costumbre de la nación, de los derechos subsidiarios, y de las leyes extravagantes. En la segunda parte la obra trata sobre el derecho público portugués combinado con el derecho público universal, además de otras materias propias de la historia del derecho portugués ${ }^{523}$. Otro autor, Antonio Ribeiro dos Santos ${ }^{524}$, será el contrapunto del absolutismo real y reacio a las ideas limitadas de ley fundamental que entonces circulaba. Para este autor, que escribe "Notas al Plan del Nuevo Código", el derecho público nacional debía sufrir una codificación, aunque bifurcado en dos vertientes: las Leyes Fundamentales primordiales de los Estados, resultantes de la convención tácita o expresa, y las Leyes Públicas Civiles, que son las que serían emanadas del soberano, derivadas, por lo tanto ${ }^{525}$. En sus Notas al "Plan del Nuevo Código", nos interesará comentar más adelante las notas sobre el Título IV del Plan del Nuevo Código, que trata sobre la Religión y Fe Católica, que intentaremos comentar mejor en el Capítulo IV, cuando tratemos de los aspectos confesionales presentes en los textos constitucionales aquí abordados ${ }^{526}$.

También destacó fuera del ámbito universitario, Manuel de Almeida e Sousa de Lobão, a quien ya hicimos referencia, y Joaquim José Caetano Pereira de Sousa, abogado de la Casa de

\footnotetext{
${ }^{523}$ SOUSA E SAMPAIO, F. C.: Prelecções do Direito Pátrio Público e Particular, (Oferecido a D. Joao - Príncipe do Brasil), $1^{\mathrm{a}}$ e $2^{\mathrm{a}}$ Parte, Real Imprensa da Universidade - Com licença da Real Mesa da Comissão Geral sobre o Exame e Censura dos Livros, Coimbra, 1793, p. IV. Además de estas preleciones, volverá a publicar unas "Observações às Prelecções de Direito Pátrio", Lisboa, 1805. Se puede consultar más sobre estas obras y este autor em HESPANHA, A. M.: Poder e Instituição na Europa do Antigo Regime. Colectânea de Texto, Lisboa, 1984, pp. 395 y ss. También MERÊA, P.: Notas sobre alguns lentesde Direito Pátrio no período 1772/1804 in Boletim da Faculdade de Direito, Vol. XXXVI, pp. 325 y ss.

${ }^{524}$ Este autor publicó Notas ao Plano do Novo Código de Direito Público de Portugal, do Doutor Paschoal José de Mello, feitas e apresentadas na Junta da Censura e Revisao pelo Doutor Antonio Ribeiro em 1789, Imprensa da Universidade, Coimbra, 1844. También se puede hacer una consulta más reciente sobre este autor en ESTEVES PEREIRA, J.: O pensamento político em Portugal no século XVIII: Antonio Ribeiro dos Santos, Lisboa, 1983, p. 27 y ss. Además se puede consultar a ALMEIDA COSTA, M. J.: op. cit., p. 58 y ss. Otro autor del siglo XIX con una gran profusión de obras fue Manuel de Alemeida e Sousa de Lobão, pero, mucho más volcado en la ciencia practica del derecho. Para este último autor véase también a LOUREIRO, José Pinto: O Jurisconsulto Manuel de Alemeida e Sousa, Vol. I, Editorial de Coimbra, 1942, pp. 240 y ss.

525 "O Livro II do Novo Código sobre leis e o costume devia ser um de dois. Ou abrangia o direito público constitucional e, então, devia conter: 1- a reforma suprema do governo (summum imperium); 2 - a ordem de sucessão da coroa; 3 - a forma de exercício dos direitos do soberano no direito particular português; 4 - o sistema de administração pública; 5 - os direitos e deveres dos particulares relativamente ao príncipe; 6 - os privilégios das ordens que constituíam o Estado; 7 - o estatuto das cortes; 8 - o direito da fazenda pública, 9 - as matérias de interesse público, como a população, a religião, a educação, a polícia, etc... (ibd., "Exame do Plano", 6). Ou, então, se no Código se decidisse não incluir este direito constitucional, não devia tão pouco haver qualquer referência às leis fundamentais (ibid., "Notas ao título dos direitos reais", p. 72)." HESPANHA, A. M.: Guiando a mão..., op. cit., p. 38.

${ }^{526}$ Otra obra de este autor es SANTOS, Antonio Ribeiro: De sacerdotio, et império selectae dissertationes..., Typographia Regia, Olisipone, 1770.
} 
Suplicación, que escribió obras dedicadas al proceso civil y al derecho penal ${ }^{527}$. Además de este último, también llama la atención la obra de Vicente José Ferreira Cardoso da Costa ${ }^{528}$. La obra más relevante de este último autor fue "Que he o Código Civil?",529, lo que demuestra que este autor estaba perfectamente sintonizado sobre las teorías de la codificación y el movimiento que propugnaba por esta innovación de la sistemática jurídica, que tiene su mayor exponente, y al cual ya hicimos referencias anteriormente en Jeremy Bentham ${ }^{530}$.

Como ya hemos dicho, hay una profusión y dispersión de la legislación portuguesa, aliada a las nuevas ideas codificadoras, con sus ventajas y modernidad. El decreto de 3 de marzo de 1778, por el cual María I determina que se procediese a una refundición de las leyes en un Nuevo Código, con el objetivo de reformar y actualizar las vetustas Ordenaciones Filipinas. Aquél decreto creará una Junta de Ministros ${ }^{531}$ con este objetivo específico; que como ya adelantamos no cumplirá con lo determinado. Recaerá esta tarea en Paschoal José de Mello Freire dos Reis, que llevará a cabo la encomienda de la reina con excelente resultados, a la vez que veremos en seguida las "Notas ao Novo Código" hechas por Antonio Ribeiro de Sousa, como ya hicimos también referencia. Nos dirá el profesor Antonio Manuel Hespanha, que el proyecto constitucional de Santos, crítico de Mello Freire, sería mucho más semejante a otros programas europeos, sobre todo, alemanes e italianos, de reforma constitucional y no

${ }^{527}$ PEREIRA E SOUSA, Joaquim José: Primeiras linhas sobre o proceso criminal (1785), Typografia Rollandiana (Com licença da Meza do Desembargo do Paço), Lisboa, 1820. Tambíen del mismo autor, Primeira sobre o processo civil, Lisboa, 1810/1814. También la misma obra, con adaptaciones para los Fueros de Brasil, hasta el año de 1877, de Teixeira de Freitas, Tomo III, Typografia Perseverança, Rio de Janeiro, 1870.

${ }^{528}$ Sobre este autor véase la monografía de BANOND ALMEIDA, Isabel Maria: Monografia sobre a Vida e Obra de um Autor do Século XIX: Vicente José Ferreira Cardoso da Costa in: Estudos em Homenagem ao Professor Doutor Manuel Gomes da Silva, Edição Faculdade de Direito da Universidade de Lisboa, Coimbra Editora, 2001, pp. 883 a 896. También una tesis más reciente trata sobre este autor, de Luis Otávio Pagano Tasso: Considerações Politicas e Econômicas Sobre Portugal 1808-1812, Universidade de São Paulo, 2010, pp. 43 a 52 . Vicente José Ferreira Cardoso da Costa, nació en la província de Bahía, Brasil, y que se destacó como jurisconsulto, pero fuera del ámbito universitario, como casos ya citados de Manuel de Almeida e Sousa de Lobão y Joaquim José Caetano Pereira e Sousa. Fue efímera su relación con la universitaria, en donde ejerció como opositor en el año académico de 1788/1789, como nos cuenta ALMEIDA COSTA, M. J.: op. cit., p. 418.

${ }^{529}$ CARDOSO DA COSTA, Vicente José Ferreira: Que he o Código Civil? Typografia de A. Rodrigues Galhardo, Lisboa, 1822.

${ }^{530}$ Jeremy Bentham, como ya comentamos antes, fue un activo correspondiente con las Cortes Portuguesas de 1821, y llegó a ofrecer a aquellas unos proyectos de Código Constitucional, un Código Civil y un Código Penal, que no fueron aceptados por las Cortes de entonces. Sin embargo, Bentham fue muy leído y comentado entre los juristas portugueses y era muy apreciado. Dos autores comentan Bentham, VERLINDEN, Jacques: Code et codification dans pensé de Jeremy Bentham in: Révue d'Histoire du Droit (Tijdschrift vor Rechtsgeschiedenis), Tomo XXXII, La Haye, 1964, pp. 45 y ss. También se puede saber más con la obra de EL SHAKANKIRI, Mohamed: La philosophie juridique de Jeremy Bentham, Paris, 1970.

${ }^{531}$ El Decreto de 31 de marzo de 1778, trae el rol de ministros que compondría aquella Junta: estaba presidida por el Visconde de Vila Nova de Cerveira, entonces Ministro y Secretario de Estado de los Negocios del Reino. Eran vocales los doctores José Ricalde Pereira de Castro (Desembargador do Paço), Manuel Gomes Ferreira (Desembargador de los Agravios de la Casa de Suplicación), Bartolomeu José Nunes Giraldes de Andrade (Procurador da Fazenda Real), Gonçalo José da Silveira Preto (Procurador de la Hacienda Real) y Joao Pereira Ramos de Azeredo Coutinho (Procurador de la corona). Collecção da Legislação Portugueza (desde a última recopilação das Ordenações, redigida pelo desembargador Antonio Delgado da Silva - Legislação de 17751790), Typografia Maigrense - Com a licença da Mesa do Desembargo do Paço, Lisboa, 1828, p. 168. 
revolucionaria. El problema de este Nuevo Código estaba en innovar sin prescindir del antiguo $^{532}$. Estas críticas serán rebatidas por Mello Freire, desde las hileras del despotismo iluminista $^{533}$. Se buscaba no alejarse tanto de la sistematización de las vetustas ordenaciones del reino, dado que, según las críticas de Duarte Alexandre Holbeche - dirigidas a este tipo híbrido de codificación - la adopción de métodos nuevos podría dificultar las tareas de los juzgadores, puesto que ya estaban familiarizados con las antiguas usanzas de las ordenaciones ${ }^{534}$. Aunque dentro de la propia Junta de Ministros surgió varias divergencias de cómo realizar los trabajos para alcanzar el objetivo establecido en el Decreto de 31 de marzo. Lo que la reina decretaba como códigos nuevos estaba muy lejos de la concepción más moderna de código, en donde confluían las aspiraciones del pensamiento Iusracionalista e iluminista, por ejemplo, la defendida por el publicista inglés, Jeremy Bentham ${ }^{535}$. Con el encargo de la Reina, de revisar y modernizar la legislación, atribuido a Mello Freire en 1783, este procede a la revisión del Libro II de las Ordinaciones del Reino, y también del Libro V, que trataban de los temas de derecho público-político-administrativo y del derecho criminal respectivamente ${ }^{536}$.

Al fin y al cabo, no van a tener éxito los proyectos de código de Derecho Público ni el de Criminal de Mello Freire. En realidad solamente serán publicados póstumamente ${ }^{537}$ como vimos. Mello Freire se verá prisionero del sistema punitivo de las Ordenaciones del Reino, sin pasar a las nuevas tendencias e ideas del periodo, innovadoras por lo tanto, con los nuevos

\footnotetext{
532 “O Novo Código (i) deveria ter uma ordem sistemática que permitisse a economia da exposição e a sua fácil memorização e (ii) deveria ser curto, livre de excessivos detalhes e prolixidades." HESPANHA, A. M.: Guiando a mao..., op. cit., p. 41.

533 “1843, "Resposta que deu o Desembargador Paschoal José de Mello Freire dos Reis (à primeira censura), 63100; (à segunda censura), 101-112; tréplica de António Ribeiro dos Santos: ("Notas à resposta à primeira cesura"), 115-144." In Ibidem.

${ }^{534}$ Esta crítica se puede encontrar en CHORAO, Luís Bigotte: O Discurso de Duarte Alexandre Holbeche Subsídios para a História do Novo Código in: Estudos em Homenagem ao Professor Doutor Manuel Gomes da Silva, Coimbra Editora, Coimbra, 2001, p. 1129 y ss. Véase sobre este jurista en Diccionario Aristocratico Contendo os Alvarás dos Foros de Fidalgos da Casa Real (Que se achao registrados nos livros das Merces, hoje pertencentes aos Arquivos da Torre do Tombo desde os mais antigos que neles há até os atuais), Tomo I (A-E), Imprensa Nacional, Lisboa, 1840, p. 455.

${ }^{535}$ Véase más en SUBTIL, José: La vida de los desembargadores durante la crisis, las reformas y la Revolución Liberal en Portugal (1750-1820) in: NARANJO, Esteban Conde (Ed.): Vidas por el Derecho, Ediciones Universidad Carlos III, Madrid, 2012, p. 169 y ss.

${ }^{536}$ Se puede ampliar sobre el tema con la lectura de ALMEIDA COSTA, M. J.: op. cit., p. 421 y ss. Como resultado del encargo de la reina a Mello Freire, surge los ya mencionados Projecto de Código de Derecho Público y del Código Criminal. Y para analizarlos se expide un Decreto en 3 de febrero de 1789, con el cual se crea una "Junta de Censura y Revisión" que estaba integrada entre otros juristas, por lo ya nombrado Antonio Ribeiro dos Santos, que escribió las mencionadas notas sobre la obra de Mello Freire.

${ }^{537}$ La primera edición del proyecto del Código Criminal va a ser publicado en Lisboa solamente en el año 1823 . A su vez la primera edición del Código de Derecho Público sale a la luz en el año 1844. La Universidad de Coimbra volverá a publicar la tercera edición del Proyecto del Código Criminal ya con las críticas hechas por Ribeiro Santos a la reforma del derecho público, también vino acrecido con la respuesta de Mello Freire. Se puede aprender más con la lectura de Almeida Costa, M. J.: op. cit., pp. 422 y ss. Sobre la discusión de estos proyectos véase a ALMEIDA LANGHANS, F. P.: O Novo Código de Direito Público de Portugal in: Estudos de Direito, Coimbra, 1957, pp. 357 y ss.
} 
paradigmas trazados por Cesare Beccaria. En cuanto a lo que concierne a las Institutiones, estas se revelaron mucho más acorde con las ideas iluministas y humanitaristas, corrientes ideológicas, que como tuvimos ocasión de comentar, eran muy bien conocidas por los ilustrados portugueses. En esta disparidad, nos aclara Almeida Costa que posiblemente Mello Freire fuese consciente de la realidad carcelaria en Portugal y los medios necesarios para introducir estas novedades del pensador italiano, quizás no existieran en ese momento.

\subsubsection{La presencia francesa en Portugal y la "Súplica Constitucional".}

Otro elemento que pesará en la balanza ideológica y que reflejará en la Constituyente de 1821 portuguesa será la presencia militar francesa y el gobierno de Junot en Portugal. Según Antonio Manuel Hespanha, la invasión francesa va a constituir el segundo momento en Portugal en que se buscó una reforma constitucional; el otro momento, y primero por lo tanto, sería el proceso que comentamos un poco antes que fue el Proyecto de Nuevo Código (1786), y toda la discusión que provocó el Libro de Derecho Público de este mismo Proyecto ${ }^{538}$. Además, ya hemos hablado un poco más arriba sobre la huida de la Familia Real Portuguesa hacia Brasil y de sus consecuencias para Portugal. Así como tendremos ocasión de hablar sobre estas influencias en Brasil. Como ya resaltamos antes, no fue solo la Familia Real que se trasladó a Brasil, sino casi todo el aparataje del Estado Portugués. La trasferencia de la corte portuguesa fue vista jurídicamente como una abdicación por parte de los Braganza a la corona de Portugal $^{539}$, como bien sentencia una proclama emitida por el cabeza de los franceses. El Comandante en Jefe, Junot, dirá en esta Proclama que se rodearía, en la tarea de gobernar a Portugal, de los hombres más instruidos del reino, y de la buena voluntad de todos sus habitantes. Trazará unas líneas maestras para la administración, ejércitos y educación pública en Portugal, a través de esta proclama, que aparecerá en los articulados del decreto expedido en el mismo día. Junot optará así, como se hizo en España, por la manutención de la religión y su

\footnotetext{
${ }^{538}$ Se puede consultar también en HESPANHA, A. M.: Guiando a mão invisivel. Direitos, Estado e lei no Constitucionalismo Monárquico Português, Editora Almedina, Coimbra, 2004, pp. 34 y 35. Sobre la afirmación que recorremos de este autor de los dos momentos de tentivas de reformas constitucionales se puede encontrar em HESPANHA, A. M.: Bajo el Signo de Napoleón. La Súplica Constitucional de 1808, Cuadernos de Historia Moderna. Anejos, 2008, VII, 299-218, p. 300. También tuvimos acceso a una versión de lengua portuguesa de este texto, HESPANHA, A. M.: Sob o Signo de Napoleão. A Súplica Constitucional de 1808, Almanack Braziliense $\mathrm{n}^{\circ}$ 7, maio de 2008, pp. 80-101.

539 "Le Prince du Brésil en abandonnât le Portugal, a renoncé à tours ses droit à la souveraineté de ce Royaume. La Maison du Bragance a cessé de régner sur le Portugal. L'EMPEREUR NAPOLEON veut que ce pays soit administré et gouverné tout entier en son Nom, et par le Général en Chef de son Armée." Proclama de $1^{\circ}$ de fevereiro de 1808 (Le Gouverneur de Paris, Premier Aide de Champ de S.M. l'EMPEREUR et ROI, Général en Chef: Habitants du Royaume de Portugal), Collecção de Decretos, Editais, etc., Typografia Rollandiana, Lisboa, 1808, p. 141. La tesis de la renuncia también es defendida por FIGUEIREDO MARCOS, R. M.: Rostos Legislativos de D. Joao VI no Brasil, Coimbra, 2008, pp. 21 y ss. También está compartido por ALMEIDA COSTA, M. J.: op. cit., pp. 423 y ss.
} 
protección, pero libre de supersticiones que la deshonran, como explica la misma proclama ${ }^{540}$. Tarea que ve fácil por contar con un "Peuple Spirituel, Patient et Brave" ${ }^{541}$, como eran los portugueses. Y para combatir el desorden, los salteadores, principalmente a la mendicidad, no solamente fueron criminalizados, aunque la proclama lo habla indirectamente, pero sí que habla de darles una función útil en la sociedad, puesto que estaban visto como el inicio de todos los males de ésta ${ }^{542}$. Además de todo, los ojos vigilantes del emperador fijados en el pueblo portugués eran un elemento que se añadía al proyecto gubernativo de General en Jefe, como se encargó de matizar éste en su proclama.

El articulo II del Decreto de $1^{\circ}$ de febrero de 1808, impondrá al Consejo de Regencia el cese en sus funciones: "O Conselho de Regencia criado por Sua Alteza Real o Principe do Brasil, no momento en que este príncipe abandonou o Reino de Portugal, fica suprimido". En su lugar, el art. III, del citado decreto, crea un "Conseil de Gouvernement présidé par le Général en Chef (Junot)", compuesto por un "Secrétaire d'Etat" (V. Mr. Hermann), encargado de la administración del Interior y de las Finanzas, por dos "Conseillers de Gouvernement", encargados, uno por la Repartición del Interior (D. Pedro de Mello) y el otro por la Repartición de la Finanzas (Sr. d’Azevedo. De otro "Secrétaire d Etat" encargado de la Repartición de la Guerra y de la Armada (Mr. Lhuitte), con un "Conseiller de Gouvernement" encargado de la repartición de la Guerra y de la Armada (Sr. Conde de Sampaio). También de un "Conseillers de Gouvernement" encargado de la Justicia y de los cultos, con el título de Regidor (Sr. Principal Castro). Además de un "Secrétaire Général du Conseil", encargado de los archivos (Mr. Vienez-Vaublanc). Aunque hubo la disolución del Consejo de Regencia, creado por el Príncipe Regente, D. João, el decreto mantiene en sus puestos los demás Encargados de la Administración Pública. Para la administración de las Provincias, el art. VI crea la figura de un Administrador General con el título de "Corrégidor-Mor". Y al final de todo, para mantener el orden en las provincias, y con funciones militares, el decreto de Junto crea un "Officier Général'. Así, en resumen, y de forma simplificada estaba organizado el gobierno napoleónico en Portugal.

La presencia francesa va a interferir en el ordenamiento jurídico portugués, primero con la introducción de nuevas fórmulas para marcar el cambio de titularidad del Estado, pero

\footnotetext{
540 “La Religion de vos Pères, celle que nous professons, sera protégée et secourue par la même volonté qui a su la rétablir dans le vaste Empire Français, mais délivrée des superstitions qui la déshonorent: la Justice sera rendue avec Equité, et débarrassée des longueurs et l'arbitraire qui l'entravaient". Collecção de Decretos, Editais, etc., Typografia Rollandiana, Lisboa, 1808, p. 143. Proclama de $1^{\circ}$ de fevereiro de 1808.

${ }^{541}$ Proclama..., op. cit., p. 142.

542 “(...) Des maisons de répression seront établies pour cela; le pauvre estropié, y trouvera un asyle, et le fainéant y sera employé à un travail nécessaire, même à sa conservation". Proclama..., op. cit., p. 143.
} 
también va a introducir algo de las doctrinas francesas. Además, entender como abdicación de los derechos a la corona el hecho de que los príncipes de Braganza se marcharan a Brasil era casi una interpretación suareciana del tema, sólo que la soberanía recaería en el conquistador francés y en consecuencia en su emperador. Dado que, en el art. I, del ya mencionado decreto, dice claramente que el Reino de Portugal, a partir de aquél momento sería administrado en su integralidad, y gobernado en nombre de S.M. el Emperador de los franceses, Rey de Italia, por el General en Jefe de los ejércitos franceses en Portugal, o sea, el propio Junot; el cual emite decretos no numerados, y proclamas, con fórmulas que preceden al propio decreto. Así, en otro decreto, también del día $1^{\circ}$ de febrero de 1808 , establece las fórmulas que inician los Actos Públicos, leyes, sentencias etc., que antes se procesaban en nombre de S.A.R. o Príncipe Regente de Portugal, pasan a enunciarse con la fórmula siguiente: "Em Nome de S.M. o Imperador dos franceses, Rei de Italia, Protector da Confederação do Reno" ${ }^{\text {"543 }}$. Ya en los Actos Administrativos y de ejecución, relativo a cualquiera decreto, u orden, emanada del actual gobierno, se añadirá a aquélla fórmula anteriormente citada, la siguiente formulación: " $E$ em consequência do Decreto, ou das Ordens de Sua Excelência o Governador de Paris, Primeiro Ajudante de Campo de S.M., e General em Chefe do Exercito francês em Portugal" ${ }^{544}$. Solo utilizaremos estos dos ejemplos de fórmulas prescritas por el decreto, para evitar que seamos demasiados prolijos, pero el decreto sigue desmenuzando fórmulas para las demás ocasiones administrativas del reino. En razón de este segundo decreto, el nuevo Secretario de Estado del Interior y de la Finanzas, Mr. Hermann escribe una carta al impresor de la Gazeta de Lisboa, Antonio Rodrigues Galhardo, por haber publicado en el día 02 de febrero de 1808 este periódico con las armas reales portuguesas y con la tradicional leyenda en donde decía: "Com privilegio de S.A. Real" ${ }^{545}$. Galhardo para acatar el "pedido" de Mr. Hermann, puesto que luego se refleja en los suplementos al nº 5 y en el n ${ }^{\circ} .6$ de la Gazeta traerá apenas el mote: "Com privilegio do governo"

Así que Junot va a legislar a la moda francesa, y aplica lo máximo posible la legislación francesa en Portugal, como ha aclarado Lopes Praça. El derecho penal será lo que más sufrirá

\footnotetext{
${ }^{543}$ Collecção de Decretos, Editais, etc., Typografia Rollandiana, Lisboa, 1808, p. 151. Decreto de $1^{\circ}$ de Fevereiro de 1808 .

544 Idem, p. 152.

545 "Tendo aparecido hoje a Gazeta de Lisboa impressa pela antiga forma, contra as ordens de Sua Excelência o Governador de París, Primeiro Ajudante de Campo de Sua Majestade o Imperador e Rei, General em Chefe; determina Sua Excelência que imediatamente se suprima a folha hoje publicada, reimprimindo-se e substituindose as palavras - Com privilegio do Governo -, sem lhe por o antigo selo de armas; o que se prosseguirá da mesma sorte no futuro, ficando vossa mercê nessa Inteligência. Deus guarde a Vossa Mercê. Secretaria de Estado dos Negócios das Finanças, 2 de fevereiro de 1808. Francisco Antonio Hermann (sic)." Solamente en el día 16 de septiembre de 1808, con salida de los franceses de Lisboa, la Gazeta vuelve a imprimir las antigas armas del reino. ${ }^{546}$ Pero, las armas del Emperador francés solo aparecerán en el suplemento del $\mathrm{n}^{\circ}$. 16, del día 22 de abril de 1808. GAZETA DE LISBOA, Suplemento do N.16, Sexta-Feira, 22 de abril de 1808, portada.
} 
de la influencia francesa. De tal modo que el Decreto de 8 de mayo de $1808^{547}$, hace alusión a la aplicación del Código Penal francés. La propia Proclama del día $1^{\circ}$ de febrero de 1808 , como ya tuvimos ocasión de mencionar, está bastante concatenada con la ideología del derecho francés, cuando prescribe casas de trabajos a los vagos, como forma de ponerlos al nivel de la sociedad $^{548}$. Sin embargo, Francia ha sido siempre un escaparate de doctrinas e ideologías, y a aquella altura más aún. Además, "el Corso" las fue esparciendo por toda Europa con sus conquistas. Napoleón va a contar no sólo con la feroz resistencia en Portugal, que expulsará a sus tropas a cabo de algunos meses, pero también contará con colaboracionistas, como pasó en España con los afrancesados.

Lo cierto es que la presencia francesa y la ausencia del rey será un catalizador para que algunos grupos presentasen sus ideas de gobernabilidad del Estado, pro Junot o en favor de los Braganza, o ninguna de estas opciones, pero a favor de Napoleón y de una constitución. El obispo de Coimbra y rector de la Universidad, D. Francisco de Lemos se prestará a los planes de Junot de enviar una diputación ${ }^{549}$, que debía encontrar al Emperador en Bayona, entre los días 1 y 10 de abril, conforme a la carta enviada al obispo por Junot, e incita al Senado del Ayuntamiento de Lisboa a elegir a los diputados que compondrán dicha diputación ${ }^{550}$. Tras los sucesos en Bayona y malograda la diputación, el obispo regresa a Portugal en situación poco clara en 1810. Pero, iniciada una investigación sobre este suceso, tras el regreso de la Regencia absolutista, el obispo presenta en 1811 una serie de razones para justificar esta diputación, excusándose de la acusación de colaboracionista y traedor que pudiese pesar sobre él. A D. Lourenço de Lima, entonces presidente de la diputación de Lisboa, desde Bayona, la diputación le dirige un escrito en donde figuraban artículos destinados a preservar la integridad del reino y

\footnotetext{
${ }^{547}$ LOPES PRAÇA, J.J.: Collecção de Leis e subsídios para o Estudo do Direito Constitucional Portuguez, vol. II, Coimbra, 2000, p. VIII.

${ }^{548}$ Véase esta afirmación en FIGUEIREDO MARCOS, R. M.: op. cit., p. 26 y ss. Además de ALMEIDA COSTA, M. J.: op. cit., p. 423 y ss.

${ }^{549}$ La GAZETA DE LISBOA de 13 de mayo de 1808 da noticias sobre la partida de dicha deputación - (sic.) "A Deputaçao Portugueza, Enviada Junto a Sua Magestade, o Imperador dos Francezes, Rei da Itália, Protector da Confederaçao do Rheno, aos Seus Compatriotas".

550 "La Régence, Monsieur, m`avait montré le désir d'envoyer une Députation à sa Majesté, l'Empereur et Roi mon Maître, et ce væu mât été exprimé depuis par toutes les classes du Royaume. Sur la compte, que jai rendu à sa Majesté, elle y a consenti et approuvé la liste, que je lui ai adressée, et dont faites partie. En conséquence vous voudrez bien, Monsieur, prendre vos mesures de manière à être rendu à Bayonne du premier au dix Avril prochain et dans cette ville vous recevrez du Ministre des Relations Extérieures des Instructions, qui régleront votre marche ultérieure. Recevez, Monsieur, l'assurance de ma parfaite considération. Junot. Monsieur l'Evêque de Coimbra". - Resposta que, vindo da França, fez o Bispo de Coimbra, D. Francisco de Lemos a Sua Alteza Real, o Príncipe Regente, Nosso Senhor -, in HESPANHA, A. M.: Bajo el signo..., op. cit., p. 300. La diputación frente al dialogo con Napoleón, creyendo, según nos cuenta el obispo de Coimbra, era contraproducente para Portugal, resuelve, según nos cuenta Manuel Hespanha, enviar a Portugal una carta con los artículos llevados al Emperador para ser publicada. Al final la Carta fue enviada desde Bayona, el 27 de abril, según comenta SERRAO, Joaquim Verissimo: História de Portugal, Lisboa, Verbo, 1984, 7, 37, n. 71. Que hace referencia a una copia de dicho documento en la Biblioteca de la Academia de Ciencias en Lisboa. Así también lo describe la GAZETA DE LISBOA de 13 de mayo de 1808.
} 
abogar por los Braganza. Lo que el Emperador, según nos cuenta Manuel Hespanha, no estaba dispuesto a ceder. De la exposición de motivos sobre dicha diputación, D. Francisco de Lemos aclara en el proceso abierto contra él que, Portugal, en Palabras de Napoleón, debía abandonar a su rey, su constitución y sus leyes, porque estas instituciones serían poco liberales. Es, según análisis del propio profesor Hespanha, la única mención que hace D. Francisco de Lemos al término constitución. Ya para José Acúrcio das Neves, la diputación fue en realidad requerir un nuevo rey y una constitución para el reino, pero buscaba garantizar, principalmente, la independencia frente a España. Por lo tanto, hay dos versiones para esta diputación portuguesa junto a Napoleón, una es la del obispo y rector de la Universidad de Coimbra, D. Francisco de Lemos y la otra de José Acúrsio das Neves ${ }^{551}$. También Junot va a intentar aprovechase de este momento para promover su nombre como posible candidato junto al Emperador para gobernar Portugal. De este modo, manda reunir la Junta de los Tres Estados, en conjunto con el Senado del Ayuntamiento de Lisboa, que ya se les reconocía al momento cierta legitimidad representativa, para dirigir un mensaje a Napoleón el 24 de mayo de 1808. Otro grupo que no pactaba con las pretensiones de Junot ni tampoco con el regreso de los Braganza y que estaba formado por juristas de la talla de Ricardo Raimundo Nogueira ${ }^{552}$, va a animar al Juez del Pueblo de Lisboa, José de Abreu Campos a que presente a la Junta de los Tres Estados una "Suplica" 553 , que será redactada por el Doctor Gregório José de Seixas y que contendría las principales reivindicaciones del reino - una constitución y un rey constitucional ${ }^{554}$.

Esta diputación va a encontrar al emperador en Bayona, el talón de Aquiles de España, peticionándole un rey y una constitución, en la visión de José Acúrsio das Neves. De este modo, estos francófilos van a redactar, para que se entregue a Napoleón, la famosa Súplica de $1808^{555}$. La suplica es muy curiosa porque evoca un parentesco con los franceses desde la

\footnotetext{
${ }^{551}$ NEVES, José Acúrsio das: História Geral da Invasao dos francezes em Portugal e da Restauraçao deste Reino, (Com Licença da Mesa do Desembargo do Paço), Officina de Simao Thaddeo Ferreira, Vol. II, Lisboa, 1811, pp. 15 y ss. Además se puede consultar a RESENDE, Marques: Breves reflexões sobre um escrito em que se ofende a chamada deputação portuguesa que foi a França em 1808, Lisboa, 1871 - Biblioteca Nacional de Lisboa, H. G. 9645//4P. También es interessante consultar um Discurso proferido na Junta que tentava pedir a Napoleão um Rei para Portugal - Biblioteca da Ajuda, C IX/ 1-17, fl. 3. Estos documentos se encuentran también citados por HESPANHA, A. M.: Bajo el signo..., op. cit., p. 303.

${ }^{552}$ Sobre la supuesta participación de Nogueira habíamos ya hecho referencia un poco antes en el texto, pero para aclarar sobre tal cuestión se puede consultar a FREITAS, P. M. M. G. C.: Un testemunho na transição..., op. cit. También a MACEDO, José Agostinho de: Elogios históricos..., op. cit. Como también a HOMEM, Antonio Pedro Barbas: “Algumas notas sobre a introdução do Código de Napoleão em Portugal”, Revista Jurídica, 2 e 3, 1985 , p. 103. Afirma Manuel Hespanha que la participación en este evento por Nogueira no está de todo probado, lo dice en HESPANHA, A. M.: Bajo el signo..., op. cit., p. 303.

${ }^{553}$ A cerca de dicha suplica hace referencia en su obra Antonio Pedro Barbas Homem. También hace referencia a dicha suplica la obra ya citada de MESQUITA, A. P.: op. cit., pp. 38 y ss.

${ }^{554}$ HESPANHA, A. M.: Ibidem.

${ }^{555}$ Sobre dicha Súplica de 1808 se puede encontrar en HORST DIPPEL, H. (Ed.): Constitutions of the world from the late $18^{\text {th }}$ Century to the Middle of the $19^{\text {th }}$ Century (Verfassungen der Welt vom späten 18. Jahrhundert bis
} 
expulsión de los moros en 1147, y hace curiosamente referencia a 1640, en donde los franceses habrían ayudado a la independencia frente a la corona española. Un hecho que parece también un rechazo al infamante tratado de Fontainebleau. Unos de los objetivos de la diputación, justo lo que nos interesa, es el pedido al emperador para que Portugal se someta a una legislación de la familia continental, francesa por lo tanto. Así que, en la súplica se pide directamente "uma constituição e um rei constitucional”, y "que seja príncipe de sangue de vossa real família”. De este modo, los dos pedidos vienen muy bien definido. A la petición de conceder una constitución se solicita el modelo de constitución dada al Gran Ducado de Varsovia ${ }^{556}$. Y matizan el pedido diciendo que este modelo es ideal por ser la Constitución de Varsovia también confesional, pues ponía la Religión Católica Apostólica Romana como oficial del Estado $^{557}$; igual que pasó en España con el Estatuto de Bayona, pero este será intolerante con las demás religiones. Los portugueses propugnan por la libertad de culto y de conciencia, así que van a pedir que sean admitidos "os princípios da última Concordata entre o Império francês e a Santa Se $e^{558}$ pela qual sejam livres todos os cultos, e gozem da tolerância civil e do exercício público". Pedían además que hubiese una injerencia del emperador en la organización territorial del imperio portugués, con división del reino en ocho provincias, sobreponiendo la jurisdicción civil a la eclesiástica, de modo que hubiese apenas un arzobispo y siete obispos. En cierta medida era casi una atribución de la prerrogativa regia portuguesa del patronato ${ }^{559}$, y que a la vez estaba así previsto en el Estatuto de Varsóvia.

En cuanto a las colonias se pedía que fuesen transformadas en provincias o distritos y que fueran partes integrantes del reino de Portugal. Piden un ministerio especial para la instrucción pública, además de libertad de la imprenta, igualdad ante las leyes y responsabilidad ministerial en el Consejo de Estado, etc. Se defiende una división de poderes, en donde el

Mitte des 19. Jahrhunderts), Editora De Gruyter, Berlin, 2010, pp. 27 y ss. También se puede consultar a HESPANHA, A. M.: Guiando a mão invisível. Direitos, Estado e Lei no Liberalismo monárquico português, Editora Almedina, Coimbra, 2004, pp. 55 a 59.

${ }^{556}$ Este Estatuto Constitucional sigue el modelo de la Constitución Francesa del Año VIII (13.12.1799). Del mismo modo también se hará en muchos otros estados bajo la dominación napoleónica. HESPANHA. A. M.: Bajo el signo de Napoleón. La Suplica Constitucional de 1808, Cuadernos de Historia Moderna, Anejos, 2008, VII, 299-318, p. 306.

${ }^{557}$ STATUT CONSTITUTIONNEL DU DUCHÉ DE VARSOVIE (Le Moniteur, Paris, 1 août), Art. $1:$ La religion catholique, apostolique et romaine est la religion de l'Etat. II - Tous les cultes sont libres et publics. III Le duché de Varsovie sera divisé en six diocèses; il y aura un archevêché et cinq évêchés. IV - L'esclavage est aboli ; tous le citoyens sont égaux devant la loi ; l'État des personnes est sous la protection des tribunaux.

${ }^{558}$ En el art. 8 del Concordato firmado entre Napoleón y Pio VII, trae las fórmulas de la oración que debían decirse al final de los oficios divinos en todas las iglesias católicas de Francia, y que dice mucho del contenido de este documento: "Domine, salvam fac remplublicam. Domine, salvos fac cónsules". Caballero Artaud (traducida al castellano por Don Andres Borrego): Historia de la vida y del pontificado del Papa Pio VII, Imprenta de la Compañía Tipográfica, Madrid, 1837, p. 149. Así también en el art. 16 se le reconoce a Napoleón los derechos y prerrogativas que gozaban los antiguos reyes de Francia. De esta manera el catolicismo era reconocido como la religión de la mayoría de los franceses, pero no la religión oficial del Estado.

${ }^{559}$ LOPES PRAÇA, J. J.: op. cit., pp. VIII y ss. 
legislativo sea ejercido por dos cámaras ${ }^{560}$ y con la concurrencia de la autoridad ejecutiva. Y lo más importante, que el Poder Judicial sea independiente, y que el Código Napoleónico comience a regir en Portugal $^{561}$. Dentro de una economía judicial, se solicita que las sentencias sean proferidas con justicia, publicidad y prontitud. Que se acceda a los empleos públicos por méritos, y que además sean ejercidos por nacionales ${ }^{562}$, como determina el artículo $2^{\circ}$ de la Constitución del Ducado de Varsovia. Se pide entre otras cosas, una reformulación de la política de impuestos en Portugal. Y por último se requiere que la organización del personal de la administración civil, fiscal y judicial esté de acuerdo con el sistema francés ${ }^{563}$. Según nos cuenta Gomes da Silva, entre los que redactaron la Súplica a Napoleón estaba Ricardo Raimundo Nogueira, Simão de Cordes Brandão e Ataíde y Francisco Duarte Coelho ${ }^{564}$.

Parece que no solamente el Código Civil o el Penal eran conocidos en Portugal, ya que el primero de ellos fue traducido al portugués por Joaquim Fernando de Moura. Y además de los citados, el "Code de Commerce” de 1807, otra "maravilla” legislativa de Napoleón había sido traducido al portugués ${ }^{565}$.

Junot en carta a Napoleón va a confesarse escéptico sobre la adopción del "Code Civil" en Portugal; de hecho no se llega a promulgar oficialmente este código en Portugal ${ }^{566}$. De plano él veía un abismo en materia sucesoria entre la legislación y la práctica portuguesa y la

\footnotetext{
560 “Avançava-se mesmo que uma constituição semelhante à do Grão-ducado de Varsóvia seria bem recebida pelos portugueses, alterando-se apenas o modo de eleger os representantes nacionais que devia realizar-se pelas câmaras" ALMEIDA COSTA, M. J.: op. cit., p. 425.

561 "Algunas diligências práticas chegaram mesmo a realizar-se nesse sentido. Sabe-se que Napoleão gostaria de ver publicado e impresso em Portugal o seu Código Civil. Dúvida não há de que Joaquim Ferreira de Moura promoveu a tradução e a impressão do Código civil francês. Ecos da pretensão chegaram aos meios forenses. $\mathrm{O}$ desembargador Francisco Duarte Coelho foi acusado de, em plena Casa da Suplicação, ter alvitrado a aplicação do Code Civil em vez das nossas Ordenações." Ibdem. Sobre la introducción del Código napoleónico en Portugal, se puede leer más en BARBAS HOMEM, P.: Algumas notas sobre a introdução do Código Civil de Napoleão em Portugal em 1808 in: Revista Jurídica, Nova Série, n. 2, Lisboa, 1985, pp. 97 y ss.

${ }^{562}$ Con la Unión de las Coronas Ibéricas, este tema había sido antes sido fijado por las Cortes de Tomar en 1581.

${ }^{563}$ Estas afirmaciones y las anteriores están en la Súplica Constitucional de 1808 dirigida a Napoleón por la Junta de los Tres Estados en 24 de mayo. Esta suplica está contenida en PRAÇA LOPES, J. J.: Collecção de Leis e Subsidios para o Estudo do Direito Constitucional Portuguez, Vol. II, Coimbra, 1894, pp. VIII y ss.

${ }^{564}$ Aunque esta lista de nombres no aclare completamente el papel de los afrancesados. Uno de ellos es Ricardo Raimundo Nogueira, que precisamente no se sabe cuanto estaba implicado en esto. Para mayores esclarecimientos léase la obra de GOMES DA SILVA, Nuno J. Espinosa: Reflexões sobre a gênese do chamado Projeto de Constituição de 1808, a outorga por Napoleão a Portugal in: Direito e Justiça, vol. XVIII, tomo II, Lisboa, 2004, pp. 39 y ss. También véase en CARIDADE DE FREITAS, Pedro: op. cit., pp. 183 y ss.

${ }_{565}$ Almeida Costa afirma que el propio Junot fue quien pasó la información de esta traducción al portugués.

${ }^{566}$ Aunque el uso del Cógido Napoleónico no llega a ser implantado, sí que llegó a ser aludido en los tribunales, como vimos. Era posible su utilización como una fuente subsidiaria al derecho portugués, dado que en los Estatutos de la Universidad de Coimbra de 1772 lo permitían, ya que se mandaba aplicar directamente en amplios dominios del derecho, las leyes de las naciones cultas y civilizadas de Europa. Sobre este tema trata mejor SILVA, Nuno E. Gomes da: História do Direito Portugues, Vol. I, Fundaçao Calouste Gulbenkian, Lisboa, 2006, pp. 483 a 485. Como también se debe consultar a HESPANHA. A. M.: Bajo el signo..., op. cit., p. 305.
} 
francesa, y además recomendaba hacer un estudio previo sobre las ventajas y desventajas de la adopción de este cuerpo legislativo en dominios lusos ${ }^{567}$.

La reunión de estos procesos, que conforman el pensamiento político del tardo iluminismo portugués, deja trascender el interés de este movimiento por el pensamiento constitucional, como afirma Manuel Hespanha. De este modo, se percibiría un carácter voluntarista del orden político, dado que el derecho y la constitución habrían ambas sido instituidas por el legislador primitivo, ya en el contrato social, o por el legislador derivado, pero bajo la protección de poderes que advenían de la conformación de dicho contrato. Esto contradecía la pretensión del jusnaturalismo clásico, que pretendía que aquel proceso adviniera de la naturaleza y de la tradición. La propia razón evocada por la ley pombalina dejaba claro que aquella se ganaba la primacía por delante de la propia ley. Era ya una razón vinculada con la modernidad y no tanto con la tradición ${ }^{568}$. La reforma universitaria llevada a cabo, deja claro que elementos y autores de la Europa traspirenaica iban a conformar las cátedras de derecho público durante todo el período que antecede al proceso revolucionario liberal en Portugal. Por decirlo así, las bases filosóficas del iluminismo contractualista se adaptaron básicamente a la teoría del primer liberalismo, en donde apenas se desmarcaban del método metafísico y deductivo del jusracionalismo ${ }^{569}$. De ahí que percibimos en las discusiones entre Antonio Ribeiro dos Santos y Mello Freire sobre el proyecto de nuevo código. La posición vencida de Santos permanecerá dormida hasta despertar en los estertores Vintista por la libertad. Dado que el contenido normativo de un Nuevo Código debía ser claro, asequible y manejable, en donde constasen los derechos de una nación y un cuerpo político definidos por una ley fundamental, reducida a escrito, y dotada de medios de garantía que los pudiesen sostener y defender ${ }^{570}$. Santos buscaba preferentemente una mera descripción de los reglamentos y procesos en el Nuevo Código, pero buscaba también una real arquitectura del sistema de las magistraturas públicas, del gobierno y de las administraciones de Portugal. La idea empieza a tomar forma y se defiende un código constitucional escrito, pero no solamente eso, se debía, a través de este instrumento, percibir con claridad los derechos y deberes de los monarcas y de los ciudadanos

\footnotetext{
${ }^{567}$ Véase también en ALMEIDA COSTA, M. J.: op. cit., pp. 425 y 426.

${ }^{568}$ Véase más en HESPANHA, A. M.: Cultura Jurídica..., op. cit., p. 65.

${ }^{569}$ Para ampliar sobre el tema se puede consultar las influencias y emanaciones del iluminismo portugués en el primer liberalismo vintista en CASTRO, Zília Osório de: Constitucionalismo vintista..., op. cit., p. 67. También en lo que escribe Antonio Manuel Hespanha sobre la materia en HESPANHA, A. M.: Guiando a mao..., op. cit., p. 34 y ss.

${ }^{570}$ La ley fundamental aquí descrita, debía está lejos del simplificado y limitado concepto que hasta entonces se tenía del término, que se habían convertido en una doctrina política común a finales del absolutismo portugués y que fue tan criticada por Antonio Ribeiro dos Santos, ya que propugnaba por un concepto realmente mucho más complejo y amplio, en donde se limitase al absolutismo real y promoviese las garantías personales. HESPANHA, A. M.: Guiando a mao..., op. cit., p. 38 y ss.
} 
respectivamente. Se debía objetivar la dilucidación de los contornos del pacto político, en donde el ciudadano era partícipe en la garantía de su contenido normativo y de su ejecución, teniendo en consideración aquellos principios ya citados de economía procesal ${ }^{571}$. Pero, en menoscabo de una cierta discusión más airada y más modernista, Mello Freire va a seguir siendo la postura oficialista en Portugal, moldeando la cultura universitaria para varias generaciones de estudiantes de derecho. Sin embargo, y si se quiere, Mello Freire va a traer otra faceta más moderna, al menos en el plano teórico, en donde aportaba un ambiente dominado por el contractualismo y por el racionalismo ${ }^{572}$. Así, dirá Antonio Manuel Hespanha, en una alocución curiosa, que la influencia de Mello Freire va a ser, paradoxalmente, fundadora de la cultura jurídica liberal en Portugal ${ }^{573}$.

Tras una serie de reformas y cambios en el último cuartel del siglo XVIII, principalmente en las dos últimas décadas, ya se empiezan a sentir los efectos del reformismo jusracionalista, que pasa a hacer parte del pensamiento en todas las esferas de poder, principalmente en el ambiente académico. Y toda una generación, según Manuel Hespanha, se había formado bajo los auspicios de la reforma pombalina ${ }^{574}$. Así que toda una cultura política se desarrolló en el período que antecede al proceso constitucionalista del vintismo. Fueron establecidos y cultivados todo un conjunto ideas y teorías acerca del aspecto contractualista del poder de los monarcas, y de ahí una variedad de corrientes sobre la revocabilidad o no de este contrato $^{575}$. Será la construcción en este período de una identidad individualista-contracturalista

\footnotetext{
${ }^{571}$ En este aspecto léase en Manuel Hespanha, Idem., p. 41 y ss. Se debe complementar la lectura sobre estos reflejos del pensamiento del iluminismo portugués en el proceso revolucionario vintista con CASTRO, Zília Osório de: Constitucionalismo..., op. cit., p. 621 y ss. Hay que prestar atención al hecho de que mientras Mello Freire representa el ala más conservadora del Iluminismo absolutista, Ribeiro dos Santos va a promover, juntamente con otros, la creación de un ala reformista en el régimen que se transformó en cada vez más influyente en los círculos académicos, hasta gubernamentales, y que va a ser responsable de inumerables proyectos de reformas políticas. Véase esta y otras reformas en HESPANHA, A. M.: O projeto Institucional do tradiconalismo reformista, op. cit., p. 12.

${ }^{572}$ Teorías estas típicas del constitucionalismo del Polizeistaat, en donde había una recepción de los principios del derecho universal, la subordinación de la iglesia al Estado, el anti-feudalismo y anti-corporativismo. HESPANHA, A. M.: Guiando a mão..., op. cit., p. 42 y ss. "Paradoxalmente, a concepção constitucional de Mello Freire podia estar mais perto da via reformista do que o garantismo histórico-jurídico de Ribeiro dos Santos, pois dava uma mais ampla margem de manobra ao rei para levar a cabo reformas da constituição social.” Ibdem, p. 43.

${ }^{573}$ Sobre la generación de juristas y publicistas del primer liberalismo portugués, como de la enseñanza jurídica de la época, véase a MARQUES, Mario Reis: Codificaçao..., op. cit., 467 y ss.

574 A la reforma pombalina, mayormente en el ámbito académico, la estudiará muy bien TORGAL, L. R. y VARGUES, I. N.: A Revoluçao de $1820 \ldots$, op. cit., pp. 19 y ss. Antonio Manuel Hespanha también nos aclara que no solamente en el ámbito académico pura y secillamente se hizo sentir aquellos cambios, también en los escritos, los periódicos, como el Investigador portugués em Inglaterra (1811-1819) o el Jornal de Coímbra (1812-1820). HESPANHA, A. M.: Guiando a mao..., op. cit., p. 45 y ss.

${ }^{575}$ Estaba presente autores en la Universidad de Coimbra, en donde sus compendios, leídos por los alumnos serian el propulsor de estas ideas mismas. En las signaturas de Derecho Natural, en donde se leía al compendio de HEINECII, Joan Gottlieb: Elementa iuris naturae et Gentium, Ex Officina Emman - Martini, 1776. Ya para la signatura del Derecho Patrio era conocido y leído el compendio de MARTINI, Caroli Antonii de: De lege naturali (Ad Ilustrandas Posiciones Suas de Lege Naturali), Confluentiae - Sumtibus J. C. Huber, 1781. Y como ya vimos,
} 
que facilita la transición doctrinal de aquel reformismo llevado a cabo en el ocaso del Ancien Regime y el período posrevolucionario. El periodo de transición es tan simbiótico y gradual que va a permitir la evocación de un historicismo en las Cortes Constituyentes, en donde se evita hablar de Revolución, y llama al proceso político, según Antonio Manuel Hespanha, de Regeneración. Y el propio nombre tradicional de cortes será utilizado, evitando la denominación de parlamento, y a los problemas políticos se aportan matices y soluciones históricas ${ }^{576}$. Aquí vemos una inequívoca semejanza al proceso de las Cortes de Cádiz, del cual nos habla Portillo Valdez (véase en el primer capítulo), puesto que el constitucionalismo se funda en la soberanía de la nación, esencial e indivisa, y católica. Además, el constitucionalismo será el producto de un pacto histórico entre el rey y el reino ${ }^{577}$. Y una tercera corriente en donde el constitucionalismo debía ser fruto de una concesión real, como forma de adaptación a los nuevos tiempos y conceder algo de participación en el poder a los súbditos. La penúltima idea de pactismo se reflejará en una serie de proyectos constitucionales, tradicionalistas en el año de 1823; donde se involucran nombres conocidos, como Antonio Ribeiro dos Santos y Francisco Trigoso de Aragão Morato ${ }^{578}$. El último se dará en Brasil, con la concesión en 1824, y en Portugal en 1826, en donde la primera sirve de modelo a la segunda ${ }^{579}$. De esta manera, no solamente la centralización del tardo jusracionalismo va a instalar todo un ambiente favorable de per sí a la política y administración portuguesa, como va a favorecer un ambiente generado por tales prácticas de una especie de circulo virtuoso, si se puede decir de esta manera, que va a reflejar en lo propugnado por los liberales más tarde, en una simbiosis de factores e ideas.

\footnotetext{
la Cátedra de Derecho Pátrio estaba con Mello Freire, que seguía las corrientes de los anteriormente citados. Este se destacaba por tener una posición dual: en materia de poder estaba entre los contratualistas, en donde plegaba una versión restrictiva de derecho para los súbditos, y para la organización institucional, se le veía claramente reformista, atacando incluso la iglesia por usurpadora del poder temporal y hacer con que se confundiese crimen y pecado.

${ }^{576}$ Véase en CASTRO, Zília Osório de: “O regalismo em Portugal..., op. cit., p. 40. También em HESPANHA, A. M.: Guiando a mao..., op. cit., p. 47 y ss.

${ }^{577}$ Véase VALDEZ, Portillo: Revolución de Nación..., op. cit., pp. 122 y ss. También a HESPANHA, A. M.: Guiando a mao, op. cit., p. 47, en donde hace una esquematización precisa de los elementos del constitucionalismo portugués, llevando hasta los procesos posteriores al de nuestro interés.

${ }^{578}$ Un ejemplo es un Projecto de Carta Fundacional do Reino escrito por Antonio Carlos de Menezes de 1823 in Antonio Manuel Hespanha y Cristina Nogueira da Silva, Fontes para a Historia portuguesa, Lisboa, Faculdade de Direito da UNL e www.bn.pt - Arquivo da Biblioteca Nacional, Lisboa, 2004. Accedido en 19/03/2013.

${ }^{579}$ Silvestre Pinheiro Ferreira, también va a proponer un proyecto de constitución: Projeto de Código Politico para a Nação Portuguesa, Em Casa de Rey e Gavier, e de J. P. Aillaud, Paris, 1838
} 


\section{2.- La Constituyente luso-brasileña de 1821/1822}

La idea de convocar cortes no estuvo tan clara en los dos polos de la revolución liberal de 1820. Oporto y Lisboa no tenían la misma idea de cortes, en donde se pudiese elaborar una constitución que mantuviese la religión, la dinastía y remediase los males del reino. Estaba servida la controversia. Los gobernadores de Lisboa, con la Proclamación de 1 de septiembre de 1820, intentaron convocar las antiguas Cortes del Reino. Esta intención es contrarrestada por la Junta de Oporto y por el Gobierno de Lisboa, que apoyados por las tropas revolucionarias, consiguen hacerse fuertes para imponer la idea de unas cortes constituyentes elegidas a través del voto. De este modo, con la jura de los grandes y titulares del Reino en octubre, además de la intervención del Juez del Pueblo de Lisboa, que apuesta por las elecciones, así que, no habrá otro remedio que dejar paso a una nueva composición de cortes, a lo que accede el gobierno a través de la Instrucción de 31 de octubre de 1820. La discusión ahora era si debían las elecciones ser indirectas o directas ${ }^{580}$. La "Martinhada" de 11 de noviembre de 1820, un pronunciamiento militar al estilo español, va a imponer la adopción de un sistema directo de sufragio, usando por modelo el sistema electoral gaditano, que de hecho es adoptado formalmente ${ }^{581}$ por medio del Decreto de 7 de marzo de 1821 , expedido por D. Joao $\mathrm{VI}^{582}$.

El Capítulo I de la Constitución de 1812, española, bajo el título, Del Modo de Formar Cortes, que influye en el mundo hispanoamericano, va a ser traducido al portugués y transcrito en el Decreto de 7 de marzo; entretanto, sólo se adoptan los artículos que se adecuen a la realidad portuguesa. En el art. 27 se recogerá la definición de Cortes, que serían la reunión de todos los diputados que representan a la nación nombrados por los ciudadanos en la forma que se prescribe en los artículos que siguen, recogidos por el citado decreto, y aplicados al mundo luso-americano y todo el ultramar. Establece además en el art. 28 que la base de la representación nacional sería la misma en ambos hemisferios. El art. 29 establecerá la base de la población que participará en dichas elecciones, y lo curioso es que recorre sin hacer

\footnotetext{
${ }^{580}$ Se propugna así por un sistema indirecto de elección en donde debían votar los jefes de familia, con exclusión de los clérigos regulares, los que fuesen incapaces naturales o legítimamente, los criados de servir (que no fuesen jefes de familia). Los electores de segundo grado debían tener conocimientos científicos y medios para sostenerse, con firmeza de carácter, además de todo debían respetar la religión y amar a la patria. Esta propuesta de elección y la disputa entre el modo de convocar cortes se puede leer en HESPANHA, A. M.: Guiando a mão..., op. cit., pp. 61 y ss. En DECRETO de 18 de febrero de 1821, manda El`Rey que el Príncipe Real vaya a Portugal a convocar a los Procuradores de las Ciudades y Villas de Brasil para que en Juntas de Cortes traten de leyes constitucionales y crea una comisión encargada de preparar los trabajos en los que deben ocuparse dichos procuradores.

${ }^{581}$ El sistema electoral gaditano se establece a través de la Instrucción de 22 de noviembre de 1820, en los artículos 27 al 103. La cita de esta instrucción se encuentra en Ídem., p. 62.

${ }^{582}$ Se manda proceder en este decreto al nombramiento de los diputados a las Cortes portuguesas, y trae las instrucciones para las elecciones de los diputados, que será según los métodos de la Constitución española. Sobre la convocatoria de cortes liberales, y la ideología del vintismo, se puede encontrar más información en CASTRO, Zília Osório: Constitucionalismo vintista..., op. cit., pp. 80 y ss.
} 
alteraciones o cambios, la misma base establecida por la Constitución de Cádiz: los individuos que por las dos líneas son oriundos de los Dominios españoles; los que hubiesen obtenido carta de Ciudadanía de las Cortes; y los comprendidos en los términos del art. 21: siendo ciudadanos los hijos legítimos de extranjeros que hubiesen nacido en los Dominios españoles, sin que hubiesen dejado nunca el reino sin licencia, y que completados los 21 años se hubiesen domiciliado en cualquiera población de dichos dominios, ejerciendo en ella algún empleo, oficio u ocupación útil. Así que la ciudadanía portuguesa en este momento, formalmente, debía cumplir los mismos requisitos que la española. Pero, una nación que se pretendía bihemisférica, en palabras de Antonio Manuel Hespanha, se ha quedado muy chica en el ámbito político. Después de la jura a la Constitución de Cádiz por el rey en Brasil, y que está vigente únicamente un día incompleto, como ya resaltamos en el capítulo I, se hace un proyecto de Bases de Constitución, que fue promulgado por el Decreto de 9 de marzo de $1821^{583}$.

Una discusión recurrente en la Constitución gaditana, y que se repite en la de 1822 portuguesa es la evocación historicista de dichas constituciones ${ }^{584}$. En esta discusión ya habíamos insinuado con el comentario de Fátima Bonifacio, se evitó utilizar el término revolución y pasó a utilizar regeneración o reformismo. Se buscaba en el pasado medieval los perdidos derechos y garantías de antaño, en donde los derechos individuales fueron poco a poco siendo usurpados por los reyes inescrupulosos ${ }^{585}$. El término regeneración es mucho más suave que revolución a los oídos aún ensordecidos con los ruidos de la Revolución Francesa que aún no se había caído en el olvido ${ }^{586}$. Son las novedades que pasan por el filtro de la tradición, pero que las novedades mal conseguían disimularse ${ }^{587}$. En el "Manifesto da Naçao Portuguesa aos Soberanos e Povos da Europa” de 15 de diciembre de 1820, se patentará la idea de regreso al

${ }^{583}$ DCGENP., pp. 60 y ss. Dicho Proyecto estaba acabado antes, en 8 de enero de 1821. Está además este proyecto incluido en HESPANHA, A. M. y SIILVA, C. N. (org.): Fontes para a história... (en línea).

584 "Pereira do Carmo, o seu primeiro signatário (do Projeto de Bases da Constituição), apresenta-o como resultado, mais da reflexão sobre o antigo direito público português, do que sobre teorias políticas modernas". HESPANHA, A. M.: Guiando a mão..., p. 63.

${ }^{585}$ Se puede complementar el estudio y el abordaje del Vintismo portugués con BONIFÁCIO, M. F.: $O$ vintismo como matriz do radicalismo portugués en ÁLVAREZ CUARTERO, I. y SÁNCHEZ GÓMEZ, J. (Eds.): Visiones y revisiones de la independencia americana...., op. cit., pp. 71-86. También HESPANHA, A. M.: Guiando a mao..., op. cit., pp. 63 y ss.

${ }^{586}$ Sobre el cambio del concepto de revolución a regeneración, que el propio rey de Francia lo adopta en 1789 para intentar adaptarse a las exigencias de las reformas políticas entonces pedidas por las calles. Sobre este aspecto véase RUOCCO, Giovanni: "La rivoluzione nelle parole: dalla régénération del regno di francia al processo costituente dell'Ottantanove", in Giornale di storia constituzionale, 1 (2001), pp. 93-108.

${ }^{587} \mathrm{Al}$ que se refiere a la fuente del poder constituyente y los procesos constituyentes, la naturaleza de la constitución y la relación entre derechos y constitución. "En todos estos puntos - y aún en otros - los argumentos de continuidad se traduce una relectura de la tradición, inducida por preocupación de legitimar los cambios, pero que mal oculta las novedades". HESPANHA, A. M.: Guiando a mao..., op. cit., p. 63. HOMEM, António Pedro Barba: Judex perfectus. Funçao jurisdiccional e estatuto judicial em Portugal. 1640-1820, Coimbra, Almedina, 2003, pp. 112 y ss. Para saber más sobre los antecedentes doctrinales del vintismo véase a CASTRO, Zília Osório de: "Constitucionalismo vintista. Antecedentes e pressupostos", in Cultura, História e Filosofía, 5 (1986), pp. 497652. 
pasado: "não é uma inovação, é a restituição de suas antigas e saudáveis instituições corrigidas e aplicadas segundo as luzes do século e as circunstâncias políticas do mundo civilizado; é a restituição dos inalienáveis direitos que a natureza lhes concedeu, como concede a todos os povos; que os seus maiores constantemente exercitaram e zelaram, e de que somente há um século foram privados, ou pelo errado sistema do governo, ou pelas falsas doutrinas com que os vis aduladores dos príncipes confundiram as verdadeiras e sãs noções de direito público. As Cortes e a Constituição não são coisa nova nestes reinos: são os nossos direitos e os dos nossos pais" ${ }^{\prime 588}$.

El apelo historicista de la Constituyente de 1821/22 portuguesa para justificar la renovación del aparato socio-jurídico-político-cultural del Estado, es bastante curioso. Es el modelo de constitucionalismo moderno encubierto sobre la capa del modelo constitucionalista histórico, aunque quepan controversias. De hecho, este constitucionalismo vintista se encaja más o menos con el concepto de constitucionalismo liberal que nos da Mateucci y Canotillo. Así que para estos autores, el constitucionalismo es la teoría, o ideología, que instituye al principio de gobierno limitado, que es imprescindible para garantizar a los derechos que están inmersos en la dimensión de la estructura de la organización político-social de una comunidad. El constitucionalismo moderno representará una "técnica específica de limitación del poder con fines garantísticos". Esta conceptuación está inmersa en un profundo juicio de valor ${ }^{589}$. "En otra acepción -histórico-descriptiva- se habla de constitucionalismo moderno para designar el movimiento político, social y cultural que, sobre todo a partir de la mitad del siglo XVIII, cuestiona en el plano político, filosófico y jurídico los esquemas tradicionales de dominio político, sugeridos, a la vez, como invención de una nueva forma de ordenación y fundamentación del poder político. Este constitucionalismo, como el propio nombre indica, pretende oponerse al llamado constitucionalismo antiguo, esto es, el conjunto de principios consuetudinarios fundamentados en la existencia de derechos estamentales frente al monarca y simultáneamente limitadores de su poder. Estos principios se habrían sedimentado en un tiempo largo - desde finales del período Medieval hasta el siglo XVIII" ${ }^{590}$, según alocución del profesor Gomes Canotillo. Dicho autor, explica el modelo de constitución moderna como una ordenación sistemática y racional de la comunidad política a través de un documento escrito en el cual se declara las libertades y los derechos y se fijan a los poderes políticos. Así que desde

\footnotetext{
${ }^{588}$ Manifesto da Naçao Portuguesa aos Soberanos e Povos da Europa" de 15 de diciembre de 1820, disponible en: http://www.arqnet.pt/portal/portugal/documentos/manifesto nacao.html Accedido en 25.03.2013.

${ }^{589}$ Véase en CANOTILLO, J. J. G.: Direito Constitucional e teoría da constituiçao, 6 a Ediçao, Almedina, Coimbra, 1993, p. 47 y ss. También se puede consultar a MATTEUCI, "La Costituzione statunitense ed il moderno costituzionalismo", in Costituzione Statunitense e il suo significato odierno, II Mulino, Bologna, 1989.

${ }^{590}$ CANOTILLO, J. J. G.: Direito Constitucional..., op. cit., p. 48.
} 
un plano ideal se puede desdoblar este concepto de constitución moderna en: "1- ordenación jurídico-político plasmada en un documento escrito; 2- declaración, en esta carta escrita, de un conjunto de derechos fundamentales y del respectivo modo de garantía; 3- organización del poder político según esquemas tendentes a convertirlo en un poder limitado y moderno. Este concepto de constitución se ha convertido progresivamente en uno de los presupuestos básicos de la cultura jurídica occidental, hasta el punto de ser llamado concepto occidental de constitución" 591 .

El concepto histórico de Constitución, continúa Canotillo, obliga a entenderla como un “conjunto de reglas, escritas o consuetudinarias, y de estructuras institucionales conformadora de un cierto orden jurídico-político en un determinado sistema político social. Este concepto utilizado sobre todo por los historiadores - sirve también para amonestarnos (a los constitucionalistas) en relación a las interpretaciones retroactivas de organizaciones políticas y sociales de otras épocas en que rigen instituciones, reglas, principios y categorías jurídicopolíticas radicales diferentes de los conceptos y de las categorías de la modernidad política" ${ }^{\text {"592 }}$. Además va este autor más lejos diciendo que hay que verificar hechos históricos que definirán determinadas categorías que vemos desde el lejano presente, y que no se comprenden por si solas $^{593}$.

Por lo tanto, en las novedades constitucionales, antiguos términos van a sufrir una resignificación - como ya se había comentado en el I Capítulo - en el contexto del liberalismo hispanoamericano, discutido en el ámbito de las ideas defendidas por el profesor Roberto Breña. Es notable que términos que parecen en el léxico de la ilustración - por quedarse en un periodo más cercano - cambien su significado y asuman otra faceta de significación que difiera en uno y otro periodo histórico. El término "Nación”, por ejemplo, sufre un cambio no sólo en su significado sino también en su personalización. En el período en que éste será

\footnotetext{
${ }^{591}$ Esta es una división ideal tomada de Rogerio Soares por Canotillo, y que por supuesto no tiene en consideración al modelo inglés de constitución no escrita. Ibídem. Para un concepto más amplio de constitucionalismo véase a DOGLIANI, Mário: Introduzione al Diritto Costituzionale, II Mulino, Bologna, 1994, p. 152. Véase también a SOARES, Rogério: "O Conceito Ocidental de Constituição", in RLJ, 1 19, pp. 36 y ss.

${ }^{592}$ CANOTILlO, J. J. G.: Direito Constitucional..., op. cit., p. 49. Para la explicación de las categorías, como el concepto de "Estado Moderno" y no guarda relación con el concepto de "domínium" medieval, o "soberanía territorial", que no se identifica con el concepto de "poder y territorio" en el Periodo Medieval. Tampoco se identifica la idea de "nación" a la de "pueblo" o "pueblos" en los esquemas políticos medievales. El propio concepto de "jurisdictio" medieval estaba identificado con el rey, y nada tiene que ver con la definición moderna del término, que está concebida como la función jurisdiccional ejercida por un poder jurisdiccional separado de los otros poderes del Estado. HESPANHA, A. M.(org.): Poder e Instituições na Europa do Antigo Regime, Fundação Calouste Culbenkian, Lisboa, 1984.

593 También cabe aquí explicar los modelos constitucionales trazados por Maurizio Fioravanti, pero que dejaremos un poco más para adelante cuando confrontaremos estos modelos; en FIORAVANTI, Maurizio: Los Derechos Fundamentales. Apuntes de la historia de las constituciones, Editorial Trotta, Universidad Carlos III de Madrid, 1996.
} 
constitucionalizado, pasa a ser detentador de la propia soberanía, la "libertad del Estado", sobreponiéndose al pueblo, y co-dividiéndola con el propio rey, antiguo propietario de esta. Ya con la revolución liberal, el término "Nación", según nos cuenta Manuel Hespanha, pasa a evocar el momento político revolucionario, reunida en la asamblea "nacional", que pasa a representar la unión indisociable de todos los ciudadanos, en donde la idea de pacto y contrato social se presenta bastante marcado. El vínculo contractual también se fundamenta en el amor de los individuos a la patria, a la nación. Surge la idea de constitucionalizar la obligatoriedad del amor hacía la nación ${ }^{594}$. Los artículos 14 y 18 de la Constitución portuguesa de 1822 marca la nación como esencial ${ }^{595}$ detentadora de la soberanía, así como en la Constitución gaditana, se excluye al pueblo como titular de la soberanía. En cambio sí fue reconocido en la Constitución francesa del Año I, de $1793^{596}$. Esta misma alocución veremos más tarde que se repite también en la Constitución del Imperio de Brasil de 1824.

Así que, separar del pueblo la titularidad de la soberanía y atribuir a la nación su titularidad, va a estar, según el elaborado estudio de Maurizio Fioravanti, lleno de significado político $^{597}$. Era una forma de alejarse de la radicalidad de los años más duros de la Revolución Francesa $^{598}$. Era evidente que con el alejamiento del pueblo se pretendía evitar que aquellos subvirtiesen el orden. Para Manuel Hespanha era el antídoto contra el voluntarismo y el

\footnotetext{
${ }^{594}$ Estas referencias a la obligatoriedad de amor a la nación y la importancia que esta recobra en estos momentos revolucionarios, para la Constitución de Cádiz podemos consultar a PORTILLO VALDEZ, J. M.: Revolución y nación. Orígenes de la cultura constitucional en España, 1780-1812, Centro de Estudios Políticos y Constitucionales, Madrid, 2000, pp. 313 y ss. En cuanto a la nación como realidad política revolucionaria véase a HESPANHA, A.M.: Guiando a mão..., op. cit., pp. 64 y ss. Y para el término nación en la revolución liberal portuguesa y sus modificaciones, sus significantes, lo comprobamos en Manuel Hespanha en las páginas citadas, además de VERDELHO, Telmo: "As palavras e as ideias na revolução liberal de 1820", Coimbra, INIC, 1981. El artículo 19 de la Constitución Portuguesa de 1822 va a establecer como unos de los principales deberes de los portugueses amar la patria.

${ }^{595}$ DCGECNP, 1821, pp. 124 y 125. El diputado Brandão, en la Constituyente de 1821, traerá a debate el término "esencialmente" que no figuraba en principio en el Proyecto de Bases de la Constitución. Les parece apropiado ahora la inserción porque la idea de que la soberanía debía está asentada originalmente en la nación, y que esta fue transferida momentáneamente a la asamblea para la formación de la constitución. También el diputado Trigoso va a matizar y marcar los usos de la soberanía: siendo un poder originario, de donde emana el poder constituyente, y su uso de manera actual, o si se quiere derivada, en donde se transforma en un poder meramente legislativo. También sobre esta discusión, y habla de los citados diputados, se puede ampliar más con la lectura de PEREIRA, Manuel Pedro Cunha da Silva: "A limitação jurídica do poder político nos trabalhos das assembleias constituintes portuguesas do período liberal, Relatório de mestrado da cadeira de direito constitucional", Faculdade de Direito da Univ. de Lisboa, Lisboa, 1987, pp.11 y ss.

${ }^{596} \mathrm{El}$ artículo $1^{\circ}$ de la Constitución francesa de 1791 fue tomado como ejemplo para la redacción de los artículos referente a la soberanía, tanto para Cádiz como para la portuguesa, donde figuraba la siguiente alocución: " $\mathrm{La}$ souveraineté est une, indivisible, inaliénable et imprescriptible. Elle appartient à la nation; aucune section du peuple, ni aucun individu, ne peut s'en attribuer l'exercice.

${ }^{597}$ FIORAVANTI, Maurizio: Appunti di storia dele costituzioni moderne. Le libertà: presuposti culturali e modelli storici, G. Giappichellii Ed., Torino, 1991, pp. 102 y ss.

${ }^{598}$ Con la titularidad atribuida de la soberanía atribuida a la nación, según nos cuenta Manuel Hespanha, en consonância con Fioranvanti, "se pretendia recusar a concepção jacobina de que na origem da constituição e das leis estava o povo, entendido como universalidade dos cidadãos vivos, de cuja vontade momentânea dependeria o desenho das instituições políticas". HESPANHA, A. M.: Guiando a mao..., op., cit., p. 66.
} 
contractualismo revolucionarios, evitándose con esto la libre voluntad del individuo y los cambios que pudiesen incidir en las instituciones políticas. Aunque el artículo $1^{\circ}$ de la Constitución Francesa de 1791, inspiradora de los constitucionalismos español y portugués, y aún más en el texto de la de 1793, figuraba una voluntad sobretodo anti monárquica, principalmente cuando decía que la soberanía era inseparable e indivisible, y que ningún individuo podía ejercerla individualmente ${ }^{599}$.

El propio uso de la palabra constitución, con el significado impreso por el pensamiento liberal es algo nuevo a estas alturas. Está claro que el término no ha cambiado radicalmente su significado, pero, ya al inicio del sigo XIX, tenía otras atribuciones añadidas. El diccionario de la Lengua Castellana del año 1729, definirá la palabra Constitución, en términos más jurídicos, como: "Ordenanza, establecimiento, estatuto, reglas que se hacen y forman para el buen gobierno y dirección de alguna República o Comunidad. Es del latino 'Constitution', que significa esto mismo" ${ }^{\circ 00}$. Es sobre todo en el Ancien Regime la ley del príncipe. Pero también es utilizada en sentido religioso, como las constituciones de los obispados ${ }^{601}$ o constituciones sinodales $^{602}$. La palabra también aparece en el Manifesto aos Portugueses de 31 de octubre de 1820 de la Junta Provisional del Gobierno Supremo del Reino: “(...) Lei e vontade será em vós a mesma coisa; direito e justiça, palavras sinónimas; dignidade e igualdade, significações recíprocas; interesse e virtude, qualificação idêntica; sacrifícios e inclinações, hábitos inseparáveis; e a honra dos cidadãos a nobreza mais alta a que possa aspirar vossa ambição. Tereis, em uma palavra, Constituição (...). Tal Código criador, (...) debalde o esquadrinhareis nas reiteradas tentativas das Cortes precedentes" ${ }^{603}$. La misma alocución se dará en el preámbulo de la Constitución Portuguesa de 1822, haciendo un rescate de las antiguas leyes

\footnotetext{
${ }^{599}$ DCGECNP, p. 1473. En la jura de las Bases de la Constitución portuguesa, el rey D. Joao VI mantiene su poder de origen absoluta en su discurso: "pela graça de Deus e pela Constituição, rei do Reino Unido de Portugal, Brasil e Algarve".

${ }^{600}$ Diccionario de la Legua Castellana..., (dedicado al Rey D. Felipe V), Compuesto por la Real Academia Española, Tomo II - que contiene la letra "C", Imprenta de Francisco del Hierro - impresor de la RAE, Madrid, 1729 , p. 536.

601 "Constituição também é sinônimo de lei, e é o nome que também se dá a Ordenações, e Regulamentos feitos pelo Soberano, ou por Superiores legítimos. Dividem-se as constituições em civis e eclesiásticas, e umas e outras são gerais, e particulares". PEREIRA E SOUSA, Joaquim José Caetano: Esboço de Hum Decionarios jurídico, theoretico e pratico remissivo às leis compiladas e extravagantes, Tomo I (A-E), Typographia Rollandiana, Lisboa, 1825. Ao que parece, aqui aún se mantiene la definición jurídica muy poco liberal.

602 "Esta tensão entre disposição natural e decisão de autoridade não era particularmente sentida na teoria jurídica e política do Antigo Regime, pois era consensual que os imperantes não inventavam o direito, mas o iam colher a uma fonte natural. 'Governar' (iurisdictionem habere) era 'fazer a justiça' (iustitam dare), sendo, por isso, a lei mais do que um acto de vontade, um acto de razão". HESPANHA, A. M.: Guiando a mao..., op. cit., p. 68. La ley como establecimiento, algo dado desde una fuente natural; esta idea se recogía en la Ley de Siete Partidas del siglo XIII, del Rey Don Alfonso X, el Sabio.

${ }^{603}$ SANTOS, Clemente José dos: Documentos para a história das Cortes Geraes da Nação Portugueza (18201828), Imprensa Nacional, Lisboa, 1883-1888, pp. 80 y 81 in HESPANHA, A. M.: Guiando a mão..., op. cit., pp. 68 y 69 .
} 
fundamentales del reino: "As Cortes Extraordinárias e Constituintes da Nação Portuguesa, intimamente convencidas de que as desgraças públicas, que tanto a têm oprimido e ainda oprimem, tiveram sua origem no desprezo dos direitos do cidadão, e no esquecimento das leis fundamentais da Monarquia; e havendo outrossim considerado que somente pelo restabelecimento destas leis, ampliadas e reformadas, pode conseguir-se a prosperidade da mesma Nação e precaver-se que ela não torne a cair no abismo, de que a salvou a heróica virtude de seus filhos; decretam a seguinte Constituição Política, a fim de segurar os direitos de cada um, e o bem geral de todos os Portugueses" ${ }^{604}$. Mientras tanto, había diputados que en su discurso cortaban el enlace con esta idea de restauración de las leyes fundamentales del reino; es el caso del diputado Pessanha, Eanes de Carvalho o Brandão. El diputado Margiochi llegará a decir que se iba a hacer una constitución sin relación alguna con aquellas antiguas leyes fundamentales del reino ${ }^{605}$. Pero el producto de la constitución evidenciará que estos son votos vencidos. De esta manera, este nuevo modo de emplear el término constitución, en donde se busca asegurar derechos individuales de los ciudadanos portugueses en el Título I de la Constitución busca además, obedeciendo a la clave de la garantía del principio de la división de los poderes, establecida por Montesquieu, imponer límites al poder mismo, y por lo tanto garantizar aquellos derechos civiles de los ciudadanos ${ }^{606}$. Equilibrar estas pretensiones opuestas, poder y derechos civiles, será algo un tanto complicado; de acuerdo a la teoría liberal, propugnada por John Locke ${ }^{607}$, el fin de la sociedad política se refleja en el incremento de los derechos civiles, tornándolos en una Súper garantía ${ }^{608}$.

Los derechos individuales vendrán declarados en el Título I de la Constitución, contrariando a las recomendaciones de Jeremy Bentham. Como ya discutimos antes, es una gran innovación dentro de la perspectiva de apenas restablecer los derechos fundamentales del reino, figurando en el preámbulo de la propia Constitución. Esto va a suponer un importante cambio de paradigma dentro del viejo orden del reino ${ }^{609}$. Implica, además, una transición del

\footnotetext{
${ }^{604}$ CONSTITUIÇAO POLITICA DA NAÇAO PORTUGUEZA, Imprensa Nacional, Lisboa, 1822, p. 5. De este discurso político impreso en el preámbulo, dirá Antonio Manuel Hespanha que "en ella se compaginan dos vertientes, comunes en el constitucionalismo europeo - la componentes de garantías de los derechos, tal como resultaba del célebre libro XI del Espirit des lois, de Montesquieu; pero también de la consagración de la estructura fundamental del Estado - organización y límites de los poderes políticos del Estado”. HESPANHA, A. M.: Guiando a mao..., p. 69.

${ }^{605}$ DCGECNP, pp. 1478, 1528 y 1531.

${ }^{606}$ MONTESQUIEU, Baron de: Del espíritu de las leyes (traducido al castellano por D. Juan López de Peñalver), Tomo I, Imprenta de Villalpando, Madrid, 1820, pp. 158 y ss.

${ }^{607}$ LOCKE, John: Tratado del Gobierno Civil (Traducida de la séptima edición francesa publicada en Paris, por los ciudadanos D. G. C. y L. C, Alfares de Caballería), Imprenta de Minerva española, 1821.

${ }^{608}$ HESPANHA, A. M.: Guiando a mao..., p. 69 y ss.

${ }^{609}$ Acerca de las novedades introducidas en el proceso constituyente en Portugal, véase a ALMEIDA, Carlos Alberto Neves: Os direitos fundamentais nas constituintes de 1821/1822, Lisboa, 1987. Relatorio de mestrado de
} 
Estado de policía (Polizeistaat), según Marizio Fioravanti, en donde la discrecionalidad del Estado es limitada, no por los derechos individuales en sí mismos, sino por las normas protectoras, efectivas en la sociedad civil $^{610}$. De este modo el embate entre ley y derecho es recurrente. La ley, para A. M. Hespanha, en consonancia con M. Fioravanti, sería la voluntad del poder instituido por el pacto político. Esta aparece no tanto como origen de los derechos, sino como instrumento para su protección. Por lo tanto, proviniendo de la ley la garantía y protección civil de los derechos, la idea de reclamar una garantía de estos contra la ley, es algo subversivo del orden mismo de las cosas ${ }^{611}$. La ley no puede, frente a los objetivos del contrato social, quebrantar a los derechos naturales, sino garantizarlos y protegerlos. Sin embargo, no puede que los derechos naturales sean invocados contra el orden civil mismo, solo restando contraponerse a los abusos del poder la propia reacción política ${ }^{612}$. Que se da a través de controles políticos previstos en la constitución, o utilización, in extremis, de la resistencia o rebelión contra un gobierno tiránico, que sería una parcela del poder que se quedaría fuera del pacto social al momento del traspaso del poder. De esta forma, los derechos no se bastan a sí mismos, sino cuando están garantizados por la protección de la ley civil segundo A.M. Hespanha. Ahí está la base jurídica, the point of view, que prevalece en los textos constitucionales de Portugal $^{613}$.

También está dentro del espectro de cambios paradigmáticos, de la hegemonía de la ley democrática, la creación de mecanismos que equilibren y garanticen los derechos de los

direito constitucional, Faculdade de Direito, Universidade de Lisboa. Um conocimieto más completo sobre las sociedades corporativas del Antiguo Régimen se puede consultar a HESPANHA, A. M.: "O individuo face ao poder. Portugal Séculos XVI-XVII”, em L’individu face au pouvair, Société Jean Bodin, Bruxelas, 1989, $131-151$.

${ }^{610}$ Es un embate entre derecho y ley que se verifica en el pensamiento político de la primera fase de la Revolución Francesa, trata deste tema FIORAVANTI, Maurizio: Appunti di storia..., op. cit., pp. 49 y ss.

611 Jeremy Bentham persuadía con la idea de que los legisladores debían está conducidos por una ciencia legislativa, en donde se alcanzaría una felicidad, llevada al mayor número de personas posible, y no dejarse intimidar por la mera invocación de los derechos naturales. Ya que la preexistencia de unos derechos naturales, en donde se invoca la anterioridad y superioridad frente a la ley, no estaba del todo probada. Lo que sí se podía demostrar era las facultades jurídicas derivadas de la propia ley. BENTHAM, J.: Principes de législation, in oeuvres, Bruxelas, 1840, Vol. I, pp. 11 y ss.

${ }^{612}$ FIORAVANTI, Maurizio: Appunti di storia..., op. cit., pp. 49 y ss.

613 "Basta considerar a definição de liberdade que é, segundo o texto das Bases da Constituição, a faculdade (...) de faze tudo o que a lei não pró́be. A conservação desta liberdade depende da exacta observância das leis (art.2). Embora nesta definição confluam várias coisas, o que é certo é que a lei (a vontade geral - art. 24) está, no estado político, antes dos direitos; como o tinham ensinado J.-J. Rousseau, J. Bentham e, em geral, toda a tradição republicana; mas também, como vimos, os próprios pais fundadores do liberalismo, como J. Locke. A segurança está igualmente consubstancia no principio da legalidade (nomeadamente em matéria penal, (arts. 4 a 6), ao passo que a propriedade é um direito sagrado e inviolável (...) de dispor à sua vontade de todos os seus bens, segundo a lei (art.7); e a liberdade de comunicação do pensamento - um dos mais preciosos direitos do homem responsabiliza pelos abusos nos casos e na forma que a lei determinar (art. 8). Perante a omnipotência do legislativo, ao cidadão é concedido apenas o direito de apresentar por escrito à Cortes e ao Poder executivo reclamações, queixas, ou petições, que deverão ser examinadas (art. 15). Nada, em contrapartida, de aberto reconhecimento de meios judiciais de garantia dos direitos individuais contra o Estado, embora isso pudesse caber na promessa de que os ministros incorreriam em responsabilidades (qual?), entre outras coisas, por violação de direitos.” HESPANHA, A. M.: Guiando a mão..., op. cit., p. 73. 
ciudadanos. De este modo el establecimiento de la supremacía del legislativo, en donde el rey guarda apenas el veto suspensivo (art. 23); la reserva de la iniciativa legislativa a las Cortes (art. 25); la prohibición del rey está presente en las sesiones de dichas Cortes (art.26); la interdicción al rey, por voluntad propia, de aplazar o suspender la convocatoria de las Cortes (art.27); la inviolabilidad de los diputados (art.28); la imposición de la responsabilidad ministerial por la transgresión de la ley (art.31), vienen a ser puntos nuevos que garantizan la existencia también de los derechos individuales, en una protección indirecta a estos ${ }^{614}$.

Mientras tanto, en un nuevo proyecto liberal, la ley se sobrepone a los derechos, como nos cuenta Maurizio Fioravanti ${ }^{615}$. Para este autor, el Estado liberal de derecho va a corporificarse como una reacción al proyecto jacobino en la Revolución Francesa de definición del voto, arbitrario y momentáneo, de los representantes del pueblo, un nuevo modelo de sociedad y de poder, y consecuente redefinición, voluntarista y contractual, de los derechos, tanto de los individuos, como del propio Estado. De esta manera el liberalismo se verá bastante crítico con el contratualismo revolucionario, reinventando nuevas soluciones, dado que el modelo revolucionario, creó una cultura de derechos y de libertades incapaces de garantizar condiciones mínimas de estabilidad, tanto en la sociedad civil, pasando por los dominios políticos, como por las pretensiones de los individuos y de las fuerzas sociales ${ }^{616}$. Así que, el proyecto político liberal estará mayormente dominado por la preocupación de restablecer la positividad de un orden político $^{617}$.

Pero, más allá de las reformas en la sociedad que son signos de modernidad constitucional, las pervivencias del antiguo orden de cosas del Ancien Regime va a hacerse presente en el primer texto constitucional luso-brasileño, y matizará el concepto propio de ciudadanía. En el art. 17 de la Constitución de 1822, se impondrá la religión católica, apostólica y romana como la religión de la nación, que tendrá, según Manuel Hespanha, consecuencias institucionales bastantes serias ${ }^{618}$. Este principio confesional del Estado es un elemento que pervive del Antiguo Régimen. Era un elemento que imponía el bautismo como forma de

\footnotetext{
614 "Neste contexto, o menos que se podia desejar era um Estado (garante) de direitos (Rechtsbewährungsstaat); o que se queria era, antes, um Estado em que o predomínio da vontade do poder (materializada na lei) se impusesse. Já tinha tendido para este modelo o Estado reformista do absolutismo ilustrado e, agora, tendia para ele o Estado liberal, com a diferença de que, de um para o outro, mudara o conceito de lei, de vontade do soberano para vontade geral." Idem, p. 74.

${ }^{615}$ FIORAVANTI, M.: Appunti di storia..., op. cit., p. 101 y ss.

${ }^{616}$ Idem, p. 107 y ss.

${ }^{617}$ HESPANHA, A. M.: Guiando a mao..., op. cit., p. 75 y ss.

${ }^{618}$ En discusión en las Cortes, hubieron diputados que se manifestase de la opinión que la profesión de fé sería una condición inapelable para el goce de los derechos políticos, aunque no lo era para el goce de los derechos naturales. DCGECNP, p. 1805. También se debe consultar a HESPANHA, A. M.: Guiando a mao..., op. cit., p. 77.
} 
adquisición de la ciudanía portuguesa. También otros elementos, como el carácter monárquico y hereditario del gobierno (art. 18), y la imposición de la Casa de Braganza como casa dinástica. Sin embargo, también las permanencias se hacen con los silencios constitucionales. Así que no hay una política clara de desguace de la estructura fiscal del Antiguo Régimen, aunque los artículos 11 y 13 establezcan respectivamente la no tolerancia a los privilegios de fueros y la igualdad de accenso a los cargos públicos, siendo criterios únicamente los talentos y las virtudes $\operatorname{propias}^{619}$. Se evita así, declarar positivamente la igualdad jurídica para hacer frente a estas discriminaciones.

Es indicativo del núcleo ideológico y normativo del texto constitucional portugués, el propio preámbulo constitucional. En él, cuando se evoca el nombre de la "Santísima e Indivisible Trinidad" sobre todo el cuerpo constitucional ya se hace una idea de aquellas permanencias de que venimos hablando ${ }^{620}$. Dado que, la idea historicista, reformista, decía que la Constitución debía ser el restablecimiento de la memoria constitucional tradicional, de las leyes fundamentales de la monarquía ${ }^{621}$.

Por lo tanto, el pedido de constitución para el reino estaba condicionado a la propuesta de reformar las antiguas leyes fundamentales de la monarquía. Las Cortes empezaban así sus trabajos de posesión de un poder constituyente trastocado, limitado por aquella condición ${ }^{622}$. Aunque la ilusoria idea de cubrir con el manto reformista la labor constitucional, las novedades rebozaban por todos los lados. Mientras era novedoso que las cortes se apropiasen del poder constituyente, y la propia idea de este poder, había los que aún atribuía a la constitución del reino no un pacto social, sino un origen natural ${ }^{623}$.

\footnotetext{
${ }^{619}$ A los abominables foros solamente les han trastocado algunas normas, sin entretanto abolirlos. El Decreto de 3 de junio de 1822 los reduce a la mitad, y por lo cual también se extinguen las "lutuosas" y otras contribuciones extraordinarias in FRANCO, Francisco Soares: Explanação à lei de 5 de junho de 1822 sobre a reforma dos foraes, Lisboa, Rollandiana, 1822, pp. 22 y ss. Pero, mucho antes, desde la Carta Régia de 7 de marzo de 1810 ya se prometía de reducir o acabar con dichos derechos forales. No solo esta cobranza de contribuciones era contestada, también las banalidades, el diezmo, el beneficial, los morgadios, capelas etc.

${ }^{620}$ CASTRO, Zília Osório de: "Constitucionalismo vintista...”, op. cit., p. 599. Para Ruocco, el origen es francesa de la que las constituciones modernas son nada menos que restructuraciones de las antiguas constituciones tradiconales del reino, que fueron corrompidas por constantes injusticias. RUOCCO, Giovanni: "La Rivoluzione nelle parole...", op. cit.

${ }^{621}$ HESPANHA, A. M.: Guiando a mão..., op. cit., p. 80 y ss.

${ }^{622}$ El propio rey de Francia, Luis XVIII, en el preámbulo de la Charte de 1814, va a expresar este sentido de regeneración constitucional. Lo trata bien el traspaso de la idea de regeneración a la idea de constitución la obra de RUOCCO, Giovanni: "La Rivoluzione nelle parole...", op. cit. También HESPANHA, A. M.: Guiando a mão..., op. cit., p. 80 y ss.

623 "Nenhuma Constituição resulta, ou pode resultar de uma deliberação, porque não se pode deliberar do que está eternamente na essência do homem como animal sociável, ou nascido para a sociedade dos seus semelhantes. Os direitos dos povos não se podem escrever, nem estão escritos, nem a Constituição factícia o que eles já têm por natureza (...) aquilo a que VV.SS. chamam, com tão inchadas bochechas, Constituição, não são constituições, são ajustes, são convenções entre homens." Así se manifestaba José Agostinho de Macedo, un pensador político antirevolucionario y legitimista. MACEDO, José Agostinho de: Bazes eternas da Constituição Política achada na
} 


\subsubsection{Los diputados brasileños en la definición de la ciudadanía en las Constituyente de 1821/1822.}

El depósito de la soberanía en la Nación, como venimos hablando, hará que la conceptualización del término sea bastante restrictiva cuando va a referirse a los habitantes del reino. No será ni general ni tampoco inclusiva en sentido absoluto. Mismo el grupo que fue incluido verá trastocados sus derechos en muchos puntos por las exclusiones. Un ejemplo recurrente e interesante para nosotros es el tema de la confesionalidad. La religión será un excelente instrumento de exclusiones en todo el universo constitucional, pero no solamente la religión, como venimos hablando ${ }^{624}$. En el texto portugués se verá confluir todo el universo de los naturales del reino para la confusión de los términos "nacionales" y "ciudadanos del reino". Aunque allí en aquella definición se refería a los portugueses propiamente dichos, hijos de padres portugueses. De este modo la "Nación" estaba alejada del pacto constitucional, hincándose en un carácter orgánico y por lo tanto no en un pacto social ${ }^{625}$, posición esta defendida por el profesor Manuel Hespanha. La designación de naturales del reino en las Ordenaciones Filipinas tampoco dejaba margen imaginar o formar un ciudadano ${ }^{626}$. Eran vistos como naturales los nacionales del Reino de Portugal y/o los miembros de las otras partes del reino. Así que la Constitución vintista al atribuir la soberanía a la nación no amplia mucho el espectro del ciudadano portugués, aunque siempre hay que afirmar que la declaración de derechos del Título I es un gran avance y un signo de modernidad constitucional ${ }^{627}$, además de ser mucho más amplia de lo que fue la Constitución de Cádiz, su inspiradora. Sin embargo, la necesaria distinción entre "portugueses" y "ciudadanos portugueses" no aparece en la Carta de 1822 como se puede apreciar en el proyecto ofrecido a las Cortes Constituyentes en 1821. En dicho proyecto la distinción es clara entre portugueses y ciudadanos portugueses ${ }^{628}$ :

Cartilha do Mestre Ignacio pelo sacristão do Padre Cura D`Aldeia, Lisboa, Impressa da Rua Formosa, 1824, pp. 37 y 38 .

${ }^{624}$ La nación como ente en donde la soberanía se decanta, por ser la detentadora de esta, se conforma también de elementos tradicionales, incompatible en tantos aspectos con los conceptos del universalismo e igualitarismo que fueron doctrinas dimanados de la Revolución francesa, fue recreado de esta manera en Cádiz e inspiradora de la Carta portuguesa de 1822. Esta es una idea que ya fue mencionada en el primer capítulo de este trabajo se puede encontrar en PORTILLO VALDÉS, José María: Revolución de Nación. Orígenes de la cultura constitucional en España, 1780-1812, Ed. CEPC/BOE, Madrid, 2000, pp. 313 y ss.

${ }^{625}$ MACEDO, José Agostinho de: Bazes eternas da Constituição Política achada na Cartilha do Mestre Ignacio pelo sacristão do Padre Cura D`Aldeia, Imprensa da Rua Formosa, Lisboa, 1824, pp. 37 y 38.

${ }^{626}$ MENDES DE ALMEIDA, C.: Código Filipino ou Ordenação do Reino de Portugal, Rio de Janeiro, Tipografia do Institutuo Filomático, $14^{\mathrm{a}}$ Edição, 1870, p. 489.

627 "Neste ponto - teóricamente central e, na práctica, muito relevante -, a Constituição afasta-se da distinção entre 'portugueses`e 'cidadãos portugueses`, que constava no projeto.” HESPANHA, A. M.: Guiando a mão..., op. cit., p. 82 .

${ }^{628}$ Aquí nos referimos a un proyecto porque hubieron de hecho varios proyectos presentados a las Cortes Constituyentes como aportaciones individuales al proyecto liberal de Estado. A uno de ellos haremos referencias un poco más adelante. Luego después que entra en vigor la Constitución de 1822, aparecen otros tantos proyectos para modificar dicha constitución. Uno de los más completos códigos presentado como solución legal para 
Paragrafo $1^{o}$ - A Nação Portugueza he a reunião de todos os portuguezes, pertencentes ao Reino de Portugal e Algarves.

Paragrafo $2^{\circ}$ - Os outros Portuguezes pertencentes às ilhas adjacentes, África, Ásia, e ao Reino do Brasil também formarão parte da Nação Portugueza, quando queiram acceder a Constituição, que agora proclama a sua Metrópole. Paragrafo $4^{o}$ - São Portuguezes todos os naturais dos Reinos de Portugal, e Algarve ${ }^{629}$.

El párrafo $5^{\circ}$ trae un elenco en numerus clausus para ser considerado natural del reino, con cinco incisos. Para ello era necesario ser hijo de padres portugueses, haber nacido en el reino y seguir residiendo en este, para el primer caso. También era considerado natural si hubiese nacido de padre extranjero, mientras su madre fuese portuguesa, pero se requería para eso que poseyese bien de raíz o tuviese una profesión o industria útil. Además, era necesario tener seis años de residencia continua. Eran naturales también los que hubiesen nacido fuera del reino, pero que sus padres estuviesen a servicio del Estado. Se atribuía también la naturaleza a los llamados espurios (ilegítimos), siempre que su madre tuviese la condición de natural del reino. El quinto y último caso estaba atribuido a los extranjeros que hubiesen conseguido carta de naturaleza de las Cortes. Pero el art. $6^{\circ}$ viene con los requisitos para que el extranjero consiga dicha carta de naturaleza, y entre tales requisitos se exigía que estuviese casado con una portuguesa y residiese en el reino, entre otros requisitos ${ }^{630}$.

Y Finalmente el Párrafo $7^{\circ}$ dice quiénes son ciudadanos del reino:

He cidadão Portuguez todo o natural destes Reinos, que tem, a idade de vinte e cinco anos: e todo o que he cidadão está hábil para o exercício dos Empregos Públicos sem distincção alguma, salvo aquella que provem das virtudes, e talentos.

Además, los párrafos que siguen, expresamente el Párrafo $8^{\circ}$, enumera en sus incisos los motivos que llevan a perder la condición de ciudadano portugués; y el Párrafo $9^{\circ}$ que trata de la quiebra de la calidad de ciudadano portugués, y por lo tanto, son excluidos de la calidad de ciudadano por la constitución de algunos puestos públicos temporaria o permanentemente. Ya el Párrafo $10^{\circ}$ trata de la suspensión de la calidad de ciudadano portugués en sus cinco incisos.

Portugal fue el proyecto presentado por el Ministro de Estado Honorario, Socio de la Academia de Ciencias de Lisboa e Correspondiente del Instituto de Francia, Silvestre Pinheiro Ferreira: Projeto de Código Político para a Nação Portugueza, Em Casa de Rey e Gravier e de P. J. Aillaud, Paris, 1838.

${ }^{629}$ Projeto da Constituição Política para a Naçao Portugueza, offerecido às Cortes que se vão congregar em janeiro de 1821, Typographia Rollandiana, Com licença da Comissão de Censura, Lisboa, 1820, pp. 29 y ss.

630 "Tratava-se, de fato, de uma refundação da Nação, pois se substituía o tradicional ius sanguinis a uma modalidade de ius soli, incorporando à Nação todos os filhos de estrangeiro que tivessem nascido e habitasse o território português, o que constituía uma alteração dramática do âmbito pessoal da Nação portuguesa, sobretudo no ultramar." HESPANHA, A. M.: Guiando a mão..., op. cit., p. 82. 
Sin embargo, las “Bases da Constituição da Nação Portuguesa” presentadas por el Sr. Moura, en nombre de la Comisión de Constitución en la sesión de 8 de febrero de 1821, no traía tan clara la distinción entre ser "ciudadano" y ser "portugués"631. En la Sesión I, intitulada “Dos Direitos Individuais dos Cidadãos" ${ }^{632}$, y en su artículo $1^{\circ}$, aprobado en la sesión del día 12 de febrero, dirá:

"A Constituição Política da Nação Portuguesa deve manter a liberdade, segurança, e propriedade de todo cidadão."

Ya la Sesión II, intitulada “Da Nação Portuguesa, Religión, Gobierno y Dinastía”633 , y en su artículo 16, que fue discutido y aprobado en la sesión del día 17 de febrero, dirá:

"A Nação Portuguesa é a união de todos os Portugueses de ambos os hemisférios”.

Dichas Bases Constitucionales, está muy bien aclarado por su preámbulo aprobado en la Sesión del día 12 de febrero de 1821:

"A regência do Reino, em nome de el-rei o senhor D. João VI, faz saber que as Cortes gerais, extraordinárias e constituintes, da Nação Portuguesa têm decretado o seguinte: As Cortes gerais, extraordinárias e constituintes da Nação Portuguesa, antes de procederem a formar a sua constituição política, reconhecem os mais adequados para assegurar os direitos individuais do cidadão, e estabelecer a organização e limites dos poderes públicos do Estado ${ }^{634}$ ”.

Las nombradas Bases Constitucionales fueron aprobadas para servir de parámetro a la nueva constitución en el día 9 de marzo de 1821 por las Cortes Constituyentes y Extraordinaria de la Nación Portuguesa. Desde la Sesión del día 26 de enero los trabajos y las discusiones tendían, desde dentro del proyecto liberal, a una sustitución de las antiguas leyes fundamentales del reino, evocada siempre como buenas, en los primeros momentos revolucionarios, como ya tuvimos ocasión de dilucidar, en donde se evitaba aquél término, para hablar de regeneración de la nación. La pretendida sustitución sería por las nuevas leyes aprobadas en las cortes constituyentes. También se buscaba que la Constitución de Cádiz, 1812, no fuese un catecismo ciego que todos debían seguir. Pero ya vimos que ni una cosa y ni otra se fijarán en la

\footnotetext{
${ }^{631}$ Bases da Constituição da Monarquia Portuguesa, apresentadas pelo Sr. Moura, em nome da Comissão de Constituição na sessão de 8 de fevereiro de 1821, Tipografia de J. F. M. de Campos, Com licença da Comissão de Censura, Lisboa, 1821.

${ }^{632}$ La Sesión I es una "Declaración de Derechos", que está muy acorde con lo establecido en las primeras enmendas a la Constitución de los Estados Unidos de 1787, que en términos genéricos era conocida como "Bill of Rights" y por la "Declaration de l'Homme et du Citoyen" francesa de 26 de agosto de 1789.

${ }^{633}$ La Sesión II definía las bases políticas y constitucionales y la futura organización del Estado liberal. Así que tales bases fueron informadoras y acondicionadoras de la Constitución de 1822.

${ }^{634}$ Bases da Constituição da Monarquia Portuguesa, apresentadas pelo Sr. Moura, em nome da Comissão de Constituição na sessão de 8 de fevereiro de 1821, Tipografia de J. F. M. de Campos, Com licença da Comissão de Censura, Lisboa, 1821.
} 
constitución, sino justo todo lo contrario, el preámbulo de la Constitución de 1822 habla de regeneración de las antiguas leyes fundamentales del reino y la Constitución Gaditana será un guía muy útil, tanto en las tareas electorales como en la confección del articulado de la Constitución portuguesa. Aunque en lo que toca a la definición de ciudadano y al tema de la confesionalidad del Estado se evitará coger los radicalismos e intolerancias gaditanas, al menos no del todo, como veremos en seguida.

Desde el ámbito de la Nación, el horizonte de eventos hacía que abarcase una amplia gama de individuos, entretanto, la relación entre portugueses y ciudadanos de la misma nación era una relación dual, principalmente en lo que se refiere a la representación nacional, dado que el voto estaba relacionado apenas a la condición de ciudadanos. La "Nación alargada", en palabras de Antonio Manuel Hespanha, garantiza derechos civiles a muchos y derechos políticos a unos pocos. Este principio de ciudadanía dual, al que hicimos referencia en el Capítulo I, será una de las influencias de la Constitución Francesa de 1791, en donde había distinción entre "ciudadanos pasivos" e "ciudadanos activos" "635. Afirma, aquél autor, que estas soluciones no se plasman del todo en el texto final de la Constitución de 1822, optándose así por las soluciones del derecho patrio. Principalmente la fijación de la adquisición de la naturaleza por el ius soli, en determinados casos, que sustituía al tradicional ius sanguinis en el citado proyecto $^{636}$. Veremos más adelante que en la Constitución del Imperio de Brasil se adoptó completamente por la bipolaridad ciudadana. Entretanto, hay que notar que seguían

\footnotetext{
${ }^{635}$ Se puede ampliar más el tema en SEWELL, William H.: “Le citoyen/la cotoyenne: Activity, Passivity, and the Revolutionary Concept of Citizenship.” In BAKER, Keith Michael (Ed): The French Revolution and the Creation of Modern Political Culture, vol. 1, The Political Culture of the Old Regime, Oxford: Pergamon Press, 1987, pp. 105 a 123. Para Portugal el tema será tratado por ALMEIDA, Pedro Tavares de: "Eleitores, voto e representantes." In CATROGA, Fernando y ALMEIDA, Pedro Tavares de (cords.) "Res Pública": Cidadania e Representação Política em Portugal 1820-1926, Biblioteca Nacional de Portugal/Assembleia da República, Lisboa, 2010, pp. 61 a 89. También con la lectura de un artículo reciente de SILVA, Jairdilson da Paz: "Bipolaridad de una ciudadanía confesional: la definición dada por la Constitución Imperial de Brasil” in AGUIRREGABIRIA, Alejandra Ibarra (coord. Ed.): Actas del Tercer Encuentro de Jóvenes Investigadores de la AHC (Religiosidad y Laicismo), Instituto Universitario de Historia Social Valentín de Foronda, ISBN: 978-84-9860-636-2, LG/D.L.: BI-540-2012, VitoriaGasteiz, 2012. También se puede leer más en HESPANHA, A. M.: Guiando a mão..., op. cit., pp. 82 y ss. Esta fue un posición defendida por el Abade Sièyes que hizo muchos panfletos tratando de los derechos de los ciudadanos en Francia como la Déclaration des Droits de L'Homme en Société, Chez Baudouin - Imprimeur de L'ASSEMBLÉE NATIONALE, A Versailles, 1789; Déclaration des Droits du Citoyen François, Détachée du Préliminaire de la Constitution, 1789 ; Opinion sur la Jurie Constitucionnaire, Suivie d Observations sur l’ouvrage de Siéyes 1795; Préliminaires de la Constitution, Reconnaissance et Exposition Raisonnée (Des Droits de 1'Homme et du Citoyen. Lu les 20 et 21 Juillet 1789, au Comité de Constitution), Chez Baudouin - Imprimeur de L'ASSEMBLÉE NATIONALE, A Paris, 1789 ; Projet de Déclaration des Droits, Par un Membre de l'Assemblée Nationale, 1789 ; Qu`est-ce que le Tiers-État?, Pamphlet Publié en 1789, Par Siéyes, précédé d'une étude sur l'Auteur, par M. Chapuys-Montlaville, député, et orné d’un portrait de Siéyes, Pagnerre Editeur, Paris, 1839.

${ }^{636}$ Aunque se nos aclara Cristina Nogueira da Silva que la sangre y/o el nacimiento en el territorio (portugués) fueron considerados los mejores indicios del sentimiento que contaba cuando se querría distinguir quienes hacían parte o no del pueblo portugués. SILVA, Cristina Nogueira da: Da "Carta de Alforria" ao "Alvará de Assimilação": a cidadania dos "Originários de África” na América e na África portuguesa, séculos XIX e XX in BERBEL, Márcia e OLIVEIRA, Cecília H. de Salles (orgs.): A experiência constitucional de Cádiz. Espanha, Portugal e Brasil, Alameda Casa Editorial, São Paulo, 2012, pp. 111 y ss.
} 
siendo excluidas de la nacionalidad y de la ciudadanía la población nativa no cristiana de los territorios de ultramar. Además de los esclavos que no detentaban siquiera los derechos civiles $^{637}$.

En fin, el proyecto de constitución portuguesa fue inspirado como ya se sabe de la Constitución española de 1812, en donde se hacía distinción entre ser portugués - que no contaba con derechos políticos, apenas con los derechos civiles -, y ser ciudadano participantes de la vida política del Imperio. Por factores que influyeron directamente en los debates de la asamblea constituyente, como veremos, esta posición no figurará en el texto final de la Constitución portuguesa. Esta posición es interpretada como señal de "libertad" en las intervenciones de los diputados de la época ${ }^{638}$. En la sesión del día 27 de febrero de 1821, se declarará: “(...) todos os que estão unidos por um Pacto Social em uma só cidade, são Cidadãos. Onde isto não sucede, assim é onde, por exemplo, há escravos “639. El horizonte de la universalización de esta afirmación estará bastante recortado, por ello se dejó fuera de las fronteras ciudadanas a los esclavos, que desde luego existían, como muchos otros grupos de portugueses. Y fue así porque los diputados tenían claro, y en especial Correia de Seabra, que: “(...) é verdade que não fazemos diferença de português, a cidadão português; mas pela terceira vez digo que fazemos, em não podemos deixar de fazer diferença, e distinção de direitos políticos, a direitos civis" ${ }^{\prime 640}$. De este modo la constitución presentaba diferencias entre ciudadanos, principalmente establecidas en las legislaciones electorales, categorizándolos en ciudadanos pasivos y ciudadanos activos. Tomamos aquí la conclusión de la profesora Cristina Nogueira da Silva, cuando dice que los diputados portugueses en el afán de separarse de la definición de ciudadanía gaditana, se quedaron tan cortos como aquellos, dado que la diferencia figuraba apenas en las formas, ya que la solución presentada, en realidad, era muy parecida a la gaditana.

En este sentido, el art. 21 de la Constitución portuguesa de 1822 va a establecer, de forma perentoria y amplia, que todos los portugueses son ciudadanos, para en seguida esclarecer quienes realmente gozan de esta calidad en los cuatro incisos que siguen. De este modo queda establecido que todos los hijos de padres portugueses nacidos en el Reino Unido, o en país extranjero, con la condición de que establezca domicilio en el reino, seria ciudadano. Entretanto, cesa la necesidad de tal residencia si el padre estaba en el extranjero a servicio de la

\footnotetext{
${ }^{637}$ Idem, p. 83.

${ }^{638}$ Aquí también recogemos una afirmación de la profesora Nogueira da Silva para afirmar este cambio de posición de los diputados en relación al proyecto de la constitución. Ídem, p. 112.

${ }^{639}$ DCGECNP, sesión de 27 de febrero de 1821, p. 1.

${ }^{640}$ DCGECNP, sesión de 31 de mayo de 1822, p. 332. Tambíen la sesión de 3 de agosto de 1821, p. 1764 a 1771.
} 
Nación. Tiene derecho también a la ciudadanía los hijos nacidos ilegítimos de madre portuguesa nacidos en el Reino Unido, o si nacidos en el extranjero venga establecer domicilio en el reino, siempre y cuando el padre no lo reconozca, pues en así siendo cambia completamente el modo de adquisición de la ciudadanía. Los denominados como "expuestos" (huérfanos) por la Constitución, en cualquiera parte del Reino, y siempre que se desconozca a los padres, tendrá derecho a la ciudadanía. Los esclavos manumitidos también alcanzarían la ciudadanía para el texto constitucional. Los hijos de padres extranjeros, que nazcan y adquieran domicilio en el Reino Unido, pueden ser declarados ciudadanos, con tanto que al llegar a la mayoridad declaren formalmente, firmado el libro del Ayuntamiento de su domicilio, que quieren ser ciudadanos portugueses. $\mathrm{Y}$ por último, son ciudadanos los extranjeros que obtuvieren carta de naturaleza ${ }^{641}$.

En este orden, los artículos que siguen hablan del tema de la ciudadanía, como el 22 que trata de los requisitos para que los extranjeros la adquieran; el 23 que establece las formas de pierda de la condición de ciudadano; y el art. 24 el modo de suspensión de goce de los derechos políticos $^{642}$.

Sin embargo, un universo tan amplio de ciudadanía, comparado a los texto constitucionales de la época, patentada por el art. 21 de la Constitución portuguesa, en donde la afirmativa que todo portugués es ciudadano, comporta matizaciones, como venimos diciendo. Las exclusiones pasan a existir dentro de las inclusiones. Aunque vale recordar que dos elementos citados por la constitución, en los incisos III (expuestos) y IV (libertos) del mismo artículo 21, son excepciones a la regla del ius sanguinis ${ }^{643}$. Ejemplos de estas exclusiones se detrae de la habla del diputado Sr. Samento en la Sesión de las Cortes del día 17 de abril, cuando trata de los vagos. Dicho diputado dice haber sustraído el término y el concepto de la Constitución española, contenido en el párrafo $4^{\circ}$ del artículo 25: "vadio, aquelle que não tem emprego, officio ou modo de viver conhecido”. Sigue el mismo diputado en sus catilinarias en contra de los votos de los vagos para diputados, evocando a publicistas conocidos de la época

\footnotetext{
${ }^{641}$ CONSTITUIÇAO POLITICA DA MONARQUIA PORTUGUEZA, Imprensa Nacional, Lisboa, 1822, p. 12.

${ }^{642}$ Idem, p. 13.

${ }^{643}$ El ius sanguinis es la regla del derecho patrio portugués para acceder a la naturaleza y por consiguiente, si se acata determinados requisitos, aunque se haga una excepción al ius solis, en el propio texto constitucional. Pero, cuando el Art. 21 establece en el inciso III la atribución de la ciudadanía a los expuestos (huérfanos), se abstrae que la paternidad recae sobre el Estado, y por lo tanto hijo natural del mismo se concede la ciudadanía. Pensamiento igual tiene Cristina Nogueira da Silva cuanto a los manumitidos. El liberto, al ser manumitido, nace civil y políticamente con la carta de manumisión recibida en el territorio portugués, algo semejante a lo que pasa con el principio del ius sanguinis, aunque sea una ficción legal. NOGUEIRA DA SILVA, Ana Cristina: A cidadania nos trópicos. O ultramar no constitucionalismo monárquico português (1820-1880), tesis de doctorado, Universidade Nova de Lisboa, Lisboa, 2004. HESPANHA, A. M.: Guiando a mão..., op. cit., p. 84.
} 
para respaldar una excepción a la regla de la ciudadanía universal propalada por los constituyentes:

Eu sei perfeitamente, que admitidas às formas democráticas no systema representativo da nossa Constituição, era uma consequência à doutrina do suffragio universal, porém esta doutrina tem as suas excepções; o nosso velho amigo Jeremias Bentham também estabelece excepções. Alguns ainda que tenham comprehensao, e virtude, são excluídos, em atenção a outras coisas, como as mulheres, apesar de que entre nós, aonde não tem vigor a determinação das leis sálicas, as linhas femininas são chamadas à sucessão do throno, na falta de linhas masculinas: todavia os deveres do sexo, a paz domestica, e outras considerações fazem com que as mulheres sejam excluídas de votar nas eleições de representantes da Nação, apesar de se não duvidar que as mulheres são capazes de amarem a pátria, e de terem todo o discernimento para fazerem boa escolha de Deputados. Há também um principio que estabeleceu um dos maiores apaixonados, que a liberdade teve nos nossos dias, o grande Carlos Jaime Fox; dizia elle que o melhor principio para a representação nacional he aquelle, que põe em atividade o maior numero de votos independentes, e excluem aquelles, cujas circunstancias fazem com que não possam deliberar ${ }^{644}$.

En la discusión a ser entablada en las próximas líneas partiremos del análisis de unos elementos que no conforman nuestra línea de investigación, que es el liberto africano y afrodescendiente, pero nos dará pistas para reconocer al ciudadano que podría profesar otra religión que es el extranjero, establecido en el art. 25, y los mecanismos usados para su exclusión.

En realidad, a lo que se refiere a las discusiones llevadas a cabo en las Cortes Constituyente portuguesas, que se puede constatar en el Diário das Cortes Gerais e Extraordinárias da Nação Portugueza de 1821/22, los debates referentes a la ciudadanía y esclavitud no llenaron muchas páginas. Era un punto más o menos pacifico que no se debía derivar para la absoluta exclusión de los esclavos o manumitidos africanos ${ }^{645}$, como pasaba en las colonias inglesas, tampoco se prestaban a seguir los duros criterios para la obtención de la

644 DIARIO DAS CORTES GERAIS, EXTRAORDINARIAS, E CONSTITUINTES DA NAÇAO PORTUGUEZA, (Segundo Anno da Legislatura), Imprensa Nacional, Lisboa, 1822, pp. 832.

${ }^{645}$ La institución de la manumisión cumplía un papel importante a la vez que curioso en el Imperio portugués, principalmente en la porción americana del Imperio. Aquél era un instrumento usado para adquisición de la ciudadanía, por lo tanto se constata un elevado número de este instrumento en la primera mitad del siglo XIX en Brasil, según nos cuenta Rafael de Bivar Marquese. MARQUESE, Rafael de Bivar: "O poder da escravidão: um comentário aos 'Senhores sem Escravos"' in Almanack braziliense, n.6, 2007. La manumisión era así una oportunidade de acenso social, a la vez que reproducia el mismo orden social en Brasil. La importancia numérica de este grupo, casi la mitad de la población de la América portuguesa, presionaba a que se les concediesen la ciudadanía. Además, era la forma de manutención de la esclavitud, dado que era una condición transitória, y a la vez se mantenía al tráfico de esclavos de África. Y esto sin que el mundo de la esclavitud fuese conflitivo con el mundo de los libertos. Esta es la posición defendida por MATTOS, Hebe Maria: Escravidao e cidadanía no Brasil Monárquico, Rio de Janeiro, 2000, p. 7. También por BERBEL, Márcia Regina y MARQUESE, Rafael de Bivar: "Ausencia da raça...," op. cit., p. 25. Y la afirmación de que la manumisión era un componiente importante para la conservación del sistema esclavista es afirmada por SOARES, Márcio de Sousa: A remissao do cativeiro, A dádiva da alforria e o governo dos Campos dos Goitacases, c. 1750 - c.1850, Apicuri, Rio de Janeiro, 2009, pp. 153 a 178. También analisa este aspecto SILVA, Cristina Nogueira da: "Da Carta de Alforria" ..., op. cit., pp. 110 y ss. 
ciudadanía por parte de los africanos, establecida por la Constitución gaditana ${ }^{646}$. Así que tanto por parte de los diputados brasileños como de los portugueses hubo una concordancia para que en la definición de la ciudadanía en el texto constitucional el tema racial no fuese un problema $^{647}$. De este modo fue adoptada una política más incluyente en relación a los esclavos africanos y sus descendientes ${ }^{648}$.

La lógica de los diputados vintistas de una definición de ciudadanía que incluyera a la población de afro-descendentes, libertos y libres, evitaba adoptar "el color de la piel" como criterio válido a la hora de atribuir la condición de ciudadano. Eso porque, sabían tales diputados, que la población de libertos y sus descendientes, principalmente en el Reino de

\footnotetext{
${ }^{646}$ Nogueira da Silva nos da algunas pistas sobre la inclusión de los afro-descendentes libertos y libres en la ciudadanía. Por una lado porque la inclusión en la ciudadanía de los libertos buscaba omitir la incómoda discusión sobre la esclavitud y sobre el tráfico. Por otro lado por la importancia numérica de aquellos individuos en la porción americana del Imperio portugués. Pero se evitó sobretodo buscar una "racialización" del tema de la ciudadanía, en donde llama la atención que "el color de la piel" no fue un criterio valido para la atribución o no del estatus de ciudadano. Hecho este que sirvió como criterio de exclusión tanto en el Imperio británico, en algunos Estados de la América del Norte, como también en Cádiz. Puesto que los diputados de las Cortes constituyentes portuguesas sabían lo que había sucedido con el trato de la ciudadanía española, que había excluido a los originarios de África, en el art. 22 de la Constitución de Cádiz. Además, dicha constitución, en su art. 29, no contabilizó a la población afrodescendientes en el cálculo de la representación en el ultramar, originando con esto importantes discordias entre los diputados españoles de ultramar y los diputados peninsulares. Estas y otras consideraciones se puede encontrar en SILVA, Cristina Nogueira da: Da "Carta de Alforria" ao "Alvará de Assimilação"..., op. cit., pp. 116 y ss. Para un lectura complementar al tema es interesante la lectura de BERBEL, M. R. y MARQÚESE, R. B.: Esclavitud, ciudadanía e ideología proescalvista en las Cortes de Lisboa y la Asamblea Constituyente de Rio de Janeiro (1821-1824) in CHUST, M. e FRASQUET, I (eds.): Los colores de las independencias iberoamericanas. Liberalismo, etnia y raza, Consejo Superior de Investigaciones Científicas, Madrid, 2009, pp. 124 y ss. También se puede ampliar esta discusión con otro texto de los mismo autores BERBEL, Márcia Regina e MARQUESE, Rafael de Bivar: “Ausência de raça: escravidao, cidadania e ideología pró-escravista nas Cortes de Lisboa e na Assembléia Constituinte do Rio de Janeiro (1821-1824)", papera presentado a la Conferencia Slavery, Enlightenment, and Revolution in Colonial Brazil and Spanish America, New York: Fordham Univesity, 2001, pp. 3 a 5. También BERBEL, Márcia, MARQUESE, Rafael e PARRON, Tâmis: Escravidao y Politica: Brasil e Cuba, c. 1790-1850, São Paulo, 2010, pp. 155 y ss.

${ }^{647}$ Más o menos el tema fue tratado pacíficamente en las Cortes por los diputados de ambos hemisferios. Para comprender este hecho se puede recurrir a la tesis defendida por Márcia Berbel y Rafael Bivar de que, principalmente en el Brasil ya independiente de Portugal, la inclusión de los liberto fomentaría la supervivencia del tráfico de esclavos venidos de África, dado que la oportunidad de ascensión social por medio de la manumisión, y consecuentemente el acceso a la ciudadanía, primero en el Imperio portugués y después en el Imperio de Brasil. Eso dinamizaba y progresaba material e intelectualmente a la nació. BERBEL, Márcia Regina e MARQUESE, Rafael de Bivar: "Ausência de raça..., op. cit., p. 25. También la tesis de Márcio de Sousa Soares es esclarecedora, en donde la manumisión sería un componente importante en la conservación del sistema esclavista. SOARES, Márcio de Sousa: A remissao do cativeiro. A dádiva da alforria e o governo dos escravos nos Campos dos Goitacases, c. 1750-c.1850, Apicuri, Rio de Janeiro, 2009, p. 153 a 178. Del analisis de estos autores también Cristina Nogueira da Silva saca importante es esclarecedoras conclusiones en este sentido. SILVA, Cristina Nogueira da: Da "Carta de Alforria” ao "Alvará de Assimilação” ..., op. cit., pp. 119 y 120.

648 "Términos marcados por connotación racial, a pesar de que ésta no fuese una categoría para los lusoamericanos9, aparecen pocos. Durante dos años de discusiones diarias, los parlamentarios jamás usaron la palabra negro para calificar al descendiente de África, y cuando utilizaron la palabra en plural (negros), hicieron esa asociación apenas ocho veces y, en la mayor parte de ellas, sin sentido político alguno. Moreno aparece sólo una vez en la referencia al africano y morenos, nueve veces. Otros términos, también indicadores de ese origen, como mulato, mameluco, cabra, pardo, criollo, mestizo o liberto son aún menos frecuentes. Y, por fin, la noción de casta, tan común en el ámbito hispano, no existe en el vocabulario portugués. La palabra fue usada con frecuencia como sinónimo de tipo y en apenas seis ocasiones lo hace con relación a diferencias sociales o étnicas". Ibídem.
} 
Brasil, daban señales de pertenecer ya a la comunidad de los portugueses, tal y como fue pensada en cuanto comunidad. Así se deprende de la lectura del art. 19 de la Constitución de 1822, en donde decía que: "Todo portugués debe ser justo. Sus principales deberes son venerar la Religión; amar la patria; defenderla con las armas, cuando fueren llamados por la ley; obedecer a la Constitución y las leyes; respetar las Autoridades públicas; y contribuir para los gastos del Estado". Se buscaba con eso, en palabras de Nogueira da Silva, formar una comunidad homogénea, principalmente desde el punto de vista lingüístico, cultural, religioso y a la forma constitucional de gobierno ${ }^{649}$. Es bastante cierto que los diputados brasileños van a matizar esta cuestión, en donde se busca incluir a toda la población de libertos, evitando imponer criterios raciales para la adquisición de la ciudadanía, como se deprende de la intervención de Cipriano Barata, diputado por Bahía: “(...) seguem a mesma religião, falam a mesma língua, obedecem ao mesmo Rei, abraçam e defedem a mesma Constituição libre „650. Esta intervención de Barata no fue contestada directamente por otros diputados, pero tampoco fue seguida a raja tabla. Entretanto, en la interpretación de Nogueira da Silva, sirvió para esclarecer que tanto la lengua como la religión en común, así como el sentimiento de amor a la patria y la adhesión al gobierno constitucional debían ser el norte constitucional para que los diputados fijasen una mayor inclusión ciudadana, dado que pertenecían así a la comunidad nacional $^{651}$. Estos mismos criterios van a servir para excluir a los libertos no nacidos en el territorio portugués de la ciudadanía plena, así como a los extranjeros, dado que estos carecían del necesario amor por la patria para ser un completo ciudadano. Aun así, el art. 21 de la Constitución va a admitir, con algunas limitaciones el acceso a los derechos políticos por parte de los extranjeros, dado que el art. 34 va a establecer como absolutamente inelegibles, en el inciso VI, a los extranjeros, y en el inciso VII, a los libertos nacidos en país extranjero. Así que, como hablamos antes, la sangre y/o el nacimiento en el territorio portugués se tornaron criterios validos a la hora de fijar la ciudadanía portuguesa con suficiente "amor" por la patria ${ }^{652}$.

\footnotetext{
${ }^{649}$ SILVA, Cristina Nogueira da: Da “Carta de Alforria” ao “Alvará de Assimilação” ..., op. cit., p. 117.

${ }^{650}$ DCGECNP, sesión de 13 de agosto de 1822, p. 139. Otro diputado de las Cortes, el jurista Basílio Albuquerque de Sousa Pinto (1793-1881) hará alusión al requisito del amor a la patria, cuando dice: "Porquanto já dissemos que a qualidade de cidadao tem o seu fundamento no Amor à Pátria, o qual se pode conhecer ou pelo sangue, ou pelo nascimento". PINTO, Basílio Alberto de Sousa: Lições de Direito Público Constitucional, Lição n. 9, 1840, p. 21. http://www.fd.unl.pt/ConteudosAreasDetalhe.asp?Titulo=Biblioteca Digital\&Area=BibliotecaDigital "Biblioteca Digital - Faculdade de Direito da Universidade Nova de Lisboa". Se coaduna este pensamiento con lo establecido en el citado art. 19 de la Constitución, en donde pliega el amor a la patria, además de venerar a la religión como deberes del ciudadano.

${ }^{651}$ SILVA, Cristina Nogueira da: Da “Carta de Alforria” ao “Alvará de Assimilação” ..., op. cit., p. 117.

${ }^{652}$ La tesis de Nogueira da Silva es que los motivos que llevaron a una mayor inclusión ciudadana en las Cortes Constituyentes vintista estaban íntimamente relacionados a la porción americana del Imperio, dado que Brasil era un caso peculiar dentro del sistema colonial, y fue motivo incluso para que el constitucionalismo portugués se distanciase del constitucionalismo gaditano a la hora de fijar los criterios para conceder la ciudadanía, evitando con eso las discusiones raciales en la tentativa de conservar el territorio brasileño que empezaba a dar señales de querer
} 
En esta discusión, primero hay que esclarecer, que la inclusión de estas poblaciones afro-descendientes está muy relacionada a la cuestión de la representación en la Cortes de los diputados del ultramar, y la determinación del número de estos en las Cortes. Esta discusión fue capitaneada principalmente por los diputados provenientes de Brasil, dado que las amenazas de secesión estaban presentes en el momento de las discusiones, que al final, como se sabe se dará. Pero, se llega a aprobar el art. 38 de la constitución, inciso III, en donde se dice que en lo que respecta a Brasil una ley posterior decidirá cuantas divisiones deban corresponder a cada provincia, y cuantos deputados a cada división, siempre regulado el número a la razón de un diputado por cada treinta mil "habitantes libres". Mientras que, en el inciso IV, del mismo artículo, determina para las demás parte del Imperio, cada uno de los distritos formaría una división y daría al menos un diputado, "cualquiera que fuese el número de sus habitantes libres". Así que era interesante incluir en el horizonte ciudadano a los afro-descendientes en Brasil. Pensando de esta manera, se buscó alejarse de lo establecido por el art. 5 de la Constitución de Cádiz - "los hombres libres nacidos y domiciliados en los dominios de las Españas" - y recogido por el proyecto portugués (la Constitución de Cádiz cerraba la puerta a los esclavos, principalmente los de origen africano, a la nacionalidad y a la ciudadanía). En este artículo se hacía distinción clara entre los hombres "libres" y "no libres" 21 del texto definitivo portugués optará por establecer que serían ciudadanos los esclavos que alcanzasen la manumisión. Esto elevaba bastante la población requerida para determinar el número de los diputados dispuesto en el art. 37 de la Constitución portuguesa de 1822. Con la ciudadanía restrictiva, los diputados americanos se retiraron de las Cortes gaditanas y llenaron las filas de las independencias, lo que sabían y querían evitar los diputados portugueses ${ }^{654}$.

Entretanto, no será todo esclavo manumitido que entren en el goce de la ciudadanía plena. Las inelegibilidades absolutas del art. 34, que prevé que los extranjeros (inciso VI) y los libertos nacidos en país extranjero (inciso VII) no puedan ser elegidos; trazan un paralelismo entre estas dos categorías de individuos que no encajan en el criterio del ius solis para la obtención de la integralidad de los derechos políticos, aunque les permitía el voto en las

sesionarse del Imperio portugués. SILVA, Cristina Nogueira da: "Representação Política e Cidadania no Império" in CATROGA, Fernando y ALMEIDA, Pedro Tavares de (cords.): "Res Pública": Cidadania e Representação Política em Portugal 1820-1926, Biblioteca Nacional de Portugal/Assembleia da República, Lisboa, 2010, pp. 91 a 111.

${ }^{653}$ Esta discusión se la puede ampliar más en SILVA, Cristina Nogueira da: Da "Carta de Alforria" ao "Alvará de Assimilação" ..., op. cit., p. 114 y ss.

${ }^{654}$ También se puede saber más sobre este aspecto de la ciudadanía en la Constitución de Cádiz en VALDES, Roberto: "El 'problema americano" en las primeras Cortes Liberales españolas (1810-1814)" in AAVV: Los Orígenes del Constitucionalismo Liberal en España e Iberoamérica: un estúdio comparado, Junta de Andalucía, Sevilla, 1993. p. 82. Tambíen se encuentra en LORENTE, Marta: "De Monarquía a Nación: la imagen de América y la cuestión de la ciudadanía hispana" in XIII Congreso del Instituto Internacional de Historia del Derechos Indiano (21-25 mayo de 2000), Vol. II, Asamblea Legislativa de Puerto Rico, San Juan, 2003. 
elecciones parroquiales. Era un tipo de exclusión parcial de la ciudadanía, porque los extranjeros naturalizados: "não poderem estar bem ao fato de todos os nossos costumes, $e$ também porque não podem ter tanto amor à Pátria, e aos nosso concidadãos" ${ }^{655}$. Tanto el liberto nacido en África carecería de una formación educacional y civilizadora, y por lo tanto no podía amar a la patria como era requerido, como el extranjero carecía también de este último elemento, dado que, según los mismo diputados aquél amor solo vendría por el nacimiento o por el sangre. Eran situaciones jurídicas análogas, por lo tanto ${ }^{656}$.

Nos cuenta Berbel y Marquese que las discusiones sobre el tema de la raza vinculada a las discusiones de atribución de ciudadanía no estuvo muy politizada en las Cortes Portuguesas $^{657}$. Aunque afirmen, y lo pudimos constatar, que en las sesiones de los días 17 de abril, 21 de mayo, 26 de junio y 13 de agosto de $1822^{658}$ hubo una mayor politización en este sentido.

La sesión del día 17 de abril fue bastante concurrida a lo que toca a votaciones sobre exclusiones del ámbito de la ciudadanía. Tales propuestas de cambios del texto constitucional tenían por objetivo excluir de la participación electoral y política de algunos seguimientos de la sociedad de la época. En primer lugar se debatió si los extranjeros naturalizados debían tener derecho a votar en las elecciones para diputado. Unos de los primeros a pronunciarse fue el diputado Franzini, que dijo que se opone "a esta cláusula do artigo, pois que o projeto da Constituição tem já sido assaz liberal para com os estrangeiros; y não convêm agrava-lo mais. Se também os excluirmos de poderem votar nas eleições dos Deputados, não vejo quais sejam os direitos que vai adquirir o estranho, que se naturaliza cidadão português ${ }^{\text {659 }}$. Después de una minguada discusión se votó en favor de conceder a los extranjeros naturalizados el derecho de votar en las elecciones de diputado de las Cortes. En seguida se procedió a discutir sobre los vagos -que ya hicimos referencias- y el resultado fue por la negativa de estos poder votaren para diputados. El diputado Varella, además, propuso excluir de la ciudadanía también a los celibatarios mayores de 60 años, lo que fue negado por el pleno tal propuesta de aditamento del diputado. Entonces se pasó a discutir si se debía negar el derecho de votar a los analfabetos.

\footnotetext{
${ }^{655}$ DCGECNP, sesión de 12 de octubre de 1821, p. 2625 - se pronuncia el diputado Guerreiro; también en el mismo sentido se pronuncia el diputado Borges Barros en la sesión de 3 de abril de 1821, p. 713; como también el diputado Pinto de França, en la sesión de 14 de enero de 1822; en la sesión de 12 de octubre de 1821, p. 2627, el diputado Castelo Branco Manoel; en la sesión de 12 de octubre de 1821, p. 2638, el diputado Sarmento.

${ }^{656}$ Esta debate se puede encontrar también en SILVA, Cristina Nogueira da: Da "Carta de Alforria" ao "Alvará de Assimilação" ..., op. cit., p. 118 y ss. Ya acerca del sentimiento de amor a la patria como argumento de exclusión, utilizado en Cádiz véase en HERZOG, Tamar: Citizenship and community in Eighteenth Century Spain, Polic, 2002, p. 243 y ss.

${ }^{657}$ BERBEL, M. R. y MARQÚESE, R. B.: Esclavitud, ciudadanía..., op. cit., p. 124.

${ }^{658}$ DCGECNP, pp. 830 y ss.

${ }^{659}$ Ídem., p. 831.
} 
Hubo una acalorada discusión a respecto. Dado que el número de excluido sería muy grande, y no se llegaba a un consenso razonable, se decidió por una medida salomónica con una proposición de aditamento del diputado Fernandes Thomaz: "todos os que tiverem atualmente 17 anos de idade, ou daí para baixo, e para o futuro não poderão votar nas eleições, ainda que cheguem a idade competente, em quanto não souberem ler, e escrever" ${ }^{~} 60$. Puesta en votación el aditamento fue aprobado sin ningún cambio por el pleno de las Cortes.

Entretanto, la proposición de aditamento en contra de la participación de los libertos en las elecciones para diputado fue la que más causó discusiones en esta sesión de las Cortes del día 17 de abril, principalmente porque se vio una defensa por parte de los diputados brasileños allí presentes en contra de tal aditamento discriminatorio. Como ya tuvimos ocasión de comentar, el decreto daba las instrucciones electorales, tomado de la Constitución gaditana, no mencionaba los grupos que naturalmente, desde la lógica española, estaban excluidos del proceso electoral y por supuesto de la ciudadanía ${ }^{661}$. Nada decían, tales instrucciones electorales, ni hacían ninguna referencia a la existencia de la esclavitud o de las poblaciones descendientes de los antiguos esclavos, como bien comenta Berbel y Marquese ${ }^{662}$. Por lo tanto, el diputado Miranda propuso en el pleno un aditamento al art. 21 para que los libertos y sus hijos no tuviesen derecho a votar en las elecciones. Se verán una serie de argumentos, principalmente de los representantes de Brasil, sobre tal proposición. El diputado Peixoto es el primero en alzar la voz en contra de tal proposición con el siguiente argumento: "Se nós admitimos os cidadãos naturalizados, porque não havemos de admitir os libertos? Por terem tido a desgraça de suportarem ferros iníquos?" ${ }^{663}$ El diputado Fernandes Thomaz en su intervención, sensatamente dice preferir que se manifiesten y den sus opiniones los señores diputados del ultramar. El diputado por la provincia de Río de Janeiro, Custodio Gonçalves Ledo dirá perentoriamente que no hay razón alguna para privar a los libertos de este derecho, ya que "hay muchos libertos en Brasil que hoy interesan mucho a la sociedad, y tienen grandes ramos de industria, muchos tienen familias; por eso sería cometer una gran injusticia privar a estos ciudadanos de poder votar y hasta podría decir que es agravar en mucho el mal de la esclavitud" ${ }^{\prime 664}$. Otro diputado, el Sr. Feio, se manifiesta que todos los hombres nacen iguales y todos libres, y que ser esclavizado es una desgracia y ser hijo de un esclavo o liberto es un

\footnotetext{
${ }^{660}$ Ídem., p. 838.

${ }^{661}$ Sobre las discusiones sobre problemas raciales en las independencias iberoamericanas, vale la pena consultar a CHUST, Manuel y FRASQUET, Ivana: Problemáticas del Liberalismo: la etnia y la raza en las independencias en Iberoamérica in CHUST, M. e FRASQUET, I (eds.): Los colores de las independencias iberoamericanas. Liberalismo, etnia y raza, Consejo Superior de Investigaciones Científicas, Madrid, 2009, pp. 9 y ss.

${ }^{662}$ BERBEL, M. R. y MARQÚESE, R. B.: Esclavitud, ciudadanía..., op. cit., p. 125.

${ }^{663} D C G E C N P$, pp. 838 y ss.

${ }^{664}$ Ibídem.
} 
accidente que no debe ser punido como si se tratase de un crimen cometido por estos. El diputado Lino Coutinho era de la opinión que los libertos debían votar y que el sistema antiguo no hacía distinción de libertos para alcanzar dignidades. Para el diputado Villela, se debía hacer caso omiso de este asunto en la Constitución, pero estaba a favor del derecho al voto de los hijos de los libertos. El diputado Correa de Seabra es mucho más taxativo al tratar del tema con las siguientes palabras: "Esta indicação deve ser rejeitada, porque vai escandalizar classes numerosas no Brasil, e legalizar prejuízos que obstam a prosperidade daquele país, e que é necessário trabalhar pelos desterrados: e por tanto eu convido o Congresso que nem mesmo discuta esta indicação" ${ }^{, 665}$.

Los argumentos aportados por el diputado que propuso la enmienda, el Sr. Miranda, tampoco iba en el sentido de discutir temas raciales, como bien comenta Berbel y Marquese. El proponente de la enmienda defenderá la discusión con el argumento de que es...

"Impossível que um escravo que ainda está marcado com o ferrete da servidão, possa ter os mesmos sentimentos que outro qualquer homem livre. Há muita diferença entre um estrangeiro, e um escravo; o escravo não vem dos países livres, como o estrangeiro que se naturaliza: o escravo está sempre debaixo do jugo do seu senhor (...). Custa-me por isso a crer que ele tenha a mesma nobreza de sentimentos que tem outro qualquer cidadão português"

Por lo tanto, no ofrece el diputado Miranda una razón con substancia para que la enmienda tenga seguimiento, además, los diputados brasileños ofrecen una dura resistencia a que pase tal proposición al texto de la constitución.

Un fuerte argumento aporta el diputado por la Provincia de Bahía, Marcos Antonio de Sousa:

"Sr. Presidente, admitida esta indicação se iria fazer um grande cisma no Brasil, aonde um terço da sua população consta de libertos, e entre eles há homens de muita inteireza e probidade: por isso não deve ser excluídos de modo algum. Nós não estamos no caso de admitir todas as coisas do direito romano; e além disso existem em seu vigor as leis do Sr. D. José, pelas quais era concedido aos libertos servirem cargos públicos: o Marques de Pombal conheceu que esta medida era necessária para o Brasil, para bem do qual se deviam empregar estes homens. Não devemos pois estabelecer princípios de tanta restrição, que certamente não convém, e hão de produzir muitas intrigas. Nós o que devemos fazer é unir todos os cidadãos, construir uma boa sociedade, e não provocar discórdia, que é de que devia servir esta indicação" ${ }^{\text {667 }}$.

\footnotetext{
${ }^{665}$ DCGECNP, pp. 839 y ss.

666 Ibídem.

${ }^{667}$ Ibídem.
} 
También el diputado Pinto França vota en contra de la propuesta, presentando, según las palabras del propio diputado, argumentos de principios liberales, dado que el esclavo ha logrado cambiar su suerte, y haber alcanzado la clase de ciudadano, debería este entrar en el goce de todo que es atribuido a un ciudadano. También el diputado Sarmento se pronuncia en contra de la medida. Otro diputado, el Sr. Vaconcellos, hará una comparación entre los esclavos que fueron manumitidos y la patria portuguesa, en contraposición al argumento de otro diputado de que una vez bajo los grilletes no se podía gozar de verdadera libertad. Dice el mismo diputado que "a Nação Portuguesa era escrava, quebrou os ferros da escravidão, hoje é mais livre do que aquelas que nasceram livres" ${ }^{\text {"668 }}$. También vota contra la medida el diputado Fernandes Thomaz, siguiendo la recomendación de los diputados brasileños de que tal medida peligraría la seguridad de Brasil. Por fin, persuadido por los argumentos de los representantes brasileños, el diputado proponente de la emenda, el Sr. Miranda, retira su indicación para el tema. Y para rematar, el último argumento, antes de la votación, fue de un diputado brasileño, Lino Coutinho, que dijo que a pesar de ser brasileño siempre tuvo horror a la esclavitud. Así que puesta en votación la enmienda, por unanimidad se decidió que los libertos pudiesen $\operatorname{votar}^{669}$.

Como pudimos deducir de la intervención de los señores diputados, y en consonancia con las conclusiones de Berbel y Marquese, como también de Cristina N. Silva, los argumentos para que se negase tal medida está en el hecho de en ese momento había un gran inserción de los libertos en las actividades productivas. También era respetable la proporción numérica de estos en el seno de las provincias de Brasil. Y además de todo, se constataba una profunda integración de los libertos en cargos públicos o militares como resultado del derecho adquirido desde la época de las reformas pombalinas en el reinado de D. José, como vimos ${ }^{670}$. Aunque, como ya lo decimos, no sea nuestro objeto de estudio el universo propiamente dicho de la institución de la esclavitud, principalmente en Brasil, vale la pena hacer estas matizaciones para poder ir demarcando los ámbitos del alcance de la ciudadanía, muy relacionada con la confesionalidad del Estado, que es lo que buscamos aquí. Aun así, sabemos que la inclusión de los libertos en el ámbito de la ciudadanía está vinculada a presupuestos de utilidad ${ }^{671}$. Es notoria la falta de personal que padecía Portugal en la tarea colonizadora, los mestizos jugaron un papel

\footnotetext{
${ }^{668}$ Ibídem.

${ }^{669}$ D.C.G.E.C.N.P., pp. 840 y ss.

${ }^{670}$ BERBEL, M. R. y MARQÚESE, R. B.: Esclavitud, ciudadanía..., op. cit., pp. 126 y ss. También afirma António Manuel Hespanha que en el ámbito del universo de personas incluidas, hay que destacar la situación de los libertos y de los expuestos (huérfanos) en territorio nacional, que son incluidos en el universo político. HESPANHA, A. M.: Guiando a mao..., op. cit., pp. 84 y ss. También se trata de esta inclusiones en NOGUEIRA DA SILVA, Cristina: A cidadanía en los trópicos..., op. cit., pp. 60 y ss.

${ }^{671}$ BERBEL, M. R. y MARQÚESE, R. B.: Esclavitud, ciudadanía..., op. cit., pp. 126 y ss.
} 
crucial en esta labor, luego es fácil deducir que ya estaban demasiado inmiscuidos en la sociedad para prescindir de ellos de un plumazo constitucional; "la inserción de los libertos era una realidad ya bastante antigua (...), era necesidad apremiante y estructuradora del orden social y político de la América portuguesa",672.

El cenit de la discusión sobre los ámbitos de la ciudadanía portuguesa, como ya insinuamos, se dará en la sesión de las Cortes del día 13 de agosto de 1822. Ya tuvimos ocasión de hablar sobre el artículo 21 del proyecto de la Constitución y su contenido; con la expresión: "Son ciudadanos portugueses", nos deja pensando como de inclusiva pudiera ser esta alocución. Así dicho, y comparado con los textos que influencian directamente al texto luso-brasileño, no encontramos paralelismo en la Constitución española de 1812, tampoco en la Constitución francesa de 1791. Ni siquiera en el Proyecto de Constitución de 1823 de Brasil, en donde muchos de los diputados que estuvieron en Lisboa regresan como diputados en las Cortes de Río de Janeiro. Tampoco se plasma esta universalización de la ciudadanía en la Constitución del Imperio de Brasil otorgada en $1824^{673}$. Al ser puesto en votación el art. 21, el presidente, Sr. Freire, propone que en lugar de la expresión "Son ciudadanos portugueses" se debía utilizar la expresión "Todos los portugueses son ciudadanos: y gozan de esta calidad (...)", la proposición fue de inmediato aceptada por el pleno de las Cortes. Para luego en seguida tomar la palabra un diputado de Brasil, de la Provincia de Bahía, Cipriano Barata:

(...) Pareceu-me que em alguns lugares estavam confundidos os direitos naturais com os civis; ou políticos; porque no $5^{\circ}$ artigo se lê: a casa do cidadão português; quando para o Brasil eu desejo que se diga nos artigos as indicações: a casa de todo o individuo. E a razão é porque, tendo aquele país de ser povoado de muitos estrangeiros, devem estes ter em suas casas igualmente asilos respeitados como qualquer Português: este direito de asilo, é natural, pertence a todos: é verdade que um Francês ou Inglês não pôde votar nem ocupar cargos públicos, porque estes direitos são políticos; mas suas casas devem ser asilo como de direito natural e civil: ora se o estrangeiro está sujeito às leis civis do país, com igual razão deve participar daquilo que emana das leis da natureza, e civis ${ }^{674}$.

Logo en seguida hace llamar la atención hacía el término "portugués":

"E tornando para minha reflexão sobre a palavra 'português', digo que também ontem foi sancionado o artigo $1^{o}$ do tít. $2^{o}$ : eu respeito às decisões das cortes, mas também reparo na palavra português. Esta palavra, Sr. Presidente, pode mover grande ciúme nos povos do Brasil, e causar dano: eu já advirto que nos artigos adicionais há de declarar-se do modo seguinte: de todos os Portugueses de

\footnotetext{
672 Ibídem.

${ }^{673}$ Para saber más sobre la universalización de esta ciudadanía véase en NOGUEIRA DA SILVA, Cristina: A cidadanía en los trópicos..., op. cit., pp. 75 y ss. También en BERBEL, M. R. y MARQÚESE, R. B.: Esclavitud, ciudadanía..., op. cit., pp. 127 y ss. Además de la lectura en HESPANHA, A. M.: Guiando a mao..., op. cit., pp. 84 y ss.

${ }^{674}$ DCGECNP, (Tomo VII), pp. 138 y 139.
} 
todas as castas de ambos os hemisférios. Não pense o soberano Congresso que isto é indiferente: no Brasil temos Portugueses brancos europeus, e Portugueses brancos brasileiros: temos mulatos, que são os filhos de todos aqueles Portugueses com as mulheres pretas, ou estas sejam crioulas do país ou sejam da costa da Mina, Angola, etc.: temos também mulatos, filhos da combinação dos mesmos mulatos: e temos cabras, que são os filhos dos mulatos com as pretas: temos caboclos ou índios naturais do país: temos as misturas destes, isto é, os mamelucos, que são o produto dos brancos misturados com os referidos caboclos: e temos os mestiços, que são a prole dos Índios combinados com a gente preta. Além disto, temos também pretos crioulos, que são os nascidos no país; e finalmente temos os negros da costa da Mina, Angola, etc ${ }^{675}$."

También advierte sobre el reflejo en la sociedad brasileña del periodo al descuidar de una mayor precisión al utilizar el término:

"A falta de cuidado nestes artigos pode fazer grande mal; porque toda a gente de cor no Brasil clamaria que lhe queiram tirar os direitos de cidadão, e de voto; é por isso que eu digo que a palavra português, no Brasil é equivoca; concluo pois que se deve tirar toda a duvida nos artigos adicionais, ou mesmo aqui; porque todos aqueles habitantes do reino do Brasil seguem a mesma religião, falam a mesma língua obedecem ao mesmo Rei, abração e defendem a mesma Constituição livre ${ }^{676 . "}$

El diputado bahiano va a ser el único, en palabras de Berbel y Marquese, en desnudar la diferenciación étnica de la población de Brasil. Aunque ya acompañamos las discusiones sobre la inclusión del liberto en el rol de ciudadanía, se precavía el diputado de que un término tan locuaz pudiese encubrir futuras exclusiones de forma colateral. Buscaba que en el Capítulo $3^{\circ}$ se debiese acrecentar al artículo 33, del proyecto, un párrafo en donde se diga que "os libertos e seus filhos não são excluídos de votar" ${ }^{677}$. Su preocupación residía en que hijos de portugueses de todas las castas, con la gente preta (negra) da costa da Mina, que no sería territorio portugués, se quedasen fuera de lo que llama "precioso derecho de ciudadano", perdiendo, con eso, el derecho de votar, y muchas otras ventajas inherentes a la ciudadanía plena. Lo mismo se aplicaría a los "crioulos filhos dos pretos" da costa de la Mina, y de los hijos de los indígenas, mulatos y cabras $^{678}$. De hecho hace también una anticipación que lo que vendría a ser establecido en la Constitución Imperial de Brasil de 1824, cuando dice que lo mejor para Brasil sería dividir a los ciudadanos en "activos" y "pasivos", siguiendo lo que había teorizado el

\footnotetext{
${ }^{675}$ DCGECNP, (Tomo VII), p. 139.

${ }^{676}$ Ibídem.

${ }^{677}$ Ibídem.

${ }^{678}$ Consultada el estudio que hizo sobre esta materia los profesores Marcia Berbel y Rafael Marquese, preferimos igual que los citados autores mantener los términos mulatos y cabras en el original en portugués. BERBEL, M. R. y MARQÚESE, R. B.: Esclavitud, ciudadanía..., op. cit., pp. 125 y ss.
} 
Abbade Siéyes y otros publicistas, lo que sería más conveniente a los negocios de los brasileños $^{679}$.

Propugnaba el mismo diputado que en los artículos adicionales que se referían a la ciudadanía debían tener la siguiente redacción: "São cidadãos portugueses, todos os filhos de portugueses, ou de brasileiros, ainda que ilegítimos, de qualquer cor ou qualidade, nascidos no reino do Brasil; e mesmo todos crioulos, e os libertos" ${ }^{280}$. De este modo, explicitados los individuos en los que recaería la ciudadanía, evitaba así malas interpretaciones futuras, y posibles exclusiones de los que acreditaba deberían estar incluidos en la alocución "ciudadano portugués". La discusión no fue muy lejos, dado que los demás diputados entendieron que estaba bastante esclarecida que no se trataba de raza en el texto constitucional para proceder a exclusiones. El diputado Soares de Azevedo no ve necesidad para tal discusión, y dice: “Por ventura quando a Constituição trata dos filhos de país portugueses, fala de brancos ou pretos? Não se entendem todos? Tem acaso a cor alguma influencia por estas coisas?" 681 Entra en esta discusión el diputado Borges Carneiro:

"Em sessão de 30 de maio determinou-se que ficasse esta doutrina para os artigos adicionais relativos ao Brasil; porém neles não se trata disso, e esta doutrina não é só própria do Brasil, mas também de África, e Ásia, onde há libertos. Como, pois os libertos não são excluídos de votar, segundo aqui se acha sancionado no artigo 33, e a razão disso é porque são cidadãos, pois sem isso não poderiam exercitar um direito politico (...)."

Al final se decide acrecentar, por indicación del diputado Villela Barbosa de Río de Janeiro, al art. 21 un numero $6^{\circ}$, que en el texto final pasa a ser el $4^{\circ}$, en donde se configuraba la discusión en los siguientes términos: "Os escravos, uma vez que tenham alcançado carta de alforria" ${ }^{682}$. Este mismo diputado más adelante va a proponer que fuesen inelegibles todos aquellos que hubiesen obtenido la manumisión, siendo apenas los hijos de los libertos elegibles para diputados, no por criterios raciales, sino por cuestiones de instrucción formal, dirá el mismo diputado. Uno de los pocos diputados a apoyar tal exclusión fue el Sr. Castro e Silva, diputado por Pernambuco. Otro diputado brasileño para defender la propuesta fue el Sr. Fernandes Pinheiro, diputado por Sao Paulo, alegando el ejemplo de la América-Septentrional, marcadamente en los Estados de Carolina y Virginia, en donde no se permitía que los libertos accedieran al parlamento. Aunque el diputado Villela haya recibido apoyo de portugueses y brasileños en su proposición, en la votación final ésta fue rechazada por el pleno de las Cortes.

\footnotetext{
${ }^{679}$ D.C.G.E.C.N.P. (Tomo VII), p. 139.

${ }^{680}$ Ibídem.

${ }^{681}$ D.C.G.E.C.N.P. (Tomo VII), p. 140.

${ }^{682}$ Ibídem.
} 
Así es que, en consonancia con la interpretación hecha por Berbel y Marquese, los criterios raciales no sirvieron de baliza para establecer la ciudadanía en el texto constitucional. Era una concepción liberal de ciudadanía bastante amplia, que buscaba incluir, en esta primera experiencia constitucional luso-brasilera, a todos los hombres libres, pero ante se buscaba incluirlos por ser productivos y ya bastante inmersos en los negocios públicos. "La unidad entre estos portugueses/ciudadanos era vista como cultural e histórica, y debía ser mantenida y ampliada por medio de la acción racional y la educación" ${ }^{683}$. Por ello esta experiencia es bastante interesante, puesto que no se buscaba excluir ni a los extranjeros. "La definición del portugués/ciudadano fue incluyente en varios sentidos porque pretendió soldar fisuras de una identidad ya fuertemente cuestionada" ${ }^{684}$. De esta manera se buscó afirmar la igualdad entre todos los portugueses, de ambos hemisferios, y una identidad de nación no fijada en criterios raciales.

${ }^{683}$ MARQUESE, R. B.: Esclavitud, ciudadanía..., op. cit., pp. 129.

684 Ídem, p. 130. 


\subsection{El Estado confesional y la ciudadanía en el Imperio Luso-brasileño}

El Imperio portugués se esparció con la meta de la cristianización de la conquista, haciendo que la construcción de la identidad portuguesa se hiciera por la fuerza, a la dimensión providencial y mesiánica. La catolicidad fue promovida a elemento de identidad en el Imperio, pero, también es verdad que fue un elemento destructivo de esta misma unidad. Dado que la mera conversión no satisfacía como elemento aglutinador de la búsqueda de la homogenización del Imperio. "Portugal, nación fidelísima, tenía como principal misión combatir los infieles y dilatar la fe de Cristo" ${ }^{\text {685 }}$. En el estatuto colonial faltaba el cariz de la unificación desde las más diversas facetas. Así que eran considerados "naturales" los nacidos de padres portugueses, según las Ordenaciones Filipinas (II, 55), y por lo tanto gozaban del estatuto pleno de ser portugués, usaban el derecho portugués y se sujetaban a la justicia portuguesa. Mientras tanto había en el imperio los que eran considerados como extranjeros, liberados de la obediencia al gobierno y al derecho portugués. De esta forma estaban considerados los "sobas amigos, pero no vasallos" de Angola ${ }^{686}$ - a los cuales hacía referencia el Regimiento de los Gobernadores - y los "indios bravíos" brasileños ${ }^{687}$.

Sin embargo, hubo, según Fernando Catroga, una "estatalización” del cristianismo a partir del siglo XVI, fruto de la alianza entre el trono y el altar para justificar el poder absoluto de los monarcas. El principio fijado en el Tratado de Westfalia, firmado en 1649, tras las guerras religiosas, era el de "un roi, une foi, une loi", que era establecida como una premisa para la salvación colectiva. Esta también será la justificativa para la revocación del apaciguador Edito de Nantes en 1685. La creciente simbiosis del poder temporal al inmiscuirse en los asuntos de la iglesia, hace que los monarcas asuman el papel central para imponer las premisas de Westfalia. La necesidad de sedimentar el poder va a imponer la necesidad de crear una patria communis, que el Estado-Nación precisará más que nunca, para sostener que exista una "patria grande", y hará falta para eso, una unidad legal, religiosa y lingüística. Así que la

\footnotetext{
${ }^{685}$ La estrategia portuguesa era, principalmente en el caso que nos interesa más, Brasil, cristianizar para homogeneizar la conquista y el imperio. Pero, se mostró un verdadero fracaso, como destaca Ronald Raminelli, en el caso de los pueblos tupinambás de Brasil. Para saber más léase en RAMINELLI, Ronald: Império da fé: Ensaio sobre os portugueses no Congo, Brasil e Japão in FRAGOSO, Joao, BICALHO, Maria Fernanda y GOUVÊA, Maria de Fátima (orgs.): O Antigo Regime nos trópicos. A dinâmica imperial portuguesa (Séculos XVI-XVIII), Civilização Brasileira, Rio de Janeiro, 2001, pp. 245 y ss.

${ }^{686}$ SILVA, Cristina Nogueira da: A cidadania nos trópicos..., op. cit., pp. 28 y ss.

${ }^{687}$ HESPANHA, Antônio Manuel: A constituição do Império português. Revisão de alguns enviesamentos correntes in FRAGOSO, Joao, BICALHO, Maria Fernanda y GOUVÊA, Maria de Fátima (orgs.): O Antigo Regime nos trópicos. A dinâmica imperial portuguesa (Séculos XVI-XVIII), Civilização Brasileira, Rio de Janeiro, 2001, pp. 170 y ss.
} 
heterogeneidad se quedó fuera de los planes, en un imperio multifacético: cultural, lingüística y religiosamente ${ }^{688}$.

Las teorías del contrato social, en palabras de Fernando Catroga, secularizaran los conceptos de soberanía del Estado, desarrollado por Jean Bodin, como también el sentido del poder constituyente que pasará a residir en el pueblo o en la nación, de acuerdo al sistema constitucional. El derecho de resistencia frente al soberano, al poder absoluto, pasa por la modernización y aplicación en los movimientos revolucionarios tanto en las Colonias Anglosajonas de América, como en Francia. Allí se verá por primera vez plasmarse en un documento escrito los derechos y deberes de los ciudadanos. Por lo tanto, se constitucionalizan tales derechos, puesto que no sólo son declarados sino que se establecen los instrumentos de protección a estos mismos derechos. Dado que las teorías contractuales (Locke, Hobbes, Rousseau), y la presencia del jusnaturalismo van a declarar y componer estos derechos, mientras que la teorización de la división de los poderes del Estado (Montesquieu) va a ser la garantía de pervivencia y aplicación de estos mismo derechos de los ciudadanos ${ }^{689}$. Serán tanto Rousseau como Locke quienes estarán presentes en aquellos procesos revolucionarios descritos, como también los pasados en la península ibérica, dado que son tributarios del proceso francés ${ }^{690}$. Es verdad que para concretar la secularización del Estado, siempre se ha sufrido un antagonismo de las religiones históricas y, sobretodo, de la Iglesia Católica. "Se puede decir que, en esta experiencia, en la herencia de la religión civil de Rousseau se desarrolló todas sus potencialidades para transformar en una estricta religión política (...)”, además, "el Estado no se limitará a una actitud de indiferencia delante de los que consideraban sus adversarios, pero reaccionaba para conseguir nacionalizar a las conciencias" ${ }^{\prime 691}$.

La constitucionalización de la soberanía nacional fue el reflejo de las teorías de la autosuficiencia del Estado y fue potencializado por las teorías del contrato social. Siéyes, cuando escribe, el ya citado ensayo Quest-ce que le tiers état? en1789, demostrará una

\footnotetext{
${ }^{688}$ CATROGA, Fernando: Em nome da Nação en CATROGA, F. y ALMEIDA, Pedro Tavares de (Cord.): Res Pública: Cidadania e representação politica em Portugal, 1820-1826, Biblioteca Nacional de Portugal-Assembleia da República, Lisboa, 2010, pp. 22 y ss.

${ }^{689}$ Ídem, p. 24.

690 "Devido ao peso francês nos processos revolucionários, em particular nos de Espanha e Portugal, ir-se-á dar relevo a Rousseau. Como outros contratualistas (Hobbes, Locke), o autor das Confissões também pensava que a ausência de autoridade conduziria ao estado de guerra. Daí a necessidade de os indivíduos se associarem para superar a precariedade do seu estado de natureza. Todavia, para ele (ao contrário de Locke), a sociabilidade não era uma característica pré-existente ao contrato, mas fruto do consentimento de seres livres. E seria contraditório que cada indivíduo detivesse uma autoridade natural sobre o outro. Só a convenção, baseada na vontade unânime de todos, legitimaria um pacto social que possibilitasse a liberdade recíproca dos seus membros, organizados em comunidade política”. Ibídem.

${ }^{691}$ CATROGA, Fernando: Entre deuses e césares. Secularização, laicidade e religião civil, $2^{\text {a }}$ Edição, Editora Almedina, Coimbra, 2010, pp. 223 y ss.
} 
interconexión entre las concepciones de soberanía popular y soberanía nacional, pronosticando una anterioridad de la relación entre gobernantes y gobernados, dado que el poder constituyente estaba identificado con la nación entera, y el pueblo identificado con los gobernados. Estas ideas, para Catroga, se reflejaron en la Declaración de 1789, en la tentativa de evitar una fragmentación corporativa semejante al del Antiguo Régimen: "El origen de toda soberanía reside esencialmente en la Nación. Ningún órgano, ni ningún individuo pueden ejercer autoridad que no emane expresamente de ella" (art. 3) ${ }^{692}$. Este mismo principio pasará a la Constitución francesa de 1791, igualmente en el artículo $3^{\circ}$, como también a los constitucionalismos de influencia francesa, como la Constitución española de 1812, la portuguesa de $1822^{693}$, así como la brasileña de 1824 .

Es intrínseco a la génesis del Estado Moderno, según Zília Osório de Castro, la centralización desde la visión del poder, lo que va a provocar una confrontación entre el Estado y la Iglesia. En Portugal, para aquella autora, se notarán dos fases de aquella relación: la primera en la fase pombalina, el paralelismo de poder que ejercía la iglesia rivalizando con el poder del proprio Estado dentro de sus fronteras parecía inaceptable y conflictuosa. Mitigando sobre manera la noción de soberanía del Estado a la época. Ya en la segunda fase, en el ámbito de la concepción liberal vintista el poder religioso será visto como un poder inherente a la concepción misma del Estado, o sea, un instrumento al servicio del Estado. De este modo, el sentimiento religioso defendido en su sacralidad, seria confrontado con una dimensión laica, cuando puesto en el ámbito de la perspectiva política ${ }^{694}$.

Con base en este art. $3^{\circ}$ de la Declaración francesa, podemos conectar con la discusión que venimos antes estableciendo, con base en los estudios del profesor Manuel Hespanha, sobre las permanencias del Antiguo Régimen y las innovaciones liberales que se reflejaron en la Constitución vintista ${ }^{695}$. En flagrante contradicción miramos al art. 26 de la Constitución portuguesa, inspirado en la Declaración francesa, aprobada por la Asamblea Nacional, el 26 de agosto de 1789, que dirá: "La soberanía reside esencialmente en la Nación. No puede por lo tanto ser ejercitada sino por sus representantes legalmente electos. Ningún individuo o corporación ejerce autoridad pública, que no derive de la misma Nación"; y el art. 25, de la

\footnotetext{
${ }^{692}$ DECLARATION DE DROITS DE L'HOMME ET DU CITOYEN (1789), Art. $3^{\text {o }}$ - "Le principe de toute souveraineté réside essentiellement dans Ia nation. Nul corps, nul individu ne peut exercer d'autorité qui n'en émane expressément"

${ }^{693}$ CATROGA, Fernando: Em nome da Nação..., op. cit., p. 27 y ss.

694 "Daí, enfim, a complexidade de uma evolução marcada por tensões mais ou menos profundas a nível ideológico, institucional, político e religioso, encaradas como incidências particularizadas de um mesmo movimento cultural." CASTRO, Zília Osório de: Cultura e Política. Manuel Borges Carneiro e o Vintismo, Volume II, Instituto Nacional de Investigação Cientifica/Universidade Nova de Lisboa, Lisboa, 1990, p. 587.

${ }^{695}$ HESPANHA, A. M.: Guiando a mão..., op. cit., pp. 90 y ss.
} 
misma constitución, en donde se declara la confesionalidad de la Nación portuguesa. Como dirá aquél profesor, la soberanía seguía guardando determinados déficits, como se verá en el ámbito del art. 25, que instituye que: "La Religión de la Nación Portuguesa es la Católica Apostólica Romana. Aunque se permita a los extranjeros el ejercicio particular de sus respectivos cultos" $^{, 696}$. Esta opinión de respetar a los extranjeros la libertad de culto, pero con restricciones, figura en el art. $8^{\circ}$ de un proyecto constitucional que aparece en el año de 1821, firmado por un Lusitano Filántropo ${ }^{697}$.

Destacadamente se nota un poder externo que se inmiscuye en la máxima del art. 26; la Religión Católica Apostólica Romana es presentada por la misma constitución como el elemento, o corporación, que vulnera a la autosuficiencia de la soberanía de la Nación. Así también pasa con la ciudadanía, dado que en el art. 19 de la Constitución vintista se fijaba como uno de los principales deberes de esta, el de venerar a la Religión ${ }^{698}$. No que con esto llegase a desnaturalizar a los no católicos ${ }^{699}$. Pero, no era solamente en esta materia donde la soberanía cedía paso. En el art. $8^{\circ}$, se preveía ceder la apreciación de los abusos de la libertad de imprenta en materia religiosa a la censura episcopal. Como también se preveía celebrar, para marcar el inicio de los trabajos de las asambleas electorales, una misa al Espíritu Santo (art.52), como en los demás actos electorales (art. 70). Se instituye, además, que en el juramento -sobre los Santos Evangelios- del rey, de los diputados electos y de los Consejeros de Estado, por encima de todo, estaba el compromiso de mantener la Religión Católica Apostólica Romana (arts. 78, 126 y 166). Además, la Constitución empieza en su preámbulo con la invocación del "Nombre de la Santísima e Indivisible Trinidad"700. Y en donde el rey tendrá el tratamiento de "Majestad Fidelísima" en el art. 127.

\footnotetext{
696 "Esta disposição he, não só incompatível com o principio da tolerância, principio essencial em um systema verdadeiramente constitucional, mas além d’isso inexequível. Ninguém sobre a terra tem direito para prescrever aos cidadãos portugueses que pensem de tal ou tal modo em matéria de religião. Ninguém lhe pode prohibir quaisquer praticas que se chamem religiosas, quer profanas, uma vez que elas não ofendam nem a liberdade, nem a propriedade, ou o bom nome de alguém.” FERREIRA, Silvestre Pinheiro: Breves observações sobre a Constituição Política da Monarchia Portugueza decretada pelas Cortes Geraes Extraordinarias e Constituintes reunidas em Lisboa no anno de 1821, Rey E. Gravier, Paris, 1837, p. 9.

697 "Sobretudo estabeleçamos boa educação e instrução, pois que os fins procedem dos princípios: e como felizmente professamos a Religião Catholica Romana, as mais sejam toleradas quanto aos estrangeiros sem sinal exterior de culto, mas o publico sustente só aquela e os seus ministros." Fantasias Constitucionaes, seguidas por algumas reflexões, da Razão, e da Experiência, Publicadas por um Lusitano Filantropo, Imprensa Nacional - Com licença da Comissão de Censura, Lisboa, 1821, p. 5.

${ }^{698}$ Silvestre Pinheiro Ferreira ve a estos consejos de moral como impropios de la legislación. FERREIRA, Silvestre Pinheiro: Breves observações sobre a Constituição Política da Monarchia Portugueza decretada pelas Cortes Geraes Extraordinarias e Constituintes reunidas em Lisboa no anno de 1821, Rey E. Gravier, Paris, 1837, p. 17; está republicada en HESPANHA, A. M. y SILVA, Cristina Nogueira da (dir.): Fontes para a história constitucional portuguesa, Faculdade de Direito da UNL, Lisboa, 2004 - Sitio de la Biblioteca Nacional, Lisboa.

${ }^{699}$ HESPANHA, A. M.: Guiando a mão..., op. cit., pp. 90 y ss.

${ }^{700}$ Para Silvestre Pinheiro Ferreira "esta invocación es incongruente de la parte de una Asamblea Legislativa que no pretende derivar su poder del llamado derecho divino; y es inútil, porque no influye en el cumplimiento de la
} 
La fórmula de sanción a las leyes dada por el rey, prevista en el art. 113: "Don F... por la gracia de Dios y por la Constitución de la Monarquía (...)", hacía que "se incluyera en la titulación regia una perturbadora referencia a la doble origen y legitimidad del poder real" ${ }^{, 701}$. Era igualmente perturbador el hecho de que en el art. 31 se estableciese que la dinastía reinante era la Serenísima Casa de Braganza. Esta doble definición de donde proveía la soberanía en dicha constitución, hizo con que Silvestre Pinheiro Ferreira, un destacado publicista portugués, hiciese la siguiente critica:

"Não se achando os monarcas colocados no alto emprego que ocupam por efeito duma graça mais especial da divindade do que qualquer outro funcionário público; não achamos razão para se conservar no regime constitucional esta cláusula do absolutismo. No antigo sistema ela significava que não era pela vontade da nação, mas só por uma especial determinação da divindade, e dela imediatamente, que os monarcas haviam recebido o seu poder. Mas em uma constituição que assenta no principio da soberania do povo aquela frase ou é absurda, ou absolutamente ociosa ${ }^{702}$."

Aunque el hecho de no ser católico el rey, no estaba expresamente previsto entre los impedimentos de acceso al trono, como está el hecho de que fuera extranjero ${ }^{703}$. Sin embargo, la confesionalidad del Estado portugués rendía también a éste partes del poder en materia religiosa, como el establecimiento del Patronato, que permitía presentar los obispos y controlar algunos beneficios eclesiásticos, reglamentado en el art. 123, V. También reservaba al rey el privilegio de conceder el Beneplácito regio, otorgando o negando la eficacia en el reino a cualquieras decretos conciliares, cartas papales o constituciones eclesiásticas, art. 123, XII. Pero, al final el artículo $10^{\circ}$ de la Declaración de Derechos del Hombre y del Ciudadano de 1789 no será transpuesto de todo al texto portugués vintista. Aquél artículo declara que: "Nadie debe ser inquietado por sus opiniones, incluso religiosas, en tanto que su manifestación no altere el orden público establecido por la ley”. Más o menos una síntesis de éste artículo se puede divisar en el art. 25 de Constitución de 1822.

Como ya destacamos en el momento que discutimos sobre el concepto de ciudadanía en la Constitución portuguesa, el término "ciudadano portugués" trajo algunas incertezas y temores de algunos diputados, principalmente brasileños, pero no solamente, de que las poblaciones autóctonas de los cuadrantes del Imperio pudiesen quedar fuera de la declaración,

constitución”. FERREIRA, Silvestre Pinheiro: Breves observações sobre a Constituição Política da Monarchia Portugueza decretada pelas Cortes Geraes Extraordinarias e Constituintes reunidas em Lisboa no anno de 1821, Rey E. Gravier, Paris, 1837, p. 1; está republicada en HESPANHA, A. M. y SILVA, Cristina Nogueira da (dir.): Fontes para a história constitucional portuguesa, Faculdade de Direito da UNL, Lisboa, 2004 - Sitio de la Biblioteca Nacional, Lisboa.

701 Ídem, p. 91.

${ }^{702}$ FERREIRA, Silvestre Pinheiro: Breves observações..., op. cit., p. 17.

${ }^{703}$ HESPANHA, A. M.: Guiando a mão..., op. cit., pp. 91 y ss. 
formalmente universalizante, del texto constitucional. Provocando, por lo tanto, el principio de la incerteza por parte de las poblaciones nativas acerca de la ciudadanía y de la nacionalidad, pues que el texto constitucional no hacía clara diferenciación entre una u otra definición.

Nos dirá Cristina Nogueira da Silva que, al declarar la religión católica como religión oficial del Estado, y al omitir los problemas relacionados con el pluralismo religioso de las sociedades ultramarinas, el texto constitucional portugués conducirá a una serie de indefiniciones e incertezas existentes alrededor de la propia definición de ciudadanía y de la nacionalidad del universo de las poblaciones autóctonas del ultramar portugués, no católicas. A pesar de que hubiese adoptado como criterio para fijar la ciudadanía el ius solis en detrimento del ius sanguinis ${ }^{704}$.

Está claro que aquí no buscaremos tratar todas y cada una de las partes y problemas del Imperio portugués en el tema de la ciudadanía relacionada con el problema de la confesionalidad del Estado, sino que, por el contrario, tenderemos a redefinir y direccionar la discusión para lo que toca a la parte americana del Imperio, sobre todo Brasil.

La discusión que se generó entre juristas y políticos en la época de los trabajos constituyentes dejaba claro que sería imposible deducir del texto constitucional las nociones claras de quien era ciudadano, extranjero u otra clase de individuos que residía dentro de las fronteras del imperio. Principalmente por el simple hecho de que la naturaleza y la connotación civilizacional del concepto de ciudadanía del siglo XIX eran demasiado elitista para una real inclusión. Además, el concepto de "Nación", para tales juristas y políticos, era la de una asociación voluntaria, un conjunto de individuos unidos por la adhesión de un mismo "contrato social", aunque no se llevase en cuenta el color de la piel, la cultura o la religión ${ }^{705}$. Esto estaba en los discursos, pero era muy diferente en la práctica. Silvestre Pinheiro Ferreira al analizar el art. 21 de la Constitución portuguesa dirá que hacer diferencia entre la fruición o no de los derechos civiles por nacionales y extranjeros, sería inútil, dado que todos deben tener estos derechos. Pero, en cuanto a los derechos políticos...

\footnotetext{
${ }^{704}$ SILVA, Cristina Nogueira da: Liberdade e tolerância religiosa: “portugueses não católicos" no ultramar do século XIX, Historia Constitucional (revista electrónica), n. 8, 2007. http://hc.rediris.es/08/index.html, p. 42. Además, los problemas relacionados a la ciudadanía en este período fue discutido ampliamente en SILVA, Cristina Nogueira da: A cidadania nos Trópicos. O Ultramar no constitucionalismo monárquico português (c. 1820-1880), Dissertação de doutoramento apresentada à Universidade Nova de Lisboa (Faculdade de Direito), Lisboa, 2004, polic. A cerca de la administración portuguesa en África, principalmente en Angola, véase el trabajo de SANTOS, Catarina Madeira: Um governo “polido” para Angola, reconfigurar dispositivos de domínio (1750-c. 1800), Dissertação de doutoramento apresentada à Universidade Nova de Lisboa (Faculdade de Ciências Sociais e Humanas), Lisboa, 2005, polic.

${ }^{705}$ SILVA, Cristina Nogueira da: Liberdade e tolerância religiosa..., op. cit., pp. 42 y ss.
} 
"A sua importância é tal, que seria barateá-los conferir o exercício deles a alguém, só porque nasceu em tal, ou tal pais, e de tais, ou tais pessoas. Estas circunstâncias não tem ligação alguma com as condições de capacidade. Outras são as provas que a lei deve exigir, quer dos nacionais, quer dos estrangeiros, para eles poderem exercer aqueles direitos políticos ${ }^{706}$."

Además, Silvestre Pinheiro Ferreira, en el Titulo II (De los Derechos Civiles), Capítulo I (De las Garantías Individuales), del Proyecto de Ley Fundamental de su autoría, se pronuncia de este modo sobre la libertad de conciencia:

"Art. 17 - Em virtude do direito de liberdade, e nos termos do artigo 13, é licito ao cidadão: paragrafo I. - Professar quaisquer doutrinas religiosas e praticar quaisquer atos de culto externo, segundo os ditames da própria consciência ${ }^{707}$.”

Al más puro estilo revolucionario francés, el publicista portugués propone una libertad de conciencia. Y de una manera más tolerante, en el proyecto de Leyes Orgánicas, en la Parte I, Capítulo V (De la Naturalización de los Extranjeros), en el art. 478, trata del proceso de naturalización de los extranjeros ${ }^{708}$, lo que está bastante al estilo liberal. En realidad, "la Nación portuguesa era por ellos (juristas y políticos) identificada desde un registro doble, como un contrato, pero también como una comunidad orgánica, un conjunto de personas ligadas por la misma lengua, cultura, genealogía y religión. Era también una comunidad afectiva, basada en los lazos que ligaban los ciudadanos portugueses a la comunidad, privilegiando los sentimientos de amor, fidelidad e implicación moral, facilitados por la convivencia histórica e intergeneracional. En el Ultramar, en donde vivían personas con hábitos, costumbres, religión y razas diferentes, no era fácil saber quién era o no era portugués",709.

Como ya pudimos constatar, el modelo constitucional en materia de confesionalidad había sido el modelo gaditano, aunque bien más intolerante que el texto portugués. Era así, porque Portugal tiene una construcción histórica diferente de la española, como se puede imaginar, como también es importante resaltar los tratados de 1810 firmados cuando del desembarco del rey D. Joao VI, entonces príncipe regente, con Inglaterra, que preveía la libertad de culto para los ingleses en el territorio del imperio portugués, destacadamente en Brasil, en donde se encontraba la Corte en estos momentos. El Tratado de Amistad y Alianza

\footnotetext{
${ }^{706}$ FERREIRA, Silvestre Pinheiro: Breves observações..., op. cit., pp. 7 y 8.

${ }^{707}$ FERREIRA, Silvestre Pinheiro: Projeto de Código Político para a Nação Portugueza, (Ministro de Estado honorário, sócio da Academia das Sciencias de Lisboa e correspondente do Instituto de França), Em Casa de Rey e Gravier e de J. P. Aillaud, Paris, 1838, p. 6.

708 Ídem, p. 126.

${ }^{709}$ SILVA, Cristina Nogueira da: Liberdade e tolerância religiosa..., op. cit., pp. 42 y ss. Véase también en SOBRAL, José Manuel: "O Norte, o Sul, a raça, a nação - representações da identidade nacional portuguesa (séculos XIX-XX)”, in Análise Social, Vol. XXXIX, n 171, 2004, pp. 277 e ss.
} 
entre Portugal y Gran Bretaña garantizaba que el Tribunal de la Inquisición continuaría sin tener jurisdicción sobre la porción americana de los dominios portugueses y que los vasallos británicos seguirían gozando de las exenciones ya pactadas, y previstas en el art. $5^{\circ}$ del Tratado firmado en $1654^{710}$. Entretanto, es el Tratado de Comercio y Navegación, también de 1810, la norma que garantizaba la libertad de conciencia a los súbditos de su majestad británica, con la siguiente dicción:

Art. XII - "Sua Alteza Real O Príncipe Regente de Portugal declara e se obriga no seu próprio Nome, e no de Seus Herdeiros e Sucessores, a que os Vassalos de Sua Majestade Britânica residentes nos seus Territórios, e Domínios não serão perturbados, inquietados, perseguidos, ou molestados por causa da Sua Religião, mas antes terão perfeita liberdade de Consciência, e licença para assistirem, e celebrarem o Serviço Divino em honra do Todo Poderoso Deus, quer seja dentro de suas Casas particulares, quer nas suas particulares Igrejas, e Capelas, que Sua Alteza Real agora, e para sempre, graciosamente lhes concede a permissão de edificarem, e manterem dentro dos seus domínios. (...) De mais estipulou-se, que nem os Vassalos da Grande Bretanha, nem outros quaisquer Estrangeiros de Comunhão diferente da Religião Dominante nos Domínios de Portugal, serão perseguidos, ou inquietados por matérias de Consciência tanto nas Suas Pessoas como nas Suas Propriedades, em quanto eles conduzirem com Ordem, Decência, e Moralidade, e de uma maneira conforme aos usos do País, e ao Seu Estabelecimento Religioso, e Político ${ }^{711}$."

También en este Tratado, que preveía reciprocidad para los ciudadanos portugueses en materia religiosa en Gran Bretaña, cuenta igualmente con una parte en donde describe la apariencia que debía tener la iglesia de fe protestante y prohibía el uso de las campanas para marcar la hora de los servicios religiosos. Además, contaba el art. XII de una parte penal, en donde se describía las infracciones en materia religiosa y las respectivas penas a ser aplicadas, de acuerdo al caso.

\footnotetext{
${ }^{710}$ CARTA DE LEI DE 26 DE FEVEREIRO DE 1810 - Ratifica o Tratado de Amizade e Aliança entre o Príncipe Regente de Portugal e El Rey do Reino Unido da Grande Bretanha e Irlanda, assinado no Rio de Janeiro a 19 desde mês e ano. Art. IX - Não se tendo até aqui estabelecido, ou reconhecido no Brazil a Inquisição, ou Tribunal do Santo Officio, Sua Alteza Real O Príncipe Regente de Portugal guiado por uma illuminada e liberal Politica aproveita a opportunidade que Lhe offerece o Presente Tratado, para declarar espontaneamente no Seu Próprio Nome, e nos Seus Herdeiros e Successores, que a Inquisição não será para o futuro estabelecido nos Meridionaes Domínios Americanos da Coroa de Portugal. Sua Majestade Britannica em consequência desta Declaração da Parte de Sua Alteza Real o Príncipe Regente de Portugal, se obriga da Sua Parte, e declara, que o Quinto Artigo do Tratado de mil seiscentos cincoenta e quatro, em virtude do qual certas Isenções da Autoridade da Inquisição eram concedidas exclusivamente aos Vassallos Britannicos, será considerado como nullo e sem ter efeito nos Meridionaes Domínios Americanos da Coroa de Portugal. E Sua Magestade Britânica consente que esta abrogação do Quinto Artigo do Tratado de mil seiscentos cincoenta e quatro, se estenderá também a Portugal, no caso que tenha logar a abolição da Inquisição naquele País por Ordem de Sua Alteza Real o Príncipe Regente, e geralmente a todas as outras Partes dos Domínios de Sua Alteza Real, onde venha a abolir-se para o futuro aquelle Tribunal.

${ }^{711}$ CARTA LEI DE 26 DE FEVEREIRO DE 1810 - Ratifica o Tratado de Comercio e Navegação entre o Príncipe Regente de Portugal e El'Rey do Reino Unido da Grande Bretanha e Irlanda assinado no Rio de Janeiro aos 18 deste mês e ano.
} 
Así que, en caso de incumplimiento, por parte de los ciudadanos británicos, con el deber de respetar a la religión oficial del Estado, estaban previstas varias puniciones. Aunque los mismos tratados firmados entre el rey portugués y el rey británico preveían la extraterritorialidad para los ciudadanos británicos, esto es, tendrían jueces y jurisdicción propios. Entretanto, en caso de que hagan proselitismo, los británicos que así delinquieren, podrán ser mandados salir del país, en donde la ofensa fuera cometida. También preveía que los que en público se portaran con falta de respeto o con improbidad con los ritos y ceremonias de la Religión católica dominante, les será llamada la Policía Civil, que podrá castigar con multas o prisión domiciliaria. Y en caso de que la ofensa sea muy grave, y tan abultada que perturbe la tranquilidad pública, y ponga en peligro la seguridad de las Instituciones de la Iglesia, y del Estado, establecidas por las leyes, para estas personas que fuesen autoras de tales ofensas, en existiendo pruebas de hecho, podrán ser mandadas salir de los dominios de Portugal. Se pacta también, de forma recíproca, que los portugueses les permitirán a los británicos que lleven a cabo sus funerales, en sitios convenientes para esto, sin que se les perturben, por motivo cualquiera, los dichos funerales o las sepulturas de los muertos ${ }^{712}$.

En las Bases de la Constitución portuguesa, aprobadas en 1821, ya preveía en su art. 17 que la Religión Católica Apostólica Romana seria la religión de la Nación portuguesa, discutida y aprobada en la sesión de las Cortes constituyentes del día 17 de febrero de 1821. También en esta misma sesión se decreta la suspensión de la Orden de Expulsión de los judíos, decretada por el Rey D. Manuel, en diciembre de 1496 y ejecutada al principio de la cuaresma de 1497. Las Cortes decretan además, que de esta fecha en adelante se quedan renovados, confirmandos y puestos para que vigoren todos los derechos, facultades, libertades y privilegios que los primeros reyes del reino de Portugal concedieron a los judíos, y que constaban en las Ordenaciones Alfonsinas L. $2^{\circ}, n^{\circ}$. 7. Este decreto también es extensivo a los moros expulsados de $_{\text {Portugal }}^{713}$. De modo que, en las Cortes constituyentes portuguesa, al contrario de lo que se pueda pensar, muchos diputados propugnaron por la conciliación entre derechos políticos y libertad religiosa, así que no imperaba la intolerancia religiosa completamente, como veremos de las dicciones de los señores diputados.

Puesto para ser discutido en el pleno, el art. 25 del proyecto de la Constitución, en la sesión del día 3 de agosto de 1821, causó entre los diputados numerosas cuestiones sobre ser tolerante o intolerante en relación a los extranjeros, principalmente por estar previsto en los artículos precedentes la posibilidad de darse la ciudadanía también a extranjeros. El primero de

\footnotetext{
712 Ídem, art. XII, del tratado.

${ }^{713}$ DCGECNP, Sesión del día 17 de febrero.
} 
los diputados a pronunciarse fue el Sr. Trigoso; dicho diputado veía como correcta la declaración de que sea la religión oficial del Estado la Católica Apostólica Romana, pero, aludía a una cuestión de derecho, en donde se declarase que la Religión Católica es y será la religión de la Nación portuguesa. Mientras tanto, este mismo diputado era de opinión que la segunda parte del artículo no debía entrar en la Constitución, en donde se preveía libertad de conciencia a los extranjeros. Y de modo a no causar perjuicios ni a la Religión ni a la sociedad, se debía reglamentar dicha libertad a los extranjeros, puesto que sería una temeridad permitir " $a$ todos os estrangeiros o exercício particular dos seus respectivos cultos, sem ao mesmo tempo estabelecer leis regulamentares que restrinjam o exercício destes cultos particulares" ${ }^{\text {714 }}$. Otro diputado, el Sr. Obispo de Béja, apreciaba que una nación no estaba obligada a permitir a los extranjeros el ejercicio de los respectivos cultos, pero, matizaba que existe esta obligación prevista en tratados y concesiones legales que permitan a los extranjeros el libre ejercicio de su culto. Además, opinaba que la religión católica era una religión de concordia, desde su condición de obispo, así va a decir que:

"Não me oponho à tolerância, pelo contrario sempre sustentei que a tolerância civil se ajuste com o espirito, e máximas do cristianismo. A religião cristã proscreve os erros, mas ela nos ensina a suportar os errantes, pois a sua base é a caridade. Não é uma religião de discórdia, como falsa, e temerariamente Rousseau a descreve no seu contrato social: pelo contrario ela tende a reunir todos os homens, ensinando-nos que todos são irmãos, impondo-nos uma rigorosa obrigação de obedecer às autoridades legítimas, ainda que sejam heterodoxas, e perseguidoras. Ela não quer conquistar senão pela persuasão ${ }^{715}$."

Opinión interesante trajo el ilustrísimo diputado, Sr. Antonio Pereira; primero con una constatación asaz importante de que al declarar como Religión oficial la Católica, se deducía que todo portugués debiese profesar dicha religión, y en segundo lugar, igualmente se debe inferir que ningún portugués puede adoptar otra religión diferente de esta, que la Nación autoriza. Así que pensaba que el artículo debiese ser redactado de forma aún más intolerante, con la siguiente dicción:

“A Religião da Nação Portuguesa é a Católica Apostólica Romana, deixa conseguintemente de ser cidadão Português aquele que a não professar; poderá, contudo, permitir-se aos estrangeiros o exercício particular dos seus respectivos cultos: desta maneira o artigo fica mais completo, e expressivo, e a Religião mais eficazmente garantida ${ }^{716}$."

Para el Sr. Diputado Luis Monteiro, un problema de proporción mucho más grande se preveía en la relación de declarar ciudadano al extranjero naturalizado y la declaración de

\footnotetext{
${ }^{714}$ DCGECNP, Sesión del día 3 de agosto de 1821, pp. 1771 y 1772.

${ }^{715}$ DCGECNP, Sesión del día 3 de agosto de 1821, p. 1772.

${ }^{716}$ DCGECNP, Sesión del día 3 de agosto de 1821, p. 1773.
} 
confesionalidad de la Nación. Dado que la ecuación no parecía tan simple, como opinaban algunos diputados, puesto que, contemplar a los extranjeros y contentar a la religión en el texto constitucional, resultaba asaz difícil, de modo que juzgaba que esta discusión debía ser aplazada:

"Parece que este artigo devia ficar adiado, porque tem conexão com o outro, porque, por exemplo, se admitirem como cidadãos Portugueses os filhos dos estrangeiros, é preciso depois combinar se os filhos dos Protestantes criados na Religião de seus pais hão de obrigar-se à força a seguirem a Religião Católica; ou se se devem excluir da sociedade. Temos Portugueses nas possessões da África com diferentes seitas, ora se todos estes homens são tidos por vassalos Portugueses, é necessário ver se havemos de prescindir deles serem Portugueses todos, ou se havemos de prescindir da Religião ${ }^{717}$."

Es evidente que el diputado no pretendía poner a prueba el nivel de tolerancia como se infiere de su siguiente interevención, pero trae una alerta interesante sobre el conflicto entre declarar ciudadano a los extranjeros y excluir de la ciudadanía por la declaración de que fuese la religión oficial la Católica Romana.

Una posición mucho más sensata, defendió el Sr. diputado Castello Branco, un eclesiástico, que pensaba ser tarea difícil la posición de legislador al tener que conciliar las leyes políticas con las materias religiosas:

“Nós somos Legisladores políticos, e, entretanto somos Legisladores políticos de uma nação que professa, e tem jurado professar a religião Católica Apostólica Romana; por consequência incumbe-nos uma grande obra, e vem a ser conciliar as leis politicas, e as que houvermos de fazer, com essa mesma religião, conciliar os interesses políticos da nação, que por uma parte somos obrigados a promover, com essa mesma religião, que por outra parte somos obrigados a sustentar intacta; a obra algum tanto é dificultosa, mas tudo se pode conciliar ${ }^{718}$."

Entretanto el mismo diputado veía algo de dificultad en aquella tarea de conciliación de leyes políticas con las materias religiosas, "principalmente quando já vi enunciar uma lei penal neste mesmo Congresso; e vinha a ser que todo aquele que não abraçasse esta religião não poderá ser cidadão" ${ }^{, 719}$. Opinaba el mismo diputado que este principio va a chocarse en su integralidad a los principios políticos: "não dá lugar na Constituição a admitir no nosso grêmio cidadãos estrangeiros, quando eles se acharem nas circunstancias em que a Constituição os admite ${ }^{, 720}$. Y acepta que es un punto de discusión política muy interesante, y que nadie puede desentenderse de las ventajas del asunto:

\footnotetext{
${ }^{717}$ DCGECNP, Sesión del día 3 de agosto de 1821, p. 1773.

${ }^{718}$ Ibídem.

${ }^{719}$ Ídem, p. 1774.

${ }^{720}$ Ibídem.
} 
"Ora este estrangeiro que nós vamos admitir podem ter sido criados em outra religião. Devemos nós obriga-los a largar a religião de seus pais? Nós quereríamos exclui-lo do nosso seio? Iriamos pôr uma barreira entre nós, e todos os cidadãos para admitir aqueles estrangeiros que podem aumentar a nossa população, a nossa indústria, os interesses da nação, as forças da sociedade? Nós iriamos cortar pela raiz todos os bens que dali pode resultar à sociedade ${ }^{721}$."

Va a declarar el mismo diputado que intuí de las declaraciones de los ilustres miembros de la Asamblea, aquellas afirmaciones que hizo más arriba. Además, explica que aunque sea ministro de la misma iglesia a que se atribuí la condición de religión del Estado, eso no le quita la conciencia de que también es el legislador designado para desempeñar las funciones a que fue llamado por la Nación. Así que ni todos los diputados estaban seguro de que la intolerancia religiosa, que se colisionan con los derechos políticos, debiesen ser adoptada. Al final se quedó aplazada la discusión en esta sesión acerca del art. 25.

En la sesión del día 6 de agosto de 1821, las discusiones sobre si se debía adoptar o no la tolerancia religiosa y la libertad de conciencia fueron muy duras. La primera y la segunda parte del artículo 25 fueron bastante debatidas. En la primera parte, en donde se declaraba la Religión de la Nación portuguesa la Católica Apostólica Romana suscitaba doble discusión: primero que decretar la libertad de conciencia ${ }^{722}$ y no establecer como fe protegida la Católica iba en contra del mandato recibido por los diputados, puesto que juraron lo establecido en las Bases de la Constitución que mantendría la Religión Católica. Y en segundo lugar si se debía tratar de la materia religiosa, principalmente sobre la tolerancia religiosa concedida a los extranjeros si en ámbito constitucional o en ley reglamentaria. A lo que se refiere a la segunda parte del artículo, en el cual se admite la tolerancia religiosa a los extranjeros, las discusiones iban en el sentido de que si se había atribuido ya en los Tratados de 1810 con Inglaterra la libertad de todos los cultos, por lo tanto, no era necesario discutir el tema ${ }^{723}$. Por otro lado muchos diputados, principalmente el Obispo de Béja, opinaban que no se admite la libertad de conciencia a los

\footnotetext{
${ }^{721}$ Ídem, p. 1774.

${ }^{722}$ DCGECNP, Sesión del día 6 de agosto de 1821, p. 1803. El diputado Trigoso afirmaba que no se debía ser ni totalmente intolerante ni completamente tolerante, y además afirmaba: "Os Índios devem ser catequisados, e ainda que sejam sujeitos ao império português a Constituição mesma no artigo 180, manda prover a sua conversão, e civilização. Os espanhóis tem índios nas suas Américas, e apesar disto os espanhóis decretaram que a Religião Católica Apostólica Romana era a única do país. Em quanto aos estrangeiros nós temos tido estrangeiros que tem filhos e que se tem naturalizado; nada mais resta que continuar-se a seguir acerca deles, o que até agora se tem praticado."

${ }^{723}$ DCGECNP, Sesión del día 6 de agosto de 1821, p. 1804. Deputado Soares Franco - "Apoio, pois, o artigo como está, e tiraria a palavra particular, dizendo - o exercício de sues respectivos cultos. - O tratado de 1810, diz - com tanto que não façam prosélitos, e se ofenda a tranquilidade do Estado - ela está consignada nos tratados; por consequência, não é preciso por ora, que se estabeleça; e quando for preciso não tira que ela seja posta numa lei constitucional; torno a repetir, que não sou do voto que se permita a tolerância, ou o mudar de Religião; porque em fim acaba de jurar-se a Religião Católica que é a verdadeira (...)."
} 
portugueses $^{724}$, y si estos cambiasen de religión se les debían punir con la perdida de los derechos de ciudadano, afirmación que fue contestada por otros diputados. La evocación a la historia de Portugal era algo recurrente en las discusiones, plagadas de ejemplos de tolerancia, y de las desgracias advenidas, cuando se optó por la intolerancia, con la expulsión de los judíos y moros. Ejemplifica el diputado Franzini con un hecho de la historia reciente (en su época) de Portugal de tolerancia, cuando dice:

"Nada direi a favor da tolerância depois de se ter expendido esta matéria tão sabiamente; entretanto vou a fazer uma reflexão que adoptada esta doutrina em contrario retrogradaria o sistema de princípios liberais; porque nunca vi que em Portugal deixassem de ter empregos públicos homens mesmo de outra religião; $e$ ainda ha pouco nós acabamos de ver um Vice-Rei de Portugal Protestante. Agora o decretar que qualquer ficaria excluído de todos os empregos uma vez que não praticasse a Religião Católica, seria no meu modo de pensar o mais absurdo ${ }^{725}$."

Así que muchas fueron las voces a favor de la libertad de conciencia y por la tolerancia religiosa, con sobrados argumentos históricos, tanto de la tradición portuguesa de ser tolerante como de las naciones que al momento eran ejemplo de adopción de la tolerancia y la prosperidad que deprendía de esta actitud del Estado, tales como Inglaterra, Estados Unidos de América, Holanda, Francia etc. Pero, en dos momentos se llamó la atención sobre las poblaciones autóctonas, una en el habla del diputado Trigoso y otra en la habla del diputado Borges Carneiro. Nos cuenta Cristina Nogueira, en análisis a estos mismos documentos, que “además de la hipótesis, ambiciosa, de la libertad religiosa, dos otras orientaciones surgieron en las Cortes vintistas. Una de ellas fue la tolerancia religiosa: por la cual se debía instituir la tolerancia relativamente a los protestantes y a los infieles o 'Étnicos', a los Moros y a los Judíos $^{726}$. A las otras orientaciones, por el contrario, se manifestó favorable a la exclusión de las poblaciones nativas, habiendo sido expresamente asumida por un diputado cuya opinión era de que las opciones religiosas debían valer como criterio de acceso a la ciudadanía portuguesa"727.

Estos debates continuaron en la sesión del día 8 de agosto para definir más específicamente la libertad de conciencia para los portugueses y sí era motivo de exclusión de la ciudadanía que el portugués abandonara la religión católica. El primer diputado a manifestarse fue el Sr. Pereira do Carmo que estaba a favor de que se concediese a los

\footnotetext{
${ }^{724}$ Ídem, p. 1805. Declara el Obispo de Béja, diputado de las Cortes que: "Do espirito do artigo 25 da Constituição se conclui, que aqueles Portugueses que abandonarem a Religião dominante, ou negarem algum dos seus dogmas não devem gozar dos direitos de cidadão."

${ }^{725}$ DCGECNP, Sesión del día 6 de agosto de 1821, p. 1805.

${ }^{726}$ Ídem, p. 1801, Dep. Borges Carneiro: "Isto digo dos Protestantes, a quem chamamos hereges, é aplicável aos infiéis, quero dizer Étnicos, Mouros, e Judeus. Não basta proscrever-nos a ideia de obrigá-los à força, e com coação física a seguir a nossa Religião".

${ }^{727}$ SILVA, Cristina Nogueira: "Liberdade e tolerância religiosa...", op. cit., p. 43 y 44. DCGECNP, Sesión del día 3 de agosto de 1821, p. 1773, Dep. Antonio Pereira.
} 
extranjeros la tolerancia civil. Luego otro diputado, el Sr. Bispo de Béja, suscitó la cuestión acerca de los portugueses que abandonasen la religión católica, si se debía considerarlos ciudadanos con el goce de todos los derechos o no. Además, explica que no se debía confundir tolerancia civil con protección. La primera, consistiría en no perseguir a los delitos de conciencia; la segunda, consistiría en defender a la religión de los insultos. Por lo tanto, pliega la pena de perdida de los derechos políticos a los portugueses que abandonasen a la fe dominante. Y por encima de todo, levanta otra cuestión fulminante: si lo que abandona la fe católica no está privado de la ciudadanía, tampoco estaría el rey que abandone la fe de su corona $^{728}$. Para corroborar a las ideas un tanto reaccionarias del obispo, pide la palabra el diputado Pinheiro de Azevedo, que era contrario a que se declarase directa o indirectamente la libertad de conciencia. Que sería lo mismo decretar que cualquier uno que no siga la religión dominante pueda ser ciudadano portugués. Argumenta, además, que estaría en contra de lo que estaba establecido en las Bases constitucionales. Y sigue sus imprecaciones diciendo que las naciones que decretaron la libertad de conciencia eran porque ya la tenían antes de decretar, y cita los ejemplos de Estados Unidos de América, Holanda e Inglaterra. Compara también la situación de los portugueses a de los españoles, que no decretaron la libertad de conciencia: “ $A$ liberdade de consciência iria encontrar a opinião pública; causar grandes desgostos à nação, e desacreditar o congresso" ${ }^{, 729}$.

En la misma sesión del día 8 de agosto, otro diputado, el Sr. Moura, es de la que se debe "combinar a liberdade de pensar com os interesses políticos do Estado"730. Además, defiende que el artículo 25 sea aprobado sin apenas alteraciones. Y sigue diciendo que la libertad de consciencia, o la libertad de pensar y de adoptar cualquier opinión en materia religiosa, es un derecho imprescindible e ilimitado que nadie puede contestar. En cuanto a la libertad de culto esto puede ser objeto de una legislación específica. Está convencido, además, que es verdad que proscribir el culto público de todas las religiones y adoptar un solo culto como dominante y sustituir la intolerancia civil por la intolerancia religiosa no sería ni conforme a la razón, ni a la justicia, ni a la política. Su receta para lo que denomina "indifenrentismo religioso",731 sería proclamar la tolerancia de todos los cultos.

En réplica a aquellas ideas, el diputado Correa de Seabra es de la opinón de que la tolerancia religiosa no debería ser sancionada en un artículo constitucional. Y argumenta que el decretar dicha tolerancia no estaba en la delegación que la Nación les había concedido y jurada

\footnotetext{
${ }^{728}$ DCGECNP, Sesión del día 6 de agosto de 1821, pp. 1818 y 1819, Diputado Sr. Obispo de Béja.

${ }^{729}$ DCGECNP, Sesión del día 6 de agosto de 1821, p. 1819, Diputado Pinheiro de Azevedo.

${ }^{730}$ DCGECNP, Sesión del día 8 de agosto de 1821, p. 1819, Diputado Moura.

${ }^{731}$ Íbidem.
} 
en las Bases que establecía una religión de Estado. Entretanto, va a admitir que se puede transigir sobre este tema en el futuro, con otras nociones, teniendo la tolerancia por ventaja. Es de la misma opinión del diputado Pinheiro Azevedo, de que Portugal estaría en la misma situación que España, que no sancionó la tolerancia, y las naciones que lo hicieron, era porque se hallaban en unas muy diversas circunstancias. Así que, para este diputado, se debía admitir la necesidad de que vinieran extranjeros para poblar Brasil, y por lo tanto, no se debía ser intolerante con estos. Va a decir, además, que la procuración dada por la Nación mandaba mantener a la religión católica, sin admitir otra religión para los portugueses. Y mandaba excluir de los derechos políticos a todos los que no profesasen la religión católica ${ }^{732}$. Este diputado no veía ninguna violencia al retirar los derechos políticos a los que no fuesen católicos, y cita como ejemplo el no poder nombrar para magistrado al que no esté licenciado, y no ve en eso violencia alguna o coacción a los sentimientos religiosos de cada uno. Y hace referencia de su relativismo a las poblaciones autóctonas del ultramar:

"Vejo objetar contra isso, que nós já de fato temos nos Estados Ultramarinos cidadãos que são gentios, e que não devemos agora por esta clausula da Constituição exclui-los da nossa sociedade; porém não reconheço por cidadãos Portugueses os Tapuias bravios do Brasil, ou os gentios da Costa da África: temos quando muito uma certa dominação sobre os que estão aldeados, que só dura enquanto eles querem. E se se fala desta desgraçada gente deve ser só por nos lembrarmos de cuidar com todo o zelo em os catequizar, e tratar com toda humanidade. Só a religião pode abolir na Europa a escravatura, adoçar os costumes bárbaros do norte, e melhorar os costumes corrompidos dos romanos: só ela, pregadas por ministros pios e zelosos, é quem tem podido tirar da barbárie os Tapuias e Africanos que se tem civilizado, e poderá civilizar o resto se nisso se puser o devido cuidado. Não é com a tolerância, mas só com o ensino da religião que os havemos de habilitar para serem cidadãos portugueses; porque só assim os podemos por em estado de civilização; sem o que não podem fazer parte de uma sociedade civil, em que haja ideias de justiça, amor da pátria, e obediência às leis ${ }^{733}$."

Así que deducimos de la intervención del diputado que su concepto de ciudadanía era bastante restringido para el ultramar, y pasaba además por procesos civilizacionales que incluirían tanto la educación como la religión; esta en cuanto medio ultimo para adquirir la ciudadanía, haciendo parte de la sociedad civil, imbuidos de la idea de justicia, de amor a la patria y obediencia a las leyes como bien prescribía el artículo 19 de la Constitución vintista.

\footnotetext{
${ }^{732}$ Mientras se propugnaba por excluir a los portugueses que abandonasen la religión de los derechos políticos, los ciudadanos portugueses no podían ser expulsos del Reino sino en virtud de ley o sentencia criminal. Esta afirmación se puede encontrar en LOPES PRAÇA: Estudos sobre a Carta Constitucional de 1826 e Acto Adicional de 1852, Coimbra, Imprensa Literária, 1878, p. 158.

${ }^{733}$ DCGECNP, Sesión del día 8 de agosto de 1821, p. 1821, Diputado Correa de Seabra.
} 
Entonces, en las acaloradas discusiones, entre el diputado Abade de Medroes, que irritado con la prolijidad de las cuestiones y extensión de las intervenciones de sus colegas diputados, resuelve sintetizar las cuestiones en el orden del día en la Asamblea constituyente:

"Pregunta-se em primeiro lugar, se os portugueses que não professarem a religião católica, devem gozar dos direitos dos cidadãos: em segundo lugar, se as nações estrangeiras se há de conceder a tolerância de culto, segundo as diferentes religiões: em quarto lugar (no disse la terceira), se é aqui lugar próprio para estabelecer este artigo: e ultimamente, se é melhor, suprimir inteiramente o $\operatorname{artigo}^{734}$."

Concluye dicho diputado que el consentir a los extranjeros el culto de su religión, es antes que nada, una providencia política y que poco tiene que ver con otras cuestiones de orden religioso. Y lo dice así ciertamente pensando en los Tratados de 1810, que fueron nombrados muchas veces en las sesiones de las Cortes.

El Sr. Diputado Vaz Velho, argumenta que está a favor de que en el caso de cambiar de religión, a los portugueses se les deben privar de los derechos políticos. Para ratificar su posición hace referencia al mandato concedido por la Nación en el sentido de proteger a la religión dominante ${ }^{735}$. En este sentido va a manifestarse el diputado Fernandes Thomaz, que levanta la cuestión de permitir a los portugueses la tolerancia religiosa, y piensa que la cuestión no está suficientemente debatida para seguir para la aprobación. Lo que está de acuerdo el Obispo de Bejá. En seguida el diputado Moura vuelve a la carga diciéndose que está en contra de privar de los derechos de ciudadano a los portugueses que cambien de religión.

También otro diputado, el Sr. Guerreiro, suscita algunas cuestiones en el sentido de las discusiones. Además, se declara contrario a que se prive a los portugueses que abrazaren otra religión, que no sea la del Estado, de sus derechos políticos; lo que considera un ataque a la libertad del ciudadano prohibir la mudanza de religión. Amonesta a sus compañeros que es necesario sancionar la libertad de culto aunque no sea lo de la religión dominante. Y así termina diciendo que:

"Concluo daqui que é absolutamente necessário decidir-se esta questão; o interesse da sociedade, e o direito natural exigem que se estabeleça indistintamente a liberdade de exercício particular de qualquer culto religioso. $O$ meio de estabelecer isto é muito fácil, pois basta tirar somente a palavra Estrangeiros; concebendo-se o artigo desta maneira: permite-se o exercício particular de qualquer outro culto religioso ${ }^{736}$."

\footnotetext{
${ }^{734}$ Ídem, p. 1821, Diputado Sr. Abade de Medroes.

${ }^{735}$ Ídem, p. 1822, Diputado Vaz Velho.

736 Ídem, pp. 1822-1823, Diputado Guerreiro.
} 
Por lo tanto, este diputado estaba a favor de la implantación de la libertad de conciencia en el Imperio portugués. Pero, en esta línea de discusión, el diputado Sousa Magalhaes va a decir que los redactores del artículo discutido no quisieron establecer la intolerancia. Además, hace referencia al concordato firmado entre la Santa Sede y Napoleón Bonaparte en 1801 y en la cual, por ser interesante a Francia la buena convivencia política con los protestantes, estos serían tolerados, aunque la religión católica permanecía como religión protegida de la Nación. Y era de opinión que el artículo debía pasar tal cual se encontraba en las Bases de la Constitución. De manera que para los diputados, en su mayoría, se daba el entendimiento de que los extranjeros los serian alijados de la ciudadanía por tener otra religión:

"Que não se segue da disposição do parágrafo, nem se pode seguir, de modo nenhum, que seja necessário a um estrangeiro mudar de religião para obter carta de naturalização ${ }^{737}$."

A esto contesta el diputado Guerrero:

"É certo que em nenhuma parte do projeto da constituição se opõe obstáculo ao concedimento de semelhante carta; mas se em alguma das legislaturas eu fosse deputado, e um estrangeiro me pedisse carta de naturalização, eu não a podia conceder, tendo sido aprovado este parágrafo; e a razão é clara; porque estabelecendo-se que fica permitido aos estrangeiros o exercício particular de seus respectivos cultos, logo o contrario sensu está proibido aos cidadãos portugueses, por paridade da razão não deve ser permitido ou admitir-se qualquer no numero de cidadãos portugueses sem professar a religião católica ${ }^{738}$."

Para rebatir las críticas sobre los impedimentos para que el extranjero consiguiese la carta de naturaleza, el diputado Moura alude al art. 22 de la Constitución, en donde figuraban los requisitos para que un extranjero alcanzase la naturaleza en el Imperio portugués.

"O art. 22 diz que para se conceder carta de naturalização aos estrangeiros concorrerão três requisitos; nenhum deles é a religião; logo os mais artigos da Constituição positivamente, claramente determina que só sejam os requisitos necessários, e não outros, para qualquer estrangeiro obter carta de naturalização ${ }^{739}$.”

El diputado Peixoto, era de la opinión que el artículo quedase como estaba. Pero, en cuanto a la cuestión de que se debía o no perder los naturales portugueses la ciudadanía se abrazase otra religión, él veía la conveniencia y utilidad de atribuir a los extranjeros la ciudadanía, aunque de otros credos, porque ya habían nacido en él, pero esta conveniencia y utilidad no pasaba con el natural del Imperio portugués, dado que sería un escándalo público:

\footnotetext{
${ }^{737}$ Ídem, p. 1823, Diputado Moura.

738 Ídem, p. 1824, Diputado Guerreiro.

${ }^{739}$ Ídem, p. 1824, Diputado Moura.
} 
"Estão em muito diversas circunstancias os Portugueses que abandonam a religião de seus pais, porque são infalivelmente mal vistos dos seus compatriotas; pois que por um ato positivo romperão um vinculo sagrado, que não menos que o civil, os alcançava com os seus concidadãos. É esta a ordem natural das opiniões humanas, que as leis não podem, nem devem destruir ${ }^{740 . "}$

Y viendo el peligro de que se aprobase la libertad religiosa en las Cortes, amenaza el diputado sr. Abade Mendrões:

"Toda nação se escandalizariam se nós permitíssemos a liberdade de consciência. Nós temos prometido manter a Religião Católica Apostólica Romana, e conserva-la ilesa ${ }^{741}$."

Complementa el mismo diputado que causarían aún más escándalo el portugués que largando a su religión pudiese entrar en empleo público. Y finaliza la discusión con la sugerencia del diputado Soares Franco:

"Parece-me que se deve neste artigo acrescentar a palavra e filhos; de sorte que se diga: permite-se com tudo aos estrangeiros e seus filhos. Dizendo e seus filhos $^{742}$, quando estes, querendo-se naturalizar-se, queiram conservar a religião de seus pais, o poderão fazer. Assim ficam tiradas todas as dúvidas ${ }^{743}$."

Por más sensata que pareciese la proposición del diputado, el artículo fue sometido en votación, por encontrarse ya bastante discutido, según el presidente de las Cortes, y fue aprobado tal como estaba propuesto en las Bases de la constitución. Ya vimos antes que a los extranjeros se les permitía, después de conseguida la carta de naturaleza, votar en las elecciones primarias, pero estaba vetado a que estos pudiesen presentarse para diputados, por ejemplo. Se entendía así que el portugués que adoptase otra religión perdería sus derechos políticos de ciudadano $^{744}$. Además, todos los demás naturales del Imperio eran potencialmente ciudadanos, desde que abrazasen la fe católicas, aunque esto no estuviese explícito en el texto constitucional, se desprende de la lectura del art. 19 en donde se establecía la obligación, como uno de los deberes de los ciudadanos portugueses, de profesar la religión católica.

\footnotetext{
740 Ídem, p. 1825, Diputado Peixoto.

741 Ídem, p. 1825, Diputado Abade Mendoes.

${ }^{742}$ El registro civil fue un instrumento de prueba de la nacionalidad que ni todo portugués lo poseía, católicos o no católicos. Solamente en 1878, en Portugal, a través del reglamento de 28 de noviembre se creó un registro civil, solamente para los no católicos. Aunque el gobierno no mandó aplicar de inmediato este reglamento en el ultramar, dado que allí, en muchas provincias solo ha sido instituido en el siglo XX. COELHO, Manuel Trindade: Manual político do Cidadão portuguez, Lisboa, Parceria A M. Pereira, 1906, p. 379 y ss.

743 Ídem, p. 1825, Diputado Soares Franco. Véase más en RAMOS, Rui Manuel Gens de Moura: Do direito português da nacionalidade, Coimbra, Coimbra Editora, 1992. pp. 15-16.

${ }^{744}$ Para ampliar más estas discusión léase en SILVA, Cristina Nogueira da: Liberdade e tolerância religiosa..., op. cit., pp. 45 y ss.
} 


\subsection{El proceso de independencia: adhesión a las Cortes y el desencanto con el movimiento constitucional Luso-brasileño}

Fue la decisión del Príncipe Regente, D. Joao, respaldada por la Armada británica, de trasladar a la Familia Real y todo el aparataje del Estado portugués para Río de Janeiro, juntamente con la Revolución liberal de Oporto, quienes van a configurarse como el origen de la Independencia brasileña. Mucho más que voluntad de recolonizar Brasil, por parte de la Cortes reunidas en Lisboa, y de la voluntad de las élites brasileñas en separarse de hecho del Imperio portugués, fueron los malos entendidos entre ambos bandos lo que al final va a provocar la independencia de Brasil de Portugal, según la posición defendida por Lucia Maria Pereira das Neves ${ }^{745}$.

Muchos autores, como ya tuvimos ocasión de mencionar, son de la opinión de que se trasladó a Brasil no solamente la familia real, sino todo el aparataje del Estado Imperial portugués $^{746}$. La propia Kirsten Schultz habla de una reconstitución de la corte portuguesa en la ciudad de Río de Janeiro. Por lo tanto, el montaje de una maquinaria de Estado era necesaria en la parte americana del imperio para ser la cabeza de un gobierno de amplias dimensiones, y el Príncipe Regente tomará providencias en este sentido ${ }^{747}$. El aparataje de gobierno en la América portuguesa seguía siendo caracterizado por las estructuras del Antiguo Régimen, lo que se revelará un idilio para el ya entronizado D. Joao VI en el momento de las conmociones vividas en la ciudad de Oporto, de cuño liberal ${ }^{748}$. En la coyuntura de las Guerras Napoleónicas ${ }^{749}$ los primeros actos del Príncipe Regente serán: la apertura de los puertos a las naciones amigas, en el 28 de enero de 1808 (cuando desembarca en Salvador de Bahía), y ordenes en el sentido de

\footnotetext{
${ }^{745}$ NEVES, Lucia Maria Bastos P.: Linguagens políticas do conservadorismo na época da Independência do Brasil (1821-1824), VIII Coloquio Internacional: Visiones y Revisiones de las Independencias Americanas: Realismo/Pensamiento Conservador, Universidad de Salamanca (23 a 25 de marzo de 2011) - En Imprenta, pp. 113.

${ }^{746}$ SLEMIAN, Andréa y PIMENTA, Joao Paulo G.: A corte e o mundo: Uma história em que a família real portuguesa chegou ao Brasil, Ed. Alameda, São Paulo, 2008, pp. 57 y ss. SCHULTZ, Kirsten: Tropical Versailles. Empire, monarchy, and the Portuguese Royal Court in Río de Janeiro, 1808-1821, Ed. Routledge, New York/London, 2001, pp. 101 y ss. Véase también en GÓMEZ, Julio Sánchez: El otro año 8 en ABREU, Fernando José Marroni de: Las Invasiones napoleónicas y el mundo iberoamericano, Embajada de Brasil/Universidad de Salamanca, Madrid, 2008, pp. 105-121.

747 "A vinda da família real deslocou definitivamente o eixo da vida administrativa da colônia para o Río de Janeiro, mudando também a fisionomia da cidade. Entre outros aspectos, esboçou-se aí uma vida cultural. $O$ acesso aos livros e a uma relativa circulação de ideias foram marcadas distintivas do período. Em setembro de 1808, veio a público o primeiro jornal editado na colônia; abriram-se também teatros, bibliotecas, academias literárias e científicas, para atender aos requisitos da corte e de uma população urbana em rápida expansão. Basta dizer que, durante o período de permanência de Dom Joao VI no Brasil, o número de habitantes da capital dobrou, passando de cerca de 50 mil a 100 mil pessoas (...)." FAUSTO, Boris: Historia do Brasil, Edusp, São Paulo, 1994, p. 125.

${ }^{748}$ MALERBA, Jurandir: A corte no exílio. Civilizaçao e poder no Brasil às vésperas da independência 1808-1821, Ed. Companhia das Letras, São Paulo, 2000, pp. 197 y ss.

${ }^{749}$ NEVES, Lucia M. Bastos P.: Napoleón Bonaparte y Brasil: política e imaginario (1808-1822) en ABREU, Fernando José Marroni de (ed.): Las invasiones napoleónicas y el mundo ibero-americano, Embajada de Brasil/Universidad de Salamanca, Madrid, 2008, pp. 19-73.
} 
establecer las instituciones políticas y administrativas del futuro imperio luso-brasileño. Por este último punto, empieza por formar gobierno nombrando a los ministros para las secretarias de Estado. Por lo tanto, Rodrigo de Sousa Coutinho pasa a ser ministro y secretario de Estado de los Negocios Extranjeros y de la Guerra. Pesa a favor del nombramiento de este ministro la protección de los ingleses, y por estar en contra de los franceses. Además, desde Londres fue quien hizo posible la puesta en práctica de los antiguos planes de trasladar la corte al Nuevo Mundo. Los demás puestos en el gobierno serán ocupados por D. Fernando José Portugal (futuro conde y marqués de Aguiar) en la Secretaria de Estado de los Negocios del Reino y por Joao Rodrigues de Sá e Melo Menezes e Souto Maior (vizconde y después Conde de Anadia) en la Secretaria de Estado de los Negocios de la Marina y Dominio del Ultramar. Se debe tomar nota que dichas secretarias y ministerios serán reformuladas con la intención de que funcionase desde Brasil. De hecho la Secretaria de los Negocios del Reino pasa a llamarse Secretaria de los Negocios de Brasil, desmarcándose también de la Secretaria de Dominio del Ultramar. Empieza así a individualizar la administración del Reino de Brasil. De esta manera, se crea el 1 de abril de 1808 el Consejo Supremo Militar, separándose del anterior Consejo de Guerra del Ultramar. La parte americana del imperio pasa, de este modo, por una inversión de su estatus colonial ${ }^{750}$.

Hubo, una completa reformulación de la Administración judicial. Los tribunales superiores que antes tenían sus sedes en Lisboa y que habían sido creados desde el siglo XVI, pasan a funcionar en Río de Janeiro. A través del Alvará de 22 de abril se crea el Tribunal de la Mesa del Desembargo del Palacio, que procesaba los pedidos dirigidos directamente al monarca, como supremo administrador de justicia, a través de decretos y mera gracia; y el Tribunal de la Conciencia y Orden, que se ocupaba de los asuntos religiosos, una prerrogativa real a través del instituto del Patronato Regio. Además, se elevó a Casa de Suplicación en Brasil, como tribunal superior de justicia, de apelación en última instancia la Relación de Río de Janeiro. Extendiendo su competencia tanto en las distintas partes de Brasil (Bahía, Maranhão y Pará) como también sobre los Açores y la Madeira. En los años subsecuentes dos nuevas Relaciones fueron creadas, de Maranhão en 1812, y la de Pernambuco en $1821^{751}$.

\footnotetext{
${ }^{750}$ NEVES, Lucia M. Bastos P.: Estado e Política na independência en GRINBERG, Keila y SALLES, Ricardo (org.): O Brasil Imperial, Vol. I - 1808-1831, Ed. Civilização Brasileira, Río de Janeiro, 2009, pp. 103 y ss. Véase también en MARCOS, Rui Figueiredo: "Rostos da Política Legislativa de D. Joao VI no Brasil”, Academia de Ciências de Lisboa, Comunicação Apresentada à Classe de Letras na Sessão de 8 de Maio de 2008, pp. 4-21. También se debe complementar com los trabajos de JANCSÓ, István (org.): Independência: história e historiografia, São Paulo, Fapesq/Hucitec, 2005, pp. 119-177. También em MALERBA, Jurandir (org.): A independência brasileira: novas dimensões, Ed. FGV, Río de Janeiro, 2006, pp. 76 y ss. PIMENTA, Joao Paulo G.: A independência do Brasil. Um balanço da produção historiográfica recente en CHUST, Manuel y SERRANO, José António (eds.): Debates sobre las independências ibero-americanas, Ed. Iberoamericana/Vervuet, Madrid, 2007, pp. 143-157.

${ }^{751}$ A cerca de la relación de órganos creados en la recién estrenada metrópolis véase en NEVES, Lucia M. Bastos P.: Estado e Política na independência en GRINBERG, Keila y SALLES, Ricardo (org.): O Brasil Imperial, Vol. I 1808-1831, Ed. Civilizaçao Brasileira, Río de Janeiro, 2009, pp. 104 y 105. También se puede ampliar más sobre dicha temática en SLEMIAN, Andréa: O Supremo Tribunal de Justiça nos primórdios do Brasil (1828-1841) en
} 
Otras estructuras burocráticas comienzan también a funcionar, como: la Real Junta de Comercio y Agricultura, Fábricas y Navegación del Estado de Brasil y Dominios Ultramarinos, que absorbe las funciones de la Mesa de Inspección de Río de Janeiro. Además, fueron instituidas la Cancillería-Mayor del Estado de Brasil, en los moldes de la que existía en Lisboa, y el Registro de las Mercedes. Mientras tanto fueron reconstituidos el Consejo de Hacienda y el Erario Regio. Lucia M. Bastos P. das Neves destaca que el gobierno de las colonias y de las posesiones insulares estaban atribuidas al rey y a sus ministros desde Río de Janeiro ${ }^{752}$. Se crea también la Intendencia-General de Policía. Y para la difusión de estos actos de gobierno fue fundamental el papel de la Gazeta de Río de Janeiro ${ }^{753}$.

El imperio luso-brasileño, con sede en Río de Janeiro, lejos de imaginar una secesión del imperio, impulsaba la necesidad de reformas, que eran defendidas por los ilustrados lusobrasileños, a ejemplo de Hipólito da Costa, que traspasaba aquella necesidad a su periódico Correio Braziliense ${ }^{754}$. Se veía como un cierto renacimiento el cambio de sede, y una oportunidad para acabar con los abusos de los ministros y la corrupción de los funcionarios de la monarquía. Lejos de eso acontecer, se formará una burocracia con funcionarios ávidos de poder y mercedes también en Río de Janeiro. Sin embargo, la concentración de poder en la nueva sede va a provocar recelos en otras partes del imperio, lo que hará que, algunas provincias, con el tiempo, se vean mejor relacionadas con Lisboa que con Río de Janeiro en los momentos previos a la independencia. Un ejemplo de esto, es la súplica de la Cámara de la ciudad de Bahía en 1808 dirigida al Príncipe Regente para que esta ciudad, mucho más rica y próspera que Río de Janeiro, fuese la nueva sede del imperio.

Por razones comerciales y por la proximidad geográfica, pasados algunos años de la administración de D. Joao en Río de Janeiro y ya librado Portugal de la ocupación francesa, las

LOPES, José Reinaldo de Lima (org.): O Supremo Tribunal de Justiça do Império 1828-1889, Ed. Saraiva/Fundaçao Getúlio Vargas - Série Produçoes Cientificas (Direito Desenvolvimento Justiça), São Paulo, 2010, pp. 19 y ss.

${ }^{752}$ Se puede ampliar más estas informaciones con la lectura de COSTA, Wilma Peres: Do domínio à nação: os impasses da fiscalidade no processo de independência en JANCSÓ, István (org.): Brasil, formação do Estado e da Nação, Ed. Hucitec/Fapesp, São Paulo, 2003, pp. 143 y ss. ARMITAGE, J.: História do Brasil, Livraria Editora Zelio Valverde, Río de Janeiro, 1943, pp. 9 y ss. NEVES, Lúcia M. B. Pereira das: Estado e política na Independência..., op. cit., pp. 105 y ss.

${ }^{753}$ Un ejemplo de esta divulgación se puede apreciar en la GAZETA DO RIO DE JANEIRO, n’. 9, de 12 de octubre de 1808. "O papel essencial desses atos no novo cotidiano da corte fluminense demonstra-se através dos avisos publicados na Gazeta do Río de Janeiro, que anunciavam, desde seus primeiros números, a venda de alvarás e decretos régios que instituíam esses órgãos, nas casas de dois mercadores de livros - Paulo Martin, distribuidor oficial da Gazeta, estabelecido na rua da Quitanda e na de Manuel Jorge da Silva". NEVES, Lúcia M. B. Pereira das: Estado e política na Independência..., op. cit., pp. 106 y ss. "O primeiro jornal brasileiro - A gazeta do Río de Janeiro - tinha caráter quase oficial e estava sujeita, como todas as demais publicações, a uma comissão de censura encarregada de examinar os papeis e livros que se mandassem publicar e fiscalizar que nada se imprimisse contra a religião, o governo e os bons costumes. O jornal brasileiro independente dessa época, que continha críticas à politica portuguesa, era o Correio Braziliense de Hipólito José da Costa, editado em Londres entre 1808 e 1822." FAUSTO, Boris: História do Brasil, Edusp, São Paulo, 1994, pp. 125-127.

${ }^{754}$ CORREIO BRAZILIENSE OU ARMAZÉM LITERÁRIO, v. 16, nº 93, febrero de 1816, p. 186. 
anteriormente denominadas capitanías brasileñas, ahora provincias, volvían a relacionarse directamente con Lisboa, a ejemplo de Pará, Maranhão y la Provincia de Bahía. A la vez que las élites comerciales del centro-sur de Brasil se volcaban hacía el gobierno de Río de Janeiro. Estos dos polos de élites van a mantenerse en este mismo curso a la hora de la proclamación de la independencia. El periplo de estas élites se verá tanto en la Revolución pernambucana de 1817, como también en los acontecimientos de 1822 en la proclamación de la independencia ${ }^{755}$.

Mientras la maquina burocrática empezaba a rodar en la nueva sede del gobierno y la familia real se institucionaliza ${ }^{756}$ en el Nuevo Mundo, se buscó una solución "de iure” a lo que estaba establecido de hecho. La diplomacia portuguesa va a defender junto a la Santa Alianza el reconocimiento de Río de Janeiro como nueva sede del Imperio Luso-brasileño. Así que, por sugestión de Talleyrand, para mejorar la posición de Portugal junto al Congreso de Viena, en 1815 -16 de diciembre- Brasil sube a la categoría de Reino Unido a Portugal y Algarves. Este acto tuvo triple consecuencias: la permanencia de la corte en Río de Janeiro, deseada por el rey; el ascenso del orgullo de las élites locales, que mantendrían la certeza de seguir aprovechándose de la proximidad de la corte; y la clara o aparente opción por la parte americana del imperio en detrimento de la parte europea, que se encontraba bajo el estatus de protectorado británico, sometido al mando de gobernador-general Lord Beresford. D. Joao VI también va a buscar en la tradicional política matrimonial una forma de liberarse de la intensa influencia británica sobre el imperio, por ello, casa a su primogénito Pedro con una Habsburgo. Estas actitudes del rey harán que los intereses de la parte europea del imperio se tornasen opuestos a los de la parte americana. Esto se verá claramente cuando irrumpe la Revolución liberal de Oporto y el rey se ve obligado a volver a la antigua sede metropolitana de Lisboa ${ }^{757}$. Además, por el hecho de ser el primer soberano ser coronado en el Nuevo Mundo, algo inédito para las Américas, provocará los recelos de los súbditos europeos. Un texto en un periódico, O Português, que salió poco después de la aclamación de D. Joao VI el 6 de febrero de 1818, denominó a la corte en Río de Janeiro de "gobierno Tubinambá"758. Consciente de estos recelos el gobierno de D. Joao va a

\footnotetext{
${ }^{755}$ Estas y otras afirmaciones se pueden encontrar en NEVES, Lúcia M. B. Pereira das: Estado e política na Independência..., op. cit., pp. 110 y ss. Como también, de la misma autora, en NEVES, Lucia M. Pereira das: Linguagem política do conservadorismo..., op. cit., pp. 2 y ss. Y sobre las características de la revolución pernambucana véase em MELLO, Evaldo Cabral de: A outra independência. O federalismo pernambucano de 1817 a 1824, Editora 34, São Paulo, 2004, pp. 11-36.

${ }^{756}$ Un ejemplo del impacto de la presencia de los monarcas portugueses en la crisis dinástica en España y el impacto para la América española con la presencia de la hermana de Fernando VII en Brasil se puede constar con la lectura de AZEVEDO, Francisca L. Nogueira de: Carlota Joaquina. Cartas inéditas, Ed. Casa da Palavra, $2^{a}$ Ediçao, Río de Janeiro, 2007, pp. 70 y ss.

${ }^{757}$ El sentimiento de orfandad que se genera en Portugal con la partida del rey para los trópicos fue bien discutido en un artículo relativamente reciente de NEVES, Lucia M. Pereira das: "Portugal durante a ausencia do rei", Revista USP, Sao Paulo, n. 79, setembro/novembro 2008, pp. 10-21.

${ }^{758}$ Periódico "O PORTUGUÉS”, 6 de fevereiro de 1818.
} 
expedir algunas medidas para aplacar al "Portugal olvidado", con el Alvará de 25 de abril de 1818, con tasas favorables al vino y aguardiente portuguesas. Lo mismo se dará con el Aviso de 30 de mayo de 1820, que favorecía a algunos productos portugueses en los puertos brasileños $^{759}$. Todo en vano, puesto que en 1820 la Revolución liberal de Oporto traerá estas reivindicaciones como bandera, hostilizando el "protectorado británico" y exigiendo del rey el inmediato regreso a Lisboa, para revalorizar a la parte europea del imperio luso-brasileño; además, exigía del rey que jurase las Bases de la Constitución que sería creada por las Cortes constituyentes reunidas en Lisboa.

La Revolución liberal española está para la Revolución liberal de Oporto, así como la adhesión de la porción americana del Imperio luso está para el éxito de la misma revolución liberal portuguesa ${ }^{760}$. Es de notar, como defendimos en el Capítulo I, que el movimiento liberal español se nutría, a través de los periódicos, del esparcimiento del modelo gaditano por Europa, principalmente Portugal, pero, también hay que notar que si Brasil no se hubiese adherido a la causa vintista había poco motivos de éxito de que este movimiento hubiese triunfado al punto de convocar Cortes o incluso de adoptar el modelo gaditano en el Imperio Luso.

Por lo tanto, había una gran expectativa en el congreso nacional en Lisboa sobre la adhesión de las provincias brasileñas a la causa liberal. Las noticias empiezan a llegar el 27 de marzo de 1821, siendo la Provincia del Gran-Pará la primera, que dirigiendo un oficio al nuevo gobierno, con fecha del día 10 de enero del mismo año, decía que el pueblo, las tropas y las autoridades juraban fidelidad al rey, a la dinastía de Braganza, a las Cortes Generales y a la constitución que viniese a ser creada por estas. Informaba además, que se habían elegido, al completo estilo español, una Junta Provisional para regir a la capitanía hasta que empiecen a funcionar las Cortes. Estaba firmado dicho documento por el futuro diputado de las cortes y hora miembro del gobierno provisional, Romualdo Antonio de Seixas, que declara aceptar la futura constitución, pero que se mantuviese la Religión Católica ${ }^{761}$. Los sucesos en la Provincia del Pará cupo a un joven estudiante de derecho de la Universidad de Coimbra, Felipe Alberto Patroni Martins Maciel Parente, esparcir las nuevas del movimiento por la provincia y traer con un alférez de milicias al parlamento en Lisboa el oficio de la Junta Provisional de Pará en donde

\footnotetext{
${ }^{759}$ NEVES, Lúcia M. B. Pereira das: Estado e política na Independência..., op. cit., pp. 115 y ss.

${ }^{760}$ La adhesión de sectores de Brasil fue fundamental para que el proyecto liberal vintista viniese a fructificar en Portugal, como defiende en su obra clásica el historiador CARVALHO, Manuel Emílio Gomes de: Os deputados brasileiros nas cortes..., op. cit., pp. 21 y ss. Véase también la obra de NEVES, Lúcia M. B. Pereira das: Estado e política na Independência..., op. cit., pp. 103 y ss.

761 "Só a religião estando em perigo nas Cortes, por causa do radicalismo francês e do racionalismo filosófico, dominante em Portugal, corria-lhe o dever de estipular que observaria a futura carta constitucional, respeitando esta os dogmas da Igreja. Podia omitir semelhante restrição que a sua qualidade de sacerdote deixava subentender; arriscava, porém, com o silêncio a criar um equívoco, que se não compadecia com a sua honra." CARVALHO, Manuel Emílio Gomes de: Os deputados brasileiros nas cortes..., op. cit., p. 29.
} 
les relataba los últimos acontecimientos e investía de poderes de delegado al citado estudiante; por lo tanto, estaba, dicho estudiante, acreditado como delegado del gobierno de la Capitanía del Pará ${ }^{762}$. Y el 5 de abril fue el primer americano en hablar en el Congreso constituyente ${ }^{763}$. $^{7}$

El 15 de abril de 1821 era el momento de Bahía adherirse a las Cortes de Lisboa, en un comunicado a la regencia, en donde ésta reconocía la autoridad de las Cortes y del gobierno supremo del reino ${ }^{764}$. A la vez que las Cortes providenciaban enviar tropas para la defensa de Bahía, promulgando así el Decreto de 18 de abril. En él se reconocían las Juntas creadas en las capitanías vinculadas a régimen liberal de Lisboa, y aprobaba las elecciones para diputados de las Cortes que algunas capitanías estaban ejecutando, de acuerdo a lo determinado por el Decreto de 22 de noviembre de $1820^{765}$. También Río de Janeiro se adhiere a la causa vintista, con el juramento del rey de las bases de la constitución, el 27 de abril. A la vez que llegaban noticias que también la provincia de Pernambuco se adhería a la causa liberal.

Cuando las noticias de la Revolución liberal portuense llegaron al muelle de Río de Janeiro, la primera reacción de la Gazeta de Río de Janeiro, en el número del día 9 de noviembre de 1820 , fue trivializar a los acontecimientos del otro lado del Atlántico ${ }^{766}$. Este periódico que hacía las veces de boletín del Estado, trasmite las impresiones del gobierno del reino, alegando ser dicho movimiento liberal una usurpación de la legítima autoridad del Augusto soberano. Como ya sabemos, lo sucedido en España va a contagiar a Portugal de las ideas liberales. En Brasil también se tenían noticias ya de que había triunfado la Revolución liberal en España y se había adoptado a la Constitución de Cádiz. Aunque dicha constitución ya era conocida en estos parajes, puesto que, los residentes españoles en Río de Janeiro la juraron en $1813^{767}$. En Portugal el movimiento liberal triunfa, como ya comentamos, con pedido de

\footnotetext{
${ }^{762}$ DCGECNP, Sesión del día 4 de abril de 1821, p. 455.

${ }^{763}$ DCGECNP, Sesión del día 5 de abril de 1821, p. 483. El joven estudiante importunaba a las Cortes para que lo aceptaran como diputado, aunque no dispusiese de diplomatura para tanto, llega a amenazar con la separación de los dos reinos en el caso de que no le aceptasen como diputado, como cuenta el diputado Margiocchi en la Sesión del día 14 de noviembre de 1821. La aventura del joven está mejor detallada en CARVALHO, Manuel Emílio Gomes de: Os deputados brasileiros nas cortes..., op. cit., pp. 31 y ss.

${ }^{764}$ DCGECNP, Sesión de 16 de abril de 1821, p. 600.

${ }^{765}$ CARVALHO, Manuel Emílio Gomes de: Os deputados brasileiros nas cortes..., op. cit., p. 36.

${ }^{766}$ GAZETA DO RIO DE JANEIRO, 9 de novembro de 1820.

${ }^{767}$ ARCHIVO DEL CONGRESO DE LOS DIPUTADOS EN MADRID - Hay referencia en la correspondencia enviada por D. Juan del Castillo y Carroz, Enviado Extraordinario y Ministro Plenipotenciario de S.M.C. y de S.D. Fernando VII, cerca de S.A.R. el Príncipe Regente de Portugal y de los Algarves, que se tomó la jura a la Constitución de Cádiz en Río de Janeiro, en 21 de septiembre de 1813, a los residentes españoles en aquél reino: "Certifico que en cumplimiento de las ordenes de la Regencia del Reino habiendo convocado a mi casa a todos los españoles residentes en este país para jurar la Constitución Política de la Monarquía Española en la mañana de este día asistieron y juraron los individuos siguientes (...). Siguen los individuos que también se presentaron mas no asistieron a la ceremonia, por haberla ya jurado en Montevideo, y en otras puntas de la monarquía. Por ultimo siguen algunos individuos que habiendo sido citados como los demás, no comparecieron, ni se excusaron. Cumpliendo con las referidas órdenes doy la presente certificación firmada de mi mano, y sellada con el escudo de
} 
constitución, expulsión de los ingleses, y retorno del rey a la antigua sede de la monarquía, súmanse a estos pedidos el de conservación de la Religión Católica. Aunque como ya vimos, se evitaba la palabra revolución prefiriendo utilizar la denominación regeneración para el movimiento $^{768}$. Entretanto, estaba claro en Lisboa, como ya nos referimos, que debía buscar un plano más amplio para el éxito de la revolución, se debía conquistar las demás regiones del imperio, principalmente a Brasil, con la promesa de destierro del despotismo, que era visto como el elemento de opresión general ${ }^{769}$.

Ya describimos en el Capítulo I a las instituciones creadas en Lisboa con el triunfo del movimiento liberal, tales como la Junta Provisional del Gobierno Supremo del Reino y de la Junta Provisional Preparatoria de las Cortes. Como aquí nos interesa saber los influjos que produjeron en Río de Janeiro dicho movimiento liberal, nos centraremos ahora en esta parte del Imperio luso.

En la parte americana del imperio, al contrario de lo que intentaba informar la Gazeta, la noticia de la Revolución de Oporto, en toda su extensión, se propaga a lo largo y ancho de Brasil; a través de cartas particulares, oficios de los gobernadores del reino, pero, por encima de todo, son alarmantes las noticias de adhesión de diversas provincias americanas a la causa liberal $^{770}$. Jugará un papel fundamental en la difusión de las ideas liberales, dado que se experimentaba una libertad de imprenta, principalmente en el Portugal revolucionario - o mejor dicho regenerado - a través de folletos políticos, periódicos etc., impresos tanto en el reino como en diversas provincias de Brasil. Esto, así como pasó en España, será el instrumento de difusión, pero no solamente, será también una especie de sustentación de las ideas liberales. Así que se uniformiza las críticas tanto en Portugal como en Brasil ${ }^{771}$ contra los “jorobados", así designados los partidarios del Antiguos Régimen ${ }^{772}$. A la vez que el constitucionalismo recibía

mis armas. En el Río de Janeiro a 21 de septiembre de 1813”. No trascribimos la lista de personas por no interesar en este momento. Signatura topográfica P-01000029-0001-0001 (Sig. Topográfica antigua ACD, S General, Leg. 29 n $^{\circ}$ 1, Título: Juramentos de la Constitución de 1812: Ecuador, Perú, Brasil, Callao, Uruguay, Bolivia, Panamá, Colombia, Venezuela, Argentina, Fechas extremas/Sin mes/1812-/sin mes/1812).

${ }^{768}$ Sobre este movimiento y las peleas entre "jorobados" y constitucionales, o sea, el grupo que opositaba y el que apoyaba al movimiento constitucional se puede ampliar más con la lectura de NEVES, Lucia M. Bastos P. das Neves: Corcundas e constitucionais. A cultura política da independencia (1820-1822), Editora Revan/Faperj, Río de Janeiro, 2003, pp. 141 y ss.

${ }^{769}$ NEVES, Lúcia M. B. Pereira das: Estado e política na Independência..., op. cit., pp. 117. Esta opinión también se puede encontar en CARVALHO, Manuel Emílio Gomes de: Os deputados brasileiros nas cortes..., op. cit., p. 36.

770 "No dia $1^{\circ}$ de janeiro de 1821, o Grão-Pará aderiu ao movimento liberal. Em 10 de fevereiro, a Bahia, a outras regiões mais ligadas a Portugal, jurou a Constituição a ser elaborada do outro lado do Atlântico. Por fim, em 26 de fevereiro, a pressão das tropas portuguesas no Rio de Janeiro garantiu a incorporação da cidade à regeneração." NEVES, Lúcia M. B. Pereira das: Estado e política na Independência..., op. cit., pp. 118.

${ }^{771}$ HABERMAS, Jürgen: Mudança estrutural na esfera pública, Rio de Janeiro, Tempo Brasileiro, 1984, p. 42 y ss. ${ }^{772}$ NEVES, Lucia M. Bastos P. das Neves: Corcundas e constitucionais..., op. cit., p. 95 y ss. 
una tratamiento de simplificación en los catecismos políticos para alcanzar el mayor número posible de individuos y formar adeptos ${ }^{773}$.

La conmoción liberal no solo había convulsionado al viejo reino de Portugal sino que amenazaba contaminar al idilio tropical de D. Joao $\mathrm{VI}^{774}$, como bien resaltó, a su momento, el Conde de Palmela, al cual ya hicimos referencia. De modo que, el rey llamó a consultas a los grandes del reino para así ejercer sus dos principales características, según cuenta Manuel Emilio Gomes de Carvalho, postergar las decisiones y si no hubiese manera decidir a "toque de caja", o sea de última hora y de improviso sobre estas y demás cuestiones ${ }^{775}$. Palmela al llegar al Río de Janeiro en 23 de diciembre de 1820, para asumir la Secretaria de la Guerra y de los Extranjeros se sorprendió al saber que el rey no había tomado decisión alguna en cuanto a lo sucedido en Portugal. La timorata actitud del monarca llevaba a creer que este no deseaba abandonar el Reino de Brasil y solamente lo haría en la última de las opciones. Pero, a estas alturas, según afirma Lucia M. Bastos P. das Neves, ningún escrito o manifestación propugnaba por la separación entre los dos reinos. Lo que sí estaba patente era que Brasil también querría las dádivas liberales de las que gozaba Portugal. Por lo tanto, había un presión política para que el rey jurase en principio la Constitución de Cádiz y luego las Bases de la Constitución vintista $^{776}$.

Era una situación difícil para el monarca. Las opciones que se les presentaban en aquellos momentos eran: permanecer en Río de Janeiro como monarca absoluto, cosa que deseaba ardientemente, y arriesgar perder la parte europea del imperio; o aceptar los cambios liberales y tornarse un soberano constitucional de una potencia europea de segundo orden. D. Joao va a preferir entrar en consultas con sus dos principales ministros: Vilanova Portugal y el Conde de Palmela ${ }^{777}$. El primero partidario del Antiguo Régimen y de que se quedara el rey en Brasil, y el segundo, partidario de un liberalismo moderado, plegaba que sí debía el rey regresar a la antigua metrópoli y asumir el proceso constitucional. El Conde de Palmela llega incluso a presentar un Proyecto de Carta Constitucional al rey para que este pudiese dar a los pueblos, antes que le dictasen una de forma revolucionaria. Era así el proyecto de Constitución elaborado para el Reino de Brasil, que sería desarrollado por una Junta de Procuradores de las Cámaras. Este proyecto presentaba algunos avances liberales como la división de los poderes,

\footnotetext{
${ }^{773}$ NEVES, Lúcia M. B. Pereira das: Estado e política na Independência..., op. cit., pp. 119 y ss.

${ }^{774}$ SCHULTZ, Kirsten: Tropical Versailles..., op. cit., pp. 235 y ss. Especialmente el capítulo VII - Legacies and Liberties: Constitutionalism in Rio de Janeiro.

775 CARVALHO, Manuel Emílio Gomes de: Os deputados brasileiros nas cortes..., op. cit., pp. 45 y ss.

${ }^{776}$ SCHULTZ, Kirsten: Tropical Versailles..., op. cit., pp. 240 y ss.

${ }^{777}$ CARVALHO, Manuel Emílio Gomes de: Os deputados brasileiros nas cortes..., op. cit., pp. 41 y ss.
} 
desde la perspectiva de Montesquieu, defendía la libertad individual, el derecho de propiedad, la libertad de imprenta y la igualdad tributaria ${ }^{778}$.

Inmerso en la indecisión, el monarca, contra la indicación del Conde de Palmela, manda publicar al Decreto de 18 de febrero juntamente con la Provisión del día 23 que nombraba a los miembros de la Junta Consultiva convocada por D. Joao VI. En las mismas provisiones estaban contenidas la orden de partida del príncipe D. Pedro para Portugal, para garantizar un pacto social favorable a la monarquía, pero, no le eran atribuidos poderes para aprobar en nombre del monarca dicha constitución. A la vez que hace convocar para que se reunieran en Cortes, en la ciudad de Río de Janeiro, a los procuradores electos por las Cámaras de las Ciudades y villas de jueces letrados, no solamente en la jurisdicción del Reino de Brasil sino en la Madeira y en los Açores. Estaban convocados para examinar las disposiciones constitucionales aplicables al Reino de Brasil y a las islas, que condujera a la prosperidad de ambas partes de este reino. Pero, el decreto y las medidas desagradaron sobremanera a los portugueses europeos, que veían a Brasil y a las islas quedar el margen del proyecto liberal de constitución y de la órbita de las Cortes Generales de Lisboa, además de provocar una chispa de tentación de separar a los dos reinos que hasta entonces no estaba pensando en parte alguna. Preocupaba excesivamente a los portugueses que aquella Junta Consultiva, convocada por el rey, se compusiese únicamente por los naturales del Reino de Brasil y de las islas atlánticas. Aunque eso no parecía agradar también a los brasileños, puesto que ya habían abrazado a la propuesta de contar con una constitución liberal para el reino. De manera que agradaba aún menos la idea de ver creada unas Cortes Legislativas para Portugal y una Asamblea de carácter consultivo para Brasil ${ }^{779}$. De este modo, el gusto por el constitucionalismo estaba ya instalado entre los luso-brasileños, aunque mucho más próximo de un lenguaje más conservador, bien al agrado de las élites que estudiaron en la Universidad de Coimbra ${ }^{780}$. Por este pensamiento, la revolución moldeada en el radicalismo francés debía ser evitada a todo coste. Así pensaba dos egresados de Coimbra, José da Silva Lisboa, como el futuro patriarca de la patria José Bonifácio de Andrada e Silva, que llegó a vivir en la París de la Revolución Francesa y que conocía de sobra los descaminos que

\footnotetext{
${ }^{778}$ Esta descripción se encuentra en el Oficio de 14 de enero de 1821. Estas ideas liberales, estaba dentro de la formación liberal de muchos de los políticos del momento, que en su mayoría estudiaron en Coimbra, y que conocían a Montesquieu y a Benjamin Constant, por ejemplo. NEVES, Lucia M. Bastos P. das: Corcundas e constitucionais..., op. cit., pp. 242 y 246. Se puede complementar también com la lectura de NEVES, Lucia M. Bastos P.: Linguagem políticas do conservadorismo..., op. cit., p. 4. NOVAIS, Fernando: Portugal e Brasil na crise do antigo sistema colonial (1777-1808), Ed. Hucitec, São Paulo, 1979.

${ }^{779}$ CARVALHO, Manuel Emílio Gomes de: Os deputados brasileiros nas cortes..., op. cit., pp. 45 y 46.

${ }^{780}$ NEVES, Lucia M. Bastos P.: Linguagem políticas do conservadorismo..., op. cit., p. 4.
} 
tomó dicha revolución ${ }^{781}$. Muchos de los que fueron convocados por el rey para participaran de la reunión de la Junta Consultiva, en estos momentos de crisis, en la casa del Conde de Palmela, van más tarde a participar de la constituyente de 1823 de Brasil ya independiente.

Como consecuencia de estos acontecimientos el rey se ve obligado a declarar en abril de 1821 que partiría para Portugal y dejaría en Brasil al príncipe D. Pedro como regente del reino $^{782}$. Venció así la opción por el constitucionalismo pero sin olvidar del todo el pensamiento conservador. De este modo, la independencia de Brasil no será un resultado ni de las ideas abstractas del liberalismo ni tampoco por haber formado una conciencia nacional, pero aun así, se constituirá en un imperio constitucional que durará todo el siglo $\mathrm{XIX}^{783}$.

El regente D. Pedro, con la partida del rey, pasa a detentar amplios poderes en el Reino de Brasil: le atribuía administrar a la justicia y a la hacienda; le incumbía también emitir resoluciones a las consultas relacionadas a la administración pública; proveer a los puestos públicos, incluso a las dignidades eclesiásticas, con excepción de los obispos; detentaba el poder de conmutar las sentencias de muerte y el derecho de otorgar gracias honorificas; podía declarar la guerra defensiva u ofensiva, cuando fuera imposible esperar las órdenes dictadas por el rey. El príncipe regente ejercería estos poderes auxiliado por un Consejo que estaba formado por dos secretarios de Estado. Así que el centro de mando de Brasil seguía siendo Río de Janeiro ${ }^{784}$.

Va a ser en la regencia de D. Pedro cuando se convocará las elecciones a las Cortes en Lisboa. El gobierno revolucionario de Portugal había determinado a través del Decreto de 18 de abril que se aplicara el Reglamento Electoral de 22 de noviembre de 1820 en el ultramar americano para la elección de los diputados a las Cortes Generales Constituyentes. Prescribía dicho decreto que cada provincia daría un diputado por cada 30 mil habitantes. Si lo que excediese a estos 30 mil llegase a 15 mil, contaría dicha provincia con más un diputado.

\footnotetext{
${ }^{781}$ CALDEIRA, Jorge (org.): José Bonifácio de Andrada e Silva, Editora 34 - Coleção Formadores do Brasil, Rio de Janeiro, 2002, p. 15.

782 “Os acontecimentos de 26 de janeiro, na corte do Rio, exigindo do soberano o juramento imediato das bases da futura Constituição portuguesa, a demissão de alguns membros do governo e a adoção temporária da Constituição espanhola de 1812, até a elaboração da nova Carta pelas cortes de Lisboa, apressaram a decisão, embora contornados com habilidade por D. Pedro. De qualquer forma, em 7 de março, o rei comunicou a decisão de partir e determinou a eleição dos deputados brasileiros para o Congresso de Lisboa, conforme estabelecia a Constituição de Cádiz, que, por decreto de 21 de abril, também passaria a vigorar provisoriamente. Este último ato, porém, após os tumultos ocorridos durante a Assembleia reunida na praça do Comércio, acabou anulando no dia seguinte, partindo D. Joao VI para Portugal em 26 de abril e deixando no Brasil, como regente, o príncipe D. Pedro, que passou a deter amplos poderes.” NEVES, Lúcia M. B. Pereira das: Estado e política na Independência..., op. cit., pp. 119.

${ }^{783}$ NEVES, Lucia M. Bastos P.: Linguagem políticas do conservadorismo..., op. cit., p. 4.

${ }^{784}$ VARNHAGEN, F. A. de: Historia Geral do Brazil, (dedicada a Sua Magestade Imperial o Senhor D. Pedro II), Tomo II, Casa de E. e H. Laemmert - Rua da Quitanda, Rio de Janeiro, 1857, pp. 411 y ss. En Varnhagen se puede ver la descripción del decreto que establece los poderes de la regencia de D. Pedro y los poderes de que este goza. También se puede leer la descripción de estos poderes en NEVES, Lúcia M. B. Pereira das: Estado e política na Independência..., op. cit., pp. 120.
} 
Recomendaba además que se siguiese el censo de 1801, hecho para Portugal. Y en Brasil se aplicase en dicho cálculo poblacional el censo de 1808. Aunque el mandamiento dejaba claro que la provincia que lo quisiera podría hacer nuevo censo poblacional. Las elecciones serian en cuatro grados, utilizando por lo tanto un método indirecto. Como ya comentamos antes, seguirá lo determinado por la Constitución de Cádiz, con derecho a voto todo ciudadano mayor de 25 años, que fuesen naturales de la provincia y que residiese en ella por más de siete años ${ }^{785}$. El art. 35 del Decreto de 7 de marzo de 1821 mandaba que las Juntas Electorales de las Freguesías fuesen compuestas de todos ciudadanos domiciliados y residentes en el territorio de la respectiva circunscripción, en cuyo número estarán comprendidos los eclesiásticos seculares ${ }^{786}$.

Los cuatro niveles de las elecciones previstos en el Decreto de 7 de marzo de 1821 estaban así establecidos: a cada circunscripción (freguesía) bajo la presidencia de la autoridad judiciaria o municipal, se reunirían en el consistorio o en la Iglesia los ciudadanos domiciliados en esta circunscripción (los vecinos de la localidad) para la elección de los "compromisarios". Nombrados los “compromisarios", pasarían estos a designar los "electores parroquiales". Por cada doscientos fuegos había un elector parroquial electos por once compromisarios. Entonces, luego en el domingo subsecuente, se juntaban los electores parroquiales en las cabezas de la Comarca para indicar por escrutinio secreto los últimos electores, que reunidos en la capital de la provincia, en el domingo siguiente, nombraban los diputados. De este modo, el número de electores debía ser tres veces el número de elegidos; siendo que la elección de diputados se daba por escrutinio secreto y de modo sucesivo ${ }^{787}$.

Siguiendo estas reglas, y despreciando a las fracciones del número de ciudadanos en cada provincia se quedó establecido que para el Reino de Brasil serían elegidos para la Cortes en Lisboa 72 diputados brasileños ${ }^{788}$. Varnhagen lista los diputados electos siendo 68 en el

\footnotetext{
${ }^{785}$ REGULAMENTO ELEITORAL DE 22 DE NOVEMBRO DE 1820 (Documentos para a História das Cortes Gerais, vol. $1^{\circ}$, pág. 108). Dicho reglamento diciplinaba el Decreto de 7 de marzo de 1821 que era la parte electoral de la Constitución de Cádiz traducida y adaptada para el caso del Imperio luso-brasileño.

${ }^{786}$ SOUZA, Francisco Belisário S. de: O sistema eleitoral no Império, Ed. Senado Federal, Brasilia, 1979, pp. 163 y ss. También se puede encontrar la llamada para dichas elecciones y la jura de la Constitución de Cádiz y puesta a vigorar por un día, el 21 de abril de 1821, se puede leer los hechos en VARNHAGEN, F. A. de: Historia Geral do Brazil, (dedicada a Sua Magestade Imperial o Senhor D. Pedro II), Tomo II, Casa de E. e H. Laemmert - Rua da Quitanda, Rio de Janeiro, 1857, pp. 410 y ss.

${ }^{787}$ Véase la descripción detallada de estas elecciones de cuatro niveles prescritas en el Reglamento Electoral de 22 de noviembre de 1820 en CARVALHO, Manuel Emílio Gomes de: Os deputados brasileiros nas cortes..., op. cit., p. 81. También se puede acompañar el modo peculiar de estas elecciones en NEVES, Lúcia M. B. Pereira das: Estado e política na Independência..., op. cit., pp. 120.

${ }^{788}$ DCGECNP, Sesión del día 1 de julio de 1822, p. 630. Véase también comentarios sobre dicha elección en PORTO, Walter Costa: O voto no Brasil, Ed. Topbooks, $2^{a}$ Ediçao revisada, Rio de Janeiro, 2002, p. 23. Sobre el influjo de estas elecciones en la Provincia de Minas Gerais, que se rehusó enviar los diputados electos a Lisboa esperando "mejores oportunidades políticas", como describió el príncipe regente D. Pedro en carta a su padre el rey D. Joao VI en Portugal, véase en SILVA, Ana Rosa Cloclet da: "Entre Cádiz, Lisboa e Minas Gerais.
} 
total. Pero no más que 50 de ellos llegan a tomar asiento en Lisboa. Y de estos apenas 16 serán firmantes de la Constitución aprobada en 23 de septiembre de $1822^{789}$.

Así que, antes de la partida del rey en 26 de abril de 1821, éste nombra al Consejo de Regencia para auxiliar al príncipe, que está compuesto por el ministro de los Negocios del Reino el Conde dos Arcos; para el Ministerio de Hacienda, nombra al Conde da Louza, y para ministro de la guerra nombra al Mariscal Caula; y para la Marina indica el nombre del MayorGeneral Farinha ${ }^{790}$.

La regencia de D. Pedro se mostrará muy difícil de llevar a cabo. Enfrentaba la desconfianza de las Cortes de Lisboa, problemas financieros, y total insubordinación de las provincias del norte de Brasil leales a las Cortes de Lisboa; aunque las provincias del sur de Brasil hubiesen jurado lealtad al Príncipe Regente. Uno de los momentos que pondrá a prueba la Regencia y a sus consejeros, principalmente al Conde dos Arcos, será el momento de llegada de las Bases de la constitución, promulgada en Lisboa a 10 de marzo de 1821. Argumentará tanto el príncipe cuanto el Conde dos Arcos que no se debía jurar dichas bases hasta que no llegaran copias auténticas de Lisboa mandada por las Cortes. El Príncipe Regente también argumentará que mientras no hubiese sido aprobadas dichas bases por los legítimos representantes de la nación reunidos en Cortes, como dictaba el art. 21 de las Bases, no estarían listas para ser juradas por el gobierno de la Regencia. Dichos argumentos no se sustentaban puesto que las Bases ya habían sido publicadas por el Diario de la Regencia, órgano oficial del gobierno en Lisboa. Por lo tanto, era ya oficial y debería entrar a vigorar de inmediato dichas Bases en el Reino de Brasil. La impresión general al momento era que el Regente estaba evitando jurar las Bases constitucionales para no ver sus amplios poderes recortados en Brasil. Molestó, además, el hecho de que encontrandose en Río de Janeiro los diputados elegidos para las Cortes en Lisboa y también los electores, tanto estos como el pueblo no fuesen consultados en la decisión del Regente ${ }^{791}$.

La crisis constitucional estaba instalada en Río de Janeiro, y en 5 de junio el Regente se ve obligado a jurar las Bases de la Constitución portuguesa y a cesar a los ministros nombrados

Repercursoes do Constitucionalismo à luz do contexto social mineiro (1820-1822)”, Hib. Revista de Historia Iberoamericana, ISSN: 1989-2616, Semestral, Año 2012, Vol. 5, Núm. 1, pp. 34-55.

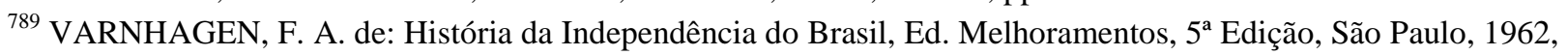
pp. 60 y ss. También se refiere a esto PORTO, Walter Costa: O voto no Brasil, Ed. Topbooks, $2^{\mathrm{a}}$ Edição, Rio de Janeiro, 2002, p. 25.

${ }^{790}$ VARNHAGEN, F. A. de: Historia Geral do Brazil..., op. cit., p. 411.

${ }^{791}$ CARVALHO, Manuel Emílio Gomes de: Os deputados brasileiros nas cortes..., op. cit., pp. 82 y ss. Seguimos también estos acontecimentos en NEVES, Lucia M. Bastos P.: Linguagem políticas do conservadorismo..., op. cit., p. 4. Como también en NEVES, Lúcia M. B. Pereira das: Estado e política na Independência..., op. cit., pp. 121 y ss. 
por el rey que componía el Consejo de Regencia ${ }^{792}$. Algunos factores llevaron a esta situación inmediata: las tropas sin cobrar los sueldos; los rumores de que pretendía el Conde dos Arcos de proclamar la independencia de Brasil y el descontento de la guarnición portuguesa. Estos elementos llevan al General Jorge de Avilez, a la cabeza de las fuerzas portuguesas en la Plaza del Rocío, a solicitar de D. Pedro que jurase las Bases Constitucionales. El Príncipe Regente va a actuar con mucha habilidad en esta crisis. En nombre del rey D. Joao VI, acepta algunas de las exigencias hechas por los revoltosos, además de jurar las Bases, acepta la petición hecha por las tropas para cesar al Conde dos Arcos. Pero, consigue elidir las demás exigencias; como la puesta en práctica de la Constitución de Cádiz y la creación de una Junta Gubernativa de nombramiento popular y que representaría la partilla de la soberanía entre el parlamento y el rey. En sustitución del Conde dos Arcos nombra el príncipe para el puesto de ministro de Estado a Pedro Alvares Diniz ${ }^{793}$. Además, fue elegida una Junta con competencia para promover la responsabilidad de los ministros en los términos del art. 31 de las Bases Constitucionales. Para la elección de dicha Junta concurrieron los electores de los diputados aun presentes en la capital y los oficiales del ejército, en razón de dos para cada cuerpo. Los nombres de los que compusieron dicha Junta fueron: Mariano J. Pereira da Fonseca; el Obispo Capelão-mor; J. de Oliveira Barbosa; J. C. Ferreira de Aguiar; J. de Oliveira Alves; J. J. Pereira de Faro; S. Luís Tinoco; P. J. Fernandes Barbosa e M. Pedro Gomes ${ }^{794}$.

Mientras el Regente asentaba su poder en Río de Janeiro, las demás provincias, principalmente las del norte formaban juntas gubernativas, elegidas por los ciudadanos a lo largo del año de 1821 y reconocidas por las Cortes de Lisboa. Esto polarizaba el poder en Brasil entre las Cortes de Lisboa y el gobierno del regente en Río de Janeiro. Dichas juntas gubernativas reforzaba el poder de las Cortes frente a la regencia de D. Pedro, y pasaba a representar las nuevas bases constitucionales en Brasil $^{795}$. Esto era publicado por un periódico llamado el Revérbero Constitucional Fluminense (1821-1822), cuyos editores, Joaquim Gonçalves Ledo y Januário da Cunha Barbosa, pasaban a noticiar sobre la formación de

\footnotetext{
${ }^{792}$ Este movimiento se quedó conocido como la "Bernarda "de 5 de junio. Nos esclarece Lucia das Neves que bernardas, en la lenguaje de la época eran las "novedades o cambios”, que se hacían en la Plaza del Rocio, una área central de la ciudad a la época, en donde se juntaban las tropas y el pueblo, para recibir dichas proclamaciones. NEVES, Lúcia M. B. Pereira das: Estado e política na Independência..., op. cit., pp. 121.

${ }^{793}$ CARVALHO, Manuel Emílio Gomes de: Os deputados brasileiros nas cortes..., op. cit., pp. 85 y ss. NEVES, Lucia M. Bastos P.: Linguagem políticas do conservadorismo..., op. cit., p. 5 y ss.

${ }^{794}$ CARVALHO, Manuel Emílio Gomes de: Os deputados brasileiros nas cortes..., op. cit., pp. 85 y ss.

${ }^{795}$ CARVALHO, Manuel Emílio Gomes de: Os deputados brasileiros nas cortes..., op. cit., pp. 86 y ss. NEVES, Lucia M. Bastos P.: Linguagem políticas do conservadorismo..., op. cit., p. 5 y ss. NEVES, Lúcia M. B. Pereira das: Estado e política na Independência..., op. cit., pp. 121 y ss.
} 
aquellas juntas gubernativas ${ }^{796}$. Las referidas juntas van a ser confirmadas a través del Decreto de 29 de setiembre de 1821, a la vez que las sometían al control directo de las Cortes en Lisboa.

Como las Cortes no hubiese conseguido doblegar al príncipe, ni ha conseguido obligarlo a regresar a Lisboa, las posturas de un lado y otro se radicalizaron. Atendiendo a los reclamos del movimiento vintista, las Cortes de Lisboa buscaban objetivamente someter al rey al control de la Asamblea, lo que incluía la rebeldía del Príncipe Regente en Brasil, y devolver a la metrópolis europea el control de las demás partes del Imperio ${ }^{797}$. A partir de esta posición de las Cortes, los rumores de tentativa de recolonización de Reino de Brasil pasa a ser frecuentes, y con el envío de tropas para asegurar el poder en las provincias en que tenía control las Cortes, quedó claro aquella posición para algunos ${ }^{798}$. La historiografía mayoritaria aboga por esta posición de recolonización, aunque hoy en día, y a bien de la verdad, ya empiezan a surgir voces en el sentido de matizar aquel enfoque, puesto que no estuvo tan clara esta posición de las Cortes en este sentido, como defiende Lucia M. Bastos P. das Neves ${ }^{799}$. Entretanto, estaba claro que el Príncipe Regente no tenía la intención de aceptar someter la corona a las Cortes liberales. ${ }^{800}$ La opción será la separación de Portugal, y aliado a las élites locales, compuesta de individuos que en su mayoría estudiaron en la Universidad de Coimbra, construirá en Brasil una monarquía más conservadora, pero constitucional, en un perfecto equilibrio de facciones, mucho más al gusto de la política británica que del ideario revolucionario francés ${ }^{801}$.

Sin embargo, el ardiente deseo de los portugueses europeos de atraer más importancia para Lisboa, perdida para Río de Janeiro, era una demanda a lo largo y ancho de Portugal ${ }^{802}$. Esto se moldeará en una política integradora, creando la idea de que no existían dos reinos, sino apenas uno, una sola entidad política. Brasil debía ser la continuación de Portugal ${ }^{803}$. Así se manifestará en las Cortes en la Sesión de día 14 de junio de 1821 el diputado Fernandes Tomás:

\footnotetext{
${ }^{796}$ REVÉRBERO CONSTITUCIONAL FLUMINENSE (1821-1822), nº 7, de 15 de diciembre de 1821 - “A instalação dos governos provisórios, autorizados pelas Cortes (...) era, depois de jurada a Constituição e suas bases, um ato necessário, como de adesão e de identificação às ideias gerais e à reforma constitucional do governo da nação".

${ }^{797}$ NEVES, Lucia M. Bastos P.: Linguagem políticas do conservadorismo..., op. cit., p. 5 y ss.

${ }^{798}$ HOLANDA, Sérgio Buarque de: A herança colonial - sua desagregação en HOLANDA, Sérgio Buarque de (dir.): História geral da civilização brasileira, Vol. I, O processo de emancipação, $2^{\mathrm{a}}$ edição, Ed. Difusão Europeia do Livro, São Paulo, 1965, pp. 13-39.

${ }^{799}$ BERBEL, Márcia Regina: A retórica da recolonização en JANCSÓ, István (org.): Independência: história e historiografia, Ed. Fapesp/Hucitec, São Paulo, 2005, pp. 791-808.

${ }^{800}$ SOUZA, Iara Lis C.: Pátria coroada: o Brasil como corpo autônomo (1780/1831), Unesp, São Paulo, 1999, pp. 30 y ss. RIBEIRO, Gladys Sabina: A liberdade em construção: identidade nacional e conflitos antilusitanos no Primeiro Reinado, Ed. Relume Dumará, Rio de Janeiro, 2002, pp. 28 y ss.

${ }^{801}$ NEVES, Lúcia M. B. Pereira das: Estado e política na Independência..., op. cit., pp. 121 y ss.

${ }^{802}$ RODRIGUES, José Honório: Independência: Revolução e contrarrevolução, Ed. Francisco Alves, Rio de Janeiro, 1975-1976, Vol. 5. NOVAIS, F. y MOTA, Carlos G.: A independência política do Brasil, Ed. Moderna, São Paulo, 1986, pp. 55 y ss.

${ }^{803}$ DCGECNP, Sesión del día 1 de julio de 1822, p. 649.
} 
"Não há distinção entre o Brasil e Portugal; tudo é o mesmo: e estas Cortes nem fazem, nem devem fazer diferença de interesses desta ou daquela província. (...) A soberania é igual para todos, e para todos são iguais os benefícios" ${ }^{804}$. Desde esta perspectiva la Regencia en Brasil cada vez iba perdiendo su importancia en la visión de las Cortes de Lisboa. Las investidas de estas mismas Cortes de atraer para Lisboa todo el poder, empieza a provocar la desconfianza y los recelos de la parte americana. Así, se realiza un matrimonio perfecto entre la posición de las élites formada en Coimbra y la disposición del príncipe a adoptar una monarquía liberal moderada, o casi un absolutismo ilustrado, empezando así a surgir la idea de un Brasil separado de Portugal. El primer paso en esta dirección fue la recusa de D. Pedro en atender las órdenes dictadas en Lisboa, de que debía regresar a Portugal, lo que le lleva a declarar, de este modo, el gesto que se quedó conocido como el día del "Fico" (me quedo) en 9 de enero de 1822. Estaba lanzada la piedra fundamental de un nuevo imperio.

\subsubsection{La Cuestión brasileña en las Cortes de Lisboa: los artículos adicionales a la Constitución referentes al Gobierno de Brasil.}

Es muy común en el grueso de la historiografía brasileña, al tratar del período de la independencia, hablar del despotismo de las "Cortes", como una entidad alienígena que pretendía recolonizar Brasil. Sin embargo, de las discusiones de los diputados en las Cortes, no se puede deducir aquella posición. Aunque, en materia comercial y económica, mucho más que en materia política, la intensión de regreso al status ante del Decreto de 1808 -que rompía el pacto colonial- y de los Tratados de 1810, era más perceptible. Por lo tanto, nos parece interesante la inserción de matizaciones en las discusiones que se procesarán en las Cortes Generales y Extraordinarias de la Nación Portuguesa, en Lisboa. No obstante, la temática de la independencia de por si no es el objeto central de nuestro estudio, vale la pena insertar estas matizaciones para mejor comprender los procesos constitucionales ibéricos, que, como sabemos, influirán en el proceso que se desarrollará en Brasil con la Constituyente de 1823. La cuestión brasileña será una de las causas de la caída del régimen liberal en Portugal. Por lo tanto, su importancia se nota en las innumerables sesiones en las que se trató de la temática, en donde se pretendía establecer las bases de las relaciones entre los dos reinos; o incluso solucionar aspectos puntuales de la política luso-brasileña, como las incidentales que llevarán al proceso de independencia. Sin embargo, no tenemos la pretensión de finalizar toda la temática

\footnotetext{
${ }^{804}$ DCGECNP, Sesión del día 14 de junio de 1821, p. 1.214. Sobre este tema véase la obra de JANCSÓ, István y PIMENTA, Joao Paulo Garrido: Peças de um mosaico (ou apontamentos para o estudo da emergência da identidade nacional brasileira) en MOTA, Carlos G. (org.): Viagem incompleta; a experiência brasileira (15002000). Formaçao: histórica, Ed. Senac, São Paulo, 2000. También la obra de PIMENTA, Joao Paulo G.: Estado e nação no fim dos impérios ibéricos no Prata, 1808-1828, Ed. Hucitec, São Paulo, 2002, pp. 36 y ss.
} 
de la Cuestión brasileña en las cortes de Lisboa, dado que, el volumen de documentos y debates en las sesiones darían por si solos para una producción específica más amplia.

Dentro de aquella cuestión buscaremos seguir uno de los aspectos estudiados por Zília Osório de Castro, que son las Bases de Gobierno; aunque aquella autora se quede con un parlamentario específico, el diputado Borges Carneiro ${ }^{805}$. No trataremos de la cuestión de las intervenciones militares ordenadas por las Cortes en las Provincias de Río de Janeiro, Bahía y Pernambuco, por ejemplo; aunque hicimos referencia antes a estas intervenciones, desde la perspectiva brasileña, que cambiaron el curso de los acontecimientos del otro lado del atlántico; y solo abordaremos parcialmente la cuestión comercial defendida por los diputados paulistas. Entretanto, en el universo a ser abordado, buscaremos fundamentarnos, principalmente en el Parecer de la Comisión Especial para los Negocios Políticos de Brasil; en el Proyecto de los artículos adicionales a la Constitución y al Proyecto que sustituirá a este último como las enmiendas constitucionales.

En el plano económico, al cual no nos extenderemos mucho, encontraremos algunas de las respuestas, dentro del concepto de Regeneración vintista, para la separación de Brasil de Portugal. Como ya hicimos referencias, la llegada de la Familia Real a Brasil, el Decreto de 1808, los Tratados de 1810 y la elevación en 1815 de Brasil ${ }^{806}$ a la categoría de reino, impidió cualquiera tentativa de hacer con que Brasil regresase a la condición de colonia. Aunque, como también hicimos referencia, esta condición nunca fue defendida abiertamente en las Cortes de Lisboa. Hubo mucho malos entendidos de ambas partes, aunque estaba claro que Portugal quería seguir siendo la sede de la monarquía con antiguos privilegios y que en Brasil la palabra recolonizar causaba escalofríos en las élites locales, principalmente en la paulistana ${ }^{807}$.

La delegación de la Provincia de Sao Paulo llegó perfilada con las "Lembranças $e$ apontamentos do Governo Provisório da Província de São Paulo para os seus deputados" $" 808$, que traía como requisito básico los recíprocos intereses para la manutención de la unión: un comercio favorable a ambos reinos, sin entrabes ni entrepuestos. De esta forma, defendían la integridad del Reino Unido, pero también la individualidad de los dos reinos. Difícil tarea de

\footnotetext{
${ }^{805}$ CASTRO, Zília Osório de: Cultura e Política. Manuel Borges Carneiro e o Vintismo, Instituto Nacional de Investigação Cientifica (Centro da Cultura da Univ. Nova de Lisboa), Cultura Moderna e Contemporânea - 5, Vol. I, Lisboa, 1990, pp. 339-375.

${ }^{806}$ Elevação do Brasil à Categoria de Reino - Carta de Lei do Príncipe D. Joao de 18 de dezembro de 1815 in: BONAVIDES, Paulo e AMARAL, Roberto: Textos Políticos da História do Brasil, Vol. I, $3^{\text {a }}$ Ediçao, Senado Federal, Brasília, 2002, pp. 454-456.

${ }^{807}$ COSTA, Jaime Rapouso: “O liberalismo vintista (1820-1822)”, Boletim da Univ. de Coimbra (Separata da Revista), Vol. 43, Coimbra, 1997, pp. 47-66.

${ }^{808}$ Véase: "Lembranças e apontamentos do Governo Provisório da Província de São Paulo para os seus deputados" aprovadas no Palácio do Governo de São Paulo, 10 de outubro de 1821 en CALDEIRA, Jorge (org.): José Bonifácio de Andrada e Silva, Editora 34 - Coleção Formadores do Brasil, São Paulo, 2002, pp. 125-133.
} 
conciliar, dado que dentro del pensamiento vintista de "regeneración" de Portugal, se buscaba proteger a la marina y la industria poco competitiva del país ${ }^{809}$. Es evidente, como nos hace ver Jaime Costa, que Brasil no era Sao Paulo, y que diferentes intereses de las élites locales eran conflictivos y a veces trillaban cominos opuestos. Como ya decimos, el Gran-Pará, la Provincia de Bahía ${ }^{810}$ y de Pernambuco se mantuvieron fieles a las Cortes de Lisboa, dado que sus intereses comerciales estaban ligados a esta parte del imperio, con relaciones privilegiadas ${ }^{811}$, a la vez que, eran contrarios a que el centro político se mantuviese en Río de Janeiro, y de ahí irradiase las decisiones para todo Brasil. Sin embargo, todas estas posiciones juntas en las Cortes era un crisol bastante difícil de manejar para obtener un concepto de unidad nacional en sentido amplio, en donde se buscase contentar a todos. Un juego que fue difícil de jugar ${ }^{812}$, dado que la falta de información sobre el Reino de Brasil pesaba a la hora de tomar decisiones por parte de las Cortes ${ }^{813}$.

La "Cuestión Brasileña" toma cuerpo en las Cortes en el momento que se declara que los diputados representaban la nación entera y no solamente a las provincias de donde provenían $^{814}$. Y como tuviesen los diputados, principalmente los de Sao Paulo, posiciones comerciales bien definidas, al momento de la discusión del proyecto ${ }^{815}$ comercial entre Brasil y Portugal, la posición de los diputados europeos y paulistas se tornaron incompatibles ${ }^{816}$. No solamente nombres paulistas como Antonio Carlos Ribeiro de Andrada defendieron los

\footnotetext{
${ }^{809}$ COSTA, Jaime Rapouso: “O liberalismo vintista...”, op. cit., p. 52.

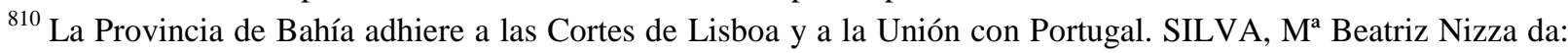
"Liberalismo e separatismo no Brasil" en Cultura, História e Filosofia, Vol. IV, Instituto Nacional de Investigaçao Científica, Lisboa, 1996, p. 156. También trata del tema en SILVA, Ma Beatriz Nizza da: A repercussao da Revoluçao de 1820 no Brasil. Eventos e Ideologias en Revista de História das Idéias, Vol. II, Instituto de História e Teoria das Ideias, Universidade de Coimbra, 1978-79, pp. 22 y ss.

${ }^{811}$ COELHO, Geraldo Martins: Anarquistas, Demagogos e Dissidentes. A imprensa liberal no Pará de 1822, CEJUP Editora, Belém, 1993, pp. 95-112.

${ }^{812}$ COSTA, Jaime Rapouso: “O liberalismo vintista...”, op. cit., p. 52.

${ }^{813}$ Esta falta de información sobre la antigua colonia se quedará evidente al observar a la imprenta portuguesa del periodo. ASTRO DA LUSITÂNIA (Periódico constitucional publicado en Lisboa entre 30 de octubre de 1820 a 15 de abril de 1823), n $265-266$ de 12 y 13 de octubre de 1821 , el no 268 de 16 de octubre y el no 356 de 4 de febrero de 1822.

${ }^{814}$ CARVALHO, M. E GOMES DE: Os deputados brasileiros nas Cortes..., op. cit., pp. 71 y ss. COSTA, Jaime Rapouso: “O liberalismo vintista...”, op. cit., p. 53. Véase también la "Representação de São Paulo dirigida a D. Pedro em 31 de dezembro de 1821" en CALDEIRA, Jorge (org.): José Bonifácio..., op. cit., pp. 134-145. También dicha representación fue publicada en el periódico BORBOLETA CONSTITUCIONAL, $\mathrm{n}^{\circ} 119$ de 24 de mayo de 1822.

${ }^{815}$ PROYECTO COMERCIAL PARA BRASIL Y PORTUGAL: art. $1^{\circ}$ - "O comercio entre os reinos de Portugal, Brasil e Algarves, será considerado como de Províncias de um mesmo continente". Art. $2^{\circ}$ - "É permitido unicamente a navios de construção e propriedade portuguesa fazer o comércio de porto a porto em todas as possessões portuguesas".

${ }^{816}$ DCGCNP, Tomo V, Sesión de 1 de abril de 1822, pp. 185 y 186. Véase también sobre el tema en COSTA, Jaime Rapouso: A Teoria da liberdade. Período de 1820 a 1823, Universidade de Coimbra, 1976, pp. 140 y 142. También en CALASANS, José: Os Vintistas e a Regeneraçao de Portugal, S.A. Artes Gráficas, Bahia, 1959, pp. 143 y ss.
} 
beneficios para el comercio local con la manutención del Decreto de 1808, que liberalizaba el comercio en Brasil, como también el bahiano Cipriano José Barata de Almeida ${ }^{817}$. Los artículos primero y segundo del citado proyecto comercial será puesto a votación en las sesiones de los días 1 y 9 de abril de 1822, que saldrán aprobados por las Cortes. Este proyecto comercial virtualmente abrogaría al Decreto de 1808, haciendo con que el exclusivo comercial, que beneficiarían a las elites comerciales de Lisboa y Oporto, volviese a estar vigente. Esta aprobación provocará repercusión en la independencia entre los diputados brasileños ${ }^{818}$. Dicha aprobación, entretanto, contó con la reacción del diputado paulista Antonio Carlos Ribeiro de Andrada, que veía en esta actitud de las Cortes la oposición total a los intereses brasileños y acusó al destacado diputado portugués Borges Carneiro de está confundiendo intereses del comercio con intereses de comerciantes. Además, ha destacado que el Decreto de 1808 ya estaba arraigado a la tradición comercial en Brasil, y que abolirlo sería un grave error, destacadamente en el sentido del liberalismo económico ${ }^{819}$. Todo en vano. En el imaginario de la Regeneración vintista, la revalorización de Lisboa como sede de la monarquía y entrepuesto comercial, no dejaba ver que el endurecimiento de estas posiciones echaría a perder la unión entre los dos reinos ${ }^{820}$. Aunque no se debe únicamente la secesión a las posiciones de los diputados portugueses ${ }^{821}$.

Un factor que fue preponderante en la velocidad de los acontecimientos fue la libertad de imprenta que vino con la revolución liberal. Así como en España que los papeles públicos jugarán un importante papel en la difusión de las ideas y manutención del régimen liberal, en el Imperio Luso-brasileño, a partir del año de 1821, los papeles circulan en una velocidad alucinante. En Brasil estos papeles tendrán una acogida muy grande, puesto que al contrario de los discursos en las Cortes, que hablaban de los peligros de la independencia, se imprimían ideas en el sentido de divulgar las ventajas que dicha independencia traería para la américa

\footnotetext{
${ }^{817}$ Sobre la materia comercial que enfrentaron los diputados peninsulares y de la américa portuguesa véase en CASTRO, Zília Osório de: Cultura e Política. Manuel Borges Carneiro..., op. cit., pp. 376-387. Notadamente al Capítulo IV, intitulado la Política Brasileña, con el un epígrafe intitulado de Relaciones comerciales.

${ }^{818}$ El periódico BORBOLETA CONSTITUCIONAL, Edición no 210, de 19 de septiembre de 1822, publica en sus páginas la "Refutação ao Projeto de Comercio de Portugal com o Brasil", en donde resaltaba que la unión entre los dos reinos debía ser por lazos de amistades y no por la dependencia.

819 "Numa atitude conciliatória de interesses, o deputado brasileiro propôs que a liberdade de cabotagem fosse temperada, onerando com direitos extraordinários os navios estrangeiros que se empregassem nesse ramo de atividade o que estimularia o desenvolvimento da marinha portuguesa sem afetar gravemente o comercio brasileiro." COSTA, Jaime Rapouso: “O liberalismo vintista...”, op. cit., p. 55.

${ }^{820}$ FRANCO, Afonso Arinos de Mello: A Câmara dos Deputados. Síntese Histórica, Obra comemorativa do Sesquicentenário de Instalação da Câmara dos Deputados, Centro de Documentação e Informação, Coordenação de Publicações, Brasília, 1976, pp. 15 y 16.

${ }^{821}$ Como bien se puede deprender de la lectura de SILVA, Ma Beatriz Nizza da: "Liberalismo e separatismo...", op. cit.
} 
portuguesa $^{822}$. No solamente en el periódico "Mnemosine Constitucional” se publicó puntos favorables a la independencia de Brasil, sino también la Imprenta Nacional publicaba en Lisboa, en 1821, un papel intitulado "Reflexões sobre o Pacto Social e acerca da Constituição de Portugal", que había sido escrito en octubre de 1820, cuyo autor se intitulaba "Hum Cidadão Portuguêz" ${ }^{, 823}$.

Mientras que la lectura de las actas de las Cortes nos deja la impresión de que éstas intentaban hacer creer que la independencia de Brasil sería un desastre a los intereses de este, y eludía al tema de la mejor forma posible. Los papeles en circulación demostraban que el tema estaba bastante candente de un lado y otro del atlántico ${ }^{824}$.

Así, candente la situación en la parte americana del imperio, hizo con que, con la lectura en la Sesión del día 12 de marzo de 1822 de la carta que el Príncipe Regente D. Pedro ${ }^{825}$ había enviado a su padre, el rey, informando de la situación de Río de Janeiro y demás provincias, surgiese la petición de creación de una Comisión Especial para tratar de los negocios políticos de Brasil $^{826}$. En la misma sesión el diputado Vilela Barbosa, levanta la oportunidad de esperar la llegada de los demás diputados de Brasil, antes de formar dicha comisión. Acto seguido, el diputado Camelo Fortes va a pronunciarse favorable a la creación de dicha comisión. Pero, otro diputado, José Antonio Guerreiro, va mucho más lejos en defensa de la creación de la comisión:

"Proponho que se nomeie uma comissão de 15 membros, tirados do seio deste Congresso, em que entrem deputados de todas as províncias do Brasil, que já os têm nele, a qual seja encarregada de preparar todos os artigos constitucionais que são requeridos pela especial situação e circunstâncias das províncias ultramarinas, para serem discutidos ao tempo da revisão da constituição. E, outrossim, seja

\footnotetext{
822 "Um desses folhetos (...) redigido em francês, circulou na cidade do Rio de Janeiro nos finais do mês de janeiro e foi publicado em Lisboa, em versão portuguesa, no jornal Mnemosine Constitucional, edição de 12 de maio. O texto a favor da independência do Brasil está dividido em seis proposições (...)." COSTA, Jaime Rapouso: “ $O$ liberalismo vintista...”, op. cit., p. 55. También se puede complementar con la lectura de SILVA, Ma Beatriz Nizza da: “A repercussão da Revolução de 1820 no Brasil...”, op. cit. MNEMOSINE CONSTITUCIONAL (Periódico salido en Lisboa de 25 de septiembre de 1820 a 30 de junio de 1821), no 112 de 12 de mayo de 1821 y n $\mathrm{n}^{\circ} .113$ de 13 de mayo de 1821.

823 "Reflexões sobre o Pacto Social e acerca da Constituição de Portugal”, autor: Hum Cidadão Portuguêz, outubro de 1820. Primeiro mês da liberdade lusa, Imprensa Nacional, Lisboa, 1821, pp. 80 y 81.

${ }^{824}$ Se puede abstraer dicha posición con la lectura de la Revoluçao anti-constitucional em 1823. Suas verdadeiras causas e efeitos. Publicados pellos editores do popular Jornal Portuguez em Londres. Impresso por L. Thompson. $\mathrm{Na}$ oficina Portuguesa, 1823, pp. 14 y 15. Véase también sobre la circulación de papeles impresos y las guerras de ideas propinadas por estos la completíssima obras sobre el tema de LUSTOSA, Isabel: Insultos impresos. A guerra dos jornalistas na independencia, 1821-1823, Companhia das Letras, Sao Paulo, 2000, pp. 174 y ss.

${ }^{825}$ En una carta del príncipe al rey de 14 de marzo de 1822, este hace alusión a tres elementos interesantes, a su concepto de ser constitucional, a la visión que se tenía de las Cortes en Brasil, y de su concepto sobre el despotismo: "Os Brasileiros, e eu somos constitucionais, mas constitucionais, que buscamos honrar o Soberano por obrigação de súbditos, e para nos honrarmos a nós, por tanto a raiva é só a estas facciosas Cortes, e não ao sistema de Cortes deliberativas, que este sistema nasce com o homem, que não tem alma de servil, e que aborrece o despotismo". Cartas dirigidas a Sua Magestade o Senhor D. Joao VI, pelo príncipe real o Senhor D. Pedro de Alcantara, Imprensa Nacional, Lisboa, 1822.

${ }^{826}$ DCGCNP, Tomo V, Sesión del día 12 de marzo de 1822, pp. 444 y 445. Diputado Pereira do Carmo.
} 
encarregada de redigir e apresentar com urgência os projetos de leis gerais que devem regular todos os ramos da pública administração naquelas províncias." 827

Hubo una inmensa discusión en las Cortes acerca de la oportunidad de formar dicha comisión y cual el número de miembros que la integraría. Al final se aceptó provisoriamente la propuesta del diputado Borges de Barros para que se fijara en trece el número de diputados que integraría la Comisión. Borges Carneiro era uno de los diputados que pensaba diferente la situación de Brasil y para tanto se exigían medidas diversas de las que orientaba las otras partes del imperio ${ }^{828}$. Después de mucha discusión sobre la conveniencia o no de la formación de la Comisión Especial, se vota por formar dicha comisión, estando ella compuesta por doce miembros ${ }^{829}$ : siendo seis brasileños y seis portugueses ${ }^{830}$.

Formada la comisión, se puso a trabajar, y en la Sesión del día 18 de marzo tenía ya un parecer sobre la relación política entre Portugal y Brasil. Dicho parecer trae un largo preámbulo, en donde describe primero los motivos de creación de la Comisión Especial, destacando la carta enviada al rey por el Príncipe Regente, también los oficios enviados por la Junta Administrativa de Pernambuco, además de lo que la comisión llama de fermentación y tendencias peligrosas de los ánimos en las provincias de Sao Paulo, Minas Gerais y Río de Janeiro. También declara que "a Comissão deplora o engano em que laboram os brasileiros, $e$ não concebe como se possam atribuir ao Congresso vistas contrarias aos sentimentos liberais, que lhe deram nascimento, e que certo o animam" ${ }^{831}$. Sigue el preámbulo haciendo un largo recorrido por los acontecimiento recientes. Al final del preámbulo se declara que el objetivo era el de demostrar que el Congreso era leal a las pretensiones del Reino de Brasil.; y por tanto, diez puntos son aclarados para desvanecer a la crisis brasileña. Entre las más importantes está la antigua promesa de no crear una Junta provisional en Río de Janeiro, por está allí presente el Príncipe Regente y se corría el riego de sobreponer jurisdicciones, y por lo tanto provocar desorden, en caso de creación de dicha Junta. Además, determinaba que el Príncipe Regente organizase el gobierno general de Brasil. Mandaba que el príncipe pusiese en vigencia los decretos que abolían los tribunales simultáneos, que existían con igual funciones que los de

\footnotetext{
${ }^{827}$ DCGCNP, Tomo V, Sesión del día 11 de marzo de 1822, p. 445. Diputado José Antônio Guerreiro.

${ }^{828}$ CASTRO, Zília Osório de: Cultura e Política. Manuel Borges Carneiro..., op. cit., p. 341.

${ }^{829}$ DCGCNP, Tomo V, Sesión del día 11 de marzo de 1822, p. 450. Diputado Borges Carneiro.

${ }^{830}$ Ídem, p. 460. Los diputados escogidos fueron los siguientes: Francisco Manuel Trigoso de Aragão Morato (Beira), Antônio Carlos Ribeiro de Andrada Machado e Silva (S. Paulo), Bento Pereira do Carmo (Extremadura), Custódio Gonçalves Ledo (Rio de Janeiro), José Joaquim Ferreira de Moura (Beira), Luís Paulino de Oliveira Pinto da França (Baía), Manuel Borges Carneiro (Extremadura), Joaquim Pereira Anes de Carvalho (Extremadura), Inácio Pinto de Almeida e Castro (Pernambuco), José Antônio Guerreiro (Minho), Joaquim Antônio Vieira Belford (Maranhão), Manuel Marques Grangeio (Algarve). Véase también sobre este proceso de escoja de los diputados en CASTRO, Zília Osório de: Cultura e Política. Manuel Borges Carneiro..., op. cit., p. 343.

${ }^{831}$ DCGCNP, Tomo V, Sesión del día 18 de marzo de 1822, pp. 531-532. Diputado José Antônio Guerreiro.
} 
Lisboa. El punto más sensible que enfrentaba paulistas y peninsulares fue tratado en el artículo sexto:

"6". Que se discuta e desde logo se remeta às Províncias do Reino do Brasil o projeto do decreto sobre as relações comerciais, que a Comissão reputa um dos mais fortes vínculos da união; neles não descobrirão os brasileiros um só artigo que não ressumbre a mais perfeita igualdade e reciprocidade: antes convencer-seão que o Congresso trata o Brasil como verdadeiro irmão e amigo ${ }^{832}$."

Por fin, el artículo $10^{\circ}$ trata del tema de la organización administrativa de Brasil, en donde las discusiones se centraron en decidir si se debía tener una sede, la de Río de Janeiro, o dos sedes, con ésta otra en Bahía, o incluso tres sedes, en el caso que lo necesitase crear una para las provincias del norte, aunque se tenía más o menos claro que por la proximidad de aquellas debiesen está vinculadas directamente a Lisboa:

"10". Que se indique em termos enérgicos, e claros às províncias do Reino do Brasil, que o Congresso não tem dúvida de conceder àquele reino um ou dois centros de delegação do poder executivo, que previnam os inconvenientes da grande distancia daquele Reino a este, ficando imediatamente subordinadas ao poder executivo aquelas províncias, que assim o requererem por convir à sua posição, e interesses ${ }^{833}$."

Además, la Comisión decía que salvo el principio esencial de la unión, y promete colaborar para lo que más convenga a Brasil para su administración interna. También llama a la obligación a todas las provincias para la creación del edificio constitucional, alertando que no se debe admitir en política que un veto de una provincia inutilice las operaciones de la Asamblea de toda la Nación. Y por fin trata del polémico tema de las tropas portuguesas en las provincias de Brasil.

La prontitud con que la Comisión desempeñó su incumbencia no reflejó en el interés de las Cortes en discutir de inmediato el Parecer presentado. Solamente pasados dos meses, en la Sesión del día 25 de mayo de 1822 será puesto en el orden del día para ser discutido, y aun así, se propuso y se aprobó la posposición de las discusiones ${ }^{834}$. Por tanto, se presentaba la excusa de que el "horizonte político" de Brasil había cambiado y convenía esperar porque era inminente la llegada a Portugal de una representación de Brasil a las Cortes.

\footnotetext{
832 Íbidem.

833 Íbidem. Ha firmado dicho Parecer: Paço das Cortes em 18 de Março de 1822. - Antônio Carlos Ribeiro de Andrada Machado e Silva; Bento Pereira do Carmo; Joaquim Pereira Annes de Carvalho; José Joaquim Ferreira de Moura; Luís Paulino de Oliveira Pinto da França; Manoel Borges Carneiro; Francisco Manoel Trigoso d’Aragão Morato; Custodio Gonçalves Ledo; Joaquim Antônio Vieira Belford; Ignácio Pinto d`Almeida e Castro; Manoel Marques Grangeiro; José Antônio Guerreiro.

${ }^{834}$ DCGCNP, Tomo V, Sesión del día 25 de mayo de 1822, p. 273. También dicha discusión se encuentra comentada en CASTRO, Zília Osório de: Cultura e Política. Manuel Borges Carneiro..., op. cit., p. 343.
} 
Aunque, para algunos diputados, entre ellos portugueses, había cierta urgencia en discutir la Cuestión brasileña para disuadir las intrigas y disipar las noticias negativas que infundían al pueblo sobre los propósitos de las Cortes en relación a Brasil:

"Deveremos deixar aqueles negócios tomar a carreira que espontaneamente tomarem, ou talvez aquela que lhe derem os facciosos, sem cuidarmos de lhes dar direção alguma? Deveremos deixar continuar as desconfianças de escravidão $e$ vassalagem em que alguns facciosos têm lançado aqueles povos? É evidente que não, e que pelo contrário devemos apressar-nos a mostrar por obras e por decretos ao Brasil quão liberal é o governo que lhe preparamos, e quão falazes e absurdas as instigações dos áulicos e oligarcas do Rio de Janeiro e de S. Paulo ${ }^{835}$."

De este modo, se percibía prisa en el discurso de algunos diputados para reglamentar las relaciones luso-brasileñas, y buscar así, atender lo posible de las demandas americanas, a la vez que, buscar desestructurar los apoyos dados a la causa de la independencia ${ }^{836}$. Lo que llama la atención del parecer era la sintonía presentada con las demandas de Río de Janeiro y el deseo recíproco de unión entre Brasil y Portugal que desprendían de las alocuciones del texto ${ }^{837}$. Al final, en la sesión de día 22 de julio de 1822 la mayoría vota contrario al parecer, incluso uno de los diputados firmantes de dicho parecer, Borges Carneiro:

"Uma coisa nos tem faltado: a energia; tomara eu agora um Marquês de Pombal com o poder que teve e os meios que presentemente há, e ver-se-ia tudo pronto em poucos momentos e os negócios do Brasil entrarem em seu devido andamento ${ }^{838}$."

Otra comisión fue formada para cuidar de los asuntos brasileños: la Comisión encargada de redactar los artículos adicionales a la Constitución relativos a Brasil ${ }^{839}$. Esta Comisión va a presentar concluso sus trabajos en la Sesión de 17 de julio de 1822, lo que conformará una especie de bases de los artículos adicionales que al final figurará en la Constitución vintista. Estas "bases" traían un preámbulo explicando lo que la motiva y los fines a que se pretende. Allí se enunciaba la imposibilidad de conciliar los intereses de Brasil completamente a los intereses que las Cortes pretendían para el Imperio luso. Por lo tanto declaraba la imposibilidad de una integral unidad entre los dos reinos. Va a ser encargado de la lectura del parecer de la

\footnotetext{
${ }^{835}$ Ídem, p. 273. Diputado Borges Carneiro.

${ }^{836}$ CASTRO, Zília Osório de: Cultura e Política. Manuel Borges Carneiro..., op. cit., p. 344.

${ }^{837}$ Ídem, p. 345.

${ }^{838}$ DCGCNP, Tomo VI, Sesión del día 22 de julio de 1822, p. 890.

${ }^{839}$ Dicha Comisión estaba compuesta por los siguientes diputados: José Feliciano Fernandes Pinheiro (S. Paulo), Antônio Carlos Ribeiro de Andrada Machado e Silva (S. Paulo), José Lino Coutinho (Bahía), Francisco Vilela Barbosa (Rio de Janeiro), Pedro de Araújo Lima (Pernambuco). DCGCNP, Tomo VI, Sesión del día 17 de Junio de 1822, p. 467. De este tema trata dos autores: CASTRO, Zília Osório de: Cultura e Política. Manuel Borges Carneiro..., op. cit., pp. 356-369. También en CARVALHO, M. E GOMES DE: Os deputados brasileiros nas Cortes..., op. cit., pp. 340-356.
} 
Comisión el Sr. Andrada, diputado por Sao Paulo, que empieza el parece diciendo que se busca con los artículos adicionales nada más que la unión entre el Imperio luso-brasileño. Además, dice el parecer que se oyó a los diputados brasileños en las Cortes, así como se llevó en consideración la representación de las Cámaras de Río de Janeiro, del vice-presidente del Gobierno de Minas Gerais y las cartas de la Junta Provisional de Pernambuco. De este modo declara que "o sistema de unidade inteira dos dois Reinos é quase de absoluta impossibilidade". Otros dos puntos establecidos son: que la legislatura que respecta a ciertos negocios, dada la diversidad, debe ser diferente en los dos reinos; y que el Poder Ejecutivo, solo sería efectivo en Brasil con una delegación permanente y amplia, y que sus ramificaciones deben ser independientes inmediatamente de Portugal.

De este modo la Comisión estaba convencida de que se debía dotar a Brasil de Cortes particulares, lo que satisfaría las ideas de independencia. Además, sentencia la comisión al final del preámbulo del parecer que:

"O conhecimento da ilusão será o começo da independência; separar-se-á o Brasil de Portugal: e perderão na sua consideração política de ambos os Reinos, que unidos podiam, e deviam formar uma grande, e respeitável Nação ${ }^{840 " .}$

De los quince artículos presentados por la Comisión se desprende un ideario institucional para el Reino de Brasil, dotado de instituciones autónomas en relación a Portugal, pero, a la vez, integrante del Imperio Luso-brasileño. Lo que más llama la atención en los primeros artículos es la creación de dos Congresos especiales (para Brasil y Portugal) y unas Cortes Generales para ambos reinos. Las partes polémicas de la propuesta estaba en permitir (art. $3^{\circ}$ ) que las provincias de Asia y la África portuguesa declaren a que Reino se quieren incorporar, para tener parte en la respectiva representación del Reino a que se unirán ${ }^{841}$. Eso alejaría la idea de centralidad de la sede de Lisboa, propuesto por el ideario vintista. Llama la atención también las funciones de las Cortes Generales, que tenía prerrogativa de revisora de las leyes aprobadas en los parlamentos especiales o individuales de cada Reino, además, contaba con competencias legislativas privativas en los siguientes asuntos: relaciones comerciales entre los dos reinos, relaciones con el extranjero, hacer leyes generales sobre la defensa del Reino Unido, de la parte militar de la guerra y de la marina ${ }^{842}$. En el ejercicio de su competencia revisora de las leyes aprobadas en los parlamentos especiales, le competía observar dos criterios: que la ley aprobada no se oponga al bien del Reino hermano, y que no

\footnotetext{
${ }^{840}$ DCGCNP, Tomo VI, Sesión del día 17 de Junio de 1822, p. 466.

${ }^{841}$ Ídem, p. 467.

${ }^{842}$ Íbidem.
} 
ofenda a la Constitución general del Imperio (párrafo $3^{\circ}$, del art. $\left.10^{\circ}\right)^{843}$. Cuanto a la sanción de las leyes, cabía provisoriamente al Príncipe Regente en Brasil sancionar las leyes particulares del Reino, pero estas solo pasarían se puesto en vigor firme y definitivamente después de la revisión de las Cortes y la definitiva sanción del rey (arts. 6, 7 y 10, párrafo $\left.3^{\circ}\right)^{844}$. Lo interesante es notar que en el art. $2^{\circ}$ fija la capital en Río de Janeiro para el Reino de Brasil, pero, se preveía la creación de una nueva capital en el centro de Brasil ${ }^{845}$.

Dentro de nuestro estudio de la confesionalidad del Estado, lo que más va a interesarnos será una de las excepciones de la delegación de poderes al Príncipe Regente en Brasil. En el párrafo $1^{\circ}$ del art. $13^{\circ}$ se fija que cabrá al rey la parte importante del Patronato Regio. Por lo tanto, la competencia de nombrar a los arzobispos y obispos para el proveimiento de los cargos será del rey, siéndole presentados en lista tríplice y refrendadas por el Secretario de Estado de la repartición dedicada a estos negocios. Se preveía, además, en el art. 14 la creación de un Tribunal Supremo de Justicia para el Reino de Brasil ${ }^{846}$. En la lectura del artículo $11^{\circ}$ parece que claramente se opta por una sola sede en el Reino de Brasil, puesto que, indica que en la capital de Brasil se establecerá una delegación del Poder Ejecutivo. Se delega este poder al Príncipe D. Pedro, como regente actual ${ }^{847}$.

Así que, en el preámbulo y artículos presentados por la Comisión, dos órdenes de problemas toman relevancia: la necesidad de reglar las relaciones mutuas, perteneciente a un todo; y la fijación de criterios para legislar los intereses particulares de cada reino. Para tanto, el primer punto cuidaría unas Cortes Generales, constituidas por representantes de ambos reinos y distintas partes del Imperio, y unas Cámaras especiales - o Asambleas territoriales - en donde se legislarían asuntos locales ${ }^{848}$.

Empiezan los debates para la aprobación de los artículos adicionales a la Constitución, presentados en el proyecto de la Comisión formada para eso. Y en la Sesión de 26 de junio de 1822 se verá los más vehementes protestos de los diputados portugueses, en donde se habla que el proyecto de artículos adicionales abre puertas a la independencia del Reino de Brasil. El primer diputado en tomar la palabra será el Sr. Girao, que dice sentir la sangre hervir en las venas al ver el proyecto de artículos adicionales, que califica de monstruoso y una zumbaría al congreso constituyente, por lo que llama de una independencia formal de Brasil ${ }^{849}$. Uno de los

\footnotetext{
${ }^{843}$ Íbidem.

844 Íbidem.

845 Íbidem.

846 Íbidem.

847 Íbidem.

${ }^{848}$ CASTRO, Zília Osório de: Cultura e Política. Manuel Borges Carneiro..., op. cit., p. 356.

${ }^{849}$ DCGCNP, Tomo VI, Sesión del día 26 de junio de 1822, pp. 559-560.
} 
miembros de la Comisión que presentó dicho proyecto, el diputado por Sao Paulo, el Sr. Andrada lo va en seguida defender los artículos con mucha ferocidad y virulencia contra el anterior preopinante ${ }^{850}$. Así que los ánimos estaban bastantes exaltados al discutir estos artículos adicionales que dotaban a Brasil de instituciones separadas de las de Portugal.

El miedo que provocaba en las Cortes esta declaración de autonomía de Brasil en relación a Portugal era tamaño que algunos diputados llegaron a declarar que dichos artículos adicionales serían contrarios a las Bases de la Constitución ya jurada por todos. También se temía, entre estos el Diputado Borges Carneiro, si esta concesión de autonomía a la Regencia en Brasil se revertería realmente en una unión duradera entre los dos reinos. Así que, después de mucho debatir la cuestión y de no llegar a un denominador común se postergan las discusiones. De los artículos del parecer presentado por la Comisión dos partes quedan aprobadas en la sesión de 5 de julio de 1822: la existencia de una delegación del Poder Ejecutivo en Brasil y de la creación de una regencia.

Pero, había discordancia cuanto a la localización de la aquella delegación, que no debía ser en Río de Janeiro, ni tampoco la regencia debía recaer en la persona del príncipe D. Pedro o cualquier otro miembro de la familia real, por no poder atribuirles responsabilidad por sus actos de gobierno.

"Se um poder legislativo criado no Brasil contrariava as Bases da Constituição, dilacerava a unidade do governo, induzia um corpo monstruoso com duas cabeças e abria caminho à separação do Reino Unido, nada disso acontecia com a criação de uma ou mais delegações do poder executivo no Brasil; antes se verificam a respeito dela algumas das razões expendidas na prefação do parecer da Comissão (...). Esta delegação do poder executivo no Brasil não destrói a unidade do governo do Reino, porque tende a executar umas mesmas leis com obediência e responsabilidade ao mesmo Rei, e a umas só Cortes ${ }^{851 ~ ", ~}$

No era un punto pacífico que hubiese una única delegación del Ejecutivo, tampoco su localización en Río de Janeiro:

"Meu parecer que são pelo menos necessárias duas delegações no Brasil: uma ao sul que poderá ter assento no Río de Janeiro, e outra ao centro que; o poderá ter na Bahia, ficando as províncias do norte correspondendo-se diretamente com Portugal. Não deixo, contudo de me inclinar muito que haja ainda outras, e mesmo tantas, quantas dantes eram as capitanias, em que havia capitães-generais, o que não pode fazer mal algum, pois de todas existe em Portugal um centro comum ${ }^{852}$."

La conmoción fue tanta con la discusión del proyecto de los artículos adicionales que decidió el pleno de las Cortes devolver a la misma Comisión para reelaborar los artículos y

\footnotetext{
${ }^{850}$ Ídem, pp. 560-562.

${ }^{851}$ DCGCNP, Tomo VI, Sesión del día 5 de julio de 1822, p. 709. Diputado Borges Carneiro.

${ }^{852}$ Íbidem.
} 
volver a presentarlos para ser discutidos. Siendo dos puntos que quedaron pacíficos y aprobados: que se permitiría una delegación del Poder Ejecutivo en Brasil y que dicha delegación no recaería en la persona del actual Príncipe Regente ${ }^{853}$. También la Comisión debía tener en cuenta el artículo $10^{\circ}$ del Parecer de la Comisión especial de los negocios políticos de Brasil aprobado en la Sesión de 18 de marzo de $1822^{854}$. La propuesta presentada por el diputado Soares Franco también debía tener en cuenta $^{855}$. Además de la siguiente propuesta que hizo Borges Carneiro:

"I. ${ }^{\circ}$ Em cada uma das províncias do Brasil que se designar e da África Oriental, e Ásia, haverá uma delegação do poder executivo. $2{ }^{\circ}{ }^{\circ}$ Esta delegação será cometida a uma junta composta de cinco vogais, que o rei nomeará sobre proposta tripla do Conselho de Estado, dos quais dois serão brasileiros, dois europeus, e o presidente sorteado entre um brasileiro e um europeu. $3 .^{\circ} \mathrm{O}$ rei poderá livremente demitir a qualquer dos ditos vogais. $4 .^{\circ}$ A dita junta exercitará também o governo ordinário da província, sendo em tudo responsável às Cortes e ao $\operatorname{Rei}^{856} . "$

Después de dicha revisión, fue presentado el denominado de Proyecto de 30 de julio que fue leído en la Sesión del día 2 de agosto de 1822, con algunas modificaciones ${ }^{857}$. El nuevo proyecto contó con diez artículos. Cuanto a la cuestión de cuantas sedes en Brasil debía tener una delegación del Ejecutivo, se quedó determinado así:

"1. Haverá no reino do Brasil uma delegação do poder executivo, à qual ficarão sujeitas todas as províncias daquele reino: será intitulada Regência do Reino do Brasil, terá o tratamento de majestade; residirá na parte mais conveniente do Brasil, que a lei designar ${ }^{858, "}$.

Se prevé, además, en el artículo $8^{\circ}$ que dicha Regencia pueda suspender a los secretarios de Estado, nombrados por ésta, en caso de prevaricación, como la propia Regencia sería responsable junto a la figura del rey. Entre los secretarios de Estado, que serían en número de tres, se nombraría un Secretario de Justicia y Eclesiásticos. Así como en el anterior proyecto, permanecía en el actual, en el párrafo $1^{\circ}$ del artículo $10^{\circ}$, defeso a la Regencia del Reino de Brasil ejercer en la plenitud el Patronato Regio. Por lo tanto, no le era permitido presentar candidatos para los arzobispados y obispados, pero, les era ordenado enviar listas tríplices,

\footnotetext{
${ }^{853}$ DCGCNP, Tomo VI, Sesión del día 6 de julio de 1822, p. 723.

${ }^{854}$ DCGCNP, Tomo V, Sesión del día 18 de marzo de 1822, p. 533. Parecer.

${ }^{855}$ DCGCNP, Tomo VI, Sesión del día 6 de julio de 1822, p. 723.

${ }^{856}$ DCGCNP, Tomo VI, Sesión del día 6 de Julio de 1822, p. 710. Diputado Borges Carneiro.

${ }^{857}$ DCGCNP, Tomo VI, Sesión del día 2 de agosto de 1822, pp. 19 y 20. El Proyecto de 30 de julio estaba firmado por los diputados que se siguen: Luis Martins Basto (Rio de Janeiro), João Fortunato Ramos dos Santos (Espírito Santo), Joaquim Antônio Vieira Belford (Maranhão) e Francisco Vilela Barbosa (Rio de Janeiro).

858 Íbidem, presentación del Proyecto.
} 
refrendadas por el Secretario de Estado de la repartición, de los que fuesen más idóneos, para que el rey escogiese uno ${ }^{859}$.

Fue puesto a discusión, el nuevo Proyecto de los artículos adicionales, en la Sesión del día 7 de agosto del mismo año. Aunque el contenido del proyecto seguía las propuestas hechas por las mismas Cortes y diputados de ella, el revuelo fue inmenso cuando se pusieron a discutirlo. El primer diputado en pronunciarse, una vez más fue el Sr. Girao. Llegadas noticias recientes, él temía que ya se hacía en las Cortes un trabajo en vano, puesto que algunas provincias, entres este Pernambuco, se habían adherido a la causa de Río de Janeiro y del Príncipe Regente:

"Ontem vieram papeis, nos quais se conhece que a mão que os escreveu, é paga para meter a ridículo quanto aqui fazemos; bastava só isto para decidir que nada mais se fizesse, porque legislar para quem não quer obedecer é dar motivo à Europa para que se ria de nós. Chegaram também ontem noticias de Pernambuco, que eu me não persuado sejam verdadeiras, porém que asseguram que adeririam às sugestões do Río de Janeiro: logo aquelas províncias não querem obedecer às Cortes. Pernambuco une-se a elas; para quem temos de legislar? Além disso, pegam em todas as palavras dos decretos e ordens das Cortes, e as interpretam, dizendo que se dirigem a coloniza-los; para que nos temos de estar a matar ${ }^{860}$ ?"

También parece que dicho diputado estaba convencido ya del empleo de la fuerza para reducir a Brasil. En este sentido así se pronuncia:

"Em uma palavra, não há já silogismos que possam convencê-los, se não os silogismos de aço; se tivéssemos dez mil homens disponíveis, que pudéssemos mandar àquelas províncias, talvez ficassem convencidos, e os decretos das Cortes seriam respeitados; mas se não temos essa força, para que havemos de fazer leis, que não sejam respeitadas, não há de tornar objetos de escarnio ${ }^{861}$ ?”

De este modo los daños hechos por los papeles en circulación llegan a las Cortes y van cambiando poco a poco los ánimos de los diputados portugueses para encontrar una salida diplomática para la Cuestión brasileña:

“Entre outras coisas dizem: 'o que podemos fazer em beneficio de Portugal, a respeito do comercio, é que quando aqui estiverem seus navios com a bandeira a meio pau, carreguem primeiro que os Estrangeiros; e como temos gêneros em abundancia, não nos pode ocasionar prejuízo`. Isto verdadeiramente é fazer mofa de seus irmãos. Dizem também: que como terão abundantemente manufaturas das fabricas que vão estabelecer, não precisará das nossas! Em fim, meu voto é que se esperem noticias seguras do Río de Janeiro, e se, com efeito, forem tais, quais as que se espalham, se tiverem reunidas as cortes, então de nada valem nossos

\footnotetext{
${ }^{859}$ Íbidem.

${ }^{860}$ DCGCNP, Tomo VII, Sesión del día 7 de agosto de 1822, p. 72. Diputado Girao.

${ }^{861}$ Íbidem.
} 
decretos: é necessário empregar medidas de outra espécie. Se pelo contrario, quiserem obedecer, então se verá o que se há de decretar a seu respeito ${ }^{862}$."

Con un discurso tan duro, el propio presidente prevé que la discusión del proyecto no tendría buena acogida entre los ilustres diputados. Se pronuncia después de la intervención del presidente el diputado por Sao Paulo, Sr. Andrada, que dice apoyar el posponer de la discusión, pero con una condición, que se declaren vacantes los asientos de los diputados brasileños, visto que nada tendrían que hacer en dicho congreso. Se sometió a votación la posposición la discusión del proyecto, pero fue rechazado.

Dando, por lo tanto, seguimiento a las discusiones, el diputado Manuel Antonio de Carvalho va a pronunciase en el sentido de que se deben disipar las desconfianzas que han surgido en Brasil de que Portugal lo quiere colonizar, y los artículos adicionales serán la prueba contraria a este sentido común. Pero, otro diputado, el Abade Medroes será de la opinión que se use la fuerza para reconducir a Brasil en el rumbo trazado por las Cortes. Éste evoca los poderes del rey, que según él no los había perdido aún, para tanto, y se propone para ser capelán de una posible expedición, y va a completar:

"Se não querem ser constitucionais, deixa-los que sejam escravos: mande-se uma expedição, que os façam entrar nos seus deveres, e eu mesmo não teria duvida em ser o capelão ${ }^{863}$."

Como se puede ver los ánimos estaban bastante exaltados en la discusión sobre la proposición de los artículos adicionales. Las noticias de convocatoria de cortes en Río de Janeiro, ya había llegado a las Cortes en Lisboa, como vimos en la intervención del diputado Girao. Esto todo era un crisol de malos entendidos en las Cortes. El talón de Aquiles era el tema de las delegaciones, si se debía tener una, dos o tres sedes en Brasil. En contra de la existencia de más de una delegación del poder ejecutivo y, por lo tanto, a favor de la doctrina del proyecto se han pronunciado la casi totalidad de los diputados brasileños, a excepción del Obispo del Pará $^{864}$. Al final se aprobó y figurará en la Constitución de 1822 que hubiese una sola delegación (art. 128) y que el número de esta fuera de cinco miembros nombrados por el rey, oído el Consejo de Estado, y estableciendo ser prohibido al príncipe e Infantes ser miembros de dicha regencia (art. 129). En la Constitución, el Capítulo II, intitulado "Da delegação do Poder

\footnotetext{
${ }^{862}$ Ídem, p. 73.

863 Íbidem.

864 “(...) Mas a respeito do que se diz, de haver uma ou duas delegações do poder executivo, calculando os incômodos, e as vantagens, tudo isso se poderia aplanar, colocando a delegação num só sitio mais cômodo: mas apesar disso me parece que haja duas delegações pelo menos. Pará, Maranhão, Rio Negro, Mato Grosso, e Goiás, esta porção chamada antigamente país do Amazonas, está muito longe de qualquer centro que se possa criar. É por esta razão que eu me inclino a que haja pelo menos duas delegações: na minha província, essa é a vontade geral.” Ídem, p. 77. Diputado Sr. Obisdo do Pará.
} 
Executivo no Brasil”, en su art. 128, dirimirá los ánimos contrarios con un apaciguador: "Haverá no reino do Brasil uma delegação do poder executivo, encarregada duma Regência, que residirá no lugar mais conveniente que a lei designar. Dela poderão ficar independentes algumas províncias, e sujeitas imediatamente ao Governo de Portugal ${ }^{865}$ ". Se establece en el art. 130 de la Constitución que un Secretario cuidará de la justicia y de los asuntos eclesiásticos. En el art. 132, I, se mantiene fuera de la competencia de la regencia presentar para los obispados candidatos; entretanto, podrá proponer al rey una lista de tres personas las más idóneas, que serán refrendadas por el respectivo secretario. En el inciso VIII del mismo artículo, les promete conceder o negar el Beneplácito de los decretos de los concilios, letras pontificias, y cualesquiera otras constituciones eclesiásticas, que contengan disposiciones generales.

Al final, el texto definitivo de la Constitución será aprobado en 23 de septiembre de 1822, mientras que el rey D. Joao VI la jurará en 1 de octubre del mismo año. En cuanto a Brasil los artículos adicionales que compondrán el Capítulo II no llegan a ser puesto en vigor en dicha parte del Imperio porque ya había proclamado su independencia del Reino de Portugal, a la vez que ya habían convocado sus propias Cortes, que se reunirían al año siguiente. 



\section{Capítulo III}

\section{CONSTITUCIONALISMO, CIUDADANÍA Y CONFESIONALIDAD DEL ESTADO: EL PROBLEMA DEL DERECHO AL SUFRAGIO}

\subsection{El Liberalismo de la Restauración y el principio monárquico: la solución para un imperio, una constituyente y un emperador}

Dos modelos constitucionales se veían enfrentados en Europa en el período posnapoleónico, como ya señalamos previamente: el modelo gaditano preferido por los movimientos revolucionarios de entonces y la Carte Constitutionnelle francesa de 1814, preferida por el movimiento reaccionario de la Santa Alianza. Estos dos modelos combatirán por ganar terreno en la Península italiana, con el sur borbónico, capitaneado por el Reino de Dos Silicias (que adoptará efectivamente la constitución gaditana) y el norte, en donde la influencia austriaca era bastante fuerte ${ }^{866}$. También Brasil se verá afectado por esta disyuntiva.

La "Era de las Revoluciones", según Hobsbawm, en la primera oleada (1820-1824), traerá también a Brasil los vientos cargados de ideas liberales, de todos los matices ${ }^{867}$. En la lectura del discurso ${ }^{868}$ del primer emperador de Brasil en la apertura de la Asamblea Constituyente, en la Sesión del día 3 de mayo de 1823, podemos percibir tanto los ideales liberales revolucionarios en su intervención oral como también los límites del liberalismo que querría el emperador para el nuevo texto constitucional:

"O Brasil sempre sincero, no seu modo de obrar, e mortificado por haver sofrido o jugo de ferro por tanto tempo antes, e mesmo depois de tal medida, imediatamente que em Portugal se proclamou a liberdade, o Brasil gritou Constituição portuguesa (...) ${ }^{869}$."

Cuando el emperador, en el mismo discurso, apuesta por una constitución liberal matizará su rechazo a los modelos constitucionales que califica como de inexequibles, o sea, el modelo revolucionario:

\footnotetext{
${ }^{866}$ En un trabajo reciente hecho en la Università degli Studi di Messina podemos observar esta lucha de modelos constitucionales en Europa, principalmente en el norte de Italia: SILVA, Jairdilson da Paz: La Stampa y la Rivoluzione..., op. cit., pp. 48 y ss. También del mismo autor y que trata del mismo tema, SILVA, Jairdilson da Paz: Flujo y reflujo revolucionario..., op. cit., pp. 59 y ss.

${ }^{867}$ Aquél autor afirma que fue notoria la incapacidad de los gobiernos de entonces de evitar una segunda Revolución Francesa, o peor aún una catastrófica revolución europea generalizada con base en el modelo francés. HOBSBAWM, Eric J.: A Era das Revoluções..., op. cit., pp. 183 y ss.

${ }^{868}$ Este discurso también está recogido en la clásica obra de Paulo Benavides y Paes de Andrade, así como la respuesta que el presidente de la Constituyente, D. José Caetano da Silva Coutinho ofrece al emperador. BONAVIDES, Paulo y ANDRADE, Paes de: História Constitucional do Brasil, Editora OAB, $4^{\text {a }}$ Edición, Brasilia, 2002, pp. 25-36.

${ }^{869}$ ASSEMBLÉA GERAL CONSTITUINTE E LEGISLATIVA DO IMPERIO DO BRAZIL (ahora en adelante AGCLIB), SESIÓN DE 3 DE MAYOR DE 1823 - Annaes do Parlamento Brazileiro. Assembléa Constituinte, 1823, Tomo I, Typographia - Parlamentar, Rua do Hospício, 218, Rio de Janeiro, 1823, p. 38. Este discurso de apertura de la Asamblea Constituyente fue proferido por el emperador en la Sesión de 3 de mayo de 1823 establece los límites del liberalismo a ser empleado en texto constitucional.
} 
"Todas as constituições, que à maneira das de 1791 e 92, tem estabelecido suas bases, e se tem querido organizar, a experiência nos tem mostrado, que são totalmente teoréticas e metafísicas e por isso inexequível; assim o prova a França, Espanha, e ultimamente Portugal ${ }^{870}$."

Estas constituciones no habían traído la felicidad general deseada, sino una licenciosa libertad, y su fruto era el despotismo y la horrorosa anarquía, continua diciendo el emperador. Y por tanto, incitaba a los diputados constituyentes a definir en el nuevo texto brasileño los "verdaderos principios constitucionales":

"Vós não os ignorais, e eu, certo, que a firmeza nos verdadeiros princípios constitucionais, que tem sido sancionado pela experiência, caracteriza cada um dos deputados, que compõe esta ilustre assembleia, espero, que a constituição, que façais, mereça a minha imperial aceitação, seja tão sabia, e tão justa, quanto apropriada à localidade, e civilização do povo brasileiro (... $)^{871}$.",

El conocido como patriarca de la patria, José Bonifacio de Andrada e Silva, articulador de la solución moderada del liberalismo brasileño, formado en la Universidad de Coimbra, cargará junto con el emperador contra aquellos procesos liberales revolucionarios que hacía poco tiempo España y Portugal habían pasado, y aún se sentían sus reflejos en el propio seno de la Asamblea Constituyente. Y buscará desmarcar el proceso brasileño del modelo seguido por la América española, más radical ${ }^{872}$, cuando dice:

"Que quadro nos apresenta a desgraçada América. Há 14 anos que se dilaceram os povos, que tendo saído de um governo monárquico pretende estabelecer uma licenciosa liberdade; e depois de terem nadado em sangue, não são mais que vitimas da desordem, da pobreza e da miséria. Que temos visto na Europa todas as vezes que homens alucinados por princípios metafísicos, e sem conhecimento da natureza humana, quiseram criar poderes impossíveis de sustentar? Vimos os horrores da França; as suas constituições apenas feita logo destruídas, e por fim um Bourbon que os franceses tinham excluído do trono, e até execrado, trazer-lhes a paz e a concórdia ${ }^{873}$ !"

El principio monárquico o de la legitimidad del rey va a aparecer tanto en el discurso del emperador como en la intervención oral de su articulador político, el Sr. Andrada e Silva, en la Sesión de las Cortes del día 6 de mayo de 1823:

“Na Espanha, onde o povo se levantou, não para pedir constituição, mas para se defenderem dos exércitos franceses que pretendiam domina-la, também os hipócritas e os libertinos se aproveitam das circunstâncias para formar uma constituição que ninguém lhes encomendara, enquanto o povo corria a atacar os

\footnotetext{
${ }^{870}$ AGCLIB, Sesión de 3 de mayo de 1823, p. 42.

${ }^{871}$ Ibídem.

${ }^{872}$ A cerca de la relación entre Brasil y el modelo hispanoamericano en el periodo de las independencias véase en PIMENTA, Joao P. G.: Brasil y las independencias de Hispanoamérica, Universitat Jaume I, Castellón, 2007, pp. $11 \mathrm{y} \mathrm{ss}$.

${ }^{873}$ AGCLIB, Sesión de 6 de mayo de 1823, p. 53.
} 
invasores. E que sucedeu? Entrou Fernando VII, de repente, seguiram-se horrores, levantou-se o partido das baionetas, dizendo-se o defensor da vontade do povo, $e$ desde essa época está nadando em sangue a infeliz Espanha. Portugal, o desgraçado Portugal, que tem ganho? Pelas ultimas noticias o sabemos ${ }^{874}$."

Después de estas explicaciones, a su manera, de los hechos acaecidos tanto en América como en la Europa revolucionaria, el preopinante pasará a las siguientes amonestaciones a sus colegas diputados de la Asamblea:

"Enfim, senhores, confiemos nos princípios constitucionais do imperador, e procuremos com todas as forças fazer feliz a minha pa(t)ria; oxalá que eu pudesse firmar sua permanente ventura? Mas protesto à face da assembleia, e à face do povo que não concorrerei para a formação de uma constituição demagógica, mas sim monárquica, e que serei o primeiro a dar ao imperador o que realmente lhe pertence $^{875}$."

Al manifestarse en contra de este pronunciamiento, el diputado Carneiro da Cunha parece bastante bien informado de los hechos recientes de la historia revolucionaria española y portuguesa. Llama a Fernando VII de "Nero dos nossos días". Además deja caer en su discurso el gran debate alrededor de aquellos dos modelos constitucionales a que hicimos referencia: si se debía concebir un parlamento bicameral, para soportar la nobleza, o si se debía concebir un parlamento unicameral, apenas con los diputados representantes de la nación. La primera proposición se encontraba en el discurso de los defensores de la Carta Otorgada francesa de 1814, y la segunda proposición se podía encontrar en los ideales de la constitución gaditana. Además, dicho diputado, hace elogios a la constitución que ahora era solo de Portugal: "Fosse qual fosse a constituição de Portugal, tivesse uma ou duas câmaras"; aunque entre Brasil y Portugal existía el germen de la desunión, de la rivalidad y de la diferencia de intereses y derechos, "não pelos defeitos daquelas constituições". Y añade:

"Antes pelo contrario a maior parte do povo a quer e deseja com aquelas modificações que podem as diferentes circunstâncias que existem entre o Brasil e Portugal”.

\footnotetext{
${ }^{874}$ AGCLIB, Sesión de 6 de mayo de 1823, p. 53. Diputado Sr. Andrada e Silva.

${ }^{875}$ Ibídem. El destacado en el texto fue retirado del discurso del emperador por el mismo diputado. Al final de su discurso los taquígrafos recogen el "apoyado" de los demás diputados reunidos en el pleno de la Asamblea. Sin embargo, no solo fueron apoyo que recibió este discurso. El diputado Carneiro da Cunha contestará punto por punto a las afirmaciones reacionarias, o si se quiere, liberal doctrinario, del Sr. Andrada e Silva, con las siguientes palabras: "Não era de esperar que o ilustre preopinante, que acabou de falar, em lugar de defender os direitos daqueles que o constituíram seu representante, apresentasse uma declaração contra os povos, contra os constitucionais da França, da Espanha e de Portugal, que no seu entender, são os demagogos daquelas três nações; e é para lamentar que não declamasse contra os puros realistas, esses desorganizadores, fautores do despotismo, que nos podem causar maiores males, ou a menos tantos quantos ele imaginar que resultaram do furor demagógico. Se pretende reforçar seu argumento com o estado atual da guerra civil da Espanha, eu posso mostrar-lhe que ela não procede da forma da sua constituição, sim de hábitos inveterados, prejuízo e aferro a suas antigas instituições; sendo muito difícil, ou quase impossível, o reformar-se um governo sem estas comoções. Demais Fernando VII é, e foi o primeiro autor de todas as desordens e desgraças que tem sofrido e está sofrendo aquela tão briosa como infeliz nação”. Ídem, Diputado Sr. Carneiro da Cunha.
} 
Así que va a parecernos que, a partir de los discursos de los diputados, diferentes corrientes del liberalismo estarán enfrentadas en la primera constituyente del Brasil independiente de Portugal. Brasil buscará formar su propio modelo a partir de aquellos ya citados, y adoptará el modelo liberal que mejor tradujese los intereses de las élites y una forma de acomodar a su poliédrica sociedad, que contaba con algunos factores extremamente disonantes al discurso del liberalismo radical.

Si es verdad que los influjos liberales, tanto de las Cortes de Cádiz como de su tributaria la constitución vintista portuguesa, aparecerán en la Constituyente brasileña de 1823, reflejando aquellos ideales en el proyecto constitucional, también es verdad que, el definido por Emilia Viotti da Costa y Alberto Vivar Flores, como el "Liberalismo brasileño",876, se plasmará en la Carta Otorgada de 1824 y será la base de toda organización política y social del Imperio de Brasil hasta el ocaso de la monarquía a fines del siglo $\mathrm{XIX}^{877}$. Este último elemento surge como influjo de la Carte de 1814, francesa.

El eclectismo será la marca registrada del "Liberalismo brasileño", que en palabras de Alberto Vivar Flores y de Emilia Viotti da Costa, fue el Liberalismo Doctrinario o de la Restauración adaptado a la realidad nacional, siendo el modelo europeo la referencia para los liberales brasileños, pero, con caracteres autóctonos ${ }^{878}$. Como habíamos matizado antes, esto se deduce del habla de los diputados a lo largo de las sesiones de la Asamblea Constituyente, pero, principalmente en la manifestación de aquellos diputados en las sesiones preparatorias de la Asamblea Constituyente ${ }^{879}$. En realidad, dichas transformaciones/adaptaciones del Liberalismo Doctrinario $^{880}$ al contexto brasileña pasarán por el filtro de las élites que, como bien comenta

\footnotetext{
${ }^{876}$ Véase en FLORES, Alberto Vivar: "El liberalismo constitucional en la fundación del Imperio brasileño", Historia Constitucional (Revista electrónica), n.6, 2005. http://hc.rediris.es/06/index.html Accedido en 26/11/2012.

${ }^{877}$ La solución liberal encontrada en el caso brasileño será estudiada por ITAGIBA, Ivair Nogueira: O Pensamento Político Universal e a Constituição Brasileira, Gráfica Tupy Ltda, Rio de Janeiro, 1947, pp. 242-256. También en este caso es importante el estudio de COSTA, Emilia Viotti (Comentarios): "Liberalismo brasileiro, uma ideología de tantas caras", en Folha de Sao Paulo/Folhetim, Sao Paulo, 24/02/1985, nº 423, p. 6.

${ }^{878}$ FLORES, Alberto Vivar: "El liberalismo constitucional...," op., cit., pp. 149 y 150. COSTA, Emilia Viotti (Comentarios): "Liberalismo brasileiro...," op., cit., p. 6 y ss.

${ }^{879}$ AGCLIB, Sesión de 30 de abril de 1823, pp. 27-31. La preocupación por el edificio teórico europeo y las posiciones asumidas por América del Norte va a materializarse en dichas sesiones preparatorias, principalmente en la de 30 de abril de 1823, en donde los diputados Sr. Andrada Machado, Sr. Muniz Tavares y Sr. Costa Aguiar expone sus ideas. Esto demuestra que los diputados, principalmente los que participaron de la Constituyente Lusobrasileña de 1821-22, estaban informados de las ideologías y teorías que circulaban en Europa. Pero, también la mayoría de los diputados, que eran pertenecientes a la élite local habían estudiado en la Universidad de Coimbra, cuyos influjos teóricos ya tuvimos ocasión de demostrar. Y para ampliar dicho tema se indica la lectura de VELOSO, Mariza y MADEIRA, Angélica: Leituras Brasileiras, Itinerários no Pensamento Social e na Literatura, Ed. Paz e Terra, Sao Paulo, 1999, p. 67. También se puede complementar este comentario con la lectura de FLORES, Alberto Vivar: "El liberalismo constitucional...," op., cit., p. 150.

${ }^{880}$ El liberalismo no fue un cuerpo ideológico sólido e imperecedero que perduró como tal, estático, en el siglo XIX. Eso sirve, según Jean Touchard para el siglo XVIII, pero no para el siglo XIX, que verá una fragmentación
} 
Murilo de Carvalho, son detentadoras de alguna "fuerza social" de control que sea dominante, sea a través del dinero, tierras, conocimiento o religión ${ }^{881}$; y por ello, resalta Wolkmer, formadoras de una ideología más adecuada para servir de base a los intereses de las oligarquías de los grandes propietarios de tierra y al clientelismo que estaba vinculado a la monarquía imperial $^{882}$. Aunque, Viotti da Costa enfatiza que aquella ideología liberal revolucionaria sufrirá transformaciones para beneficiar a los que fueron definidos como ciudadanos ${ }^{883}$, quedando resumido a una minoría perteneciente a las élites detentadoras de portentos emanados de aquellos poderes enumerados por Murilo de Carvalho. Estas mismas élites estaban en la lógica imperial colonialista como difusoras y sostenedoras de un modelo emanado de la potencia metropolitana, y solo con el rompimiento del acuerdo de intereses van a asumir y enarbolar la bandera de la libertad y de la liberación de la potencia colonizadora ${ }^{884}$. Aunque en Brasil, también esta lógica sufrirá una matización, dado que la presencia del legítimo heredero del Imperio portugués le permitirá asumir el discurso de las élites locales y lideraba, bajo el principio de la legitimidad dinástica con matices y tintes liberales, un proceso de independencia ${ }^{885}$.

Así podemos afirmar que los elementos que conformaban el Liberalismo brasileño no pueden ser meramente clasificados como conservadores o respondiendo a la importación del conservadurismo europeo. Se encuentran dichos elementos en el conjunto del debate liberal, teniendo sus raíces en el reformismo ilustrado portugués, que ya tuvimos ocasión de dilucidar. De ahí se puede comprender la figura del emperador como el depositario del poder concedido por la sociedad. Los miembros de dicha sociedad estaban clasificados a partir del criterio de la

del liberalismo en varias ideologías distintas. TOUCHARD, Jean: Historia de las Ideas Políticas, Ed. Tecnos, Madrid, 1996, pp. 402 y ss.

${ }^{881}$ CARVALHO, José Murilo de: A construção da ordem. Teatro das sombras, Ed. Civilização Brasileira, Rio de Janeiro, 2003, pp. 23 y ss.

${ }^{882}$ WOLKMER, Antônio Carlos: História do direito no Brasil, Ed. Forense, Rio de Janeiro, 1998, p. 75 y ss.

${ }^{883}$ COSTA, Emilia Viotti (Comentarios): “Liberalismo brasileiro...,” op., cit., p. 7 y ss. También se puede encontrar dicha discusión en FLORES, Alberto Vivar: “El liberalismo constitucional...,” op., cit., pp. 149 y 150.

${ }^{884}$ Sobre cómo se portaba y a que se dedicaba la élite brasileña léase en CARVALHO, José Murilo de: A construção da ordem. Teatro das sombras, Ed. Civilização Brasileira, Rio de Janeiro, 2003, pp. 51 y ss. Por lo que se refiere al comportamiento de las elites frente a las relaciones coloniales véase en SAID, Edward W.: Cultura e Imperialismo, Companhia das Letras, São Paulo, 1995, p. 325. FLORES, Alberto Vivar: "El liberalismo constitucional...,” op., cit., p. 151. COSTA, Emilia Viotti (Comentarios): “Liberalismo brasileiro...,” op., cit., p. 9 y ss. Sobre el proceso de resistência en la colónia frete al poder colonial y su perfil autóctono se puede ampliar los conocimientos con la lectura de CARVALHO, Gilberto Vilar de: A liderança do Clero nas Revoluçoes Republicanas de 1817-1824, Ed. Vozes, Petrópolis, 1980, p. 100 y ss.

885 "El nacimiento de un Estado independiente, de corte monárquico constitucional en los inmensos dominios portugueses de América, se enmarca, según Emilia Viotti da Costa, dentro de un amplio proceso 'relacionado, de um lado, com a crise do sistema colonial tradicional e com a crise das formas absolutistas de governo e, de outro lado, com as lutas liberais e nacionalistas que se sucedem na Europa desde os fins do seculo XVIII. Esto está muy relacionado con los acontecimientos europeos de comienzos del siglo XIX en los que, no solo la Península Ibérica, sino también toda Europa se vio involucrada, de manera más o menos intensa, como fueron los relacionados con la expansión napoleónica." BRANCATO, Braz A. A.: Don Pedro I de Brasil posible rey de España (una conspiración liberal), Coleção História - 26, EDIPURS, Porto Alegre, 1999, p. 167. 
libertad, con base en la propiedad; y el papel del Estado es estructurado con base en el principio de la autoridad, como instrumento de manutención de la cohesión y de la jerarquía social, o sea el mantenedor del "Orden" 886 . De este modo, el pensamiento liberal estaba bastante identificado con el sentimiento de identidad nacional, venciendo la posición que lo identificaba como instrumento de oposición a la dominación metropolitana. Como Instrumento de identidad nacional, el ideario liberal sirvió de garantía y construcción de la hegemonía de los propietarios de tierras y esclavos, permitiendo con eso vincular los conceptos de propiedad, de libertad, autoridad, "orden" y cohesión de la identificación de sus propios intereses a los del conjunto de la sociedad. El ejercicio del poder de dicha clase veía en la corona su garante para manutención de los privilegios y el status quo social ${ }^{887}$.

El influjo de los egresados de la Universidad de Coimbra en el proceso ideológico de formación del Estado/Nación brasileño será algo patente. Aunque acusados de conversadores, estos eran mucho más partidarios del Liberalismo Doctrinario, en donde los cambios debían seguir por unos raíles seguros sin los descarriles de los procesos más radicales que pudiese subvertir el orden estatuido. Es evidente que el flujo de ideologías liberales no llegó solamente de las manos que aquellos viejos egresos de Coimbra o mismo en vísperas de proclamarse la independencia. Todo el proceso antes descrito de la llegada de la Familia Real con todas sus consecuencias, como la Apertura de los Puertos a las Naciones Amigas, los tratados con Inglaterra y la propia Revolución de Oporto, fueron aportes más que necesarios para que diversas corrientes ideológicas matizasen la Asamblea Constituyente de $1823^{888}$, que, además, recibió aporte de los diputados regresados de las Cortes de Lisboa, como ya tuvimos ocasión de exponer ${ }^{889}$.

La propia Constitución de Cádiz, como ya nos referimos en el Capítulo II, fue jurada por los residentes españoles en Río de Janeiro en $1813^{890}$. Así que nos hace deducir que se la dio a

\footnotetext{
${ }^{886}$ PIÑEIRO, Théo Labarinhas: "O projetos liberais no Brasil Império", Passagens. Revista Internacional de História Política e Cultura Jurídica, Rio de Janeiro: vol. 2 no.4, maio-agosto 2010, p. 130-152.

${ }^{887}$ Ídem, p. 149 y ss.

${ }^{888}$ SCHIAVINATTO, Iara Lis: "Cultura política do primeiro liberalismo constitucional. A adesão das Câmaras no processo de autonomização do Brasil", Araucaria. Revista Iberoamericana de Filosofia, Políticas y Humanidades, No 18. Segundo Semestre de 2007, pp. 220-235.

${ }^{889}$ SILVA, M Meatriz Nizza da: A cultura luso-brasileira: da Reforma da Universidade à Independência do Brasil, Editorial Estampa, Lisboa, 1999, pp. 209 y ss. También véase en GRIMBERG, Keila: O fiador dos brasileiros, cidadania, escravidão e direito civil no tempo de Antônio Pereira Rebouças, Ed. Civilização Brasileira, Rio de Janeiro, 2002, p. 53 y ss.

${ }^{890}$ ARCHIVO DEL CONGRESO DE LOS DIPUTADOS EN MADRID - Correspondencia enviada por D. Juan del Castillo y Carroz, Enviado Extraordinario y Ministro Plenipotenciario de S.M.C. y de S.D. Fernando VII, cerca de S.A.R. el Príncipe Regente de Portugal y de los Algarves, que se tomó la jura a la Constitución de Cádiz en Rio de Janeiro, en 21 de septiembre de 1813, a los residentes españoles en aquél reino. Signatura topográfica P01000029-0001-0001 (Sig. Topográfica antigua ACD, S General, Leg. 29 n ${ }^{\circ}$ 1, Título: Juramentos de la
} 
conocer mucho antes de que fuese adoptada por el rey D. Joao VI en Río de Janeiro a través del Decreto de 24 de enero de 1821. De este modo, los vectores de entrada en Río de Janeiro de los nuevos pensamientos liberales fueron inúmeros; desde la presencia de extranjeros, de egresados de la universidad, hasta la prensa que creció exponencialmente en aquél periodo. Contrariando a la censura y a las dificultades de circulación de los papeles que no tenían el carácter oficial, ya en 1822 se veía salir del "prelo" una cantidad asombrosa de mil y cien periódicos. Desde la llegada de la Familia Real en 1808 hasta los momentos decisivos para la independencia de Brasil en 1822, se verá un construcción lenta de una noción moderna de libertad, contraponiéndose a la noción que ya se tenía de la libertad de los antiguos, republicana clásica o la noción constitucional a la antigua usanza, o simplemente del concepto del Antiguo Régimen de libertad como privilegio; la noción pasada ahora por tales periódicos era el concepto de isonomia, de libertad basada en los derechos y garantías individuales de los ciudadanos ${ }^{891}$. Pero, nos alertará el profesor Lynch que antes de que sedimentase el liberalismo en sentido político en la sociedad brasileña de la época, habrá una sedimentación de los principios del liberalismo económico, fruto, en gran medida, de la apertura de los puertos por el Decreto Real de 1808. Entonces, algunos pensadores brasileños mandarán sus escritos a la imprenta a modo de contribución a este proceso de introducción de las nuevas ideas. Uno de ellos fue el Vizconde de Cairú, José da Silva Lisboa (1756-1835) ${ }^{892}$. En aquél año de 1808, y como contribución a la causa y demostrando las ventajas de la libertad comercial, publica el Vizconde las "Observações sobre o comercio franco no Brasil" $"$ " Antes, en 1804, el Vizconde lanza los "Principios de Economia Politica, para servir de introdução à tentativa económica do author dos Principios de Direito Mercantil" ${ }^{894}$. De este modo, las concepciones liberales empiezan a superar a las concepciones comerciales mercantiles, que pasan por un cambio conceptual en el seno de la sociedad. Así lo muestra la edición del Diccionario de Antonio de Morais e Silva de 1813, que para definir lo liberal decía: "largo no dar, e despender, sem avareza, nem

Constitución de 1812: Ecuador, Perú, Brasil, Callao, Uruguay, Bolivia, Panamá, Colombia, Venezuela, Argentina, Fechas extremas/Sin mes/1812-/sin mes/1812).

${ }^{891}$ LYNCH, Christian Edward Cyril: "O conceito de liberalismo no Brasil (1750-1850)", Araucaria, Revista Iberoamericana de Filosofía, Política y Humanidades, No 17, mayo de 2007, pp. 212-234.

${ }^{892}$ José da Silva Lisboa (1756-1835) era un anglófilo abogado bahiano. El futuro Visconde de Cairú fue uno de los que convencieron al entonces Príncipe Regente D. Joao de poner término al monopolio comercial y abrir los puertos de Brasil a la Naciones Amigas. También era una exigencia inglesa para conseguir salir airosa ante el Bloqueo Continental impuesto por la Francia napoleónica.

${ }^{893}$ MARTINS, Wilson: História da Inteligência brasileira. Vol. II (1794-1855), Ed. Cultrix, São Paulo, 1974, p. 19. ${ }^{894}$ LISBOA, José da Silva: Princípios de Economia Politica, para servir de introdução à tentativa económica do author dos Princípios de Direito Mercantil, Por Ordem Superior na Imprensa Regia, Lisboa, 1804, p. IV. “(...) Revolvi-me a preludiar com a presente introdução, em que indico as primeiras ideias de Economia, e exponho os motivos porque recomendo a lição da imortal obra da Riqueza das Nações do celebrado Adam Smith, e o sigo nas teses cardeais de seu sistema; persuadido de ter sido ele o primeiro que dissiparam as escuridades da Economia Politica, levantando a facha de luz para esclarecer as Nações e Governos sobre os seus genuínos interesses, que são inseparáveis dos da Humanidade”. 
mesquinharia". También clasificaba de Liberal aquellos trabajos no mecánicos, dado que eran "livre, franco" 895 . Ya en la edición de 1831 del mismo diccionario, para la definición del término liberal, trae un añadido de cuño político-económico: “princípios, sistema liberal dos governos, que não limitam, não restringem com meios regulamentos, com impostos, e meios opressivos a indústria, o comercio etc. También amplia la acepción del término liberal a otros significados, como: Ingenho - espírito - de homem ingênuo, dotados de sentimentos nobres, não plebeus, nem tacanhos. Arte Liberal - a que não é manual, mecânica. Não servil. Próprio de almas sem preocupações" también político de la sociedad.

Como ya previamente hemos dicho antes, el elemento a ser utilizado para informar a la mayoría de las ideas liberales, principalmente las de cuño político será la prensa. Por tanto, el periódico surgido aun en el período joanino, el "Correio Braziliense" o "Armazém Literário" fundado por Hipólito José da Costa (1774-1823) que se publicaba en Londres en el período comprendido entre 1808 a 1823, era en la época muy leído en Brasil. En este periódico moderado se propugnaba por una reforma de la monarquía por el modelo inglés, como también la defensa de la libertad de imprenta ${ }^{897}$.

Es evidente que solamente después de que las noticias de la Revolución Liberal de Oporto hubiesen llegado a Brasil, servirá de catalizador a las nociones poco claras del liberalismo que ya existía en la sociedad brasileña. Como ya hemos destacado, la convocatoria de Cortes en Lisboa contaminará a Brasil de un ambiente constitucional. El liberalismo que llegaba del movimiento vintista portugués, que a su vez estaba influenciado por el liberalismo

\footnotetext{
${ }^{895}$ SILVA, Antônio de Morais e: Dicionário da Língua Portugueza, recompilado dos vocabulários impressos até agora, e nesta segunda edição novamente emendada, e muito acrescentado, Tomo II F - Z, Typographia Lacerdina, Lisboa, 1813.

${ }^{896}$ SILVA, Antônio de Morais e: Dicionário da Língua Portugueza composto por Antônio de Morais e Silva, natural do Rio de Janeiro. Quarta Edição, reformada, emendada, e muito acrescida pelo mesmo autor: posta em ordem, correcta, enriquecida de grande número de artigos novos e dos synonymos por Theotônio José de Oliveira Velho. Tomo II F - Z, Na Impressão Régia, Com Licença, Lisboa, 1831, p. 232. La estrecha relación entre liberalismo económico y liberalismo político en el imaginario político brasileño presente en la inaugurada Asamblea Constituyente de 1823, el líder de la oposición, el diputado por la provincia de Minas Gerais, Bernardo Pereira de Vasconcelos (1795-1850), va a defender que se debía guardar un respeto religioso a la propiedad y a la libertad del ciudadano brasileño. SOUSA, Otávio Tarquínio de: Bernardo Pereira de Vasconcelos, Ed. Itatiaia, Belo Horizonte, 1988, p. 73.

${ }^{897}$ Así que, tanto para la libertad de expresión como la difusión de ideas liberales por el Correo Braziliense, se pueden ampliar los conocimiento en este campo con la lectura de COSTA, Hipólito José de: Antologia do Correio Braziliense. Organização e Seleção de Barbosa Lima Sobrinho, Ed. Cátedra, Rio de Janeiro, 1977. Acerca de Hipólito José da Costa y sus ideas en el Correo Braziliense véase también en LUSTOSA, Isabel: Insultos impressos. A guerra dos jornalistas na Independência. 1821 - 1823, Ed. Companhia das Letras, São Paulo, 2000, pp. 71 y ss. "O articulista do Correio Braziliense estava particularmente preocupado com os meios de viabilizar um governo liberal no Brasil, cuja história recente era, segundo ele, marcada exclusivamente pelo despotismo do Antigo Regime; onde não havia sequer, como em Portugal, a lembrança de uma constituição estamental que, viabilizando a articulação de um discurso antiquário, servisse para combater os excessos do poder (...)”.LYNCH, Christian Edward Cyril: “O conceito de liberalismo...” op., cit., p. 218 y 219.
} 
gaditano, traía concepciones tachadas de ideas radicales en esa época. Este liberalismo estaba plagado del ideario republicano clásico y del contractualismo ${ }^{898}$. En realidad, nos dirá Vivar Flores, este liberalismo identificado con el radicalismo jacobino francés, era nada más nada menos que la corriente moderada de la época de la Revolución Francesa ${ }^{899}$. Esto todo en franca oposición a la Francia liberal doctrinaria de la Carta de 1814 de Luis XVIII. Sin embargo, la efervescencia literaria del período se compara a la "periodicomania" vivida en la España del Trienio liberal ${ }^{900}$.

Ya en el momento de la independencia, en 1822, surge el "Compadre do Rio de Janeiro" que reflejaba la guerra de palabras entre Portugal y Brasil que inundaba las calles con papeles impresos ${ }^{901}$. Era la guerra de los radicales que insultaban con sus ideas, principalmente a los identificados como "corcundas" o anticonstitucionales. Estos radicales estaban muy atentos a las ideas que circulaban en Europa. Uno de los escritos que es muy significativo en este sentido es la "Memória Constitucional e Política Sobre o Estado Presente de Portugal, e do Brasil” en donde, dirigiéndose al rey D. Joao VI, se hacía un inventario del estado del Reino Unido y las posibles soluciones para aquellos males:

"Senhor... Quando ha comoções políticas, e a Pátria está em perigo, quando os espíritos demagogos semeiam a anarquia, a qual quando não produza a subversão, e dissolução do Estado, faz quase sempre derramar torrentes de sangue, causando males incalculáveis ${ }^{902}$."

Resuelve el mismo autor a narrar con "franqueza" las "verdades" de la nación, y evitando ser cortesano u hombre de corte, decía dichas verdades del estado de cosas del reino, y para ello hace alusión al Seneca portugués Sá e Miranda, en una epístola dirigida a D. Joao III, en donde decía:

"Homem de um só parecer,

De hum só rosto, huma só fé,

D`antes quebrar, que torcer;

Elle tudo pôde ser

Mas de corte homem não he".

\footnotetext{
898 Ídem, p. 219.

${ }^{899}$ FLORES, Alberto Vivar: “El liberalismo constitucional...,” op., cit., pp. 156 y ss.

${ }^{900}$ LUSTOSA, Isabel: Insultos impressos. A guerra dos jornalistas na Independência. 1821 - 1823, Ed. Companhia das Letras, São Paulo, 2000, pp. 79 y ss.

${ }^{901}$ Este papel impreso surge como respuesta al Compadre de Lisboa: Compadre do Rio de Janeiro, Justa Retribuição dada ao Compadre de Lisboa em Desagravo dos Brasileiros Defendidos por Várias Asserções, que Escreveu na sua Carta em Resposta ao Compadre de Belém, Segunda Edição Correta e Augmentada, Typographia Nacional, Rio de Janeiro, 1822, p. 5 y ss.

902 MIRANDA, José Antônio de: Memoria Constitucional e Política Sobre o Estado Presente de Portugal, e do Brasil; Dirigida a El Rey o Senhor D. Joao VI. E oferecida a Sua Alteza o Príncipe Real do Reino Unido de Portugal, Brasil e Algarves, e Regente do Brasil, por José Antônio de Miranda, Fidalgo Cavalleiro da Caza de Sua Magestade, e ouvidor eleito do Rio Grande do Sul, Na Typographia Nacional, Com Licença de S. A. R., Rio de Janeiro, 1821, p. 13
} 
De este modo, José Antônio Miranda se desmarcaba de las ideas palaciegas para exponer los problemas del reino de forma muy atenta a las nuevas ideas liberales. Por tanto ello en la exposición de sus ideas pasa a citar nombres conocidos, como: Fénelon, Filangieri, D`Alambert, Sidney, Locke, Vattel, Raynal, Duprat, Montesquieu y Rousseau ${ }^{903}$. Así que, de este y otros escritos se va desvelando el concepto de "liberal", "liberalismo" o "liberalidad de las ideas". En este sentido, un folleto publicado en 1821, "O triunfo dos Liberais $e$ o arrependimento do Servilismo", presentaba el termino liberal como opuesto al de ser servil ${ }^{904}$. Según nos cuenta Lucia Bastos P. das Neves, el término Liberalismo era algo más raro en los papeles impresos de la época ${ }^{905}$; buscaban utilizar términos sinónimos, en un lado y otro del Atlántico, tales como constitucionalismo o gobierno representativo ${ }^{906}$. Dichos conceptos estaban entremezclados en estos momentos, dado que solamente estaba identificado como liberal quienes estaban a favor de una constitución y de un gobierno representativo. Y términos hiperbólicos eran utilizados para sobreponerse al liberalismo de los demás:

"O Ministro da Guerra e Marechal de Campo, Carlos Frederico de Caula, fezme o favor de apresentar a S. A. R., e, no ato de lha entregar, confessou-lhe ingenuamente, como he próprio do seu caracter, que a Memoria era feita por individuo que desejava oferecer-lha, mas que todavia era muito liberal, e muito constitucional. A estas palavras tornou-lhe o Príncipe em resposta, com um ar mais serio, e como estranhando a reflexão que lhe fazia de ser muito Constitucional. Pois que Caula! Há alguém mais constitucional do que eu? Mais Constitucional do que eu só a mesma Constituição!!! Pensamento sublime que por si só basta para faze-la apologia a um Príncipe ${ }^{907}$."

Según un otro escrito, "Amigos dos Homens e da Pátria", que salía a la luz en Salvador de Bahía en el año de 1822, definía al término "Constitución” como un vehículo que permitía la existencia de un gobierno representativo, así que, "era la norma o la regla, que una sociedad unánimemente establece para su general conservación, tranquilidad y bien estar"908. En el

\footnotetext{
${ }^{903}$ LYNCH, Christian Edward Cyril: “O conceito de liberalismo...” op., cit., p. 219.

904 "O jornal $O$ Correio do Rio de Janeiro, ao transcrever um artigo intitulado - "Do liberal e do servil" procurava também identificar o significado de cada termo. O liberal representava aquele que desejava tanto "o bem da sua pátria", quanto "a liberdade", transformando- se no "amigo da ordem e das leis". Era o cidadão ideal porque "ama o monarca, respeita-o, quando é respeitável, amaldiçoa-o quando é indigno e tirano, e prefere a morte a um jugo insuportável". NEVES, Lucia $\mathrm{M}^{\mathrm{a}}$ Bastos Pereira das: Corcundas e Constitucionais..., op., cit., p. 146

905 “Embora fosse uma expressão menos utilizada nos escritos, liberalismo surgiu inicialmente relacionado a uma qualidade dos liberais. A Causa do Brasil referindo-se à regência de d. Pedro informava que ela tem sido conforme a santidade de seu juramento: "à circunspecção e liberalismo com que ela tem sido exercida, esta Província do Rio de Janeiro deve a sua salvação e tranquilidade”. Ídem, p. 147. Véase también la obra de VERDELHO, Telmo dos Santos: As Palavras e as Idéias na Revoluçao Liberal de 1820, Instituto Nacional de Investigaçao Cientifica, Coimbra, 1981, pp. 36 y ss.

${ }^{906}$ LYNCH, Christian Edward Cyril: “O conceito de liberalismo...” op., cit., p. 220.

${ }^{907}$ MIRANDA, José Antônio de: Memoria Constitucional..., op., cit., p. IX.

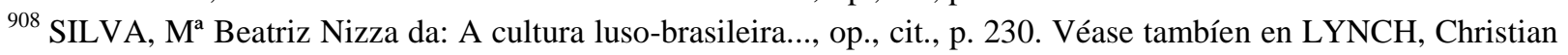
Edward Cyril: “O conceito de liberalismo...” op., cit., p. 220.
} 
mismo sentido, otro papel, "Um Patriota Amigo da Razão", definía al término "constitución" como una composición de "leyes fundamentales por las cuales un pueblo estableció el modo por el cual quiere ser gobernado y determina los límites del poder que confiere a las autoridades a que se sujeta" 909 .

Establecidas las Cortes Constituyentes en Lisboa, como ya hicimos notar, traerá la impresión de la regeneración política de todo el reino, recobrando la antigua constitución de Portugal, perdida por los malos gobernantes. Esta idea es abrazada por Brasil y defendida por muchos, aunque Brasil no tenía en su pasado dichas constituciones históricas. Pero, los defensores del vintismo en Brasil, Januário da Cunha Barbosa y Joaquim Gonçalves Ledo, van a oponerse a la idea de un constitucionalismo antiguo en Brasil ${ }^{910}$. Algunos teóricos y políticos de la época buscan desmarcarse del constitucionalismo histórico, medieval portugués, trazando un paralelo entre la moderna concepción de constitución enlazándola con el concepto de derechos fundamentales. Ejemplo de eso fue uno de los representantes del vintismo paulista, Diogo Antonio Feijó. Las garantías, decía Feijó, solo pueden estar en una constitución que fuese jurada, y que, fijase la naturaleza y los límites de los poderes. Del mismo modo, para Feijó, el mejor gobierno, cualquiera que fuese su forma, solo puede ser aquél que garantice los derechos de cada uno de los ciudadanos, y que se someta a la misma constitución ${ }^{911}$. Muchos otros pensadores buscaban trazar un línea de un liberalismo político más moderado, tales como el jurista bahiano Joaquim José Carneiro de Campos, Marques de Caravelas, como también el Marqués de Barbacena. Esta misma línea de moderantismo estaba estampada en un periódico carioca "A Aurora Fluminense", de Evaristo Ferreira da Veiga, que decía:

"Nada de jacobinismo de qualquer cor que seja. Nada de excessos. A linha está traçada - é a Constituição. Tornar prática a Constituição que existe sobre o papel deve ser o esforço dos liberais."

En este embate de ideas, en donde entran los liberales radicales y los más moderados, con el advenimiento de la Constitución francesa de 1814 los grupos más moderados, o los liberales doctrinarios, van a identificarse más con este modelo constitucional, quedándose los identificados como radicales o jacobinos mucho más ligados al modelo constitucional gaditano. Por lo tanto, muy pronto, dos términos, "constitucionalismo" y "liberalismo", que parecían sinónimos, van a ganar connotaciones antagónicas. Así que, constitucionalistas podrían ser más

\footnotetext{
${ }^{909}$ NEVES, Lucia M ${ }^{\text {a }}$ Bastos Pereira das: Corcundas e Constitucionais..., op., cit., p. 149. Se puede encontrar dicha definición en LYNCH, Christian Edward Cyril: “O conceito de liberalismo...” op., cit., p. 220.

${ }^{910}$ O Reverbero Constitucional Fluminense, Escrito por Dous Brasileiros Amigos da Nação e da Pátria, Tomo II, Typographia Nacional, Rio de Janeiro, 1822, p. 24.

911 FEIJÓ, Diogo Antônio: Diogo Antônio Feijó. Organização, introdução e notas de Jorge Caldeira, Ed. 34, São Paulo, 1999, 144 y ss.
} 
o menos liberales conforme concediesen mayores o menores atribuciones al parlamento en detrimento del rey. Mientras que, los liberales, principalmente para el grupo vintista, inmediatamente se relacionaban con el modelo español de constitución, que concebía un parlamento unicameral, sometiendo el monarca al poder de la nación representada en el parlamento $^{912}$. De este modo se configurarán de forma clara las tendencias liberales que se verán enfrentadas en la construcción del Estado/Nación en Brasil. Sin embargo, los denominados "corcundas" o "serviles", identificados como partidarios del Antiguo Régimen, se oponen a los denominados "constitucionales" ${ }^{913}$. En la quinta sesión preparatoria de la Asamblea Constituyente de 1823, el diputado José Custodio Dias, proclamaba su respeto al emperador:

"Reconhece o imperador constitucional a quem prestou, e fará legalmente prestar o devido respeito, enquanto é análogo á causa a que a mesma assembleia se opõe $(. . .)^{914}$.”

Sigue el mismo diputado diciendo que, hasta el punto de que fuese constitucional dicho respeto, dado que, lo demás, según el mismo diputado, era "servilismo"915.

El año de 1822, fue el año largo en el proceso político brasileño, de modo que las ideologías buscaban acomodarse en uno u otro partido de la independencia. Así que los vintistas brasileños no solamente identificaban como "corcundas" o serviles a los partidarios del absolutismo monárquico, sino también a aquellos que buscaban una forma más moderada de constitucionalismo, los doctrinarios, identificados con la Carte de 1814 francesa, se veían tachados de reaccionarios. A estos moderados, se identificaba, por ejemplo, por el ya citado editor del "Correio Braziliense", Hipólito José da Costa, que por su larga permanencia en Londres, pasó a defender un moderantismo a la inglesa en su periódico. Entre estos moderados estaba una figura de peso que era José Bonifácio de Andrada e Silva; éste, además, buscaba una cierta preponderancia de la corona, como vimos al inicio, con sus intervenciones en las Cortes, y por ello era el líder de los egresos de Coimbra. Ya había mostrado su opción por el centralismo monárquico y por el principio de la legitimidad al redactar las "Notas sobre a Organização Política do Brasil, quer como Reino Unido a Portugal, quer como Estado Independente" ${ }^{916}$. Además, será el mentor y el redactor de un documento que llevaron en

\footnotetext{
${ }^{912}$ LYNCH, Christian Edward Cyril: “O conceito de liberalismo...” op., cit., pp. 223 y ss.

${ }^{913} \mathrm{La}$ diferencia entre los dos grupos, con un estudio detallado sobre las posiciones partidarias y liberales en la época de la independencia fue estudiado ampliamente por NEVES, Lucia $\mathbf{M}^{\mathrm{a}}$ Bastos Pereira das: Corcundas e Constitucionais..., op., cit.

${ }^{914}$ AGCLIB, Sesión de 2 de mayo de 1823, p. 36. Diputado Sr. José Custódio Dias.

915 Ibídem.

${ }^{916}$ CALDEIRA, Jorge: José Bonifácio..., op. cit., pp. 119-124.
} 
bloque los diputados paulistas a las Cortes de Lisboa sobre cómo se quería organizar el Reino de Brasil y que papel debía desempeñar el Príncipe Regente D. Pedro: "Lembranças $e$ Apontamentos do Governo Provisório da Província de Sao Paulo para os seus Deputados" ${ }^{917}$. También para hacer frente a los decretos y órdenes de las Cortes de Lisboa dos "Representações ao Príncipe" 918 serán redactadas en el sentido de incentivar al Príncipe Regente a no abandonar el Reino de Brasil y la otra representación de las Cámaras paulistanas para que se tomasen medidas contra los injuriosos decretos de las Cortes de Lisboa para con el Gobierno del Príncipe Regente. Aquél estaba ayudado por José Joaquim Carneiro de Campos y José Severiano Maciel da Costa, que también eran adversarios de los vintistas.

Afirma Cyril Linch que aquellos combativos del vintismo brasileño eran todos discípulos del ministro progresista del rey D. Joao VI, Don Rodrigo de Sousa Coutinho, Conde de Linhares, y que juntamente con éste compartían la visión de que el Estado debía tener la función de un agente transformador de las realidades socioeconómicas, que era una visión típicamente del despotismo ilustrado ${ }^{919}$. Para aquellos burócratas, de acuerdo con el discurso del emperador en la Asamblea Constituyente, que ya recogimos al inicio de este epígrafe, los principios del vintismo era enteramente teoréticos e inexequibles, que llevaba a la anarquía de muchos y luego después al despotismo de un solo hombre. José Bonifácio, en su intervención en la Asamblea Constituyente, en la Sesión de 6 de mayo, vinculará las desgracias por las que pasaba la América hispánica, la propia España y Portugal a aquél liberalismo radical que emanaba de las Cortes de Cádiz ${ }^{920}$. A decir verdad, el grupo de los egresados de Coimbra preferían asociar el absolutismo como algo coligado al régimen colonial y la dependencia extranjera, y, por lo tanto, contraria al proceso de independencia. Así que, abrazaron un Liberalismo más moderado, al cual venimos haciendo reiteradas referencias, el Liberalismo de la Restauración o los también denominados Doctrinarios. De este modo, rechazaba al vintismo la élite formada en Coimbra, pero, no rechazaba al ideario del Liberalismo o del sistema representativo, sino que buscaba antes filiarse a los teóricos que defendían el principio

\footnotetext{
917 Ídem, pp. 125-133.

918 Ídem, pp. 134-145. Véase también en CAVALCANTE, Berenice: Razao e Sencibilidade. José Bonifácio. Uma história em tres tempos, FGV Editora, Rio de Janeiro, 2001, p. 29; principalmente el epígrafe intitulado: Tempos Ilustrados.

${ }^{919}$ LYNCH, Christian Edward Cyril: “O conceito de liberalismo...” op., cit., p. 224. También en FLORES, Alberto Vivar: El liberalismo constitucional..., op. cit., pp. 164 y ss. WEFFORT, Francisco: Formaçao do Pensamento Político do Brasil. Idea e Personagens, Editora Ática, São Paulo, 2006, p. 163; principalmente el epígrafe intitulado José Bonifácio e Bernardo de Vasconcelos: liberalismo e conservadorismo. Véase también en JANCSÓ, István: Brasil. Formaçao do Estado e da Naçao, Ed. Hucitec, São Paulo, 2003, pp. 195 y ss; principalmente el epígrafe intitulado Iluminismo e jusnaturalismo; p. 431, Elites regionais e o constitucionalismo do Estado; p. 469, O ministério dos Andradas; p. 677, Burke, Cairú e o Império do Brasil.

${ }^{920}$ AGCLIB, Sesión de 6 de mayo de 1823, p. 53. Dip. José Bonifácio de Andrada e Silva.
} 
monárquico franceses de 1789, tales como Malouet, Mounier y Clermont-Tonnerre ${ }^{921}$. Era esta corriente del Liberalismo la que se desprendía del en el discurso del emperador en la Sesión de 3 de mayo de 1823. Lo que vino, como ya vimos defender a su escudero, por entonces, el ministro José Bonifácio de Andrada e Silva, en las sesiones que se siguieron en el parlamento.

Sin embargo, aunque el bloque de los moderados no se identificaba con el absolutismo monárquico, sus detractores, los vintistas brasileños, les metían en el mismo saco de los absolutistas, y por ello, les pasaron a llamarles "servis", "corcundas", "pés-de-chumbo", “despóticos" o simplemente absolutistas ${ }^{922}$. Así también pensaba el vintista pernambucano Joaquim do Amor Divino Rabelo, "O Frei Caneca", muy crítico con el ministerio de José Bonifácio de Andrada e Silva, que le apodaba de "despótico"923. Sus ideas más radicales van a inundar un periódico llamado "Typhis Pernambucano". A su vez aquellos tachaban a los vintistas de "republicanos", "demagogos" o "jacobinos"924.

Este enfrentamiento entre moderados y radicales va a trasladarse a la Asamblea Constituyente reflejando a veces en discusiones infructíferas en las sesiones preparatorias sobre cómo debía ser el ceremonial de entrada del emperador en la Constituyente entre otras cuestiones. Estos enfrentamientos culminarán con el cierre de la Asamblea por el emperador y con la promesa de dar una constitución duplicadamente más liberal de la que se hacía en las Cortes. Si es verdad que vemos un pacto en la política imperial para la consolidación del Estado entre dichos conservadores y los liberales radicales ${ }^{925}$, como afirma la mayoría de la historiografía, también nos parece razonable afirmar que el pacto no fue algo estático sino que el conflicto aparecerá durante todo el periodo de vigencia de la Carta de $1824^{926}$. Los liberales

\footnotetext{
${ }^{921}$ LYNCH, Christian Edward Cyril: “O conceito de liberalismo...” op., cit., pp. 225 y ss.

922 Sobre la utilización de estos términos vinculados al grupo conocido como "Coimbrao", se puede encontrar mejor y ampliadas explicaciones con la lectura de NEVES, Lucia Ma Bastos Pereira das: Corcundas e Constitucionais..., op., cit., 375; principalemente el epígrafe intitulado: Absolutismo ilustrado de D. Pedro. También se hace referencia a estos grupos en LYNCH, Christian Edward Cyril: “O conceito de liberalismo...” op., cit., pp. 225 y ss. Véase también

${ }^{923}$ FERRAZ, Socorro (org.): Frei Caneca. Acusação e Defesa, Ed. Universitaria UFPE, ColeçaoNordestina, Recife, 2000. MOREL, M: Frei Caneca: cristianismo e revolução, Ed. Brasiliense, São Paulo, 1987. RABELO, Joaquim do Amor Divino (Frei Caneca): Ensaios políticos: críticas da Constituição Outorgada; Bases para a formação do pacto social e outros, PUC/Rio, Rio de Janeiro, 1976. LYNCH, Christian Edward Cyril: "O conceito de liberalismo..." op., cit., p. 225.

${ }^{924}$ El propio José Bonifácio tachava a los vintistas de "facçao oculta e tenebrosa de furiosos demagogos e anarquistas". LYNCH, Christian Edward Cyril: "O conceito de liberalismo...” op., cit., p. 226. Estos insultos e provocaciones de ambos partidos se puede lérse en LUSTOSA, Isabel: Insultos impressos..., op. cit., pp. 60 y ss.

${ }^{925}$ La prevalencia de un "pensamiento conservador" en donde los conflictos con el pensamiento liberal era algo circunstancial y no de forma permanente se observa con la lectura de CARVALHO, José Murilo de: A Construção da Ordem..., op. cit. También se puede encontrar en la lectura de MERCADANTE, Paulo: A Consciência Conservadora no Brasil, Editora Saga, Rio de Janeiro, 1965.

${ }^{926}$ DOLHNIKOFF, Mirian: O pacto imperial. Origens do federalismo no Brasil, Editora Globo, São Paulo, 2007, pp. 23 y ss. También a cerca de estas cuestiones relacionadas al pacto liberal véase en PIÑEIRO, Théo Labarinhas: "Os projetos liberáis...", op. cit., pp. 132 y ss.
} 
de corte radical no se darán por vencidos, sino que introducirán muchas de sus reivindicaciones en la propia Carta Constitucional ${ }^{927}$. Sin embargo, el grupo más conservador (liberales doctrinarios) defendía una concentración de poderes en el emperador, mientras que no abdicaban de una constitución que garantizase las posiciones conquistadas en la sociedad brasileña. Este grupo va a posicionarse en el momento de la independencia para extinguir las restricciones coloniales, garantizando así, la libertad de comercio conquistada con la Apertura de los Puertos en 1808. Propugnaban además, la autonomía administrativa y la manutención del orden, de la propiedad, incluso en su modalidad esclavista. Así que, los principios liberales adoptados y defendidos por este grupo eran principalmente los que colisionaban con la realidad de la dominación colonial ${ }^{928}$.

Por otro lado, estaba el grupo al cual se veía al emperador, en su discurso, calificar de demagogos y radicales, y que estaba apoyado por el ministro José Bonifácio de Andrada e Silva, grupo de liberales o democráticos, en la acepción más radical de la palabra, en la intervención del propio ministro, veía como fundamental la defensa de la constituyente y de la constitución. Defendía, además, que el modelo de Cádiz, impusiese restricciones al poder del emperador, ampliando el derecho de voto y el fin de las instituciones aun vinculadas al Antiguo Régimen. Pero, también consideraban que la libertad económica y la autonomía política se configuraban como de suma importancia en su proyecto político ${ }^{929}$. En este último aspecto, mucho más relacionados con el ideario republicano, propugnaban por una monarquía federal, lo que de cierta forma va a configurarse en el Periodo de la Regencia (1831-1840), con la abdicación de D. Pedro I; y se institucionalizará con el Acto Adicional a la Constitución ${ }^{930}$. Entretanto, Sérgio Adorno va afirmar que estos dos grupos hicieron concesiones mutuas que debían reflejar en un ideario simplificado, en el cual el liberalismo, de inicio, y con el fin de conformar el Estado/Nación imperial brasileño, servirá para organizar los autóctonos en

\footnotetext{
${ }^{927}$ COSTA, Emília Viotti da: “A Consciência Liberal nos primórdios do império” en COSTA, Emília Viotti da: Da Monarquia à República: momentos decisivos, 5ª Edição, Editora Brasiliense, São Paulo, 1987, pp. 119-138. LYNCH, Christian Edward Cyril: "O conceito de liberalismo...” op., cit., pp. 226 y ss. Véase también en MATTOS, Ilmar Rohloff de: O Tempo Saquarema, Editora HUCITEC/INL, Sao Paulo/Brasilia, 1987.

${ }^{928}$ Esta y otras afirmaciones se pueden encontrar tanto en COSTA, Emília Viotti da: "A Consciência Liberal...”, op. cit., pp. 65 y ss. Así como en PIÑEIRO, Théo Labarinhas: “Os projetos liberáis...”, op. cit., pp. 135 y ss. También en SALlES OLIVEIRA, Cecília Helena L. de: A astucia liberal. Relaçoes de Mercado e Projetos Políticos no Rio de Janeiro (1820-1824), Ícone Editora, Rio de Janeiro, 1999, pp. 28 y ss.

${ }^{929}$ PIÑEIRO, Théo Labarinhas: "Os projetos liberáis...", op. cit., pp. 135 y ss. Véase también en ALEXANDRE, Valentim: Os Sentidos do Imperio. Questao Nacional e Questão Colonial na Crise do Antigo Regime Português, Biblioteca das Ciencias do Homeme/Ediçoes Afrontamento, 1993, Porto, pp. 660 y ss.

${ }^{930}$ DOLHNIKOFF, Mirian: O pacto imperial..., op. cit., pp. 81 y ss. Se puede ampliar la lectura del tema en BONAVIDES, Paulo: Teoria Constitucional da democracia participativa. Por un Direito Constitucional de luta e resistência. Por uma Nova Hermenêutica. Por uma repolitizaçao da legitimidade, Editora Malheiros, São Paulo, 2001, pp. 190 y ss.
} 
oposición a la metrópoli colonial en la lucha y acción política ${ }^{931}$. Aliados en un primer momento, después de la independencia los dos grupos van a separarse enseguida, siendo los aristocráticos (liberales doctrinarios) los ganadores y en la imposición de su modelo constitucional, pasan a perseguir a los liberales dichos democráticos ${ }^{932}$. Con la derrota de los democráticos, también perderán los aristocráticos en la pugna por el poder. Eso hizo que el emperador se hiciera fuerte, y disolviera la constituyente y otorgase la Carta de 1824, como tendremos mejor ocasión de aclarar y exponer ${ }^{933}$.

931 ADORNO, Sérgio: Os Aprendizes do Poder: Bacharelismo Liberal na Política Brasileira, Editora Paz e Terra, Rio de Janeiro, 1988, pp. 45 y ss. También se puede ver en PIÑEIRO, Théo Labarinhas: “Os projetos liberáis...", op. cit., pp. 135 y ss.

932 NOVAIS, Fernando A. y MOTA, Carlos Guilherme: A independência politica no Brasil, 2ª Edição, Editora Hucitec, São Paulo, 1996, pp. 67 y ss.

933 PIÑEIRO, Théo Labarinhas: “Os projetos liberais...”, op. cit., pp. 136 y ss. 


\section{2.- La convocatoria de la Asamblea Constituyente}

Fundamentado en las peticiones de los diputados paulistas a las Cortes Constituyentes de Lisboa, en el día 3 de junio ${ }^{934}$, el Príncipe Regente D. Pedro expide un Decreto convocando una Asamblea Constituyente en Brasil ${ }^{935}$. En la Sesión del día 26 de agosto, las Cortes Constituyentes de Lisboa debaten la noticia de convocatoria de Cortes en Brasil. La noticia llega por una carta enviada al rey D. Joao VI por el Príncipe Regente D. Pedro, fechada en Río de Janeiro a 19 de junio de $1822^{936}$. En esta carta, se dividen en tres los grandes programas de D. Pedro para los dos reinos: ponerse al frente del carro revolucionario en Brasil; declarar su posición frente a las Cortes de Lisboa; y preparar a su hermano D. Miguel para casarse con su hija María da Glória para en el futuro, sin decirlo ahora, reinar sobre Portugal. En esta misma carta recuerda el príncipe las palabras de su padre, el rey, antes de marcharse a Lisboa, convocado por las Cortes:

"Eu ainda me lembro, e me lembrarei sempre do que Vossa Magestade me disse, antes de partir dois dias, no seu quarto (Pedro, se o Brasil se separar, antes seja para ti, que me has de respeitar do que para alguns desses aventureiros). Foi chegado o momento da quase separação, e estribado eu nas eloquentes e singelas palavras expressadas por Vossa Magestade, tenho marchado adiante do Brasil, que tanto me tem honrado ${ }^{937}$."

934 “A matéria fazia parte do projeto 232, apresentado em 18 de março pela comissão especial constituída de europeus e americanos. Devera entrar em discussão apenas submetida ao parlamento, mas, como a parcialidade exaltada das Cortes não queria tratar das coisas de além-mar sem que o Congresso primeiro considerasse rebeldes José Bonifácio e outros adversários dos decretos de 29 de setembro, a comissão condescendeu com Fernandes Tomás e outros regeneradores de peso. Mandadas submeter a processo as autoridades de São Paulo em $1^{\circ}$ de julho, na sessão imediata o Congresso entrou a examinar o relatório de 18 de março. CARVALHO, Manuel Emílio Gomes de: Os deputados brasileiros nas Cortes..., op. cit., p. 278. Véase también la Providências sobre a Assembleia Geral Constituinte e Legislativa do Brasil -5 de janeiro de 1823-José Bonifácio de Andrada e Silva In: BONAVIDES, Paulo e AMARAL, Roberto: Textos Políticos..., op. cit., p. 716.

${ }^{935}$ Esta convocatoria había sido reflejo de inumerables peticiones dirigidas al por entonces Príncipe Regente D. Pedro, tales como: Convocação da Assembleias Constituinte e Legislativa - Representação do Povo do Rio de Janeiro ao Príncipe Regente em prol da convocação de uma Assembleia Geral - Representação que à $S$. A. R. o príncipe regente constitucional e defensor perpetuo do Reino Unido do Brasil, dirige o povo do Rio de Janeiro pela Câmara desta Corte in: BONAVIDES, Paulo e AMARAL, Roberto: Textos Políticos da História do Brasil, Vol. I, $3^{a}$ Edição, Senado Federal, Brasília, 2002, pp. 571-579. Vereação Extraordinária do Senado da Câmara destas Cortes (Rio de Janeiro) em 23 de maio de 1822 - Solicitação de Convocatória de uma Assembleia Geral in: Ídem, pp. 580-581. Fala do Senado da Câmara dirigida ao Príncipe D. Pedro a Propósito da Convocação de uma Assembleia Geral solicitada pelo povo em 23 de maio de 1822 in: Ídem, pp. 582-588. Representação da Vila Real da Praia Grande (Niteroi) pedindo a convocação de uma Assembleia Legislativa para o Brasil em 26 de maio de 1822 in: Ídem, pp. 589-591. Representação que à $S$. A. R. príncipe regente levaram os procuradores e o ministério, corroborando a suplica do povo dirigida pelo Senado da Câmara no dia 23 de maio - Súplica de convocatória de Assembleia Geral do dia 3 de junho de 1822 in: Ídem, pp. 592-594. Agradecimento pela convocação da Assembleia Constituinte e Legislativa - Representação do Senado da Câmara do Rio de Janeiro em 10 de junho de 1822 in: Ídem, pp. 595-597.

936 DIARIO DAS CORTES GERAIS, EXTRAORDINARIAS, E CONSTITUYENTES DA NAÇAO PORTUGUEZA, Segundo Anno da Legislatura, Tomo VII, Na Imprensa Nacional, Lisboa, 1822, pp. $223-224$. Sesión de 26 de agosto de 1822.

937 Ídem. 
Anejo a la carta también envía al rey: la "Representação da Câmara do Rio de Janeiro, duas vereações extraordinárias, resposta do Príncipe Real; decreto de $1^{o}$ de junho de 1822 para a instalação de Cortes no Rio; outro de 3 sobre os abusos da Liberdade de Imprensa; falas da câmara, e dos Procuradores de São Paulo, Minas, e Rio de Janeiro etc”. Termina además dicha carta declarando a su Magestad ser: "Subdito fiel, e filho obidientissimo, que lhe beija a sua Real Mão - Pedro ${ }^{938, " . ~ T a m b i e ́ n ~ r e c u e r d a ~ a l ~ r e y ~ q u e ~ l o s ~ b r a s i l e n ̃ o s ~ l e ~ s o n ~ f i e l e s ~ y ~}$ todo lo que sucede es resultado de la tiranía de las Cortes de Lisboa. Aunque proteste ser un "subdito constitucional" de su magestad, dirá de la Cortes:

"Por elles verá Vossa Magestade o amor que os Brasileiros honrados lhes consagram a sua sagrada, e inviolável pessoa, e ao Brazil, que a providencia divina lhes deu sorte livre, e que não quer ser escravo de Lusos-Hespanhois quais os infames déspotas (Constitucionais in nomine) dessas facciosas, horrorosas, e pestíferas Cortes."

Es evidente que la independencia estaba medio declarada, o en algunas alocuciones del Príncipe Regente, declarada por entero. En otras cartas y proclamas publicadas en la Sesión de 26 de agosto de 1822, se deduce que el Príncipe pasa a la ofensiva para conquistar el apoyo de las provincias del Norte. Así que entre el Gobernador de Armas de la Provincia de Bahía, Ignario Luis Madeira de Melo, y el Príncipe, empieza un largo altercado, primero de palabras y luego después en los campos de Batalla en Pirajá. En una proclama del Príncipe a los "Amigos Bahianos", fechada a 17 de junio de 1822, y firmada por el Príncipe Regente, empieza con una llamada a los bahianos a seguir los mismos caminos que los demás hermanos brasileños. Y prosigue el príncipe:

"Os honrados Brasileiros preferem a morte à escravidão, vós não sois menos; também o deveis fazer para conosco entoardes vivas à independência moderada do Brasil, ao nosso bom e amável Monarca El Rei o Senhor D. Joao VI, e à nossa assembleia geral constituinte e legislativa do Reino do Brasil."

De acuerdo con la alocución del Príncipe Regente de "Independência moderada do Brasil", en la carta dirigida al rey - su padre -, dirá aquél a cerca de la independencia, que:

"Ainda que isso aconteça, o que espero que não, conte Vossa Magestade que eu serei Rei do Brasil, mas também gozarei da honra de ser de Vossa Magestade Subdito, inda que em particular seja, para mostrar a Vossa Magestade a minha consideração, gratidão, e amor filial tributado livremente. (...) A separação do Brasil é inevitável ${ }^{939}$."

Como que para justificar aquella independencia moderada, dirá el Príncipe a su padre: “(...) Não querem senão as leis da sua Assembleia Geral Constituinte e Legislativa, criada por

\footnotetext{
${ }_{938}$ Ídem.

939 Ídem, pp. 223-224.
} 
sua livre vontade para lhes fazer uma Constituição, que os felicite in eternum se for possível" 940 . Y prosigue explicando a su padre acerca de la inevitabilidad de la separación, pero no una ruptura completa, dado que “(...) Pernambuco proclamou-me Príncipe Regente sem restrição alguma no Poder Executivo, aqui consta-me, que querem aclamar a Vossa Magestade Imperador do Reino Unido, e a mim Rei do Brasil" ${ }^{941}$. En los actos de reconocimiento de Brasil como Estado libre por parte de Portugal y a través del Tratado de Amistad, firmados entre los años de 1825-26, constataremos más adelante la verdad de las palabras de D. Pedro, puesto que D. Joao VI recibirá el título de Emperador de Brasil.

En otra carta, dirigida al Presidente y diputados de la Junta Provincial del Gobierno de Bahía, fechada en Río de Janeiro a 15 de junio de 1822, y firmada conjuntamente por el Principe Regente y por su ministro José Bonifácio de Andrada e Silva, amonesta a aquellos el Príncipe, que el Reino de Brasil en breve vendrá a ser "Um dos Reinos Constitucionais mais felizes do mundo ${ }^{942,}$

Un oficio del Gobernador de Armas de Bahía confirma la convocatoria por parte del Príncipe Regente de la Asamblea Constituyente para el Reino de Brasil. Además, habla de las adhesiones a la causa, no solamente en Pernambuco, como también en la afueras de la capital de Bahía:

“(...) Foi a sedição fazendo progressos no Recôncavo, e ultimamente aclamouse em Cachoeira no dia 25 de junho à Sua Alteza o Príncipe Real, Regente e Perpetuo Defensor, e Protetor do Reino do Brazil, e se instalou uma junta, a que chamam os facciosos daquele distrito - Junta Interina conciliatória, e de defesa ${ }^{943} . "$

La ciudad de Salvador de Bahía, que permanecía fiel al Congreso de Lisboa, bajo las tropas de Madeira de Melo, se ve obligada a aclamar al Príncipe Regente en un acto frustrado en el día 12 de junio. Al final, la Cámara de la Ciudad de Bahía envía un Oficio al rey negando los hechos y prometiendo fidelidad, exponiendo lo ocurrido en los "Termos da Vereação" en el día 26 del mismo mes. De suerte que fueron leídos en dicha sesión del día 26 innúmeros documentos, cartas, oficios etc., en donde se constataba que a lo largo y ancho de Brasil se iban desprendiendo de las Cortes de Lisboa para Aclamar al Príncipe Regente.

\footnotetext{
940 Ídem, p. 223.

941 Ibídem.

942 Ídem, p. 225.

${ }^{943}$ Ibídem. El Príncipe va a conseguir imponerse como jefe del Ejecutivo en Brasil. A través del principio de la legitimidad dinástica, consigue reunir el apoyo necesario para capitanear el proceso de independencia. Es evidente que eso causará conflicto en el futuro en el momento en que se discuta en la Asamblea convocada por el entonces Príncipe, si la soberanía recaía en el pueblo o en el emperador. En el Segundo Oficio, enviado por Ignacio Luis Madeira de Melo al rey de Portugal desde Bahía, en el 7 de junio de 1822, este promete no obedecer las órdenes que no provengan del rey, y del soberano de Lisboa.
} 
Después de las declaraciones de independencia de algunas provincias de Brasil, que se adhirieron al Príncipe Regente, una indicación surgió en el Congreso lisboeta para tornar nulas las procuraciones de aquellos diputados que proveían de aquellas provincias rebeldes:

"Como as províncias de S. Paulo, Rio de Janeiro, Minas Gerais, Rio Grande do Sul, e outras estão em perfeita união com o Príncipe Real, e dissidência com Portugal, e o Príncipe Real já convocou Cortes Gerais e Constituintes no Rio de Janeiro, o que implica soberania separada, e o fez a votos dos procuradores das ditas províncias, proponho que se declarem nulas as representações das províncias, que aderem ao governo de S. A. R. - Antonio Carlos Ribeiro de Andrada; José Feliciano Fernandes Pinheiro; José Ricardo da Costa Aguiar de Andrada; Antônio Manuel da Silva Bueno ${ }^{944}$."

Se pronunciará Antônio Carlos Ribeiro de Andrada, en donde razona que "he especial a representação de províncias que estão separadas". Por la reacción conformada del diputado, tan combativo, parece que ya tenía en mente evadirse del Congreso en Lisboa, como al final lo hará, para reunirse en las Cortes convocadas en Brasil:

"O Congresso está bem informado, os papeis políticos mostraram desgraçadamente uma separação política e absoluta: he preciso pois que se tome alguma medida; eu não sei como possa ser, que nós estejamos votando em medidas que são contra o país, que nos deu nossas procurações ${ }^{945}$."

Se hizo una segunda lectura de la indicación, se constató la urgencia y se remitió a la Comisión de Constitución. Si es verdad que con la independencia de Brasil las Cortes de Lisboa perdieron su naturaleza y con ella el régimen liberal, por no conseguir cumplir con la promesa de regeneración de la patria; también es verdad que por acatar a las peticiones de Sao Paulo de convocatoria de Cortes para Brasil, la definición por el principio monárquico y depósito de la autoridad en el Príncipe Regente se patentará ${ }^{946}$. La convocatoria de Cortes reflejará en la Aclamación del Príncipe en el 12 de octubre y en su coronación en el $1^{\circ}$ de diciembre. Este capítulo de la formación del Estado/Nación se inicia con aquellos actos y se cierra en el año de 1831 cuando el emperador es forzado a abdicar a favor de su hijo, el futuro D. Pedro II. Esto estuvo directamente relacionado con el cierre de la Constituyente al final del año de 1823. Este acto inauguró un régimen centralizado en el Primero Reinado, con la otorga de la Constitución de 1824, que calló a la oposición hasta la reunión en 1826 del Parlamento electo. Con la

\footnotetext{
944 Ídem, p. 243.

945 Ibídem.

946 Véase en BERBEL, Márcia Regina: "A Constituição espanhola no mundo Luso-americano (1820-1823)", Revista de Indias, 2008, vol. LXVIII, núm. 242, págs. 225-254, ISSN: 0034-8341, p. 246.
} 
reunión del parlamento también regresa la oposición pública de los grupos provinciales a la política autoritaria del emperador $^{947}$.

Dos actos aquí citados merecen ser destacados: la Aclamación del Príncipe y su posterior Coronación. La primera tendrá un carácter liberal en donde la nación le confiere sus poderes al Príncipe Regente, mientras que el segundo será, por su simbología un acto del Antiguo Régimen cargado del principio del derecho divino de los reyes; fue un acto lleno de significantes religiosos ${ }^{948}$.

Con la convocatoria de Cortes a través del Decreto de 3 de junio, confirmado por el Decreto de 1 de agosto de 1822, Brasil ya era un Reino independiente, como también se quedó patente en la Sesión del día 26 de agosto en las Cortes de Lisboa. Pero faltaba la legitimación política para aquél acto de independencia de la metrópoli. Una proclama que se estampó en los periódicos de Río de Janeiro en el 21 de septiembre, tras el famoso "Grito do Ipiranga" en 7 del mismo mes en Sao Paulo, aventaba la posibilidad de ratificación política de estos actos. Tal proclama atribuída a Gonçalves Ledo, se expresaba así:

\section{“CIDADÃOS..."}

“O Deus da natureza fez a América para ser independente e livre: o Deus da natureza conservou no Brasil o príncipe regente para ser Aquele que firmasse a Independência deste vasto continente. Que tardamos? A época é esta. Portugal nos insulta... a América nos convida... a Europa nos contempla... o príncipe nos defende... Cidadãos! Soltai o grito festivo... Viva o Imperador Constitucional do Brasil, o senhor d. Pedro Primeiro ${ }^{949 . "}$

Esta propuesta de aclamar a D. Pedro Imperador Constitucional de Brasil surge en la mazonería, la Logia del Grande Oriente, en donde se congregaba la élite brasileña adepta del liberalismo vintista, y Gonçalves Ledo era su grande portavoz. Esto, según análisis de Lúcia $\mathrm{M}^{\mathrm{a}}$ Bastos P. das Neves, reflejaba toda una pugna por el poder e imposición de modelos por parte de los "brasilienses" (vintistas) y los egresados de Coimbra (liberales de la restauración, conservadores). Esta proposición fue enviada a las provincias, que tuvo una relativamente amplia aceptación como vimos en la documentación leída en la Sesión del día 26 de agosto de

\footnotetext{
${ }^{947}$ Para estas y otras cuestiones se recomienda la lectura de DOLHNIKOFF, Miriam: O Pacto Imperial. Origens do federalismo no Brasil, Editora Globo, São Paulo, 2005, pp. 17 y ss.

${ }^{948}$ Esta correspondencia lo hizo magistralmente la profesora Lúcia Ma Bastos Pereira das Neves. Aquí nos cabrá matizar la parte religiosa de los actos, puesto que el ceremonial de coronación nos permite jugar con nuestro tema aquí discutido, como forma de introducción a la confesionalidad del naciente Estado brasileño. Estas discusiones se puede encontrar en NEVES, Lúcia Ma Bastos P. das: Corcundas e Constitucionais..., op. cit., pp. 375-411.

${ }^{949}$ Correio Extraordinário do Rio de Janeiro. n ${ }^{\circ}$ 3, 21 setembro 1822. Publicada también en el Diário do Rio de Janeiro. 24 setembro 18 In: NEVES, Lúcia Ma Bastos P. das: Corcundas e Constitucionais..., op. cit., p. 375.
} 
1822 en las Cortes de Lisboa ${ }^{950}$. El 4 de octubre la indicación para la Aclamación de D. Pedro como Defensor Perpetuo do Brasil fue recibida con entusiasmo, mientras que otro masón, Domingo Alves Branco, propuso además que el Príncipe Regente debiese ser aclamado Imperador de Brasil ${ }^{951}$. Así que se quedó acordado que en 12 de octubre, cumpleaños del Príncipe, se procedería a la Aclamación. El propio Joaquim Gonçalves Ledo preside la Sesión de 9 de septiembre como $1^{\circ}$ Grande Vigilante, en el impedimento del Gran-Maestro, que por entonces era José Bonifácio,...

“...dirigia do Sólio um enérgico e fundado discurso demostrando com as mais sólidas razoes, que as atuais políticas, circunstancias de nossa pátria o rico, fértil e poderoso Brasil, demandavam a exigir imperiosamente que a sua categoria fosse inabalavelmente formada com a proclamação de nossa independência, e da realeza constitucional na pessoa do augusto príncipe, perpetuo defensor do Reino do Brasil $^{952,}$.

En esta misma sesión del Grande Oriente se instó que la doctrina política proclamada en el periódico intitulado de "Regenerador" era subversiva a los principios constitucionales que fueron jurados por los miembros de esta Augusta Orden, puesto que, pretendía persuadir a los pueblos de Brasil la instalación de principios aristocráticos que en nada se concordaban con la libertad constitucional que los brasileños anhelan. Tales principios aristocráticos serian diametralmente opuestos al sistema constitucional abrazado, que había sido proclamado, jurado y seguido por el augusto príncipe y perpetuo defensor de Brasil. Por lo tanto, los áulicos de Río de Janeiro en consonancia con las Cortes de Lisboa pretendían establecer el despotismo. Lo que se proclamó falsas estas acusaciones impresas en aquél periódico. El redactor de dicho periódico fue llamado a declarar en la sesión del día 12 de septiembre, y se montó un tribunal para juzgarle. El redactor dirá que siempre estuvo comprometido con "a regeneração política e a santa causa do Brasil" ${ }^{953}$. Además, se defendió diciendo que como buen masón estaba comprometido y había contraído la obligación de la causa de Brasil y de su independencia, por debajo de su augusto defensor perpetuo, que cuya liberalidad constitucional se irroga la más atroz injuria. Al final las excusas del acusado son aceptadas y perdonadas por el Grande Oriente.

\footnotetext{
${ }^{950}$ DCGECNP, Segundo Anno da Legislatura, Tomo VII, Na Imprensa Nacional, Lisboa, 1822, pp. 223-224. Sesión de 26 de agosto de 1822.

${ }^{951}$ Atuação da Maçonaria na Independência - Certidão das Atas das Sessões de Agosto a Outubro de 1822 da Loja Maçônica Grande Oriente do Brasil de 29 de Agosto de 1861 in: BONAVIDES, Paulo e AMARAL, Roberto: Textos Políticos..., op. cit., pp. 695-702. También se encuentra en NEVES, Lúcia Mª Bastos P. das: Corcundas e Constitucionais..., op. cit., p. 375.

${ }^{952}$ Atuação da Maçonaria na Independência - Certidão das Atas das Sessões de Agosto a Outubro de 1822 da Loja Maçônica Grande Oriente do Brasil de 29 de Agosto de 1861 in: BONAVIDES, Paulo e AMARAL, Roberto: Textos Políticos..., op. cit., p. 696.

${ }^{953}$ Ídem, p. 698.
} 
También se acordó que para evitar ser sobrepasada por esta augusta empresa de aclamación del príncipe como augusto defensor perpetuo y rey constitucional de Brasil, debían los masones ser los primeros en dar este necesario impulso a la opinión pública, adelantarse en poner en ejecución los medios para que ninguna corporación civil pretendiese tomar para si la gloria de esta honrada empresa. Así, se determinaba que se enviase a las distintas provincias de Brasil emisarios encargados de propalar la opinión defendida y adoptada por el Grande Oriente. También se proponía crear una Caja para dicha empresa. El propio Príncipe, que había sido elegido con el grado de Gran-Maestro con el nombre de Guatimozim en la Sesión de 4 de octubre, había enviado saludos al Grande Oriente por sus decisiones y apoyo.

Después de que se quedara acordado en la Sesión de 4 de octubre del Grande Oriente, en presencia de su Gran-Maestro, el Príncipe Regente, se decidió por la aclamación:

"Em seguida resolveu a assembleia que a aclamação civil tivesse lugar no dia 12 de outubro, e que todos os maçons se espalhassem pelos lugares de maior concurso, principalmente no campo de St. ${ }^{a}$ Ana onde deveriam efetuar-se o mesmo solene ato, a fim de procurarem conservar a necessária tranquilidade e conveniente decoro. Por esta ocasião propôs o maçom José Clemente Pereira, os vivas que como presidente do Senado da Câmara tencionava dar - à religião - ao Sr. D. Pedro $1^{o}$ Imperador Constitucional do Brasil -à sua augusta esposa- e à independência do Brasil ${ }^{954}$."

Además, el Guatimozim, recordó que se debían dar unas vivas más por la Asamblea Constituyente y Legislativa. Mientras tanto, la Comisión encargada de las festividades de la Aclamación presentó el programa, consistiendo en cinco arcos y que estas y demás despensas se quedasen bajo la responsabilidad de los miembros del Grande Oriente. Siguiendo en las demostraciones de fidelidad a la causa del príncipe y de la nación propuso el masón Joao Mendes Viana, en la Sesión del día 5 de octubre, que el título de defensor perpetuo de Brasil fuese hereditario en la familia del emperador. La medida fue aprobada, pero, un miembro del Grande Oriente recordó que era necesario el consentimiento del pueblo para aprobar tal medida.

"Reconhecida a legalidade da medida, encarregou-se o maçom José Clemente Pereira de a propor na primeira vereação da Câmara, de que era presidente, para que fosse adotada se assim conviesse ${ }^{955^{5}}$."

Las tensiones entre el grupo de los egresados de Coimbra y la élite brasileña (vintista) no se hacen esperar. Era patente que en la construcción del Estado/Nación brasileño entraban en materia dos grandes grupos que generaban conflictos ideológicos. Habían los que deseaban un gobierno basado en la soberanía popular, con el Príncipe D. Pedro como jefe escogido por el

\footnotetext{
954 Ídem, p. 700.

955 Ídem, p. 701.
} 
pueblo, debiendo este, en el más puro estilo revolucionario, quedar subordinado a los representantes de la Nación, o sea al parlamento. Por otro lado estaban los defensores de una constitución que diese poderes limitados a las Cortes legislativas, y que aceptase la autoridad del soberano como un derecho legalmente heredado, a través del principio dinástico ${ }^{956}$. Comenta, además, Lúcia $\mathrm{M}^{\mathrm{a}}$ Bastos $\mathrm{P}$. das Neves que el propio título ofrecido a D. Pedro revelaba el dualismo de la propuesta. De algún modo este dualismo se reflejará en la Constitución de 1824 en su art. 11 que dice que los representantes de la Nación Brasileña son: el Emperador y la Asamblea General. A la vez que en el art. 12 dice que todos estos poderes del Imperio de Brasil son delegaciones de la Nación. Y antecediendo a todo esto, en el art. $3^{\circ}$ proclama un Gobierno Monárquico Hereditario, Constitucional y Representativo. Proclama además en el art. $4^{\circ}$ que la dinastía imperante es la del Sr. D. Pedro I, actual emperador, e Defensor Perpetuo de Brasi1 ${ }^{957}$. Ahí estaba las múltiples facetas de la soberanía entendida por el grupo de los egresados de Coimbra. Dirá la citada autora, además, que el título ofrecido de emperador, cogitado como vimos en la masonería por el brigadero Domingos Alves Branco, será algo inusual hasta el momento, una tentativa de disociación de los derechos dinásticos de la casa bragantina, dado que no era un título trasmitido por derecho de herencia o legitimidad personal. El propio acto de Aclamación civil parecía un acto de elección por parte de la población. Pero, no solamente eso, pretendía además ser el punto de conciliación entre las diferentes corrientes de opinión política de la nación ${ }^{958}$. Sin embargo, entre José Bonifácio, el emperador y una buena parte de la élite procedente de Coimbra no era del todo absurdo una reconstrucción en el futuro de un Imperio Luso-Brasileño, puesto que D. Pedro era el legítimo heredero del trono de Portugal.

Había prisa en aclamar a D. Pedro emperador, dado que esta aclamación debía ocurrir antes de que se reunieran las Cortes Constituyentes, para evitar una preeminencia de éstas sobre el emperador. Sería así porque la “Assembleia não seria detentora de toda a soberania, pois o monarca era um componente essencial da representação nacional, configurando-se o pacto entre ele e o povo ${ }^{959, " . ~ J o s e ́ ~ B o n i f a ́ c i o ~ n o ~ c o n c o r d a b a ~ e n ~ t o d o ~ c o n ~ l a ~ e ́ l i t e ~ b r a s i l e n ̃ a ~(v i n t i s t a), ~}$ dado que rechazaba la idea de una soberanía que recayese exclusivamente en la Nación. El proyecto que Antônio Carlos de Andrada presentó en la Asamblea Constituyente, gran

\footnotetext{
${ }^{956}$ NEVES, Lúcia Ma Bastos P. das: Corcundas e Constitucionais..., op. cit., p. 376.

${ }^{957}$ Projeto de Constituição para o Império do Brasil, Organizado no Conselho de Estado sobre as Bases Apresentadas por Sua Magestade Imperial o Senhor D. Pedro I. Imperador Constitucional, e Defensor Perpetuo do Brasil, Na Typographia Nacional, Rio de Janeiro, 1823, pp. 3-5.

${ }^{958}$ Estas y otras afirmaciones hacemos en consonancia con el pensamiento que se puede encontrar en NEVES, Lúcia Ma Bastos P. das: Corcundas e Constitucionais..., op. cit., p. 376.

${ }^{959}$ Ibídem.
} 
tributario de la Constitución de 1824 , dirá en su art. $40^{\circ}$ que todos los poderes del Imperio de Brasil son delegación de la Nación. Esto está de acorde con el art. 12 de la Constitución de 1824. Pero el proyecto de 1823, complementa aquella alocución, diciendo al final del artículo que sin dicha delegación cualquier ejercicio del poder es una usurpación ${ }^{960}$. Pero, el sistema monárquico para el Estado va a ser formado de forma más o menos pacífica entre los dos grandes grupos. Hasta el ex-republicano que participó en la Revolución de 1817 en Pernambuco, Antônio Carlos de Andrada, combativo diputado en las Cortes de Lisboa, y después diputado en la Asamblea Constituyente en Río de Janeiro, que va a ser el principal autor del proyecto constitucional presentado a las Cortes, ya se había convertido a la causa monárquica ${ }^{961}$.

Los choques ideológicos entre el ministro José Bonifácio de Andrada y el Grande Oriente llevan al emperador, que además era el Gran-Maestro, en la sesión de 25 de octubre de 1822, que fue presidida por Joaquim Gonçalves Ledo, a mandar suspender los trabajos en el Grande Oriente. Ledo presenta el orden en dicha sesión por la cual el Gran-Maestro (Guatimozim) manda suspender los trabajos del Grande Oriente, así como de todas las oficinas del círculo hasta segunda orden. Mandaba aquél tanto en la calidad de Gran-Maestro de la Masonería brasileña como de emperador y defensor perpetuo del Imperio ${ }^{962}$. La masonería estaba muy comprometida con la causa de la independencia, pero ésta también frustraba los intereses del poderoso ministerio de los Andradas.

Si por un lado el Príncipe Regente representaba para ambos bandos la unidad nacional, los egresados de Coimbra, formados en una tradición política ilustrada de Portugal, buscaban trasladar dicha tradición política a Brasil, en donde se concebía un gobierno monárquico como la opción más viable. Como ya resaltamos antes, la mayor parte de la élite brasileña se había formado cultural e intelectualmente en la Universidad de Coimbra. Por otro lado, había una parte de esta élite, que afiliada al liberalismo vintista, entendía que la opción de la monarquía constitucional no excluía, en la formación de la patria, a las ideas democráticas. Este grupo pretendió alejar del poder al ministro José Bonifácio, el máximo representante de los egresados

\footnotetext{
${ }^{960}$ Projeto de Constituição para o Império do Brasil (Antônio Carlos de Andrada) in: MIRANDA, Jorge: O constitucionalismo liberal luso-brasileiro, Comissão Nacional para as Comemorações dos Descobrimentos Portugueses, Lisboa, 2001, p. 210.

${ }^{961}$ El mismo diputado esclarece su posición Declaração do deputado Antônio Carlos Ribeiro d'Andrada, sobre o que dele publicou em Lisboa o Astro da Lusitânia. 5 novembro 1822. Londres. Correio Braziliense. v. 29, novembro In: NEVES, Lúcia $\mathrm{M}^{\mathrm{a}}$ Bastos P. das: Corcundas e Constitucionais..., op. cit., p. 376.

${ }^{962}$ Atuação da Maçonaria na Independência - Certidão das Atas das Sessões de Agosto a Outubro de 1822 da Loja Maçônica Grande Oriente do Brasil de 29 de Agosto de 1861 in: BONAVIDES, Paulo e AMARAL, Roberto: Textos Políticos..., op. cit., pp. 701-702. "Declaro que da sobredita Ata de 13 do $5^{\circ}$ mês do ano de 1822 (2 de agosto) consta também, que antes de ter lugar a iniciativa do príncipe regente, foram recebidos no Grande Oriente como visitantes para assistirem a esse ato os maçons Felipe Nery Ferreira, membro do Governo Provisório de Pernambuco, e Lucas José Obes, procurador da Província Cisplatina, que na sessão antecedente, em 11 do mesmo mês, haviam sido nomeados delegados do Grande Oriente nas ditas províncias”. Ídem, p. 702.
} 
de Coimbra, y por tanto, buscando crecer en prestigio junto al Príncipe Regente, van a elegirlo, como vimos, Gran-Maestro del Grande Oriente, en el puesto de aquél poderoso ministro ${ }^{963}$

La presencia del Príncipe Regente y futuro monarca de Brasil en el proceso de independencia, hizo que los discursos de fundación del Estado/Nación estuviesen llenos de dudas en cuanto a la titularidad de la soberanía. Dudoso era también el alcance que aquélla independencia política debía tener. Esto se deduce de la lectura de las cartas enviadas al rey por el Príncipe Regente. En una de estas cartas fechada el 4 de agosto de 1822, el propio Príncipe expresaba en un decreto anexo a dicha carta, el de $1^{\circ}$ de agosto del mismo año, cuál era su conciencia del valor que debía tener el principio dinástico en el proceso; y cuanto estaba dicha conciencia disfrazada en determinadas expresiones, como la de aclamación de los pueblos; como ilustra el preámbulo del citado decreto:

"Tendo-Me sido conformada por unânime consentimento e espontaneidade dos Povos do Brazil, a Dignidade e Poder de Regente deste Vasto Império, que ElRey Meu Augusto Pai Me tinha outorgado, Dignidade que as Cortes de Lisboa, sem serem ouvidos todos os Deputados do Brazil, ousaram despojar-Me, como é notório: e tendo Eu aceito outrossim o Título e encargos de Defensor Perpetuo deste Reino, que os meus Povos tão generosa e lealmente me conferiram: cumprindo-Me portanto em desempenho dos meus Sagrados Deveres, e em reconhecimento de tanto amor e fidelidade, Tomar todas as medidas indispensáveis à salvação desta Máxima parte da Monarquia Portuguesa, que em Mim se confiou, e cujos direitos Jurei Conservar ilesos de qualquer ataque: e como as Cortes de Lisboa continuam no mesmo errado sistema, e a todas as luzes injusto, de recolonizar o Brasil, (...) apesar de o mesmo já Proclamado a sua Independência Política, a ponto de já está legalmente convocada pelo Meu Real Decreto de três de junho próximo passado uma Assembleia Geral Constituinte e Legislativa a requerimento geral de todas as Câmaras (... $)^{964}$."

La noción que tenía el Príncipe de la legitimidad dinástica, se plasmaba también en una otra afirmación en el mismo preámbulo de aquél decreto, cuando compara la convocatoria de Cortes que él hace para Brasil y el modo como se convocan las Cortes de Lisboa:

“(...) Procede-se assim com uma formalidade, que não houve em Portugal, por ser a convocação do Congresso em sua origem somente um ato de clubes ocultos e facciosos: e considerando Eu igualmente a Sua Magestade ElRei o Senhor D. Joao Sexto, e cujo Nome e Autoridade pretende as Cortes servir-se para os seus fins sinistros, como Prisioneiro naquele Reino, sem vontade Própria, e sem aquela liberdade de Ação, que he dada ao Poder Executivo nas Monarquias Constitucionais (.... $)^{965}$.”

\footnotetext{
${ }^{963}$ NEVES, Lúcia Ma Bastos P. das: Corcundas e Constitucionais..., op. cit., p. 378.

${ }^{964}$ Carta II, enviada a D. Joao VI por el Príncipe Regente D. Pedro en 4 de agosto de 1822 y decreto anexo de $1^{\circ}$ de agosto de 1822. (John Carter Brown Library) Cartas e Documentos dirigidos a Sua Magestade o Senhor D. Joao VI pelo Príncipe Real o Senhor D. Pedro de Alcântara: e que forao presentes as Cortes em Sessao de 28 de Setembro de 1822, Na Imprensa Nacional, Lisboa, 1822, p. 5.

965 Ídem, pp. 5 y 6.
} 
Así también se expresará D. Pedro en un "Manifesto aos Brazileiros - De S. A. R. o Príncipe Regente Constitucional, Defensor Perpetuo do Reino do Brazil aos Povos deste Reino", en donde evoca los reconocidos derechos de la Augusta Casa de Braganza. Se pone a sí mismo como la clave de la manutención del orden y agludinador de los ideales de autonomía política de Brasil, como el polo y unificador del reino. Pero también coloca a Brasil dentro de la órbita del soñado Imperio Luso-Brasileño:

"Resolvi-me por tanto, tomei o partido que os Povos desejavam, e mandei convocar a Assembleia do Brazil, a fim de cimentar a Independência Politica deste Reino, sem romper com tudo os vínculos da Paternidade Portugueza; harmonizando-se com decoro, e justiça todo o Reino Unido de Portugal, Brazil, e Alarves, e conservando-se debaixo do mesmo Chefe duas famílias separadas por imensos mares, que só podem viver reunidas pelos vínculos da igualdade de direitos, e recíprocos interesses ${ }^{966}$."

D. Pedro tenía claro su papel en todo este proceso y que partido político pretendía favorecer. En perfecta consonancia con el discurso que pronunciará el 3 de mayo de 1823, en la apertura de la Asamblea Constituyente, como ya tuvimos ocasión de explicar, se manifestó un año antes, en el "Manifesto aos Brazileiros", qué tipo de cortes le gustaría ver reunida y que corriente ideológica querría ver alejada del proceso; de este modo dirá:

"Que vos resta, pois, Brazileiros? Resta-vos reunir-vos todos em interesses, em amor, em esperanças; fazer entrar a augusta Assembléa do Brazil no exercício das suas funcções, para que maneando o leme da razão, e prudência, haja de evitar os escolhos, que nos mares das revoluções apresentam desgraçadamente França, Hespanha, e o mesmo Portugal; para que marque com mão segura, e sabia a partilha dos Poderes, e firme o Código da nossa Legislação na sã filosofia, e o applique ás vossas circunstancias peculiares ${ }^{967 . "}$

El pensamiento liberal vintista de las Cortes de Lisboa va a ser asociado a la tiranía y al despotismo, igualmente se asocian a éstos tópicos los principios democráticos defendidos también por los vintistas brasileños (la élite brasiliense). Por lo tanto, vamos a percibir en el “Falla, que a S. A. R. o Príncipe Regente Constitucional, e Defensor-Perpetuo do Reino do Brazil, dirigia o Senado da Câmara desta Cidade pela voz do seu Presidente, no acto de apresentar ao mesmo Senhor a Representação do Povo desta Cidade sobre a Convocação de uma Assembléa Geral nesta Corte.” El liberalismo de las Cortes de Lisboa estaba asociado al antagonismo que se formaba entre colonia y metrópoli. A través del discurso de algunos políticos nos deja entrever que también el antagonismo se formaba entre las propias Cortes y el poder del monarca, que en la Carta del Príncipe a su padre, el rey, lo ponía como prisioneros de

\footnotetext{
${ }^{966}$ Manifesto aos Brazileiros - De S. A. R. o Príncipe Regente Constitucional, Defensor Perpetuo do Reino do Brazil aos Povos deste Reino. Ídem, p. 11.

967 Ídem, p. 14.
} 
dichas Cortes, tiránicas, por lo tanto, y que usurpaba al legítimo Poder Ejecutivo del rey, en el ámbito de lo que entiende como definido en un gobierno constitucional. Así, se preguntará el Príncipe:

"E por que principio de liberalismo? Interessa por ventura a Nação Portugueza, que o Governo de Lisboa guarde fechada na sua destra a dispensa de todos os empregos do Brazil? Não certamente: longe de interessar perderia (... $)^{968}$.”

De lo antes expuesto podemos deducir que al propio príncipe le convenían los intereses e influencias que ejercían los Andradas. La divergencia entre ambos grupos, que intentaban atraer al emperador para su órbita ideológica, va a empeorar mucho, cuando el grupo de Gonçalves Ledo intenta imponer al Príncipe Regente, antes de su Aclamación, la jura previa de guardar, mantener y defender la futura constitución que iba a ser elaborada en la Asamblea Constituyente. Así lo debía hacer en el día de su Aclamación, día 12 de octubre ${ }^{969}$. Como pudimos ver, eso no interesaba ni al Príncipe Regente, ni tampoco a José Bonifácio, afiliado de otro pensamiento político. Sin confrontarse directamente, por miedo a un mayor daño, el ministro y el Príncipe solamente se manifestarán después de la Aclamación, con el cierre de los trabajos del Grande Oriente, como ya vimos. Aunque con la Aclamación, los brasilienses (vintistas) hubiesen conseguido un poder momentáneo. La gran victoria de este grupo se quedará confirmada cuando la propuesta nacida en la sesión de la Logia del Grande Oriente se propuso que pasara por votación del pueblo sobre dicha aclamación. Esto se dará en la "Vereação" de 10 de octubre en el Senado de la Cámara de Río de Janeiro, en la cual, se hacía aclamar al emperador por la voluntad general de los pueblos. Así que la aclamación era un evento de origen popular que le atribuía el poder como consecuencia de la autonomía política, poniendo en segundo plano el hecho de que fuera el legítimo heredero de la corona portuguesa $^{970}$. Y para ampliar más esta base popular, las Cámaras de las principales ciudades fueron informadas y llamadas a respaldar la Aclamación ${ }^{971}$, desde que "debaixo da condição de prestar previamente um juramento de jurar, manter, guardar e defender a Constituição, que

\footnotetext{
${ }^{968}$ Falla, que a S. A. R. o Príncipe Regente Constitucional, e Defensor-Perpetuo do Reino do Brazil, dirigia o Senado da Câmara desta Cidade pela voz do seu Presidente, no acto de apresentar ao mesmo Senhor a Representação do Povo desta Cidade sobre a Convocação de uma Assembléa Geral nesta Corte. (Archivo de la John Carter Brown Library) Cartas e mais Documentos dirigidos a Sua Magestade o Senhor D. Joao VI pelo Príncipe Real o Senhor D. Pedro de Alcântara com as datas de 19 e 22 de junho deste anno: e que forão presentes às Cortes Gerais Extraordinárias e Constituintes da Nação Portugueza. Em a Sessão de 26 de Agosto do mesmo anno, Na Imprensa Nacional, 1822, p. 23.

969 "Na circular de 17 de setembro do Senado do Rio de Janeiro, enviada às diversas Câmaras municipais, reforçava-se a idéia do juramento prévio, subordinando d. Pedro a tudo que a Assembléia decidisse, numa situação semelhante à de Portugal, onde o Soberano Congresso se sobrepunha ao rei." NEVES, Lúcia M ${ }^{a}$ Bastos P. das: Corcundas e Constitucionais..., op. cit., p. 379.

970 Ibídem.

${ }^{971}$ As Câmaras e a Independência, Tomo III, Conselho Federal de Cultura, Rio de Janeiro, 1973, p. 38. (Arquivo Nacional). Formação Constitucional do Brasil, Tipografia do Jornal do Comercio, Rio de Janeiro, 1914, p. 78.
} 
fizer a Assembléia Geral Constituinte e Legislativa do Brasil ${ }^{972, " . ~ A l ~ f i n a l, ~ b a j o ~ l a ~ e x c u s a, ~ e n t r e ~}$ diversas otras, de que no era el momento apropiado se quedó definido que el juramento se debía pronunciar en la ceremonia de coronación ${ }^{973}$.

Dicha ceremonia de Coronación se revelará una verdadera antípoda de los intereses de la élite vintista. Mientras la Aclamación se caracterizaría como un acto cívico, de participación popular, aunque algunos aspectos religiosos fuesen introducidos, la Coronación se revelará un perfecto acto del Antiguo Régimen, con aspectos inusitados hasta para la tradición lusa. La atribución de solemnidad cívica al 12 de octubre buscaba diferenciarse de las fiestas religiosas del Antiguo Régimen, aunque esta no fue una conmemoración precisamente secularizada, dado que tales aspectos no eran una característica del liberalismo luso-brasileño. Pero, algunas prácticas laicizadas fueron introducidas en dicha manifestación cívica, como nos cuenta Lúcia M $^{\text {a }}$ Bastos Pereira das Neves. Se buscó introducir discursos, recitales de poesías constitucionales y vivas participaciones del pueblo en el final de la ceremonial. El pueblo pasaba de espectador retirado a un elemento partícipe del proceso. El acto religioso solamente fue introducido al final de la ceremonia de Aclamación, con el "Te Deum" en la Capilla Imperial $^{974}$.

Un hecho interesante es que disintiendo de la conmemoración actual de la Independencia que es el 7 de septiembre, pues que coincide con el famoso "Grito do Ipiranga" en la Província de Sao Paulo, algunos documentos de época marcan al 12 de octubre como la fecha de la independencia política de Brasil. Plancher-Seignot, impresor librero de S.M.I, que se había encargado de la reimpresión de la Colección de todas las leyes, decretos del gobierno, desde la época de la independencia, dirá en la primera parte de su obra, que principia en el 12 de octubre de 1822, que fue el "dia da Proclamação da Independência do Brasil nesta Corte, e sua elevação à categoria de Império ${ }^{975,}$. El editor, además, se dirige al público diciendo:

\footnotetext{
972 Auto de Aclamação da Câmara da vila de Vitória. In: Arquivo Nacional. As Câmaras Municipais e a independência. Rio de Janeiro, Arquivo Nacional/ Conselho Federal de Cultura, 1973, (v. 1), pp. 193-9. Termo de Vereação da Câmara da vila de Santa Maria do Baependi. Termo de Vereação da Câmara de vila Nova da Rainha do Caeté. Termo de Vereação da cidade de Mariana. In: Arquivo Nacional. Ibidem. (v. 2), pp. 12-18, 5961 e 157-9, respectivamente. In: Ídem, p. 380.

${ }^{973}$ Contrariando a esta definición del poder como teniendo origen popular, la Gaceta de Rio de Janeiro, va a decir, en su comentario sobre la ceremonia de Aclamación que el título de emperador ya podía haber sido tomado por el Príncipe hace mucho, y que se no lo había hecho era porque no lo deseaba. Eso daba a entender la prevalencia que tenía el poder del emperador al poder que pudiese albergar un Congreso con miembros elegidos por la nación. Gazeta do Rio de Janeiro. $\mathrm{n}^{\circ} 124,15$ outubro 1822.

${ }^{974}$ Lúcia $M^{\text {a }}$ Bastos P. das Neves hace una descripción precisa sobre los actos de Aclamación basándose en con periódicos y documentos de época. NEVES, Lúcia Ma Bastos P. das: Corcundas e Constitucionais..., op. cit., pp. 380 y ss.

${ }^{975}$ Collecçao das Leis e Decretos do Império do Brasil, desde a feliz época da sua Independência, obra dedicada a Assembleia Legislativa; precedida de um discurso preliminar, e terminada por huma taboa alfabética, e
} 
"O dia 12 de Outubro de 1822, memorável nos Fastos do Brasil, por ser aquelle em que este Estado proclamou a sua Independência Política pela voz do Povo desta Capital, que depois ressoou em todas as Províncias; tomando a categoria de Império, e adoptando o systema liberal de hum Governo Representativo, fixa huma épocha tão notável em sua Legislação quanto he a diversidade dos princípios (... $)^{976}$.”

Así que fue victorioso el acto de Aclamación del emperador y memorable acto cívico que marca el proceso de independencia. Aunque la laicización del acto fue pretendida, no se dejaba de atribuir "santidad" a determinados aspectos liberales, tales como la "santa federación", la "santa ciudadanía”, como se deprende del "Fala que a Sua Majestade Imperial e Defensor Perpétuo do Brasil dirigiu o Prezidente do Senado da Câmara do Rio de Janeiro no Fausto Dia 12 de outubro de 1822”, que afirma que el gobierno y la nación estaban ahora en adelante sedimentados en un "pacto social" y en una "Constituição liberal, santa e justa"977, todo esto inspirado en la soberanía popular ${ }^{978}$.

Con la aceptación del título de Emperador Constitucional y Defensor Perpetuo de Brasil, por parte de D. Pedro, el presidente del Senado de la Cámara de Río de Janeiro se pronuncia diciendo:

"Viva a nossa santa religião, Viva o Imperador Constitucional do Brasil, o senhor d. Pedro I, Viva a Imperatriz do Brasil, e a Dinastia de Bragança, imperante no Brasil, Viva a Independência do Brasil, Viva a Assembleia Constituinte e Legislativa do Brasil, Viva o povo constitucional do Brasil ${ }^{979}$."

De este modo, los primeros vivas se dirigen a la "Santa Religião" en este acto cívico, y por último a la Asamblea y al pueblo constitucional de Brasil. No solamente en Río de Janeiro se verificaron aquellas festividades, en muchas otras ciudades del Brasil ahora independiente de Portugal, también Aclamaron al nuevo emperador con grandes galas, con la diferencia, según analiza de Lúcia M $\mathrm{M}^{\mathrm{a}}$ Bastos P. das Neves, estuvieron mucho más al gusto del Antiguo Régimen, con ceremonias más religiosas que cívicas, dado que las ideas liberales habían penetrado poco o casi nada en aquellos rincones de la nación ${ }^{980}$.

El decreto del día 13 de octubre traía patentado el ideario del grupo de los licenciados de Coimbra, como grandes vencedores inmediatos de la pugna política tras la Aclamación. En este

arrosoada, por M.M., Na Imperial Typographia de P. Plancher-Seignot, Rua do olvidor, $\mathrm{n}^{\circ}$. 95, Rio de Janeiro, 1827, pp. V-VI.

976 Ídem, p. VII.

${ }^{977}$ Fala que a Sua Majestade Imperial e Defensor Perpétuo do Brasil dirigiu o Prezidente do Senado da Câmara do Rio de Janeiro no Fausto Dia 12 de outubro de 1822, Rio de Janeiro: Off. Silva Porto \& Ca., 1822, pp. 5 e 6.

${ }^{978}$ NEVES, Lúcia M ${ }^{\mathrm{a}}$ Bastos P. das: Corcundas e Constitucionais..., op. cit., pp. 382 y ss.

${ }^{979}$ El cerimonial fue reproducido por la Gazeta do Rio de Janeiro. n ${ }^{\circ} 124,15$ outubro 18.

${ }^{980}$ NEVES, Lúcia M ${ }^{\mathrm{a}}$ Bastos P. das: Corcundas e Constitucionais..., op. cit., pp. 387 y ss. 
decreto el emperador asume la investidura dada en el día anterior por los "Povos desta Capital" y por varias otras provincias del Imperio, de forma unánime, que lo habían Aclamado solemnemente Emperador Constitucional y Defensor Perpetuo de Brasil, buscaba el emperador imprimir la nueva y alta dignidad en la expedición de "Alvarás", Provisiones y otros diplomas que se emitan a su nombre. Así que, en los Tribunales y demás Reparticiones Públicas, se le atribuya el título de Majestad Imperial. Cuando se referiese directamente a la Augusta persona del emperador se debía utilizar la siguiente formula: "Dom Pedro, pela graça de Deos, e unánime Aclamação dos Povos, Imperador Constitucional, e Defensor Perpetuo do Império do Brasil, Faço saber etc ${ }^{981}$ ". Ya em los "Alvarás" se debe utilizar la siguiente fórmula: "Eu o Imperador Constitucional e Defensor Perpetuo do Império do Brasil, faço saber etc ${ }^{982, . ~ E l ~}$ análisis de esta fórmula imperial nos deja entrever que mientras la Aclamación es un acto cívico, expresión de la soberanía popular, al inicio de la fórmula se imprime el derecho divino de los reyes, en evocación directa a la práctica política del Antiguo Régimen.

Con el culto a la personalidad de D. Pedro I, José Bonifácio terminará la obra de su arquitectura política en dos actos sucesivos, cierre de los principales periódicos, con persecución de sus adversarios políticos, entre ellos Gonçalves Ledo, y la preparación de otro acto para contrarrestar lo cívico de la Aclamación, que era la Coronación del emperador ${ }^{983}$. Pero, antes de este último va a enfrentar la oposición del grupo vintista perseguido, lo que forzará la dimisión del Ministerio de los Andradas ${ }^{984}$. Acto seguido regresa al poder dicho ministerio conducido por las fuerzas que comulgaban con sus ideas políticas, mientras que sus enemigos políticos seguirán perseguidos y sin los medios necesarios para su defensa ${ }^{985}$. Estas persecuciones eran fruto de la necesidad de José Bonifácio de alejar al grupo más radical para imponer a sus ideas y conductas políticas, lo que va a combinar perfectamente con el gusto del emperador por poder más autoritario.

\footnotetext{
${ }^{981}$ DECRETO DE 13 DE OCTUBRE DE 1822 - Collecção das Leis e Decretos do Império do Brasil, desde a feliz época da sua Independência, obra dedicada a Assembleia Legislativa; precedida de um discurso preliminar, e terminada por huma taboa alfabética, e arrosoada, por M.M., Na Imperial Typographia de P. Plancher-Seignot, Rua do olvidor, $\mathrm{n}^{\circ}$. 95, Rio de Janeiro, 1827, p. 12.

982 Ibídem.

${ }^{983}$ NEVES, Lúcia Ma $M^{\text {a }}$ Bastos P. das: Corcundas e Constitucionais..., op. cit., pp. 394 y ss.

${ }^{984}$ Demissão de Ministros e Secretários de Estado e Nomeação do Barão de Santo Amaro e outros - Decreto do Imperador de 28 de outubro de 1822. Representação popular pelo retorno de José Bonifácio ao Ministério em 30 de outubro de 1822. Reintegração dos Ministros e Secretários de Estado que haviam sido demitidos - Decreto do Imperador em 30 de outubro de 1822. Este y otros decretos se encuentran respectivamente en BONAVIDES, Paulo e AMARAL, Roberto: Textos Políticos..., op. cit., pp. 703, 704 y 706.

985 "Classificados de "vis carbonários", "demagogos", "republicanos", "sans-culottes", "caluniadores", "mal intencionados", "intrigantes", os membros da elite brasiliense, em especial, Gonçalves Ledo, Clemente Pereira e Luís Pereira da Nóbrega, não tiveram grande oportunidade de defesa, pois seus canais de expressão - O Correio do Rio de Janeiro e o Revérbero Constitucional Fluminense não mais circulavam." NEVES, Lúcia $\mathrm{M}^{\mathrm{a}}$ Bastos $\mathrm{P}$. das: Corcundas e Constitucionais..., op. cit., p. 401.
} 
Si Gonçalves Ledo hiciera los preparativos a través de la Logia del Grande Oriente para una Aclamación cívica del emperador, en la tentativa de imponer su ideario político, José Bonifacio del mismo modo, y buscando una forma de socavar la pretensión de aquél, propugnará por un acto de Coronación de D. Pedro I en $1^{\circ}$ de diciembre de $1822^{986}$, una forma de poner todo en su sitio, coronando así, también su propio ideario político como vencedor en el teatro del poder imperial ${ }^{987}$.

El acto de coronación, que involucraba todo un aparato religioso, amparado en el derecho divino de los reyes, chocaba, así como el acto de la Aclamación y atribución del título de emperador en el mundo luso-brasileño, como una gran novedad. Ya los reyes de Portugal, desde la desaparición de D. Sebastián, en la Batalla de Alkacer-Quibir en Marruecos, no eran coronados, puesto que se había devotado a la virgen la corona real. La comisión formada para dicha tarea va a buscar no solamente en las monarquías del Antiguo Régimen (ceremonial de coronación de los reyes de Hungría), sino también en el ceremonial de coronación de Napoleón Bonaparte $^{988}$.

La jura de la futura constitución que quería imponer al emperador en el día de su Aclamación el grupo de Gonçalves Ledo solo ocurrirá en los actos de la Coronación, pero con términos muy distintos; juraba defender a Brasil y "a liberal Constituição digna do Brasil e digna de seu Imortal Defensor como a pedem os votos dos verdadeiros amigos da Pátria"989. En la línea de esta jura se dará el discurso de apertura de la Asamblea Constituyente, desplazando, por lo tanto, el discurso de la soberanía popular de Gonçalves Ledo y su grupo.

En cuatro actos se dividió la ceremonia de Coronación, entremezclado con acto litúrgicos: "sagração", coronación, juramento y un sermón ${ }^{990}$. Terminados los actos de coronación el Obispo-mor canta el “Te Deum”. Después de esto, empieza la lectura del evangelio por parte del frade Francisco de Sampaio. Era el mismo que había proferido la

\footnotetext{
${ }^{986}$ FLEIUSS, Max: “Centenario da Aclamaçao de D. Pedro I (12 de Outubro de 1822)”. In: Revista do Instituto Histórico e Geografico Brasileiro. O Anno da Independência, Tomo Espercial, Imprensa Nacional, Rio de Janeiro, 1922, p. 342.

${ }^{987}$ NEVES, Lúcia M ${ }^{\mathrm{a}}$ Bastos P. das: Corcundas e Constitucionais..., op. cit., pp. 406 y ss.

988 “O cerimonial foi elaborado por uma comissão de que participaram José Bonifácio, o bispo capelão-mor, o barão de Santo Amaro, monsenhor Sampaio Fidalgo e frei Antônio de Arrábida, antigo mestre do imperador; ou seja, um homem da nobreza titulada, três altas dignidades da Igreja e um ministro vitorioso.” Ídem, p. 407. Véase también Cerimonial da sagração e coroação do Imperador Pedro I, na Capella Imperial de Nossa Senhora do Monte Carmo do Rio de Janeiro, pelo Bispo Capelão-Mór, no dia 1 de dezembro de 1822, Typographia Nacional, Rio de Janeiro, 1822.

${ }^{989}$ O Espelho. $\mathrm{n}^{\circ}$ 109, 3 dezembro 1822.

${ }^{990}$ Véase los detalles en la ceremonial en Cerimonial da sagração e coroação do Imperador Pedro I, na Capella Imperial de Nossa Senhora do Monte Carmo do Rio de Janeiro, pelo Bispo Capelão-Mór, no dia 1 de dezembro de 1822, Typographia Nacional, Rio de Janeiro, 1822. Tambíen el periódico $O$ Espelho. $\mathrm{n}^{\circ}$ 109, 3 dezembro 182, describe los detalles de esta ceremonia.
} 
oración congratulatoria en la Aclamación, pero aquella estaba cargada del discurso político. Ahora, en la ceremonia de coronación el tono político había cedido paso a la necesidad de vínculo entre el monarca y la religión, en donde debería buscar la soberanía de su poder, para poder legitimarlo, o sea, enteramente al gusto del Antiguo Régimen: "Nunca a religião se apresenta com maior soberania, com todos os atributos de seu poder e de sua glória do que quando os reis, os poderosos do mundo, conhecen sua fraqueza vão procurar aos pés dos altares esta força, que nem o nascimento, nem a política, nem o entusiasmo dos povos lhes podem comunicar ${ }^{991}$ ”. Y sigue el cura en sus catilinarias afirmando que tanto el 12 de octubre como el $1^{\circ}$ de diciembre había amalgamado la religión a la política, lo que fortalecía al Imperio Constitucional de Brasil.

Después de las exequias religiosas el emperador profiere su juramento:

"Eu, Pedro I, imperador do Brasil, pela graça de Deus e vontade unânime do povo, juro observar e manter a religião católica, apostólica e romana, juro observar e fazer observarem constitucionalmente as leis do Império; juro defender com todas as minhas forças a conservação de sua integridade e juro sobre os santos Evangelhos ${ }^{992}$."

Más o menos en estos términos se presentará D. Pedro I en la Sesión de 3 de mayo de 1823, en la primera sesión de la Asamblea General, Constituyente y Legislativa del Imperio de Brasil para pronunciar su discurso inaugural ${ }^{993}$. En este día repetirá que:

"Como imperador constitucional, e mui principalmente como defensor perpetuo deste império, disse ao povo no dia $1^{o}$ de Dezembro do anno próximo passado, em que fui coroado, e sagrado, que com a minha espada defenderia a pátria, a nação e a constituição, se fosse digna do Brazil e de mim $^{994}$."

\subsubsection{Comentarios al Proyecto Constitucional de 1823}

El enfrentamiento de los dos grupos políticos que acabamos ver en el epígrafe anterior, se trasladará a la Asamblea Constituyente. El discurso del emperador causará extrañeza en algunos diputados, que acreditaban ser representantes de la nación para hacer una constitución digna de ésta, y que no debiese esperar la imperial aprobación por parte de D. Pedro. Así que en la Sesión de 5 de mayo de 1823, el diputado Andrada Machado va a proponer una diputación

\footnotetext{
${ }^{991}$ Este sermón del Frade Francisco Sampaio se puede encontrar en Discurso reproduzido em O Regulador Brasileiro. $\mathrm{n}^{\circ}$ 21, 11 dezembro 1822. También lo reproduce NEVES, Lúcia $\mathrm{M}^{\mathrm{a}}$ Bastos P. das: Corcundas e Constitucionais..., op. cit., p. 406 y ss.

${ }^{992} \mathrm{La}$ jura del emperador se puede encontrar en su forma latina, aquí reproducimos la traducción. O Espelho. $\mathrm{n}^{\circ}$ 109, 3 dezembro 182. Véase también en NEVES, Lúcia Ma Bastos P. das: Corcundas e Constitucionais..., op. cit., p. 409.

${ }^{993}$ DAGCL, Tomo I, Sesión de 3 de mayo, pp. 38-42.

${ }^{994}$ Ídem, p. 41.
} 
para llevar al emperador un voto de gracia de la Asamblea por su intervención pronunciada en la Sesión de apertura del parlamento, y que dicha diputación declare a Su Majestad Imperial que:

"1. Que a assembleia reconhece com ternura a generosidade e grandeza d'alma de Sua Magestade Imperial, que desprezando sentimentos acanhados, e vistas curtas e interessadas foi o primeiro a convocar a representação nacional, que deve limitar o poder que de facto possuíam os seus antecessores. $2^{o}$. Que a assembleia louva, e agradece a atividade de Sua Magestade Imperial, que lhe abriu o caminho às reformas precisas, e facilitou assim os trabalhos da assembleia. $3^{\circ}$. A assembleia reconhece mais na fala de Sua Magestade Imperial os sentimentos de verdadeira constitucionalidade, e os princípios de genuína liberdade a que aspiraAntonio Carlos Ribeiro de Andrada Machado-foi remetido à mesa ${ }^{995}$.”

En seguida el Sr. Secretario França, opina que el discurso del emperador debía ser objeto de discusión en el pleno de la Asamblea. En la Sesión de 6 de mayo es sometido a discusión el discurso del emperador. El primero en pronunciarse el Sr. Andrade Lima, diciendo que el monarca se constituye en juez de causa propia y pretende por si solo juzgar la bondad de la constitución, y persuadido de que está la Asamblea empeñada en hacer una constitución digna de Brasil y de su monarca constitucional, propone una nueva redacción para el voto de gracia: "A assembleia se persuade não poder deixar de fazer uma constituição digna do imperante e do Brazil, por assim confiar dos seus sentimentos nobre e patrióticos"996. El diputado Andrada Machado no ve inconveniente en que se declare en estos términos el voto de gracia. El Sr. Muniz Tavares, se pronuncia sobre el intervensión de emperador calificándola como muy juiciosa y franca. Otro diputado, Sr. Dias, decepcionado por el discurso del emperador se pronunció diciendo estas palabras: "parece-me que o julgar se a constituição, que se fizer, é digna do Brasil, só compete a nós como representantes do povo, e aos mais que ainda faltam de muitas províncias" ${ }^{\text {"997. }}$.

La discusión sobre la jura previa del emperador a la futura constitución se trasladó al pleno de las Cortes en la intervención del Sr. Maia. El preopinante se manifiesta sobre el discurso del emperador diciendo que:

"Parece-me que se conforma com o sentimento dos povos que já renunciaram, por meio de suas câmaras, ao juramento prévio de Sua Magestade à constituição; mas também me parece que, concedendo-lhe nós o veto absoluto sobre ella, deveremos tomar todas as cautelas para que não aconteça trabalharmos $e$ perdermos o tempo. (...) Não posso deixar de considerar que esta nação, antes de ser representada nesta augusta e soberana assembleia, já tinha aceitado Sua Magestade por seu imperador constitucional, já o tinha aclamado, já tinha

\footnotetext{
995 DAGCL, Tomo I, Sesión de 5 de mayo, pp. 44-45.

${ }^{996}$ DAGCL, Tomo I, Sesión de 6 de mayo de 1823, p. 50.

${ }^{997}$ Ibídem.
} 
assistido à sua sagração, e ouvido o juramento que ele então prestara sem condição alguma; e portanto agora que se acha representada não pode deixar de considerar o imperador um contratante de alta e reconhecida dignidade, que deve ser atendido e respeitado na organização da Constituição ${ }^{998}$."

Por ello el mismo diputado, convencido de que no estaban los diputados allí para perder el tiempo, se debía invitar al emperador a que por si o por sus ministros diga las condiciones con que quiere entrar en el pacto social, "pois se não forem justos e razoáveis, não se lhe aceitam, e não será reconhecido imperador, se não quiser concorrer com esta assembleia para o bem do Brasil ${ }^{999, "}$. Y en este tono, hace intrépidamente el Sr. diputado Accioli, una conjetura: "Pergunto, se a assembleia fizer uma constituição liberal, e estabelecer o equilíbrio dos três poderes, dando a cada um as atribuições competentes pode por ventura Sua Majestade deixar de aceita-la ${ }^{1000}$ ?" La respuesta a esta pregunta, como veremos, será negativa.

El Sr. Andrada Machado, el combativo diputado de las Cortes de Lisboa, aunque perfectamente de acuerdo con las ideas políticas de su hermano José Bonifácio y con el emperador, dirá que respeta al poder real en la monarquía, en tanto cuanto se debe respeto, dado que ir en la condición de mendicantes a suplicar las bases de la constitución al emperador era algo que no admitiría jamás, puesto que: "entrar no pacto social ninguém é obrigado". Y añade en respuesta a las proposiciones del diputado Sr. Maia que:

"As câmaras desta cidade desistiram do juramento prévio a que a câmara desta cidade queria obrigar o imperador, e daqui pretende deduzir o ilustre deputado que tendo sido esta condição rejeitada, como contraria à ordem, por isso mesmo podia deixar de aceitar a constituição, a que se não obrigara ${ }^{1001}$."

Resalta además, dicho diputado, que las cámaras renunciaron porque era un juramento promisorio, un juramento que podía recaer en un hecho torpe, sobre una constitución indigna de Brasil, por lo tanto, incapaz de darle felicidad. Y sale en defensa del hecho de no haber jurado el emperador, puesto que: "Isto é o que as câmaras tiveram em vista; não quiseram forçar a religião do imperador a abraçar inépcias e monstruosidades, só por prestar o juramento sem

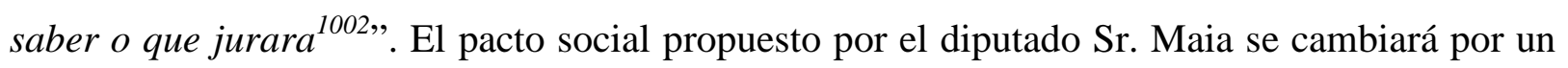
pacto constitucional del Sr. Andrada Machado cuando afirma que "somos os eleitos da nação; temos obrigação de formar o pacto constitucional; de dar-lhe leis conformes à razão, adequadas ao estado de civilização do Brasil, e que sejam a expressão da vontade geral".

\footnotetext{
998 Ídem, p. 51.

999 Ibídem.

${ }^{1000}$ Ibídem.

1001 Ibídem.

1002 Ibídem.
} 
En esta discusión el Sr. Munis Tavares resume perfectamente las fuerzas políticas que se encuentran en la Cortes en aquél momento:

"Sr. presidente, o ilustre deputado o Sr. Maia, querendo inculcar uma grande cópia (de) ideias liberais, desgraçadamente caiu, talvez sem considerar, no detestável absurdo em que caem os patronos da legitimidade na Europa. Sr. Presidente, nós fomos eleitos para fazer uma constituição; e para a fazermos não se nos mandou pedir bases ${ }^{1003}$."

En un momento de clarividencia que va a acometer a los ilustres diputados, el Sr. Andrada Machado dirá que la constitución que va a ser elaborada debía ser el espejo de la nación, que reflejaba, además, para el bien del orden social, la manutención de las legítimas prerrogativas de la corona, dado que garantizando uno estaría garantizado el otro, y que todo estaba acorde con el concepto de libertad defendido por Burke. Y añade en una proposición, que entremezcla aquél concepto de soberanía popular defendido por el grupo vintista (la elite brasiliense) con los principios de la legitimidad dinástica:

"A nação, Sr. presidente, elegeu um imperador constitucional, deu-lhe o poder executivo, e o declarou chefe hereditário; nisto não podemos nós bulir; o que nos pertence é estabelecer as relações entre os poderes, de forma porem que se não ataque a realeza; se o fizermos será a nossa obra digna do imperador, digna do Brazil e da assembleia ${ }^{1004}$."

Y en esta línea de clarividencia el diputado Sr. Dias dirá que el pueblo brasileño puso su confianza en los diputados, por lo tanto, se debe hacer una constitución digna de él. Así que suscitaba una cuestión: "se Sua Magestade Imperial merece mais amor ao público, e tem mais influencia na opinião geral do que a assembleia, pois em tal caso poderá dar uma constituição, ou por meio da força descoberta, ou por qualquer maneira injusta ${ }^{1005 ", ~(m a l ~ s a b i ́ a ~ e l ~ i l u s t r e ~}$ diputado que el emperador en breve escogería la primera de las opciones). Y será así porque, como afirmó el diputado Ribeiro de Andrada, "não constava que o povo tivesse declarado as

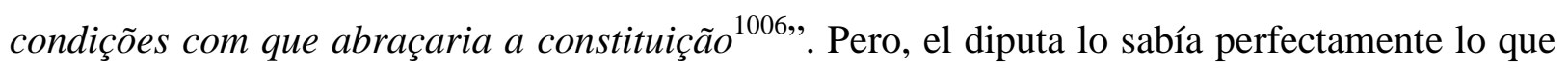
querría el emperador:

"Uma constituição bem equilibrada, é a constituição, que quer Sua Magestade, é a que nós queremos; não vamos confundir tudo, uma coisa é legislação ordinária, outra coisa, Sr. Presidente, é legislação constituinte, e outra coisa é pacto social. Constituição firma o pacto social, e é que marca as formulas do mesmo pacto social ${ }^{1007}$."

\footnotetext{
1003 Ídem, p. 52.

1004 Ídem, p. 52.

1005 Ibídem.

1006 Ibídem.

1007 Ídem, p. 54.
} 
De este modo el citado diputado afirmaba que el pacto social sería conformado en la constitución y no sería algo previo a esta. Muniz Tavares dirá que basta con decir que se hará una constitución digna de Brasil. Pero, en consonancia con su teoría de que el pacto social debiese ser fijado en el contenido de la constitución, se dispone el diputado Andrada Machado en aclarar la distinción que hay entre pueblo y nación. Para dicho diputado, nación comprende al soberano y a los súbditos. Y el pueblo únicamente comprende a los súbditos. El soberano es la razón social, colección de razones individuales, y el pueblo es el cuerpo que obedece a la razón. Dice además que la confusión de los términos lleva a la "Inphylosophica" soberanía popular, que ensangrentaron a Europa y que también en este momento amenaza a Brasil. Por lo tanto, opina que se sustituya a la palabra pueblo por la palabra nación todas las veces que se hable de soberanía ${ }^{1008}$. Y al final queda aprobada la fórmula para ser enviada al emperador en el voto de gracia en los siguientes términos: "A assembleia confia que fará uma constituição digna da nação brasiliana, digna de si mesma, e do imperador" ${ }^{\prime 1009}$.

Esta discusión sobre el concepto de soberanías que se ven enfrentadas se percibirá un poco antes, en las sesiones preparatorias, en donde se votaba el ceremonial para recibir al emperador en la sesión de apertura de los trabajos de las Cortes. Se discutía como entraría el emperador en la Asamblea, cubierto con la corona y los símbolos de la monarquía o sin éstos; si debía el trono estar a la altura del presidente de la asamblea, abajo de este o a la misma altura $^{1010}$. Así que, los diputados se perdían en cuestiones de formas, pero, a la vez se revelaban los enfrentamientos de las distintas ideas liberales presentes en las Cortes. Eso llamó la atención del diputado Rodrigues de Carvalho: "Srs., é para mim do maior espanto ouvir as desconfianças que reinam nesta assembleia, das quais não posso perceber a razão" ${ }^{\prime 1011}$.

Incluso con todas las disensiones que había en las Cortes entre los diputados, como ya dimos a entender antes, la Comisión de Constitución será formada en la Sesión del día 5 de mayo con siete miembros:

"Procedeu-se então à votação, e saíram nomeados membros da comissão de constituição, os Srs.: Antônio Carlos Ribeiro de Andrada, com 40 votos; Antônio Luiz Pereira da Cunha, com 30; Pedro de Araújo Lima com 20; José Ricardo da Costa Aguiar, com 19; Manoel Ferreira da Câmara, com 18; Francisco Muniz Tavares, com 16; José Bonifácio de Andrade e Silva, com 16 ${ }^{1012}$."

\footnotetext{
${ }^{1008}$ Para estas y demás afirmaciones, Ídem, p. 55.

1009 Íbidem.

${ }^{1010}$ Habrá cinco sesiones preparatorias en donde se discutirán estas y otras cuestiones. DAGCL, Tomo I, Sesiones de 17,18 y 30 de abril; y las Sesiones de $1^{\circ}$ y 2 de mayo, pp. 23-37.

${ }^{1011}$ DAGCL, Tomo I, Sesión de 6 de mayo de 1823, p. 52.

${ }^{1012}$ DAGCL, Tomo I, Sesión de 5 de mayo de 1823, p. 49.
} 
Algunos de los diputados de la Asamblea Constituyente, como ya décimos, eran provenientes de las Cortes de Lisboa, como es el caso de Antônio Carlos Ribeiro de Andrada. El "Manifesto de Falmouth lançado por los constituintes brasileiros que abandonaram as Cortes de Lisboa em 22 de outubro de 1822 ${ }^{1013 "}$ " muestra el abandono de algunos diputados y explica los motivos porqué lo hicieron. Entretanto, algunos diputados brasileños van a jurar y firmar la Constitución de Portugal de 1822, como lo demuestra el "Termo de Juramento dos Deputados das Cortes Gerais Extraordinárias e Constituintes da Nação Portuguesa - assinada pelos Deputados Brasileiros em 30 de setembro de 1822"1014. El Proyecto de Constitución de Antônio Carlos Ribeiro de Andrada ${ }^{1015}$ estaba muy inspirado en las mismas ideas liberales presentes en la Constitución (Luso-brasileña) de 1822. Presentaba muchas formulaciones de aquélla Constitución, tendría además un destino similar ${ }^{1016}$. Dicho proyecto influenciará en algunos puntos en la Carta creada en el Consejo de Estado y Otorgada en 1824, que a su vez será la base para la Constitución de 1826 de Portugal $^{1017}$.

Después de la apertura de los trabajos de la Asamblea Constituyente y Legislativa del Imperio de Brasil, ésta, hasta que se presentó el proyecto de constitución se dedicó a tareas eminentemente legislativas. Además de la Comisión de Constitución se crearon otras, y entre éstas una que nos va interesar es la Comisión Eclesiástica. En la labor legislativa varias leyes van a ser elaboradas, y entre ellas va a interesarnos la ley que marcaba cuales leyes continuaban

${ }^{1013}$ Manifesto de Falmouth lançado por los constituintes brasileiros que abandonaram as Cortes de Lisboa em 22 de outubro de 1822 in: BONAVIDES, Paulo e AMARAL, Roberto: Textos Políticos..., op. cit., pp. 669-670. Firman dicho manifiesto los siguiente diputados: Cipriano José Barata de Almeida, Francisco Agostinho Gomes, José Lins Coutinho, Antônio Manuel da Silva Bueno y Diogo Antônio Feijó.

${ }^{1014}$ Termo de Juramento dos Deputados das Cortes Gerais Extraordinárias e Constituintes da Nação Portuguesa - assinada pelos Deputados Brasileiros em 30 de setembro de 1822 in: BONAVIDES, Paulo y AMARAL, Roberto: Textos Políticos..., op. cit., p. 668. En la Sesión de las Cortes Gerais Extraordinárias e Constituintes da Nação Portuguesa de 30 de septiembre de 1822, el Sr. presidente Francisco Manuel Trigoso de Aragão Morato presto el juramento de guardar la Constitución de la Monarquía Portuguesa, decretada y firmada en la Sesión de 23 del mismo mes. Siendo los diputados brasileños que prestaron dicho juramento en la Sesión del día 30, los Señores: Alexandre Gomes Ferrao (Bahía); Romualdo Antônio de Seixas (Pará); Custódio Gonçalves Ledo (Rio de Janeiro); Domingos da Conceiçao (Piauí); Domingos Malaquías de Aguiar Pires Ferreira (Pernambuco); Filipe José Tavares Lira (Pernambuco); Francisco Manuel Martinas Ramos (Alagoas); Francisco Muniz Tavares (Pernambuco); Francisco de Sousa Moreira (Pará); Francisco Vilela Barbosa (Rio de Janeiro); Francisco Xavier Monteiro da França (Paraíba); Inácio Pinto de Almeida e Castro (Pernambuco); Joao Lopes da Cunha (Rio Negro); Joao Soares de Lemos Brandao (Rio de Janeiro).

${ }^{1015}$ Antônio Carlos Ribeiro de Andrada e Silva nació en Santos, en 1783, siendo el más joven de los Andradas. Del mismo modo que sus hermanos, estudió en la Universidad de Coimbra, en la Facultad de Derecho. Se licenció en 1797, a los 24 años, mientras los demás hermanos se tornaron naturalistas. A pesar de la diversidad de la formación entre los hermanos, todos se destacaron en el plano político en el ciclo histórico de la independencia. Antônio Carlos estaría entre los diputados brasileños que, al abandonar las Cortes de Lisboa, por disentir de la orientación dominante, exiliase en Inglaterra, de donde regresó a Brasil. Convocada la Asamblea Constituyente que se instaló en 17 de abril de 1823, Antônio Carlos se encontraba entre los diputados elegidos, en la condición de diputado por Sao Paulo. En la Asamblea rápidamente se convierte en un líder reconocido, delegándole las responsabilidades de elaborar el proyecto de Constitución.

1016 BONAVIDES, Paulo: "Constitucionalismo luso-brasileiro: influxos recíprocos" en Perspectivas Constitucionais, Obra colectiva, I, Lisboa, 1996, pp. 51 y 52.

${ }^{1017}$ MIRANDA, Jorge: O constitucionalismo liberal..., op. cit., p. 24. 
a vigentes en el Imperio, después de la Independencia, de autoría del diputado Pereira da Cunha. Hubo una febril actividad legislativa, con 241 pareceres emitidos por las diversas comisiones, 13 memorias ofrecidas por los constituyentes y diez diputaciones al emperador. La primera de las leyes aprobada buscaba marcar la soberanía de la casa, así, buscaba regular la forma de promulgación de los Decretos de la Constituyente ${ }^{1018}$, que no estaban sujetos a la sanción imperial ${ }^{1019}$. Reunía dicha Asamblea lo mejor de la élite ilustrada brasileña, según el cómputo del Barao Homem de Melo, de un total de 100 miembros electos, 45 eran licenciados en derecho, 22 de éstos, además eran "desembargadores" (jueces de segunda estancia), y 7 eran de cánones. Así que la inmensa mayoría era versada en leyes. Además, completaban el grupo 3 licenciados en medicina, 19 curas, siendo uno de ellos obispo, 7 militares, siendo tres mariscales y dos brigaderos ${ }^{1020}$, en gran parte formados en la Universidad de Coimbra o en otras universidades europeas. El proyecto de la Comisión de Constitución saldrá a la luz el 30 de agosto de $1823^{1021}$. Sirviéndose de su naturaleza constituyente la Comisión de Constitución va a elaborar un proyecto con 272 artículos, de los cuales apenas 24 artículos fueron puestos a votación en el pleno de las Cortes. El ministerio de los Andradas imprimirá su liberalismo monárquico y moderado de la restauración ${ }^{1022}$, próximo del teorizado en Europa con base en Montesquieu, Burke y Benjamin Constant ${ }^{1023}$. Aunque la presencia de las ideas de este último

${ }^{1018}$ DAGCL, Sesión de 12 de junio de 1823. Dicha ley tuvo por base un proyecto elaborado en la Comisión de Constitución, que fue relator el diputado Araújo Lima. El debate se desarrolló en torno a la pertinencia de la sanción imperial a los proyectos de ley de la Asamblea, resaltando la supremacía de la constituyente. Esta ley marcaba el momento de disensiones entre la Asamblea y el emperador. A cerca de la dispensa de sanción imperial, debatirán fuertemente dos diputados: Carneiro de Campos y Antônio Carlos Ribeiro de Andrada.

${ }^{1019}$ Este balance legislativo se puede encontrar com más detalles en BONAVIDES, Paulo y ANDRADE, Paes de: História Constitucional do Brasil, 4ª Edição, Editora OAB, Brasília, 2002, pp. 52 y ss.

${ }^{1020}$ LEAL, Aurelino: História Constitucional do Brasil, Rio de Janeiro, 1915, p. 74. Además, véase em RODRIGUES, Honório José: A Assembleia Constituinte de 1823, Editora Vozes, Petrópolis, 1974, p. 82.

${ }^{1021}$ Lo firma Antônio Carlos Ribeiro de Andrada Machado e Silva, José Bonifácio de Andrada e Silva, Antônio Luiz Pereira Cunha, Manuel Ferreira da Câmara de Betencourt e Sá, Pedro de Araújo Lima (com retricciones), José Ricardo da Costa Aguiar d’Andrada y Francisco Moniz Tavares. PROJECTO DE CONSTITUIÇAO PARA O IMPERIO DO BRASIL - A Assembleia Geral, Constituinte e Legislativa do Império do Brasil, depois de ter religiosamente implorado os auxílios da Sabedoria Divina, conformando-se aos princípios de justiça, e da utilidade geral, Decreta a seguinte Constituição, no Rio de Janeiro, 30 de Agosto de 1823 In: MIRANDA, Jorge: O constitucionalismo liberal..., op. cit., pp. 205-236. El proyecto fue leído en el pleno de la Asamblea en la Sesión de 1 septiembre de 1823. Diário da Assembleia Geral, Constituinte e Legislativa do Império do Brasil, Sessão de $1^{\circ}$ de setembro de $1823, n^{\circ} 65$, pp. 689 y ss.

${ }^{1022}$ El grupo identificado por Liberales Radicales, así identificados en relación al Liberalismo Doctrinario, sustentaban una Monarquía Constitucional, que en el proyecto serán resaltados como modelos la Constitución Francesa de 1791, la Constitución española de Cádiz de 1812 y la Portuguesa de 1822. Ya para la Constitución Imperial Otorgada de 1824, sobrepondrá a aquellas la Constitución Francesa de la Restauración de 1814. Estas y otras cuestiones a cerca de la trasmutación de las doctrinas liberales véase en FLORES, Alberdo Vivar: "El liberalismo constitucional...", op. cit., pp. 159 y ss.

${ }^{1023}$ Este Jurisfilosofo, político de la restauración francesa fue la obra de cabecera de algunos políticos brasileño de la época, del propio emperador y del Consejo de Estado para conformar en el Proyecto de la Carta de 1824 el cuarto poder, el Poder Moderador. CONSTANT, Benjamin: Cours de Politique Constitutionnelle au Collection des Ouvranges Publiés Sur le Gouvernement Représentativ (Avec une introduction et des Notes par M. Édouard Laboulaye - Membre de l'Institut), Tome Premier, Librairie de Guillaumin Etc, Paris, 1861. 
se aprecian mejor en la Constitución Otorgada de $1824^{1024}$. Otro gran publicista de la época que mantuvo contacto con las Cortes fue Jeremy Bentham ${ }^{1025}$, y además, según parece, sus teorías eran conocidas por muchos diputados.

Los enfrentamientos entre la Asamblea Constituyente y el emperador serán una constante hasta el Golpe de Estado de D. Pedro I que cerró a la Constituyente el 12 de noviembre de $1823^{1026}$. Aquí entra en escena un elemento importante, pues Brasil, a través del Decreto de 16 de diciembre de 1815 había accedido a la categoría de Reino, como vimos, lo que sirve tácitamente para formar una Monarquía confederada con el nombre de Reino Unido de Portugal, Brasil y Algarves. Por lo tanto, los congresistas de la Santa Alianza reunidos en Verona, a través de la "Circular" del 14 de diciembre de 1822, van a declarar que la independencia se dará bajo los auspicios de su Príncipe natural ${ }^{1027}$; corroboraba el hecho de que esta fuese la emperatriz María Leopoldina, una Archiduquesa Habsburgo-Lothringen en los trópicos, hija del emperador Francisco I de Austria. Aunque la muerte de la Regente y Emperatriz del Imperio en 11 de diciembre de 1826, por causas atribuidas a D. Pedro, manchará enormemente su figura ante la opinión pública devota de una emperatriz embarazada y enferma. El primer hecho concuerda con lo estudiado acerca de cómo se procesó la Aclamación y la Coronación de D. Pedro. Además, esto impactará en la no declaración de la titularidad de la soberanía en el pueblo. El segundo hecho, influyó en su abdicación en 1831. De este modo, como veremos un poco más adelante, era el soberano quien predominaba frente a la Asamblea Constituyente, y precedía incluso a la Constitución. Poco a poco nos vamos dando cuenta, como ya vimos reflejada en la documentación estudiada, que la Asamblea y la Constitución estaban a disposición de la corona. Tanto es así, que cuando le convino disolvió la Asamblea y otorgó él mismo una Constitución ${ }^{1028}$.

Sin embargo, el edificio constitucional llevado a cabo por la labor de la Asamblea Constituyente fue enorme y no será desperdiciado por el Consejo de Estado en la elaboración de la Carta de 1824. De este modo, en lo que toca a los derechos individuales viene al inicio del Proyecto de Antonio Carlos, cosa que como ya vimos, Jeremy Bentham desaconsejaba, como

\footnotetext{
${ }^{1024}$ Projeto de Constituição para o Império do Brasil, Organizado no Conselho de Estado sobre as Bases Appresentadas por Sua Magestade Imperial o Senhor D. Pedro I. Imperador Constitucional, e Defensor Perpetuo do Brasil, Typographia Nacional, Rio de Janeiro, 1823.

${ }^{1025}$ BONAVIDES, Paulo y ANDRADE, Paes de: História Constitucional..., op. cit., p. 55.

1026 Ídem, p. 55 y ss.

${ }^{1027}$ Véase en "José da Silva Lisboa (Visconde de Cairú)" In: Revista do Instituto Histórico e Geografico Brazileiro, 1904, p. 187. También trata el tema FLORES, Alberto Vivar: "El liberalismo constitucional...", op. cit., p. 160. Estos enfrentamientos entre Asamblea y emperador se puede también acompañar en BONAVIDES, Paulo y ANDRADE, Paes de: História Constitucional..., op. cit., pp. 43-84.

${ }^{1028}$ FLORES, Alberto Vivar: “El liberalismo constitucional...”, op. cit., pp. 162 y ss.
} 
hizo en la Constituyente en Lisboa. El Capítulo II, del Título II, bajo el título "Dos Direitos Individuais dos Brasileiros", en los artículos $7^{\circ}$ y siguientes, pero antes, en el Capítulo I define “Dos Membros da Sociedade do Império do Brasil", en los artículos 5 y 6; en otros capítulos también se diseminarán los derechos individuales, como en los artículos $200^{\circ}, 250^{\circ}$ y ss; también 258 y ss. El principio de la igualdad vendrá firmado en el art. $260^{\circ}$, pero sometiéndolo al principio de la utilidad a ser reglamentado por leyes ordinarias, causando inestabilidad en este sentido. La esclavitud es nombrada en el art. $263^{\circ}$, que le da el estatus de contrato entre los amos y los esclavos, atribuyendo al gobierno la vigilancia de la manutención de dichos contratos. Entretanto, pone bajo competencia exclusiva de la ley el poder para determinar los límites al ejercicio de los derechos individuales (art. $259^{\circ}$ ). La ley retroactiva en el tiempo para punir, bajo el art. 34, queda prohibida. En este sentido el art. $35^{\circ}$ dice que es deber del brasileño negarse a ser ejecutor de ley injusta ${ }^{1029}$.

La defensa de la libertad personal es contundente, en donde se desprende de la lectura de los arts. $7^{\circ}$ y $9^{\circ}$. Además, proclama la libertad de industria, la abolición de las corporaciones de oficio, la libertad de imprenta en general y la libertad de declaración (respectivamente, arts.: $7^{\circ}$ y $17^{\circ}, 7^{\circ}$ y $12^{\circ}$ ). Una flagrante influencia de la Constitución vintista de 1822 estaba en el artículo que trataba de la instrucción pública (art. 254º . Además, llama la atención en este mismo artículo por hablar de dos categorías sociales que no veremos repetidas en la Constitución de 1824. Dirá el art. 254": "Terá igualmente cuidado de criar Estabelecimentos para a catequese, e civilização dos Índios, emancipação lenta dos Negros, e sua educação religiosa, e industrial'. Así que tanto los esclavos como los indios eran nombrados en dicho proyecto $^{1030}$.

Como era de esperar en una monarquía representativa, art. $36^{\circ}$, se proclamaba la división de los poderes del Estado: Ejecutivo, Legislativo y Judicial, que son declarados como delegación de la nación (art. $40^{\circ}$ ). Y acorde con las palabras del relator del proyecto, el diputado Antonio Carlos, en donde se manda cambiar por el término nación cuando se quiera hablar de soberanía, y por lo tanto se establece que los representantes de la nación, en el art. $38^{\circ}$, son el emperador y la Asamblea Constituyente. A diferencia de la Constitución de 1822, el Poder Legislativo se delega en la Asamblea General y en la persona del emperador, y además, no se sigue el modelo gaditano, y se adopta claramente la doctrina del liberalismo de la restauración,

${ }^{1029}$ PROJECTO DE CONSTITUIÇAO PARA O IMPERIO DO BRASIL - A Assembleia Geral, Constituinte e Legislativa do Império do Brasil, depois de ter religiosamente implorado os auxílios da Sabedoria Divina, conformando-se aos princípios de justiça, e da utilidade geral, Decreta a seguinte Constituição, no Rio de Janeiro, 30 de Agosto de 1823 In: MIRANDA, Jorge: O constitucionalismo liberal..., op. cit., pp. 205-236. Estas y otras consideraciones hace el mismo autor en las páginas 24-26.

${ }^{1030}$ Ibídem. 
estableciendo un parlamento bicameral (art. $43^{\circ}$ ). Los diputados son elegidos para cuatro años por voto indirecto (arts. $78^{\circ}, 122^{\circ}$ y ss.). Los Senadores son vitalicios, nombrados por el emperador en una lista tríplice; la primera formación debía ser por elecciones en las provincias y después en la sala de los diputados (arts. $92^{\circ}, 99^{\circ}$ y ss.). Es vetado al emperador cerrar la Asamblea, pero puede aplazar su convocatoria (art. 55 $)$. La denegación de las leyes tiene mero efecto suspensivo (art. 113 ${ }^{\circ}$ ). Las modificaciones hechas en la Constitución no necesitan de la sanción imperial (art. 191 ${ }^{\circ}$, inciso I). El poder ejecutivo es delegado en el emperador, que puede nombrar libremente y cesar a sus ministros (arts. $138^{\circ}$ y $142^{\circ}$ ). Pero, aquellos deben refrendar los actos del emperador, además, puede ser diputados a la vez y participar de las discusiones de las propuestas de leyes en ella (arts. $\left.174^{\circ}, 68^{\circ}, 70^{\circ}, 111^{\circ}\right)^{1031}$.

Se define qué materias tendrían rango constitucional, y entre éstas se delimitan las atribuciones de los Poderes Políticos y los Derechos Políticos e individuales de los Ciudadanos $\left(\right.$ art. $267^{\circ}$ ). La reforma de la constitución se hace por un procedimiento complejo: se necesita una decisión favorable a la alteración por mayoría de dos tercios en cada una de las Cámaras en tres legislaturas consecutivas. Se convocan elecciones a una "Asamblea de Revista" para la realización de esta tarea específica, y en cuanto finalice se disuelve automáticamente (arts. $269^{\circ}$ y ss.). Todas las materias que no tengan el status constitucional pueden ser alteradas en las legislaturas ordinarias, siendo que se deben aprobar por dos tercios de las Cámaras (art. $268^{\circ}$ ). Siguiendo a lo prescrito en la Constitución francesa de 1795 , en su artículo $336^{\circ}$ y SS., el proyecto de Antônio Carlos prevé también que el sistema de revisión constitucional sea doble ${ }^{1032}$.

En materia religiosa, en el artículo $7^{\circ}$, se observará en el inciso III, la libertad religiosa. Esta libertad estaba adscrita a las confesionalidades cristianas (art. 14 ${ }^{\circ}$ ). A estos les extiende el goce de los derechos políticos, las demás religiones son toleradas, y su profesión inhibe el ejercicio de los derechos políticos, art. $15^{\circ}$. A la vez que en el art. $16^{\circ}$ declara la confesionalidad del Estado, siendo la religión Católica, Apostólica, y Romana la única mantenida por el Estado. $\mathrm{El}$ art. $24^{\circ}$ da a los Obispos el derecho de censura de los escritos acerca de dogma y moral, pero, solamente en el caso de que los publicadores sean de la religión católica ${ }^{1033}$.

Se aprecian muchas semejanzas con la Constitución portuguesa de 1822, pero también muchas innovaciones hechas por el legislador brasileño. Entre las semejanzas están: las normas referentes a las garantías individuales; prescripción de deberes a los ciudadanos; la censura

\footnotetext{
1031 Ibídem.

1032 Ibídem.

1033 Ibídem.
} 
eclesiástica sobre moral y dogma; las normas acerca de la instrucción pública y el establecimiento de la caridad. En el ámbito de las diferencias, o innovaciones del constituyente brasileño, están: algunos aspectos de la libertad religiosa; la no proclamación del principio de la soberanía nacional; el sufragio más ensanchado con “capacitario” en Portugal (art. 33 , inciso VI) y censitario en Brasil (art. 123\%); el establecimiento de elecciones indirectas; el bicameralismo; la participación de los ministros en los trabajos de las Cámaras; un Consejo de Estado con miembros propuestos por las Cortes al rey (Const. Portuguesa) y un Consejo Privado, con consejeros nombrados por el emperador (art. $180^{\circ}$ del Proyecto) ${ }^{1034}$.

Aunque toda la labor legislativa y constitucional hubiese logrado un sólido edificio jurídico para el país en formación, la Asamblea, como vimos entró en ruta de colisión con el emperador. Muchos fueron los motivos, y entre estos, están el proceso para pedir explicaciones al emperador por parte de la Asamblea de una "Portaria" (un acto del ejecutivo) secreta que incorporaba una parte de las tropas portuguesas de Madeira de Melo en la Provincia de Bahía al ejército brasileño, era la gota que colmaba al vaso ${ }^{1035}$.

En el Decreto de 12 de noviembre de 1823, el emperador acusa de perjura a la Asamblea, que no mantuvo el juramento que prestó a la nación de defender la integridad del Imperio, su independencia, y la dinastía. Además, utiliza el paralelismo de las fórmulas: él convoca y él disuelve la Asamblea Constituyente, como siendo él dueño y señor del poder constituyente del Imperio. En este sentido, promete convocar nuevas elecciones para elegir a una nueva Asamblea Constituyente, que deberá trabajar en el Proyecto de Constitución que él, emperador, debe presentar. Dicho proyecto, promete el emperador, será “duplicadamente” más liberal que el que acaba de hacer la Asamblea ${ }^{1036}$. Al día siguiente, provocado por las reacciones, el emperador emana el Decreto de 13 de noviembre de 1823, en donde afirma que no pretendía acusar de perjura a la totalidad de la Representación Nacional y que sabía perfectamente distinguir los facciosos, anárquicos, y los beneméritos de la patria.

En otro decreto, también de 13 de noviembre, el emperador confirma la convocatoria de elección y la oferta de un Proyecto elaborado por él a la nueva Asamblea. Pero, también crea un Consejo de Estado, compuesto de diez miembros, siendo seis sus actuales ministros - que ya

\footnotetext{
1034 Ibídem.

${ }^{1035}$ Paulo Bonavides y Paes de Andrade trae muy buenas explicaciones para el cierre de la Asamblea Constituyente, basados en vasta documentación. BONAVIDES, Paulo y ANDRADE, Paes de: História Constitucional..., op. cit., pp. 58-79.

${ }^{1036}$ DECRETO DE 12 DE NOVIEMBRE DE 1823 - Collecção das Leis e Decretos do Império do Brasil, desde a feliz época da sua Independência, obra dedicada a Assembleia Legislativa; precedida de um discurso preliminar, e terminada por huma taboa alfabética, e arrosoada, por M.M., Na Imperial Typographia de P. Plancher-Seignot, Rua do olvidor, $\mathrm{n}^{\circ} .95$, Rio de Janeiro, 1827, p. 138.
} 
son consejeros natos, fijado por la Ley de 20 de octubre de 1823 -, el "Desembargador" del Palacio Antônio Luis Pereira da Cunha, además de los consejeros de Hacienda Barón de Santo Amaro, José Joaquim Carneiro de Campos y Manuel Jacinto Nogueira da Gama ${ }^{1037}$.

No fue bien acogida la disolución de la Asamblea en la sociedad. Así, el Emperador va a dirigir una Proclama justificando la convocatoria de una nueva Asamblea Constituyente, también el día 13 de noviembre del mismo año. En esta proclama él establece las bases de la felicidad del Imperio: "Independência do Império, integridade do mesmo e sistema constitucional". Justifica además que si la Asamblea no hubiese sido disuelta, se correría el peligro de ver destruida la "nossa santa religião". Vuelve a afirmar que está convocada una nueva Asamblea, que trabajara en el proyecto de constitución dado por él, y que es posible que el mismo pasase a servir como constitución, aunque provisoriamente. Justifica que los encarcelamientos fueron tratados como despóticos por los enemigos, pero que así no es. Y vuelve a sobreponerse a la soberanía de la Nación: "A salvação da pátria, que me está confiada, como defensor perpetuo do Brasil e que é a Suprema lei, assim o exigem". Y finaliza la proclama pidiendo unión a los brasileños: "quem aderio a nossa sagrada causa, quem jurou a independencia deste imperio é brasileiro" ${ }^{1038}$.

Para asegurar aún más todas estas justificativas, lanza el emperador un "Manifesto de $S$. M. o Imperador aos Brasileiros" en el día 16 de noviembre de 1823. En este manifiesto vuelve a acusar al grupo radical de querer la revolución y el desorden de la nación. Rebate las críticas hechas a su gobierno, como la posible unión con Portugal. Vuelve a defender el sistema constitucional, como el único que puede traer felicidad al Imperio. Y resalta que los pueblos de las provincias están seguros de su magnanimidad y de sus principios constitucionales ${ }^{1039}$. Concluye, además, que la solución constitucional para luchar contra los facciosos fue disolver a la Asamblea y cesar a los ministros.

Publica otro decreto, el día 17 de noviembre, en donde confirma la convocatoria de elecciones con las mismas bases que la anterior Asamblea General Constituyente y Legislativa del Imperio. Para tanto, manda convocar a elecciones de diputados con base en el sistema establecido en la Instrucción de 19 de junio de 1822, combinadas con el Decreto de 13 de agosto del mismo año ${ }^{1040}$.

\footnotetext{
${ }^{1037}$ DECRETO DE 13 DE NOVIEMBRE DE 1823 - Ídem, p. 139.

${ }^{1038}$ Proclamação de 13 de novembro de 1823 - Ídem, p. 140.

1039 Manifesto de S. M. o Imperador aos Brasileiros de 16 de noviembre de 1823 - Ídem, pp. 140-143.

${ }^{1040}$ DECRETO DE 17 DE NOVIEMBRE DE 1823 - Ídem, p. 43.
} 
Con la dimisión del Ministerio de los Andradas, D. Pedro I va a formar el conocido gabinete portugués, mucho más propenso a las ideas absolutistas. En el Decreto de 20 de noviembre de 1823, va a dar ejecución al Decreto de 14 de enero del mismo año, en donde garantizaba a los portugueses que con residencia temporal en el Imperio de Brasil se les concediese el fuero de Ciudadano Brasileño, debiendo tener residencia fija y prestar juramento solemne a las Cámaras a la fidelidad de la causa de Brasil y al emperador. Dirá además que le cabrá defender a la tranquilidad de los pueblos, por enemigos que se enmascaran de Ciudadanos brasileños, ciudadanía esta tan fácilmente conseguida, a despecho de lo que exigen las naciones civilizadas. Anuncia que lo hará provisionalmente, hasta que se reúna la Asamblea Constituyente y marque las condiciones indispensables para conseguir el honroso título de Ciudadanos Brasileños ${ }^{1041}$.

El Consejo de Estado ya reunido propone en la Sesión del día 15 de noviembre de 1823, presidida por D. Pedro I, que aprueba la: "Ata de Deportação de Ex-Deputados à Assembleia Constituinte - Sessão do Conselho de Estado". El art. $5^{\circ}$ de dicha Acta describe los nombres de los diputados a ser deportados, son ellos: José Bonifácio, Antônio Carlos, Martim Francisco, José Joaquim da Rocha, Montezuma y Belquior. Además, manda poner en libertad al diputado Vergueiro. En el art. $6^{\circ}$, manda proceder a una investigación policial, serviendo de cuerpo de delito, algunos números del periódico "Tamoyo" y del "Sentinela da Praia Grande" Ley de Imprenta, hecha por la Asamblea, solo vendrá a ser confirmada por el emperador en el Decreto de 22 de noviembre de 1823. Así que, cerrada la Asamblea e iniciadas las "devasas públicas" la reacción de los llamados liberales radicales no se hizo esperar ${ }^{1043}$. De este modo se cerraba un capítulo en donde se intentó crear en los trópicos una Constitución, convocando para eso un parlamento, pero con la presencia de un rey fuerte, diferentemente de Portugal y España que tenían ausentes al rey en el momento que se reunían en Cortes. Además, las Cortes

\footnotetext{
${ }^{1041}$ DECRETO DE 20 DE NOVIEMBRE DE 1823 - Ídem, pp. 143-144.

${ }^{1042}$ Ata de Deportação de Ex-Deputados à Assembleia Constituinte - Sessão do Conselho de Estado em 15 de novembro de 1823 In: BONAVIDES, Paulo y AMARAL, Roberto: Textos Políticos..., op. cit., p. 743 y 744. Los firmantes de dicha Acta, miembros del Consejo de Estado, fueron: Clemente Ferreira França, Luís José de Carvalho e Melo, Antônio Luis Pereira da Cunha, Barão de Santo Amaro, Pedro de Araújo Lima, Pedro José da Costa Barros, Francisco Vilela Barbosa, Manuel Jacinto Nogueira da Gama y José Joaquim Carneiro de Campos.

1043 BERBEL, Marcia Regina: "A Constituição española...”, op. cit., p. 246. Véase también en SLEMIAN, Andréa: "Sob o império das leis: Constituição e unidade nacional na formação do Brasil (1822-1834)", Tese de doutoramento, Universidade de São Paulo - Faculdade de Letras e Ciências Humanas, São Paulo, 2006, pp. 80 y ss. También se puede complementar com la lectura de SLEMIAN, Andréa: "Um pacto constitucional para um novo Império: Brasil, 1822-1824” en CUARTERO, Izaskun Álvarez y GÓMEZ, Julio Sánchez (Eds.): Visiones y Revisiones de la Independencia Americana. La Independencia de América: la Constitución de Cádiz y las Constituciones Iberoamericanas, Editora Universidad de Salamanca, Salamanca, 2007, pp. 177-194. Véase también en BERBEL, Márcia Regina y MARQUESE, Rafael de Bivar: "Esclavitud, Ciudadanía e Ideología pro Esclavista en las Cortes de Lisboa y en la Asamblea Constituyente de Rio de Janeiro (1821-1824)" en CHUST, Manuel y FRASQUET, Ivana (Eds.): Los colores de la independencia iberoamericanas. Liberalismo, etnia y raza, Consejo Superior de Investigación Científica - Colección América, Madrid, 2009, pp. 119 y ss.
} 
brasileñas fueron objeto de una convocatoria a través del establishment por medio de un decreto, a diferencia de aquellos países que tuvieron convocadas dichas cortes a través de procesos revolucionarios. 


\subsection{La entrada en vigor de la Carta Constitucional de 1824}

Disuelta la Asamblea Constituyente el emperador recrea el Consejo de Estado, órgano de donde saldrá la Constitución que estará vigente durante casi todo el siglo XIX y servirá de modelo a la Portuguesa de 1826. Instituido dicho Consejo, primeramente en febrero de 1822, fue extinto un año después. Fue recreado otra vez por decreto del emperador, como vimos, en 1823 y volverá a ser extinto en 1832, un año después de la abdicación del emperador. El Consejo de Estado va a funcionar, en palabras de José Honório Rodrigues, como una primera cámara legislativa, dado que, era obligatorio oírlo en cuestiones esenciales de la vida parlamentar, como por ejemplo, en la elección de los Senadores y en la disolución de las Cámaras ${ }^{1044}$. El anterior Consejo de Procuradores de las Provincias, creado por el Decreto de 15 de febrero de 1822, fue extinto con una ley aprobada en la Asamblea Constituyente, dado que los representantes de la nación se encontraban ahora congregados en Cortes. El proyecto de dicha ley fue presentado por Antônio Carlos de Andrada en la sesión de 21 de mayo de $1823^{1045}$. Como no existen actas del Consejo entre los años de 1823-1827, no sabemos quién ejerció las funciones de secretario, ni tampoco con exactitud el redactor de la Constitución de 1824; tampoco las discusiones procesadas en el seno de dicho órgano. Probablemente fue el redactor del texto constitucional el consejero José Joaquim Pereira de Campos, curiosamente el último en firmar el texto constitucional ${ }^{1046}$. El Barón Homem de Melo dirá que la fuente en la cual se inspiró Campos fue el proyecto de Antônio Carlos de Andrada ${ }^{1047}$.

El proyecto de Constitución del Consejo de Estado surge como una síntesis ecléctica de varias corrientes que venimos estudiando hasta ahora. Los liberales constitucionalistas brasileños impone una capacidad de articulación bastante amplia, en donde adopta y adapta al

1044 CONSELHO DOS PROCURADORES GERAIS DAS PROVINCIAS DO BRASIL (1822-1823) In: Archivo Digital do Senado Federal. RODRIGUES, José Honório: O Parlamento e a Evolução Nacional, Introdução Histórica 1826-1840, Senado Federal, Brasília, 1972.

1045 DAGCL, Sesión de 21 de mayo de 1823. BONAVIDES, Paulo y ANDRADE, Paes de: História Constitucional..., op. cit., p. 53.

${ }^{1046}$ El Consejo de Estado en el cual se elaboró la Constitución del Imperio estaba compuesto por las mismas personas que fueron nombradas con el Decreto de 13 de noviembre de 1823, con cuatro consejeros y demás ministros de Estado. Firman estos la Constitución en el 11 de diciembre de 1823 y fue confirmada por el Decreto de 24 de marzo de 1824, por los siguientes miembros: João Severiano Maciel da Costa (ministro del Imperio); Luís José de Carvalho e Melo (ministro de los Extranjeiros); Clemente Ferreira França (ministro de Justiça); Mariano José Pereira da Fonseca (ministro de Hacienda); João Gomes da Silveira Mendonça (ministro de Guerra); Francisco Vilela Barbosa (ministro de Marina); además de los cuatro consejeros: Barón de Santo Amaro (José Egídio Álvares de Almeida); Antônio Luís Pereira da Cunha, Manuel Jacinto Nogueira da Gama, José Joaquim Carneiro de Campos. Projecto de Constitución para o Império do Brasil, organizado no Conselho de Estado sobre as Bases apresentadas por Sua Magestade Imperial o Senhor D. Pedro I. Imperador Constitucional, e Defensor Constitucional, e Defensor Perpetuo do Brasil, Na Typorgraphia Nacional, Rio de Janeiro, 1823.

1047 MELO, Barão Homem de: Escritos Históricos e Literários, Rio de Janeiro, 1868, Anexo A, 57-137, especialmente 117-119, onde são transcritos os artigos relativos ao Conselho Privado do projeto Antônio Carlos, e o Conselho de Estado, do projeto do Conselho de Estado. Tavares de Lyra reproduziu esta parte, ob. cit., 13-14. 
Liberalismo Doctrinario -Constitución francesa de 1814- a las necesidades del Imperio, pero, como vimos no desperdicia el proyecto constitucional de la Asamblea Constituyente, fuertemente influenciada por las idea vintistas, y consecuentemente por las emanadas de las Cortes de Cádiz. Así que va a adoptar desde la ciudadanía doble (pasiva y activa) teorizada por Sièyes y defendida por Benjamin Constant, como la introducción del cuarto poder defendido por este último en la Constitución del Imperio ${ }^{1048}$.

Con la participación del emperador, en menos de un mes el proyecto constitucional del Consejo de Estado estaba concluido, y el 20 de diciembre de 1823 salía de la Tipografía Nacional $^{1049}$, la que se convertiría en la Carta Otorgada de 1824. Como la reacción había sido dura por parte de la Nación por el cierre de la Asamblea Constituyente, tenía prisa el emperador de dotar a la nación de un texto constitucional como había prometido en el acto de disolución. Como no había cumplido la promesa, como vimos en los decretos de noviembre de 1823, de que convocaría una nueva Asamblea Constituyente, necesitaba el emperador dar cierta legitimidad al proyecto elaborado en el Consejo de Estado. Para ello, se buscó utilizar nítidamente el proyecto de Antonio Carlos para la elaborar el que se quedó conocido como el proyecto de Carneiro de Campos. En seguida, se comenzó otra fase más complicada que fue legitimar el proyecto frente al país, acabando, por lo tanto, con las críticas. Se buscó una legitimación consensual en las Cámaras municipales, que era en esa época una importante base del poder más cercana al pueblo. Así como la Aclamación en 1822 del emperador pasó por las Cámaras municipales para atribuirle legitimidad, también se hizo lo mismo con el proyecto de Carneiro de Campos. Disuelta la Asamblea Constituyente, solamente en las Cámaras municipales se podría encontrar órganos políticos locales, una "achicada representación nacional”, que podría legitimar el Golpe de Estado de D. Pedro I en forma de Constitución ${ }^{1050}$.

Sin embargo, la búsqueda de legitimidad por parte del emperador a su proyecto constitucional levantó tanto algunas Cámaras en contra como otra en su favor. En este

\footnotetext{
${ }^{1048}$ Esta tesis de la introducción y adaptación del Liberalismo Doctrinario se puede ampliar más con la lectura de FLORES, Alberto Vivar: "El liberalismo constitucional...", op. cit., pp. 164 y ss. "Fueron las condiciones sociales de existencia, propias del recién Estado/Nación brasileño, las que hicieron posible que el Liberalismo Doctrinario as idéias fora de lugar - , pues - se convirtiera en el Liberalismo brasileño de la Carta Constitucional de D. Pedro I". Ídem, p. 166. "O Liberalismo brasileiro, no entanto, só pode ser entendido com referência à realidade brasileira. Os liberais brasileiros importaram princípios e fórmulas políticas, mas as ajustaram às suas próprias necessidades". COSTA, Emilia Viotti: Da Monarquia à Republica. Momentos Decisivos, UNESP, São Paulo, 1999, p. 132.

1049 (Archivo John Carter Brown Library) - Projecto de Constitución para o Império do Brasil, organizado no Conselho de Estado sobre as Bases apresentadas por Sua Magestade Imperial o Senhor D. Pedro I. Imperador Constitucional, e Defensor Constitucional, e Defensor Perpetuo do Brasil, Na Typorgraphia Nacional, Rio de Janeiro, 1823.

${ }^{1050}$ BONAVIDES, Paulo y ANDRADE, Paes de: História Constitucional..., op. cit., pp. 86 y 87. NOGUEIRA, Octaviano: A Constituição de 1824 (Coleção - Constituições Brasileiras), Senado Federal, Brasília, 1999, pp. 15 y ss.
} 
movimiento que Paulo Bonavides y Paes de Andrada llamaron de "Plebiscito Municipalista Indirecto", salieron voces a favor del juramento y de la otorga inmediata, así como de total rechazo al proyecto. El Senado de la Cámara de Río de Janeiro fue absolutamente dócil a la aprobación del proyecto. Pero, en la sesión de 20 de diciembre de 1823 mandó abrir dos libros para que los munícipes también participasen en la decisión. Al final, el libro de aprobación se quedó lleno, y se aprobó por unanimidad el proyecto del emperador ${ }^{1051}$.

Entretanto, no todo fueron docilidades. La Cámara de la ciudad de Itú, en la Provincia de Sao Paulo, en donde la acción de un muy liberal Diogo Antônio Feijó, futuro regente del Imperio, hizo redactar unas "Reflexões sobre o Projeto da Constituição", sugiriendo severas modificaciones al proyecto ${ }^{1052}$. En dichas Reflexiones se hace una dirigida al art. 102, que trata de las atribuciones del Poder Ejecutivo, principalmente en su inciso II, que trata del nombramiento de los Obispos, y la provisión de Beneficios Eclesiásticos. Se dirá en las Reflexiones, que tal como está redactado el inciso dificultaría mucho que se hiciese la tan necesaria reforma en el ámbito eclesiástico. Reflejando, por lo tanto, en críticas al declarado poder de patronato que ejercía el emperador en el texto constitucional.

La reacción más dura vino de la Villa de Campo Maior en la Provincia de Ceará. Después de la disolución de la Asamblea, el Senado de la Cámara va a declarar depuesto al emperador y extinta la dinastía, además, se proclama una República estable y liberal ${ }^{1053}$. Los contactos entre las provincias del norte se vuelven una constante, en donde se buscaba una unión para defenderse de la amenaza de intervención militar de Portugal y repudiar al proyecto constitucional del emperador. Ejemplo de esto viene desde la ciudad de Crato en la Provincia de Ceará: "Se Pernambuco não jurar a Constituição já, também esta Província não jura - Carta de José Martiniano de Alencar a Manuel de Carvalho Paes de Andrade - 5 de maio de 1824" ${ }^{\prime 1054}$. Contribuye mucho a esta repulsa la disolución de Asamblea y la imposición de juramento del Proyecto de Constitución de Carneiro de Campos. Corrobora en esto un

${ }^{1051}$ Pedido para que seja Jurado como Constituição o Projeto Apresentado pelo Imperador - Representação do Senado da Câmara do Rio de Janeiro - 6 de janeiro de 1824 in: BONAVIDES, Paulo y AMARAL, Roberto: Textos Políticos..., op. cit., p. 749 y 753.

${ }^{1052}$ Reflexões dirigidas ao Imperador sobre o Projeto da Constituição (Oficio da Câmara de Itu de $1^{\circ}$ de fevereiro de 1824) in: BONAVIDES, Paulo y AMARAL, Roberto: Textos Políticos..., op. cit., p. 754 y 761 . Firmará dichas Reflexiones: Joao Paulo Xavier, José Galvão de Barros França, Diogo Antônio Feijó, José Rodrigues do Amaral e Melo, Candido José da Mota, Fernando Dias Paes Leme, Manoel Ferraz de Camargo, Francisco Pacheco da Fonseca y Joao de Almeida Prado.

${ }^{1053}$ Ata da Câmara Municipal de Campo Maior (Quixeramobim, CE) Destituindo o Imperador D. Pedro I e Proclamando a República (Termo da Sessão Extraordinária que mandaram fazer o presidente e mais oficiais da Câmara, com assistência do Clero, Nobreza e Povo) - 9 de janeiro de 1824 In: BONAVIDES, Paulo y AMARAL, Roberto: Textos Políticos..., op. cit., p. 771 y 772.

${ }^{1054}$ Se Pernambuco não jurar a Constituição já, também esta Província não jura - Carta de José Martiniano de Alencar a Manuel de Carvalho Paes de Andrade - 5 de maio de 1824 In: BONAVIDES, Paulo y AMARAL, Roberto: Textos Políticos..., op. cit., p. 764 y 765. 
manifiesto dirigido a los pernambucanos de todas las clases, eclesiástica, civil, y militar hecho por los diputados pernambucanos que abandonaron Río de Janeiro al ser disuelta la Asamblea: "Manifesto dos Deputados Pernambucanos - 7 de junho de 1823",1055.

La Provincia de Pernambuco va a convertirse en la resistencia más feroz de todas al cierre de la Asamblea Constituyente y la Otorga de la Constitución de $1824^{1056}$. La provincia siempre fue reducto de los liberales, como pasó con el movimiento revolucionario de 1817. Así que, cuando D. Pedro nombró otro presidente de la provincia, los pernambucanos van a amotinarse bajo la autoridad del Gobernador depuesto, el liberal Manuel de Carvalho Paes de Andrada. El movimiento tuvo un carácter separatista, republicano, urbano y popular. Esta revuelta se amplió con la adhesión de las provincias de Río Grande del Norte, Ceará y Paraíba. Estos insurgentes proclamaron la Confederación del Ecuador. Van a intentar atraer otras dos provincias, caso de Bahía y Alagoas. Entre los principales líderes del movimiento se encontraba el destacado Joaquim do Amor Divino, conocido como Frei Caneca. Gran constitucionalista, con ideas republicanas, difundidas por su periódico el "Typhis Pernambucano" 1057 . En sus "Bases para a Formação do Pacto Social", establece en 32 artículos los derechos de los ciudadanos. En el art. 25 va a proclamar la soberanía como una, indivisible e inalienable, debiendo dicha soberanía recaer en la Nación. Además, lanza un "Manifesto" en donde critica las actitudes del emperador y hace una severa crítica al constitucionalismo de D. Pedro, principalmente a la introducción del cuarto poder, el Poder Moderador, de influencia de Benjamin Constant. A este poder, Frei Caneca llamaba de la nueva invención maquiavélica y la clave maestra de la opresión de la nación brasileña y el garrote más fuerte a la libertad de los pueblos. En este sentido, recomienda en dicho manifiesto "que eu sou de voto, que se não adote e muito menos jure o projeto de que se trata, por ser inteiramente mau, pois não garante a independência do Brasil, ameaça a sua integridade, oprime a liberdade dos povos, ataca a soberania da nação, e nos arrasta ao maior dos crimes contra a divindade, qual o perjúrio, e nos é apresentado de maneira mais coativa e tirânica ${ }^{1058, " . ~ T a m b i e ́ n ~ p a r t i c i p o ́ ~ C i p r i a n o ~ B a r a t a ~}$

${ }^{1055}$ Manifesto dos Deputados Pernambucanos - 7 de junho de 1823 In: BONAVIDES, Paulo y AMARAL, Roberto: Textos Políticos..., op. cit., p. 766 y 768. Firman dicho manifiesto: "O vigário Joao Evangelista Leal Periquito (pelo Clero); Basílio Quaresma Torreão (pelo Militar); Joao Francisco Bastos Junior (pelo Civil)".

1056 “Confederação do Equador - Manifesta dos Deputados à Assembleia Constituinte pelas Províncias de Pernambuco, Paraíba e Ceará (13 de dezembro de 1823)” In: BONAVIDES, Paulo y AMARAL, Roberto: Textos Políticos..., op. cit., p. 769 y 770.

${ }^{1057}$ En sus ensayos políticos, Frei Caneca va a escribir las "Bases para a Formação do Pacto Social" In: BONAVIDES, Paulo y AMARAL, Roberto: Textos Políticos..., op. cit., p. 773 y 775.

${ }^{1058}$ Manifesto do Frei Caneca (1824) In: BONAVIDES, Paulo y AMARAL, Roberto: Textos Políticos..., op. cit., p. 776 y 784. Otro documentos van a incendiar las províncias del norte, principalmente cuando la Secretaria de Estado por médio de una Portaria comunica que com la posibilidad de Invasión por aprte de Portugal, cada província debía arreglasela sola: Participação ao Presidente de Pernambuco sobre a Providencia para a Defesa da Província - Portaria da Secretaria dos Negócios do Império (11 de junho de 1824) In: BONAVIDES, Paulo y 
dirigente del periódico "Sentinela da Liberdade" de Pernambuco. La reacción del emperador fue dura para con la Confederación del Ecuador ${ }^{1059}$. Esta confederación adoptará la Constitución de Colombia provisoriamente. Vale la pena conferir el grado de confesionalidad de dicha constitución:

"Art. 5" - A Religião única por excelência, manteúda pelo Estado, he a Cathólica Apostólica, Romana ${ }^{1060}$.”

En el "Analise do Projeto de Governo para as Províncias Confederadas", el autor anónimo llama de burlesco al proyecto: "mortal sentença de Liberdade dos Povos da Conjuração do Equador". En analice de este art. 5, dijo el autor, que faltó decir que la religión seria enseñada por los Catecismos de los capellanes del antiguo filósofo de Potsdam. Además, dice que el gobernador rebelde el Sr. Paes ha cambiado todo menos lo que afectaba a la religión $^{1061}$.

Como la mayoría de las Cámaras locales votasen a favor de jurar al proyecto y pedir la inmediata otorga como Constitución del Imperio, el Decreto de 11 de marzo de 1824 hace la "Disposição sobre o Juramento do Projeto da Constituição Política do Império do Brasil"1062, en donde fija para el día 25 de marzo la jura de la Constitución. De este modo, a través de la “Carta de Lei" de 25 de marzo de 1824 el proyecto es otorgado como la Constitución Política del Imperio, pero, se condiciona a una revisión en la futura Asamblea Constituyente a ser convocada; tal vez, una promesa para acallar a las revueltas de las provincias del norte:

"Dom Pedro Primeiro, por graça de Deus e unanime aclamação dos povos, Imperador Constitucional e Defensor perpétuo do Brasil: Fazemos saber a todos os súditos, que, tendo-nos requeridos os povos deste Império, juntos em Câmaras, que

AMARAL, Roberto: Textos Políticos..., op. cit., p. 785. También estará el Manifesto dirigido a las províncias del norte, principalmente conclamando a Bahía y Alagoas para participaren de la Confederación del Ecuador; este manifiesto estaba escrito por el presidente depuesto Manuel de Carvalho Paes de Andrade - Manifesto da Proclamação da Confederação do Equador (2 de julho de 1824) In: BONAVIDES, Paulo y AMARAL, Roberto: Textos Políticos..., op. cit., p. 786 y 788. Además, tiene un contenído interesante las Proclamações do Presidente da Confederação do Equador (2 de julho de 1824) In: BONAVIDES, Paulo y AMARAL, Roberto: Textos Políticos..., op. cit., p. 789 y 794.

${ }^{1059}$ Criaçao de Comissao Militar para Processar os Chefes do Movimento - Decreto do Imperador (26 de julho de 1824) In: BONAVIDES, Paulo y AMARAL, Roberto: Textos Políticos..., op. cit., p. 795. Se establece el primer Estado de Sítio de Brasil - Decreto do Imperador de 26 de julho de 1824. Sentença de Morte de Joao Guilherme Racticlife e outros - Acordão de 12 de marzo de 1825 In: BONAVIDES, Paulo y AMARAL, Roberto: Textos Políticos..., op. cit., pp. 796 y 801.

1060 (Archivo John Carter Brown Library) - Analise do Projeto de Governo para as Províncias Confederadas, e que se deve reger em Nome da Soberania das Mesmas Províncias, Offerecido a todos os Brasileiros em Geral, e em particular aos das Províncias do Norte, especialmente aos Pernambucanos, por Manuel de Carvalho Paes de Andrade, Presidente do Governo de Pernambuco, Na Typographia Nacional, Rio de Janeiro, 1824, pp. 1-8.

1061 Ibídem.

1062 DECRETO DE 11 DE MARZO DE 1824 - Collecção das Leis e Decretos do Império do Brasil, desde a feliz época da sua Independência, obra dedicada a Assembleia Legislativa; precedida de um discurso preliminar, e terminada por huma taboa alfabética, e arrosoada, por M.M., Na Imperial Typographia de P. Plancher-Seignot, Rua do olvidor, $\mathrm{n}^{\circ}$. 95, Rio de Janeiro, 1827. 
nós quanto antes jurássemos e fizéssemos jurar o Projeto de Constituição, que havíamos oferecido às suas observações para serem depois presentes à nova Assembleia Constituinte, mostrando o grande desejo que tinham de que ele observasse já como Constituição do Império, por lhes merecer a mais plena observação, e fazemos observar a Constituição, que d'ora em diante fica sendo, deste Império $(. . .)^{1063}$."

Al día siguiente se publica el Decreto de 26 de marzo de 1824, por el cual, se afirma no convocar más a la Asamblea Constituyente y llama a la elección de los diputados para una Asamblea General Legislativa ${ }^{1064}$; este será uno de los elementos que agudiza la revuelta de las provincias del norte contra la política tiránica del emperador. Dirá Raymundo Faoro que la Asamblea Constituyente no conseguirá estructurar el orden político de modo a conciliar, orgánicamente el emperador con el país ${ }^{1065}$. Así, veremos que el 12 de noviembre de 1823 estará íntimamente relacionado con el 7 de abril de 1831, cuando el emperador fue obligado a abdicar del trono ${ }^{1066}$.

La Constitución se concibe "Em nome da Santisima Trindade", y de rodillas los ministro toman al emperador el juramento a la Constitución del Imperio:

"Juro manter a Religião Catholica, Apostólica, Romana, a integridade, e indivisibilidade do Império: observar, e fazer observar como Constituição Política da Nação Brasileira o presente Projecto de Constituição que ofereci, e a mesma Nação aceitou, e pediu que fosse desde logo jurado como Constituição do Império: Juro guardar, e fazer guardar todas as Leis do Império, e prover ao bem geral do Brasil, quanto em mim couber. Assim Deus Me ajude, e por estes santos evangelhos ${ }^{1067}$."

Así que, primero se va a jurar mantener a la Religión Católica Apostólica Romana y encima de los santos evangelios, estaba marcada, por lo tanto, la total alianza entre el Estado/Nación brasileño y la iglesia del Estado. De este modo también va a jurar la emperatriz:

${ }^{1063}$ DECRETO DE 25 DE MARZO DE 1824 - CONSTITUIÇAO POLÍTICA DO IMPERIO DO BRASIL Collecção das Leis e Decretos do Império do Brasil, desde a feliz época da sua Independência, obra dedicada a Assembleia Legislativa; precedida de um discurso preliminar, e terminada por huma taboa alfabética, e arrosoada, por M.M., Na Imperial Typographia de P. Plancher-Seignot, Rua do olvidor, ${ }^{\circ}$. 95, Rio de Janeiro, 1827.

${ }^{1064}$ DECRETO DE 26 DE MARZO DE 1824 - Collecção das Leis e Decretos do Império do Brasil, desde a feliz época da sua Independência, obra dedicada a Assembleia Legislativa; precedida de um discurso preliminar, e terminada por huma taboa alfabética, e arrosoada, por M.M., Na Imperial Typographia de P. Plancher-Seignot, Rua do olvidor, $\mathrm{n}^{\circ}$. 95, Rio de Janeiro, 1827. También se puede consultar en BONAVIDES, Paulo y AMARAL, Roberto: Textos Políticos..., op. cit., p. 763.

${ }^{1065}$ FAORO, Raymundo: Os Donos do Poder, Editora Globo, Rio de Janeiro, 1989, p. 291 y ss.

${ }^{1066}$ A esta conclusión, a cual llegan muchos autores, aporta con propiedad documentación en este sentido, en donde podemos ampliar nuestras lecturas, en BONAVIDES, Paulo y ANDRADE, Paes de: História Constitucional..., op. cit., p. 89.

1067 (Archivo John Carter Brown Library) - Cerimonial para o Juramento Solemne que há de prestar o Imperador Constitucional Defensor Perpétuo do Brasil Pedro I à Constituição Política da Nação Brasileira, Na Impressão Nacional, Rio de Janeiro, 25 de março de 1824. 
"Juro aos Santos Evangelhos obedecer, e ser fiel à Constituição Política da Nação Brasileira, a todas as suas Leis, e ao Imperador Constitucional, Defensor Perpétuo do Brasil Pedro I ${ }^{1068}$.”

Después de la jura del emperador y de la emperatriz, sigue el acto con el ministro del Imperio leyendo de pie y en voz alta a los presentes el juramento prestado por el emperador. Así, el Aferes-mayor, juntamente con todos los paramentos, se dirige al balcón y allí vuelve a repetir el juramento del emperador a los presentes en voz alta, dando al final los siguientes tres vivas:

"Viva a nossa Santa Religião Cathólica, Apostólica Romana. Viva a Constituição Política da Nação Brasileira. Viva o Imperador Constitucional, Defensor Perpétuo do Brasil Pedro I, e toda a Sua Dinastia ${ }^{1069}$.”

Acto seguido, tras el juramento de todos, el maestro de ceremonias hizo introducir en la Capilla-Mayor a las personas que habían jurado, todos de rodillas, con la mano derecha por encima del Evangelio, y diciendo apenas, "Juro". Ya prestado este juramento el Obispo levantará el himno - Te Deum Laudamus - finalizando así la ceremonia de juramento del emperador, de la emperatriz y de la Corte a la Constitución otorgada de 1824.

De modo que la Constitución se fundamenta en una perfecta simbiosis entre las ideas liberales y la tradición monárquica europea. Esta dualidad percibimos cuando leemos el preámbulo conformado por la Carta de Ley de 25 de marzo, en donde dice "fazemos saber a todos os suditos", para luego en el art. 1 de la Constitución decir que "O Império do Brasil he a associação Política de todos os Cidadãos Brasileiros" ${ }^{1070}$. Tratados como súbditos y ciudadanos, el pueblo brasileño va a vivir en esta dualidad indefinida durante toda la vigencia de la Carta Imperial.

No haremos un estudio detallado de la Constitución para evitar que nos sobrepasemos en nuestro objetivo, puesto que van a interesarnos aquí, mucho más las definiciones de ciudadano, la confesionalidad del Estado y el proceso electoral ${ }^{1071}$. Aun así, buscaremos

\footnotetext{
1068 Ibídem.

1069 Ibídem.

${ }^{1070}$ (Archivo John Carter Brown Library) - Constituição Politica do Império do Brasil (Independência ou Morte), Na Typographia de Plancher, Impressor-Livreiro de Sua Magestade Imperial, Rio de Janeiro, 1824.

${ }^{1071}$ Desde muy temprano muchos publicistas en el siglo XIX van a dedicar algunas analices de la Constitución de 1824. De estos se destacan algunos como: BUENO, Pimenta: Direito Público Brasileiro e Análise da Constituição do Império, Rio de Janeiro, 1857; VASCONCELOS, Zacarias de Goes: Da natureza e limites do poder moderador, Rio de Janeiro, 1862; SOUZA, Bras Florentino Henrique de: Do Poder Moderador, Recife, 1864; LIMA, Oliveira: O Império Brasileiro, São Paulo, 1927; RUSSOMANO, Rosah: Facetas da Constituição de 1824 in Revista de Informação Legislativa, Janeiro-Março, 1974; FIGUEIREDO Sara Ramos: A primeira Constituição Brasileira in Revista de Informação Legislativa, Abril-Junho, 1985; NOGUEIRA, Octaviano: A Constituição de 1824, op. cit.; BONAVIDES, Paulo: A Constituição de 1824 in Constituições do Brasil, Obra coletiva, Brasília, 1987. También más recentemente tenemos a SILVA, José Afonso da: Curso de Direito Constitucional Positivo, $15^{\circ}$ Edição
} 
establecer algunos parámetros en el capítulo que trata de los derechos individuales, como algunos abordajes a modo de cumplir con nuestro objetivo. De este modo, afirmamos que el Imperio está basada en de una Constitución en donde el pacto social se hizo después, en la elaboración del texto y la jura de este. Si tomamos la dicción de la Declaración de Derechos del Hombre de del Ciudadano de 1789, en su artículo $16^{\circ}$, que dice: "Toda la sociedad en la cual la garantía de los derechos no está asegurada ni la separación de poderes establecida, no tiene Constitución"1072. Así que es obligado pensar que en esta Constitución se entregaba la clave política al emperador a través del Poder Moderador (art. 98), siendo delegado exclusivamente al emperador; además, éste también cumulaba el Poder Ejecutivo (art.102) ${ }^{1073}$.

En lo referente a los derechos a lo que toca a los derechos fundamentales estatuidos en la Constitución de 1824, vemos inmediatamente fijados algunos principios liberales (art. 13 y ss.), cuando se declara la igualdad de todos delante de la ley, una verdadera reproducción del art. 1 de la Declaración de Derechos de 1789. El artículo 179 trae la reserva legal, dado que nadie puede ser obligado a hacer o dejar de hacer alguna cosa sino en virtud de ley preexistente (art. $4^{\circ}$ de la Declaración). El propio art. $1^{\circ}$ que declara al Imperio de Brasil como la asociación política de todos los ciudadanos brasileños, corresponde más o menos al art. $2^{\circ}$ de la Declaración: "La meta de toda asociación política es la conservación de los derechos naturales e imprescriptibles del hombre ${ }^{1074}$. Estos derechos son: la libertad, la propiedad, la seguridad y la resistencia a la opresión”. Así que, la Constitución del Imperio reconoce la libertad de expresión sin dependencia de censura (art. 179, inciso IV); la libertad de religión (respetada la religión del Estado), inciso V; la libertad de locomoción, inciso VI; de industria y comercio, incisos 24 y 25 . Se reconocen las garantías de derecho en los procesos penales, prohibiéndose así la retroactividad de las leyes (art. 179, inciso III); inviolabilidad de domicilio y de correspondencia (incisos VII y XXVII); independencia del poder judicial (inciso XII); se establece la responsabilidad de los empleados públicos (inciso XXIX); el derecho de quejarse el ciudadano (art. XXX); se prevé un Código Civil y Criminal (art.18) ${ }^{1075}$. Así como la

Revisada, Editora Malheiros, São Paulo, 1998, pp. 76 y ss. Además de FRANCO, Afonso Arinos de Melo: Estudos de Direito Constitucional, Editora Forense, 1957; y Curso de Direito Constitucional Brasileiro, 2 Volume, Editora Forense, Rio de Janeiro, 1959.

1072 Projet de Déclaration des Droits, Par un Membre de l'Assamblée Nationale (Abade Sièyes), 1789.

1073 (Archivo John Carter Brown Library) - Constituição Politica do Império do Brasil (Independência ou Morte), Na Typographia de Plancher, Impressor-Livreiro de Sua Magestade Imperial, Rio de Janeiro, 1824. Se puede aprofundar más esta discusión con la lectura de FLORES, Alberto Vivar: "El liberalismo constitucional...", op. cit., pp. 167 y ss. También en ALTAVILA, Jayme: Origem dos Direitos dos Povos, Ícone Editora, Sao Paulo, 1989, p. 293.

${ }^{1074}$ MIRANDA, Jorge: O constitucionalismo..., op. cit., pp. 28 y ss. FLORES, Alberto Vivar: El liberalismo constitucional..., op. cit., pp. 168 y ss.

${ }^{1075}$ MIRANDA, Jorge: O constitucionalismo..., op. cit., pp. 27-29. SILVA, José Afonso da: Curso de direito..., op. cit., pp. 76 y ss. 
Constitución vintista, se establece la instrucción primaria gratuita (art.31), y la creación por parte del Estado de escuelas y universidades (art.33). Se evita hacer una declaración directa del detentador de la soberanía, como hace el art. $3^{\circ}$ de la Declaración de Derechos: "El origen de toda soberanía reside esencialmente en la Nación. Ningún órgano, ni ningún individuo pueden ejercer autoridad que no emane expresamente de ella". Así que, el art. 11 va a establecer que los representantes de la Nación Brasileña son, el Imperador y la Asamblea General. Y el art. 12 dirá que todos los poderes del Imperio de Brasil son delegaciones de la Nación. Una clara influencia del proyecto de Antônio Carlos de Andrada está en la delimitación de las materias constitucionales, restringiéndose a los límites y atribuciones de los Poderes Políticos y los derechos de los ciudadanos (art. 178) ${ }^{1076}$.

Así que, en todo el contenido del texto constitucional se observa la intención del legislador constituyente en equilibrar de forma ecléctica los valores tradicionales con los valores revolucionarios, equilibrio propio del Liberalismo doctrinario o aquí denominado Liberalismo brasileño. De este modo, establecer un título en la Constitución relativo a las Garantías de los Derechos Civiles y Políticos de los Ciudadanos Brasileños en nada se contradecía con garantizar un régimen monárquico y hasta una salvaguarda del poder imperial, la institucionalización del Poder Moderador, una forma peculiar del "Pouvoir Neutre" o "Pouvoir Royal" de Benjamin Constant, teorizado en su "Réflexions sur les Constitutions et les

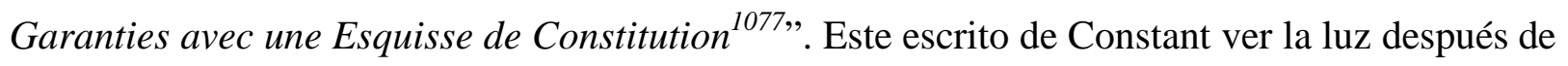
la "Declaración de Saint-Ouen""1078, en 2 de mayo de 1814, pero un poco antes de la "Charte Constitutionnelle", de 4 de junio de 1814. El gran crítico de Gaetano Filangieri va a reelaborar la doctrina de la división de poderes de Montesquieu. Bajo el fuerte influjo de la restauración, tanto la introducción de una cámara alta, en donde contemplar elementos de la nobleza, así como un fortalecimiento del poder real va a hacer que Constant redistribuya los poderes en cuatro: “Les pouvoirs constitutionnels sont: le pouvoir royal, le pouvoir exécutif, le pouvoir

\footnotetext{
${ }^{1076}$ MIRANDA, Jorge: O constitucionalismo..., op. cit., pp. 27 y ss.

${ }^{1077}$ Es más conocida esta obra como : CONSTANT, Benjamin: Cours de Politique Constitutionnelle au Collection des Ouvranges Publiés Sur le Gouvernement Représentativ (Avec une introduction et des Notes par M. Édouard Laboulaye - Membre de l'Institut), Tome Premier, Librairie de Guillaumin et Cie, Paris, 1861, pp. 160-373.

${ }^{1078}$ LAMARTINE, A. de: Historia General de Francia. Historia de la Restauración, Tomo III, Libro XIV, Librería Española - Calle Relatores n 14/Madrid y Librería Española - Calle Ancha/Barcelona, 1854, p. 89. "Cansada la Francia de tantas guerras concibió algunas esperanzas de paz. La Declaración de Saint-Ouen, que encerraba muchos principios fundamentales de la revolución tranquilizó los ánimos. Los senadores a los cuales Luis XVIII dio por compañeros a muchos miembros de la antigua nobleza, formaron una cámara de pares. El rey la convocó ni más ni menos que al cuerpo legislativo del imperio que quedó convertido en una cámara de diputados. Luis XVIII que en su declaración había prometido adoptar una Constitución liberal, presentó una carta constitucional." BIGNON, MIGNEL, CHIERS, LUTAURE y LESSUR: Anales Pintorescos de la Era Revolucionaria. Desde 1789 hasta nuestros días, Texto Según, Librería de la Señora V. de Bazola, Calle de la Concepción Gerónima $n^{\circ}$ 2/MADRID, Imprenta de Llorens-Hermanos, Calle Acha/Barceona, 1845, p. 301.
} 
représentatif, le pouvoir judiciaire ${ }^{1079, "}$. Benjamin Constant creó la teoria donde se diferencia el "pouvoir royal" del "pouvoir exécutif", de este modo:

"On s'étonnera de ce que je distingue le pouvoir royal du pouvoir exécutif. Cette distinction, toujours méconnue, est très-importante. Elle est peut-être la clef de toute organisation politique. Je n'en réclame pas l'honneur: on en trouve le germe dans les écrits d'un homme fort éclairé, qui a péri durant nos troubles,

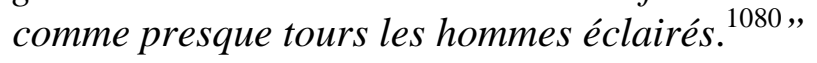

Así que el propio Clermont-Tonerre define su invención de este modo:

"Hay (...) en el poder monárquico dos distintos; el ejecutivo, que tiene prerrogativas positivas, y el real, que se halla sostenido por la memoria perene y tradiciones religiosas $^{1081}$."

De cara a fortalecer la posición de la política llevada a cabo por Luis XVIII, con un Liberalismo de la Restauración, dirá:

"La monarquía constitucional tiene esta gran ventaja, porque crea el poder neutro en la persona de un rey rodeado de las tradiciones de una memoria respetable y de un poder de opinión, que sirve de base al político. El interés verdadero de este rey no es en alguna manera el que el uno de los poderes destruya al otro, sino el que todos se apoyen, se comuniquen entre sí, y obren de concierto $^{1082}$."

Del mismo modo aparecerá en la Constitución Política del Imperio de Brasil de 1824, en el título III, art. 10:

“Os Poderes Políticos reconhecidos pela Constituição do Império do Brasil são quatro: o Poder Legislativo, o Poder Moderador, o Poder Executivo, e o Poder Judicial ${ }^{1083}$."

Además, sigue la misma explicación dada por Benjamin Constant para el Poder Moderador en el art. 98:

"O Poder Moderador he a chave de toda a organização Politica, e he delegado privativamente ao Imperador, como Chefe Supremo da Nação, e Seu Primeiro Representante, para que incessantemente vele sobre a manutenção da Independência, equilíbrio, e harmonia dos mais Poderes Políticos ${ }^{1084}$."

\footnotetext{
${ }^{1079}$ CONSTANT, Benjamin: Cours de Politique Constitutionnelle..., op. cit., p. 175.

1080 Ídem, p. 176. Benjamin Constant dice que no pretende la gloria de la descubierta de la división en cuatro poderes, por lo tanto cita a M. de Clermont-Tonnerre.

${ }^{1081}$ CONSTANT, Benjamin: Curso de Política Constitucional, (Traducido al español por D. Marcial Antonio Lopez), Tomo I, Imprenta Lawalle Jóven y Sobrino, Búrdeos, 1821, p. 71.

1082 Ídem, pp. 72 y 73.

1083 (Archivo John Carter Brown Library) - CONSTITUIÇAO POLÍTICA DO IMPERIO DO BRASIL (Independência ou Morte), Na Typographia de Plancher, Impressor Livreiro de Sua Magestade Imperial, Rio de Janeiro, 1824, p. 3.

1084 Ídem, p. 27.
} 
Así, la soberanía pasa a recaer en el Emperador y en la Asamblea General (art. 11); además, el parlamento pasa a ser bicameral: senado y cámara baja (arts.14, 40 y 35). Y para elegir a los representantes entraba en juego la ciudadanía. Así se elegían a los diputados, senadores para las cámaras alta y baja del parlamento brasileño. Dichas elecciones se utilizaban tanto para componer a la Asamblea General (nacional), cuanto a un especie de parlamento local llamados Consejos Generales de las Provincias (art. 90). Las elecciones se procesaban de forma indirecta, participando en las elecciones los ciudadanos activos en las llamadas Asambleas Parroquiales los Electores de Provincias, quienes a su vez elegían a los Representantes de la Nación y de las provincias. Sin embargo, el proceso estaba lejos de ser democrático, dado que las exclusiones se daban dentro de las propias inclusiones del texto constitucional (arts. 91-95). Había toda una gradación de derechos para elegir, ser electo y poder votar; y por lo tanto, pertenecer a la categoría de los "Ciudadanos activos", que estaban en el pleno goce de sus derechos políticos ${ }^{1085}$.

\subsubsection{Ciudadanía, confesionalidad y derecho al sufragio en el texto constitucional brasileño de 1824}

Los parámetros liberales de ciudadanía que fueron delimitados en el texto constitucional de 1824 no abarcaban a toda población del Imperio de Brasil, como ya venimos señalando ${ }^{1086}$. Aunque se asumiese una política tolerante en el ámbito del Estado confesional, la religión fue un elemento que sirvió para recortar los derechos políticos de los ciudadanos. Así que, el voto será la máxima expresión de esta tolerancia religiosa, como también expresará la forma de recorte de los derechos políticos de dichos ciudadanos. Es evidente que no es el único elemento que excluye al individuo de la ciudadanía o que recorta los derechos políticos, pero, constituye el objeto central de nuestro estudio dentro del ámbito de la construcción del Estado/Nación brasileño. Aquí no pretendemos hacer un estudio de todos los excluidos de la ciudadanía, pero sí dentro del movimiento de exclusión/inclusión, los que están incluidos a la vez que ven sus derechos políticos disminuidos en función de la religión oficial del Estado.

\footnotetext{
${ }^{1085}$ FLORES, Alberto Vivar: "El liberalismo constitucional...”, op. cit., pp. 174 y 175. También se puede observar este tema en SOUSA, Joaquim Rodrigues: Analyse e Comentário da Constituição Política do Império do Brazil, Volume I, Typographia B. de Mattos, São Luiz, 1867, p. 267 y ss. Además, en BUENO, José Antônio: Direito Público Brasileiro e Análise da Constituição do Império, Senado Federal, Brasília, 1978, p. 192.

${ }^{1086} \mathrm{El}$ pensamiento liberal de las elites formadas en el Seminario de Olinda, en las instrucciones jurídicas que recibían, se conformaba de las ordenaciones, reglas y definiciones del derecho romano, el Código Napoleónico, la praxis, principios de filosofía del derecho, juntamente con las teorías de Benjamin Constant, y todo esto bajo las inspiraciones de Jeremy Bentham. Esto, de cierta forma conformará el pensamiento liberal de ciudadanía presente en las élites. NABUCO, Joaquim: Um Estadista do Império, 4ª Ediçao, Editora Nova Aguiar, Rio de Janeiro, 1975, pp. 15 y ss. El pensamento de John Locke, Mill, Constant y Tocqueville, entre otros pensadores, apareceran en las discusiones de la Asambléa sobre el grado de interferencia que debía tener el Estado en la vida del ciudadano. MATTOS, Ilmar Rohloff de: O Tempo Sacuarema, Editora Hucitec/INL, Sao Paulo/Brasília, 1987, pp. 30 y ss. Véase también em PIÑEIRO, Théo Labarinhas: “Los proyectos liberales...”, op., cit., p. 138.
} 
La propiedad será un elemento íntimamente intrínseco a la conceptualización de la ciudadanía en la Constitución del Imperio. Un lenguaje relacionado al pensamiento lockeano. John Locke ve al hombre esencialmente como propietario, en cuanto atributo inherente a su naturaleza. Así que, la propiedad va a ser el elemento que lo define como hombre, debiendo la sociedad civil y el Estado garantizar dicho status quo. Por lo tanto, podemos abstraer dos presupuestos del pensamiento de Locke: la igualdad debida a los propietarios y la desigualdad natural, principalmente entre los poseedores de propiedad y los desposeídos de tal elemento. De este modo, la declaración constitucional de ciudadanía y la existencia de esclavos, propiedad de los primeros, no era en absoluto incompatible con el pensamiento lockeano ${ }^{1087}$. Dicho pensamiento se caracteriza por ser eminentemente individualista, siendo la propiedad el instrumento fundamental de defensa de las libertades individuales ${ }^{1088}$. En este paso, la legitimidad de la libertad es inherente a la condición de propietario de bienes y de personas. Así, la libertad no será un derecho de todos, ésta solo beneficia a los que, en la condición de propietarios, aunque de su propia libertad, están considerados ciudadanos, y por lo tanto dotados de plenos derechos de ciudadanía. El concepto de libertad en Brasil va a forjarse en el propio concepto lockeano de libertad vinculado al concepto de propiedad. Aunque, el principio liberal consagrado en el texto constitucional brasileño en el art. 179, inciso I, dice que: "Nenhum Cidadão pode ser obrigado a fazer, ou deixar de fazer alguma coisa, senão em virtude da lei". Este principio de reserva legal va a oponer otros dos presupuestos políticos: libertad y autoridad. En este sentido, también Jeremy Bentham, un publicista que influenció el pensamiento liberal brasileño, dirá que la propiedad produce la felicidad en una relación directa entre una y otra ${ }^{1089}$. La ley en este contexto sirve para restringir la libertad, pero también garantiza lo que Bentham ver como necesaria, la promoción de la felicidad a un mayor número

1087 "Los nombres de Amos y Sirvientes son tan antiguos como la historia (...). Hay otra especie de sirvientes que llamamos esclavos, los que habiendo sido hechos prisioneros en una guerra justa, están por derecho natural sujetos a la dominación absoluta y al poder arbitrario de sus dueños. Semejantes gentes habiendo merecido perder la vida, a la cual por consiguiente no tienen ya derecho, así como tampoco a su libertad ni bienes; y hallándose en un estado de esclavitud, que es incompatible con el goce de ninguna cosa propia, no pueden en este estado considerarse como miembros de la sociedad civil, cuyo fin principal es conservar y mantener los bienes propios." LOCKE, John: Tratado del Gobierno Civil (Traducida de la séptima edición francesa publicada en París por los ciudadanos D. G. Cy L. C Aferes de Caballería), Imprenta de la Minerva Española - A cargo de J. Fernández, Madrid, 1821, pp. 131-133.

1088 ALVES, Cleber Francisco: "A influencia do pensamento liberal de Benjamin Constant na formação do Estado Imperial Brasileiro”, Revista de Informação Legislativa, Brasília a. 45 n. 180 out./dez. 2008, p. 66. La introducción del voto censitário está acorde con el pensamento de Constant, como aparece en los artículos de la Constitución del Imperio de Brasil (arts. 92, V; 94, I; 95, I). El pensador entendía que la propiedad era la condición para el ejercicio de los derechos políticos.

${ }^{1089}$ BENTHAM, Jeremy: Principios de legislación y codificación, extractos de la obra del filósofo inglés (Por Francisco Ferrer y Valls, Tomo I, Imprenta de D. Tomas Jordan, Madrid, 1834, pp. 48 y ss. Véase principalmente en el Cap. VI - De la valoración de los placeres y de las penas). Esta cuestión, con base en el pensamiento de Bentham, también es discutida en PIÑEIRO, Théo Labarinhas: “Los proyectos liberales...”, op., cit., pp. 139 y ss. Es interesante también observar el Capítulo X de la obra de Bejamin Constant, intitulado: De las condiciones de la propiedad con respeto a los individuos que han de componer la representación nacional en CONSTANT, Benjamin: Curso de Política Constitucional..., op. cit., pp. 237 y ss. 
posible de personas ${ }^{1090}$. En este sentido, la oposición entre libertad y autoridad, en el marco legal brasileño, va a darse solo en la apariencia, dado que tales conceptos serán complementarios, pues uno garantizaba el ejercicio del otro ${ }^{1091}$. Otro aspecto importante para la formación del pensamiento político brasileño del periodo, que refleja el concepto y ejercicio de la propia libertad, está en la distinción entre libertad antigua y libertad moderna presentes en el pensamiento de Benjamin Constant. Consonante al pensamiento griego, la primera consiste en la participación política directa del ciudadano en la vida política, mientras que la segunda el ciudadano lo hace a través de sus representantes ${ }^{1092}$.

Propiedad y ciudadanía era un binomio que se casaba perfectamente con la imagen proyectada de sí misma por la élite brasileña, lo que también va a reflejar en la adaptación del liberalismo a las peculiaridades brasileña, como vimos antes. La élite brasileña a comienzos del siglo XIX va a alejarse del modelo liberal rousseauniano francés, así como del modelo republicano de la América del Norte. Adopta, como vimos, el modelo monárquico como un elemento que garantizaba la manutención del "orden" y del status quo de la élite local en el proceso de independencia. Así que, dicha élite va a preferir filiarse al modelo inglés, inspirándose también en la experiencia continental pos-napoleónica, entrando aquí el pensamiento de Benjamin Constant ${ }^{1093}$. La influencia de este pensador encaja perfectamente en la realidad histórica vivida por Brasil en aquellos momentos. Justo por este motivo, se perciben muchas referencias hechas por los diputados reunidos en la Asamblea Constituyente a aquél publicista. Así dirá el mismo pensador que el nacimiento en el país o la mayoría edad no bastan para el ejercicio de los derechos de ciudadanía, y que los indigentes y extranjeros solo debían participar de los beneficios de la patria indirectamente ${ }^{1094}$. De ahí que la introducción del voto censitario en el texto constitucional era un reflejo directo del pensamiento de Constant, así como en otros aspectos.

De este modo, si por un lado la definición de ciudadanía tendrá una apariencia de ser, en el texto constitucional, bastante amplio e incluyente, por otro lado, estaba el legislador brasileño -tanto de la constituyente de 1823 como del Consejo de Estado en 1824- convencido de que no todos debían ejercer los derechos políticos. Así que, unos ciudadanos podían gozar de los derechos políticos y otros apenas de los derechos civiles; esto estaba muy acorde con el

\footnotetext{
1090 Ibídem.

${ }^{1091}$ PIÑEIRO, Théo Labarinhas: “Los proyectos liberales...”, op., cit., p. 140.

1092 CONSTANT, Benjamin: Curso de Política Constitucional..., op. cit., pp. 180 y ss. Es importante la lectura de los capítulos VII y VIII, respectivamente: Del Poder Representativo y modo de Ejercerle; Del Modo de Formarse la Representación Nacional.

1093 ALVES, Cleber Francisco: “A influencia do pensamento liberal...”, op. cit., p. 68 y ss.

${ }^{1094}$ CONSTANT, Benjamin: Curso de Política Constitucional..., op. cit., pp. 180 y ss.
} 
pensamiento de Emmanuel Joseph Sièyès. De este modo, los ciudadanos brasileños serían divididos por la Constitución de 1824 en dos categorías: "Ciudadanos Activos" y "Ciudadanos Pasivos". El Abad Sièyès va a hacer en sus escritos políticos en la Asamblea Nacional Francesa la distinción entre los derechos naturales y civiles de los ciudadanos de los derechos políticos de los mismos. Esto se reflejará en la Constitución Francesa de 1791, que dividía a los ciudadanos franceses en activos y pasivos. Distingue aquellas dos clases de derechos del siguiente modo: "La diferencia entre estas dos clases de derechos consiste en que los derechos naturales y civiles son aquellos para cuyo mantenimiento y desarrollo se ha formado la sociedad; y los derechos políticos son aquellos mediante los cuales la sociedad se forma"1095. Así que, algunos ciudadanos serán denominados "Ciudadanos Activos", que eran, nada más nada menos, los brasileños en pleno goce de los derechos políticos (art. 91, inciso I de la Constitución) ${ }^{1096}$.

Como ya hemos señalado, evitaremos hacer una comparación entre los derechos de propiedad y la declaración de la ciudadanía en un estudio exhaustivo, aunque todos estos elementos convergen en la misma constitución del Imperio de Brasil; por no ser éste el objetivo de nuestro trabajo. Así que, no trataremos de las exclusiones/inclusiones que se procesan en relación a los esclavos y libertos de origen africano para evitar extendernos demasiado en la definición de la ciudadanía. Pero, esto no quiere decir que no abordaremos de forma tangencial algunas cuestiones en este sentido, dado que, en este proceso de exclusión/inclusión, como ya hablamos antes, estará directamente vinculado a la preferencia del legislador brasileño en contraer un "Pacto Constitucional" en vez de un "Pacto o Contrato Social", que fuese original y originante ${ }^{1097}$. Esta elección demuestra que no concordaba en todo el legislador brasileño con el pensamiento del Abad Sièyès ${ }^{1098}$. Pero, en relación a las cuestiones vinculadas a los esclavos y

\footnotetext{
1095 MORAN, David Pantoja (comp.): Escritos Políticos de Sièyès, Fondo de Cultura Económica, México, 1993, p. 183. También se puede acompañar este aspecto de la ciudadanía doble del pensamiento francés en FLORES, Alberto Vivar: "El liberalismo constitucional...", op. cit., p. 175.

1096 “Mejor será, para dar mayor claridad al lenguaje, llamar a los primeros derechos pasivos, y a los segundos, derechos activos. Todos los habitantes de un país deben disfrutar de los derechos del ciudadano pasivo. Todos tienen derecho a la protección de su persona, de su propiedad, de su libertad, etc.; pero no todos tienen derecho a desempeñar un papel activo en la formación de los poderes públicos; no todos son ciudadanos activos." Ibídem. Para la versión francesa de sus escritos: SIÈYÈS, Emmanuel Joseph: Déclaration des Droits de L`Homme en Sociètè, Chez Baudouin - Imprimeur de L`Assemblée Nationale, Versailles, 1789, pp. 3-14. SIÈYÈS, Emmanuel Joseph: Opinion sur la Jurie Constitutionnaire (Suivie d Observations sur l’ouvrange de Sièyès), Eschasseriaux laainé, dans la discussion sur le jury constitutionnaire dans la Séance de la Convention nationale du 24 thermidor, 1795. SIÈYÈS, Emmanuel Joseph: Préliminaire de la Constitution. Reconnoissance et Exposition Raisonnée Des Droits de l'Homme et du Citoyen. Lu les 20 et 21 Julliet 1789, au Comité de Constitution, Chez Baudouin Imprimeur de L`Assemblée Nationale, Paris, 1789, pp. 3-32. SIÈYÈS, Emmanuel Joseph: Quest-ce que le TiersÉtat?, Pamphlet Publié en 1789 (Precede d une Etude sur l'Auteur par M. Chapuys-Montlaville, deputé et orné d`un portrait de Sièyès), Pagnerre Editeur, Paris, 1839, pp. 1-192.

1097 Véase en FLORES, Alberto Vivar: "El liberalismo constitucional...”, op. cit., pp. 176 y ss.

1098 "Lo que se constituye no es la nación, sino su establecimiento político (...). El poder constituyente tiene capacidad para todo a este respecto. No está sometido de antemano a una Constitución dada.” MORÁN, David Pantoja: Escritos Políticos..., op. cit., p. 28.
} 
a los libertos de origen africano es necesario un abordaje, aunque de forma tangencial, dado que, las soluciones de ciudadanía pasaban también por la definición de quienes eran brasileños y quienes eran extranjeros. Sabemos sobradamente, como ya precisamos en el capítulo anterior, que con la firma de los Tratados de 1810 con Inglaterra, la aceptación del elemento extranjero así como de su libertad de conciencia estaban reconocidos en dichos tratados, y eso influirá en algunos aspectos de la ciudadanía, y también de la libertad religiosa.

La conexión entre algunos elementos jurídicos tratados en las Cortes de Lisboa y las Cortes de Río de Janeiro se revelará en muchos artículos; así como también entre el Proyecto de Constitución de Antônio Carlos de Andrada y el Proyecto de Carneiro de Campos ${ }^{1099}$. El tratamiento dado al tema de la esclavitud fue una de estas aproximaciones, aunque la Constitución otorgada de 1824 guardará silencio sobre el tráfico negrero o la simple referencia a la institución de la esclavitud. De este modo, mientras que la Constituyente de 1823 optará por la solución del Congreso de Lisboa, no haciendo distinción entre nacionales y ciudadanos, dando así, a los africanos manumitidos y a sus descendientes la posibilidad de acceder a los derechos de ciudadanos del Imperio. La Constitución de 1824, por su parte, va a modificar levemente aquel precepto haciendo que los derechos de los ciudadanos solo pudiesen recaer en los libertos nacidos en Brasil, excluyendo por lo tanto a los esclavos manumitidos que hubiesen nacido en África. Nos dirá Marcia Regina Berbel que la distinción en el texto constitucional de los libertos brasileños y los libertos africanos tenía dos presupuestos básicos: el trafico negrero transatlántico tendría seguimiento; y se buscaba atender al principio denominado como la "primera Ley de los Estados", que vislumbraba a la seguridad pública, como tal, una medida de control social, distinguiendo, por lo tanto, los libertos brasileños de los libertos africanos. Eso daba a los primeros la posibilidad de acceder a la ciudadanía, mientras que a los segundos no. Era así, porque se entendía que los nacidos en Brasil estarían más apegados a la defensa del orden social que los segundos ${ }^{1100}$. Aun así, las Cortes de Río de Janeiro llevarán a cabo una construcción conceptual de ciudadanía bastante amplia, con los parámetros inclusivos de las Cortes de Lisboa y marcando distancia, por lo tanto, de las Cortes de Cádiz, en donde la racialización de la ciudadanía fue mucho más evidente ${ }^{1101}$.

Sin embargo, al contrario de lo que pasó en las Cortes de Lisboa, en Brasil, la Constituyente buscaba fomentar una identidad en construcción, así que, la definición de la

\footnotetext{
${ }^{1099}$ HOMEM DE MELO, Francisco I. M.: Escriptos Históricos e Litterarios (I - A Constituinte perante a história, $2^{\text {a }}$ Edição), Editores Eduardo e Henrique Laemmert, Rua do Ouvidor 68, Rio de Janeiro, 1868, pp. 59-146.

${ }^{1100}$ BERBEL, Márcia Regina: “A Constituição Espanhola no mundo Luso-Americano (1820-1823)”, Revista de Índias, 2008, vol. LXVIII, núm. 242. Págs. 225-254, ISSN: 0034-8341, p, 247.

${ }^{1101}$ Ibídem.
} 
ciudadanía pasó también por la delimitación del nacional, lo que exigía una contraposición al extranjero $^{1102}$. Por lo tanto, no se tendrá en cuenta el color de la piel, ni se hará discusión alrededor de temas raciales para la exclusión del esclavo manumitido de los derechos de ciudadanía, sino que, se cuestionará sí era nacido en Brasil o en África para acceder a dichos derechos después de la manumisión ${ }^{1103}$.

Por ser la Constitución de 1824 otorgada, como ya sabemos, buscaremos en las intervenciones de algunos diputados algunas claves sobre la definición de la ciudadanía en el Imperio de Brasil, aunque, como ya lo dijimos, dicha Constituyente será disuelta por el emperador, pero, muchos de sus preceptos y definiciones pasarán tal cual al texto constitucional de 1824; y de no ser así, en otros preceptos nos dará ciertos parámetros para comprender determinadas definiciones presentes en el texto constitucional ${ }^{1104}$. Por lo tanto, en el Titulo II "Del Imperio de Brasil" -, Capítulo I - "De los Miembros de la Sociedad del Imperio de Brasil" -, y en los art. $5^{\circ}$ (Son Brasileños) y el art. $6^{\circ}$ (Pueden obtener carta de naturaleza) definen a los ciudadanos brasileños del Imperio en el proyecto de Antonio Carlos de Andrada ${ }^{1105}$. Dichos artículos serán debatidos en la Asamblea Constituyente en las sesiones del día 23 hasta el día 30 de septiembre de 1823. Mientras que los debates sobre los artículos que tratan de los extranjeros y sus religiones se procesarán en los meses de octubre y noviembre.

En la Sesión de 23 de septiembre, se sometió a votación el capítulo I del proyecto. El diputado Nicoulau dos Campos Vergueiro, por la provincia de Sao Paulo y "egresado" de las Cortes de Lisboa va a proponer una enmienda que retomaba los términos de la Constitución portuguesa de $1822^{1106}$, sustituyendo el epígrafe "Dos Membros da Sociedade do Império do Brasil" por "Cidadaos do Império do Brasil", y añade: "si es que se llaman ciudadanos a los miembros del Imperio" "1107. Esta propuesta de sustitución resaltará el hecho de que gran parte de los habitantes del Imperio se encontraba en situación de esclavitud. Así que, la enmienda pasará

\footnotetext{
${ }^{1102}$ Véase la discusión que se hace sobre esclavitud y ciudadanía en MATTOS, Hebe Maria: Escravidao e cidadanía no Brasil monárquico, $2^{\text {a }}$ Ediçao, Jorge Zahar Editor, Rio de Janeiro, 2000, pp. 32 y ss. Se puede ampliar más el tema com la lectura de CARVALHO, José Murilo de: Cidadania no Brasil. O longo caminho, $9^{\text {a }}$ Edição, Civilização Brasileira, Rio de Janeiro, 2007, pp. 25 y ss.

${ }^{1103}$ BERBEL, Márcia Regina y MARQUESE, Rafael de Bivar: "Esclavitud, Ciudadanía e Ideología proesclavista en las Cortes de Lisboa y la Asamblea Constituyente en Rio de Janeiro (1821-1823)" en CHUST, Manuel y FRANQUET, Ivana: Los colores de las independencias Iberoamericanas. Liberalismo, etnia y raza, Consejo Superior de Investigación Científica - Colección América, Madrid, 2009, p. 130.

${ }^{1104}$ HOMEM DE MELO, Francisco I. M.: Escriptos Históricos e Litterarios..., op. cit., pp. 59 y ss.

1105 PROJECTO DE CONSTITUIÇAO PARA O IMPÉRIO DO BRASIL (Asamblea Constituyente de 1823) In: MIRANDA, Jorge: O constitucionalismo..., op. cit., p. 206.

1106 BERBEL, Márcia Regina y MARQUESE, Rafael de Bivar: “Esclavitud, Ciudadanía...”, op. cit., p. 131 y ss.

1107 ANNAES DO PARLAMENTO BRAZILEIRO - ASSEMBLEIA CONSTITUINTE, 1823, Tomo V, Typographia H. J. Pinto, Rua Nova do Ouvidor n. 31, Rio de Janeiro, 1880, p. 211. Sesión de 23 de septiembre de 1823 - Diputado Sr. Vergueiro. En adelante: APBAC.
} 
por ciertas ponderaciones, y de plano fue rechazada. Acorde con las ideas de Sièyès, dirá el Sr. diputado Montezuma:

"Eu quisera que se adotasse a emenda do Sr. Vergueiro para desvanecer a ideia de que se há de fazer diferença entre brasileiros e cidadãos brasileiros. Separemonos nesta parte de algumas constituições. Ser brasileiro, é ser membro da sociedade brasílica: portanto todo o brasileiro é cidadão brasileiro: convém sim dar a uns mais direitos e mais deveres do que a outros; e eis aqui cidadãos ativos e passivos ${ }^{1108}$."

En esta estela el Sr. diputado Manuel José de Sousa França, por la provincia de Río de Janeiro, recordará la heterogeneidad de la sociedad brasileña puesto que no se podría dejar de hacer diferencia o división entre brasileños y ciudadanos brasileños. Y añade que "según la calidad de nuestra población, los hijos de los negros, criollos cautivos, son nacidos en el territorio de Brasil, pero, todavía no son ciudadanos brasileños ${ }^{109,}$. Y concluye:

"Devemos fazer esta diferença: brasileiro é o que nasce no Brasil, e cidadão brasileiro é aquele que tem direitos cívicos. Os índios que vivem nos bosques são brasileiros, e contudo não são cidadãos brasileiros, enquanto não abraçam a nossa civilização ${ }^{1110}$.”

El Sr. Montezuma dirá en la secuencia -acerca de los indios y de los criollos cautivosque se debe cuidar apenas de los que hacen parte de la sociedad brasileña, y que hablaba él de los súbditos del Imperio de Brasil cuando hacía referencia a ser ciudadano, puesto que, son los "únicos que gozan de las comodidades de nuestra sociedad, padecen de sus incomodos, que

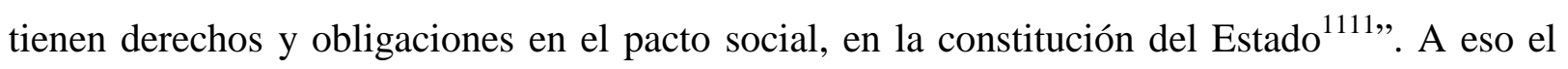
diputado Maia, dirá que comprende la expresión "miembros de la sociedad” del epígrafe como refiriéndose a los ciudadanos brasileños, evitado los redactores hacer diferencias entre “brasileños” y “ciudadanos brasileños", admitiendo apenas la distinción entre ciudadanos activos y pasivos. De este modo, tendría la Comisión evitado seguir el modelo español, que dividía la sociedad en "españoles simples" y "españoles ciudadanos". Y redundantemente, dirá el diputado que entiende como miembros de la sociedad del Imperio de Brasil los que forman actualmente la sociedad brasileña ${ }^{1112}$. Entonces rebate el Sr. França para definir categóricamente qué habitantes no son ciudadanos:

"Todos os homens libres, diz, habitantes do Brasil, nele nascidos, são cidadãos brasileiros. Agora pergunto eu, um Tapuia é habitante do Brasil? É. Um Tapuia é nascido no Brasil? É. Um Tapuia é livre? É. Logo, é cidadão brasileiro? Não, posto que, aliás, possa chamar brasileiro, pois os índios no seu estado

\footnotetext{
1108 Ídem, Sr. Montezuma.

1109 Ídem, Sr. França.

${ }^{1110}$ Ibídem.

${ }^{1111}$ Idem. Sr. Montezuma.

${ }^{1112}$ Idem, p. 212. Sr. Maia.
} 
selvagem não são, nem se podem considerar como parte da grande família brasileira. Nós, é verdade, que temos lei que lhes outorgue os direitos de cidadão, logo que eles abraçam os nossos costumes e civilização, antes disso porém estão fora da nossa sociedade ${ }^{1113}$."

El diputado Maciel da Costa resumirá de forma brillante lo que se pretende para la sociedad brasileña. Dirá el diputado que por "derechos civiles" se entiende que "todos los individuos que compone la gran familia brasileña, de los cuales se trata en este capítulo, tienen derecho a ser protegidos por la ley en el ejercicio, y goce de aquellos derechos para cuya conservación y seguridad de los hombres se unieron en sociedad: libertad individual, seguridad personal, derecho o seguridad de propiedad, a los cuales acrecen otros secundarios, como la accesibilidad general a los empleos, habiendo aptitud para ellos etc". Ya para los "derechos políticos", que según el diputado, no todos los individuos de la familia brasileña podía entrar en su goce, son "el derechos de elección y de elegibilidad para tener parte en la legislación del país, porque estos derechos son, digámoslo así, de convención social, y dependiente de ciertas condiciones que no se pueden encontrar en todos los individuos" ${ }^{\text {1114 }}$. De este modo, vemos claramente que tanto la comisión que elaboró el proyecto como los diputados, en su gran mayoría, estaban decantados por la solución revolucionaria francesa de Sièyès en dividir la sociedad en ciudadanos pasivos y activos, e ignorar a los que no perteneciesen al pacto social. Matiza el mismo diputado, que si se quiere emplear en la inscripción la palabra "ciudadano", por fuerza hay que hacer la distinción entre ciudadanos activos y pasivos. Además, el diputado en su réplica, dirá que los simples brasileños para poder entrar en el grupo de los ciudadanos activos era necesario cumplir algunas condiciones, tales como tener una cierta propiedad y capacidad moral. Comprendemos así la idea censitaria de constitución del diputado, que de hecho ya estaba recogida en el proyecto, que fue llamado "Constitución de la Yuca", porque exigía a los ciudadanos activos determinada cuantidad de tierra plantada con Yuca; esta concepción censitaria también pasará a la Constitución de 1824. Con esto, el diputado pretende criticar a la Constitución de Lisboa por no haber hecho la diferenciación entre nacionales y ciudadanos, puesto que, sería "un cuerpo más informe y contradictorio que se conoce" $" 1115$. Pero, esta misma posición ya la había defendido el diputado bahiano Cipriano Barata en el Congreso de Lisboa en agosto de 1822, en el momento en que se discutía la extensión de la ciudadanía a los libertos. Barata abogaba que con dicha extensión era necesaria también la distinción entre ciudadanos activos y pasivos, que al marco social de Brasil sería mucho más adecuada ${ }^{1116}$.

\footnotetext{
${ }^{1113}$ Idem. Sr. França.

${ }^{1114}$ Idem, p. 213. Diputado Sr. Maciel da Costa.

${ }^{1115}$ Ibídem.

${ }^{1116}$ BERBEL, Márcia Regina y MARQUESE, Rafael Bivar: “Esclavitud, ciudadanía...”, op. cit., p.132.
} 
El diputado Almeida de Albuquerque aboga por una extensión mayor de los miembros de la sociedad brasileña, que abrace, entre otros grupos, a los extranjeros naturalizados y los que lleguen a naturalizarse, puesto que, entraron en la formación del pacto social. Pero, que no serían ciudadanos inmediatamente con la simple dicción legal, ya que, "sería una imprudencia dar desde ya el título de ciudadano brasileño indistintamente a cualquiera el individuo ${ }^{117}$ ". El diputado Ferreira França opina que la expresión "Miembros de la Sociedad Brasileña" quiere decir mucho más que la expresión "Ciudadanos Brasileños”, y explica: "la sociedad brasileña contiene solamente hombres libres, o también esclavos? La sociedad del imperio brasileño se compone de nacionales y de extranjeros, de libres y esclavos" ${ }^{\prime 118}$. De forma que la poliédrica sociedad brasileña era una tarea difícil de conformar bajo la denominación indistinta de ciudadanos, para algunos diputados. Sometida a votación la enmienda del Sr. Vergueiro en la Sesión de 24 de septiembre, fue rechazada, y pasó el epígrafe tal y como estaba en el proyecto "De los Miembros de la Sociedad del Imperio de Brasil""1119.

En la misma Sesión del día 24 de septiembre se sometió a discusión el art. 5º que dice: “Son Brasileños”, inciso I - "Todos los hombres libres habitantes en Brasil, y en él nacidos”. El diputado França no participa del enunciado y propone una enmienda al art. 5º que debía decir: "Son Ciudadanos Brasileños". Hay un profundo debate entre los diputados para marcar el ser brasileño y ser ciudadano brasileño, con varias intervenciones. El futuro creador del proyecto que se transformará en la Constitución otorgada de 1824, Francisco Carneiro de Campos, diputado por la Provincia de Bahía, dirá que es de la opinión que se añada la palabra “ciudadano" al art. 5. Sigue el mismo diputado, diciendo, que como en la Asamblea no se ha especificado la noción de ciudadano, ni tampoco se dijo en la inscripción "De los Miembros de la Sociedad Civil del Imperio", dirá que es necesario que se explique la idea que compone el capítulo, cosa que no se hizo hasta ahora, y dirá:

"Ora, por exemplo, os escravos e os estrangeiros também se poderão entender membros no sentido deste capitulo? Não, por certo; entram na sociedade de homens, mas não na sociedade de homens que gozão dos direitos de cidade conforme a constituição. O nosso intento é só determinar quais são os cidadãos brasileiros, e estando entendido quais eles são, os outros poder-se-ão chamar simplesmente brasileiros, a serem nascidos no país, como os escravos, crioulos ou indígenas, etc ${ }^{1120 . "}$

Y sigue el diputado señalando que la constitución no se encargó de aquellos grupos, que viven en medio de la sociedad civil, pero, rigurosamente no hacen parte integrante de ella. Lo

\footnotetext{
${ }^{1117}$ APBAC, p. 214. Diputado Sr. Almeida de Albuquerque.

1118 Idem, p. 215. Diputado Sr. Ferreira França.

1119 Ídem, p. 227. Sesión de 24 de septiembre de 1823.

${ }^{1120}$ Para estas y otras afirmaciones, Idem, p. 228. Diputado Sr. Francisco Carneiro de Campos.
} 
curioso es el diputado Araujo Lima no ver cualquier problema en poner la palabra ciudadano, puesto que él no veía ninguna dificultad, dado que no por la introducción de tal palabra se iba a atribuir los derechos inherentes que les ponen los publicistas en dicha palabra. Y añade que en "la lengua portuguesa, de donde derivamos la nuestra, así como en la española, la palabra ciudadano tiene una significación muy particular, ella designa el morador o vecino de la ciudad"1121. Al final la sesión quedó aplazada y se retomaron las discusiones en el día 25 de septiembre. En la sesión de este día se votó la enmienda del Sr. França y fue aprobada que sí. Así que en la reformulación del art. $5^{\circ}$ este precepto quedará dividido en dos tópicos: "Son Brasileños" y "Son Ciudadanos Brasileños"1122.

Sobre la adopción del "ius solis" o del "ius sanguinis" para la atribución de la ciudadanía tuvieron lugar muchos debates, a la luz del inciso I, del art. 5. El diputado França, por ejemplo, veía tres requisitos en el dispositivo legal: libres, habitantes y nacidos. Estos tres requisitos, según dicho diputado, podrían llevar a equívocos a la hora de conceder la ciudadanía a un extranjero de paso con su mujer embarazada que diese la luz en el puerto de Río de Janeiro, por ejemplo, el niño se encajaba en las tres posibilidades: era libre, habitante y había nacido en Brasil. Dicho diputado veía como un equívoco adoptar tales requisitos ${ }^{1123}$. En esta estela dirá el diputado Montezuma:

"Eu entendo por brasileiro não só o nascido no Brasil, mas o não nascido, mas domiciliado, e com os requisitos próprios para que entre no gozo de nossos direitos, reconhecendo os deveres impostos a cada um dos indivíduos da sociedade que formamos ${ }^{1124}$."

Así pues, el diputado aprecia como concesión de la ciudadanía en el primer caso por la naturaleza y en el segundo por la ley. Y recobraba los elementos que definían a la ciudadanía que se había configurado en las Cortes de Lisboa: los mismos usos y costumbres, y la misma

\footnotetext{
${ }^{1121}$ Idem, p. 229. Diputado Sr. Araújo Lima. En el diccionario de la lengua castellana que consultamos dirá lo siguiente: "CIUDADANO: el vecino de una Ciudad, que goza de sus privilegios, y está obligado a sus cargas, no revelándole de ellas alguna particular exención. Diccionario de la Lengua Castellana, en que se explica el verdadero sentido de las voces, su naturaleza y calidad con las frases y modos de hablar, los proverbios y refranes, y otras cosas convenientes al uso de la lengua. Dedicado al Rey Nuestro Señor Don Felipe V (que Dios guarde), a cuyas reales expensas se hace esta obra. Compuesto por la Real Academia Española. Tomo II - que contiene la letra $C$, En la Imprenta de Francisco del Hierro, Impresor de la Real Academia Española, Madrid, 1729, p. 364. Algo parecido encontramos en el Diccionario da Lingua Portugueza recompilado dos vocabularios impressos até agora, e nesta segunda edição novamente emendado, e muito accrescentado, por Antonio de Morais Silva natural do Rio de Janeiro, offerecido ao muito alto, e muito poderoso Principe Regente Nosso Senhor, Tomo I - A-E, Na Typographia Lacerdina, Com Licença da Meza do Desembargo do Paço, Lisboa, 1813, p. 395. "CIDADAO: o homem que goza dos direitos de alguma Cidade, das isenções e privilégios que se contem no seu foral, posturas, homem bom”.

${ }^{1122}$ APBAC, Sesión de 25 de septiembre de 1823, p. 234.

${ }^{1123}$ Idem, p. 235. Diputado Sr. França.

${ }^{1124}$ Idem, p. 235-236. Diputado Sr. Montezuma.
} 
lengua ${ }^{1125}$. El tercer elemento era la misma religión, pero, como se había ya decidido por implementar una cierta libertad de conciencia en el Imperio, no lo enumeraba el referido diputado. Al final, el inciso I se sometió a votación y fue aprobado tal y como estaba redactado, perjudicando así a todas las demás enmiendas ${ }^{1126}$.

Siguiendo la apreciación y discusión de los incisos del art. 5º el inciso II pasó con la enmienda del diputado Lopes Gama, con la siguiente dicción: “Todos los portugueses domiciliados en Brasil antes del 12 de octubre de 1822, que expresa o tácitamente se hubiesen vinculados a la sociedad brasileña"1127. Ya los incisos III (Los hijos de padres brasileños nacidos en países extranjeros, que vengan a establecer dominio en el Imperio), IV (Los hijos de padre brasileño, que estuviesen en país extranjeros a servicio de la Nación, entretanto no viniese establecer domicilio en el Imperio) y V (Los hijos ilegítimos de madre brasileña, que, habiendo nacido en país extranjero, viniesen a establecer dominio en el Imperio) pasaron como estaban redactados en el proyecto ${ }^{1128}$.

En la discusión del inciso VI, si se debía conceder la ciudadanía a los libertos, menos que la raza lo que más llamó la atención de los diputados era la dicotomía de ser extranjero y ser ciudadanos, por lo tanto, muchos diputados no estaban a favor de que se concediese la ciudadanía a lo libertos africanos, no nacidos en Brasil. En este sentido se pronunció el diputado Silva Lisboa:

"Uma vez que adquirirão a qualidade de pessoa civil, merecem igual proteção da lei e não podem ter obstáculo de arrendar e comprar Terras, exercer qualquer indústria, adquirir prédio, entrar em estudos publicas, alistar-se na milícia o marinha do império. Ter a qualidade de cidadão brasileiro é, sim, ter uma denominação honorifica, mas que só dá direitos cívicos e não direitos políticos, que não se tratam no capitulo em discussão e que são objeto do capitulo seguinte, em que se trata do cidadão ativo e proprietário considerável, tendo as habilitações necessárias á eleição e nomeação dos empregos politicas do império ${ }^{1129}$."

Después de una larga alegación antiesclavista el diputado Silva Lisboa propondrá y se aprobará la siguiente enmienda al inciso VI: "Los libertos que adquieran su libertad por cualquier título legítimo ${ }^{1130,}$.

Como la religión a la que los legisladores pretendían beneficiar con la relativa libertad de conciencia, a ser implantada en el Imperio, era la cristiana protestante, profesada

\footnotetext{
1125 Ibídem.

${ }^{1126}$ Idem, p. 236.

${ }^{1127}$ APBAC, Sesión de 26 de septiembre de 1823, p. 240. Diputado Sr. Lopes Gama.

${ }^{1128}$ APBAC, Seiones de 26 y 27 de septiembre de 1823, pp. 250-255.

${ }^{1129}$ APBAC, Sesión de 30 de septiembre de 1823, p.260. Diputado Sr. Silva Lisboa.

${ }^{1130}$ Idem, p. 267.
} 
principalmente por la mayoría inglesa, y defendida por los Tratados de 1810; nos interesan las discusiones llevadas a cabo en el Congreso Constituyente en torno a la concesión de ciudadanía a los extranjeros (incisos VII y VIII del art. $5^{\circ}$ y el art. $6^{\circ}$ del Proyecto). El diputado Fernandes Pinheiro, en la Sesión de 30 de octubre se pronunciará de acuerdo a la doctrina de Vattel ${ }^{1131}$ y Burlamaqui $^{1132}$ en torno a la relación afectiva que tienen las personas con el sitio de su nacimiento, y, por lo tanto, los extranjeros para su naturalización debían hacer constar una declaración expresa, revestida de formalidad, para la aceptación de la nueva nacionalidad ${ }^{1133}$. Así, el diputado propone la siguiente enmienda: "Los hijos de extranjeros... los cuales en el período de la mayoría de edad ratificaren, por un término en la comarca, la voluntad de ser ciudadanos brasileños”, fue apoyada esta proposición por los demás diputados. El Sr. Carvalho e Mello tampoco estaba a favor de la concesión de la ciudadanía a través de "Ius solis", puesto que, dirá el diputado, "el nacimiento solamente no es lo bastante para dar a los hijos de extranjeros nacidos en el imperio la calidad de ciudadanos brasileños"1134. El argumento de la necesidad de aumentar la población era recurrente en los discursos de los ilustres diputados; también en el caso del diputado Andrada Machado, relator de la comisión que elaboró el proyecto de constitución, que optó por la adopción del "Ius Solis", sin otro criterio más para la concesión de la ciudadanía a los hijos de los extranjeros nacidos en Brasil ${ }^{1135}$. En esta discusión el diputado Ferreira França presentó otra solución, la del domicilio, que sería mucho más eficaz que el solo nacimiento para adquirir los hábitos y costumbres de una nación: “O mouro já grande nunca é bom cristão ainda que se passe para esta religião; mas um mouro ainda criança se for batizado e criado entre os cristãos parece-me que não ha de ficar mouro ${ }^{1136 " . ~} \mathrm{Al}$ final el principio del "Ius Solis" prevaleció en la redacción dada al proyecto para el inciso VII: “Os filhos de Estrangeiros nascidos no Império, contanto que seus Pais não estejam em serviço de suas respectivas Nações ${ }^{1137,}$.

\footnotetext{
${ }^{1131}$ VATTEL, Emer de: El Derecho de Gentes o Principios de la Ley Natural, aplicados a la conducta y a los negocios de las naciones y de los soberanos (Traducidos en Castellano por D. Lucas Miguel Otarena de la última edición francesa publicada en Paris en 1820, corregida y aumentada con notas del autor y de los editores), Tomo I, Por Ibarra - Impresor de Cámara de S. M., Madrid, 1820. Es interesante mirar la primera parte que trata del Derechos de Gentes (Ideas y principios generales del derecho de gentes), pp. 2 y 23.

${ }^{1132}$ BURLAMAQUI, Jean-Jacques: Elementos del Derecho Natural (Traducido de la última edición francesa), Imprenta y Librería de Sanz, Granada, 1838. Para mejor entender la intervención del citado véase el capítulo I (De la naturaleza del hombre considerado con respecto al derecho), pp. 7-12.

${ }^{1133}$ APBAC, Tomo VI, Sesión de 1 de octubre de 1823. Diputado Sr. Fernandes Pinheiro.

${ }^{1134}$ Idem, p. 7. Diputado Sr. Carvalho e Mello.

${ }^{1135}$ Idem, p. 7. Diputado Sr. Andrada Machado.

${ }^{1136}$ Idem, p. 10. Diputado Sr. Ferreira França.

${ }^{1137}$ PROJECTO DE CONSTITUIÇAO PARA O IMPÉRIO DO BRASIL (Asamblea Constituyente de 1823) In: MIRANDA, Jorge: O constitucionalismo..., op. cit., p. 206.
} 
El inciso VIII, también fue puesto a discusión en la misma sesión del día 1 de octubre, y traía dos principios correlativos que nos interesan, la concesión de la ciudadanía a los extranjeros y la religión que estos profesaban. Es cierto que de la letra del inciso se desprendía una total tolerancia: "Os Estrangeiros naturalizados, qualquer que seja a sua Religião ${ }^{1138, " . ~ S i n ~}$ embargo, el diputado Andrada Machado, hace una reflexión en relación a la expresión "cualquiera que sea su religión": "nao sei se fui liberal de mais, isto merece ser bem pensado $^{1139}$, . En este particular explica el diputado en su intervención cuales eran sus intenciones cuando redactó este inciso en la Comisión de Constitución. Afirma el mismo diputado que su intención era atraer a los judíos ricos del Suriname de origen lusitano, y como éstos habían manifestado muchas veces la intención de unirse al trono luso, quiso el diputado “tentarles, dándoles los derechos civiles, para que viniesen a establecerse en Brasil ${ }^{1140 ", ~ P e r o, ~}$ añadirá el diputado, que como esta cláusula "abarca a todas las religiones del mundo, merece

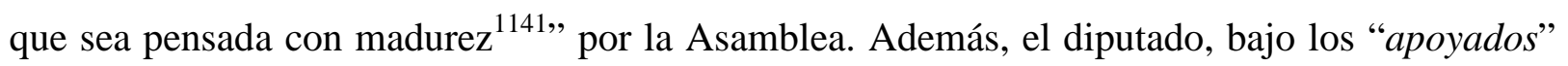
de sus colegas sostenía que se concedía la ciudadanía "una vez que se reconozca un Dios, porque quien no conoce a Dios es enemigo de la sociedad ${ }^{1142, "}$. Sin embargo, el monoteísmo cristiano aparece claro en el habla del diputado y se reflejará en el art. 15 del Proyecto: "As outras religiões, além da Cristã, são apenas toleradas, e a sua profissão inibe o exercício dos Direitos Políticos ${ }^{1143,}$. Así que a los judíos les pretendían conceder apenas los derechos civiles pero no los derechos políticos. Otros diputados van a presentar enmiendas en el sentido de que se incluyesen los requisitos adicionales del domicilio por más de siete años y el matrimonio con una brasileña para la concesión de la ciudadanía a los extranjeros. El Sr. França, yendo mucho más allá dirá que este inciso debería ser materia de ley reglamentaria y no estar disciplinado en un artículo constitucional. Explicaba el diputado que la naturalización civil sólo era concedible en tales y cuales circunstancias. Lo que dependerá de un título ostensivo, que es la autenticidad de su nueva condición adquirida en el país que habita. No podría el extranjero prescindir de la obtención de una carta que lo declaraba ciudadano; lo que está regulado en el art. $6^{\circ}$ del mismo proyecto. En el inciso I de este artículo están las premisas para la obtención de dicha carta de naturaleza. Entiende el diputado que la Carta de naturaleza a la luz de aquel artículo se referiría a los colonos y no a la naturalización de los extranjeros por el simple hecho de sus orígenes y

\footnotetext{
1138 Ibidem.

${ }^{1139}$ APBAC, Tomo VI, Sesión de 1 de octubre de 1823, p. 10. Diputado Sr. Andrada Machado.

1140 Ibidem.

1141 Ibidem.

1142 Ibídem.

${ }^{1143}$ PROJECTO DE CONSTITUIÇAO PARA O IMPÉRIO DO BRASIL (Asamblea Constituyente de 1823) In: MIRANDA, Jorge: O constitucionalismo..., op. cit., p. 206.
} 
nacimientos. Y aclara más, el diputado, que "no exercício pratico dos direitos induziria isso uma confusão consequência, principalmente nas assembleias das eleições, onde o direito de votar é denegado ao estrangeiro em regra, e é mister provar a exceção ou privilegio imediatamente por um titulo decisivo ${ }^{1144,}$. Aunque se diesen ciertas resistencias por parte de algunos diputados el inciso VIII pasa tal cual estaba redactado en el proyecto en la votación realizada en la sesión de 2 de octubre.

En la sesión del mismo 2 de octubre se discutió la parte final del Capítulo I del Título II. Así que, el art. $6^{\circ}$ entrará a debate con la siguiente redacción: "Podem obter Carta de naturalização"; y el inciso I: "Todo o Estrangeiro de maior idade, que tiver domicílio de agricultura, comercio e indústria, ou havendo introduzido, ou exercitado algum comércio, ou indústria útil, ou feito serviços importantes à Nação" ${ }^{1145}$. El carácter de patrimonialidad y utilidad de los extranjeros candidatos a instalarse en Brasil era flagrante, en una formulación lockeana de nacionalidad. El Sr. diputado Carvalho e Mello se pronuncia de completo acuerdo con la dicción del inciso, dado que, en palabras del diputado, el establecimiento de dichos requisitos estaba juiciosamente de acuerdo a lo que plegaba las demás constituciones de la época. Y matizará el diputado que "tienden al principio general flanquear, cuanto se pueda, la entrada de extranjeros" en el país. La necesidad de brazos para la construcción de la nación parecía imperiosa a todos los diputados, incluso de religión distinta a la cristiana, así que, Carvalho e Mello vuelve a afirmar que:

“Os Ilustres compiladores tanto seguiram no projeto o principio geral de franquear a entrada, que até estabeleceram, que seriam admitidos estrangeiros, qualquer que fosse a sua religião ${ }^{1146}$."

En el ámbito que interesaba la atribución de ciudadanía, para la adquisición de derechos civiles, el Sr. França nos aclara diciendo que interesaban los extranjeros que reunieran las calidades de capitalistas y propietarios. Esto coincide perfectamente con la noción de ciudadanía propietaria de Locke y Jeremy Bentham ${ }^{1147}$. En esta línea, en una atmósfera bastante liberal, que se desprendía de la intervención de algunos diputados, nos pareció que estaban bastante comprometidos con la tarea de la construcción del Estado/Nación brasileño. La necesidad de una constitución liberal, al gusto de los europeos, para garantizar la inmigración en Brasil se desprende de la intervención del diputado Carneiro de Campos, futuro redactor de

\footnotetext{
${ }^{1144}$ Idem, p. 11.

1145 PROJECTO DE CONSTITUIÇAO PARA O IMPÉRIO DO BRASIL (Asamblea Constituyente de 1823) In: MIRANDA, Jorge: O constitucionalismo..., op. cit., p. 206.

${ }^{1146}$ APBAC, Sesión de 2 de octubre de 1823, p. 15. Para esta y demás afirmaciones del Sr. diputado Carvalho e Mello.

${ }^{1147}$ APBAC, Sesión de 3 de octubre de 1823, p. 23. Sr. Diputado França.
} 
la Constitución de 1824. Así era la percepción de dicho diputado sobre el momento y de la oportunidad que se les presentaba:

"Lembremo-nos, senhores, que as dissidências religiosas e politicas deram outr'ora no norte da América esses varões ilustres a quem hoje os Estados-Unidos devem os seus costumes sóbrios, grande amor ao trabalho, e em geral todas as virtudes morais e politicas que o têm feito capazes da liberdade que lhes mantém as suas instituições. Com homens tão abalizados não sejamos mesquinhos, franqueemos-lhes e alarguemos-lhes a entrada da nossa associação política, concedamos-lhes a existência civil e politica ${ }^{1148}$."

Así pues, los diputados parecían tener bastante presente el modelo de Estados Unidos como ejemplo de tolerancia y los frutos que ésta traía a la Nación. Principalmente la tolerancia religiosa, incluso en un país confesional como era Brasil. Sin embargo, el propio Carneiro de Campos alertaba: "Não nos iludamos com o exemplo dos Estados-Unidos, nós somos noviços na liberdade, e eles são já veteranos ${ }^{1149}$ ". Llama la atención también el exceso de filantropía y liberalidad para con los extranjeros. Pero, Carneiro de Campos va a hacer un aditamento a la enmienda propuesta por el diputado Ferreira França incluyendo "al hombre injustamente perseguido por opiniones políticas y religiosas" $" 1150$ como una posibilidad más para acceder a la ciudadanía brasileña. A este aditamento se opone radicalmente el Sr. Silva Lisboa. Y aportaba el ejemplo del reinado de Jorge III de Inglaterra que afirmaba no tener persecución en su reinado, y que igual se pudiese decir en Brasil: "no império do Brasil não há perseguição de qualquer estrangeiro, contanto que não turbe o culto publico, nem viole as leis do Estado ${ }^{1151 \text { ", }}$ Alertaba, además, de la dificultad de identificar y juzgar si el motivo de la persecución era por delito civil o por meras opiniones religiosas y políticas, dado que, bajo la consigna de liberales estaban los que buscaban propalar sus opiniones religiosas, infieles e impías, haciendo prosélitos, minando la constitución buena o mala del Estado. Y aludía al famoso caso del americano Thomas Paine, que hacía proselitismo de formas de gobierno y sectas religiosas en Inglaterra, y que aunque dicho país fuese tolerante no dejó de perseguir a dicho panfletario ${ }^{1152}$. Y terminaba aludiendo a la Revolución liberal de Nápoles:

“Com semelhante pretexto de perseguido em Nápoles veio o general dos revoltosos Peppe refugiar-se á Portugal, dando-lhe as cortes uma pensão de quatro contos de réis, que nunca deram ao maior servidor do estado ${ }^{153}$."

\footnotetext{
${ }^{1148}$ Idem, p. 24. Sr. Diputado Carneiro de Campos.

${ }^{1149}$ Idem, p. 25.

1150 Ibidem.

${ }^{1151}$ Idem, p. 26. Sr. Diputado Silva Lisboa.

1152 Ibidem.

1153 Ibidem.
} 
Al final se aprobó el inciso tal y como estaba redactado con algunas modificaciones las que ya hicimos referencia. Principalmente las sugeridas por los diputados: Sr. Silva Lisboa; Sr. França; y Sr. Montezuma ${ }^{1154}$. El inicio II del art. $6^{\circ}$, contradictoriamente traía el principio del "ius sanguinis", dado que se concedía la ciudadanía a los hijos de brasileños que habían perdido la ciudadanía. En la Sesión del día 7 de octubre los diputados buscaron hacer añadidos en este capítulo regulando las formas que llevaban a un ciudadano a perder sus derechos civiles, a ejemplo del art. 31 que disciplinaba la perdida de los derechos políticos. La enmienda del Sr. Carneiro es interesante, más que las sugeridas por el Sr. Verguiero, dado que un poco repetía las condiciones dictadas ya en el art. 31. Y es interesante tal enmienda por establecer la muerte civil por sentencia firme como forma de pérdida de la ciudadanía ${ }^{1155}$.

El Capítulo I, del Título II, estaba dedicado a la concesión, como vimos, de derechos civiles a determinados extranjeros que profesaban una religión distinta a la cristiana. El Capítulo II, del mismo título contemplaba los "Derechos individuales de los Brasileños". En este capítulo se marcaba a determinadas categorías de extranjeros, que profesaban determinadas religiones que podían acceder a los derechos políticos, como veremos. Será en la sesión de 7 de octubre cuando empezaron las discusiones del Capítulo II del mismo título, que hasta ahora venimos tratando. En este capítulo se regulaban los derechos políticos, o la ciudadanía activa, según la división constitucional ${ }^{1156}$. El art. $7^{\circ}$ dirá: “A Constituição garante a todos os

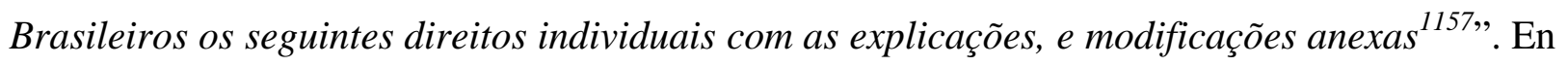
la discusión de este artículo se dejaran translucir las opiniones de Jeremy Bentham que presentamos en el Capítulo I de nuestro trabajo. Las discusiones eran en el sentido de que se declarasen los derechos de los ciudadanos al inicio o al final de las constituciones. Evitando el modelo revolucionario francés, Cádiz, aunque sea hija de aquél modelo, no trae en su frontispicio tal declaración, pero, al revés lo hace la Portuguesa de 1822, contrariando las recomendaciones de Jeremy Bentham. Atento a estas formulaciones del publicista ingles, el diputado Maciel da Costa dirá: “Antes de passar avante direi que não sou da opinião dos que pensam que sem este cabeçalho de direitos e deveres do cidadão não há constituição política". Y expondrá sus motivaciones:

“ $1^{o}$, porque uma constituição politica pressupõe esses direitos; $2^{o}$, porque não é uma tal declaração, por mais faustosa que ela seja, que ha de segurar esses direitos, visto que isso depende, além de outras cousas auxiliares ou secundarias,

\footnotetext{
1154 Idem, p. 27.

${ }^{1155}$ APBAC, Sesión de 7 de octubre de 1823, p. 50. Sr. Diputado Carneiro.

1156 Ibidem.

${ }^{1157}$ PROJECTO DE CONSTITUIÇAO PARA O IMPÉRIO DO BRASIL (Asamblea Constituyente de 1823) In: MIRANDA, Jorge: O constitucionalismo..., op. cit., p. 206.
} 
da boa distribuição dos poderes políticos, de boas garantias, etc.; $3^{\circ}$, porque não casa bem com um código politico essa exposição doutrinal e dogmática; $4^{o}$, porque essa numeração de direitos demanda definições, e elas são dificílimas em matéria tal, e nesse pelago têm naufragado os mais abalizados políticos, quais os da assembleia constituinte em França, como mostram as judiciosas criticas que se publicaram contra essa pomposa declaração de direitos ${ }^{, 1158}$.

Sin embargo, el diputado dice no quiere corregir a los que mantenga dicha declaración, pero, habría que citar la libertad de movimiento en el rol de la demás libertades personales; de este modo, complementa:

"1", porque a constituição deve dar um tipo ou padrão, digamos assim, com que possamos comparar e confrontar os factos ou ações que tratarmos de caracterizar de ofensivas dessa liberdade; $2^{\circ}$, para facilitar aos que trabalharem nos códigos a desenvolução e aplicação das providencias; $3^{\circ}$, para não ficar duvida ao leitor se estes casos especificados nos ditos artigos são trazidos aqui para exemplos, ou se a liberdade só neles se verifica; $4^{\circ}$, finalmente, para facilitar aos povos o decorarem, e trazerem impressa na memoria, a ideia da sua liberdade, como trazem as verdades do catecismo cristão ${ }^{1159}$."

El art. $7^{\circ}$, en juicio, hacía una amplia declaración de derechos, sin desmenuzarlas. De esta forma declaraba en los incisos: I - la libertad personal; II - el juicio por jurados (el Tribunal de jurados); III - la libertad religiosa; IV - la libertad de industria; V - la inviolabilidad de la propiedad; VI - la libertad de imprenta ${ }^{1160}$. Además el propio diputado Maciel da Costa va a decir que se debían declarar los términos o límites de dichas libertades, pero, que en el momento de la formación del Estado/Nación brasileño se debían aprobar tal y como estaban en ese momento redactadas. El diputado quiso referirse a los arts. 14 y 15 en donde se trata de la libertad religiosa. El Sr. Costa Aguiar también era de la opinión que pasase dicha declaración de derechos tal como estaba. Puesto que ya se había declarado la naturalización de los extranjeros cualquiera que fuese su religión, no había cabida limitarla en el artículo que sigue:

"Acresce que estando já vencido o numero $8^{\circ}$ do art. $5^{\circ}$, que considera como cidadãos brasileiros os estrangeiros naturalizados, qualquer que seja a sua religião, é por isso necessário que passe este numera, ora em questão, tal qual está, como passarão os anteriores, porque depois no art. 14 se dirá então até onde se estende esta mesma liberdade religiosa ${ }^{1161}$."

Al parecer, de los seis principios de la declaración de libertades civiles, solamente la religiosa llamó la atención de los diputados. El diputado Sr. Obispo Capelán-mayor no veía

\footnotetext{
${ }^{1158}$ APBAC, Sesión de 7 de octubre de 1823, p. 51. Sr. Diputado Maciel da Costa.

1159 Ibidem.

${ }^{1160}$ PROJECTO DE CONSTITUIÇAO PARA O IMPÉRIO DO BRASIL (Asamblea Constituyente de 1823) In: MIRANDA, Jorge: O constitucionalismo..., op. cit., p. 206.

${ }^{1161}$ Idem, p. 53. Sr. Diputado Costa Aguiar.
} 
inconveniente que permaneciese el inciso III que declaraba la libertad religiosa, principalmente por haber ya pasado los incisos I y II del artículo $7^{\circ}$, porque apenas eran enunciación de derechos, que luego serían discutidos con sus matizaciones en los arts. $14^{\circ}$ y $15^{\circ}$. Crítica severa realizó el diputado Maciel da Costa, que volvió a la carga en contra de la libertad religiosa amplísima. Para dicho diputado, no se debía consentir que el ciudadano fuese "perseguido por sus opiniones religiosas, mientras él no la esparza o plegue de forma sediciosa; (también) no se debía consentir que el ciudadano fuera espiado hasta en el seno de su familia para conocer el gobierno sus ideas ${ }^{1162, "}$. Además, se debían evitar investigaciones del gobierno para saber cómo el ciudadano observa sus preceptos religiosos, sacando de ahí motivos para denuncias y persecuciones. El diputado también hizo una división de la alzada del gobierno y el ámbito privado. Por lo tanto, a "rigor de derecho público la alzada del gobierno se limita en los actos públicos, que ofendan la tranquilidad y el respeto debido al culto nacional". Concluye el mismo diciendo que:

"Feito isso, temos - Liberdade Religiosa - grande liberdade religiosa, a única de que necessitamos, a única que nos pode ser útil ${ }^{163}$."

También llama la atención el diputado que, en el pacto social se había ya jurado mantener la Religión Católica Apostólica Romana. De tal modo que, permitir la facultad de adoptar al ciudadano brasileño la religión que bien entienda y tener protegido el ejercicio público de ella, sigue del principio para decretar la libertad religiosa, pero, que también es consecuencia de decretar la religión oficial del Estado:

“Demais, Sr. presidente, para quem legislamos nós? Para brasileiros, isto é, católicos romanos. Quem representamos nós aqui? Brasileiros, isto é, católicos romanos. De quem recebemos procurações? De brasileiros, isto é, católicos romanos. E para que? Para decretarmos que nós, eles, nossos filhos, nossa posteridade teremos o direito de apostatar da verdadeira religião, da religião de nossos gloriosos maiores? Não, Sr, presidente, não. Tal poder nos não foi outorgado em nossas procurações, e nem podia, nem devia ser. A religião católica romana é a religião dos brasileiros; mas os brasileiros animados de princípios liberais e generosos não querem excluir do seu seio homens uteis ao nosso império nascente, só porque eles não são católicos ${ }^{1164}$."

Por ello vamos a ver una verdadera batalla campal -que el diputado Sr. França llamó de mare magnum de la disputa- entre los defensores del principio liberal de la libertad religiosa amplia y los que la deseaban de forma utilitaria, o sea, que sirviese apenas para asegurar la vinculación de los industriosos (emprendedores) extranjeros a Brasil. Si el relator había declarado que dicha libertad seria motivada por la atracción de los judíos ricos de Suriname, las

\footnotetext{
1162 Idem, p. 54. Sr. Diputado Maciel da Costa.

${ }^{1163}$ Ididem. Para estas y otras afirmaciones del diputado.

${ }^{1164}$ Idem, p. 53. Sr. Diputado Maciel da Costa.
} 
discusiones en las Cortes se procesaban en otra órbita, la de los protestantes. La presencia inglesa, como venimos hablando, era fuerte en la sociedad brasileña de entonces, y los Tratados de 1810 les garantizaban la libertad religiosa, así que, creemos que era imposible para los diputados salvar este detalle de forma tan simple ${ }^{1165}$, principalmente porque dichos tratados serán, en 1826, reeditados en el ordenamiento jurídico brasileño. Eso es lo que vamos a percibir en la intervención del diputado Sr. Rodrigues da Costa. Tal diputado levantaba los fantasmas de las guerras religiosas de Europa, y declaraba que de este modo "levantaríamos altar contra altar dentro da mesma nação ${ }^{1166, "}$. Y añade:

“(...) uns seguiríamos as máximas que nos ensinam os Santos Evangelhos de Jesus Cristo, e outros os perversos dogmas de Calvino, de Luthero e de muitos outros irisiarcas que se quiseram erigir em reformadores ${ }^{1167}$."

A decir la verdad, dicho diputado nombra algunas religiones no cristianas, pero, siempre con una visión estereotipada de las mismas; así que, cita la apostasía en la religión mahometana y en sus sectas. Pero, no nombra a los judíos. De este modo, el diputado veía como un escándalo público permitir a los brasileños seguir la religión que les pareciese bien, o sea, establecer tan amplia libertad religiosa. Vimos antes, que en las Cortes de Lisboa ya se estableció la libertad religiosa para los extranjeros, pero, se prohibía a los portugueses abrazaren otra religión distinta de la Católica. Parece que tal principio no regia en la Asamblea como un todo, dado que estaba disciplinado ya en el Proyecto que quedaba prohibido los derechos políticos a los que profesasen religión diversa del Estado, pero, no el acceso a la ciudadanía y el reconocimiento de derechos civiles. El discurso sigue en términos escatológicos. Y finaliza haciendo una petición al Presidente de la Asamblea, para que no se aprobase y fuese excluido semejante artículo ${ }^{1168}$.

Para rebatir tamaña profesión de fe que hizo el preopinante anterior, se levantó el Diputado Muniz Tavares, con las siguientes palabras:

"Sr. presidente, eu digo como Montesquieu, aqui sou politico, não sou teólogo; e já que felizmente, graças a Deus, não estamos nesses tempos de estupidez em que o monge S. Bernardo prometia ao Sr. De Chatillon em troco do imenso terreno, que lhe dava para a fundação da abbadia de Ligni, um espaço de igual extensão no Paraiso; como já ninguém receia ser queimado vivo, como herege, ou heterodoxo, por discordar da opinião de teólogos, não devo eu igualmente recear de dizer francamente a minha opinião sobre tão importante matéria ${ }^{1169}$."

\footnotetext{
${ }^{1165}$ En este sentido, se puede ampliar los conocimientos con la lectura de FREYRE, Gilberto: Ingleses no Brasil. Aspectos da influencia britânica sobre a vida, a paisagem e a cultura no Brasil, $3^{\mathrm{a}}$ Edição, Topbooks Editora, Rio de Janeiro, 2000, 149 y ss.

${ }^{1166}$ APBAC, Sesión de 8 de octubre, p. 56. Sr. Diputado Rodrigues da Costa.

${ }^{1167}$ Ibídem.

${ }^{1168}$ Idem, p. 57.

${ }^{1169}$ Idem, p. 57. Sr. Diputado Muniz Tavares.
} 
Seguirá el mismo diputado en sus catilinarias en contra de las opiniones reaccionarias de Rodrigues da Costa. Afirma Muniz Tavares que, la libertad religiosa es uno de los derechos más sagrados que puede tener el hombre en sociedad: "Reputo direito sagrado, porque estou certissimo, que a consciencia é um santuario, onde poder nenhum humano tem direito de entrar $^{1170,}$. El preopinante se declara católico, y en esta religión se halla cómodo, pero, en una hipótesis de que la abandonara, afirma:

“(...) se a graça me abandonar, e eu passar a seguir outra religião, não desejarei ser perseguido, nem inquietado no exercício dessa religião adoptada, e persuado-me que o nobre deputado, que acaba de falar, também não desejaria ser perseguido $^{1171}$.",

Además, en términos duros, Muniz Tavares contesta punto por punto a las alegaciones reaccionarias de Rodrigues da Costa, y va a decir que no acredita ver renovado entre los brasileños la noche de S. Bartolomé, y pregunta a Rodrigues Costa si quiere ver reaparecer al Tribunal del Santo Oficio o que se enciendan las hogueras en Brasil. Y da argumentos muy fuertes a favor de la libertad religiosa. En otra intervención, y en respuesta al mismo diputado, Tavares afirma que no es suficiente decir que no se va a perseguir a los que profesan otra religión, es preciso más:

“(...) Porém ainda isto não basta, é de absoluta necessidade para a manutenção da boa ordem, e prosperidade do país, que o governo proteja claramente a todos os seus súbditos seja qual for à religião que seguirem; que lhes não vede jamais os exercícios dos seus respectivos cultos, ao que já pelo $\S 8^{\circ}$ do art. $5^{\circ}$ se acha estreitamente obrigado para com os estrangeiros ${ }^{1172}$."

En aquél inciso, dirá el diputado, decimos que los extranjeros naturalizados, cualquiera que sea su religión son ciudadanos brasileños. Otro diputado, Henrique Resende, levanta la voz a favor de la tolerancia religiosa, y enumera algunos hechos históricos para demostrar que la intolerancia solo lleva a la desgracia; incluso cita a Fernando VII, y los problemas que la intolerancia religiosa trajo a España. Además, ofrece una enmienda al inciso, en donde se debía

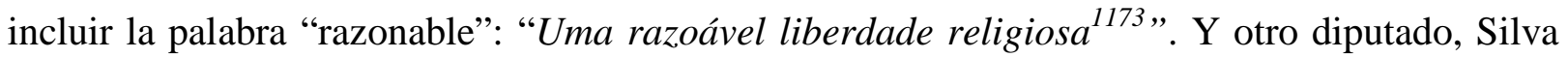
Lisboa, veía como incongruentes el juramento de "guardar a religião católica apostólica romana" con la "libertad religiosa" ${ }^{1174}$, que se pone como uno de los derechos de los ciudadanos brasileños. El diputado, va a decir que con la libertad religiosa muchos van a

\footnotetext{
${ }^{1170}$ Ibídem.

${ }^{1171}$ Ibídem.

${ }^{1172}$ Idem, p. 58. Sr. Diputado Muniz Tavares.

${ }^{1173}$ Idem, p. 59. Sr. Diputado Henrique Resende.

${ }^{1174}$ Idem, p. 60. Sr. Diputado Silva Lisboa.
} 
desertar de la católica romana. Y acusará la libertad religiosa en Brasil como "liberdade de perjurio e liberdade de apostasía ${ }^{1175, "}$. Así que, por ser perjuro, era:

"Absolutamente livre comportar-se como um herege, cismático, e ainda como judeu, maometano, pagão, com a única diferença, que das comunhões cristãs é livre a profissão publica, e que, fora delas, só se concede tolerância, para seu culto privado; a qual, contudo tem os idênticos e benéficos efeitos do governo liberal do império ${ }^{1176}$."

Hará el diputado una alusión al Congreso de Lisboa y de la tolerancia sólo para los extranjeros:

"Que dirá de nós o povo de Portugal, onde os arquitetos da sua constituição, publicamente anunciando que pretendiam faze-la, se fosse possível, mais liberal que a da Espanha, não concederão a liberdade religiosa, bem considerando a universalidade do catolicismo da nação portuguesa, pura e simplesmente declarando no titulo $2^{\circ}$, capitulo único, artigo 25: - A religião da nação portuguesa é a católica, apostólica, romana. - Permite-se com tudo aos estrangeiros o exercício particular dos seus respectivos cultos? ${ }^{1177, "}$

Dirá, además, que no hay en Brasil de forma apreciable nacionales que profesen el Luteranismo, Calvinismo u otras sectas disidentes de la religión católica ${ }^{1178}$. En su larga catilinaria, Silva Lisboa, amenazaba con el ateísmo, con el indiferentismo religioso, con toda suerte de desgracias a la Nación y al pueblo, que veía ministros y cultos extravagantes como de los metodistas. También admite que se podría esparcir la religión anglicana, que tanto era alabada como "favorable al progreso de la libertad política, sana moral y activa industria". Así que el referido diputado llega al punto en cuestión, al miedo hacía los ingleses y su influencia comercial, pasando a ser religión dominante la anglicana, y se vería repetir la intolerancia que aquellos mantienen por los irlandeses ${ }^{1179}$. Y vuelve a afirmar que la tolerancia solo es razonable para conceder derechos cívicos a los extranjeros, lo que no se aplica a los nacionales. Dado que dichos extranjeros capitalistas e industriosos de todas las naciones serían deseables. Sin embargo, otros dos diputados van a defender la libertad religiosa en la Asamblea Constituyente, el Sr. Andrada Machado, el Sr. Carneiro ${ }^{1180}$ y el Sr. Vergueiro, con fundados argumentos, principalmente a lo ya aprobado inciso VIII del art. $5^{\circ}$ del Proyecto. Además, el Sr. Carneiro va a traer el ejemplo de la libertad política de la religión en Inglaterra (salvadas las animosidades en contra de los irlandeses), de los Países Bajos, Francia y Estados Unidos, que reconocen tanto el principio de la libertad política de los cultos que hasta han prohibido que se haga ley alguna

\footnotetext{
${ }^{1175}$ Idem, p. 61. Sr. Diputado Silva Lisboa.

1176 Ibídem.

1177 Ibídem.

${ }^{1178}$ Idem, p. 62.

1179 Ibídem.

${ }^{1180}$ Idem, p. 63.
} 
acerca de la religión. Y de los portugueses cita el pasado de los judíos y su importancia en el gobierno de aquel país ${ }^{1181}$. El futuro redactor de la Constitución que estará vigente durante todo el siglo XIX en Brasil, Carneiro de Campos, se manifiesta favorable a la libertad religiosa, y dice que habla no como teólogo, sino como un publicista inspirado en el derecho público ${ }^{1182}$. La discusión concerniente la a libertad religiosa vuelve con fuerza en la sesión de 9 de octubre, y el diputado Silva Lisboa insistirá con muchos más argumentos en contra de dicha libertad. Parece que se había olvidado lo que había dicho el relator de la comisión que elaboró el proyecto, el diputado Silva Lisboa quien afirmará que es inconsecuente la regla propuesta, puesto que, si es derecho individual del ciudadano la libertad religiosa, no se pude limitar dicha libertad a las comuniones cristianas, y que se debía extender a todos los fines y efectos también a la religión judaica y a la mahometana ${ }^{1183}$. Esta sesión, así como la precedente se siguió de intensos debates, con muchos argumentos en contra y a favor de la libertad religiosa, a tal punto que Maciel da Costa llegó a decir que si fuese un combate literario, él hacía mucho había accedido a los que opinaban contra la libertad religiosa ${ }^{1184}$.

La ciudadanía estaba envuelta en un aura de santidad, puesto que sólo se debía conceder a los que abrazasen la santa religión católica apostólica romana. Esta era la opinión de muchos diputados. Pero, Maciel da Costa intentaba hacer prevalecer otro tipo de opinión cuando dice que la justa, la santa libertad que debe querer el pueblo brasileño es de otro tipo:

“(...) Essa liberdade que se pretende decretar é fundada no grande principio de que o homem é livre de adorar a Deus ao seu modo e segundo lhe ditar sua razão, liberdade que as leis humanas não devem contrariar ou atacar ${ }^{1185}$."

Pero, frente a tantos argumentos, parece que Maciel da Costa cede a la presión de los opositores a que se decrete la libertad religiosa. Al final de su discurso pide que se suprima el inciso III del art. $7^{\circ}$ y que se abra un capítulo sólo para tratar de asuntos religiosos, en donde se establezcan las condiciones que se deben imponer a los extranjeros de diferentes comuniones que se han de admitir en el Imperio. Siguiendo el debate, el diputado Montezuma, dirá:

"Quando eu li este paragrafo (inciso III del art. $7^{\circ}$ ) parecia-me que não admitiria discussão nenhuma, esta doutrina casou-se tanto com o meu modo de entender, que julguei que todo o mundo teria no coração o que diz este paragrafo, $e$ que passaria, sem haver um só deputado que entendesse o contrario ${ }^{1186}$."

\footnotetext{
${ }^{1181}$ Idem, p. 64.

1182 Idem, p. 65. Sr. Diputado Carneiro de Campos.

${ }^{1183}$ Idem, Sesión de 9 de octubre, p. 76. Sr. Diputado Silva Lisboa.

${ }^{1184}$ Idem, p. 79. Sr. Diputado Maciel da Costa.

${ }^{1185}$ Idem, p. 81. Idem.

${ }^{1186}$ Idem, p. 82. Sr. Diputado Montezuma.
} 
Parece que del mismo modo de pensar, sorprendentemente, participaba el Obispo Capelán-Mayor. El taquígrafo perdió su discurso, pero en líneas generales mostraba estar en contra de las persecuciones, intolerancias, fanatismos y barbaries. Pero, como era un obispo, igualmente, mantuvo que no podía admitir que se estableciese la tolerancia legal de todas las religiones o el indiferentismo filosófico ${ }^{1187}$. Después de la intervención del obispo, el relator del proyecto Sr. Andrada Machado hizo un duro discurso a favor de la libertad religiosa aportando algunas definiciones: "Liberdade religiosa é o direito de seguir cada um a religião que quiser, isto é, de dar a Deus o culto que a sua consciência lhe ditar por melhor ${ }^{, 1188}$. Después de otras dos intervenciones el presidente sometió a votación el inciso III del art. $7^{\circ}$, y preguntando si pasaba tal y como estaba redactado, se votó que sí. Iba venciendo, por ahora, la libertad religiosa $^{1189}$.

Los enfrentamiento en el tema de la religión vuelven al plenario en la sesión de 29 de octubre, con la discusión del art. 14 que declaraba que: "A liberdade religiosa no Brasil só se estende às Comunhões Cristas; todos os que as professarem podem gozar dos Direitos Políticos do Império" ${ }^{1190}$. El diputado Ornellas dirá que ésta es una extensión a las demás religiones cristianas, principalmente a las doctrinas de Lutero y Calvino. Así, será de la opinión que las demás religiones, sin distinción, fueron apenas toleradas y que el culto público estuviese reservado solamente a la religión católica. Recuerda el mismo diputado que si Francia lo había hecho es porque su diversidad religiosa lo permitía, lo que no cabría en Brasil en donde había una uniformidad religiosa. Así que el diputado Ornellas propondrá la siguiente enmienda:

"Proponho que em lugar da doutrina do $\$ 14$ se lhe substitua a seguinte - a liberdade religiosa consiste em que nenhum cidadão ou estrangeiro possa ser inquietado e perseguido, de qualquer modo que seja, pelas suas opiniões religiosas, uma vez, que se conforme com as leis do estado, e não perturbe a ordem social nele estabelecida. Quanto, porém, ao culto publico, só é permitido no Brasil aos da comunhão católica apostólica romana ${ }^{1191}$."

La libertad de culto será siempre un problema en el ámbito de la libertad religiosa para un país católico como era el Brasil Imperio. El art. $14^{\circ}$ trataba apenas de la libertad religiosa respeto a las creencias cristianas, en donde se preveía la atribución de los derechos políticos a los ciudadanos que profesasen dichas religiones. Por haber discrepancias profundas en esta materia propuso y fue apoyada por el diputado Sr. Paula e Mello que se analizasen en conjunto

\footnotetext{
${ }^{1187}$ Idem, p. 83. Sr. Diputado Obispo Capelão-mor.

${ }^{1188}$ Idem, p. 83. Sr. Diputado Andrada Machado.

${ }^{1189}$ Idem, p. 84.

${ }^{1190}$ PROJECTO DE CONSTITUIÇAO PARA O IMPÉRIO DO BRASIL (Asamblea Constituyente de 1823) In: MIRANDA, Jorge: O constitucionalismo..., op. cit., p. 206.

${ }^{1191}$ APBAC, Sesión de 29 de octubre de 1823, p. 212. Sr. Diputado Ornellas.
} 
los arts. $14^{\mathrm{o}}, 15^{\mathrm{o}}$ y $16^{\mathrm{o}}{ }^{1192}$. El art. $15^{\circ}$, trataba de las otras religiones. De manera que así se expresaba: “As outras religiões, além da Crista, são apenas toleradas, e a sua profissão inibe o exercício dos Direitos Políticos" $" 1193$. Y el art. $16^{\circ}$ proclamaba la confesionalidad del Estado: “A Religião Católica Apostólica Romana é a Religião do Estado por excelência, e única mantida por ele" ${ }^{, 194}$.

En la misma sesión, el diputado relator del proyecto, Sr. Andrada Machado, va a plasmar algunas demandas en la propuesta de tres enmiendas a los artículos en discusión, aunque, la esencia de los artículos permaneciese más o menos igual:

"14. Cada membro das comunhões cristãs pode professar a sua religião no recinto destinado para esse fim. Todos os que professarem estas comunhões podem gozar dos direitos politicas. 15. As outras religiões, além da cristã, são apenas toleradas, e só lhes compete o culto doméstico; e a sua profissão inibe o exercício dos direitos políticos. 16. A religião católica apostólica romana é a religião do estado, e a única manteúda por ele; e só a ela compete o culto externo fora das igrejas $^{1195}$."

Las reformas propuestas iban en el sentido de que no se autorizase a las demás religiones el culto público. Quedaba reservado apenas a la religión católica dicho atributo, por ser la religión oficial del Estado. Y en perfecta sintonía con Andrada Machado, el diputado Rocha Franco, propuso una enmienda al art. $14^{\circ}$ extendiendo la libertad religiosa a los judíos, pero elimina de la enmienda cualquier referencia a la concesión de derechos políticos a los mismos: "A liberdade religiosa no Brasil, se estende às comunhões cristas e ao judaísmo ou religião judaica ${ }^{1196 . " ~ M u c h o ~ m a ́ s ~ l i b e r a l ~ f u e ~ e l ~ d i p u t a d o ~ H e n r i q u e s ~ d e ~ R e s e n d e, ~ q u e ~ d e f e n d i o ́ ~}$ los principios presentados por Andrada Machado, y además, alerta que: "no Brasil ha muitos fanáticos: os inimigos da constituição não deixarão de lançar mão disto para suscitarem os povos" ${ }^{\prime 197}$. Dicho diputado, movido por el miedo de las masas, según sus propias palabras, va a proponer una enmienda al art. $16^{\circ}$, para que se prive de los derechos políticos a los que apostataren en contra de la religión oficial. Se le enfrenta el diputado França, para criticar los desvaríos reaccionarios de algunos diputados, cuando dice: "Nao sejamos pois maus políticos à custas de parecermos mui católicos" $" 1198$. Así pues vuelve a defender Henriques Resende que se supriman los derechos políticos a los católicos que abandonen su religión. Esta discusión nos

\footnotetext{
${ }^{1192}$ Idem, p. 212. Sr. Diputado Paula e Mello.

${ }^{1193}$ PROJECTO DE CONSTITUIÇAO PARA O IMPÉRIO DO BRASIL (Asamblea Constituyente de 1823) In: MIRANDA, Jorge: O constitucionalismo..., op. cit., p. 206.

1194 Ibídem.

1195 APBAC, Sesión de 29 de octubre de 1823, p. 212. Sr. Diputado Andrada Machado.

${ }^{1196}$ Idem, p. 213.

${ }^{1197}$ Idem, p. 213. Sr. Diputado Henriques de Resende.

${ }^{1198}$ Idem, p. 214. Sr. Diputado França.
} 
pareció muy similar en las actas de las Cortes de Lisboa, allí se amenazaba igual a los católico apóstatas. Al parecer la defensa de la tolerancia religiosa estaba condicionada a los extranjeros, principalmente si ese extranjero era inglés o europeo. De este modo, entre las religiones cristianas que primero van establecerse en Brasil estaba la anglicana, y de ahí se deprende la tolerancia del art. $14^{\circ}$.

Muy interesante será el comentario del diputado Carvalho e Mello. Este diputado recordará el ejemplo de Estados Unidos, en donde todas las sectas del cristianismo conviven en perfecta armonía. Pero, dirá el diputado que muchos afirman que este ejemplo no serviría a Brasil, puesto que, en Estados Unidos no hay una religión oficial del Estado, y, por tanto, no necesitaba defenderla de la contaminación proselitista de las demás. Sin embargo, recuerda Carvalho e Mello que el proselitismo no es causa de guerras ni querellas en Estados Unidos, por lo tanto, puede que no lo sea tampoco en Brasil; no hay un peligro en el proselitismo, y Estados Unidos es ejemplo de ello. Llama la atención también sobre un ejemplo en el propio Brasil:

"Nós temos entre nós argumento mais poderoso. Existe uma igreja e culto anglicano, permitido pelo tratado de 19 de Fevereiro de 1810, e dele se não seguiu ainda o mais leve perigo, nem receio de desassossego, apesar de que deslizando-se os ingleses algum tanto do que lhes fora permitido, construirão igreja com exterior próprio delas, o que lhes fora expressamente denegado ${ }^{1199}$."

Así que en Brasil ya había una tolerancia religiosa de cierta forma arraigada, dado que las discusiones se procesaban trece años después de la firma del Tratado de 1810. Sobre la concesión de los derechos políticos a los que profesaren una creencia diversa de la católica, pero siendo esta de base cristiana, Carvalho e Mello se pronuncia a favor de la concesión de los derechos políticos:

"Se os que as professarem forem cidadãos brasileiros, por nascimento ou naturalização, injusto será priva-los dos direitos politicas só pela diferença de crença, e exemplo temos na cristianíssima França, onde todos os cidadãos gozam de iguais direitos; e para notar é, que pela teimosa porfia com que os ingleses privam os católicos irlandeses dos empregos politicas, se têm suscitado querelas religiosas, e discussões, que talvez sejam a origem principal da anarquia $e$ desgraças da Irlanda ${ }^{1200}$."

En esa misma línea, Silva Lisboa va a proponer la unión de los arts. 24 y el 143 del proyecto por entender que van conexos a las discusiones de los arts. 14, 15 y 16. El art. 24 concede a los obispos, con auxilio del Estado, el poder de censura a los escritos publicados sobre de dogma y moral. Y el 143, obliga al emperador a jurar y mantener la religión católica. En esto veía el citado diputado dos problemas. Con la dicción del art. 24 veía una incongruencia

\footnotetext{
${ }^{1199}$ Idem, p. 217. Sr. Diputado Carvalho e Mello.

${ }^{1200}$ Ibídem.
} 
castigar solo a los que profesasen la religión católica y publicasen dichos papeles. Y el art. 143, criticaba el hecho de que se obligase al emperador a jurar y mantener a la religión católica, pero no le obligaba expresamente a que observase e hiciese observar la misma religión, como sí se hacía en relación a la constitución ${ }^{1201}$. Usando dichos argumentos, se pregunta el diputado en cuestión: "Como o imperador poderá manter tal religião, se os brasileiros tem liberdade de não observa-la? ${ }^{1202} "$ Así que, Silva Lisboa continuará con sus catilinarias en contra de la libertad religiosa, y llega a decir que aún le duele haber aprobado el inciso VIII del art. $7^{\circ}$.

El diputado Sr. Obispo Capelao-mor, en la sesión de 30 de octubre propondrá tres enmiendas a los artículos en discusión. Siendo que para el $14^{\circ}$ propone que allí se diga que: "Ninguém será perseguido por suas opiniões religiosas, uma vez que não ofendam as leis e os costumes" ${ }^{1203}$. En el art. 15 se declaraba la confesionalidad del Estado. Y para el art. $16^{\circ}$, lo más curioso: "Algumas outras religiões serão toleradas, quando se verificarem motivos justos e urgentes; e o seu culto particular ou público será determinado por lei"1204. De este modo, buscaba el diputado alejar de la constitución la protección de la libertad religiosa y de culto, dejando dicha libertad como objeto de ley reglamentaria. El diputado Montezuma dirá que las proposiciones del Obispo son antes fruto del ministerio religioso que ocupa, que de los principios de derecho civil. Rebate así completamente el argumento del diputado obispo ${ }^{1205}$.

La discusión en torno a estos artículos que se ocupaban de la libertad religiosa regresó de nuevo en la sesión de 5 de noviembre; ésta ya era la quinta sesión desde que se empezó a discutirse el asunto. Los argumentos a favor o en contra eran recurrentes y no pocas veces iban a ser más de lo mismo. Silva Lisboa era siempre protagonista de extensas catilinarias en contra de la libertad religiosa, llenas de eruditismos. También otros diputado, como Lopes Gama, seguirá defendiendo arduamente la libertad religiosa, así como muchos otros diputados. Numerosas enmiendas son planteadas, desde la del diputado Lopes Gama que prohibía acceder al legislativo y a los alto cargos a quienes profesasen religión diversa de la católica, hasta las enmiendas presentadas por los diputados Brant Pontes y del Sr. Vergueiro, en las cuales propusieron reunir los tres artículos en uno solo, declarando la religión católica como la oficial y mantenida por el Estado, así como tolerando las demás religiones, pero, ninguna palabras sobre a atribución de los derechos políticos. La discusión de la materia fue una vez más

\footnotetext{
${ }^{1201}$ Idem, p. 218. Sr. Diputado Silva Lisboa.

1202 Ibídem.

1203 APBAC, Sesión de 30 de octubre de 1823, p. 224. Sr. Diputado Obispo Capelao-mor.

${ }^{1204}$ Idem, p. 225.

${ }^{1205}$ Ibidem. Sr. Diputado Montezuma.
} 
aplazada, bajo las protestas del Sr. diputado Vergueiro, que dijo, no sin razón, que dicha discusión se debía ultimar, puesto que, de lo contrario nunca tendría fin ${ }^{1206}$.

En la sesión del 6 de noviembre se vuelve a la discusión. El diputado Sr. Francisco Carneiro planteó una enmienda, que de cierta forma es una reproducción del Tratado de 1810 en cuanto a la tolerancia religiosa a los extranjeros y la prohibición del culto público a dichas religiones no católicas. La fórmula se presentaba de esta manera:

"Quanto ás outras religiões e seitas que por via de colonos, ou quaisquer outros estrangeiros que as professem, e seus descendentes tenham já, ou possam vir a ter existência no império, elas serão todas toleradas, e seus sectários grosarão do livre exercício do seu culto, quer nas casas de sua habitação, quer dentro do recinto dos seus respectivos templos e capelas, construídas sem campanários, e na forma usada nos países civilizados, nem serão jamais incomodados, ou privados do uso deste direito, com tanto que respeitem a moral publica e o estabelecimento religioso do país, e que a titulo de religião e proselitismo não turbem de modo algum a segurança, paz, e tranquilidade do império, e os direitos que a constituição garante a seus habitantes ${ }^{1207}$."

Al fin y al cabo fueron sometidos a votación los artículos 14, 15 y 16 en la sesión de 6 de noviembre. Fueron aprobados separadamente, pero de forma mutilada. El art. 14 fue dividido en dos partes. La primera parte en donde se dice que la libertad religiosa solamente se extiende a las comunidades cristianas no fue aprobada. Pero, la segunda parte sí que pasó, y en ello se garantizaban los derechos políticos. Aunque se siguieron vivas discusiones acerca de las enmiendas ofrecidas a la primera y segunda parte. Entretanto, consultó el presidente a la Asamblea si se debía someter a la votación la segunda parte de dicho artículo, y se decidió que no por encontrarse fuera de lugar. Igual suerte tuvo el art. 15 en su totalidad y el art. 16 tampoco pasó. De las enmiendas planteadas permanecieron las del Sr. Andrada Machado, Sr. Vergueiro y Sr. Francisco Carneiro. Consultada la Asamblea cuales de las enmiendas tenían mayor amplitud, venció la del Sr. Andrada Machado. Así que se procedió a la votación:

"Propôs então o Sr. presidente a $1^{\circ}$ parte da emenda do Sr. Andrada Machado ao art. 14 até ás palavras destinado para esse fim. Foi aprovada por 57 votos, E porque devesse preferir, na votação da $2^{a}$ parte do artigo, a do Sr. Vergueiro, por ser supressiva, foi oferecida à votação e aprovada por 38 votos. A $1^{a}$ parte da emenda ao art. 15 até as palavras culto domestico foi aprovada por uma grande maioria, suprimindo-se a $2^{a}$ parte deste artigo por se julgar deslocada como já se tinha praticado com a do art. 14, reservando-se portanto o tratar desta matéria em lugar apropriado. A emenda ao art. 16 passou com grande maioria. $O$ aditamento do Sr. Rocha Franco ao art. 14, posto à votação em lugar competente, foi rejeitado. $O$ do Sr. Vergueiro também não passou. $O$ do Sr. Henriques de Resende ao art. 16

\footnotetext{
1206 APBAC, Sesión de 5 de noviembre de 1823, p. 254. Sr. Diputado Vergueiro.

${ }^{1207}$ APBAC, Sesión de 6 de noviembre de 1823, p. 259. Sr. Diputado Francisco Carneiro.
} 
foi reservado para se tratar conjuntamente com as emendas do Sr. Andrada Machado por conterem matéria idêntica ${ }^{1208}$."

Es importante recordar que cinco días antes de que el emperador cerrase la Asamblea Constituyente el tema de la ciudadanía y sus relaciones con la declaración de confesionalidad del Estado no estaba claramente definida. Posiblemente, por la repercusión que tuvo la discusión de la libertad religiosa en los periódicos, además de los malentendidos entre la Asamblea y el emperador, en la sesión de 7 de noviembre hubo un caudal de declaraciones de los diputados explicando los motivos personales de su votació, es decir aclarando el voto. A modo de ejemplo recogeremos las explicaciones de un diputado arduo defensor de la libertad religiosa y de conciencia, el Sr. Montezuma:

"Declaro que votei contra as restrições da liberdade religiosa vencidas na sessão de ontem, assim como votei contra o não conceder-se culto publico ao judaísmo; aprovando em tudo e por tudo que a religião católica apostólica romana fosse a religião do estado, única manteúda por ele, e cujas funções se pudessem exercitar fora dos seus templos. - O deputado Montezuma ${ }^{1209}$.”

También, en la misma sesión, el diputado Sr. Andrada Machado propuso que las restricciones de la libertad religiosa no formasen artículo constitucional, y que pudiese ser alterada por las legislaturas ordinarias. También requirió el diputado que entrase en el orden del día de las votaciones por tratarse de materia conexa con los artículos vencidos en la sesión antecedente, y ganó el sí ${ }^{1210}$. El diputado Silva Lisboa va a manifestarse en contra de la discusión de la proposición de Andrada Machado, siendo de la opinión que la materia solamente volviese a ser discutida conjuntamente con el art. 268 del proyecto, en donde se declaraban los artículos no constitucionales. Y usando de un tono triunfalista, dirá:

"É maravilha que as que tantas vezes intitulou verdades eternas - por súbita metamorfose se mostrem - verdades efémeras. - Assim se desfaz o proposito daqueles artigos; pois deixa-se ao arbítrio de outras legislaturas a sua alteração $^{1211}$."

Y añade, además, que para el bien de la nación, ésta debía permanecer en perfecta concordia entre el sacerdocio y el imperio, y que no se debía prescindir jamás del complicado sistema de las opiniones populares, con el que se ha regido la monarquía, cuya legislación permanece tan escrupulosa, a lo en que atañe a la materia eclesiástica. Eran palabras enigmáticas que querrían solo decir una sola cosa: el Estado debía permanecer confesional a lo

\footnotetext{
1208 Ibidem.

1209 APBAC, Sesión de 7 de noviembre de 1823, p. 265.

${ }^{1210}$ Idem. Sr. Diputado Andrada Machado.

${ }^{1211}$ Idem, p. 266. Sr. Diputado Silva Lisboa.
} 
largo y ancho de sus instituciones. Y complementa sus argumentos con el ejemplo de Napoleón:

"Espero que este iluminado congresso, bem calculando o estado da nação, até se lembre da prudência politica de Bonaparte, que só pôde sustentar o império francês sobre a base da religião católica, fazendo nova concordata com o sumo pontífice, não obstante a nação antes gozar das que se intitulavam liberdades da igreja gallicana ${ }^{1212}$."

Esta advertencia a los diputados no serviría de mucho en materia constituyente, pues ya no sobraría tiempo para tratar de la ciudadanía en los términos que hasta el momento se vino discutiendo. Como ya decimos, el 12 de noviembre un decreto del emperador disolvía la Asamblea Constituyente. El último artículo a ser sometido a discusión fue el art. $24^{\circ}$ que trataba de la censura de los escritos en materia de dogma y moral, que había sido colocado bajo la autoridad de los obispos. Aun así, el diputado Almeida Albuquerque había ofrecido una enmienda que indicaba la supresión de dicho artículo, había sido apoyado, y las discusiones aplazadas, pero eso no se produjo nunca, como ya dijimos ${ }^{1213}$. Entretanto, tales discusiones, aunque no conclusivas, nos servirá de mucho para pasarnos al texto constitucional otorgado, principalmente para comprender la relación del binomio ciudadanía/confesionalidad en materia de derechos políticos.

Así que, la definición formal de ciudadanía en el texto constitucional de 1824 tenía sus matices, en un juego de inclusiones y exclusiones bastantes curioso. El título I, dedicado al territorio, gobierno, dinastía y religión del Imperio de Brasil, formalmente en el art. $1^{\circ}$ declaraba que "O Império do Brasil é a associação Política de todos os Cidadãos Brasileiros". Hasta aquí pensamos en una vasta inclusión en el texto constitucional. Y el título II de la Constitución se dedicaba a decir quiénes eran los "Cidadãos Brasileiros". El art. $6^{\circ}$ del mismo título y en sus cinco incisos definirá la calidad de ciudadano, que era en cierto modo bastante amplio y asequible. El inciso I, dirá que los que hubieren nacidos en Brasil, sean ingenuos o libertos, aunque el padre sea extranjero, una vez que no estén al servició de su propia nación, pueden acogerse a la ciudadanía del Imperio. En el inciso II, se dice que los hijos de padre brasileño, y los ilegítimos de madre brasileña, aunque nacidos en el extranjero, si vinieren a establecer domicilio en el Imperio, pueden acceder a dicha ciudadanía. Para el inciso III, la definición es que los hijos de padre brasileño, que esté al servicio del Imperio, y venga a domiciliarse en él, es brasileño. El inciso IV extiende a todos los nacidos en Portugal y en sus posesiones, que siendo residente en el momento de la independencia, en las provincias en que

\footnotetext{
${ }^{1212}$ Idem, p. 267. Sr. Diputado Silva Lisboa.

1213 APBAC, Sesión de 11 de noviembre de 1823, p. 290. Sr. Diputado Almeida Albuquerque.
} 
habitaban, se hubieren adherido expresamente a la causa de Brasil, o de forma tácita por la residencia continuada, también estaba considerado como siendo brasileño. Y por fin, en el inciso $\mathrm{V}$, se concede la ciudadanía a los extranjeros naturalizados, y se añade, cualquiera que sea su religión. Aunque deja a una ley ordinaria la tarea de determinar los requisitos necesarios para obtener la carta de naturaleza ${ }^{1214}$. De este modo, tanto el criterio del "Ius solis" como del “Ius sanguinis" son adoptados para la concesión de la ciudadanía.

Los derechos políticos de los ciudadanos brasileños no solamente se ganan, sino que también se pierden y se suspenden. El art. 7 cuidará de la perdida de la condición de ciudadano. El inciso I no admite la doble ciudadanía, y el que se naturalice en país extranjero, pierde la condición de brasileño. También pierde él que acepte empleo, pensión o condecoración de cualquiera gobierno extranjero, sin licencia del emperador (inciso II). Él que fuera banido por sentencia, también pierde aquella calidad de ciudadano (inciso III). Además, el ejercicio de los derechos políticos del ciudadano se puede suspender en las siguientes posibilidades: por incapacidad física o moral (inciso I); por sentencia condenatoria de prisión o pena de degredo, mientras dure los correspondientes efectos (inciso II) ${ }^{1215}$.

Los horizontes marcados por la constitución para declarar un individuo ciudadano del Imperio hacían que muchos se quedaran fuera de dichos horizontes. Incluso dentro de los límites trazados para la ciudadanía había recortes y limitaciones. Considerando la dicción de los artículos $3^{\circ}$ y $16^{\circ}$ de la Declaración de Derechos del Hombre y del Ciudadano, en donde el primero dice que la soberanía reside esencialmente en la Nación, y el segundo habla de la división de poderes; podemos deducir con la lectura del art. $9^{\circ}$ de la Constitución de 1824, en donde dice que la división y armonía de los poderes políticos es el principio conservador de los derechos de los ciudadanos, y es, además, el más seguro medio de hacer efectivas las garantías que la Constitución ofrece; así que, la existencia de un Poder Moderador en el Imperio, como vimos, vulneraba al pleno ejercicio de dichos derechos de los ciudadanos ${ }^{1216}$.

Cierto es que el legislador constitucional estaba determinado a no conceder a todos la ciudadanía por el inmenso contingente de esclavos existentes en el Imperio, que ni siquiera son nombrados en el texto constitucional. Sin embargo, también están seguros de que los titulares de la ciudadanía debían ser divididos en dos grupos, siguiendo la solución constitucional francesa de 1791, que fue adoptada en el proyecto de Antonio Carlos y que ahora también lo

\footnotetext{
1214 (Archivo John Carter Brown Library) - CONSTITUIÇAO POLÍTICA DO IMPERIO DO BRASIL (Independência ou Morte), Na Typographia de Plancher, Impressor Livreiro de Sua Magestade Imperial, Rio de Janeiro, 1824, pp. 3 y 4.

1215 Ibídem.

1216 Ibídem.
} 
vemos plasmado en la Constitución del Imperio. Es evidente que el criterio censitario adoptado por el texto de 1824 dotaba al ciudadano de un carácter elitista, y que también sirvió para excluir los otros del derecho de sufragio. Así pues, según el art. 92, V, en donde se excluía de votar en las elecciones parroquiales a los que no poseyesen una renta líquida anual de cien mil reales por bienes de raíz, industria, comercio o empleo público ${ }^{1217}$.

Dentro de estas perspectivas aparece el papel del ciudadano "acatólico" en el proceso electoral del Imperio de Brasil. En la arquitectura constitucional las relaciones entre ciudadanía, religión y voto ganan nuevos adornos en el frontispicio político. Así que, después de las discusiones procesadas en la Asamblea Constituyente en materia religiosa, el art. $5^{\circ}$ del texto constitucional otorgado establecerá para casi todo el siglo XIX en Brasil que: "A religião Católica Apostólica Romana continuará a ser a religião do Império. Todas as outras religiões serão permitidas com seu culto doméstico ou particular, em casas para isso destinadas, sem forma alguma exterior de Templo" ${ }^{1218}$. En el art. $6^{\circ}$, incisoV, también pasó a determinar que eran ciudadanos: "Os estrangeiros naturalizados, qualquer que seja a sua religião"1219. Más adelante en el texto constitucional (art. 95, III), veremos que no podían ser electos diputados los que no profesasen la religión del Estado. El art. 102, II, establecia el Patronato Régio, atribuyendo al emperador el poder de "nomear bispos e prover os beneficios eclesiásticos". El inciso XIV del mismo artículo establece, además, que el emperador debía “conceder, ou negar o Beneplácito aos Decretos dos Concílios, e Letras Apostólicas, e quaisquer outras Constituições Eclesiásticas que se não opuserem à Constituição; e precedendo aprovação da Assembleia, se contiver disposição geral". La garantía de una controvertida libertad religiosa solamente va a aparecer en el Título $8^{\circ}$ - "Das Disposições Gerais, e Garantias dos Direitos Civis, e Políticos" -, en donde en el art. 179, V, se establecia que: "Ninguém pode ser perseguido por motivo de religião, uma vez que respeite a do Estado e não ofenda a moral pública $^{1220 " . ~ A s i ́ ~ q u e, ~ l o s ~ d e r e c h o s ~ p o l i ́ t i c o s ~ a t r i b u i d o s ~ a ~ l o s ~ " a c a t o ́ l i c o s " ~ v e r a ́ n ~ b a s t a n t e s ~}$

\footnotetext{
1217 Ibídem.

${ }^{1218}$ Idem, p. 1. Es interesante notar que el modelo constitucional brasileño, tributario del modelo ibérico, volverá a Portugal con la Carta de 1826, otorgada por D. Pedro I de Brasil (Pedro IV en Portugal). El art. $6^{\circ}$ de la Carta portuguesa reproducirá al art. $5^{\circ}$ de la Constitución del Imperio de Brasil en materia religiosa, con una pequeña diferencia, pues mantiene, así como la Carta de 1822, la libertad religiosa apenas a los extranjeros: "Art. $6^{\circ}-A$ religião católica apostólica romana continuará a ser a religião do reino. Todas as outras religiões serão permitidas aos estrangeiros com seu culto domestico, ou particular, em casas para isso destinadas, sem forma alguma exterior de templo". Véase en FERREIRA, Silvestre Pinheiro: Observações sobre a Constituição do Império do Brasil, e sobre a Carta Constitucional do Reino de Portugal, Segunda Edição, Aumentada com as observações do mesmo autor sobre a lei das reformas do Imperio do Brasil, Em casa de Rey e Gravier y J. P. Aillaud, Paris, 1835, p. 5.

${ }^{1219}$ Idem, p. 1.

${ }^{1220}$ Está claro que esta enunciación de libertad religiosa presente en el art. 179, V, de la Constitución de Brasil de 1824, sigue el artículo X de la Declaración de los Derechos del Hombre y del Ciudadano 1789, que dice que: "Nadie debe ser inquietado por sus opiniones, incluso religiosas, en tanto que su manifestación no altere el orden
} 
disminuidos en este texto constitucional. Como dirá Guilherme P. Neves, muy lejos de lo que podíamos deducir de los debates planteados en la Asamblea Constituyente, en el texto otorgado había desaparecido la libertad religiosa ${ }^{1221}$; aunque pensamos que había sido diluida en el texto para no declararla tajantemente, ni tampoco negarla. Dirá Joaquim Souza, comentador de la Constitución de 1824, que había tres sistemas o modelos en el mundo de entonces sobre las relaciones entre religión y Estado. Así expondrá los tres sistemas el publicista:

“Como assunto político conta a religião três sistemas - Proteger o Estado todas as religiões sem ter uma por sua, sem suprimir alguma - Adotar uma e fazer suas despesas, permitindo as outras à custas daqueles que as professam, ou mesmo do tesouro público. - Reconhecer somente a católica com a exclusão de todas as outras. O $1^{o}$ sistema prevaleceu nos Estados Unidos: o $2^{\circ}$ na França, o $3^{\circ}$ na Espanha e Portugal. Nenhum deles podia o legislador brasileiro adotar; $e$ mormente o $1^{o}$, sendo a religião Católica Apostólica Romana a única religião dos brasileiros. (...) Garantindo a dita liberdade, permitiu as outras religiões com seu culto doméstico ou particular, em casas para isto destinadas sem forma alguma exterior de templo. ${ }^{1222,}$

En este precepto constitucional, según Joaquim Souza, el legislador sigue las doctrinas de Wattel, afirmando que, refiriéndose al extranjero que profesa religión distinta de la que adopta el Estado:

“(...) Deve cada um contentar-se com servir a Deus segundo suas luzes em sua casa, persuadindo-se que a Providencia não exige dele um culto público, colocando-o em circunstancias em que o não pode prestar sem perturbar o Estado ${ }^{1223}$.”

Es interesante observar la arquitectura constitucional proyectada por el legislador brasileño de 1824. En ella se establece, en el art. 5, que la religión del Estado es la Católica Apostólica Romana, a la vez que permite, con culto privado, a las demás religiones. Ya en el art. 179, inciso $\mathrm{V}$, proclamará la no persecución religiosa, o sea, protegiendo indirectamente a las demás religiones "acatólicas". Aunque afirmamos que la discusión liberal sobre la libertad religiosa no morirá con la disolución de la Asamblea Constitucional en 12 de noviembre de

público establecido por la ley”. Esto se repetirá también en el proyecto abortado de Constitución de la Asamblea Constituyente, en donde se consagraba la libertad religiosa en el art. 7, III; art. 15, culminados con el art. 256. Para el Proyecto de Constitución de Antonio Carlos, véase en MIRANDA, Jorge: O constitucionalismo liberal..., op. cit., pp. 206, 207 y 235. Para la Constitución de 1824, véase en (Archivo John Carter Brown Library) CONSTITUIÇAO POLÍTICA DO IMPERIO DO BRASIL (Independência ou Morte), Na Typographia de Plancher, Impressor Livreiro de Sua Magestade Imperial, Rio de Janeiro, 1824, p. 48. Ya para la comparación entre el Proyecto constitucional de 1823 y la Constitución de 1824 en esta materia, véase en MELO, Francisco I. M. Homem de: Escriptos Historicos e Litterarios. I - A Constituiçao perante a historia (2 $2^{\mathrm{a}}$ Ediçao), Editores Eduardo e Henrique Laemmert, Rio de Janeiro, 1868, p. 61.

${ }^{1221}$ NEVES, Guilherme Pereira das: "A religião do império e a Igreja” en GRINBERG, Keila y SALLES, Ricardo (org.): O Brasil Imperial, Volume I - 1808-1831, Coleção - Civilização Brasileira, Rio de Janeiro, 2009, p. 395.

${ }^{1222}$ SOUSA, Joaquim Rodrigues de: Analyse e Commentario da Constituição Política do Império do Brazil ou Theoria e Pratica do Governo Constitucional Brazileiro, Volume I, São Luiz do Maranhão, 1867, p. 28.

${ }^{1223}$ Idem, p. 29. 
1823; opina, con dicción clara y precisa, el publicista Joaquim Souza, que tampoco podía el legislador ordinario suprimir la religión del Estado:

"Não podem alterar a religião do Estado, porque, para sempre garantiu-a a Constituição nas palavras - a Religião Católica Apostólica Romana continuará a ser a Religião do Império. O art. 95, inciso $3^{\circ}$, e o art. 103, o art. 141, incisos $1^{\circ}$ e $2^{\circ}$, da Lei de 19 de agosto de 1946 são outras garantias da perpetuidade da Religião do Estado. ${ }^{124, ”}$

De la misma forma, al comentar el art. 179, inciso V, Joaquim de Souza fundamenta el sentido de libertad religiosa dentro de la lógica confesional del Estado. De tal modo dirá:

"Com isto nada ofende os direitos, a liberdade da razão e consciência do individuo, ou do hospede do país, que professa outra religião: crendo ele ser da essência desta o culto público, cumpre-lhe deixar a terra, cujas leis só o culto particular lhe permitem, não consentindo, entretanto, que ninguém seja perseguido por motivo de religião, uma vez que respeite a do Estado, e não ofenda a moral pública $^{1225}$."

En este capítulo no pretendemos agotar la cuestión electoral vinculada a la cuestión religiosa; eso lo dejaremos para el siguiente capítulo pues el desdoblamiento del tema a lo largo del siglo XIX culminará con la promulgación de la Ley Saraiva. Aquí vamos a ver dicho tema en el ámbito constitucional, aunque vez por otra cotejando con la legislación electoral del período inmediatamente anterior al proceso de independencia y del período de formación de las Asamblea Constituyente de 1823 y la Asamblea Legislativa de 1826. Así pensamos, poder haber demarcado un periodo concreto de análisis, desde 1823 con el funcionamiento y desarrollo de los trabajos constituyentes hasta 1831, con la abdicación del emperador Pedro I. La generación que el emperador siega después de haber disuelto las Cortes, y en donde se propugnaba por una libertad religiosa, solamente será rehabilitada después de la abdicación. Tras esta rehabilitación veremos el regreso de los programas liberales, incluyendo ahí la libertad religiosa, que solamente se concretará con la promulgación de la referida Ley Saraiva, que otorgará a los "acatólicos" todos los derechos políticos en el Imperio, además de promover una reforma electoral, eliminando la doble fase de votación; y eso se dará sin que se hiciesen cambios directos en el texto constitucional. De este modo, nos aclara el Baron Homem de Melo, que "os acontecimentos tem uma lógica fatal e tirânica. Sete de abril (1831) é o resultado de 12 de novembro (1823). (...) Era a reconciliação, política e solene, como o seu glorioso passado

\footnotetext{
${ }^{1224}$ Idem, p. 68.

${ }^{1225}$ SOUSA, Joaquim Rodrigues de: Analyse e Commentario da Constituiçao Política do Império do Brazil ou Theoria e Pratica do Governo Constitucional Brazileiro, Volume II, São Luiz do Maranhao, 1870, pp. 462-463.
} 
de 1822. A geração da Independência estava reabilitada ${ }^{1226 "}$. Por lo tanto, los diputados que fueron perseguidos por el emperador después del cierre de la Asamblea Constituyente pudieron volver y postularse a la Cámara Baja del Parlamento; el propio Antonio Carlos volverá y será elegido diputado y después senador del Imperio. Así que, las ideas liberales van a regresar con fuerza, después de 1831, al Parlamento.

Entretanto, en el Capítulo VI, art. 90, de la Constitución de 1824, dedicado a las elecciones, establecía que los nombramientos para Diputado, Senadores (para la Asamblea General) y de los miembros de los Consejos Generales de Provincias, se daba por Elecciones indirectas $^{1227}$. El mismo artículo divide a los votantes en dos grupos: los que votan en las Asambleas Parroquiales para elegir a los electores de provincias, y estos últimos que eligen a los Representantes de la Nación y de las Provincias mismas ${ }^{1228}$. En dichas elecciones Primarias, el art. 91, II, se daba derecho a voto a los Extranjeros naturalizados, sin hacer referencia a su condición religiosa. Aunque, como ya vimos, el art. $6^{\circ}$, inciso $\mathrm{V}$, atribuía la ciudadanía a los “estrangeiros naturalizados, qualquer que seja a sua Religião". Así como, en las exclusiones al voto en las elecciones de las Asambleas Parroquiales prescriptas en los arts. 92 y 93 no constan los extranjeros naturalizados, tampoco en la segunda fase de las Elecciones Primarias ${ }^{1229}$; del mismo modo, aparecía en el contenido del art. 94 cualquier exclusión de los extranjeros para participar en las Elecciones Secundarias ${ }^{1230}$, siendo posible ser elegidos electores de Provincias y votar en las Elecciones para Diputados. Solamente en el art. 95 se hará referencia al tema religioso, em donde se dirá que "todos os que podem ser Eleitores, hábeis para serem nomeados Deputados. Excetuam-se"; inciso III, "os que não professarem a Religião do

\footnotetext{
${ }^{1226}$ MELO, Francisco I. M. Homem de: Escriptos Historicos e Litterarios. I - A Constituiçao perante a historia (2 $2^{\mathrm{a}}$ Ediçao), Editores Eduardo e Henrique Laemmert, Rio de Janeiro, 1868, p. 49.

${ }^{1227}$ (Archivo John Carter Brown Library) - CONSTITUIÇAO POLÍTICA DO IMPERIO DO BRASIL (Independência ou Morte), Na Typographia de Plancher, Impressor Livreiro de Sua Magestade Imperial, Rio de Janeiro, 1824, p. 24.

${ }^{1228}$ Tanto Francisco Belisário como muy posteriormente Walter Costa Porto van a afirmar que el sistema de doble grado de las elecciones del Brasil imperial no había calificado adecuadamente a los electores de Parroquias. A estos, la Constitución nombraba genéricamente como la "massa dos Cidadãos ativos". Será Francisco Belisario el primero en hacer la distinción precisa en las Elección Primarias entre "Votantes" y "Eleitores". Dirá el mismo: "No gênero que nos ocupa, o votante divide-se em varias categorias: ou é agregado, ou dependente de certo indivíduo em cujas terras vive; ou é mais ou menos independente e baldio". SOUZA, Francisco Belisário Soares de: O Sistema Eleitoral no Império, Senado Federal, Brasília, 1979, p. 34. Pero, en realidad, la expresión "Votante", que caracterizaba al elector de primero grado, según nos cuenta Walter Costa Porto, vino a ser definida por el Decreto 157, de 4 de mayo de 1842. Pero en las discusiones parlamentares y en los relatos de imprenta de la época ya se utilizaban largamente las denominaciones de "Votantes" y "Electores", para definir o caracterizar a los dichos atores de la escena electoral. PORTO, Walter Costa: O Voto no Brasil. Da Colônia à $6^{a}$ República, Editora Topbooks, 2 ${ }^{a}$ Edição Revisada, Rio de Janeiro, 2002, p. 44.

${ }^{1229}$ SOUZA, Francisco Belisário de: O Sistema Eleitoral..., op. cit., pp. 36 y ss.

${ }^{1230}$ Idem, pp. 41 y ss. Dirá el art. 94: "Podem ser Eleitores, e votar na eleição dos Deputados, Senadores, e Membros dos Conselhos de Província todos, os que podem votar na Assembleia Paroquial". (Archivo John Carter Brown Library) - CONSTITUIÇAO POLÍTICA DO IMPERIO DO BRASIL (Independência ou Morte), Na Typographia de Plancher, Impressor Livreiro de Sua Magestade Imperial, Rio de Janeiro, 1824, p. 26.
} 


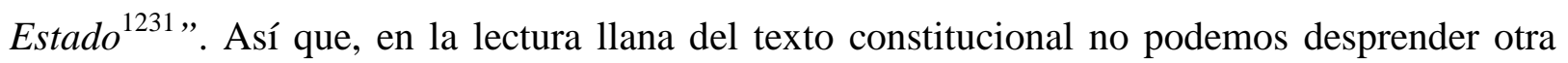
conclusión, aunque de forma inmediata, de que los "acatólicos" - como eran denominados en la prensa y en los debates parlamentarios - podían participar, en tesis, del proceso electoral hasta las Elecciones Secundarias, sin poder, postularse a los puestos públicos. De este modo, podían votar en las dos fases de la Elección Primaria y en la Elección Secundaria. Entretanto, algunos puestos públicos como el de Regente o Emperador no estaban vedados directamente a los que no profesasen la religión del Estado, sino por la exigencia de proferir al juramento del art. 103 de la Constitución de 1824:

"Juro manter a Religião Católica Apostólica Romana, a integridade, e indivisibilidade do Império; observar, e fazer observar a Constituição Política da Nação Brasileira, e mais Leis do Império, e prover ao bem geral do Brasil, quanto em mim couber ${ }^{1232}$."

Sin embargo, el art. $5^{\circ}$ de la Constitución, como ya vimos, permitía el culto doméstico o particular, en casas para esto destinadas, sin forma exterior de templo. Esta fórmula era mucho más liberal que la adoptada por el Proyecto Constitucional de Antonio Carlos de 1823, pero, solamente para las religiones no cristianas, dado que las religiones cristianas, como vimos en el Proyecto, gozaban de todos los derechos políticos. Aunque el texto Constitucional de 1824 no hacía diferenciación entre acatólicos cristianos y no cristianos, era mucho más probable, como vimos en el art. 14 del Proyecto de Antonio Carlos, que establecía la libertad religiosa en Brasil, que el "acatólico" cristiano saldría mejor contemplado que los demás en la adquisición de los derechos políticos; dado que, en dicho Proyecto, tales derechos solo se extendían a las Comuniones Cristianas, por lo tanto, "todos os que as professarem podem gozar dos Direitos Políticos do Império ${ }^{1233,}$,

Paralelamente a aquella fórmula, el art. 15 del Proyecto de la Asamblea Constituyente preveía la inhibición de los Derechos Políticos a los que profesasen religión distinta de la cristiana, puesto que, estas eran apenas toleradas en el Imperio ${ }^{1234}$. De este modo, los cargos públicos, por consecuencia les estaban también prohibidos, como las funciones de Regente y Monarca. Y los "acatólicos", de una forma en general, cristianos o no cristianos, en el texto Constitucional de 1824 estaban alejados de dichos cargos públicos a la razón de lo que preveía el art. 95, III (diputado) y del juramento del art. 103. Para el cargo de senador, el art. 45 no traía prohibiciones explícitas en la Constitución para que los "acatólicos" fuesen electos y luego escogidos en listas tríplices por el emperador, lo que causaba problemas era a la hora de entrar

\footnotetext{
1231 Ibídem.

1232 Idem, p. 31.

${ }^{1233}$ MIRANDA, Jorge: O constitucionalismo liberal luso-brasileiro..., op. cit., p. 207.

${ }^{1234}$ MIRANDA, Jorge: O constitucionalismo liberal..., op. cit., p. 207.
} 
en posesión del cargo de senador, puesto que, estaban obligados por el Reglamiento Interno de la Cámara Alta, desde 1826, a que jurasen en los Santos Evangelios:

"Cumprir fielmente as obrigações de Senador, manter a Religião Católica Apostólica Romana, a integridade do Império, observar sua Constituição política, ser leal ao Imperador e promover o bem estar da Nação ${ }^{1235}$."

Las elecciones en Brasil no eran algo nuevo, en cuanto perteneciente al Imperio Portugués. Pero, la tradición preveía apenas en dos grados dichas elecciones para la elección de jueces, concejales, almotacenes y otros oficiales ${ }^{1236}$. Fue solamente con la Revolución de Oporto, contaminada por el proceso liberal español, que revivió la Constitución de Cádiz, cuando se dio en el Imperio Portugués, y principalmente en Brasil un elaborado y complejo proceso electoral en cuatro niveles. Ya vimos en los Capítulos I y II sobre de la jura y adopción momentánea de la Constitución de Cádiz en Brasil por el Rey D. Joao VI. Lo que no fue momentáneo fue la ley electoral gaditana que fue aplicada en las elecciones para las Cortes de Lisboa. Fue a través del Decreto de 7 de marzo de 1821 cuando se mandó proceder al nombramiento de los diputados a las Cortes portuguesas ${ }^{1237}$. Dicho decreto trae las instrucciones para las elecciones de los diputados de las Cortes, según el método establecido en la constitución española, e que fue adoptado para el Reino Unido de Portugal, Brasil e Algarves. Las instrucciones electorales del citado decreto se contiene en el Título III (De las Cortes), Capítulo I (Del modo de formarse las Cortes) de la Constitución de Cádiz (arts.27103), pero, con algunas modificaciones, abrogaciones y adaptaciones al caso portugués ${ }^{1238}$.

\footnotetext{
1235 PORTO, Walter Costa: “Católicos e Acatólicos: o Voto no Império”, Revista Liberdade e Cidadania - Ano 2 n.5 - junho/setembro, 2009, p. 2. - www.flc.org.br Accedida en 08/08/2012. La Ley de 26 de agosto de 1826 marca la formula propia para el juramento del príncipe heredero al trono del Imperio de Brasil, reglamentando al art. 15, párrafo $3^{\circ}$ de la Constitución del Imperio. Véase en Collecção das Leis e Decretos do Império do Brasil, desde a feliz época da sua Independência: Obra dedicada à Assembleia Legislativa; precedida de hum discurso preliminar, e terminada por huma taboa alfabética, e arrosoada por MM., Imperial Typographia de P. PlancherSeignot, Rio de Janeiro, 1827, pp. 281 y ss. Para el juramento del emperador, príncipes imperiales, emperatriz y regentes, véase los arts. 25 a 35 en ANNAES DO SENADO DO IMPÉRIO DO BRAZIL. Regimento Interno da Assembleia Geral, Rio de Janeiro, 1910 - Sesión de 10 de julio de 1827. Extrato del Volumen de la Sesión de 10 de julio, pp. 1-7. Un casi idéntico juramento era exigido a los médicos, licenciados en Derecho, ingenieros al graduarse. Dirá Magalhaes Junio que también a los licenciados en ciencias o letras del Colegio Don Pedro II se exigia que jurasen "manter a religião do Estado, obedecer e defender a S.M. o Sr. Pedro II e as instituições pátrias"; véase en MAGALHAES JUNIOR, R.: O Império em chinelos, Civilização Brasileira, Rio de Janeiro, 1957, pp. 30 y ss.

${ }^{1236}$ SENA, Nelson Coelho de: "Participação dos deputados brasileiros nas cortes portuguesas de 1821" en Livro do Centenário das Câmaras dos Deputados (1826-1926), Emp. Brasileira Editora, 1926, p. 18. También comenta el tema PORTO, Walter Costa: O Voto no Brasil..., op. cit., p. 22. También a cerca de las elecciones coloniales en el mundo portugués, hay un trabajo más específico en esta materia, que se puede consultar en LEAL, Victor Nunes: Coronelismo, enxada e voto. O município e o regime representativo no Brasil, ( $3^{\mathrm{a}}$ Edição $-3^{\mathrm{a}}$ Reimpressão), Editora Nova Fronteira, Rio de Janeiro, 1997, pp. 127 y ss.

${ }^{1237}$ Collecção das Leis do Império do Brasil, Volume I, Typographia Nacional, Rio de Janeiro, 1882, p. 29 y ss.

${ }^{1238}$ Véase también en la Constitución de Cádiz el contenido de los artículos citados, que son repetidos en el decreto portugués, pero, como ya decimos, con algunas notas a bajo de cada artículo para adaptarlo al proceso portugués.
} 
En el art. 27 del Decreto de 1821, afirma que las Cortes serán formadas por la reunión de los diputados, representantes de la Nación, y aludidos por los ciudadanos. Y en el art. 29 se dirá como está compuesta la población española y como ésta se involucrará en el proceso electoral. Como no hay aditivos en el artículo, se presupone que las características que determinaban a los ciudadanos de las Españas también serán utilizadas para caracterizar a los portugueses:

"Art.29. Esta base é a população composta dos indivíduos, que pelas duas linhas são oriundas dos Domínios espanhóis; dos que tiverem obtido carta de Cidadão das Cortes, e dos compreendidos nas disposições do art. 21 que diz assim: - São, outrossim, cidadãos os filhos legítimos dos estrangeiros domiciliados nas Espanhas, que, tendo nascido em Domínios Espanhóis, nunca os tiverem deixado sem licença do Governo, e que tendo 21 anos completos, se domiciliarem em qualquer povoação dos ditos domínios, exercendo nela algum emprego, oficio ou ocupação útil ${ }^{1239}$."

Caracterizado dicho ciudadano, el contenido del decreto que reproduce al texto constitucional gaditano, como ya dijimos, se producirá una gradación de la categoría de ciudadano. El art. 45 dice que para ser nombrado Elector de Parroquia es necesario ser ciudadano mayor de 25 años y ser morador y residente en dicha parroquia. De la misma forma, el art. 49 trae un dispositivo penal para punir a los calumniadores y a los ciudadanos acusados de cohecho o soborno, siendo la pena para dichos delitos la perdida por parte de los ciudadanos del "voto activo y pasivo"1240. Todo el proceso además, estaba acompañado de ceremonias religiosas, como la formación de las Asambleas de Parroquia, que debía tener la asistencia del Párroco (art. 46), o la misa solemne del Espirito Santo, celebrada por el párroco (art. 47), o en el momento de la verificación del nombramiento de los electores, en donde los ciudadanos que formaron la Junta trasladan a los electores, presidente, escrutiñadores y secretario a la parroquia para la celebración de un Te-Deum solemne (art. 58). Y siguen las solemnidades religiosas al inicio y término de cada etapa del proceso electoral. Así que, para los electores de comarca (partido en la Constitución de Cádiz) ${ }^{1241}$, el art. 75 pedirá los siguientes requisitos:

Constitución Política de la Monarquía Española, Promulgada en Cádiz a 19 de marzo de 1812, Reimpresa en la Imprenta Nacional, Madrid, 1820, pp. 12 y ss.

${ }^{1239}$ Collecção das Leis do Império do Brasil, Volume I, Typographia Nacional, Rio de Janeiro, 1882, p. 30. Decreto de 7 de marzo de 1821.

${ }^{1240}$ En la traducción del artículo de la Constitución de Cádiz, el decreto habla en "voto activo y pasivo", mientras en que el original del texto constitucional, el art. 49 habla de "voz activa y pasiva". Nos llama la atención dicha alocució, porque ya venimos hablando de la división hecha por Sièyes entre ciudadanos pasivos y activos, que vimos en la Constitución brasileña de 1824 .

1241 "Na tradução portuguesa, no art. 34 das instruções que acompanham o decreto de 7 de março de 1821, as juntas eleitorais de paróquia se transformam em de freguesia, as de partido, em de comarcas." PORTO, Walter Costa: O Voto no Brasil..., op. cit., p. 24. 
"Para ser Eleitor de Comarca, é preciso ser Cidadão, estar em exercício dos seus direitos, ser maior de 25 anos, domiciliado e residente na Comarca, seja qual for o seu estado, ou Secular, ou Eclesiástico Secular; podendo recair a eleição, nos cidadãos que compõem a Junta, ou nos que não entram nela ${ }^{1242}$."

De la misma suerte, el art. 91 contiene los requisitos para ser elegido diputado:

"Para ser Deputado das Cortes é preciso ser Cidadão, e estar em exercício dos seus direitos, ser maior de 25 anos, ter nascido na Província, ou ser domiciliado nela com residência de 7 anos, pelo menos, quer seja do estado Secular, quer do Eclesiástico Secular, e podendo recair a Eleição nos Cidadãos que formam a Junta, ou nos que não entram nela ${ }^{1243}$."

También el art. 92 enuncia el carácter censitario de tales elecciones. Pero, en todas estas características, como más o menos era de esperar, no hace cualquier referencia a la figura del elector "acatólico", tal vez porque, la propia Constitución de Cádiz, de donde provienen dichos artículos era totalmente intolerante en materia religiosa. Aunque en los añadidos que adecuan los artículos a la situación portuguesa ni siquiera se hace referencia a este tipo de elector. Solamente en el art. 96 se hará referencia directa a los extranjeros, lo hace no para incluirlos en el final del proceso electoral, sino para excluirlos, y dirá:

"Não podem da mesma sorte ser eleitor Deputados das Cortes os Estrangeiros, ainda que tenham Carta de Cidadão passada pelas Cortes ${ }^{1244}$."

Terminadas las elecciones, el art. 99 manda que los electores otorguen poderes amplios a los diputados electos en forma de Diploma para ser presentado en las Cortes. Los términos de este otorga se encuentran en el art. 100, que en el añadido portugués al artículo prevé que uno de los poderes de la concesión era mantener "a Religião Catholica-Apostolica-Romana ${ }^{1245, "}$ Entretanto, ya hemos dicho que el resultado en la Constitución luso-brasileña de 1822, fue el de permitir a los extranjeros la libertad religiosa y el ejercicio particular de sus respectivos cultos (art. 25). También en el texto constitucional se permitirá votar a los extranjeros con Carta de ciudadanos en las elecciones primarias (art. 33), aunque fuesen absolutamente inelegibles (art. $34, \mathrm{VI})^{1246}$. Estas instrucciones electorales gaditanas también servirán para la elección del Consejo de Procuradores Generales de las Provincias de Brasil, mandada realizar por el Decreto de 16 de febrero de $1822^{1247}$.

\footnotetext{
${ }^{1242}$ Idem, p. 35.

1243 Idem, p. 37.

1244 Ibídem.

1245 Idem, p. 39.

${ }^{1246}$ Constituição Política da Monarchia Portugueza, Imprensa Nacional, Lisboa, 1822, pp. 16 y ss.

${ }^{1247}$ Se puede saber más, aunque de forma fragmentada a cerca de las elecciones antes del proceso de independencia de Brasil, así como del periodo inmediatamente después, con la lectura de CÂNDIDO, Joel J.: Direito Eleitoral Brasileiro, 12a Edição, Editora Edipro, São Paulo, 2006, pp. 30-32. También es esclarecedora la
} 
Después del proceso de independencia y de la expedición del decreto de 3 de junio de 1822 que convocaba elecciones para la Asamblea Constituyente, nuevas instrucciones electorales van a conducir dicho proceso electoral ${ }^{1248}$. Allí, por primera vez, se habla de elecciones directas, propuestas por el consejero Gonçalves Ledo. Pero, al final, se queda el largo proceso gaditano reducido a dos grados, permaneciendo así la forma indirecta para las elecciones. De esta modo, saldrá la Decisión no 57 del Ministerio del Reino, en 19 de junio de $1822^{1249}$, y firmada por el ministro José Bonifácio, por la cual el pueblo en cada una de las "freguesias" (las parroquias en el proceso de la Constitución gaditana), indicaría los electores de parroquias, que nombrarían los diputados ${ }^{1250}$.

La Decisión n ${ }^{\circ}$ 57, en el Capítulo I, 7, califica quienes tiene derecho a voto en las Elecciones Primarias:

"Tem direito a votar nas Eleições Paroquiais todo o Cidadão casado e todo aquele que tiver de 20 anos para cima sendo solteiro, e não for filho-família. Devem, porém, todos os votantes ter pelo menos um ano de residência na Freguesia onde derem o seu voto ${ }^{1251}$."

Debemos recordar una vez más que los Tratados de 1810 con Inglaterra estaban en pleno vigor en el momento en que se celebraron dichas elecciones y que garantizan, como vimos la libertad religiosa a los ciudadanos británicos, y la no persecución de las demás religiones. Así que, en el Capítulo I, 9, solamente se excluyen a los extranjeros que no hubiesen obtenido Carta de naturaleza del proceso electoral. Entretanto, esta Decisión no 57 está llena de ceremonias religiosas para marcar el inicio y el final del proceso electoral. Por lo tanto, en el Capítulo II, 6, se va a decir quien no puede ser Elector:

"Não pode ser Eleitor quem não tiver (além das qualidades requeridas para votar) domicílio certo na Província, há quatro anos inclusive pelo menos. Além disso, deverá ter 25 anos de idade, ser homem probo e honrado, de bom entendimento, sem nenhuma sombra de suspeita e inimizade à Causa do Brasil, e de decente subsistência por emprego, ou indústria, ou bem ${ }^{1252}$."

lectura de FERREIRA, Manoel Rodrigues: "Evolução do Sistema Eleitoral Brasileiro", 1956, BE-TRE-SP 124/2339 a 2342 etc. Véase también en MOTA, Aroldo: "Legislação Eleitoral no Brasil" en Revista Brasileira de Direito Eleitoral, $2^{\circ}$ número, Fortaleza, CE, 1987, p. 39. Además, es esclarecedora la consulta a BRAGA, Hilda Soares: Sistemas Eleitorais do Brasil (1821-1988), Senado Federal - Secretaria de Edições Técnicas, Brasília, 1990, pp. 22 y 33.

${ }^{1248}$ Decreto de 3 de junio de 1822 - SOUZA, Francisco Belisário Soares de: O Sistema Eleitoral..., op. cit., pp. 177 y ss.

${ }^{1249}$ Decisão no $^{\circ} 7$ de 19 de junio de 1822 - Idem, pp. 178 y ss.

${ }^{1250}$ Este proceso en dos grados está descritos en el Capítulo I, 1 y 2, de la Decisión no 57.

${ }^{1251}$ Idem, p. 178.

${ }^{1252}$ Idem, p. 180. 
Aunque la legislación, como venimos hablando, contemplase indirectamente y muchas veces directamente a los extranjeros con carta de naturaleza en el proceso electoral en las Elecciones Primarias, se volvía, en muchos aspectos difícil para los "acatólicos", con carta de ciudadano, elidir las ceremonias religiosas previstas; no obstante, se puede deducir que esto será el comienzo para lo que se desarrollará a lo largo del siglo XIX, y que culminará con la adopción del principio, nunca muerto, pero latente en el texto constitucional de 1824 , de la libertad religiosa:

"Reunidos os Eleitores, os Cidadãos que formaram a Mesa, levando-os entre si e acompanhados do Povo, se dirigirão à Igreja Matriz, onde se cantará um TeDeum solene. Fará o Pároco todas as despesas de altar, e as Câmaras todas as outras; bem como proverão de papel e livros todas as Juntas Paroquiais ${ }^{1253}$."

También, para ser nombrado diputado, el Capítulo IV, párrafo 2, prescribía los siguientes requisitos y condiciones:

"Para ser nomeado Deputado cumpre, que tenha, além das qualidades exigidas para Eleitor no (párrafo) $6^{\circ}$, capítulo II, as seguintes: Que seja natural do Brasil ou de outra qualquer parte da Monarquia Portuguesa, contanto que tenha 12 anos de residência no Brasil, e sendo estrangeiro que tenha 12 anos de estabelecimento com família, além da sua naturalização; que reúna à maior instrução, reconhecidas virtudes, verdadeiro patriotismo e decidido zelo pela causa do Brasil ${ }^{1254}$."

Podemos relacionar el contenido dicción de estos artículos estudiados con las discusiones en torno a la libertad religiosa que ya vimos en la Asamblea Constituyente. Ya decimos que el principio está recogido en el art. $14^{\circ}$ del Proyecto de Antonio Carlos, principalmente para los "acatólicos" cristianos, ya que, las demás religiones no cristianas, en la letra del art. 15 serían apenas toleradas, y quienes las profesasen tendrían sus derechos políticos inhibidos. Entretanto, los mismos principios adoptados por la Decisión n 57 se trasladarán al proceso electoral descrito en el Título V (Das Eleições) del Proyecto de Constitución de Antonio Carlos de 1823. Así que, en el art. 123으. II, se concederá a los extranjeros naturalizados la condición de "Ciudadanos Activos" para que votasen en las Asambleas Primarias, o llamadas también Parroquiales. Y en el art. $130^{\circ}$, I, (combinado con el art. $129^{\circ}$ ) se dirá que pueden ser electores, pero están excluidos de ser nombrados Diputados Nacionales los extranjeros naturalizados. Se les prohíbe, así, a la participación activa en los procesos de las Elecciones

\footnotetext{
${ }^{1253}$ Idem, p. 181. Decisão no 57, Capítulo III, 6.

${ }^{1254}$ Idem, p. 183. Decisão no 57 , Capítulo IV, párrafo $2^{\circ}$.
} 
Segundarias, aunque el principio de la libertad religiosa esté claramente recogido en el texto del proyecto constitucional $^{1255}$.

La ley electoral que estará vigente juntamente con el texto Constitucional de 1824 será el Decreto de 26 de marzo de $1824^{1256}$. Las instrucciones electorales que acompañaban al decreto saldrán para explicar el proceso electoral un día después de otorgada la Constitución del Imperio. Este decreto y las elecciones para el parlamento bicameral brasileño de 1826 cubrirán el periodo que nos propusimos a estudiar, en principio, que va hasta 1831 con la abdicación de D. Pedro I, finalizando así el primer imperio. Cómo será la primera vez que se reúnan los parlamentarios de la Cámara Alta, el proceso se dará a través de elecciones similares a las de los diputados de la Cámara Baja, con la diferencia que aquellos formaran listas triples para que el emperador elija entre los candidatos los senadores, como dice el Párrafo $4^{\circ}$ del Capítulo V del citado decreto $^{1257}$.

Atendiendo a la convocatoria de elecciones generales para senador, diputado y miembros de los Consejos Generales de Provincias, el proceso electoral se dará en dos etapas, siendo los electores de parroquias, escogidos en las Elecciones Primarias, quienes votarán en aquellos cargos públicos siguiendo los requisitos de los artículos constitucionales (art. 91 y $92)^{1258}$. A modo de iniciar los trabajos, el Capítulo I, párrafo $2^{\circ}$, de las Instrucciones electorales de 1824, prevé la formación de una Asamblea electoral presidida por el "Juiz de Fora" con la asistencia del Párroco. Toda parroquia dará tantos electores, cuantas veces contenga el número de fuegos en la población. Si el número de fuegos no llegan a doscientos, pero pasaren de los ciento cincuenta, habrá dos electores; pasando de doscientos cincuenta, dará tres, y así progresivamente como establece el párrafo $4^{\circ}$ de las Instrucciones ${ }^{1259}$. La identificación de los votantes queda a cargo del Párroco, quien debería fijar un bando en las puertas de sus Iglesias, en donde constase el número de fuegos de su "Freguesía", además, estaba responsable por su exactitud (Capítulo I, párrafo $5^{\circ}$ ). Estaba legalizada la vinculación de las Iglesias al proceso

\footnotetext{
${ }^{1255}$ Para los artículos citados del Proyecto de Constitución de Antonio Carlos Andrada, véase en MIRANDA, Jorge: O constitucionalismo liberal..., op. cit., pp. 220 y ss.

${ }^{1256}$ Decreto de 26 de marzo de 1824. SOUZA, Francisco Belisário Soares de: O Sistema Eleitoral..., op. cit., p. 187.

${ }^{1257}$ Idem, p. 195.

${ }^{1258}$ Ya hicimos un poco antes la diferenciación y la calificación de los términos electorales: "Votante" y "Eleitor". (Archivo John Carter Brown Library) - CONSTITUIÇAO POLÍTICA DO IMPERIO DO BRASIL (Independência ou Morte), Na Typographia de Plancher, Impressor Livreiro de Sua Magestade Imperial, Rio de Janeiro, 1824, p. 24. Decreto de 26 de marzo de 1824 - Capítulo I (De las Elecciones de las Asambleas Parroquiales), párrafo $1^{\circ}$, en SOUZA, Francisco Belisário Soares de: O Sistema Eleitoral..., op. cit., p. 187 y ss.

${ }^{1259}$ El término "Fuegos" solamente tendrá definición en las Instrucciones contenidas en el Decreto electoral de 4 de mayo de 1842: "Art. $6^{\circ}$ - Por Fogos entende-se a casa, ou parte dela, em que habita independentemente uma pessoa ou família; de maneira que um mesmo edifício pode ter dois ou mais Fogos”. Francisco Belisário Soares de: O Sistema Eleitoral..., op. cit., p. 202.
} 
electoral. Sin embargo, mucho antes, en las Instrucciones electorales de la Constitución española, adoptadas por el Decreto de 7 de marzo de 1821, en su art. 47, determinaba que:

"Chegada a hora da reunião, a qual se fará nas casas do Conselho, ou no lugar de costume, achando-se juntos os Cidadãos que tiverem concorrido se dirigirão com o Presidente à Igreja Matriz, e nela celebrará o Pároco a Missa solene do Espírito Santo, e fará um discurso análogo às circunstancia ${ }^{1260}$."

El aditivo português del mismo art. 47 dirá:

"Aonde não houver casa do Conselho, ou esta não for suficiente, a Igreja será o lugar destinado à celebração destas Assembleias ${ }^{1261}$."

Y allí se desarrollará todo el proceso electoral durante casi todo el siglo XIX en el Brasil imperial, hasta las reformas introducidas por la Ley Saraiva en 1881.

Aunque estuviesen presentes las garantías constitucionales, principalmente las previstas en el art. 179, V, de la Constitución del Imperio, y la segunda parte del art. 5º era muy poco probable que los "acatólicos", en posesión de los derechos civiles y políticos pudiesen acudir a las elecciones primarias para las Asambleas Parroquiales. Dado que, los Párrocos controlaban gran parte del proceso, con ceremonias religiosas y la propia elección se daba en el interior de los templos religiosos. Aun así, el Capítulo I, párrafo $6^{\circ}$, establecerá que tienen voto en las elecciones primarias:

“ $1^{\circ}$ Os cidadãos brasileiros, que estão no gozo de seus direitos políticos; $2^{\circ}$ Os estrangeiros naturalizados, contanto que uns e outros sejam domiciliários da freguesia, ou tenham pelo menos ali a sua residência desde a dominga da Septuagésima, que é quando os Párocos devem fazer os róis de seus fregueses, e tomar deles conhecimento. Os que depois deste dia mudar de freguesia, devem ir votar na que antes residiam ${ }^{1262}$."

Los derechos políticos que quedaban reconocidos a los "acatólicos" estaban muy mitigados por las excepciones constitucionales (art. 95) ${ }^{1263}$ por la legislación infraconstitucional, además del proceso electoral prescripto en las instrucciones. De esta forma, no se les reconocía a los "acatólicos" la posibilidad de ser votado y de asumir ciertos cargos públicos. Era un verdadero "simulacro de libertad religiosa"1264, dado que se garantizaba en la

\footnotetext{
${ }^{1260}$ Collecção das Leis do Império do Brasil, Volume I, Typographia Nacional, Rio de Janeiro, 1882 , p. 32. Decreto de 7 de marzo de 1821.

1261 Ibídem.

1262 Decreto de 26 de marzo de 1824, Capítulo I, párrafo 6º. Francisco Belisário Soares de: O Sistema Eleitoral..., op. cit., p. 188.

1263 (Archivo John Carter Brown Library) - CONSTITUIÇAO POLÍTICA DO IMPERIO DO BRASIL (Independência ou Morte), Na Typographia de Plancher, Impressor Livreiro de Sua Magestade Imperial, Rio de Janeiro, 1824, p. 26.

${ }^{1264}$ HOLANDA, Sergio Buarque de: História geral da civilização brasileira, Tomo II, Volume $4^{\circ}$, Editora Difel, São Paulo, p. 319.
} 
Constitución dicho derecho, para luego recortado en los reglamentos parlamentarios, Estatutos de facultades etc $^{1265}$. Entretanto, persistía la apariencia de libertad religiosa y la posibilidad de que accediesen los "acatólicos", al menos en el ámbito constitucional, a algunos puestos públicos.

${ }^{1265}$ Sergio Buarque de Holanda, estudiando este proceso de exclusión afirmaba que el art. $5^{\circ}$ y el párrafo $3^{\circ}$ del art. 95 excluían a los "acatólicos" del derecho fundamental de tornarse representantes del pueblo. Aunque, como ya afirmamos antes, cosa que es corroborada por Walter da Costa Porto, el "acatólico", en los términos de la constitución podría ser elegido senador, diputado para las Asambleas Provinciales y concejales. Solamente habría impeditivo a la hora de asumir al cargo público y tener que prestar el juramento, principalmente los previstos en el art. 127, para regente, y en el art. 141, para Consejero de Estado, que era el de "Manter a Religião Católica Apostólica Romana". HOLANDA, Sergio Buarque de: História geral..., op. cit., p. 329. Véase también en PORTO, Walter Costa: O voto..., op. cit., p. 46. Para los artículos citados de la constitución véase en (Archivo John Carter Brown Library) - CONSTITUIÇAO POLÍTICA DO IMPERIO DO BRASIL (Independência ou Morte), Na Typographia de Plancher, Impressor Livreiro de Sua Magestade Imperial, Rio de Janeiro, 1824, pp. 1, 26,36 y 38 respectivamente a los artículos citados. 



\section{CODA}

\section{EL PRINCIPIO DE LA ELEGIBILIDAD DE LOS ACATÓLICOS: LA SOLUCIÓN A LO LARGO DEL SIGLO XIX, HASTA LA VIGENCIA DE LA LEY SARAIVA EN 1881}

En el Capítulo III tratamos como la ciudadanía de los no católicos estaba restringida por la declaración de confesionalidad del Estado. Aludimos primero al proyecto de Antonio Carlos de la Constituyente de 1823. En dicho proyecto la ciudadanía estaba fundida con el concepto de nacional. Por lo tanto, el concepto de ciudadanía presente en el texto del proyecto era el mismo del modelo revolucionario francés, que dividía la ciudadanía en ciudadanos activos y ciudadanos pasivos. A los no católicos cristianos estaba reservada la ciudadanía plena, con derecho civiles y derechos políticos. Y para los que eran denominados "acatólicos" no cristianos, solo les estaban reservados los derechos civiles. Este proyecto discutido en la Asamblea Constituyente trajo numerosos problemas a la hora de conceder la ciudadanía a los no católicos. Sin embargo, como el principio de la libertad religiosa había sido adoptado en el proyecto de Antonio Carlos, no conceder a los no católicos cristianos los derechos políticos se presentaba muy complicado. La discusión fue intensa en el parlamento acerca de esta materia. Pero el principio de la elegibilidad de los no católicos cristianos quedaba obviada en las discusiones parlamentarias.

Con el cierre de la Constituyente de 1823 por el emperador D. Pedro I el proyecto de Antonio Carlos fue abortado. El emperador encomendó un nuevo proyecto al Consejo de Estado, con plataforma en unas bases presentadas por él mismo. Este proyecto fue aprobado por las Cámaras municipales y se convirtió en la nueva constitución del Imperio, otorgada en 1824. Dicho texto constitucional contenía nuevas bases para los "acatólicos". El sistema revolucionario francés de división ciudadana permanecía, pero los derechos políticos de los no católicos cristianos quedaban soslayados. Es verdad que el principio de la libertad religiosa estaba reconocido por el art. $5^{\circ}$ de la Constitución, así como el principio de la no persecución por motivos religiosos, previsto en el art. 179, V. Ello rememoraba lo establecido en los Tratados de 1810 firmados con Inglaterra. Lo que quedó diferente en el texto constitucional del proyecto de Antonio Carlos fue que los acatólicos ahora se quedaban fuera de los derechos políticos. El art. 95, III de la Constitución de 1824 decía que todos los que pueden ser Electores (o sea los elegibles), eran hábiles para ser nombrados diputados, con excepción de los que no profesasen la religión del Estado. De esta forma se restringían los derechos políticos de los "acatólicos", y se les arrancaba el principio de la elegibilidad a los cargos públicos. Con ello no se quería decir que no pudiesen votar en las elecciones primarias y que no pudiesen ser elegidos 
electores, lo que no podían ser era candidatos a diputados. No se daba tal restricción para el Senado del Imperio, pero sí había un artículo en su Reglamento Interno que preveía el juramento sobre los Santos Evangelios con base en el art. 103 de la Constitución.

Aunque se dijese en el art. 179, V que nadie seria discriminado por sus ideas religiosas, los mecanismos creados tanto en el texto constitucional, como en las leyes electorales llevaban a que los derechos de los ciudadanos no católicos se viesen recortados. Es cierto que el principio de la elegibilidad no estaba recogido en el texto constitucional, pero si lo estaba el principio de la libertad religiosa. Las leyes electorales preveían una participación de la iglesia católica muy grande en todo el proceso electoral. El párroco era quien reunían a los votantes en la parroquia, también listaba el número de fuegos en sus localidad. La relación entre iglesia y proceso electoral era muy grande. Las elecciones se celebraban en los edificios religiosos católicos, o sea, en el templo religioso. Para un no católico vencer las barreras prácticas que se establecían con la participación de la maquinaria religiosa era prácticamente imposible. Pero, como estudiamos principalmente los mecanismos de exclusiones legales no nos fue posible bajar a las actas electorales para verificar si hubo algún no católico que consiguió superar la barrera de la exclusión. Lo que constatamos sí fue los numerosos mecanismos legales y de orden práctica para excluir a los acatólicos tanto del proceso como del resultado de las elecciones, dado que el principio de la elegibilidad católica no estaba recogido directamente en el texto constitucional. Como expusimos, no quiere decir que legalmente no pudiesen participar de las elecciones, aunque existiesen las barreras de orden práctico, como era la realización de elecciones en templos religiosos o la celebración de ceremonias católicas; esto en nada favorecía la inclusión de acatólicos en el proceso electoral.

Este era el panorama que se nos presentaba en el espacio temporal propuesto para nuestro estudio, entre 1823 y 1831. Lo que sucede es que la discusión sobre la elegibilidad de los no católicos se había establecido en la Asamblea Constituyente de 1823, pero, no había pasado al texto constitucional de 1824 dicho principio. Esta cuestión se quedó latente, incluso después de reabierto el parlamento en 1826 tras el golpe que dio el emperador en 1823, con el cierre de los trabajos constituyentes. Una de las primeras trabas a ser levantada, como veremos más adelante, fue la prohibición en 1855 de la realización de las elecciones en los templos católicos, pues se decía que al no santificar las elecciones, las mismas profanaban los templos. Esto, por supuesto era un obstáculo para los no católicos, una barrera que se levantaba en el proceso practico electoral. Sin embargo, la suspensión de las ceremonias religiosas y el establecimiento del principio de la elegibilidad, a partir de nuestro marco temporal, solo se darían cincuenta años después con la Ley Saraiva en 1881, como luego veremos. Es a partir de 
entonces cuando se levanta la barrera legal a la elegibilidad de los "acatólicos", concediéndoles todos los derechos políticos. Entretanto, no hubo un cambio constitucional para albergar tal principio en el ordenamiento jurídico nacional. Una ley ordinaria concedía lo que estaba implícito en el texto constitucional, que solamente para la elección a diputado en el art. 195, III, prohibía a los que no profesasen la religión del Estado participar. Así que, con la suspensión, gracias a la Ley de los Círculos, en 1855, de la realización de las elecciones en los templos católicos, la suspensión de las ceremonias religiosas con la Ley Saraiva en 1881, y consecuentemente la adopción del principio de la elegibilidad de los no católicos quedaban suprimidas las barreras legales y de orden práctico. Pero, no de todo. Permanecía el juramento presente en algunos parlamentos, como era el caso de la Cámara de los Diputados y el Reglamento Interno del Senado Imperial; en éste debía el senador jurar por los Santos Evangelios mantener la Religión del Estado. Fue, solamente en 1882, como veremos cuando un incidente hizo chocar el principio recogido por la Ley Saraiva y dichos reglamentos internos. Hasta finales del siglo XIX la discusión establecida en la Constituyente de 1823 no tuvo un punto final.

\section{A) Las instituciones confesionales luso-brasileñas}

Las reformas emprendidas al final del siglo XVIII en el conjunto del Imperio Lusitano, como pudimos ver en el Capítulo II, se van a reflejar directamente en las relaciones sociopolítico-religiosas del Brasil del siglo XIX. El Brasil independiente fue el heredero de la política "pombalina" del reinado de D. José I, tanto en materia educacional como en materia religiosa $^{1266}$. El regalismo, en el ámbito del despotismo ilustrado del Marqués de Pombal, ensalzado con las concepciones de la soberanía del Estado, buscará someter en el ámbito del Estado nacional a la religión, tratando al clero como meros funcionarios públicos al servicio de los propósitos estatales ${ }^{1267}$.

El sistema del Patronato Regio portugués será la clave de la sumisión de los asuntos religiosos a la esfera estatal. Este sistema es resultado del proceso, en la Península Ibérica, de la

\footnotetext{
1266 “O reinado de d. José I (1750-1777) marcou-se pela presença do pulso forte do seu ministro Sebastião José de Carvalho e Mello. Pombal sacudiu a sociedade lusa em todos os níveis, realizando um esforço para superar vários problemas: tirar Portugal da inferioridade em relação às potencias europeias, reformando a economia, e fortalecer o poder do Estado, firmando a supremacia da Coroa perante a nobreza e a Igreja - incluindo-se, aqui, os jesuitas.” VILLALTA, Luís Carlos: 1789-1808. O Império luso-brasileiro e os Brasis, (Coordenação: Laura de Mello e Souza e Lilian Moritz Schwarcz), Companhia das Letras - Virando Século, São Paulo, 2000, p. 18.

${ }^{1267}$ BOEHRER, George C. A.: A Igreja no Segundo Reinado: 1840-1889, en KEITH, H. H. y EDWARDS, S. F. (org.): Conflito e Continuidade no Brasil, Civilização Brasileira (Tradução de J. L. de Melo), Rio de Janeiro, 1970, pp. 134-167. Esta asociación entre el regalismo y el sometimiento del poder espiritual al temporal se puede encontrar también en NEVES, Guilherme P.: A Religião do Império e a Igreja en GRINBERG, Keila y SALLES, Ricardo (orgs.): O Brasil Imperial, Volume I: 1808-1831, Civilização Brasileira, 2009, p. 382.
} 
Reconquista, por parte de los cristianos, de los dominios musulmanes de la península. Por lo tanto, los reyes de Portugal así como los de España serán depositarios de los poderes de patronos de las respectivas iglesias nacionales concedidos por la Santa Sede ${ }^{1268}$, tras la Reconquista. Esta institución estaba reglamentada con una extensa e intrincada legislación, que aquí no pretendemos abordar en detalles, pero, que traducía a una serie de obligaciones y de derechos entre la Iglesia Católica Apostólica Romana y un individuo o institución que asumía la condición de patrono ${ }^{1269}$. El propio Lopez Praça reconocía en el siglo XIX, en su "Ensaio sobre o padroado portugués”, que la institución del Patronato era una materia bastante espinosa para ser desmenuzada de forma tan breve ${ }^{1270}$.

Entretanto, fue en el reino de D. Joao III, en 1532, formando parte de la tentativa de organizar la administración del imperio ultramarino, cuando surgió el Tribunal en donde el rey pretendía descargar su conciencia, en materia espiritual, y en donde el propio rey aparecía como patrono de los asuntos eclesiásticos. Más adelante, dicho Tribunal pasará a ser designado como "Mesa da Consciência e Ordem", y que tendrá la función, entre muchas otras, de cuidar de la implantación y conservación del culto en la América portuguesa ${ }^{1271}$. Según Guilherme Pereira das Neves, no hay que confundir dichas atribuciones con las de la Orden de Cristo, algo jurídicamente próximo a la institución del Patronato. De modo que, el patronato implicaba en un horizonte inmenso de facultades, tales como la creación de obispados y parroquias, en la construcción de iglesias, en la designación y manutención de prelados, canónigos y pastores, que recibían las denominadas “congruas", además de otras facultades. Como contrapartida de estas obligaciones el monarca tenía el privilegio de recolectar y dar destino a los ingresos provenientes del diezmo. También le era reservado a los monarcas la indicación de obispos,

\footnotetext{
1268 "Aguirre nos assevera que é antiga e imemorial a seguida na Igreja de Espanha de fazer as provisões dos cabildos por concursos das prebendas de oficio. Em Portugal pode ver-se o provimento destas dignidades nos parágrafos 182 e 183 dos Elementos de Direito Eclesiástico Português do Sr. Dr. B. J. da S. Carneiro." LOPES PRAÇA, J. J.: Ensaio sobre o padroado português. Dissertação inaugural para o acto de conclusões magnas, Imprensa da Universidade, Coimbra, 1869, p. 8.

1269 "Foi o célebre infante d. Henrique (1394-1460), enquanto administrador da Ordem de Cavalaria de Nosso Senhor Jesus Cristo (herdeira, em Portugal, daquela ainda mais famosa dos Templários) quem, em 1456, obteve da Santa Sé o direito de padroado sobre as regiões ao sul do Equador, que os navegadores lusos iam devassando.” NEVES, Guilherme P.: A Religião do Império..., op. cit., p. 382.

${ }^{1270}$ El Patronato Régio es "uma matéria espinhosa e cheia de escolhos, atendendo quer ao padroado em si, quer as suas diversas relações com outras matérias. É coisa sabida e até palpável que a doutrina do nosso padroado está dependente de conhecimentos profundos de Teologia Revelada, e de Direito Canônico, Público, Internacional e Eclesiástico. A História Geral da Igreja, as relações das disposições canônicas como as civis, e, sobretudo, as lições da História da Igreja Lusitana são outros tantos elementos de que, do mesmo modo, não podemos prescindir." LOPES PRAÇA, J. J.: Ensaio sobre o padroado português..., op. cit., p. VII.

${ }^{1271}$ Estas definiciones se pueden encontrar en SILVA, Maria Beatriz Nizza da (coord.): Dicionário da História da Colonização Portuguesa no Brasil, Editora Verbo, Lisboa, 1994. También en VAINFAS, Ronaldo (dir.): Dicionário do Brasil Colonial (1500-1808), Editora Objetiva, Rio de Janeiro, 2000. Es, además, esclarecedora la obra de AZEVEDO, Thales de: Igreja e Estado em Tensao e Crise (A Conquista Espiritual e o Padroado na Bahia), Editora Ática, São Paulo, 1978. Fue muy inspiradora la consulta de NEVES, Guilherme P.: A Religião do Império..., op. cit., p. 383.
} 
canónigos y párrocos para que las respectivas autoridades eclesiásticas pudiesen investirlos en sus cargos. Otra prerrogativa real importante era la de conceder, dentro del paralelismo de las formas administrativas, o negar el "beneplácito" regio para las bulas y demás documentos pontificios, para que pudiesen circular y tener validez en el reino y sus posesiones. Alguna de las atribuciones regias, como la catequesis de los indios y otras muchas, fueron delegadas en determinadas órdenes religiosas que no siempre estaban dispuestas a someterse al dominio omnipresente de la corona ${ }^{1272}$.

Pudimos apreciar también en el Capítulo II el ideario de las reformas emprendidas por el Marqués de Pombal, Valido del monarca D. José I. Dentro de la concepción suareciana del depósito de la soberanía en los monarcas, por origen divino, el iluminismo potencia dicha concepción estableciendo que la soberanía recaería en el rey que no reconocía otra igual que le pudiese hacer frente, principalmente en sus dominios. Por lo tanto, pone en punto de colisión las instituciones del papado y la corona. El Valido se cebará en los jesuitas como forma de purgar los perjuicios a los intereses de la corona, con su expulsión en 1759. Por lo tanto, el Estado nacional va a encargarse de una amplia reforma educacional, que en parte estaba en manos de los jesuitas, así como pondrá en funcionamento, de forma mucho más integrada que antes, la institución del Patronato a través de la "Mesa da Consciência e Ordem", un Tribunal, como vimos, que velaba por los intereses de la monarquía en materia religiosa ${ }^{1273}$.

En el rastro de las Reformas pombalinas, en el Reinado de D. Maria I, aunque el Valido de D. José I ya hubiese caído en desgracia, un proyecto de Nuevo Código para Portugal surge del encargo que hizo la reina a Paschoal de Mello Freire dos Reis, como ya tuvimos ocasión de explicar. En el Título IV -“Religião e Fé Cathólica”- de la obra de Freire dos Reis -“Projeto para um Novo Código de Direito Público"- se buscaba disciplinar algunas relaciones en materia espiritual. Entretanto, alertaba el autor en el proemio de la obra -que se parece a una verdadera profesión de $\mathrm{fe}^{1274}$ - que la misma era incompetente para disciplinar y definir dogma, creencia y doctrina. No se trataba de subyugar a la religión católica de todos modos, al menos en el discurso, sino que se buscaba ejercer la función del patronato regio por parte de la reina, como se establecía en el párrafo $2^{\circ}$ del Título IV del Proyecto del Nuevo Código:

\footnotetext{
${ }^{1272}$ Idem, pp. 383 y ss. Véase también en LOPES PRAÇA, J. J.: Ensaio sobre o padroado português..., op. cit., pp 20 y ss.

${ }^{1273}$ VILLALTA, Luís Carlos: 1789-1808. O Império luso-brasileiro..., op. cit., pp. 19 y ss. También en NEVES, Guilherme P.: A Religião do Império..., op. cit., p. 384.

${ }^{1274}$ RIBEIRO, Antônio: Notas ao Título IV da Religião e Fe Católica do Novo Código de Direito Público de Portugal do Dr. Pascoal José de Mello. Escritas e apresentadas na Junta da Revisão pelo Dr. Antônio Ribeiro en HESPANHA, Antônio Manuel (dir.) y SILVA, Cristina Nogueira da: Fontes para a história constitucional portuguesa, Faculdade de Direito da UNL, Lisboa, 2004, p. 3 y 4.
} 
"Ainda que o corpo místico da Santa Igreja, nossa Mae, não necessite de auxilio algum humano para sua firmeza e duração, e para pureza e santidade da sua doutrina, nós, como sua devotíssima e obediente filha, a quem o TodoPoderoso concedeu o supremo poder temporal, prometemos por esta pública e soleníssima ordenação ajudar e auxiliar com ele a mesma igreja e suas determinações ${ }^{1275}$.”

Esta posición estaba reforzada en el párrafo $3^{\circ}$, en donde la reina, como Señora y soberana, protectora y defensora de la iglesia portuguesa católica, prohibía la profesión de todas las demás religiones. Así,

"Pelas mesmas razoes mandamos conservar e manter a disciplina, ritos e cerimônias eclesiásticas, e costumes louváveis recebidos na Igreja de Portugal ${ }^{1276}$.”

Con el regreso del absolutismo a ultranza, en donde el regalismo tomaba connotaciones menos ilustradas, pero, no menos tutelares en cuanto a los asuntos religiosos, el párrafo $5^{\circ}$ estableció la perfecta interacción entre el poder temporal y el eclesiástico:

"E querendo ajudar o ministério da palavra e doutrina com medo, força e terror da disciplina, ordenamos, que todos os que atentarem contra a nossa santa fé e verdadeira crença, contra as positivas determinações da Igreja, contra os ritos, cerimônias e disciplina eclesiástica recebida, na Igreja Lusitana, introduzindo outra de novo, ou contra o profundo respeito e veneração devida a Deus, a Maria Santíssima, aos Santos e lugares sagrados, e aos ministros do Senhor, ensinando, disputando, crendo ou escrevendo o contrario do que crê, manda e ensina a Santa Igreja, serão punidos e castigados com penas externas, declaradas no nosso Código Criminal ${ }^{1277}$.”

Entretanto, y desde este momento, ya se buscaba proteger a los extranjeros residentes en el reino de la conversión forzosa, o bautismo de sus hijos nacidos en el reino, o incluso los que estuviesen en razón de comercio residiendo allí, como reza el párrafo $7^{\circ}$ y principalmente el $8^{\circ}$ :

"Todas as pessoas de diversa crença e religião, que viveram e assistirem em nossos reinos em razão do comércio, ou por outra qualquer, não poderão publicamente professar as cerimonias da sua religião, nem fazer públicos ajuntamentos a este respeito, e muito menos impedir o livre uso da Católica Romana, ou desprezar por fatos, ou palavras os seus ritos, disciplina e culto externo; e fazendo o contrario, serão mandados sair destes reinos, e punidos a nosso real arbítrio, para os que nos darão contra os ministros das suas habilitações ${ }^{1278 . "}$

\footnotetext{
${ }^{1275}$ FREIRE, Pascoal de Mello: Projeto para um Novo Código de Direito Público de Portugal (feitas e apresentadas na Junta de Censura e Revisão pelo Dr. Antônio Ribeiro), Imprensa da Universidade, Coimbra, 1844, p. 9. Véase el Título IV en donde se trata de la Religión e Fe Católica.

1276 Ibídem.

1277 Ibídem.

1278 Ídem, p. 10.
} 
De la misma forma el párrafo $12^{\circ}$ prohíbe los conflictos de jurisdicciones entre el poder temporal y el eclesiástico. Pero, si esto sucedía, manda que sean enviados para ser resueltos por la "Mesa do Desembargo do Paço"1279.

Un contrapunto a todo esto serán las "Notas ao Título IV da Religião e Fé Católica do Novo Código de Direito Público de Portugal do Dr. Pascoal José de Mello Freire”, por el Dr. Antonio Ribeiro ${ }^{1280}$. Este autor, hará críticas al proyecto de Mello Freire, disintiendo del absolutismo real y reaccio a las ideas limitadas de ley fundamental que entonces estaban vigentes en Portugal. Antonio Ribeiro apreciaba poco de legislación en el Proyecto de Mello Freire, y destacaba que lo expuesto por el autor se podía reducir a tres proposiciones básicas, que sería puramente legislación civil:

"1 $1^{a}$. Que em nossos reinos se não possa publicar ou particularmente professar outra alguma religião, que não seja a Católica Romana; $2^{a}$. Que os estrangeiros de diversas crenças não possam ser obrigados a abraçar a religião do estado, nem se lhes possam tomar seus filhos para os batizarem; $3^{a}$. Que não vão missionários pregar nas conquistas sem licença do Rei ${ }^{1281}$."

A la cautela pretendida por Mello Freire en el Proemio del Proyecto para un Nuevo Código, Antonio Ribeiro rebatirá con acérrima critica, cuando se declaraba en el texto legal que no se pretendía trazar o definir dogma, creencia y doctrina; siendo dicha excusa tachada de incuria, puesto que, en Portugal príncipe alguno había jamás definido dogmas, inmiscuyéndose en el papel de la Iglesia; por lo tanto, veía como innecesario hacer dicha mención en una legislación de cuño civil. En cuanto a la parte que nos interesa en esta discusión, la crítica que hacía Antonio Ribeiro a la afirmación de Pascoal José de Mello Freire, al referirse en el Proemio que “(...) nosso supremo poder nesta parte está, para bem nosso, sujeito à Igreja santa $^{1282}$,, es algo muy esclarecedor de la relación entre la corona y la Iglesia. Dirá Antonio Ribeiro en relación a ello, que una cosa era la persona física del monarca que se somete, como cualquier otro feligrés, y otra bien distinta era el corpus mysticum del monarca ${ }^{1283}$. Añadirá, además, que:

\footnotetext{
1279 Ídem, p. 10.

${ }^{1280}$ RIBEIRO, Antônio: Notas ao Título IV da Religião e Fe Católica do Novo Código de Direito Público de Portugal do Dr. Pascoal José de Mello. Escritas e apresentadas na Junta da Revisão pelo Dr. Antônio Ribeiro en HESPANHA, Antônio Manuel (dir.) y SILVA, Cristina Nogueira da: Fontes para a história constitucional portuguesa, Faculdade de Direito da UNL, Lisboa, 2004.

1281 Ídem, p. 3.

1282 FREIRE, Pascoal de Mello: Projeto para um Novo Código de Direito Público de Portugal (feitas e apresentadas na Junta de Censura e Revisão pelo Dr. Antônio Ribeiro), Imprensa da Universidade, Coimbra, 1844, p. 9.

${ }^{1283}$ En materia de Teología Política Medieval se puede ampliar los conocimientos en KANTOROWICZ, Ernst H.: Os dois corpos do rei. Um estudo sobre Teología Política Medieval, Companhia das Letras, Sao Paulo, 1998, pp. 125 y ss.
} 
"Sujeito (o supremo poder) à Igreja Santa. Parece que aqui se confunde a qualidade de Rei com a qualidade de fiel, ou, o que é a mesma coisa, o sem poder temporal com a sua pessoa. A Igreja tem direito sobre o fiel, mas nenhum sobre a autoridade Real, para se poder dizer, como aqui se diz, que o supremo poder do Príncipe está sujeito à Igreja ${ }^{1284}$."

Hace, además, notar que no se puede seguir el error de los ultramontanos que pretendían sujetar el poder temporal de los Príncipes a la autoridad de la Iglesia. De este modo, se buscaba apoyar, con dicha doctrina, el uso del poder directo o indirecto de los Papas por arriba de las temporalidades de los Reyes. Antonio Ribero afirma además que "o supremo poder temporal nunca foi sujeito ao poder da Igreja, nem antes, nem depois da pública recepção do cristianismo $^{1285, "}$. Concluye el mismo autor que no fue así, porque dicho poder era también de origen divino $^{1286}$, y añade:

"Assim este poder civil era independente do poder da Igreja; pois que ele tinha independentemente dela toda a sua perfeição, toda a sua dignidade, e todo o seu exercício, posto que estivessem separados por séculos inteiros da verdadeira religião, e parecesse inimigo dela, não realmente em si, mas por injustas preocupações dos Príncipes, que exercitavam os seus direitos ${ }^{1287}$."

De este modo, se buscaba teorizar la independencia del poder temporal del espiritual, puesto que el primero, por tener origen también divino, nada tenía de inferioridad en relación con el segundo. Se desmarcaba así la monarquía de la tutela pontificia y le legitimaba para seguir ejerciendo los poderes de patrono de la iglesia nacional. Un ejemplo de esto fue la expulsión de los jesuitas, mucho más ligados al poder de Roma; y a los que el Marqués de Pombal acusaba de ser un Estado dentro de otro Estado.

El patronato casi siempre cuidaba mucho más de la intervención en las estructuras jerárquicas que de la disposición de recursos y manutención de templos y parroquias ${ }^{1288}$. La formación del clero en Brasil se hizo siempre de forma precaria, principalmente después de surgidos los seminarios diocesanos en el siglo XVIII, en obediencia a lo determinado en el Concilio de Trento ${ }^{1289}$. Esta precariedad en la formación del clero luso-brasileño se agravó mucho más con la expulsión de los jesuitas por el Marqués de Pombal, que suprimió una

\footnotetext{
${ }^{1284}$ RIBEIRO, Antônio: Notas ao Título IV da Religião e Fe Católica do Novo Código de Direito Público de Portugal do Dr. Pascoal José de Mello. Escritas e apresentadas na Junta da Revisão pelo Dr. Antônio Ribeiro en HESPANHA, Antônio Manuel (dir.) y SILVA, Cristina Nogueira da: Fontes para a história constitucional portuguesa, Faculdade de Direito da UNL, Lisboa, 2004, p. 5.

1285 Ibídem.

1286 Ibídem.

1287 Ídem, p. 6.

${ }^{1288}$ El estado de lastima de algunos templos católicos, lleva al presidente de la Província de Ceará en 1841 a denunciar dicha situación al gobierno central. Véase en BOEHRER, George C. A.: A Igreja no Segundo Reinado..., op. cit., p. 141.

${ }^{1289}$ NEVES, Guilherme P.: A Religião do Império..., op. cit., p. 385.
} 
institución sin poner otra en su lugar, como ya tuvimos ocasión de destacar. El clero que actuaba en el inicio del Imperio de Brasil, poco o nada seguía lo que dictaminaba el patrón tridentino ${ }^{1290}$, que preconizaba la existencia de sacerdotes instruidos en materia de fe, virtuosos en el comportamiento, activos en el atendimiento de sus ovejas y vigilantes en sus cobranzas espirituales $^{1291}$. Nada más lejos de esto ${ }^{1292}$. En el inicio del siglo XIX, el pensador Francisco de Sierra y Mariscal no solamente veía al clero de Brasil como el más ignorante y pobre del mundo cristiano, sino que además tachaba al pueblo de desposeídos de religión ${ }^{1293}$. Esto era bastante preocupante en una ambiente de disolución moral, en un mundo de enfrentamientos de doctrinas, después de las Reformas protestantes y católicas ${ }^{1294}$. Al final de cuentas, la máxima imperante para esta parte del nuevo mundo era que "Ultra Equinocialen non Peccata est", o sea, para allá del ecuador nada es pecado.

Un catecismo español de 1839 ensenaba, además de los diversos aspectos de los ritos y gestos católicos, en qué consistía la división de la doctrina cristiana, y amonestaba para evitar decaer en la fe apostatando en las doctrinas heréticas:

"Ya hemos visto como sois cristianos por el nombre y señal del cristiano; más decirme ahora ¿Cuántas cosas está obligado a saber el cristiano cuando llega a tener uso de razón? Cuatro. ¿Cuáles son? Saber lo que hay que creer, lo que hay de orar, lo que ha de obrar y lo que ha de recibir ${ }^{1295}$."

Así mismo, dicho catecismo explicaba, desde la visión católica, por supuesto, en qué consistían las doctrinas protestantes:

"Todos los sabios convienen en que la pérdida de la fe en esos hermosos reinos, que dieron tantos justos a la tierra, y tantos santos al cielo consistió en la ignorancia de los pueblos. Lutero, Calvino y los demás monstruos que la

\footnotetext{
${ }^{1290}$ El DECRETO de 3 de noviembre de 1827, declara en efectiva observancia las disposiciones del Concilio tridentino y de la Constitución del Arzobispado de Bahía acerca de la política matrimonial. Dicho decreto manda que la política matrimonial sea ejecutada por la Mesa de la Conciencia y Orden, dispuesto en un artículo único del Concilio Tridentino, en la Sesión 24, capítulo $1^{\circ}$, De Reformatione Matrimonii y de la Constitución del Arzobispado de Bahía, en el libro $1^{\circ}$, Titulo 68, artículo 291.

1291 Ibídem.

${ }^{1292}$ Aquí entra en relato del obispo de Cuiabá en 1851, que al asumir el obispado se había percatado que los padres y los párrocos, no tienen instrucción y moralidad que los harían perfectos en su condición de ministros de religión. Y de la misma forma se comportaban los feligreses, con total descompostura e ignorancia. BOEHRER, George C. A.: A Igreja no Segundo Reinado..., op. cit., p. 141 y 149.

${ }^{1293}$ NEVES, Guilherme Pereira das: E Receberá Mercê: a Mesa da Consciência e Ordens e o Clero Secular no Brasil, 1808-1828, Arquivo Nacional, Rio de Janeiro, 1997, p. 350.

${ }^{1294}$ BURKE, Peter: A Cultura Popular na Idade Moderna: Europa, 1500-1800, Companhia das Letras (Traducción de D. Bottmann), São Paulo, 1989, pp. 231 a 265. Cuanto al aspecto de la cultura popular frente a aspectos católicos como era el trato de los ritos fúnebres, véase en REIS, Joao José: A morte é uma festa. Ritos fúnebres e revolta popular no Brasil do século XIX, Companhia das Letras, São Paulo, 1998, pp. 27 y ss.

${ }^{1295}$ MAZO, Santiago J. Garcia: El Catecismo de la Doctrina Cristiana Esplicado, ò Esplicaciones del Astete que Convienen Igualmente al Ripalda, por el Licenciado Don Santiago José Garcia Mazo, Magistral de la Santa Iglesia Catedral de Valladolid, Segunda Impresión, Con las Licencias Necesarias, Imprenta de Don Julián Pastor, Valladolid, 1839, pp. 7 y 8.
} 
extinguieron en ellos, nada habrían conseguido, si los pueblos hubieran estado instruidos en la divina religión que profesaban. No extrañemos, católicos, que haya tanta poca fe y tanta corrupción de costumbres en el cristianismo. Se ignora la religión y esto basta. El deseo de aplicar algún remedio a tan lastimosos males, ha sido el principal motivo de emprender estas explicaciones ${ }^{1296}$."

Los catecismos, como se puede deducir, cumplían una función educativa y doctrinadora muy importante, principalmente en un mundo de clero poco instruido, pero también creaban barreras a los que no sabían leer.

Sin embargo, aunque prevaleciese este tipo de catecismo, en donde se polemizaban las doctrinas protestantes, era bastante conocido en el mundo luso-brasileño, la traducción al portugués de las “Lições de Direito Público Constitucional", en una publicación de 1822, del doctor por Salamanca, Ramón Salas. En dicha obra, en el capítulo X, que se intitulaba: "Liberdade de Consciência, ou de Religião", traía una visión completamente distinta de la presentada por el catecismo castellano, algo que podríamos llamar de un pensamiento liberal en la concepción religiosa ${ }^{1297}$.

La administración del culto y la política eclesiástica estaban subordinadas al Ministerio de la Justicia en el Imperio de Brasil, de modo que los poderes de patrono del emperador allí se encontraban delegados. El estadista José Thomaz Nabuco de Araújo (1813-1878), bahiano, que ocupó el cargo de ministro de Justicia del Imperio y desempeñó frente a dicho ministerio una política bastante hábil en materia eclesiástica, estaba convencido, al frente del ministerio, de que "a primeira e mais importante necessidade na situação moral de nosso país era a difusão do principio religioso no interesse da família e da sociedade ${ }^{1298, "}$. Nabuco era consciente del estado lastimable en que se encontraba el clero, y sabía que era importante intentar reformarle.

"Infelizmente o estado do clero não permitia que a sociedade pudesse colher todo o benefício do principio religioso; o esforço do governo devia como que se concentrar antes de tudo na formação de um clero capaz de servir à religião, e como o escândalo público era tanto maior quanto mais severa a regra, era principalmente para as ordens, caídas, algumas delas, na mais completa relaxação,

\footnotetext{
1296 Ídem, p. 8.

${ }^{1297}$ SALAS, Ramon: Lições de Direito Público Constitucional para as Escolas de Hespanha. Por Ramon Salas, Doutor de Salamanca; Traduzidas e Dedicadas por D. G. L de D`Andrade: Com o mesmo objeto à Regenerada Nação Portugueza, e offerecidas aos seus dignos representantes, Na Typographia Rollandiana, Lisboa, 1822, p. 84. Sobre aspectos de la religión y religiosidad en espectro más amplio la lectura de CONSTANT, Benjamin: De la Religión considerada en sus fuentes, formas y dessarrollos, (Texto íntegro presentado por Tzvetan Todorov y Étienne Hofmann. Traducción de Agustín Neira), Editorial Trotta, Madrid, 2008. En este volumen, es esclarecedor el Libro XI, en donde se trata de los Principios fundamentales de las religiones sacerdotales, pp. 411 y ss. También no llegó a manos el original francés - CONSTANT, Benjamin: De la Religion, considérée dans sa source, ses formes et ses développements, Tome Premier et Second, H. Tarlier, Rue de la Montagne, P. J. Voglet, Rue de Ruysbroek, Bruxelles, 1825.

${ }^{1298}$ NABUCO, Joaquim: Um estadista do Império. Nabuco de Araújo. Sua vida, suas opiniões, sua época, Tomo Primeiro: 1813-1857, H. Garnier, Livreiro-Editor, Rio de Janeiro/Paris.
} 
que o espírito de reforma se devia primeiro voltar. Foi este pensamento que inspirou a Nabuco suspendendo a recepção de noviços nos conventos. Nenhum ato de sua administração eclesiástica foi, entretanto, tão impugnado do lado católico como esse. A medida provisória ficou definitiva; sucederam-se mais de vinte gabinetes, nenhum a revogou, e somente com a separação da Igreja e do Estado, no novo regimen, reabriu-se os noviciados nos conventos. Nabuco é por isso tratado, ainda hoje, na polemica da imprensa e do foro como o destruidor das ordens religiosas. $O$ histórico desse incidente esquecido mostrará com a maior evidencia que o espírito que o animava não era de hostilidade às instituições monásticas do país, mas verdadeiro e sincero espírito de reforma ${ }^{1299}$."

De este modo, la vida monacal en el Brasil del siglo XIX, según la descripción de Nabuco Araújo, estaba muy alejada de los principios tridentinos. Así que propone una reforma en los conventos de acuerdo con el Sumo Pontífice, que debía consistir en:

"1". Em serem eles na parte espiritual sujeitos aos Bispos, aos quais devem competir a nomeação e demissão dos Prelados e Superiores respectivos; $2^{\circ}$. Em prestarem contas da administração temporal ao juízo competente ${ }^{1300}$."

Sin embargo, la toma de decisiones del ministro de Justicia prohibiendo nuevas admisiones en las Ordenes monacales impactará mucho en todas estas, causando reacciones adversas del prior del Monasterio de los Benedictinos en Salvador de Bahía, el más antiguo de las Américas y uno de los más prósperos de Brasil en aquel tiempo. Dicha reacción provocará al ministerio para conceder una licencia especial de cara a admisión de novicios, contrariando así el Aviso de 19 de mayo de 1855, que tenía la siguiente redacción:

"Circular - 1" Secçao - Ministerio dos Negocios da Justiça, Rio de Janeiro em 19 de Maio de 1855. S. M. o Imperador há por bem cassar as licenças concedidas para a entrada dos noviços nesta ordem religiosa até que seja resolvida a Concordata com a Santa Sé vai o Governo Imperial propor. Deus Guarde a V. P. Revma. José Thomaz Nabuco de Araújo. - Sr. Provincial dos Religiosos Franciscanos da Corte. (Na mesma conformidade aos demais Ordens Religiosas do Império) ${ }^{1301}$.”

Esto demuestra el modo como el gobierno imperial lidiaba con el poder de patrono, y las consecuencias que causaban las políticas eclesiásticas. El conflicto con el clero era una constante, y al final del Imperio uno de los puntos que llevará a la derrocada del emperador será la denominada Cuestión Religiosa. Es cierto que aquí no pretendemos hacer un estudio exhaustivo sobre la Cuestión Religiosa, generada a la causa de los constantes roces entre el gobierno en el ejercicio del poder de patrono y de las políticas administrativas empleadas en el campo eclesiástico. Lo abordamos, aunque brevemente, para resaltar principalmente el estado del clero y su formación, puesto que, eran estos párrocos quienes desempeñaban un papel

\footnotetext{
${ }^{1299}$ Ídem, pp. 304-305.

1300 Ídem, pp. 305-406.

${ }^{1301}$ Ídem, p. 307.
} 
relevante en el desarrollo de las elecciones en todo el Imperio a lo largo del siglo XIX, apenas disminuido con la edición de la denominada "Lei dos Circulos", que introdujo algunas novedades electorales en esta materia, puesto que designaba otros locales, que no eran las iglesias de las parroquias, para celebrar las elecciones primarias. Otro aspecto interesante en la intervención del gobierno en materia religiosa será la introducción del registro civil para los matrimonios mixtos, entre católicos y protestantes en el Imperio ${ }^{1302}$. Dirá, en torno a estas cuestiones, Guilherme P. das Neves, siguiendo la afirmación de Georges Boehrer, que en términos religiosos, a través de la herencia del patronato y del regalismo portugués, el Brasil, incluso después de la independencia en 1822, no había propiamente conseguido alejarse del "modelo pombalino" 1303 . En la línea de la intervención eclesiástica y usando en la forma delegada los poderes constitucionales del patronato, el Ministro Nabuco Araújo procederá a reformar los conventos; para ello, traza un proyecto de concordato con la Santa Sede sobre dicha materia, hace una convención de los bienes de los conventos, establece recursos a la corona en materia religiosa, trata de la regeneración del clero y de la creación de Facultades de Teología ${ }^{1304}$. Aunque nada de esto fue suficiente para evitar los enfrentamientos entre el clero y el gobierno, principalmente por intentar tratar a los clérigos como meros funcionarios de la corona, exigiéndoles la aplicación de determinadas medidas de los gobiernos de turno, puesto que, van a ser los ministros del gabinete formado por las abundantes elecciones en el Imperio quienes trataban de ejercer directamente los poderes de la institución del Patronato, así como conceder el Beneplácito a los documentos papales en el territorio del Imperio.

\section{B) El reconocimiento del Estado por la Santa Sede: Las Bulas Sollicita Catholicis y Praeclara Portugaliae}

Tras el proceso de independencia, el Imperio pasará por otras dos pruebas más: el reconocimiento por parte de las demás naciones de la formación de un nuevo Estado, y la búsqueda ante a la Santa Sede para que el Sumo Pontífice, como había hecho ya con los monarcas portugueses siglos antes, concediese al monarca brasileño los poderes de patrono junto a la "Iglesia brasiliense" 1305 , así denominada en los discursos parlamentarios. Por ello el gobierno imperial de Brasil va a emprender una gran ofensiva diplomática para buscar el reconocimiento de las grandes potencias de la época. Sin embargo, el reconocimiento internacional del Imperio de Brasil pasará por una peculiar negociación con el papado,

\footnotetext{
1302 Ídem, p. 312 y ss.

${ }^{1303}$ NEVES, Guilherme P.: A Religião do Império..., op. cit., p. 386.

${ }^{1304}$ NABUCO, Joaquim: Um estadista do Império. Nabuco de Araújo. Sua vida, suas opiniões, sua época, Tomo Primeiro: 1813-1857..., op. cit., pp. 304 y ss.

1305 ANAIS DA CÂMARA DOS DEPUTADOS, 1827, v. 3, sessão de 12 de julho, p. 124.
} 
principalmente por su participación creciente en las relaciones de poder en Brasil. Estas negociaciones estaban condicionadas al previo reconocimiento de Portugal, aunque la Santa Alianza ya se había manifestado antes, de forma favorable en el caso de D. Joao VI por haber elevado Brasil a la categoría de reino ${ }^{1306}$, al tratarse de su príncipe natural. Este ánimo también se dirigía a D. Pedro I, tanto por ser la emperatriz una Habsburgo, Austriaca, como por ser el emperador el legítimo heredero del trono portugués ${ }^{1307}$.

En el ámbito de la Teoría del Estado, el perímetro de definición e identificación territorial del Imperio de Brasil, se propugnó por una homogeneidad política, que correspondía a una homogeneidad cultural ${ }^{1308}$, mucho más en el ámbito formal que de hecho, dado que la lógica portuguesa en la creación del nuevo país no tenía en cuenta las culturas y religiones autóctonas, ni tampoco la contribución, en aquella materia, de la matriz africana en la formación nacional. Así que, el espacio territorial del imperio se entendía como elemento constitutivo del Estado/Nación, cuya expresión geopolítica lo convierte, en su individualidad y unidad $^{1309}$, en un claro sujeto de derechos y deberes en el ámbito del derecho internacional y de la comunidad de naciones reconocidas como tales ${ }^{1310}$. Sin embargo, para pertenecer al club de naciones, con derechos y deberes, necesita del reconocimiento de sus pares internacionales. Motivados por una geopolítica propia, los Estados Unidos de América van a ser el primer país en reconocer, el 26 de mayo de 1824, al Imperio de Brasil. En seguida, México, otra joven nación, también independizado de otra potencia peninsular, lo hará el 9 de marzo de $1825^{1311}$. De este modo, la disolución de los lazos, principalmente jurídicos, que ligaban a las entidades que conformaban al Reino Unido de Portugal, Brasil y Algarves, romperá, también en términos

\footnotetext{
${ }^{1306}$ BONAVIDES, Paulo y AMARAL, Roberto: Textos Políticos da História do Brasil, Volume I - Formação: Antecedentes (sécs. XV e XVI), Independência (sécs. XVII até 1822), Império: Primeiro Reinado (1822-1831), Regência (1831-1841), Senado Federal, $3^{a}$ Edição, Brasília, 2002, pp. 454-456.

${ }^{1307}$ Véase en SCHULTZ, Kirsten: Tropical Versailles. Empire, Monarchy, and de Portuguese Royal Court in Rio de Janeiro, 1808-1821, Routledge, New York/London, 2001, pp. 151 y ss.

${ }^{1308}$ FRANCO, Afonso Arinos de Melo: "Ideias políticas do constitucionalismo imperial" en O Pensamento Constitucional Brasileiro (Ciclo de conferências realizado no período de 24 a 26 de outubro de 1977), Câmara dos Deputados, Brasília, 1978, p. 33.

${ }^{1309}$ El Imperio, política y administrativamente era visto como un Estado unitario, aunque el Título I, Art. $2^{\circ}$ de la Constitución del Imperio hablase de división en Provincias, no se podía pensar en un Imperio federal. "Estados distintos, ou federados, sim circunscrições territoriais, unidades locais, ou parciais de uma só e mesma unidade geral (...). Por isso mesmo que o império é um e único, que ele não é dividido em províncias senão no sentido e fim de distribuir convenientemente os órgãos da administração". BUENO, José Antônio Pimenta: Direito Público Brasileiro e Análise da Constituição do Império, Senado Federal, Brasília, 1978, pp. 21 y 22. Un trabajo más reciente, en donde se analiza la política y la administración del Imperio y las provincias de Brasil en el siglo XIX, se puede encontrar de forma más detallada en GOUVÊA, María de Fática Silva: O Imperio das Provincias. Rio de Janeiro, 1822-1889, Civilização Brasileira/Faperj, Rio de Janeiro, 2008, pp. 20 y ss.

${ }^{1310}$ UDINA, Manlio: "Il Diritto Internazionale Tributario" en FEDOZZI, Prospero e ROMANO, Santi (per cura di - in collaborazione di vari autori): Trattato di Diritto Internazionale, Vol. Decimo, CEDAM - Casa Editrice Dott. Antonio Milani, Padova, 1949, pp. 139 y ss.

${ }^{1311}$ FLORES, Alberto Vivar: "El liberalismo constitucional en la fundación del Imperio brasileño", Historia Constitucional (revista electrónica), n. 6, 2005, p. 169.
} 
jurídicos, la estructura de poder que autorizaba la gestión de la organización eclesiástica por parte del nuevo soberano del independiente Imperio de Brasil. Aunque d. Pedro I fuese el legítimo heredero del trono portugués, así como el príncipe legítimo del Reino de Brasil, ahora Imperio independiente, la estructura legal que atribuía al monarca del trono portugués los poderes de patrono de la iglesia nacional de Portugal $^{1312}$ no pasaban de forma automática a la sección del Reino Unido que se había tornado un ente soberano. Mucho menos le otorgaba la maestría de la Orden de Cristo, que permanecerá bajo la tutela de D. Joao VI, hasta su muerte en 10 de marzo de $1826^{1313}$. Entretanto, estas dos instituciones, con la separación entre los entes soberanos, permanecerán vinculadas apenas a Portugal, puesto que, la asunción de la corona Portuguesa, con la muerte de D. Joao VI, no significaba la necesaria reunión de las dos coronas, porque así lo prohibía el art. $1^{\circ}$ de la Constitución del Imperio: "O Império do Brasil é a associação Política de todos os Cidadãos Brasileiros. Eles formam uma Nação livre, e independente, que não admite com qualquer outra laço algum de união, ou federação, que se oponha à sua Independência" ${ }^{, 1314}$.

La declaración formal, en el art. 5 de la Constitución del Imperio, de que la Religión Católica Apostólica Romana continuaría siendo la religión del Imperio, además de reconocer en el art. 102 que el emperador era el jefe del Poder Ejecutivo, que lo ejercita a través de sus Ministros de Estado, siendo sus principales atribuciones, nombrar Obispos y promover los Beneficios Eclesiásticos (inciso II). También en el mismo artículo, inciso XIV, al emperador, le atribuye la Constitución la prerrogativa de conceder o denegar el Beneplácito a los Decretos de los Concilios, letras Apostólicas, y cualesquiera otras Constituciones Eclesiásticas que no se opongan a la Constitución del Imperio. Entretanto, establece que procederá la aprobación de la

\footnotetext{
${ }^{1312}$ Es importante para comprender la estructura del patronato portugués, la lectura del Capítulo II (Nociones fundamentales del patronato con aplicación al patronato portugués) de la obra de LOPES PRAÇA, J. J.: Ensaio sobre o padroado portugués..., op. cit., pp. 14 y ss. Allí se define el patronato como: "o complexo dos direitos que os cânones conservavam ao patrono sobre uma igreja. Patrono é o que edificou, fundou, ou dotou uma igreja. Bento Cardoso Osorio refere as noções de padroado dos teólogos e dos canonistas. Segundo os teólogos direito de padroado é o direito de apresentar um clérigo para um benefício eclesiástico. Segundo os canonistas, direito de padroado é um direito honorífico, oneroso e útil, competindo a alguém na igreja, porque, consentindo o ordinário, a fundou, ou isto foi feito por seus antecessores. Derecho de patronato, dicen de la Serna Montalbane, se define la facultad de presentar un clérigo para que se le confiera un beneficio vacante, y de gozar de ciertos derechos, ya útiles, ya onerosos, ya honoríficos.” Ídem, p. 15.

${ }^{1313}$ NEVES, Guilherme P.: “A Religião do Império...”, op. cit., p. 386. La notificación de la muerte de D. Joao VI, rey de Portugal al papa León XII se puede ver en MONTOR, Artaud: Historia del Papa León XII (traducida ahora por primera vez al castellano de la que escribió en francés el Caballero Artaud de Montor, encargado de los negocios que fue de Francia en Roma, Florencia y Viena; individuo de la Academia de Inscripciones y Bellas Letras, de la Academia de la Crusca, de la Sociedad Gotinga y de la Academia Tiberina; Oficial de la Legión de Honor, Caballero Comendador de la Orden de San Gregorio el Grande, Comendador de la Real y distinguida Orden española de Carlos III, Tomo I, Establecimiento Tipográfico de Don Manuel Pita, Madrid, 1850, pp. 280 y ss.

1314 (Archivo John Carter Brown Library) - Constituição Politica do Império do Brasil (Independência ou Morte), Na Typographia de Plancher, Impressor-Livreiro de Sua Magestade Imperial, Rio de Janeiro, 1824, p. 1.
} 
Asamblea Legislativa, si dichos documentos pontificios contuviesen disposiciones generales $^{1315}$. Dichas declaraciones en el texto Constitucional generarán intensa discusión y tensión con la Santa Sede, dado que el patronato en el ámbito jurídico de la Iglesia Católica era una concesión del Sumo Pontífice a un monarca determinado y no poderes inherentes a la soberanía de cada Estado católico. Aunque hubiese separación en el ámbito político, en el religioso las autoridades portuguesas continuaban disfrutando y ejerciendo dichas atribuciones de la llamada Iglesia brasiliense ${ }^{1316}$. Era una cuestión que el gobierno imperial debía intentar solucionar junto al Sumo Pontífice, dado que la atribución de los poderes de patrono por la Constitución del Imperio al emperador generaba una situación de legalidad y legitimidad bastante complicada.

El gobierno imperial emprenderá una ofensiva para conseguir de las grandes potencias el reconocimiento de su independencia. Inglaterra era la gran interesada de que se procesase con presteza dicha negociación con Portugal, que sin el reconocimiento de este último país, el primero, su aliado histórico, no podía dar su reconocimiento, lo que le perjudicaba además en materia comercial, en donde Brasil jugaba un papel muy importante para la corona británica. Por tanto, se eligió a la ciudad de Londres como el punto de partida para las negociaciones en Europa. El 7 de agosto de 1824 se nombró al monseñor Francisco Corrêa Vidigal, que había servido en la Legacía de Río de Janeiro al mismo tiempo que los nuncios Caleppi y Maresfoschi, de 1808 a 1820, como plenipotenciario junto a la Santa Sede. Para asesorar al monseñor, se habilitó como secretario a Vicente Antonio da Costa. Monseñor Vidigal, con la intermediación de Austria, se acercó a Roma, y allí se instaló el 5 de enero de $1825^{1317}$. Como la emperatriz María Leopoldina fuese una archiduquesa austríaca, hija del último emperador del Sacro Imperio Romano Germánico, Francisco II (1768-1835), que desde 1804 se había coronado Emperador de Austria, con el título de Francisco I, por exigencia de Napoleón; será esta miembro de la Casa de Habsburgo-Lorena quien aportará las credenciales junto al emperador Francisco I de Austria para que abriesen las puertas de la Santa Sede a los negociadores brasileños. Aunque la muerte, en 11 de diciembre de 1826, de la emperatriz doña

\footnotetext{
1315 Ídem, pp. 10 y 11.

${ }^{1316}$ Algunos autores van a abordar dicha situación peculiar de la separación de hecho pero no de derecho de las Iglesias Católica de Portugal y de la del Brasil independiente, como: CALÓGERAS, Joao Pandiá: "A Política Exterior do Império: o Primeiro Reinado", Revista do Instituto Histórico e Geográfico Brasileiro, Tomo Especial, Imprensa Nacional, Rio de Janeiro, 1928, pp. 368-379. TORRES, Joao Camilo de Oliveira: “A Igreja e o Estado” en A Democracia Coroada: Teoria Política do Império do Brasil, Editora Vozes, Petrópolis, 1964, pp. 399-406. TORRES, Joao Camilo de Oliveira: História das Idéias Religiosas no Brasil (A Igreja e a Sociedade Brasileira), Editora Grijalbo, São Paulo, 1968, pp. 34 y ss. También con base en algunos de estos autores, se puede encontrar la temática en NEVES, Guilherme P.: “A Religião do Império...”, op. cit., p. 395.

${ }^{1317}$ Estas informaciones se pueden encontrar con más detalles en el artículo de Guilherme Pereira das Neves, Ídem, pp. 396 y ss.
} 
María Leopoldina, por causas atribuidas al propio emperador D. Pedro I, arrojó muchas sombras a la relación de éste con su suegro, el emperador de Austria. Murió poco después de asumir la corona de Portugal como reina consorte por un breve período entre 10 de marzo y 28 de mayo de $1826^{1318}$. Pero, en esos momentos, las negociaciones con la Santa Sede ya estaban bastante avanzadas, dado que, el propio rey de Portugal ya había reconocido la independencia de Brasil, y con la muerte de este último, los propios emperadores de Brasil se habían trasformado, además, en reyes de Portugal, aunque por un breve período, como ya habíamos señalado.

A pesar de todas estas credenciales ante el Vaticano, la causa brasileña chocaría con algunos impedimentos. Había subido al trono de Pedro el papa León XII ${ }^{1319}$, hacía menos de un año, sucediendo al tormentoso pontificado de Pio VII, que había firmado un Concordato con Napoleón en términos muy desfavorables en $1801^{1320}$. El corso, con las guerras del norte de la península Itálica, se había apoderado de los Estados Pontificios, o Patrimonio de Pedro, manteniendo cautivo al propio Sumo Pontífice entre 1808 y 1814. Con la derrota de Napoleón, la Santa Alianza favorecerá la Restauración de las fronteras anteriores a las investidas napoleónicas y el regreso al status quo ante. Así, Pío VII buscará restaurar también la Compañía de Jesús en 1814. Incluso, a dicho Papa y a su pontificado les alcanzaron los movimientos de las independencias americanas, y sus intervenciones en estos asuntos buscaron no confrontarse con las potencias coloniales, ni tampoco distanciarse del todo de los nuevos estados americanos. Entretanto, esta política equidistante no siempre consiguió agradar a ambos bandos $^{1321}$. Pero, no solamente el ambiente era desfavorable a los asuntos brasileños, sino que contaba con una buena dosis de oposición en la Santa Sede por parte del ministro portugués Domingos de Souza Coutinho, Conde de Funchal, que se había esforzado en sabotear la misión brasileña, dado que en este momento, Portugal no había aun reconocido la independencia de Brasil, y la Curia romana tampoco pensaba en hacerlo antes de la potencia colonizadora, al menos en teoría ${ }^{1322}$.

\footnotetext{
${ }^{1318}$ Para ampliar más los conocimientos en dicha materia se puede consultar en Kaizer, Gloria, Doña Leopoldina, un Habsburgo en el trono de Brasil, Editora Nova Fronteira, Rio de Janeiro, 1997. KANN, Betina, Souza Lima, Patricia, la selección, Cartas de una emperatriz, Editora Estação Liberdade, São Paulo, 2006. Lacombe, Américo Jacobina, el traductor, La correspondencia entre María Graham y la emperatriz Doña Leopoldina, Itatiaia Editora, Belo Horizonte, 1997. Prantner, Johanna, La emperatriz Leopoldina de Brasil, Editora Vozes, Petrópolis, 1998. RAMIREZ, Stanley Ezequiel, Las relaciones entre Austria y Brasil - 1815-1889, Colección, Brasiliana, Tomo 337, (traducción y notas de Américo Jacobina Lacombe), Companhia Editora Nacional, São Paulo, 1968.

${ }^{1319}$ MONTOR, Artaud: Historia del Papa León XII..., op. cit., pp. 276 y ss.

${ }^{1320}$ BORREGO, Andrés: Historia de la Vida y del Pontificado del Papa Pio VII, compuesta por el Caballero Artaud, Antiguo encargado de Negocios en Francia cerca de la Santa Sede. (Y traducida cuidadosamente al castellano), Imprenta de la Compañía Tipografica, Madrid, 1837, pp. 146 y ss.

${ }^{1321}$ Ídem, pp. 165 y ss.

${ }^{1322}$ NEVES, Guilherme P.: “A Religião do Império...”, op. cit., p. 396.
} 
La misión brasileña, además de bien recomendada en la Santa Sede, llevaba motivos bastantes razonables y preocupantes al Sumo Pontífice para que se diesen oído a las peticiones de Brasil. Francisco Correa Vidigal y su secretario, el habilidoso Vicente Antonio da Costa, argumentará en la Sede Romana que en el caso de que faltasen diocesanos en Brasil, el emperador, investido de los poderes de patrono por la Constitución del Imperio se veía en la obligación de nombrar a los obispos y hacerlos ungir por los metropolitanos para evitar la falta total de prelados, intentaba disuadir con esta medida la producción de daños al bien espiritual de los pueblos, alocución tan de moda en aquellos momentos. No era una amenaza directa, pero daba a entender que estas actitudes del emperador y de la Iglesia brasiliense equivaldría a un cisma dentro del seno católico. Así que manteniendo la postura de no desagradar a nadie ${ }^{1323}$, la Santa Sede no se había negado a mantener negociaciones con la misión brasileña, pero, tampoco desagradar a Portugal, de manera que postergó la recepción formal de la misión y su decisión hasta que llegase la noticia oficial de que el rey d. Joao VI había ratificado el Tratado entre Portugal y Brasil que reconocía la independencia de este último. Solamente después de esto fue que se marcó una audiencia entre Francisco Correa Vidigal y el Sumo Pontífice en 13 de enero de 1826, poco más de un año de que hubiese formado la misión, y de haber llegado ésta a Roma ${ }^{1324}$.

El acuerdo de paz de que necesitaba la Santa Sede para reconocer al plenipotenciario brasileño fue firmado entre las majestades fidelísimas de Brasil y Portugal en 29 de agosto de 1825, Tratado de Paz y Alianza entre D. Pedro I y D. Joao VI, con la intermediación de un representante de Su Majestad Británica ${ }^{1325}$. Dirá Zília Osório de Castro que Inglaterra intervino activamente en este acierto de cuentas entre Brasil y Portugal en defensa de su política y de su economía ${ }^{1326}$.

\footnotetext{
${ }^{1323}$ MONTOR, Artaud: Historia del Papa León XII..., op. cit., pp.

${ }^{1324}$ NEVES, Guilherme P.: “A Religião do Império...”, op. cit., p. 396.

1325 TRATADO DE PAZ E ALIANÇA de 29 de agosto de 1825 - Collecção das Leis e Decretos do Império do Brasil, desde a Época da sua Independência. Obra dedicada à Assembleia Legislativa; Precedida de hum Discurso Preliminar, e Terminada por huma Taboa Alfabética, e Arrosoada, Por M M., Na Imperial Typographia de P. Plancher-Seignot, Rio de Janeiro, 1827, pp. 257 y ss. A través del Decreto de 10 de abril de 1826, el gobierno imperial reconocía como mutualmente ratificado el Tratado de Paz y Alianza entre Portugal y Brasil. De la parte portuguesa se puede consultar en Collecção de Tratados, Convenções, Contractos e Actos Públicos celebrados entre a Coroa de Portugal e as mais potencias desde 1640 até ao presente, compilados, coordenados e anotados por José Ferreira Borges De Castro (Visconde de Borges de Castro); continuada por Júlio Firmino Júdice Biker, t. V, Lisboa, Imprensa Nacional, 1887, pp. 523-527.

${ }^{1326}$ CASTRO, Zília Osório de: "A "Varanda da Europa" e o "Cais do Lado de Lá" Tratado de paz e aliança entre D. João VI e D. Pedro (29-08-1825)" en CASTRO, Zília Osório de, SILVA, Júlio Rodrigues da y SARMENTO, Cristina Montalvao (Eds.): Tratado do Atlântico Sul. Portugal-Brasil, 1825-2000, Colecção Biblioteca Diplomática do MNE - Série A, Ministério dos Negócios Estrangeiros, Europress, Ltda., Portugal, 2006, p. 25. Véase también acerca del aspecto de la governaza Británica en RODRIGUES, José Honório: Independência, revolução e contrarevolução. A política internacional, F. Alves, Rio de Janeiro, 1975, p. 11.
} 
Este Tratado de Paz y Alianza celebrado entre los dos emperadores de Brasil, traduce, según lo entiende Zília Osório de Castro, bajo la fórmula legal los parámetros de los cambios que se observaban en el mundo luso-brasileño. Firmado en 1825, pero, solo ratificado en $1826^{1327}$, por el plenipotenciario portugués, Charles Stuart (consejero privado de Su Majestad Británica), y por su homólogo brasileño Luís José de Carvalho e Melo, José Egidio Alvares de Almeida, Barón de Santo Amaro, y Francisco Vilela Barbosa. Dicho Tratado dispone en once artículos los puntos acordados para efectuación del derecho de la independencia de Brasil ${ }^{1328}$. Un aspecto interesante de este Tratado es que el rey de Portugal "transfere de sua livre vontade" la soberanía del Imperio de Brasil al emperador D. Pedro I. Desmiembra, así, al Reino Unido de Portugal, Brasil y Algarves, y reconoce a su hijo como emperador de Brasil, pero, Su Majestad Fidelísima toma para sí y reserva para su persona el mismo título de emperador de Brasil, art. $1^{\circ}$. El Imperio pasa a ser casi una diarquía, con una bifronte imperial. También trata aquel diploma de asuntos comerciales, además de otros detalles que señalaremos más adelante. En el mismo día de la firma del Tratado se firma una Convención Adicional al mismo Tratado $^{1329}$. Esta Convención significará los mismos plenipotenciarios que el Tratado y se resume en cuatro artículos, y en muchos de ellos apenas aclara algunos puntos de aquél diploma legal. Estos dos documentos serán la cumbre de varios procesos socio-políticos sucedidos desde la llegada del rey portugués, la familia real y la corte portuguesa a Río de Janeiro en 1808. Puesto que, en aquél año se firmaron la Abertura de los Puertos a las Naciones Amigas, los Tratados de Alianza y Comercio con Inglaterra (1810), la creación de estructuras administrativas superiores de Estado en Río de Janeiro, como los Tribunales, a semejanza de los que antes existían en Lisboa, la ascensión de Brasil a la categoría de Reino Unido a Portugal, Brasil y Algarves (1815), la consecuente Revolución de Oporto, con la convocatoria de Cortes en Portugal y posteriormente en Brasil, y el regreso de la sede de la monarquía, con el rey, para Lisboa. Es evidente que Inglaterra tenía prisa en solucionar la posición de Brasil en el ámbito internacional, sobre todo por los aspectos económicos, pero necesitaba, además, renovar los tratados de 1810 con Brasil, que ya se iba expirando su plazo de vigencia ${ }^{1330}$.

En este acto de firma del Tratado y de la Convención entraba un sin número de cuestiones que rondaban al Imperio Portugués, como potencia marítima, y al Imperio de Brasil,

\footnotetext{
1327 TRATADO DE PAZ E ALIANÇA de 29 de agosto de 1825 - Collecção das Leis e Decretos do Império do Brasil..., op. cit., p. 257.

${ }^{1328}$ CASTRO, Zília Osório de: “A Varanda da Europa...”, op. cit., p. 24.

1329 CONVENÇAO ADDICIONAL AO TRATADO de 29 de agosto de 1825 - Collecção de Tratados, Convenções, Contractos e Actos Públicos celebrados entre a Coroa de Portugal e as mais potencias desde 1640, pp. 527-530.

${ }^{1330}$ CASTRO, Zília Osório de: “A Varanda da Europa...”, op. cit., p. 25.
} 
como el futuro recreador del soñado imperio luso-brasileño. También la necesidad que tenía D. Joao VI de garantizar en la persona de su hijo, que también era heredero del trono portugués, una futura reunificación del imperio luso fragmentado ${ }^{1331}$. Y por último, Inglaterra buscaba garantizar su posición privilegiada con Brasil sin, entretanto, enfrentarse con Portugal. Además, necesitaba garantizar la renovación de los Tratados de 1810, como efectivamente se hará, asegurando a los súbditos de Su Majestad Británica la extraterritorialidad en Brasil y la libertad religiosa de que ya gozaban sus súbditos en Portugal, y precariamente, en estos momentos, en Brasil $^{1332}$.

Una cuestión que debe ser abordada con el estudio de la firma del Tratado y de la Convención entre Portugal y Brasil, son los efectos secundarios, o mejor dicho, implícitos al propio acto. Una primera cosa, que ya aludimos, será la necesidad que tenía Inglaterra en renovar los Tratados de 1810, que ya estudiamos en el Capítulo II de este trabajo, y en donde se garantizaba a los súbditos británicos protestantes la libertad religiosa, pero, dentro de unos parámetros fijos, e incluso dispositivos penales bastante determinados, evitándose con eso la discrecionalidad del Estado brasileño. Esto por un lado. De otra parte, vamos a ver los efectos que tuvieron dichos diplomas en las negociaciones con la Santa Sede, como venimos aludiendo, para que se concediesen los poderes de patrono al emperador de Brasil, iguales que gozaban hasta la fecha los monarcas portugueses, solucionando de este modo, o extendiendo de este modo, la cuestión de la Iglesia brasiliense que formalmente continuaba dependiendo de la Iglesia portuguesa, y por lo tanto, de los poderes de patrono del rey portugués, mientras que, la Constitución del Imperio otorgaba los poderes de patrono de la Iglesia brasiliense al emperador de Brasil, creando una situación sui generis. El art. $1^{\text {o }}$ del Tratado de Paz y Alianza de 1825, al decir que Su Majestad Fidelísima cede y transfiere de su libre voluntad la soberanía del Imperio de Brasil a su hijo d. Pedro y a sus legítimos sucesores, tomando solamente y reservando para su persona el mismo título ${ }^{1333}$, nos deja antever algunas cuestiones implícitas. En primer lugar legitimaba a Su Santidad recibir a 13 de enero de 1826 al plenipotenciario de la misión brasileña en el Vaticano ${ }^{1334}$. Lo anterior venía a ser una solución bastante interesante. Con la cesión y transferencia de la soberanía de una parte de la monarquía portuguesa a un príncipe de la Casa de Braganza, se daba también la cesión de los poderes de patronato de la Iglesia, o la

${ }^{1331}$ SOUSA, Maria Aparecida Silva de: "Independência e soberania nacional na América Luso-espanhola" en COSTA, Wilma Peres y OLIVEIRA, Cecília Helena de Salles (org.): De um Império a outro. Formação do Brasil, séculos XVIII e XIX, Editora Hucitec/Fapesp, São Paulo, 2007,

1332 Ídem, pp. 28 y ss.

${ }^{1333}$ TRATADO DE PAZ E ALIANÇA de 29 de agosto de 1825 - Collecção das Leis e Decretos do Império do Brasil..., op. cit., p. 257.

${ }^{1334}$ NEVES, Guilherme P.: “A Religião do Império...”, op. cit., p. 396. 
condición in potentia de dichos poderes para el emperador brasileño. Legitimaba el hecho de elegir d. Joao VI a d. Pedro como su legítimo heredero, lo que efectivamente se dará tras su muerte en 1826, poco después de ratificar el Tratado, con la coronación de d. Pedro I de Brasil que se convertirá en D. Pedro IV de Portugal. Además, con la reserva del título de emperador de Brasil para D. Joao VI en el art. $1^{\circ}$ de Tratado, de cierta forma, en una casi forzosa interpretación, pero con sentido, Su Majestad Fidelísima que era patrono de la Iglesia Católica en el Imperio Luso-brasileño, continuaba siendo en Brasil tras la Independencia, y con la firma del Tratado tampoco dejaba la Iglesia acéfala en el caso de que denegase el Sumo Pontífice los poderes de Patrono de la Iglesia brasiliense a D. Pedro I. Aunque la Constitución del Imperio otorgase únicamente al emperador D. Pedro dicho poderes y no a D. Joao $\mathrm{VI}^{1335}$, que guardaba el título honorífico apenas de emperador de Brasil ${ }^{1336}$.

En la "Falla que Sua Magestade o Imperador pronuncia na Câmara dos Senadores no dia 6 de Maio de 1826 na Abertura da Assembléa Nacional" se hace un recuento de los hechos más inmediatos en el Imperio. En este momento el emperador comunica oficialmente a los representantes de la nación que la independencia de Brasil había sido reconocida por su Augusto padre D. Joao VI. Y que, además, en el día 15 de noviembre de 1825 les siguieron otras naciones en el reconocimiento como Austria, Inglaterra, Suecia y Francia ${ }^{1337}$. También comunica que supo el 24 de abril que se había muerto su padre, y que se encontraba ahora mismo como legítimo rey de Portugal, Algarves y de sus dominios. Así que confirma su abdicación de la corona portuguesa e informa las providencias tomadas:

"Confirmei em Portugal a Regência, que meu Pai Havia Criado; Dei uma anistia; Dei uma Constituição; Abdiquei, e Cedi de todos os indisputáveis e inauferiveis Direitos, que tinha à Coroa da Monarquia Portuguesa, e Soberania d'aqueles Reinos na Pessoa da Minha muito Amada, e Querida Filha a Princesa Dona Maria da Gloria, hoje Rainha de Portugal Dona Maria II. He o que cumpria fazer a bem da Minha Honra e do Brasil. Agora conheçam (como já deviam conhecer) alguns brasileiros ainda incrédulos, que o interesse pelo Brasil, e o amor da Sua Independência he tão forte em Mim, que Abdiquei a Coroa da Monarquia Portuguesa, que Me Pertencia por Direito indisputável, só porque para o futuro poderia comprometer os interesses do mesmo Brasil, do qual Sou Defensor Perpétuo ${ }^{1338}$."

\footnotetext{
1335 (Archivo John Carter Brown Library) - Constituição Politica do Império do Brasil (Independência ou Morte), Na Typographia de Plancher, Impressor-Livreiro de Sua Magestade Imperial, Rio de Janeiro, 1824, p. 5-8. Artículos 102, inciso III y XIV.

1336 TRATADO DE PAZ E ALIANÇA de 29 de agosto de 1825 - Collecção das Leis e Decretos do Império do Brasil..., op. cit., p. 257. Artículo $1^{\circ}$.

${ }^{1337}$ Falla que Sua Magestade o Imperador pronuncia na Câmara dos Senadores no dia 6 de Maio de 1826 na Abertura da Assembléa Nacional - Collecção das Leis e Decretos do Império do Brasil..., op. cit., pp. 263-264.

${ }^{1338}$ Ídem, p. 264.
} 
Estos son los pasos decisivos para allanar el camino hacia la Santa Sede, en donde el Sumo Pontífice reconoce los poderes al plenipotenciario de la misión brasileña, Monseñor Vidigal, y reconoce además, con dicho acto, la existencia de un nuevo Estado/Nación.

Conformado con esta situación, el papa León XII expedirá dos bulas, una en 15 de julio de 1826, Sollicita Catholicis $^{1339}$, que elevaba a la categoría de diócesis las prelacías de Goiás y Mato Grosso y nombraba a sus prelados: d. Francisco Ferreira de Oliveira (1819-1833) y el Fraile José María de Macerata (1823-1831), respectivamente. La otra bula la edita el 15 de mayo de 1827, Praeclara Portugaliae ${ }^{1340}$, que concedía al emperador de Brasil los ambicionados poderes de patrono de la Iglesia brasiliense, semejantes a los atribuidos al monarca portugués ${ }^{1341}$.

Como vimos, el 6 de mayo de 1826 se inicia la primera legislatura del Congreso recientemente elegido, que recibió la primera bula con mucha desconfianza, dada las circunstancias políticas precedidas por la disolución de la Asamblea Constituyente de 1823 y las persecuciones a muchos parlamentarios, lo que va a motivar intensos debates en el parlamento recién reabierto. La Bula Sollicita Catholicis, además de erigir dos obispados, nombraba los prelados que ocuparían las cátedras vacantes, creaba los cabildos correspondientes, definía los beneficios y creaba también dos seminarios. Dos comisiones van analizar los actos emanados por el Sumo Pontífice, y serán sometidos a votación en la Sesión de 12 de julio de 1827. Las discusiones en el parlamento culminarán en la Ley de 3 de noviembre de $1827^{1342}$, que introduce en el Ordenamiento Jurídico interno del Imperio de Brasil la Bula Sollicita Catholicis, creando los obispados de Goiás y Mato Grosso. Esta Ley sancionada por el emperador D. Pedro I recorre dos aspectos básicos de la Bula papal, evitando la ejecución de las demás prescripciones de la Bula. En el artículo $1^{\circ}$ aprueba la conversión de las prelacías de Goiás y Mato Grosso en obispados, con las mismas sedes, extensión y límites. Y en el art. $2^{\circ}$,

\footnotetext{
1339 (Archivo Secreto del Vaticano) BULA SOLLICITA CATHOLICIS de 15 de julio de 1826 - Bullarii Romani Continuatio Summorum Pontificum Clementis XIII. Clementis XIV. Pii VI. Pii VII. Leonis XII. Pii VIII. Et Gregorii XVI. Constitutionis, Literas in Forma Brevis Epistolas as Principes Viros, et Alios Atque Alloquutionis Complectens Quas Collegit Usque ad Pontificatum Pii VII. Andreas Advocatus Barbéri Curiae Capitolii Collateralis Additis Summariis, Adnotationibus, Indicibus Opera, et Studio Rainaldi Segreti I. C., Tomus Decimus Sextus Continens Potificatus Leonis XII. Annum Primum ad Tertium, Romae, 1854, pp. 462-464.

1340 (Archivo Secreto del Vaticano) BULA PRAECLARA PORTUGALIAE de 15 de mayo de 1827 - Bullarii Romani Continuatio Summorum Pontificum Clementis XIII. Clementis XIV. Pii VI. Pii VII. Leonis XII. Pii VIII. Et Gregorii XVI. Constitutionis, Literas in Forma Brevis Epistolas as Principes Viros, et Alios Atque Alloquutionis Complectens Quas Collegit Usque ad Pontificatum Pii VII. Andreas Advocatus Barbéri Curiae Capitolii Collateralis Additis Summariis, Adnotationibus, Indicibus Opera, et Studio Rainaldi Segreti I. C., Tomus Decimus Septimus Continens Potificatus Leonis XII. Annum Quartum ad Sextum, Romae, 1855, pp. 56-60.

${ }^{1341}$ NEVES, Guilherme P.: “A Religião do Império...", op. cit., p. 396.

${ }^{1342}$ LEI de 3 de novembro de 1823. Collecção das Leis e Decretos do Império do Brasil, desde a feliz época da sua Independência, obra dedicada a Assembléa Legislativa; precedida de hum discurso preliminar, e terminada por huma boa alfabética, e arrasoada, por MM., Na Imperial Typographia de P. Plancher-Seignot, Rio de Janeiro, 1827 , p. 82.
} 
trata de las congruas destinadas a los respectivos obispados, que pasan a cobrar de la Hacienda Pública el valor de 1:600\$000 Reales; este valor estaba destinado para congrua, sostenimiento, jubilación, limosna y Vicario General. Además, la ley encarga su cumplimiento al Secretario de Negocios de Justicia.

Entretanto, merece la pena observar las discusiones parlamentarias alrededor de la Bula Sollicita Catholicis. Se había remitido a tres comisiones (Constitución, Hacienda y Eclesiástica), que presentarán, dos de ellas, sus pareceres en la Sesión de 12 de julio de 1827. Tanto el parecer de la Comisión de Constitución ${ }^{1343}$ como el parecer de la Comisión Eclesiástica $^{1344}$ acerca de las Bulas Pontificales, por las cuales el Santísimo Padre León XII elevaba a obispados las prelacías de Goiás y Mato Grosso, serán leídas en la misma sesión de 12 de julio $^{1345}$.

Las dos comisiones toman posturas diversas en relación a lo prescrito en la Bula Sollicita Catholicis. La Comisión de Constitución va a entender que la Bula tratará de materia general, y que los nombramientos de los prelados están insertos en las reglas generales del derecho canónico, y que de toda suerte otorga al obispo vecino el derecho de nombrar administrador, lo que de cierta forma contrariaría a lo dispuesto en la práctica y disciplina de la Iglesia brasiliense. Además, por ponerse el documento pontificio en punto de colisión con las antiguas leyes de la monarquía y con el nuevo sistema que rige en el momento, dado que no se puede tener beneficio o ejercer jurisdicción local eclesiástica persona extranjera, al nombrar un extranjero y un ciudadano brasileño para las prelacías de Goiás y Mato Grosso, la Comisión de Constitución manda que se desconozca la parte de la Bula en que se nombra a un extranjero para la dignidad de obispo. Por lo tanto, dicha comisión emite parecer de que se aprueben en la cámara las bulas papales, salvadas las restricciones indicadas. Además, reservándose al emperador y a los obispos las regalías y prerrogativas en que en tales casos les compiten. De todas formas, la indicación del parecer es que la Bula trata de materia general en asuntos de derecho eclesiástico ${ }^{1346}$.

De modo distinto se pronunciará la Comisión Eclesiástica. Al parecer dicha comisión transitará por sendas mucho más específicas del derecho eclesiástico, y por lo tanto, contrario a

\footnotetext{
${ }^{1343}$ COMISSAO DE CONSTITUIÇAO - Pedro de Araujo Lima, Manuoel Antonio Galvao, Lucio Soares Teixeira de Gouvea, Bernardo Pereira de VAssconcellos. Anais da Câmara dos Deputados, Sesión de 12 de julio de 1827, p. 123.

http://imagem.camara.gov.br/dc_20b.asp?largura=\&altura=\&selCodColecaoCsv=A\&Datain=12\%2F07\%2F $1827 \&$ txPagina=123\&txSuplemento=0\&enviar=Pesquisar ACCEDIDO EN 17/08/2013. En adelante citada como $A C D$.

${ }^{1344}$ COMISSAO ECLESIÁSTICA - Miguel José Reinaut, Antonio da Rocha Franco, José Bento Leite Ferreira de Mello, Diogo Antônio Feijó. ACD, Sesión de 12 de julio de 1827, p. 123.

1345 ACD, Sesión de 12 de julio de 1827, pp. 123-141.

${ }^{1346} A C D$, Sesión de 12 de julio de 1827, p. 124.
} 
lo determinado en la Constitución del Imperio en materia de Beneplácito y del derecho de Patronato. Dirá la Comisión que buscó establecer una división entre la autoridad civil y la eclesiástica y sus respectivas competencias. Por lo tanto, respetando los derechos de primacía de la Iglesia Universal, así como de la Nación brasileña en la demarcación entre la autoridad civil y la eclesiástica, entre la jurisdicción temporal y espiritual. Por ello, establece cuatro observaciones a las partes específicas que tocan la Bula y que son contrarias a lo determinado en la Constitución en materia eclesiástica. Estas son: corresponde al emperador de Brasil la atribución dada por la Constitución del Imperio de nombrar obispos y de proveer beneficios eclesiásticos - derecho de patronato, ya de uso antiquísimo de la nación -, (ob. $1^{\mathrm{a}}$ ); la creación de cabidos (ob. $2^{\mathrm{a}}$ ); el establecer el valor de las congruas (ob. $3^{\mathrm{a}}$ ); la creación de seminarios y determinación de sus dotaciones (ob. $4^{\mathrm{a}}$ ). Siendo esto así, la Comisión emite parecer de que la Bula sea aprobada en la Cámara solamente en la parte que crea dos nuevos obispados, juzgando de la competencia del gobierno conceder o negar beneplácito en las partes donde se habla del nombramiento de los vicarios apostólicos. Además, se recomienda al gobierno que ruegue al Sumo Pontífice providencias en el caso de Sede Vacante en los obispados, en el caso que se decida por la no creación de los cabildos ${ }^{1347}$.

Acerca de la misma materia emite un voto por separado el Sr. Obispo electo de Maranhão, miembro de la Comisión de los negocios eclesiásticos análogo al mismo objeto. Este voto por separado de la Comisión Eclesiástica se da por no concordar el Sr. Obispo con el entero contenido del parecer de dicha comisión. Él hace recordar que fue a petición de $\mathrm{Su}$ Majestad Imperial cuando Su Santidad elevó las dos prelacías, Goiás y Mato Grosso, a obispados. Dichas prelacías habían sido creadas a través de la bula de Benedicto XIV - Candor Lucis Aeternae - de 6 de diciembre de 1747. Por lo tanto, cupo al nuevo Santo Padre, León XII, elevar a obispados y fijar suficientes congruas a los mismos, fundar seminarios, así como la creación, en cada una de las cátedras, de un cabildo. Así, el voto del Sr. Obispo es que la creación de los nuevos obispados no puede ser ejecutada sin que se cumpla las condiciones prescritas en la Bula papal.

El miembro de la comisión que presentó su voto particular ve una estrecha relación entre el poder de patrono establecido en la Constitución Imperial con el mandato papal en la Bula Sollicita Catholicis, dado que, fue a través de requerimiento dirigido al Santo Padre León XII, por el patrono de la Iglesia de Brasil, al cual cabía proponer al Supremo Pastor las nuevas creaciones. Era algo perfectamente legal y estaba ligado a las prerrogativas del emperador como patrono de la Iglesia brasiliense y las del Sumo Pontífice a través del requerimiento dirigido a

${ }^{1347}$ Ibídem. 
este último. Así como los demás creaciones de la Bula de León XII estaba relacionado a lo que decretaba el Concilio de Trento en la sesión 23, cap. 18 de la Reformatione ${ }^{1348}$. Aunque en determinados puntos de la Bula papal el miembro de la comisión opina que se consulte acerca de la rentas de los mismo cabildos y se consulte a la Comisión de Hacienda sobre la materia y la mismísima Santa Sede. Entretanto, no se opone a que se erijan los seminarios, dado que, tanto la creación como las rentas para su manutención están garantizadas por la Constitución del Imperio en el art. 170, párrafo 33. Así que, el Sr. obispo en su voto en separado ve los actos papales tanto respaldados por el Concilio de Trento como por la Constitución, en nada hiriendo los poderes de patrono del emperador.

De este modo el nombramiento de los vicarios apostólicos será reconocido por muchos canonistas como derecho primado de la Santa Sede, y se puede considerar como providencia interina, en cuanto a la competente autoridad de la metrópoli de Bahía no elegir diputados vicarios capitulares en conformidad con la sesión 24, cap. 16 de la Reformatione del Concilio de Treno, dado que no hay en la referidas diócesis, cabildos. Este modo de explicar la Bula pontificia pone a salvo los privilegios amplísimos del patrono del Imperio de Brasil y de su Iglesia, y de los poderes que dimanan del primado de la Iglesia Universal, de las cuales, hace tres siglos gozan los imperantes y patronos de este imperio. Siempre en toda intervención, tanto de los diputados como en los documentos de la época se busca vincular los poderes de patrono del miembro de la Casa de Braganza que impera en Brasil a los reyes portugueses, incluso antes de que la Bula Praeclara Portugaliae concediese de forma definitiva en definitivo los poderes de patrono al emperador de Brasi1 ${ }^{1349}$. De este modo, llama la atención por la antigüedad y anterioridad de los poderes de patrono sigue ejerciendo a esas alturas el gobierno.

Después del voto particular del Obispo de Maranhão, el Arzobispo de Bahía, Raimundo Antônio de Seixas incendia la Cámara con sus afirmaciones. Raimundo Seixas será el primero en emitir opinión sobre la bula papal; acreditaba que esta no contenía dispositivos generales, y por lo tanto, pensaba que no dependía de la aprobación de la Asamblea ${ }^{1350}$. Era así, porque el art. 102, inciso XIV, de la Constitución del Imperio establecía que los documentos papales preceden la aprobación de la Asamblea, solamente si contuvieren una parte general ${ }^{1351}$. Otro diputado, el Sr. Vasconcelos también examina si la Bula contiene o no una parte general y él opina que sí la contiene, y por lo tanto, su análisis es necesario por la Asamblea de los

\footnotetext{
1348 Ibídem.

1349 Ibídem.

1350 Ídem, pp. 125-129.

1351 (Archivo John Carter Brown Library) Constituição Política do Império do Brasil, Na Typographia de Plancher, Impressor Livreiro de Sua Magestade Imperial, Rio de Janeiro, 1824, p. 30.
} 
diputados. Dirá el mismo diputado que las determinaciones de la Bula no solamente alteran al derecho eclesiástico sino que también modifican la Constitución del Imperio. Así que, la Asamblea no aprueba la creación de los cabildos ${ }^{1352}$.

"Pois se as bulas não contêm disposições gerais, caso em que depende de aprovação ou reprovação da assembleia, como vota o Sr. Arcebispo que não sejam aprovadas pela assembleia na parte em que trata dos cabidos? Não é isto manifesta contradição? Não é confessar que elas contem disposição gerais, ao mesmo tempo que se nega? Está demostrado que estas bulas contêm disposição gerais; examinemos si estas disposições merecem a aprovação da assembleia. ${ }^{1353}$ ",

También era de esta opinión, además de Bernardo Pereira de Vasconcelos, Raimundo da Cunha Matos, Feijó, Candido de Deus, Augusto May y Vergueiros, señalando que la Bula consistía en una clara usurpación de los derechos del emperador y de las cámaras brasileñas concernientes a la Iglesia brasileña ${ }^{1354}$. Preconizaban, además, que la iglesia debía permanecer subordinada, como venía siendo, al Estado, obedeciendo al patronato establecido por la Constitución del Imperio y a las costumbres, que según el Arzobispo de Bahía ya contaba con trecientos años de tradición ${ }^{1355}$. En una apología a la independencia, asunto caro en aquellos momentos, Vasconcelos dirá que la principal causa de los cismas es la gran dependencia que provocan las Cortes de Roma en relación con los demás reinos, pero, es también de la opinión que, siendo "Cristão, e cristão verdadeiro, eu faço os mais ardentes votos para que nunca o Brasil tenha o menor rompimento com o chefe da Igreja católica" ${ }^{\text {1356 }}$. Aun así, afirma el mismo diputado que el reconocimiento del Romano Pontífice se da en la Constitución del Imperio. En cuanto a poder ejercer o no el poder de patrono por el emperador en la Iglesia de Brasil, Vasconcelos, recordando el discurso del diputado Arzobispo de Bahía, dirá:

"Lembra-me agora que o Sr. Arcebispo da Bahia no seu discurso avançou que o imperador não podia exercer o direito de padroado sem a concessão do pontífice, pois que este direito não é próprio da soberania temporal: e devo responder-lhe que a nomeação dos bispos e provimento dos benefícios eclesiásticos compete ao imperador pela constituição; não há duvida que a nação podia conferir este direito ao seu augusto chefe, o que eu mostrarei só por direito canônico, sem me fazer cargo de outros argumentos. Este direito reconhece o do padroado, quando há dotação, edificação ou reedificação de igrejas; e como no Brasil a nação é quem presta estes serviços à religião, claro está que lhe compete o direito de padroado, que muito bem podia conferir, como conferiu ao imperador ${ }^{1357}$."

\footnotetext{
${ }^{1352}$ ACD, Sesión de 12 de julio de 1827, Sr. diputado Arcebispo da Bahia, p. 129.

1353 Ídem, Sr. diputado Vasconcelos, p. 130.

1354 Ídem, pp. 129-137 y ss.

${ }^{1355}$ Del mismo modo, cotejando dicha fuente histórica, se pronuncia NEVES, Guilherme Pereira das: A Religião do Império..., op. cit., p. 397.

${ }^{1356}$ ACD, Sesión de 12 de julio de 1827, Sr. diputado Vasconcelos, p. 130.

1357 Ibídem.
} 
También era de esta opinión José Lino Coutinho, diputado por Bahía. Dicho diputado veía a Roma como una fuerza centrípeta en relación a los poderes civiles y espirituales, lo que era diametralmente opuesto al proclamado derecho político y a la independencia nacional, además de significar una sumisión por parte de la Iglesia brasiliense ${ }^{1358}$.

Receloso de la independencia política de Brasil y de la Iglesia brasiliense, el diputado Vasconcelos va a proponer la firma de un concordato entre Roma y el Estado brasileño para evitar la odiosa fuerza centrípeta que pretendía siempre ejercer Roma. Este concordato lo sugirió Vasconcelos en los siguientes términos de su enmienda:

"1. ${ }^{a}$ A nação brasileira reconhece o pontífice romano como chefe da Igreja universal. 2. ${ }^{a}$ A nação brasileira guarda e guardará os decretos dos concílios ecumênicos relativos ao dogma e à doutrina; quanto porem aos pontos de disciplina ficará salvo o direito das igrejas e nação brasileira. 3. ${ }^{a}$ À Assembleia geral compete regular o exercício do direito do padroado. $4 .{ }^{a} \mathrm{O}$ arcebispo da Bahia erigirá, desmembrará, reunirá, organizará as dioceses, conforme as demarcações civis sancionadas pela Assembleia geral. 5. ${ }^{a} \mathrm{O}$ mesmo arcebispo e, na sua falta, o mais antigo dos bispos confirmará os bispos, e estes o arcebispo. 6. ${ }^{a}$ Os bispos poderão proceder à secularização dos regulares de um e outro sexo, que o solicitarem. $7 .^{a}$ Nenhum estrangeiro exercerá ato algum de jurisdição eclesiástica no império, nem ainda por virtude de comissão. 8. ${ }^{a}$ Se dará circunstancias conta ao pontífice romano de quanto se fizer de novo no império em matéria eclesiástica. 9. ${ }^{a}$ Se a corte de Roma se recusar a uma tão ortodoxa como interessante negociação, o governo observará a disciplina dos bons séculos da Igreja ${ }^{1359}$.”

Dicha propuesta no avanzó mucho, y la Ley de 3 de noviembre de 1827 será el ejemplo de esto, como pudimos ver en su contenido, que fue el reflejo de lo que realmente pasó en el conjunto de las discusiones en la Cámara de los diputados.

Estas motivaciones y aparente conflicto entre el potentado romano y la soberanía brasileña volvieron a la tónica con la discusión de otra bula papal, la Praeclara Portugaliae Albarbeorum que Regum, de 1827, en donde el Romano Pontífice declaraba que el gran maestrado de las tres órdenes militares S. Bento d`Aviz, Santiago y de Cristo recaería en la persona del emperador de Brasil y de sus sucesores. Allí se estableció un abierto conflicto entre el privilegio concedido por la Santa Sede y la apropiación de dicho privilegio por la soberanía nacional con cierta antecedencia, dado que la tradición y la continuación al ejercer dichos privilegios hacía de esta apropiación un derecho líquido y cierto del Estado/Nación brasileño y del miembro imperante de la Casa de Braganza en Brasil. A través de dicha bula, la Santa Sede otorgaba al gobierno imperial el derecho de conservar la fe católica y la catequesis de los indios. Por lo tanto, el emperador podía recaudar y administrar los diezmos eclesiásticos en

\footnotetext{
1358 Ídem, pp. 137 y ss.

${ }^{1359}$ Ídem, p. 131.
} 
Brasil, puesto que, el emperador, así como los reyes de Portugal era gran maestro del Orden de Cristo $^{1360}$. Este privilegio fue sometido a discusión en la Sesión de 16 de octubre de 1827 en el Parlamento brasileño. El Obispo de Maranhão, como miembro de la Comisión Eclesiástica, una vez más, ofreció un voto particular al parecer de la comisión en dicha materia ${ }^{1361}$. Dirá el mismo diputado que no pretende discutir si dicha bula trae dispositivo general, puesto que, eso se abstrae de la letra de la misma y por lo tanto le afecta el art. 102, inciso XIV de la Constitución del Imperio, debiendo la misma indudablemente ser discutida en el parlamento. Tampoco se debía decir, según el mismo diputado, que los dispositivos de esta bula contradecía el art. $5^{\circ}$ de la Constitución, dado que, el mismo tolera todas las religiones y sus cultos, domésticos y particulares; entretanto, la religión Católica Apostólica Romana era la única que permanecía con su culto público en el imperio ${ }^{1362}$. Tampoco era ofensivo al art. $179^{\circ}$, IV de la Constitución, en donde se establecía la no persecución en materia religiosa. Dirá además que:

“(...) O direito de apresentação para os benefícios eclesiásticos não é intrínseco, e essencial à soberania, nem privilégios das atribuições majestáticas. $O$ mesmo se deve dizer do Padroado do Brasil, examinada a origem da sua concessão e Bula de Júlio III, datada de 25 de fevereiro de 1550 e que começa - Supers specula $^{1363}$."

De este modo, los poderes de patrono tenían naturaleza de derecho accesorio para cuya conservación concurre la nación brasileña que se había obligado a esto a través del art. $5^{\circ}$ de la Constitución, otorgada en el Imperio.

Según el parecer de la Comisión Eclesiástica, en términos estrictos, dirá que la Bula no debía ser aprobada por tratarse de dispositivos generales manifiestamente ofensivos a la Constitución del Imperio; y porque, además, se asienta en causa falsa, ociosa y hasta injusta ${ }^{1364}$. En el mismo parecer veía como una afrenta a los arts. $5^{\circ}$ y $179^{\circ}, \mathrm{V}$, determinar la catequesis de los indígenas, dado que, con el establecimiento del principio de la libertad religiosa y de la no persecución por motivos religiosos, los dispositivos de la Bula no se adecuaban a lo establecido en la Constitución ${ }^{1365}$.

"É, além disto, a Bula ociosa e inútil; porque o Imperador do Brasil tem pelo ato da sua aclamação, e pela constituição, todos estes direitos que ele pretende confirmar-lhe $e^{1366 . "}$

\footnotetext{
${ }^{1360}$ NEVES, Guilherme Pereira das: A Religião do Império..., op. cit., p. 398.

1361 ACD, Sesión de 16 de octubre de 1827, Sr. diputado Obispo de Maranhão, p. 127. http://imagem.camara.gov.br/dc 20b.asp ACCEDIDO EN 30/09/2013.

1362 Ídem, pp. 127-128.

${ }^{1363}$ Ídem, p. 128.

${ }^{1364}$ Ibídem.

1365 Ídem, 129.

${ }^{1366}$ Ibídem.
} 
Y va más allá rechazando las prebendas papales concedidas al emperador de Brasil:

"Mas, seja o que for, esses direitos e privilégios de que fala a Bula, reduzemse ao direito de padroado das Igrejas do Brasil, como pertencentes à Ordem de Cristo. Existe, porém, tal padroado? Eis uma questão importante que cumpre examinar neste lugar. As comissões decidem-se pela negativa da existência do padroado da Ordem de Cristo, e por consequência, do grão-mestrado sobre as igrejas do Brasil (... $)^{1367}$.”

Como citados beneficios (diezmos) nunca estuvieron sujetos a la Orden de Cristo, según los diputados, era inútil que el Santo Padre hiciese alegaciones y concesiones de dichas prebendas, reafirmará el parecer ${ }^{1368}$.

El diputado Feijó, en la Sesión de 16 de julio de 1828 se manifestará reticente a la creación de seminarios, como preconizaba la Bula de 1826:

"Não me oponho à criação de seminários em toda parte do império, embora me apareça que é uma instituição inútil, porque pelas leis eclesiásticas nenhum homem pobre se pode ordenar sem que tenha um patrimônio, e sem que possa viver honestamente; mas não me embaraça que os Srs. Bispos fechem os olhos a isto; vou segundo a lei que existe que diz que ninguém se pode ordenar sem ter um patrimônio do qual possa viver, e sendo assim para que serve este dinheiro? Será para pagamento dos mestres? Nos bispados onde há 14 cônegos, não podem os bispos encarregar a 3 ou a 4 do ensino destas ciências eclesiásticas, quanto todos eles recebem ordenados da fazenda pública? ${ }^{1369,}$

De este modo, la Bula papal se verá menoscabada en varios momentos, dado que, la prevalencia de los poderes de patrono del emperador se veía instituidos por la Constitución del Imperio, y, por lo tanto, ejecutados en muchos momentos por la Mesa de la Consciencia y Ordens. Sin embargo, los poderes ya asumidos constitucionalmente de nombrar los puestos administrativos de la Iglesia en Brasil va a reflejar en la promulgación de la Ley de 22 de septiembre de 1828 que extinguía al Tribunal de la Mesa de la Consciencia y Ordens ${ }^{1370}$. El Ministerio de Justicia se arrogó la responsabilidad de cuidar, a lo largo del siglo XIX, de los poderes de patronato que la Bula Praeclara Portugaliae Albarbeorum que Regum había delegado al emperador de Brasil, y que los legisladores, afirmam et probant, establecieron como algo inherente a la soberanía nacional, puesto que, la Constitución del imperio y el

\footnotetext{
${ }^{1367}$ Ibídem.

${ }^{1368}$ Haciendo referencias a la prohibición de nombrar obispos extranjeros, en 17 de mayo de 1828, un proyecto de ley fue presentado en el parlamento en este sentido. NEVES, Guilherme Pereira das: A Religião do Império..., op. cit., p. 399.

${ }^{1369}$ Diario da Câmara dos Deputados, Sesión de 16 de julio de 1828, Sr. diputado Obispo de Maranhão, p. 128. http://imagem.camara.gov.br/dc 20b.asp?largura=\&altura=\&selCodColecaoCsv=A\&Datain=16\%2F07\%2F1828\&

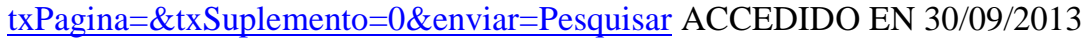

${ }^{1370}$ Collecçao das Leis do Imperio do Brasil, 1828 - Parte Primeira, Typographia Nacional, Rio de Janeiro, 1878, pp. 47 y ss. Ley de 22 de septiembre de 1828. Extingue os Tribunais das Mesas do Desembargo do Paço e da Consciência e Ordens e regula a expedição dos negócios que lhes pertenciam e ficam subsistindo.
} 
conjunto de la soberanía habían delegado al mismísimo emperador dichos poderes, como previamente vimos.

La cuestión persiste a lo largo del siglo XIX, culminando con la llamada Cuestión Religiosa, en donde los conflictos entre el poder temporal y las instancias eclesiásticas se acentúan y alcanza a la irreconciliabilidad. Una forma de explicar el ejercicio del Poder de patronato en Brasil sin que haya pasado en el Parlamento la Bula papal de 27, lo hace José Thomaz Nabuco de Araújo, al explicar que dicho ejercicio estaba garantizado, en menoscabo a la Santa Sede, en el art. 5 de la Constitución del Imperio de Brasil. La explicación, por lo tanto, es que el legislador primario hubiese reservado los poderes de patrono al emperador en la Constitución, que se reflejaba en la dicción del art.5: "A religião Católica Apostólica Romana continuará a ser a religião do Império ${ }^{1371}$." Nabuco explicaba así, el ejercicio continuado de las instituciones portuguesas en el Brasil independiente, además, del ejercicio de los poderes de patronato $^{1372}$. De tal modo que un concordato no llegó a ser firmado entre la Santa Sede y el Imperio de Brasil acerca de la materia ${ }^{1373}$.

\section{C) Los elementos confesionales en las elecciones y las leyes electorales del Imperio: el principio de la elegibilidad de los acatólicos en la Ley Saraiva}

En este acápite no pretendemos hacer un estudio exhaustivo del proceso electoral en la extensa legislación electoral del Imperio, sino verificar la situación de los "acatólicos" en dichas legislaciones y las discusiones acerca de la materia cuando las haya. Desde los momentos iniciales del sistema electoral en Brasil los ritos y también los templos católicos estuvieron involucrados en los procesos electorales. Misas solemnes al Espirito Santo iniciaban los protocolos, principalmente en las elecciones parroquiales. Como ya hicimos notar antes, tanto en las elecciones a las Cortes de Lisboa, como en las elecciones para Procuradores de Provincia (o Primer Consejo de Estado) y a la Asamblea Constituyente en Brasil, se hicieron notar los ritos católicos. El Decreto de 7 de marzo de 1821, que convocaba las elecciones a las Cortes de Lisboa en Brasil recordaba el modelo portugués de realización del proceso electoral en los "Paços do Conselho" o en edificios más adecuados ${ }^{1374}$. Pero, en la falta de estos edificios se debía realizar en la iglesia o templo católico. Esto vinculaba los procesos. También era

\footnotetext{
1371 (Archivo John Carter Brown Library) Constituição Política do Império do Brasil, Na Typographia de Plancher, Impressor Livreiro de Sua Magestade Imperial, Rio de Janeiro, 1824, p. 1.

1372 NABUCO, Joaquim: Um estadista do Império (tomo II)..., op. cit. También se puede ver dicha afirmación en NEVES, Guilherme Pereira das: A Religião do Império..., op. cit., p. 400.

${ }^{1373}$ Projeto de Concordata in NABUCO, Joaquim: Um estadista do Império. Nabuco de Araújo. Sua Vida, suas opiniões, sua época, Tomo I (1813-1857), H. Garnier - Livreiro Editor, Rio de Janeiro/Paris, pp. 304 y ss.

${ }^{1374}$ PORTO, Walter Costa: Católicos y Acatólicos: O Voto no Império, Revista Liberdade e Cidadania - Ano 2 n. 5 - Julho/setembro, 2009, pp. 1-10 www.flc.org.br ACCEDIDO EN 18/04/2010
} 
obligación del párroco identificar los "fuegos" de la comunidad y por lo tanto identificar a los electores. Solamente en el Decreto de 4 de mayo de 1842 es cuando la expresión "fuegos" será definida:

"Por Fogo entende-se a casa, ou parte dela, em que habita independentemente uma pessoa ou família; de maneira que um mesmo edifício pode ter dois ou mais Fogos $^{1375}$."

Eran los párrocos quienes fijaban en las puertas de las iglesias los pliegos que indicaban el número de fuegos existente en las freguesias y se hacían responsables de la exactitud del número. Era la relación entre la iglesia y las elecciones en el imperio, al menos legalmente, porque en la práctica ya existía esta relación mucho antes. La inviolabilidad de los derechos civiles y políticos de los ciudadanos en la Constitución de 1824 incidía tanto en el ya exhaustivamente repetido art. $5^{\circ}$ como en el art. $179^{\circ}, \mathrm{V}^{1376}$.

En las Instrucciones anejas al Decreto de 26 de marzo de 1824 el párroco continuaba siendo una figura central en el proceso electoral, y los acatólicos quedaban excluidos del segundo grado de las elecciones. El art. 5\%, de las Instrucciones deciá que “Os Párocos farão afixar nas portas de suas Igrejas editais, por onde conste o numero de fogos da sua freguesia, $e$

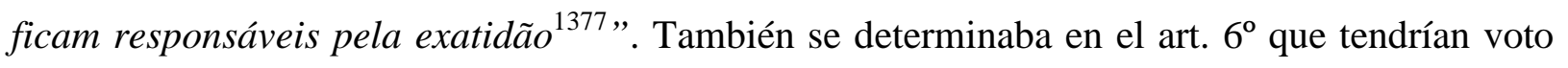
en las elecciones primarias los extranjeros naturalizados, siempre que estuviesen domiciliados en la parroquia, o tuviesen por lo menos allí su residencia, y debían los párrocos dar cuenta de los moradores de la parroquia y tomar de ellos conocimiento (inciso $2^{\circ}$ ). La relación era muy estrecha entre la iglesia y el proceso electoral, como ya lo señalamos. De la misma forma, en el Capítulo VI, intitulado De las Elecciones de los Diputados, de las mismas Instrucciones, en su art. $2^{\circ}$ se establecía que todos los que pueden ser electores son habiles para ser diputados, con la excepción, en el inciso $3^{\circ}$ de los que no profesaren la Religión del Estado. Al final de las elecciones, el Capítulo VIII, denominado "De la Última recuento de los votos", en su art. $9^{\circ}$ preveía que se cantase un Te-Deum inmediatamente después de nombrados los diputados, que serían conducidos a la Iglesia principal.

El Decreto $\mathrm{n}^{\mathrm{o}} .157$ de 4 de mayo de 1842, en el art. $1^{\circ}$ del Capítulo I procedía al alistamiento de los ciudadanos activos y a los fuegos existentes en las parroquias, con base en los arts. 91 y 92 de la Constitución. Se prever como en las anteriores legislaciones los ritos

\footnotetext{
${ }^{1375}$ Decreto de 4 de mayo de 1842.

${ }^{1376}$ Véase en PORTO, Walter Costa: O Voto no Brasil. Da Colônia à $6^{\mathrm{a}}$ República, $2^{\mathrm{a}}$ Edição Revisada, Topbooks, Rio de Janeiro, 2002, p. 45.

${ }^{1377}$ Instrucción Eleitoral do Decreto de 26 de marzo de 1824.
} 
católicos vinculados al proceso electoral, como se determina en el art. $12^{\circ} \mathrm{y}$ art. $18^{\mathrm{o}} 1378$. También, la Ley n. 387 de 19 de agosto de 1846, manda en su art. $4^{\circ}$ que los Electores de Parroquia, e igual número de suplentes, que se reúnan en día designado en el Consistorio, y si este sitio no es bastante espacioso, que sea en el cuerpo de la Iglesia Matriz o en otro edificio designado, si no puede ser realizado el proceso en la Iglesia, para que se organice la Junta de Cualificación electoral. En los arts. 17 y 18 se daban el proceso de cualificación de los electores, basados una vez más en los arts. 91 y 92 de la Constitución del Imperio. Pero, era en el art. 21, después de hecho el alistamiento y la calificación de los electores, cuando se mandaba fijar en el interior de la Iglesia Matriz, en lugar conveniente y a la vista de todos ${ }^{1379}$. También, una vez más se repite en el art. 75, al hacer la calificación de los Electores que son hábiles para ser diputados, excluyen en el inciso $3^{\circ}$ a los que no profesaren la Religión del Estado. Aunque en el art. 82, al hacer la habilitación para los que pudiesen presentarse como candidatos al Senado, no se introducía cualquiera requisito confesional en el proceso de exclusión. Como ya dejimos, será el Reglamento Interno del Senado, a la hora de jurar el cargo la norma que imponga aquel impeditivo confesional a los acatólicos.

Un proceso electoral intrigante fue lo que se desarrolló para la elección de Regente después de la abdicación de D. Pedro I en abril de 1831. Este proceso, según estudios de Walter Costa Porto, siguió muy de cerca el proceso electoral republicano de Estados Unidos ${ }^{1380}$. Sabemos, por el Acto Adicional de 1834, que los ciudadanos naturalizados estaban excluidos del proceso electoral. Pero, también sabemos, por el texto constitucional, que el juramento para los regentes (art. $127^{\circ}$ ) era análogo al juramento del emperador, previsto en el art. $103^{\circ}$. Allí se juraba mantener la Religión Católica Apostólica Romana ${ }^{1381}$, y por lo tanto los "acatólicos", naturalizados o nacionales estarían excluidos del de este proceso electoral. Otra Ley, muy discutida dentro de los parámetros del partido liberal, divide en distritos electorales, la llamada Ley de los Ciclos (Decreto n. 842 de 19 de setiembre de 1855) ${ }^{1382}$. Esta ley no altera los aspectos hasta aquí estudiados ${ }^{1383}$.

\footnotetext{
${ }^{1378}$ Colecção das Leis do Império, 1842, Tomo $5^{\circ}$, Parte $2^{\mathrm{a}}$, Secçao $39^{\mathrm{a}}$ - Decreto n. 157 de 4 de mayo de 1842, pp. 255 y ss.

${ }^{1379}$ Colecção das Leis do Império, 1846, Tomo 8º Parte 1a , Secçao 13ª - Lei n. 387 de 19 de agosto de 1846.

${ }^{1380}$ PORTO, Walter Costa: O Voto no Brasil..., op. cit., pp. 53 y ss.

1381 (Archivo John Carter Brown Library) Constituição Política do Império do Brasil, Na Typographia de Plancher, Impressor Livreiro de Sua Magestade Imperial, Rio de Janeiro, 1824.

${ }^{1382}$ Collecçao das Leis do Imperio do Brasil, Tomo 16, Parte 1 $1^{\text {a }}$, Secçao $18^{a}$ - Decreto n. 842 de 19 de setembro de 1855 , pp. 49 y ss.

${ }^{1383}$ Un Código electoral pasa a ser utilizado a partir de 1845 en el Imperio - Código de Eleiçoes para o Imperio do Brasil, Typographia Cearense de José Pio Machado, Ceará, 1845. En dicho código se pueden encontrar los papeles utilizados en las elecciones nacionales. Otro decreto altera en algunos aspectos no tan relevantes para nuestro estudios, pero esenciales para marcar las legislaciones electorales - Decreto n. 1.082 de 18 de agosto de 1860. También reforma la legislación electoral el Decreto n. 2675 de 20 de octubre de 1875.
} 
La utilización de los templos religiosos siempre suscitó discusiones en el Parlamento brasileño. Es notorio que había una gran cantidad de elecciones en el Imperio, el problema estaba siempre en la calidad de dichas elecciones, siempre marcadas por los fraudes y la violencia. En la Sesión del Senado de 28 de mayo de 1855, el senador por Pernambuco, Sr. Manoel da Fonseca dirigirá al Presidente de la Casa alertando sobre la necesidad de reformas en el sistema electoral brasileño ${ }^{1384}$. Y hablando del proceso electoral, dirá el senador que los males no eran tanto del proceso electoral sino de las costumbres y de la moralidad existentes en la época; por ello pedía reformas principalmente en un aspecto:

"Na parte que prescreve que os atos que constituem o seu processo tenham lugar nos templos, nas catedrais e Igrejas matrizes, como tem sido sempre no Brasil desde que temos instituições livres. Contra esta disposição tem representado o Sr. Arcebispo da Bahia, e outros Srs. Bispos, Assembleias provinciais e o clero de vários pontos do Império, fazendo ver os terríveis males e estragos que resultam das eleições nos templos; a experiência pois que esta disposição é nociva ${ }^{1385}$."

Es así porque, según el mismo senador, los hombres, aunque religiosos, en sus exacerbadas pasiones políticas se muestran poco religiosos en los templos en épocas de elecciones. De esta forma opina que:

"Em vez da religião santificar as eleições, como se quis e tem querido, por uma longa e amarga experiência cada um de nós esta necessariamente convencido que as eleições profanam a religião, extinguem no povo o sentimento religioso, sem o qual não há verdadeira moral, nem verdadeira liberdade, nem sociedade possível $^{1386}$."

Se pregunta el religioso senador si no está esta indiferencia en armonía con el primer tópico del juramento para entrar al Senado, y que siempre es leído por el Sr. Secretario, en el que todos juran "manter a Religião Católica e Apostólica Romana? ${ }^{1387, " ~ A d e m a ́ s, ~ p r o p o n e ~ u n ~}$ proyecto de ley, en cuatro artículos, y en donde se determina en dicho proyecto, en su artículo $1^{\circ}$, que:

"Art. $1^{o}$ - Fica proibido dentro das igrejas todo e qualquer ato do processo eleitoral, salvo as cerimonias religiosas que prescreve a lei que regula as eleições ${ }^{1388}$."

Esto llegó a ser discutido en el Senado por darse muchos casos de violencia y profanación de las imágenes sacras en el interior de los templos en la constancia de las

\footnotetext{
${ }^{1384}$ Anais do Senado do Império do Brasil. Assemblei Geral Legislativa. Sessão Legislativa Ordinária - $9^{a}$ Legislatura. Sessões de maio e junho de 1855, Senado Federal - Subsecretaria dos Anais, Brasília, 1978. Sessão de 28 de maio de 1855, pp. 147 y ss. - Senador Sr. Manuel da Fonseca.

1385 Ídem, p. 147.

1386 Ídem, p. 149.

1387 Ídem, p. 150 y 151.

1388 Ídem, p. 153.
} 
elecciones. Francisco Belisario de Souza aporta ejemplos de estos problemas que pasaban en los templos religiosos en época de elecciones. Cuenta Francisco Belisario lo que sucedía en las parroquias de la Candelaria y de Santana en la ciudad de Río de Janeiro, acerca de este tema:

"Entrai na matriz destas freguesias em dias de eleições disputadas. Na primeira, a mesa trabalha isolada, defrontada do exame de povo que dificulta o acesso e perturba todos os atos eleitorais. Vários grupos conversam mais ou menos animadamente; algumas pessoas tomam notas. Todo o trabalho é fora da igreja: consiste em avisar os votantes para responderem às chamadas, em resolver os indolentes, apáticos, despeitados a virem votar; os emissários entram e saem; o votante chega, deposita a cédula e volta para suas ocupações. A cada nome chamado responde um indivíduo conhecido de todos. Se um votante em condições diversas se apresenta, ninguém ousa contestar a identidade, receando enganar-se e expor-se a desacerto, vendo patentear-se a verdade, fácil de ser reconhecida. Em outras freguesias, a identidade do votante é, por via de regra, contestada, discutida e sofismada ${ }^{1389}$."

Tal es el uso de los templos en época de elección es que no era poco común, según Francisco Belisario, las escenas de violencia que se formaban:

"Entrai agora na matriz de sant ana. Custar-vos-á enormemente romper a multidão que se atropela na entrada. Dentro tereis o espetáculo de um pandemônio, salvo a irreverencia (que não é nossa, mas dos que ali se acham), pois estamos no interior de um templo cristão; na verdade foram retiradas todas as imagens, os círios, os candelabros, tudo quanto podia converter-se em arma ou projétil durante uma luta à mão armada. O fato tem tido lugar em tatas igrejas que estas cautelas não constituem exceções. A sagração das imagens não as garante ${ }^{1390}$."

Estas escenas impactaban a todos, llegando al Parlamento como propuesta de ley, como vimos, para retirar de los templos los actos de las elecciones que no fuesen estrictamente de carácter religioso:

"É contristador o espetáculo que em tais ocasiões oferecem algumas das nossas igrejas. $O$ cidadão ainda não calejado por tanta infâmia retira-se indignado; apenas deposita o voto, foge o mais depressa possível de um lugar em que se reputa aviltado. Os timoratos evitam o perigoso tumulto. Muitos desses mesmos que atiraram-se na vertigem da luta, refletem depois com vergonha dos atos que praticaram e consentiram se praticasse, ora em seu nome, ora com sua responsabilidade real, ou moral ${ }^{1391}$."

El proyecto de moralización de los espacios religiosos, evitándose con eso que los procesos electorales profanasen los templos vuelve a votación, con una buena parte ya aprobada en la Sesión de 9 de junio de 1855. Entra en una segunda discusión en el Senado el art. $1^{\circ}$ del proyecto del Sr. Senador Manoel da Fonseca prohibiendo dentro das iglesias todo e cualquier

\footnotetext{
${ }^{1389}$ SOUZA, Francisco Belisário Soares: O Sistema Eleitoral..., op. cit., p. 32.

${ }^{1390}$ Ibídem.

${ }^{1391}$ Ibídem.
} 
acto del proceso electoral; se aprobó sin debate el referido art. $1^{\circ}$. El primero en manifestarse es el Barón de Muritiba, y lo hace de improviso, acerca del art. $1^{\circ}$, ya aprobado.

“O projeto, depois de ter apartado das igrejas o processo eleitoral, designa os lugares em que se deverá proceder a esses atos. Mas será possível aquilo que o projeto ordena em semelhante caso? Poderá ter execução na maior parte das paróquias do Brasil? Entendo que não ${ }^{1392}$.”

El Barón de Muritiba hace notar lo dificultoso que será realizar elecciones en edificios particulares, si no se utilizaban las iglesias. Solucionados estos percances, se muestra solidario com el Senador Manuel da Fonseca, para alejar de las iglesias las peleas: "E afianço que estou muito disposto a unir o meu voto ao do nobre senador, para que se não continue a poluir as igrejas com esses derramamentos de sangue. Com esses desacatos a que às vezes as eleições dão lugar ${ }^{1393}$ ?" A esto replica el Senador Manuel da Fonseca que es una cuestión de querer hacer las elecciones en otros sítios que sean para ello designados: "E como pensar de outro modo, quando todas as outras nações têm instituições livres não fazem suas eleições nos templos ${ }^{1394}$ ?" Sigue el senador en sus catilinarias en contra de que se realicen las elecciones en los templos:

"A horrível profanação dos templos por ocasião das eleições foi agravada pela lei vigente. Durante 15 a 20 dias estão as igrejas reduzidas a secretarias eleitorais; deixa de haver missa, o que escandaliza muito; e o que tem havido nos templos? Um nobre senador me disse que já viu as imagens servirem de pedras, em alguns lugares têm corrido o sangue humano servindo de instrumento a imagem do Senhor!! E nós. Que sabemos disso, nós que temos em nossas mãos remediar isso, deixaremos de o fazer? Creio que não ${ }^{1395}$."

Tal era el escándalo de las elecciones, que se transformaban en notas extranjeras ${ }^{1396}$, como bien expone el senador Manuel da Fonseca, que el clero pedía al Parlamento la liberalización al Congreso de los templos de los incomodidades de las elecciones. Eso va a concretarse en el proyecto de ley del Senador Manoel da Fonseca, como vimos, salvadas las ceremonias religiosas previstas en la ley electoral. Dichas ceremonias solamente fueron dispensadas por el art. 15 , párrafo $2^{\circ}$ del Decreto n. 3.029, de 9 de enero de 1881 , la denominada ley Saraiva.

\footnotetext{
${ }^{1392}$ Anais do Senado do Império do Brasil. Assemblei Geral Legislativa. Sessão Legislativa Ordinária - $9^{a}$ Legislatura. Sessões de maio e junho de 1855, Senado Federal - Subsecretaria dos Anais, Brasília, 1978. Sessão de 9 de junio de 1855, p. 213. - Barão de Muritiba

1393 Ibídem.

${ }^{1394}$ Ídem, pp. 214-215. - Sr. Sendador Manuel da Fonseca.

1395 Ídem, p. 218.

${ }^{1396}$ KIDDER, D. P y FLETCHER, J. C.: O Brasil e os Brasileiros (Esboço histórico e descritivo), Editora Nacional, São Paulo, 1841, p. 204.
} 
La elegibilidad de los “acatólicos” solamente se alcanzaría con la Ley Saraiva en 1881. Esta ley aparece dentro del conjunto de las reformas liberales de la segunda mitad del siglo XIX en el Imperio de Brasil ${ }^{1397}$. Lo que Nabuco Araújo llamaría de reformas en materia de conciencia $^{1398}$. Estas reformas no solamente requerirían la elegibilidad de los acatólicos, sino también la secularización de los cementerios ${ }^{1399}$, el casamiento civil, y consecuentemente, la separación entre la iglesia y el Estado, que efectivamente solo sería alcanzado con la proclamación de la república en 1889.

Lo que resultaría la Ley Saraiva, fue un proyecto presentado por el gobierno en abril de 1880 a la Cámara. En el artículo $2^{\circ}$ de dicho proyecto decía expresamente que sería elector "todo ciudadano brasileño, nato o naturalizado, católico o acatólico, ingenuo o liberto"1400. En el art. $8^{\circ}$ del proyecto también hablaba de los elegibles que sería aptos para los cargos de senadores, diputados generales, miembros de las asambleas legislativas provinciales, concejales y Juez de Paz, cualquiera de los ciudadanos comprendidos en el artículo $2^{\circ}$. Al final, en la letra de la ley la expresión "acatólicos" fue suprimida y solo se refería indirectamente al tema. El Decreto n. 3.029 de 9 de enero de 1881, la Ley Saraiva, en su art. $2^{\circ}$, decía apenas que:

"É eleitor todo cidadão brasileiro, nos termos dos arts. 6", 91, 92 da Constituição do Império, que tiver renda liquida anual não inferior a $200 \$$ por bens de raiz, indústria, comércio ou emprego. Nas exclusões do referido art. 92 compreendem-se as praças de pret do exercito, da armada e dos corpos policiais, $e$ os serventes das repartições e estabelecimentos públicos ${ }^{1401}$."

En cuanto a la abolición de los actos religiosos del proceso electoral, como ya lo referimos, la ley lo establecerá en el art. 15, párrafo 20: "São dispensadas as cerimonias religiosas e a leitura das leis e regulamentos, que deviam preceder aos trabalhos eleitorais $^{1402 . "}$

\footnotetext{
${ }^{1397}$ PORTO, Walter Costa: Católicos y Acatólicos..., pp. 2 y ss.

${ }^{1398}$ NABUCO, Joaquim: Discursos parlamentares, Câmara dos Deputados, Rio de Janeiro, 1949, p. 201.

${ }^{1399}$ REIS, Joao José: A morte é uma festa..., op. cit., pp. 273 y ss. Los cementerios, segun nos informa Gilberto Freyre, antes de la segunda mitad del siglo XIX, era apenas para los protestantes, paganos y esclavos. Raramente para quienes fuesen católicos y pertenecientes a la nobleza rural o a la burguesía patriarcal. La gente señorial era enterrada en las iglesias, en los conventos y en las capillas particulares. FREYRE, Gilberto: A vida social no Brasil nos meados do século XIX, Arte nova/INPS, Recife, 1977, p. 112. También vease el comentário de este tema em PORTO, Walter Costa: Católicos y Acatólicos..., pp. 3 y ss.

${ }^{1400}$ PORTO, Walter Costa: Católicos y Acatólicos..., pp. 3.

${ }^{1401}$ Collecção das Leis do Império do Brasil de 1881, Parte I, Tomo XXVIII, Parte II, Tomo XLIV, Volume I, Typographia Nacional, Rio de Janeiro, 1882. Actos do Poder Legislativo - Decreto n. 3.029 de 9 de janeiro de 1881, pp. 1-28.

${ }^{1402}$ Ídem, p. 14.
} 
La polémica que vimos generada en el Senado del Imperio en $1855^{1403}$ acerca de la utilización de las Iglesias como lugar de realización del proceso electoral también será tratada por la Ley Saraiva. El párrafo 60 art. 15, dirá que: “O Governo, na Corte, e os Presidentes, nas províncias, designarão com a precisa antecedência os edifícios em que deverão fazer-se as eleições. Só em falta absoluta de outros edifícios poderão ser designados para esse fim os templos religiosos ${ }^{1404}$."

Es evidente que no pasó sin discusión el principio de la elegibilidad de los "acatólicos", aunque sin nombrar el principio en la letra de la ley. En la Sesión de 7 de noviembre de 1881 de la Cámara, Sandanha Marino, insistía que el proyecto tal como estaba redactado no era para nada lógico. Era así, porque había dejado sin aprobar lo que era accesorio o imprescindible al principio de la elegibilidad de los acatólicos: "Admitirão o principio? Sujeitem-se às consequências $^{1405}$.” Lamentaba además, que la reforma no hubiese sido muy profunda hasta el punto de suprimir el juramento que se llevaba a cabo en la cámara y en el senado: "Veremos os acatólicos nesta Câmara não prestarem o juramento e não serão por isso repelidos ${ }^{1406}$."

En el año siguiente, en la Sesión de la Cámara de 6 de febrero de 1882, Rui Barbosa va a dirigirse a la Comisión de Policía sugiriendo la extinción del juramento religioso al asumir el cargo de diputado ${ }^{1407}$. Ya desde la legislatura anterior se creaban problemas acerca de la Ley Saraiva por que al haber insertado el principio de la elegibilidad de los "acatólicos" y el juramento de mantener la Religión Católica Apostólica Romana para acceder al cargo de diputado o de senador, se producia una completa incongruencia, como ya afirmaba Saldanha Marinho $^{1408}$.

\footnotetext{
1403 "Um novo sistema eleitoral foi introduzido no país em 1855- As províncias foram divididas em distritos eleitorais (chamados na época de "círculos"), cada um elegendo um deputado. A mesa eleitoral passou a fornecer o papel no qual o eleitor devia escrever o nome do candidato. O sistema eleitoral utilizado era o de maioria absoluta: se nenhum nome obtivesse 50\% mais 1 dos votos, havia no dia seguinte uma disputa entre os quatro mais votados; se ainda assim nenhum obtivesse a maioria absoluta, no dia seguinte seria realizada uma nova eleição entre os dois mais votados. A idéia dos defensores desse sistema é que ele permitiria que as minorias, pelo menos as com votação concentrada em determinadas regiões, obtivessem representação no Parlamento. No dizer do senador Souza Ramos, era necessário que "a opinião adversa estivesse grupada em certos pontos, para dali virem seus representantes". A única legislatura eleita por esse sistema foi a de 1857-60. O objetivo da reforma foi assegurado, pois o partido minoritário (Liberal) obteve 17\% das cadeiras." Abolición del voto indirecto (1881). NICOLAU, Jairo: História do Voto no Brasil, Segunda Ediçao, Jorge Zahar Editor - Descobrindo o Brasil, Rio de Janeiro, 2004, p. 19.

${ }^{1404}$ Collecção das Leis do Império do Brasil de 1881, Parte I, Tomo XXVIII, Parte II, Tomo XLIV, Volume I, Typographia Nacional, Rio de Janeiro, 1882. Actos do Poder Legislativo - Decreto n. 3.029 de 9 de janeiro de 1881, pp. 1-28.

${ }^{1405}$ O Parlamento e a evoluçao nacional - 1871-1888, $3^{\text {a }}$ Serie, Vol. 6, Sendado Federal, Brasilia, 1979, p. 160 in PORTO, Walter Costa: Católicos y Acatólicos..., p. 4.

${ }^{1406}$ Ibídm.

${ }^{1407}$ BARBOSA, Rui: Obras Completas, Vol. IX, Tomo II, MEC, Rio de Janeiro, 1948, p. 3.

${ }^{1408}$ Walter Costa: Católicos y Acatólicos..., p. 4.
} 
Aunque hubiese reiteradas llamadas de atención de que se debía asumir el principio en su totalidad, como reiteró Sandanha Marinho, la revisión del juramento presente en el Reglamento Interno del Senado y de la Cámara no se había revisado. El Reglamento Interno de la Cámara Alta, desde 1826, como vimos, determinaba el juramento a los Santos Evangelios en:

"Cumprir fielmente as obrigações de Senador, manter a Religião Católica, Apostólica, Romana, a integridade do Império, observar sua Constituição política, ser leal ao Imperador e promover o bem estar da Nação ${ }^{1409}$."

Recoge Walter Costa Porto algunas situaciones en que chocan el principio de la elegibilidad de los "acatólicos" y el juramento de mantener la religión oficial del Estado en el parlamento. En la toma de posesión del diputado Antonio Romualdo Monteiro Manso, es donde ocurre un verdadero incidente dado que se observa la alteración del Reglamento Interno. Dicho diputado fuera elegido por el $9^{\circ}$ distrito de Minas Gerais, para el puesto de Resende Monteiro, que había sido escogido para ser Senador del Imperio. En el día 6 de septiembre de 1888, al presentarse a la Cámara para prestar el juramento de toma de posición del cargo de diputado, el mismo declaró que no podía prestar dicho juramento por en contra de sus convicciones. Solamente después de este incidente la Cámara pasó a discutir el Reglamento Interno, y la misma comisión que introdujo al diputado electo lo acompañó hacía fuera del recinto y durante cinco días la Cámara estuvo debatiendo la reforma de su Reglamento. El día $1^{\circ}$ de septiembre, se avanzó un poco más, y se decidió añadir al artículo un párrafo en donde decía que estaría dispensado del juramento el parlamentar que declarase a la mesa ser aquel voto contrario a sus creencias y opiniones políticas ${ }^{1410}$. Solamente hubo este caso, el diputado Moneiro Manso que se negó a prestar el juramento, y los debates que se generaron no se vincularon inicialmente a la llamada Cuestión Religiosa, sino que quedaron en otra esfera de los debates. Los elementos monárquicos en la Cámara, combatirán con vehemencia la reforma del Reglamento. Y Joaquim Nabuco hizo la observación de que era innecesaria la reforma del regimiento, dado que la nueva ley ya determinaba la elegibilidad de los "acatólicos", de forma que el artículo del Reglamento ya estaba tácitamente revocado, dada la jerarquía de la ley. El regimiento solo cedería en lo que se refería a la creencia del parlamentario, no liberándolo de la otra parte del juramento, que hacía alusión de observar a la constitución y guardar fidelidad a la monarquía. En estos momentos el partido republicano ya hacia mella en el gobierno de Su Majestad Imperial, hasta la proclamación, en el año siguiente al incidente de Monteiro Manso, de la Republica ${ }^{1411}$.

\footnotetext{
${ }^{1409}$ Walter Costa: Católicos y Acatólicos..., p. 2.

${ }^{1410}$ Esta descripción está en la obra de Maganhaes Junio que no nos fue posible conferir el original, y por lo tanto pasamos a hacer una recita en la obra de Walter Costa Porto. MAGALHAES JUNIOR, R.: O Império em chinelos, Civilização Brasileira, Rio de Janeiro, 1957, p. 266 y ss apud Walter Costa: Católicos y Acatólicos..., p. 2.

${ }^{1411}$ Walter Costa: Católicos y Acatólicos..., pp. 5 y ss.
} 
No se puede sostener que se hubiesen moralizado las elecciones al haber se simplificado el proceso electoral en apenas un grado ${ }^{1412}$, fundiendo las figuras de "votantes" y "electores", tampoco por haber retirado de los templos religiosos la celebración del proceso electoral en 1855, o incluso por haber retirado las ceremonias religiosas de todo el proceso gracias a la Ley Saraiva $^{1413}$. En el período siguiente, el período republicano, el proceso electoral estuvo tan viciado como el periodo monárquico:

"A República, partindo do voto direto e suprimindo o censo alto da Lei Saraiva, em tudo o mais, a bem dizer, voltou ao princípio. Dos numerosos textos de lei sobre matéria eleitoral expedidos pelo Governo Provisório do Marechal Deodoro, dois têm para nós especial interesse ${ }^{1414}$."

En el gran momento de reformas liberales, la primera experiencia de la Ley Saraiva llevó a la Cámara a 47 conservadores y a 75 liberales gubernistas, y estaba entre los derrotados el Ministro del Imperio, Barón Homem de Melo. Aunque es verdad que para formar ministerio, como resaltaba Joaquim Nabuco, bastaba con la actuación del Poder Moderador, y era Emperador quien formaba el gabinete de acuerdo a sus preferencias ${ }^{1415}$.

Este fue el periplo en el siglo XIX que recorrieron los "acatólicos" en el proceso electoral y la participación de la ciudadanía finaliza con la Ley Saraiva. Como venimos destacando, la Constitución les garantizaba los derechos civiles y la participación de las primeras fases electorales, pero, les vetaba de forma directa, como estaba previsto en la Constitución y repetido en las leyes electorales para los que no profesasen la religión oficial del Estado que accedieren al cargo de diputado, o de forma indirecta, como figuraba en el Reglamento Interno del Senado del Imperio, al obligar al senador neófito a jurar mantener la Religión Católica Apostólica Romana. La separación entre Estado e Iglesia solo se lograría con la proclamación de la República en el año de 1889.

\footnotetext{
${ }^{1412}$ Abolición del voto indirecto (1881). NICOLAU, Jairo: História do Voto no Brasil..., op. cit., p. 14. También vease acerca de la Ley Savariva (las elecciones directas) en PORTO, Walter Costa: O Voto no Brasil..., op. cit., pp. 100 y ss.

1413 “A partir de 1881, a eleição passou a ser direta e as cerimônias religiosas foram dispensadas. O lugar onde funcionava a mesa eleitoral devia estar separado por uma divisória do lugar onde ficavam os eleitores, que entravam à medida que fossem chamados. $O$ voto teria que ser escrito em papel branco ou anilado, não devendo ser transparente, ter marca, sinal ou numeração. A cédula, fechada por todos os lados e com o rótulo referente ao cargo em disputa, era colocada em um envelope fechado e depositada na urna. Depois, o eleitor assinava o livro de presença; caso não soubesse escrever, outro eleitor indicado por ele poderia assinar." Idem, p. 16.

${ }^{1414}$ LEAL, Victor Nunes: Coronelismo, enxada e voto. O município e o regime representativo no Brasil, $3^{\mathrm{a}}$

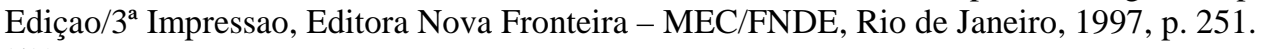

1415 Ibídem.
} 


\section{CONCLUSIONES}

PRIMERA

Identificamos a lo largo de nuestras investigaciones que el arco de intercambios de influencias teóricas y prácticas constitucionales pasó por un eje central que comenzó en la Península Ibérica y llevó las experiencias hasta el recién independiente Imperio de Brasil. Dentro de ese eje buscamos la caracterización de la ciudadanía en el ámbito de un Estado Confesional, y la forma en que éste restringía la ciudadanía definida en el texto legal. Así, abordamos el problema central de esta investigación, al cuestionarnos: Dentro del pensamiento liberal del siglo XIX, ¿cuál fue la postura adoptada por la Constitución Imperial brasileña al relacionar ciudadanía y confesionalidad? ¿En qué medida el establecimiento de la confesionalidad del Estado Brasileño restringía la ciudadanía definida en el texto constitucional? Para llegar a un denominador aceptable, como solución del problema, nos propusimos verificar el matiz adoptado por el constitucionalismo imperial brasileño al relacionar ciudadanía y confesionalidad, detectando cómo la confesionalidad del Estado restringía la ciudadanía definida por la Constitución del Imperio de Brasil. Para ello, buceamos en la legislación electoral que muy bien demostraba en la práctica como era la relación entre ciudadanía y confesionalidad. Para poder abordar mejor el tema detectamos los problemas que sirvieron de parámetro a nuestro periplo. De este modo, indagamos las influencias teóricas de la Constitución de Brasil de 1824 y los paradigmas constitucionales y sus marcos históricos. También buscamos constatar si la confesionalidad del Estado estaba presente en el texto de la Constitución Imperial de Brasil y como dicho texto definía la ciudadanía. Un punto basilar consistió en comprobar si el texto brasileño disentía de alguna forma, en lo que atañe a la confesionalidad del Estado, de los textos análogos de España (1812) y el luso-brasileño (1822). Además, intentamos verificar hasta qué punto se daba la relación entre confesionalidad y ciudadanía en el texto brasileño, y, principalmente, como la primera restringía el ejercicio de la segunda. Y por encima de todo ello, en cuanto investigación empírica, apreciamos de qué manera la legislación electoral reflejaba la restricción de los derechos políticos a los denominados, en los debates parlamentarios y en la prensa, "acatólicos".

\section{SEGUNDA}

Uno de los modelos a seguir por la Constitución brasileña de 1824 fue la Constitución de Cádiz de 1812. En la matriz euromediterranea de constituciones, Cádiz, significó una bandera enarbolada en todas las revoluciones de la década de 1820. Dicha Constitución inspiró los procesos revolucionarios en Portugal, así como en otras partes de Europa. También la 
Constitución luso-brasileña de 1822 estuvo bastante influenciada por este modelo revolucionario surgido en España. Otro texto normativo que recibió las influencias de Cádiz fue el Proyecto de Constitución de 1823, redactado por Antonio Carlos. No extraña, pues, que la Constitución brasileña, otorgada de 1824, recibiera fuertes influencias gaditanas. Esto representó un arco revolucionario que comenzó en España, pasó por Portugal y se reflejó también en el proceso de pre-independencia y de independencia en Brasil. En distintas ocasiones encontramos la Constitución de Cádiz en la historia brasileña. De acuerdo a la documentación consultada, dicha Constitución fue jurada por los españoles residentes, en Río de Janeiro, en un acto oficial en 1813. Otro momento destacable fue la jura por el propio D. Joao VI en Río de Janeiro como consecuencia de la Revolución de Oporto en 1820. Este texto, a través de un decreto, estuvo vigente en Brasil durante un día incompleto, y luego fue revocado por el propio rey. También las tropas concentradas en la Plaza del Rocío en Río de Janeiro, en 1821, pidieron el regreso de la Constitución de Cádiz, y exigieron que la jurara, sin éxito, el propio Príncipe Regente, D. Pedro. Además, sirvió de modelo a las constituciones elaboradas en este mismo periodo en Portugal y en Brasil.

\section{TERCERA}

Constatamos en nuestra investigación que otra gran influencia ejercida por la Revolución liberal española de 1820 en Portugal fue el modelo de pronunciamiento militar, que triunfó con el levantamiento de Riego. Esto servirá de paradigma a los pronunciamientos militares en Oporto y en Lisboa; lo que acarreará un total éxito a la Revolución liberal de Oporto. Además, demostramos que dicho modelo llegó también a Brasil. En la Plaza del Rocío en Río de Janeiro en 1821, aunque no se trató propiamente de un pronunciamiento formal militar, la rebelión de las tropas siguió dicho modelo, dado que exigía que el Príncipe Regente, D. Pedro, jurase la Constitución de Cádiz, y por lo tanto, estableciese un gobierno liberal. La propia independencia, proclamada por D. Pedro, en un sentido amplio seguía el modelo español. Primero, porque en junio de 1822 se había convocado una Asamblea Constituyente que debía elaborar una constitución liberal. Segundo, porque el acto de declaración de independencia estuvo muy cerca del pronunciamiento militar. Lo que se compaginaba muy bien con la creencia de cómo se debía establecer un gobierno liberal, que debía ser dirigido por las élites, y además, debía ser un acto militar para que fuese rápido y eficaz.

\section{CUARTA}

Verificamos un flujo y reflujo revolucionario en el periodo liberal español. La Revolución de Oporto estuvo muy marcada por la Revolución liberal española; por lo tanto, 
constatamos como la prensa española se hizo eco de la revolución portuguesa. Las noticias traspasaban de ambos lados de la frontera. Desde España llegaban modelos aptos para la Revolución liberal de Oporto. Además, la prensa española difundía abundantemente las noticias llegadas desde Portugal, así como de otras partes de Europa. Eso hizo que tanto dentro como fuera de España se pretendiese potenciar el sistema liberal, puesto que trasmitía una imagen de fortaleza del régimen. Era fuerte en el exterior porque había triunfado en España. Era valiosa dentro de la nación española porque se transformó en un paradigma victorioso en los países que adoptaron dicho modelo, como fue el caso de Portugal, por ejemplo. De tal modo que, una abundante propaganda hecha por los periódicos dentro de España hizo que el gobierno liberal español fuese uno de mayor duración entre los que ejerció su influencia: por ejemplo, los de Italia y Portugal. Dado el peligro que esto suponía para las monarquías absolutas restauradas de Europa, Francia procedió a enviar los Cien Mil Hijos de San Luis una vez que en Italia cayera el modelo gaditano, y de que en Portugal tuviera lugar la Vilafrancada, que se convirtió en un golpe anti-liberal.

\section{QUINTA}

El éxito de la Revolución de Oporto tuvo una relación directa con la adhesión brasileña a la Constitución de Cádiz y al modelo de revolución liberal implantado en Portugal. Sin la adhesión de la parte del Imperio luso-brasileño hubiera sido muy difícil el éxito del pronunciamiento militar y la adopción del modelo gaditano. De este modo, esta parte del arco revolucionario también significó un direccionamiento de flujo y reflujo revolucionario. Era muy fácil para el territorio más rico del Imperio, Brasil, reprimir con una expedición militar a la parte rebelde. Así que, la Revolución de Oporto fue exitosa, en cierto modo, porque la parte brasileña del Imperio se implicó positivamente, no dejando al rey otro camino más que seguir diplomáticamente las sendas del proceso liberal y constitucional.

\section{SEXTA}

La élite brasileña que participó tanto, en la primera experiencia constitucional lusobrasileña como en el propio proceso de independencia e institucionalización de Brasil se formó, en gran medida en la Universidad de Coimbra, absorbiendo, por lo tanto, una gran parte de esta reforma en los planes de estudio. Las modificaciones estructurales hechas en Portugal al final del siglo XVIII influenciaron directamente en el proceso brasileño. La formación de los ilustrados portugueses produjo una gran reforma en Portugal. La expulsión de los jesuitas en la década de 1750 se reflejará en la reforma universitaria llevada a cabo por el Valido de D. José I, el Marqués de Pombal. La "Lei da Boa Razão" fue un avance en materia procesal y una 
introducción de un ideario iluminista en el sistema judicial portugués. Además, el proyecto de un Nuevo Código para Portugal, de la Reina Maria I, significó también un gran avance, principalmente en la parte de los comentarios hechos a este código en materia religiosa. Incluso la ocupación francesa, con Junot, significará un aporte de ideas liberales francesas esparcidas por las campañas militares de Napoleón.

\section{SÉPTIMA}

Para resolver el problema presente en la hipótesis principal, trazamos un recorrido del pensamiento liberal a lo largo del siglo XIX, y vimos las posturas adoptadas por la Constitución de 1824, al relacionar confesionalidad del Estado con ciudadanía. Es verdad que la ciudadanía atribuida a los no católicos estaba restringida en su ejercicio, pero no anulaba los derechos de los "acatólicos" para poder participar en el proceso electoral, aunque en la práctica electoral, prevista en la legislación había elementos confesionales que de alguna manera podían alejar de dicho proceso a los no católicos. También pudimos ver que se propuso una solución a las discusiones suscitadas en la Asamblea Constituyente de 1823, que solo se conseguirá en 1881 con la adopción y aprobación del principio de la elegibilidad de los "acatólicos" en el Imperio de Brasil.

\section{OCTAVA}

Percibimos a lo largo de nuestro estudio que las influencias teóricas recibidas por la Constitución de 1824 se debieron principalmente a las siguientes cartas políticas: la Constitución francesa de 1791, la Constitución francesa de 1814, la Constitución española de 1812 y la Constitución luso-brasileña de 1822. Cada una aportó algún elemento. La Constitución francesa de 1791 colaboró con el concepto de la ciudadanía doble: ciudadanos activos y pasivos, una forma de fusionar el concepto de nacional y de ciudadanos, evitando los problemas de la poliédrica sociedad brasileña. La Constitución francesa de 1814 proporcionará algunos elementos aristocráticos, como fue el parlamento bicameral. Y las Constituciones de Cádiz y la luso-brasileño influyeron mucho más en el articulado del texto brasileño. Otras influencias también se conformaron en el texto de 1824, como los Tratados de 1810, en lo que hace referencia a la tolerancia religiosa. Verificamos que, aunque el principio de la tolerancia religiosa estaba recogido en la Constitución del Imperio de Brasil en el art. 179, V, también constatamos que la confesionalidad estaba recogida en el art. 5 del texto constitucional. Esta contradicción en los contenidos normativos constitucionales influenció a la hora de no reconocer derechos políticos plenos a los "acatólicos", haciendo que apenas pudiesen participar completamente en una fase de las elecciones (en las elecciones primarias). En las otras fases del 
proceso electoral, los no católicos quedaban excluidos. El principio reconocido, de forma indirecta, de participación en la ciudadanía activa en el texto constitucional no implicaba la admisión del principio de la elegibilidad de los "acatólicos".

\section{NOVENA}

La ciudadanía estaba definida en el texto constitucional de tal modo que se confundieron los conceptos de ciudadanos y nacionales. La división en ciudadanos activos y pasivos era una forma de no conceder derechos políticos a todos de la misma forma. Así que, unos ciudadanos detentaban los derechos civiles y otros detentaban los derechos políticos. Esta forma de división sufrió la influencia francesa de la Constitución de 1791. Se evitó con esto una larga discusión acerca de los distintos estratos sociales, y como estos participarían de la ciudadanía. Así que, se optó por incluir la gran mayoría de las categorías de ciudadanos y luego se empezaron a recortar derechos con la división en ciudadanos activos y ciudadanos pasivos. Comprobamos que la forma en que se reconocía el concepto de ciudadanía en los textos constitucionales español, luso-brasileño y brasileño radicaba en cómo se concebía la relación entre ciudadanía y confesionalidad del Estado. Mientras que para la Constitución de Cádiz el ciudadano que gozaba plenamente de derechos políticos y civiles era indiscutiblemente católico, para el texto luso-brasileño el extranjero, cualquiera que fuese su religión podía ser ciudadano, naturalmente con goce de derechos civiles inmediatos, e implícitamente también derechos políticos, aunque esto quedaba soslayado. El texto brasileño recogía el principio de libertad religiosa, y concedió a priori, en el proyecto de Antonio Carlos, a los "acatólicos" los derechos políticos plenos, pero se los recortó posteriormente en el texto constitucional de 1824.

\section{DÉCIMA}

Hemos podido demostrar que la relación entre ciudadanía y confesionalidad del Estado era restrictiva en lo referente a los derechos políticos en un primer elemento. En tesis se concedió el principio de la no persecución por motivo religioso, en el art. 179, V, así como, el establecimiento de que eran ciudadanos los extranjeros naturalizados, cualquiera que fuese su religión, art. $6^{\circ}$, V, para luego restringirle derechos en el art. 195, III, evitando que los que no profesasen la religión del Estado accediesen al cargo de diputado. Así pues, primero se admitió el principio general y luego se pasó a restringir derechos. Porque esto sucedió así, hasta cincuenta años después del marco temporal de nuestro estudio, en 1881, fue admitido el principio de la elegibilidad de no católicos a través de una ley ordinaria, dado que el principio general había sido previamente establecido por la Constitución del Imperio. Así pues, aunque el principio general de concesión de derechos a los no católicos estaba reconocido en la 
Constitución, las leyes electorales contenían mecanismos de orden práctico para que los "acatólicos" quedasen alejados del proceso electoral. La realización de las elecciones en el interior de las iglesias, la celebración de ceremonias religiosas en cada acto electoral, y la participación activa de los párrocos en el registro de los votantes hacían que se tornase muy difícil a los no católicos la participación en la parte que les correspondía de las elecciones. La legislación y las Constitución les permitían participar en las elecciones primarias y hasta ser elector de parroquia, pero les estaba prohibido presentarse para ser elegidos diputados. El cargo de senador, en la Constitución, no contenía límites, pero el Reglamento Interno obligaba a jurar sobre los Santos Evangelios y mantener la religión del Estado, con base en el juramento constitucional previsto en el art. 103. La solución a este problema sólo llegaría con la aprobación y entrada en vigor de la Ley Saraiva de 1881, que prohibió las ceremonias religiosas en el proceso electoral y estableció el principio de la elegibilidad de los "acatólicos". Aunque el Reglamento Interno del Senado y de la Cámara solo serían modificados en 1882, permitiendo a los no católicos elegidos no jurar mantener la religión Católica Apostólica Romana.

\section{DÉCIMO PRIMERA}

En resumen, volvemos a las preguntas iniciales: dentro del pensamiento liberal del siglo XIX, ¿cuál fue la postura adoptada por la Constitución Imperial brasileña al relacionar ciudadanía y confesionalidad? ¿Cómo el establecimiento de la confesionalidad del Estado Brasileño restringía la ciudadanía definida en el texto constitucional? Para ello, buscamos verificar el matiz adoptado por el constitucionalismo imperial brasileño al relacionar ciudadanía y confesionalidad, detectando cómo la confesionalidad del Estado restringía la ciudadanía definida por la constitución del Imperio de Brasil. Las discusiones que se iniciaron en 1823, en la Asamblea Constituyente, sobre el principio de elegibilidad de los no católicos, no se solventaron en el periodo que nos propusimos estudiar, entre 1823-1831, pero, tampoco se acabó la discusión y avanzó a lo largo del siglo XIX para ser solucionado apenas con la Ley Saraiva. Como vimos, los acatólicos tenían derecho al voto, pero no podían ser electos para los cargos públicos. Con el advenimiento de dicha ley, se admitió que los “acatólicos” pudiesen ser elegidos para todos los cargos públicos. De este modo, concluimos que aunque se hubiese reconocido el principio general de tolerancia religiosa en la Constitución de 1824, principalmente en los artículos $5^{\circ}, 6^{\circ}, \mathrm{V}$ y $179^{\circ}, \mathrm{V}$, no se había establecido el principio de la elegibilidad de los acatólicos en el texto constitucional. El principio general estaba constitucionalizado, pero no el principio específico de la elegibilidad. Como ya señalamos, esto pudo ser resuelto por la vía legal. Primero la Ley de los Círculos, que ordenó sacar de los templos católicos el procedimiento electoral, y después, con la Ley Saraiva, que permitió 
eliminar del procedimiento electoral todos los actos de carácter religioso y aquellos obstáculos de carácter práctico que dificultaban a los "acatólicos" ejercer su derecho a participar en las elecciones primarias. Finalmente, fue también la Ley Saraiva de 1881, la norma que estableció el principio de la elegibilidad de los "acatólicos", pudiendo estos, no solamente votar en las elecciones primarias, sino también ser elegidos diputado, y demás cargos públicos, en las elecciones secundarias. 



\section{REFERENCIAS BIBLIOGRÁFICAS}

ABADIA, J. Lalinde.: El eco de Filangieri en España, in Anuario de Historia del Derecho Español, tomo LIV.

ADORNO, Sérgio: Os Aprendizes do Poder: Bacharelismo Liberal na Política Brasileira, Editora Paz e Terra, Rio de Janeiro, 1988.

AGUILERA, Bruno: Influencia de la Constitución de Cádiz en Francia en ESCUDERO, José Antonio (Dir.): op. cit.

ALEXANDRE, Valentim: Os Sentidos do Imperio. Questao Nacional e Questão Colonial na Crise do Antigo Regime Português, Biblioteca das Ciencias do Homeme/Ediçoes Afrontamento, Porto, 1993.

ALMEIDA COSTA, Mário Júlio: Leis, Cânones, Direito (faculdades de), in Diccionario de Historia de Portugal, vol. II, pp. 680 y ss.

ALMEIDA COSTA, Mário Júlio: História do Direito Português, $4^{\mathrm{a}}$ Edição Revisada e Actualizada (Colabora Rui Manuel de Figueiredo Marcos), Edição Almedina, Coimbra, 2010.

ALMEIDA LANGHANS, Franz Paul de: O Novo Código de Direito Público de Portugal in: Estudos de Direito, Coimbra, 1957.

ALMEIDA, Carlos Alberto Neves: Os direitos fundamentais nas constituintes de 1821/1822, Lisboa, 1987.

ALMEIDA, Pedro Tavares de: "Eleitores, voto e representantes." In CATROGA, Fernando y ALMEIDA, Pedro Tavares de (cords.) "Res Pública": Cidadania e Representação Política em Portugal 1820-1926, Biblioteca Nacional de Portugal/Assembleia da República, Lisboa, 2010

ALMENAR, Salvador: Economía política y liberalismo en España. De Jovellanos a la Gloriosa en ROBLEDO, R.: Orígenes del Liberalismo..., op. cit.

ALTAVILA, Jayme: Origem dos Direitos dos Povos, Ícone Editora, Sao Paulo, 1989.

ALVAREZ DE MORALES, Antônio: La Reforma de la enseñanza en España y Portugal en la Ilustración: semejanzas y diferencias in Universidades: História. Memória. Perspectivas, vol. I.

ÁLVAREZ JUNCO, José \& DE LA FUENTE MONGE, Gregorio: Las consecuencias prácticas de la libertad de imprenta en MORTARI FERNÁNDEZ, Manuel \& MARTÍN MORENO, Ana (coord.): op. cit., pp. 95 y ss.

ALVES, Cleber Francisco: "A influencia do pensamento liberal de Benjamin Constant na formação do Estado Imperial Brasileiro”, Revista de Informação Legislativa, Brasília a. 45 n. 180 out./dez. 2008.

ANDRADE, Antônio Alberto: Vernei e a cultura do seu tempo, Coimbra, 1966.

ANTUNES, J.: Notas sobre o sentido ideológico da Reforma Pombalina. A propósito de alguns documentos da imprensa da Universidade de Coimbra, «Revista de História das Idéias», vol. IV, tomo. II, Coimbra, 1982.

ANTUNES, José: Notas sobre o sentido ideológico da reforma pombalina. A propósito de alguns documentos da Imprensa da Universidade, in O Marquês de Pombal e o seu tempo, (Numero especial da Revista de Historia das Ideias), tomo II, Coimbra, 1982/1983, pp. 143 y ss. 
APARISI MIRALLES, Ángela.: La Revolución Norteamericana. Aproximación a sus orígenes ideológicas, Madrid, BOE/CEC, 1995.

ARGÜELLES, Agustín: Examen de la reforma constitucional que hicieron las Cortes generales y extraordinarias desde que se instalaron en la Isla de León el día 24 de septiembre de 1810 hasta que cerraron en Cádiz sus sesiones en 14 del propio mes de 1813, En la Imprenta de Carlos Wood e hijo, Poppin`s court, Fleet Street, Londres, 1835.

ARGÜELLES, José Canga: Reflexiones sociales o idea para la constitución española, que un patriota ofrece a los representantes de cortes, Imprenta de José Estévan, Valencia, 1811.

ARMITAGE, John: História do Brasil, Livraria Editora Zelio Valverde, Rio de Janeiro, 1943.

ARNABAT MATA, Ramón: La revolución de 1820 i el Trienni Liberal a Catalunya, Vic, Eumo Editorial, 2001.

ARRIETA ALBERDI, Jon: "Entre Monarquía Compuesta y Estado de las Autonomías. Rasgos básicos de la experiencia histórica española en la formación de una estructura política plural", Ivs Fvgit, 16, 2009-2010, pp. 9-72 ISSN: 1132-8975, pp. 9 a 72 Disponible en ifc.dpz.es/recursos/publicaciones/32/06/02arrieta.pdf Consultado en 18/06/2012, 20:13h.

AZEVEDO, Francisca L. Nogueira de: Carlota Joaquina. Cartas inéditas, Ed. Casa da Palavra, $2^{\text {a }}$ Ediçao, Rio de Janeiro, 2007.

AZEVEDO, Thales de: Igreja e Estado em Tensao e Crise (A Conquista Espiritual e o Padroado na Bahia), Editora Ática, São Paulo, 1978.

BANHA DE ANDRADE, Antônio Alberto: A Reforma Pombalina dos Estudos Secundários (1759-1771), (constribuiçao para a historia da pedagogia de Portugal), Acta Universitatis Conimbrigensis, Vol. 1 (A Reforma), $1^{\text {a }}$ Parte, Coimbra.

BANOND ALMEIDA, Isabel Maria: Monografia sobre a Vida e Obra de um Autor do Século XIX: Vicente José Ferreira Cardoso da Costa in: Estudos em Homenagem ao Professor Doutor Manuel Gomes da Silva, Edição Faculdade de Direito da Universidade de Lisboa, Coimbra Editora, 2001.

BARBAS HOMEM, Anônio Pedro: Algumas notas sobre a introdução do Código Civil de Napoleão em Portugal em 1808 in: Revista Jurídica, Nova Série, n. 2, Lisboa, 1985, pp. 97.

BARBEYRAC, Jean: An Historical and Critical Account of the Science of Morality, Printed for J. Walthoe et alli, London, 1729.

BARBOSA, Rui: Obras Completas, Vol. IX, Tomo II, MEC, Rio de Janeiro, 1948.

BEAUCHAMP, Alphonse de: De la révolution de l'Espagne et de sa crise actuelle, Paris, Ponthieu, 1822.

BECCARIA, Cesare.: Dei delliti e delle pene (Nuova Edizione Corretta e Accresciutta) in Parigi, 1786, p.3. También tuvimos acceso a una versión española traducida del italiano por D. Juan Antonio de las Casas, Tratado de los delitos y de las penas, 1774.

BECCARIA, Cesare: Dei delliti e delle pene (Nuova Edizione Corretta e Accresciutta) in Parigi, 1786.

BECCARIA, Cesare: Dos delitos e das penas, Lisboa, 1998.

BENTHAM, Jeremy.: Principes de législation, in oeuvres, Vol. I, Bruxelas, 1840.

BENTHAM, Jeremy: Principios de legislación y codificación, extractos de la obra del filósofo inglés (Por Francisco Ferrer y Valls, Tomo I, Imprenta de D. Tomas Jordan, Madrid, 1834 
BERBEL, Márcia Regina e MARQUESE, Rafael de Bivar: "Ausência de raça: escravidao, cidadania e ideología pró-escravista nas Cortes de Lisboa e na Assembléia Constituinte do Rio de Janeiro (1821-1824)", paper presentado a la Conferencia Slavery, Enlightenment, and Revolution in Colonial Brazil and Spanish America, New York: Fordham Univesity, 2001.

BERBEL, Márcia Regina y MARQUESE, Rafael de Bivar: "Esclavitud, Ciudadanía e Ideología proesclavista en las Cortes de Lisboa y la Asamblea Constituyente en Río de Janeiro (18211823)" en CHUST, Manuel y FRANQUET, Ivana: Los colores de las independencias Iberoamericanas. Liberalismo, etnia y raza, Consejo Superior de Investigación Científica Colección América, Madrid, 2009.

BERBEL, Márcia Regina y MARQUESE, Rafael de Bivar: "Esclavitud, Ciudadanía e Ideología pro Esclavista en las Cortes de Lisboa y en la Asamblea Constituyente de Río de Janeiro (1821-1824)" en CHUST, Manuel y FRASQUET, Ivana (Eds.): Los colores de la independencia iberoamericanas. Liberalismo, etnia y raza, Consejo Superior de Investigación Científica - Colección América, Madrid, 2009.

BERBEL, Márcia Regina y MARQÚESE, Rafael de Bivar: Esclavitud, ciudadanía e ideología proescalvista en las Cortes de Lisboa y la Asamblea Constituyente de Río de Janeiro (1821-1824) in CHUST, M. e FRASQUET, I (eds.): Los colores de las independencias iberoamericanas. Liberalismo, etnia y raza, Consejo Superior de Investigaciones Científicas, Madrid, 2009.

BERBEL, Márcia Regina: "A Constituição espanhola no mundo Luso-americano (18201823)", Revista de Indias, 2008, vol. LXVIII, núm. 242, págs. 225-254, ISSN: 0034-8341, p. 246.

BERBEL, Márcia Regina: "A Constituição Espanhola no mundo Luso-Americano (18201823)”, Revista de Índias, 2008, vol. LXVIII, núm. 242. Págs. 225-254, ISSN: 0034-8341, $\mathrm{p}, 247$.

BERBEL, Márcia Regina: A naçao como artefato. Deputados do Brasil nas cortes portuguesa 1821-1822, HUCITEC/Fapesp, São Paulo, 1999.

BERBEL, Márcia Regina: A retórica da recolonização en JANCSÓ, István (org.): Independência: história e historiografia, Ed. Fapesp/Hucitec, São Paulo, 2005.

BERBEL, Márcia, MARQUESE, Rafael e PARRON, Tâmis: Escravidao y Politica: Brasil e Cuba, c. 1790-1850, São Paulo, 2010.

BIGNON, MIGNEL, CHIERS, LUTAURE y LESSUR: Anales Pintorescos de la Era Revolucionaria. Desde 1789 hasta nuestros días, Texto Según, Librería de la Señora V. de Bazola, Calle de la Concepción Gerónima n ${ }^{\circ}$ 2/MADRID, Imprenta de Llorens-Hermanos, Calle Acha/Barceona, 1845.

BIRMINGHAM, David: Historia de Portugal, Cambridge, Cambridge University Press, 1995.

BOEHRER, George C. A.: A Igreja no Segundo Reinado: 1840-1889, en KEITH, H. H. y EDWARDS, S. F. (org.): Conflito e Continuidade no Brasil, Civilização Brasileira (Tradução de J. L. de Melo), Rio de Janeiro, 1970.

BONAVIDES, Paulo y AMARAL, Roberto: Textos Políticos da História do Brasil, Volume I Formação: Antecedentes (sécs. XV e XVI), Independência (sécs. XVII até 1822), Império: Primeiro Reinado (1822-1831), Regência (1831-1841), Senado Federal, $3^{\text {a }}$ Edição, Brasília, 2002.

BONAVIDES, Paulo y ANDRADE, Paes de: História Constitucional do Brasil, $4^{\mathrm{a}}$ Edição, Editora OAB, Brasília, 2002. 
BONAVIDES, Paulo: "Constitucionalismo luso-brasileiro: influxos recíprocos" en Perspectivas Constitucionais, Obra colectiva, I, Lisboa, 1996.

BONAVIDES, Paulo: A Constituição de 1824 in Constituições do Brasil, Obra coletiva, Brasília, 1987.

BONAVIDES, Paulo: Teoria Constitucional da democracia participativa. Por un Direito Constitucional de luta e resistência. Por uma Nova Hermenêutica. Por uma repolitização da legitimidade, Editora Malheiros, São Paulo, 2001.

BONIFÁCIO, Mariade Fátima: $O$ vintismo como matriz do radicalismo português en ÁLVAREZ CUARTERO, I. y SÁNCHEZ GÓMEZ, J. (Eds.): Visiones y revisiones de la independencia americana. La independencia de América: la Constitución de Cádiz y las constituciones iberoamericanas, Salamanca, Ediciones Universidad de Salamanca, 2007.

BORGES DE MACEDO, Jorge: "Estrangeirados", um conceito a rever, in Brancara Augusta, $2^{a}$ Ediçao, Lisboa, 1979, vol. XXVIII.

BORREGO, Andrés: Historia de la Vida y del Pontificado del Papa Pio VII, compuesta por el Caballero Artaud, Antiguo encargado de Negocios en Francia cerca de la Santa Sede. (Y traducida cuidadosamente al castellano), Imprenta de la Compañía Tipografica, Madrid, 1837.

BRADAO, M. y LOPES DE ALMEIDA, M.: A Universidade de Coimbra. Esboço da sua história, Parte II, Coimbra, 1937.

BRAGA DA CRUZ, Guilherme: O movimiento abolicionista e a aboliçao da pena de norte em Portugal (Resenha histórica), Lisboa, 1967.

BRAGA, Hilda Soares: Sistemas Eleitorais do Brasil (1821-1988), Senado Federal - Secretaria de Edições Técnicas, Brasília, 1990.

BRAGA, Teófilo: Historia da Universidade de Coimbra, tomo III, (1700-1800), Lisboa, 1898.

BRANCATO, Braz A. A.: Don Pedro I de Brasil posible rey de España (una conspiración liberal), Coleção História - 26, EDIPURS, Porto Alegre, 1999.

BREÑA, Roberto: El primer liberalismo español y los procesos de emancipación de América, 1808-1824 (Una revisión historiográfica del liberalismo hispánico), El Colegio de México, México D.F, 2006.

BROSETA, Salvador: El trienio liberal, 1820-1823: la situación revolucionaria burguesa antifeudal en la ciudad de Valencia, en CHUST, M.: (ed.) De la cuestión señorial a la cuestión social, Valencia, Editora PUV, 2002.

BUENO, José Antônio Pimenta: Direito Público Brasileiro e Análise da Constituição do Império, Senado Federal, Brasília, 1978.

BUENO, José Antônio Pimenta: Direito Público Brasileiro e Análise da Constituição do Império, Rio de Janeiro, 1857.

BURKE, Peter: A Cultura Popular na Idade Moderna: Europa, 1500-1800, Companhia das Letras (Traducción de D. Bottmann), São Paulo, 1989.

BURLAMAQUI, Jean-Jacques: Elementos del Derecho Natural (Traducido de la última edición francesa), Imprenta y Librería de Sanz, Granada, 1838.

BUVE, Raymond: La influencia doceañista en una provincia novohispana mayormente indígena: Tlaxcala, 1809-1824 en CHUST, M. y FRASQUET, I.: La transcendencia del Liberalismo Doceañista en España y en América, Imprenta Romeu, S.L -Generalitat Valenciana - Biblioteca Valenciana, Colección Historia/Estudios, Valencia, 2004. 
CABARAL DE MONCADA, Luis: Um "Iluminista” portugués do século XVIII: Luís António Verney e Italia e Portogallo nel Settecento, in "Est. De Hist. do Dir.", cit., vol. III, Coimbra, 1950

CALDEIRA, Jorge (org.): José Bonifácio de Andrada e Silva, Editora 34 - Coleção Formadores do Brasil, Rio de Janeiro, 2002.

CALMON, Pedro: A reforma da Universidade e os dois brasileiros que a planejaram, in TORGAL, L. R. y VARGUES, I.: O Marquês de Pombal e o seu tempo (número especial da Revista de História das Ideias), Tomo II, Universidade de Coimbra, 1983.

CALÓGERAS, Joao Pandiá: “A Política Exterior do Império: o Primeiro Reinado”, Revista do Instituto Histórico e Geográfico Brasileiro, Tomo Especial, Imprensa Nacional, Río de Janeiro, 1928.

CÂNDIDO, Joel J.: Direito Eleitoral Brasileiro, 12ª Edição, Editora Edipro, São Paulo, 2006.

CANOTILLO, José Joaquim Gomes.: Direito Constitucional e teoría da constituiçao, $6^{\text {a }}$ Ediçao, Almedina, Coimbra, 1993.

CAPMANY. Antonio: Centinela contra franceses, Por Martín Trullás Impresor, Madrid, 1808.

CARDOSO DA COSTA, Vicente José Ferreira: Que he o Código Civil?, Typografia de A. Rodrigues Galhardo, Lisboa, 1822.

CARIDADE DE FREITAS, Pedro: Um testemunho na transição para o século XIX. Ricardo Raimundo Nogueira (Análise histórico-jurídica), Ed. Almedina, Coimbra, 2005.

CARMAGNANI, Marcello: América entre ilustración y liberalismo y en TERNAVASIO, M.: América y las crisis de la monarquía, ambos capitulo presentes en PORTILLO VALDÉS, J., VEIGA ALONSO, X. R. y BAZ VICENTE, Mª (eds.): A Guerra da Independencia e o primeiro liberalismo en España e América, Publicacións da Cátedra Juana de Vega - USC, Santiago de Compostela, 2009.

CARVALHO, Gilberto Vilar de: A liderança do Clero nas Revoluçoes Republicanas de 18171824, Ed. Vozes, Petrópolis, 1980.

CARVALHO, José Murilo de: "Brasil. Naciones imaginadas", en A. ANNINO y F. X. GUERRA (coords.): Inventando la Nación. Iberoamérica. Siglo XIX, Fondo de Cultura Económica, México - D. F., 2003.

CARVALHO, José Murilo de: A construção da ordem. Teatro das sombras, Ed. Civilização Brasileira, Rio de Janeiro, 2003.

CARVALHO, José Murilo de: Cidadania no Brasil. O longo caminho, 9a Edição, Civilização Brasileira, Rio de Janeiro, 2007.

CARVALHO, Manuel Emílio Gomes de: Os deputados brasileiros nas Cortes Gerais de 1821, Edições do Senado Federal Vol. 12 (Introdução de Pedro Calmon), Brasilia 2003.

CASTRO, Zília Osório de: "A "Varanda da Europa" e o "Cais do Lado de Lá" Tratado de paz e aliança entre D. João VI e D. Pedro (29-08-1825)" en CASTRO, Zília Osório de, SILVA, Júlio Rodrigues da y SARMENTO, Cristina Montalvao (Eds.): Tratado do Atlântico Sul. Portugal-Brasil, 1825-2000, Colecção Biblioteca Diplomática do MNE - Série A, Ministério dos Negócios Estrangeiros, Europress, Ltda., Portugal, 2006.

CASTRO, Zília Osório de: “Constitucionalismo vintista. Antecedentes e pressupostos", in Cultura, História e Filosofía, 5 (1986). 
CASTRO, Zília Osório de: Cultura e Política. Manuel Borges Carneiro e o Vintismo, Instituto Nacional de Investigação Cientifica (Centro da Cultura da Univ. Nova de Lisboa), Cultura Moderna e Contemporânea - 5, Vol. I, Lisboa, 1990.

CASTRO, Zília Osório de: Cultura e Política. Manuel Borges Carneiro e o Vintismo, Volume II, Instituto Nacional de Investigação Cientifica/Universidade Nova de Lisboa, Lisboa, 1990.

CATROGA, Fernando: Em nome da Nação en CATROGA, F. y ALMEIDA, Pedro Tavares de (Cord.): Res Pública: Cidadania e representação politica em Portugal, 1820-1826, Biblioteca Nacional de Portugal-Assembleia da República, Lisboa, 2010.

CATROGA, Fernando: Entre deuses e césares. Secularização, laicidade e religião civil, $2^{\mathrm{a}}$ Edição, Editora Almedina, Coimbra, 2010.

CAVALCANTE, Berenice: Razão e Sensibilidade. José Bonifácio. Uma história em três tempos, FGV Editora, Rio de Janeiro, 2001.

CHATAUBRIAND, François-René: La monarchie selon la Charte, Paris, Imprimerie de Le Normant, 1816.

CHORAO, Luís Bigotte: O Discurso de Duarte Alexandre Holbeche - Subsídios para a História do Novo Código in: Estudos em Homenagem ao Professor Doutor Manuel Gomes da Silva, Coimbra Editora, Coimbra, 2001.

CHUST, Manuel\& FRASQUET, Ivana: Problemática del liberalismo: la etnia y la raza en las independencias en Iberoamérica en CHUST, M. \& FRASQUET, I. (eds.): Los colores de las independencias iberoamericanas, liberalismo, etnia y raza, Consejo Superior de Investigaciones Científicas, Madrid, 2009.

CHUST, Manuel Y FRASQUET, Ivana (eds.): La transcendencia del liberalismo doceañista en España y en América, Imprenta Romeu, S.L -Generalitat Valenciana - Biblioteca Valenciana, Colección Historia/Estudios, Valencia, 2004.

CHUST, Manuel y FRASQUET, Ivana: Problemáticas del Liberalismo: la etnia y la raza en las independencias en Iberoamérica in CHUST, Manuel e FRASQUET, Ivana (eds.): Los colores de las independencias iberoamericanas. Liberalismo, etnia y raza, Consejo Superior de Investigaciones Científicas, Madrid, 2009.

CHUST, Manuel: “Un bienio trascendental: 1808-1810”, en CHUST, Manuel (coord.), 1808. La eclosión juntera en el mundo hispano, México D.F., FCE y Colmex: Fideicomiso Historia de las Américas. Serie Estudios, 2007.

CHUST, Manuel: Rey, Soberanía y Nación: las Cortes doceañistas hispanas, 1810-1814 en CHUST, Manuel y FRASQUET, Ivana: La transcendencia del Liberalismo Doceañista en España y en América, Imprenta Romeu, S.L -Generalitat Valenciana - Biblioteca Valenciana, Colección Historia/Estudios, Valencia, 2004.

CLAVERO, Bartolomé: Happy Constitution. Cultura y lengua constitucionales, Valladolid, Editora Trotta, 1997.

COELHO, Geraldo Martins: Anarquistas, Demagogos e Dissidentes. A imprensa liberal no Pará de 1822, CEJUP Editora, Belém, 1993.

COELHO, Manuel Trindade: Manual político do Cidadão portuguez, Lisboa, Parceria A M. Pereira, 1906.

CONSTANT, Benjamin: Cours de Politique Constitutionnelle au Collection des Ouvranges Publiés Sur le Gouvernement Représentativ (Avec une introduction et des Notes par M. 
Édouard Laboulaye - Membre de l'Institut), Tome Premier, Librairie de Guillaumin et Cie, Paris, 1861.

CONSTANT, Benjamin: Curso de Política Constitucional, (Traducido al español por D. Marcial Antonio Lopez), Tomo I, Imprenta Lawalle Jóven y Sobrino, Búrdeos, 1821.

CONSTANT, Benjamin: De la Religión considerada en sus fuentes, formas y dessarrollos, (Texto íntegro presentado por Tzvetan Todorov y Étienne Hofmann. Traducción de Agustín Neira), Editorial Trotta, Madrid, 2008.

CONSTANT, Benjamin: De la Religion, considérée dans sa source, ses formes et ses développements, Tome Premier et Second, H. Tarlier, Rue de la Montagne, P. J. Voglet, Rue de Ruysbroek, Bruxelles, 1825.

CORRÊA TElleS, José H.: Commentario Critico á Lei da Boa Razão, em data de 18 de Agosto de 1769, Lisboa, 1824 (2 ${ }^{a}$ Edição, Lisboa 1845).

COSTA, Emilia Viotti (Comentarios): "Liberalismo brasileiro, uma ideología de tantas caras”, en Folha de Sao Paulo/Folhetim, Sao Paulo, 24/02/1985, nº 423.

COSTA, Emília Viotti da: “A Consciência Liberal nos primórdios do império" en COSTA, Emília Viotti da: Da Monarquia à República: momentos decisivos, $5^{\text {a }}$ Edição, Editora Brasiliense, São Paulo, 1987.

COSTA, Emilia Viotti: Da Monarquia à Republica. Momentos Decisivos, UNESP, São Paulo, 1999.

COSTA, Hipólito José de: Antologia do Correio Braziliense. Organização e Seleção de Barbosa Lima Sobrinho, Ed. Cátedra, Rio de Janeiro, 1977.

COSTA, Jaime Rapouso: “O liberalismo vintista (1820-1822)”, Boletim da Univ. de Coimbra (Separata da Revista), Vol. 43, Coimbra, 1997.

COSTA, Jaime Rapouso: A Teoria da liberdade. Período de 1820 a 1823, Universidade de Coimbra, 1976, pp. 140 y 142. También en CALASANS, José: Os Vintistas e a Regeneraçao de Portugal, S.A. Artes Gráficas, Bahia, 1959.

COSTA, Wilma Peres: Do domínio à nação: os impasses da fiscalidade no processo de independência en JANCSÓ, István (org.): Brasil, formação do Estado e da Nação, Ed. Hucitec/Fapesp, São Paulo, 2003.

CRUZ SEOANE COUCEIRO, María: Libertad de imprenta: de vehículo de las luces a derecho del hombre en MORTARI FERNÁNDEZ, Manuel \& MARTÍN MORENO, Ana (coord.): Prensa y Libertad de Imprenta. Los periódicos en el Cádiz de las Cortes, Cádiz, Galería GH40, 2010.

CRUZ SEOANE, María: Oratoria y periodismo en la España del Siglo XIX, Valencia, Editorial Castalia, 1977.

DE VADILLO, José Manuel: Escritos presentados al Gobierno español en el año de 1809, Imprenta del Estado-Mayor General, Cádiz, 1809.

DOGLIANI, Mário: Introduzione al Diritto Costituzionale, II Mulino, Bologna, 1994, p. 152. Véase también a SOARES, Rogério: "O Conceito Ocidental de Constituição", in RLJ, 119.

DOLHNIKOFF, Mirian: O pacto imperial. Origens do federalismo no Brasil, Editora Globo, São Paulo, 2007

DUFOUR, Gérard: De la Ilustración al Liberalismo en ALBEROLA Y LA PARRA (eds.): La ilustración española, Instituto Juan Gil-Albert/Diputación Provincial de Alicante, Alicante, 1986. 
EL SHAKANKIRI, Mohamed: La philosophie juridique de Jeremy Bentham, Paris, 1970.

ELORZA, Antonio: La formación del liberalismo en España en VALLESPÍN, F. (ed.): Historia de la Teoría Política, III, Alianza Editorial, Madrid, 1995.

ENCISO RECIO, Luis Miguel.: La opinión española y la independencia hispanoamericana 1819-1820, Gráfica Andrés Martín S.A., Valladolid, 1967.

ESCUDERO, José Antonio (Dir.): Constitución de 1812, Cortes y Constitución de Cádiz 200 años, Madrid, Editora Espasa, Tomo III, 2011.

ESDRAILE, Charles: La Guerra de Independencia. Una nueva historia, Crítica Barcelona, Barcelona, 2004.

ESTEVES PEREIRA, José: O pensamento político em Portugal no século XVIII: Antonio Ribeiro dos Santos, Liboa, 1983.

FAORO, Raymundo: Os Donos do Poder, Editora Globo, Rio de Janeiro, 1989.

FAUSTO, Boris: História do Brasil, Edusp, São Paulo, 1994.

FEENSTRA, Robert: Ius commune et droit comparé chez Grotius - Nouvelles remarques sur les sources citées dans ses ouvrages juridiques, à propos d'une réimpression du 'De iure belli ac pacis`, in Revista Internacional de Direito Comparado, cit., Vol. III, pp. 7 y ss. (Republicada in "Miscellanea Domenico Maffei dedicata", cit., Vol. III, pp. 513 y ss.).

FEIJÓ, Diogo Antônio: Diogo Antônio Feijó. Organização, introdução e notas de Jorge Caldeira, Ed. 34, São Paulo, 1999.

FEIO, F. M. B.: Memorias históricas e descritivas acerca da Biblioteca da Universidade de Coimbra, e mais estabelecimentos anexos. Coimbra: Imprensa da Universidade, 1857.

FERNÁNDEZ SARASOLA, Ignacio: La Constitución de Bayona (1808), Tomo I (Colección Las Constituciones Españolas - dirigida por Miguel Artola), Madrid, Iustel, 2007, pp. 53 y ss.

FERNÁNDEZ SARASOLA, Ignacio: La Constitución de Cádiz, origen, contenido y proyección internacional, Madrid, Centro de Estudios Políticos y Constitucionales, 2011.

FERNÁNDEZ SARASOLA, Ignacio: Proyectos constitucionales en España (1786-1824), Madrid, C.E.P.C, 2004.

FERRAZ, Socorro (org.): Frei Caneca. Acusação e Defesa, Ed. Universitaria UFPE, Coleção Nordestina, Recife, 2000.

FERREIRA NETO, Osly da Silva: Os Assentos no Direito Português e as Súmulas no Direito Brasileiro: efetividade, segurança e imobilidade, disponible en la dirección: www.estig.ipbeja.pt/ ac_direito/osly.pdf Accedido en 25/02/2013.

FERREIRA, Manoel Rodrigues: "Evolução do Sistema Eleitoral Brasileiro", 1956, BE-TRESP 124/2339 a 2342 etc.

FERREIRA, Silvestre Pinheiro: Breves observações sobre a Constituição Política da Monarchia Portugueza decretada pelas Cortes Geraes Extraordinarias e Constituintes reunidas em Lisboa no anno de 1821, Rey E. Gravier, Paris, 1837.

FERREIRA, Silvestre Pinheiro: Fantasias Constitucionaes, seguidas por algumas reflexões, da Razão, e da Experiência, Publicadas por um Lusitano Filantropo, Imprensa Nacional - Com licença da Comissão de Censura, Lisboa, 1821, p. 5.

FERREIRA, Silvestre Pinheiro: Observações sobre a Constituição do Império do Brasil, e sobre a Carta Constitucional do Reino de Portugal, Segunda Edição, Aumentada com as 
observações do mesmo autor sobre a lei das reformas do Imperio do Brasil, Em casa de Rey e Gravier y J. P. Aillaud, Paris, 1835.

FERREIRA, Silvestre Pinheiro: Projeto de Código Político para a Nação Portugueza, Em Casa de Rey e Gravier e de P. J. Aillaud, Paris, 1838.

FERREIRA, Silvestre Pinheiro: Projeto de Código Político para a Nação Portugueza, (Ministro de Estado honorário, sócio da Academia das Sciencias de Lisboa e correspondente do Instituto de França), Em Casa de Rey e Gravier e de J. P. Aillaud, Paris, 1838.

FERRER Y VALLS, Francisco: Principios de Legislación y de codificación..., Tomos I y II, Imprenta de D. Tomas y Jordan, Madrid, 1834.

FIGUEIREDO MARCOS, Rui M.: A legislação Pombalina. Alguns aspectos fundamentais, $2^{\mathrm{a}}$ Edição, Coimbra, 2007.

FIGUEIREDO MARCOS, Rui M.: O jusracionalismo setecentista em Portugal, in Direito Natural e Política, vol. I, Coimbra 2005.

FIGUEIREDO MARCOS, Rui M.: Rostos Legislativos de D. Joao VI no Brasil, Coimbra, 2008.

FIGUEIREDO Sara Ramos: A primeira Constituição Brasileira in Revista de Informação Legislativa, Abril-Junho, 1985.

FILANGIERI, Gaetano: Ciencia de la Legislación, (Traducción Jaime Rubio, abogado de los Reales Consejos), Tercera Edición, Tomo I, Imprenta de Nuñez, Madrid, 1822, p. IV.

FIORAVANTI, Maurizio: Appunti di storia dele costituzioni moderne. Le libertà: presuposti culturali e modelli storici, G. Giappichellii Ed., Torino, 1991.

FIORAVANTI, Maurizio: Constitución. De la Antigüedad a nuestros días, Madrid, Editora Trotta, 2001.

FIORAVANTI, Maurizio: Constituzione e popolo sovrano, Bologna, Società Editrice il Mulino, 1998.

FIORAVANTI, Maurizio: Los Derechos Fundamentales. Apuntes de la historia de las constituciones, Editorial Trotta, Universidad Carlos III de Madrid, 1996.

FLEIUSS, Max: “Centenario da Aclamaçao de D. Pedro I (12 de Outubro de 1822)". In: Revista do Instituto Histórico e Geografico Brasileiro. O Anno da Independência, Tomo Espercial, Imprensa Nacional, Rio de Janeiro, 1922, p. 342.

FLORES, Alberto Vivar: "El liberalismo constitucional en la fundación del Imperio brasileño", Historia Constitucional (Revista electrónica), n.6, 2005. http://hc.rediris.es/06/index.html Accedido en 26/11/2012.

FLÓREZ ESTRADA, Álvaro: Constitución para la nación española (1809), Madrid, 1958.

FORONDA, Valentín de: Cartas sobre los asuntos más exquisitos de la economía-política y sobre las leyes criminales, Tomo I, Tercera Edición (Ediciones anteriores, 1789 y 1794), Imprenta de Ramón Domingo, Pamplona, 1821.

FORONDA, Valentín de: Cartas sobre los asuntos más exquisitos de la economía-política y sobre las leyes criminales, Tomo I, En la Imprenta de Manuel González, Madrid, 1789.

FRANCO, Afonso Arinos de Mello: A Câmara dos Deputados. Síntese Histórica, Obra comemorativa do Sesquicentenário de Instalação da Câmara dos Deputados, Centro de Documentação e Informação, Coordenação de Publicações, Brasília, 1976. 
FRANCO, Afonso Arinos de Melo: "Ideias políticas do constitucionalismo imperial" en O Pensamento Constitucional Brasileiro (Ciclo de conferências realizado no período de 24 a 26 de outubro de 1977), Câmara dos Deputados, Brasília, 1978, p. 33.

FRANCO, Afonso Arinos de Melo: Curso de Direito Constitucional Brasileiro, 2 Volume, Editora Forense, Rio de Janeiro, 1959.

FRANCO, Afonso Arinos de Melo: Estudos de Direito Constitucional, Editora Forense, 1957.

FRANCO, Francisco Soares: Explanação à lei de 5 de junho de 1822 sobre a reforma dos foraes, Lisboa, Rollandiana, 1822.

FRASQUET, Ivana: El liberalismo gaditano en el México independiente, 1821-1824 en CHUST, Manuel y FRASQUET, Ivana: La transcendencia del Liberalismo Doceañista en España y en América, Imprenta Romeu, S.L -Generalitat Valenciana - Biblioteca Valenciana, Colección Historia/Estudios, Valencia, 2004.

FREIRE DOS REIS, Joaquim Melo: Historiae Iuris Civilis Lusitani Liber Singularis, Lisboa, 1788; Institutiones Iuris Civilis Lusitani, cum Publici tum Privati, Lisboa, 1789/1793 (liv. I - 1789; liv. II y III - 1791; liv. IV - 1793); Institutiones Iuris Criminalis Lusitani, Lisboa, 1794. ALMEIDA COSTA, M. J.: op. cit., p. 415.

FREIRE, Pascoal de Mello: Projeto para um Novo Código de Direito Público de Portugal (feitas e apresentadas na Junta de Censura e Revisão pelo Dr. Antônio Ribeiro), Imprensa da Universidade, Coimbra, 1844.

FREYRE, Gilberto: A vida social no Brasil nos meados do século XIX, Arte nova/INPS, Recife, 1977.

FREYRE, Gilberto: Ingleses no Brasil. Aspectos da influencia britânica sobre a vida, a paisagem e a cultura no Brasil, $3^{\text {a }}$ Edição, Topbooks Editora, Rio de Janeiro, 2000.

GALVAO TELLES, Inocencio: Verney e o Iluminismo italiano, in "Revista da Faculdade de Direito da Univ. de Lisboa, cit., vol. VII.

GAMA CAETANO, F.: Nótula sobre Verney, Coimbra, 1985.

GARCÍA Malo, Ignacio: La política natural o discurso sobre los verdaderos principios del gobierno (Imprenta de Mallorca-1810), Reimpresión por Martín Trullás, Manresa, 1820.

GARRIGA, Carlos y LORENTE, Marta: Cádiz, 1812. La Constitución jurisdiccional, Madrid, CEPC, 2007.

GENOVESI, Antonio: Lecciones de comercio, ó bien de economía civil, (Traducido por Victorian de Villava, Colegial del Mayor de San Vicente Mártir de la Universidad de Huesca, y Catedrático de Código de la misma), Tomo I, Por Joachín Ibarra, Impreso de Camara de S.M., Madrid, 1785.

GIL NOVALES, Alberto: El liberalismo temprano en un diccionario biográfico en BARREIRO FERNÁNDEZ, X. R. (coord.): O liberalismo nos seus contextos. Un estado da cuestión, Santiago de Compostela, USC, 2008.

GIL NOVALES, Alberto: El trienio liberal, Madrid, Siglo Veintiuno Editores, 1989.

GIL NOVALES, Alberto: Las Sociedades Patrióticas (1820-1823), Tomo II, Madrid, Tecnos, 1975.

GIL NOVALES, Alberto: Las sociedades patrióticas (1820-1823). Vol. I, Madrid, Tecnos, 1975.

GILISSEN, John: Introdução histórica ao Direito, $6^{\circ}$ Ediçao, Fundaçao Calouste Gulbenkian, Serviços de Eduaçao e Bolsas, Lisboa, 2011. 
GOMES DA SILVA, Nuno J. Espinosa: Reflexões sobre a gênese do chamado Projeto de Constituição de 1808, a outorga por Napoleão a Portugal in: Direito e Justiça, vol. XVIII, tomo II, Lisboa, 2004.

GÓMEZ, Julio Sánchez: El otro año 8 en ABREU, Fernando José Marroni de: Las Invasiones napoleónicas y el mundo iberoamericano, Embajada de Brasil/Universidad de Salamanca, Madrid, 2008.

GONZÁLEZ ALONZO, Benjamín: Las raíces ilustradas del ideario administrativo del moderantismo español en CAPPELINI, Paolo (et ali): De la Ilustración al Liberalismo. Symposium en honor al profesor Paolo Grossi, Madrid, Centro de Estudios Constitucionales, 1995.

GONZÁLEZ DURO, Enrique.: Fernando VII. El rey felón, Salamanca, Oberon, 2006.

GOUVÊA, María de Fática Silva: O Imperio das Provincias. Rio de Janeiro, 1822-1889, Civilização Brasileira/Faperj, Rio de Janeiro, 2008.

GRIMBERG, Keila: O fiador dos brasileiros, cidadania, escravidão e direito civil no tempo de Antônio Pereira Rebouças, Ed. Civilização Brasileira, Rio de Janeiro, 2002.

GROCIO, Hugo: Derecho de la guerra y de la paz, Reus, Vol. IV, Madrid, 1925.

GUZMÁN Y GALLO, J. Pérez: El dos de mayo de 1808 en Madrid, Madrid, Estabelecimiento Tipográfico Sucesores de Rivadeneyra, Paseo de San Vicente n. 20, 1908 (ed. Facsimilar de Editorial Maxtor, 2008).

HABERMAS, Jürgen: Mudança estrutural na esfera pública, Rio de Janeiro, Tempo Brasileiro, 1984.

HALLER, Karl Ludwig von: Análisis de la Constitución española, Madrid, Imprenta de D. José de Collada, 1823.

HALLER, Karl Ludwig von: De la constitution des cortès d’Espagne, París, Nicolle, 1820.

HALLER, Ludwig von: De la Constitution des Cortès de l'Espagne, Paris, Librairie grecquelatine-allemande, 1820.

HALPERIN DONGHI, Tulio: Crisis de la monarquía hispana y nacimiento del liberalismo en PORTILLO VALDÉS, J., VEIGA ALONSO, X. R. y BAZ VICENTE, Mª. (eds.): A Guerra da Independencia e o primeiro liberalismo en España e América, Publicacións da Cátedra Juana de Vega - USC, Santiago de Compostela, 2009.

HEINECII, Joan Gottlieb: Elementa iuris naturae et Gentium, Ex Officina Emman - Martini, 1776.

HERZOG,Tamar: Citizenship and community in Eighteenth Century Spain, Polic, 2002.

HESPANHA, Antônio Manuel (org.): Poder e Instituições na Europa do Antigo Regime, Fundação Calouste Culbenkian, Lisboa, 1984.

HESPANHA, Antônio Manuel y SILVA, Cristina Nogueira da (dir.): Fontes para a história constitucional portuguesa, Faculdade de Direito da UNL, Lisboa, 2004 - Sitio de la Biblioteca Nacional, Lisboa.

HESPANHA, Antônio Manuel: "O individuo face ao poder. Portugal Séculos XVI-XVII", em L`individu face au pouvair, Société Jean Bodin, Bruxelas, 1989.

HESPANHA, Antônio Manuel: A constituição do Império português. Revisão de alguns enviesamentos correntes in FRAGOSO, Joao, BICALHO, Maria Fernanda y GOUVÊA, Maria de Fátima (orgs.): O Antigo Regime nos trópicos. A dinâmica imperial portuguesa (Séculos XVI-XVIII), Civilização Brasileira, Rio de Janeiro, 2001. 
HESPANHA, Antônio Manuel: Bajo el Signo de Napoleón. La Súplica Constitucional de 1808, Cuadernos de Historia Moderna. Anejos, 2008, VII, 299-218.

HESPANHA, Antônio Manuel: Guiando a mão invisível. Direitos, Estado e Lei no Liberalismo monárquico português, Editora Almedina, Coimbra, 2004.

HESPANHA, Antônio Manuel: Poder e Instituição na Europa do Antigo Regime. Colectânea de Texto, Lisboa, 1984.

HOBSBAWM, Eric J.: La era de la revolución: 1789-1848,Barcelona, Crítica, 2011.

HOCQUELLET, Richard: Du consensus populi à la volonté générale. La représentation du pouvoir chez les dirigeants patriotes pendant la Guerre d'Independence, Mélange de la Casa Velázquez, 35-1, 2005 apud HOCQUELLET, R.: El rey y la nación..., op. cit., p. 57.

HOCQUELLET, Richard: El Rey y la nación. Monarquía tradicional y representación moderna en PORTILLO VALDÉS, J., VEIGA ALONSO, X. R. y BAZ VICENTE, M ${ }^{a}$. (eds.): A Guerra da Independencia e o primeiro liberalismo en España e América, Publicacións da Cátedra Juana de Vega - USC, Santiago de Compostela, 2009.

HOLANDA, Sergio Buarque de (dir.): História geral da civilização brasileira, Tomo II, Volume $4^{\circ}$, Editora Difel, São Paulo, p. 319.

HOLANDA, Sérgio Buarque de (dir.): História geral da civilização brasileira, Vol. I, O processo de emancipação, $2^{a}$ edição, Ed. Difusão Europeia do Livro, São Paulo, 1965, pp. 13-39.

HOMEM DE MELO, Francisco I. M.: Escriptos Históricos e Litterarios (I - A Constituinte perante a história, $2^{a}$ Edição), Editores Eduardo e Henrique Laemmert, Rua do Ouvidor 68, Rio de Janeiro, 1868.

HOMEM, António Pedro Barba: Judex perfectus. Funçao jurisdiccional e estatuto judicial em Portugal. 1640-1820, Coimbra, Almedina, 2003.

HOMEM, Antonio Pedro Barbas: "Algumas notas sobre a introdução do Código de Napoleão em Portugal”, Revista Jurídica, 2 e 3, 1985.

HORST DIPPEL, H. (Ed.): Constitutions of the world from the late $18^{\text {th }}$ Century to the Middle of the $19^{\text {th }}$ Century (Verfassungen der Welt vom späten 18. Jahrhundert bis Mitte des 19. Jahrhunderts), Editora De Gruyter, Berlin, 2010.

ITAGIBA, Ivair Nogueira: O Pensamento Político Universal e a Constituição Brasileira, Gráfica Tupy Ltda, Rio de Janeiro, 1947.

JANCSÓ, István (org.): Independência: história e historiografia, São Paulo, Fapesq/Hucitec, 2005.

JANCSÓ, István y PIMENTA, Joao Paulo Garrido: Peças de um mosaico (ou apontamentos para o estudo da emergência da identidade nacional brasileira) en MOTA, Carlos G. (org.): Viagem incompleta; a experiência brasileira (1500-2000). Formaçao: histórica, Ed. Senac, São Paulo, 2000.

JESCHECK, H. H.: Principes et solutions de la politique criminelle dans la reforme allemande ete portugaise, in Estudos in memoriam do Prof. Dr. José Beleza dos Santos, vol. I, Coimbra, 1966.

JIMÉNEZ GREGORIO, F.: Murcia y los Decretos de 22 de mayo y 08 de junio de 1809: aportación a la historia política de la Guerra por nuestra Independencia de 1808, Publicación de la Universidad de Murcia, Murcia capital, 1946. 
JOVELLANOS,Gaspar Melchor: Memorias en defensa de la Junta Central apud MARTÍNEZ NOVAL, Bernardo: Jovellanos, (edición Facsímile, Orlando Moratinos Otero), Fundación Foro Jovellanos del Principado de Asturias, Cuadernos de Investigación, Monografías, Gijón, 2006.

JOVER ZAMORA, J.M.; GÓMEZ-FERRER, G. y FUSI AIZPÚRUA, J. P.: España: sociedad, política y civilización (siglos XIX-XX), Areté, Barcelona, 2001.

KAIZER, Gloria: Doña Leopoldina, un Habsburgo en el trono de Brasil, Editora Nova Fronteira, Rio de Janeiro, 1997.

KANN, Betina, Souza Lima, Patricia, la selección, Cartas de una emperatriz, Editora Estação Liberdade, São Paulo, 2006.

KANTOROWICZ, Ernst H.: Os dois corpos do rei. Um estudo sobre Teología Política Medieval, Companhia das Letras, Sao Paulo, 1998.

KIDDER, Daniel P y FLETCHER, James C.: O Brasil e os Brasileiros (Esboço histórico e descritivo), Editora Nacional, São Paulo, 1841.

LACOMBE, Américo Jacobina: La correspondencia entre María Graham y la emperatriz Doña Leopoldina, Itatiaia Editora, Belo Horizonte, 1997.

LAMARTINE, Alphonse de: Historia General de Francia. Historia de la Restauración, Tomo III, Libro XIV, Librería Española - Calle Relatores n 14/Madrid y Librería Española Calle Ancha/Barcelona, 1854.

LAURA MASINI, G.S.: Gerdil, una censura al Dei delliti e delle pene, in Diritto romano attuale. Storia, método, cultura nella scienza giuridica, vol. 17, Napoli, 2007.

LEAL, Aurelino: História Constitucional do Brasil, Rio de Janeiro, 1915.

LEAL, Victor Nunes: Coronelismo, enxada e voto. O município e o regime representativo no Brasil, $3^{\text {a }}$ Ediçao/ $3^{\text {a }}$ Impressao, Editora Nova Fronteira - MEC/FNDE, Rio de Janeiro, 1997.

LEMOS, Francisco: Relaçao Geral do Estado da Universidade (1777), II Centenário da Reforma Pombalina, Universidade de Coimbra, Coimbra, 1980, p. 10.

LIMA, Oliveira: O Império Brasileiro, São Paulo, 1927.

LOBAO, Manuel de Almeida e Souza de: Notas de Uso prático e Críticas. Adiçoes, Illustraçoes e Remissoes à imitação das de Miller a Struvio (Sobre todos os títulos e parágrafos do livro segundo das instituições do direito civil lusitano do doutor Pascoal José de Mello Freire), Parte II, Imprensa Nacional, Lisboa, 1963.

LOCKE, John: Tratado del Gobierno Civil (Traducida de la séptima edición francesa publicada en París por los ciudadanos D. G. C y L. C Aferes de Caballería), Imprenta de la Minerva Española - A cargo de J. Fernández, Madrid, 1821.

LOPES PRAÇA, José Joaquim:Collecção de Leis e Subsidios para o Estudo do Direito Constitucional Portuguez, Vol. II, Coimbra, 1894.

LOPES PRAÇA, José Joaquim: Collecção de Leis e subsídios para o Estudo do Direito Constitucional Portuguez, vol. II, Coimbra, 2000, p. VIII.

LOPES PRAÇA, José Joaquim: Ensaio sobre o padroado português. Dissertação inaugural para o acto de conclusões magnas, Imprensa da Universidade, Coimbra, 1869.

LOPES PRAÇA, José Joaquim: Estudos sobre a Carta Constitucional de 1826 e Acto Adicional de 1852, Coimbra, Imprensa Literária, 1878. 
LÓPEZ CEPERO, Manuel: Lecciones políticas para el uso de la juventud española, Tercera Edición, Imprenta de Villalpando, Madrid, 1814.

LORENTE, Marta: "De Monarquía a Nación: la imagen de América y la cuestión de la ciudadanía hispana" in XIII Congreso del Instituto Internacional de Historia del Derechos Indiano (21-25 mayo de 2000), Vol. II, Asamblea Legislativa de Puerto Rico, San Juan, 2003.

LOUREIRO, José Pinto: O Jurisconsulto Manuel de Alemeida e Sousa, Vol. I, Editorial de Coimbra, 1942.

LUSTOSA, Isabel: Insultos impressos. A guerra dos jornalistas na Independência. 1821 - 1823, Ed. Companhia das Letras, São Paulo, 2000.

LYNCH, Christian Edward Cyril: "O conceito de liberalismo no Brasil (1750-1850)", Araucaria, Revista Iberoamericana de Filosofía, Política y Humanidades, $\mathrm{N}^{\circ} 17$, mayo de 2007.

MACEDO, José Agostinho de: Bazes eternas da Constituição Política achada na Cartilha do Mestre Ignacio pelo sacristão do Padre Cura D`Aldeia, Lisboa, Impressa da Rua Formosa, 1824.

MACEDO, José Agostinho de: Elogio Histórico do Ilustrissimo e Excelentissimo Ricardo Raimundo Nogueira, Conselheiro D`Estado, Impressao Regia, Lisboa, 1827, p.11.

MAGALHAES JUNIOR, Raimundo: O Império em chinelos, Civilização Brasileira, Rio de Janeiro, 1957.

MALERBA, Jurandir (org.): A independência brasileira: novas dimensões, Ed. FGV, Rio de Janeiro, 2006.

MALERBA, Jurandir: A corte no exílio. Civilizaçao e poder no Brasil às vésperas da independência 1808-1821, Ed. Companhia das Letras, São Paulo, 2000.

MANUPELLA, G.: Cesare Beccaria (1738-1794) - Panorama Bibliográfico, in Boletim da Faculdade de Direito, vol. XXXIX, p. 107 y ss.

MARAVALL, José Antonio: La fórmula política del despotismo ilustrado en IGLESIAS, C. (ed.): Estudios de la historia del pensamiento español, siglo. XVIII, Mondadori, Madrid, 1991.

MARCOS, Rui Figueiredo: "Rostos da Política Legislativa de D. Joao VI no Brasil", Academia de Ciências de Lisboa, Comunicação Apresentada à Classe de Letras na Sessão de 8 de Maio de 2008.

MARQUESE, Rafael de Bivar: "O poder da escravidão: um comentário aos 'Senhores sem Escravos"” in Almanack braziliense, n.6, 2007.

MARTÍNEZ NEIRA, Manuel: La ilustración (jurídica) española en PECES-BARBA MARTÍNEZ, G., FERNÁNDEZ GARCÍA, E. \& DE ASÍS ROIG, R. (dirs.): Historia de los Derechos Fundamentales, Tomo II: Siglo XVIII, Volumen I, Madrid, Jacaryan S.A.

MARTÍNEZ SOSPEDRA, Manuel: La constitución española de 1812 (El constitucionalismo liberal a principios del siglo XIX), Facultad de Derecho, Valencia, 1978.

MARTINI, Caroli Antonii de: De lege naturali (Ad Ilustrandas Posiciones Suas de Lege Naturali), Confluentiae - Sumtibus J. C. Huber, 1781.

MARTINI, Caroli Antonii: De lege naturali, Confluentiae - Sumitibus J. C. Huber, Viena, 1781. 
MARTINS, Wilson: História da Inteligência brasileira. Vol. II (1794-1855), Ed. Cultrix, São Paulo, 1974.

MATTEUCCI, Nicola.: Historia del Constitucionalismo moderno. Organización del poder y libertadop Editora Trotta, Madrid, 1998.

MATTEUCCI, Nicola: Organización del Poder y Libertad. Historia del constitucionalismo moderno (presentación de Bartolomé Clavero), Madrid, Editora Trotta, 1998.

MATTEUCI, Nicola: "La Costituzione statunitense ed il moderno costituzionalismo", in Costituzione Statunitense e il suo significato odierno, II Mulino, Bologna, 1989.

MATTOS, Hebe Maria: Escravidao e cidadanía no Brasil monárquico, $2^{a}$ Ediçao, Jorge Zahar Editor, Rio de Janeiro, 2000.

MATTOS, Ilmar Rohloff de: O Tempo Saquarema, Editora HUCITEC/INL, Sao Paulo/Brasilia, 1987.

MAZO, Santiago J. García: El Catecismo de la Doctrina Cristiana Esplicado, ò Esplicaciones del Astete que Convienen Igualmente al Ripalda, por el Licenciado Don Santiago José Garcia Mazo, Magistral de la Santa Iglesia Catedral de Valladolid, Segunda Impresión, Con las Licencias Necesarias, Imprenta de Don Julián Pastor, Valladolid, 1839.

McFARLANE, Anthony: "Independências americanas na era das revoluções: conexões, contextos, comparações", en J. MALERBA (org.), A independência brasileira. Novas dimensões, Rio de Janeiro, Editora FGV, 2006.

MELLO FREIRE,Pascoal José : Institutiones iuris civilis lusitani, Coimbra, 1789 (trad. Miguel Pinto de Menezes [rev. A. M. Hespanha], in Boletim do Ministério da Justiça, 161 [1966], 94).

MELLO FREIRE, Pascoal José: Dissertação Histórico-Jurídica sobre os Direitos e Jurisdição do Grão- Prior do Crato, e o Seu Provisor, (Primeira Edição), Imprensa Regia, Lisboa, 1809.

MELLO, Evaldo Cabral de: A outra independência. O federalismo pernambucano de 1817 a 1824, Editora 34, São Paulo, 2004.

MELO FRANCO, Francisco y ANDRADA E SILVA, José Bonifácio: O Reino da Estupidez. Poema Heroi-comico, el original perteneciente a la Biblioteca Nacional, Rio de Janeiro, Secção de Manuscritos.

MELO FRANCO, Francisco: O Reino da Estupidez, Officina de A. Bobèe, Paris, 1818, pp. 1 y 2.

MELO, Francisco I. M. Homem de: Escriptos Historicos e Litterarios. I - A Constituiçao perante a historia ( $2^{\mathrm{a}}$ Ediçao), Editores Eduardo e Henrique Laemmert, Rio de Janeiro, 1868 .

MENDES DE ALMEIDA, Cândido: Código Filipino ou Ordenação do Reino de Portugal, Rio de Janeiro, Tipografia do Institutuo Filomático, 14ª Edição, 1870.

MENDONÇA, Manuela: Influência da Constituição espanhola de 1812 na portuguesa de 1822 en ESCUDERO, José Antonio (Dir.): op. cit., pp. 481 y ss.

MENEZES, Antonio Carlos: Carta Fundacional do Reino de 1823 in HESPANHA, Antonio Manuel y SILVA, Cristina Nogueira da: Fontes para a Historia portuguesa, Lisboa, Faculdade de Direito da UNL e www.bn.pt - Arquivo da Biblioteca Nacional, Lisboa, 2004. Accedido en 19/03/2013. 
MERCADANTE, Paulo: A Consciência Conservadora no Brasil, Editora Saga, Rio de Janeiro, 1965.

MERÊA, Paulo: Escolástica e Jusnaturalismo, cit., in Boletim da Faculdade de Direito, Coimbra, vol. XIX p. 289.

MERÊA, Paulo: Lance de Olhos sobre o Ensino do Direito desde 1772 até 1804 in Estudos da História do Ensino Jurídico em Portugal (1772-1902), Lisboa, 2005, pp. 357 y ss.

MERÊA, Paulo: Notas sobre alguns lentesde Direito Pátrio no período 1772/1804 in Boletim da Faculdade de Direito, Vol. XXXVI.

MERÊA, Paulo: O ensino do direito em Portugal de 1805 a 1836, in Jurisconsultos Portugueses do Século XIX (Direc. e colaboração de LOUREIRO, José Pinto), vol. I, Lisboa, 1947.

MIRANDA, Jorge: Manual de Direito Constitucional, Vol. I, Coimbra, Editora Coimbra, 1988, p. 230.

MIRANDA, Jorge: O constitucionalismo liberal luso-brasileiro, Lisboa, Comissão Nacional para as Comemorações dos Descobrimentos Portugueses, 2000.

MIRANDA, Jorge: O ensino do Direito Constitucional moderno, in Revista da Faculdade de Direito da Universidade de Lisboa, Lisboa, 1998, vol. XXXIX, nº 2.

MIRANDA, José Antônio de: Memoria Constitucional e Política Sobre o Estado Presente de Portugal, e do Brasil; Dirigida a El Rey o Senhor D. Joao VI. E oferecida a Sua Alteza o Príncipe Real do Reino Unido de Portugal, Brasil e Algarves, e Regente do Brasil, por José Antônio de Miranda, Fidalgo Cavalleiro da Caza de Sua Magestade, e ouvidor eleito do Rio Grande do Sul, Na Typographia Nacional, Com Licença de S. A. R., Rio de Janeiro, 1821.

MIRKINE-GUETZÉVICH, Boris: La constitution espagnole de 1812 et les débuts du libéralisme européen: esquisse d'histoire constitutionnelle comparée en Introduction à l'étude du droit comparé : recueil d`Études en l’honneur d’Edouard Lambert, Paris, Librairie Générale de Droit et de Jurisprudence, Troisième partie, Le droit comparé comme science juridique moderne, 1938.

MONTESQUIEU, Baron de: Del espíritu de las leyes (traducido al castellano por D. Juan López de Peñalver), Tomo I, Imprenta de Villalpando, Madrid, 1820.

MONTOLÍO HERNÁNDEZ, Ricardo: La reforma de la dotación de culto en el Trienio Liberal (1820-1823). Toledo, Espacio, Tiempo y Forma, Serie V, Historia Contemporánea. 14,2001 .

MORALES MOYA, Antonio: Jovellanos: Ilustración y liberalismo, 1759-1812 en MARCO, J. M. (coord.): Genealogía del liberalismo español (1759-1931), FAES, Madrid, 1998.

MORÁN ORTI, Manuel: La Miscelánea de Javier de Burgos: la Prensa en el debate ideológico del Trienio Liberal, Madrid, Artes Liberales, Serie Trivium $\mathrm{N}^{\mathrm{o}} 15,2^{\mathrm{a}}$ Edición renovada, Ediciones UEM-CEES, 1996.

MORAN, David Pantoja (comp.): Escritos Políticos de Sièyès, Fondo de Cultura Económica, México, 1993

MORANGE, Cloude: Sobre la filiación Ilustración-Liberalismo (preguntas para un debate) en ROBLEDO, CASTELLS y ROMEO (eds.): Orígenes del liberalismo. Universidad, política y economía, Ediciones de la Universidad de Salamanca/Junta de Castilla y León, Salamanca, 2003.

MOREL, M: Frei Caneca: cristianismo e revolução, Ed. Brasiliense, São Paulo, 1987. 
MORENO ALONSO, Manuel: Blanco White y la Constitución de 1812 en Inglaterra en ESCUDERO, José Antonio (Dir.): Cortes y Constitución de Cádiz. 200 años, Tomo III, Editora Espasa, Madrid, 2011.

MOTA, Aroldo: "Legislação Eleitoral no Brasil" en Revista Brasileira de Direito Eleitoral, $2^{\circ}$ número, Fortaleza, CE, 1987

MURATORI, Luis Antonio: Defectos de la jurisprudencia, (Traducido al Castellano por Vicente Maria de Tercilla - Abogado de los Reales Consejos), Imprenta de la viuda de D. Joachin Ibarra, Madrid, 1794.

MURATORI, Luis Antonio: Fuerza de la Humana Fantasia, (traducido al Castellano por Vicente Maria de Tercilla), Imprenta de D. Manuel Martín, Madrid, 1777.

MURATORI, Luis Antonio: La filosofía moral declarada y propuesta a la juventud, (Traducido por Antonio Moreno Morales), Tomos I y II, Tercera Edición, Por Benito Cano, Impresor en esta Corte, Madrid, 1790.

MURATORI, Luis Antonio: La pública felicidad objeto de los buenos príncipes, (Traducion al Castellano), Imprenta Real, Madrid, 1790.

MURATORI, Luis Antonio: Reflexiones sobre el buen gusto de las ciencias, (traducido por D. Juan Sempere - Abogado de los Reales Consejos), Imprenta de D. Antonio de Sancha, 1782.

NABUCO, Joaquim: Discursos parlamentares, Câmara dos Deputados, Rio de Janeiro, 1949.

NABUCO, Joaquim: Um Estadista do Império, $4^{\text {a }}$ Ediçao, Editora Nova Aguiar, Rio de Janeiro, 1975.

NABUCO, Joaquim: Um estadista do Império. Nabuco de Araújo. Sua vida, suas opiniões, sua época, Tomo Primeiro: 1813-1857, H. Garnier, Livreiro-Editor, Rio de Janeiro/Paris.

NEVES, Guilherme Pereira das: “A religião do império e a Igreja” en GRINBERG, Keila y SALLES, Ricardo (org.): O Brasil Imperial, Volume I - 1808-1831, Coleção - Civilização Brasileira, Rio de Janeiro, 2009.

NEVES, Guilherme Pereira das: E Receberá Mercê: a Mesa da Consciência e Ordens e o Clero Secular no Brasil, 1808-1828, Arquivo Nacional, Rio de Janeiro, 1997.

NEVES, José Acúrsio das: História Geral da Invasao dos francezes em Portugal e da Restauraçao deste Reino, (Com Licença da Mesa do Desembargo do Paço), Officina de Simao Thaddeo Ferreira, Vol. II, Lisboa, 1811.

NEVES, Lucia Maria Bastos Pereira das: Corcundas e constitucionais. A cultura política da independencia (1820-1822), Editora Revan/Faperj, Rio de Janeiro, 2003.

NEVES, Lucia Maria Bastos Pereira das: Estado e Política na independência en GRINBERG, Keila y SALLES, Ricardo (org.): O Brasil Imperial, Vol. I - 1808-1831, Ed. Civilização Brasileira, Rio de Janeiro, 2009.

NEVES, Lucia Maria Bastos Pereira das: Linguagens políticas do conservadorismo na época da Independência do Brasil (1821-1824), VIII Coloquio Internacional: Visiones y Revisiones de las Independencias Americanas: Realismo/Pensamiento Conservador, Universidad de Salamanca (23 a 25 de marzo de 2011) - En Imprenta, pp. 1-13.

NEVES, Lucia Maria Bastos Pereira das: Napoleón Bonaparte y Brasil: política e imaginario (1808-1822) en ABREU, Fernando José Marroni de (ed.): Las invasiones napoleónicas y el mundo ibero-americano, Embajada de Brasil/Universidad de Salamanca, Madrid, 2008. 
NEVES, Lucia Maria Pereira das: "Portugal durante a ausencia do rei", Revista USP, Sao Paulo, n. 79, setembro/novembro 2008.

NICOLAU, Jairo: História do Voto no Brasil, Segunda Ediçao, Jorge Zahar Editor Descobrindo o Brasil, Rio de Janeiro, 2004, p. 19.

NOGUEIRA DA SILVA, Ana Cristina: A cidadania nos trópicos. O ultramar no constitucionalismo monárquico português (1820-1880), tesis de doctorado, Universidade Nova de Lisboa, Lisboa, 2004.

NOGUEIRA, Octaviano: A Constituição de 1824 (Coleção - Constituições Brasileiras), Senado Federal, Brasília, 1999.

NOGUEIRA, Ricardo Raimundo: Prelecções sobre a História do Direito Pátrio, Imprensa da Universidade, Coimbra, 1866, p. 1 (advertências).

NOVAIS, Fernando A. y MOTA, Carlos Guilherme: A independência politica no Brasil, $2^{\mathrm{a}}$ Edição, Editora Hucitec, São Paulo, 1996.

NOVAIS, Fernando: Portugal e Brasil na crise do antigo sistema colonial (1777-1808), Ed. Hucitec, São Paulo, 1979.

OLIVEIRA MARQUES, Antonio Henrique de: Historia de Portugal II, Mexico D.F., Fondo de Cultura Económica, 1983.

ORTIZ, Juan: Fuerzas armadas y Liberalismo en México en una etapa revolucionaria: 18101821 en CHUST, Manuel y FRASQUET, Ivana: La transcendencia del Liberalismo Doceañista en España y en América, Imprenta Romeu, S.L -Generalitat Valenciana Biblioteca Valenciana, Colección Historia/Estudios, Valencia, 2004.

PARRA LÓPEZ, Emilio la: El Príncipe Inocente. La imagen de Fernando VII en 1808 en CHUST, M. Y FRASQUET, I. (eds.): La transcendencia del liberalismo doceañista en España y en América, Imprenta Romeu, S.L -Generalitat Valenciana - Biblioteca Valenciana, Colección Historia/Estudios, Valencia, 2004.

PATTARO, Enrico: Il pensiero giuridico di L. A. Muratori tra metodología e política, Milano, 1974.

PEREIRA DAS NEVES, Guilherme: "Del Imperio Luso-brasileño al Imperio del Brasil (17891822)", en $A$. ANNINO y F. X. GUERRA (coords.), Inventando la nación. Iberoamérica, siglo XIX, México, FCE, 2003.

PEREIRA E SOUSA, Joaquim José Caetano: Esboço de Hum Decionarios jurídico, theoretico e pratico remissivo às leis compiladas e extravagantes, Tomo I (A-E), Typographia Rollandiana, Lisboa, 1825.

PEREIRA E SOUSA, Joaquim José: Primeira sobre o processo civil, Lisboa, 1810/1814.

PEREIRA E SOUSA, Joaquim José: Primeira sobre o processo civil,, con adaptaciones para los Fueros de Brasil, hasta el año de 1877, de Teixeira de Freitas, Tomo III, Typografia Perseverança, Rio de Janeiro, 1870.

PEREIRA E SOUSA, Joaquim José: Primeiras linhas sobre o proceso criminal (1785), Typografia Rollandiana (Com licença da Meza do Desembargo do Paço), Lisboa, 1820.

PEREIRA, José Esteves: Antonio Ribeiro dos Santos e a Reforma Pombalina da Universidade in Universidade: História. Memória. Perspectivas, (Actas do Congresso de Historia da Universidade) - vol. I, Coimbra, 1991.

PEREIRA, Manuel Pedro Cunha da Silva: "A limitação jurídica do poder político nos trabalhos das assembleias constituintes portuguesas do período liberal, Relatório de 
mestrado da cadeira de direito constitucional”, Faculdade de Direito da Univ. de Lisboa, Lisboa, 1987.

PESET, José Luís y LAFUENTE, Antonio: Ciencia e Historia de la Ciencia en la España ilustrada, in Boletin de la Real Academia de la Historia, Tomo CLXXVIII (Cuaderno II), Madrid, 1981.

PESET, José Luís: La influencia del Barbadiño en los saberes filosóficos españoles, in Bracara Augusta, Vol. XXVIII, Braga, 1974.

PESET, Mariano: Universidad y liberalismo en España y América Latina en ROBLEDO, R.: Orígenes del Liberalismo..., op. cit.

PIMENTA, Joao Paulo Garrido: A independência do Brasil. Um balanço da produção historiográfica recente en CHUST, Manuel y SERRANO, José António (eds.): Debates sobre las independências ibero-americanas, Ed. Iberoamericana/Vervuet, Madrid, 2007.

PIMENTA, Joao Paulo Garrido: Brasil y las independencias de Hispanoamérica, Universitat Jaume I, Castellón, 2007.

PIMENTA, Joao Paulo Garrido: Estado e nação no fim dos impérios ibéricos no Prata, 18081828, Ed. Hucitec, São Paulo, 2002.

PINTO, Basílio Alberto de Sousa: Lições de Direito Público Constitucional, Lição n. 9, 1840, p. 21. http://www.fd.unl.pt/ConteudosAreasDetalhe.asp?Titulo=Biblioteca Digital\&Area=BibliotecaDigital "Biblioteca Digital - Faculdade de Direito da Universidade Nova de Lisboa".

PIÑEIRO, Théo Labarinhas: "O projetos liberais no Brasil Império", Passagens. Revista Internacional de História Política e Cultura Jurídica, Rio de Janeiro: vol. 2 no.4, maioagosto 2010.

PISAPIA, Gian Domenico: Presentazione dalla opera de Beccaria, Dei delitti e delle pene, (Reimpresión), Milano, 1973. También en PISANI, M.: Attualità di Cesare Beccaria, Milano, 1998.

PLANAS, Javier Alvarado: Fundación historicista de los derechos humanos, in GÓMEZ SÁNCHEZ, Y. y ESCUDERO, J. A. (coord.): Pasado, presente y futuro de los derechos humanos, México, 2004.

PORTILLO VALDÉS, José María: Entre la monarquía y la Nación: cortes y constitución en el espacio imperial español en PORTILLO VALDÉS, J., VEIGA ALONSO, X. R. y BAZ VICENTE, $M^{a}$. (eds.): A Guerra da Independencia e o primeiro liberalismo en España e América, Publicacións da Cátedra Juana de Vega - USC, Santiago de Compostela, 2009.

PORTILLO VALDÉS, José María: Entre la monarquía y la nación: cortes y constitución en el espacio imperial español en PORTILLO VALDÉS, J., VEIGA ALONSO, X. R. y BAZ VICENTE, $M^{a}$. (eds.): A Guerra da Independencia e o primeiro liberalismo en España e América, Publicacións da Cátedra Juana de Vega - USC, Santiago de Compostela, 2009.

PORTILLO VALDÉS, José Maria: Revolución de nación. Orígenes de la cultura constitucional en España, 1780-1812, BOE/CEPC, Madrid, 2000.

PORTILLO VALDEZ, José María: Revolución y nación. Orígenes de la cultura constitucional en España, 1780-1812, Centro de Estudios Políticos y Constitucionales, Madrid, 2000.

PORTO, Walter Costa: "Católicos e Acatólicos: o Voto no Império", Revista Liberdade e Cidadania - Ano 2 - n.5 - junho/setembro, 2009, p. 2. - www.flc.org.br Accedida en $18 / 04 / 2010$. 
PORTO, Walter Costa: O Voto no Brasil. Da Colônia à $6^{\mathrm{a}}$ República, Editora Topbooks, $2^{\mathrm{a}}$ Edição Revisada, Rio de Janeiro, 2002.

PRANTNER, Johanna: La emperatriz Leopoldina de Brasil, Editora Vozes, Petrópolis, 1998.

PUFENDORF, Samuel: De officio hominis e Civis Juxta Legem Naturalem Libri duo, Impresis Gul. Thurlbourn, Londres, 1737.

PUFENDORF, Samuel: Droit de la nature et gens ou système général des principes les plus importants de la morale, de la jurisprudence..., Jean Nours, Londres, 1760, III volumes.

RABELO, Joaquim do Amor Divino (Frei Caneca): Ensaios políticos: críticas da Constituição Outorgada; Bases para a formação do pacto social e outros, PUC/Rio, Rio de Janeiro, 1976.

RAMINELLI, Ronald: Império da fé: Ensaio sobre os portugueses no Congo, Brasil e Japão in FRAGOSO, Joao, BICALHO, Maria Fernanda y GOUVÊA, Maria de Fátima (orgs.): O Antigo Regime nos trópicos. A dinâmica imperial portuguesa (Séculos XVI-XVIII), Civilização Brasileira, Rio de Janeiro, 2001.

RAMIREZ, Stanley Ezequiel, Las relaciones entre Austria y Brasil - 1815-1889, Colección, Brasiliana, Tomo 337, (traducción y notas de Américo Jacobina Lacombe), Companhia Editora Nacional, São Paulo, 1968.

RAMOS, Rui Manuel Gens de Moura: Do direito português da nacionalidade, Coimbra, Coimbra Editora, 1992.

REIS MARQUES, Mario: Elementos para uma aproximação do estudo do "usus modernus pandectarum" em Portugal, in Boletim da Faculdade de Direito, vol. LVIII, Coimbra, 1985.

REIS, Joao José: A morte é uma festa. Ritos fúnebres e revolta popular no Brasil do século XIX, Companhia das Letras, São Paulo, 1998.

RESENDE, Marques: Breves reflexões sobre um escrito em que se ofende a chamada deputação portuguesa que foi a França em 1808, Lisboa, 1871.

RIBEIRO, Antônio: Notas ao Título IV da Religião e Fe Católica do Novo Código de Direito Público de Portugal do Dr. Pascoal José de Mello. Escritas e apresentadas na Junta da Revisão pelo Dr. Antônio Ribeiro en HESPANHA, Antônio Manuel (dir.) y SILVA, Cristina Nogueira da: Fontes para a história constitucional portuguesa, Faculdade de Direito da UNL, Lisboa, 2004.

RIBEIRO, Antônio: Notas ao Título IV da Religião e Fe Católica do Novo Código de Direito Público de Portugal do Dr. Pascoal José de Mello. Escritas e apresentadas na Junta da Revisão pelo Dr. Antônio Ribeiro en HESPANHA, Antônio Manuel (dir.) y SILVA, Cristina Nogueira da: Fontes para a história constitucional portuguesa, Faculdade de Direito da UNL, Lisboa, 2004.

RIBEIRO, Antônio: Notas ao Título IV da Religião e Fe Católica do Novo Código de Direito Público de Portugal do Dr. Pascoal José de Mello. Escritas e apresentadas na Junta da Revisão pelo Dr. Antônio Ribeiro en HESPANHA, Antônio Manuel (dir.) y SILVA, Cristina Nogueira da: Fontes para a história constitucional portuguesa, Faculdade de Direito da UNL, Lisboa, 2004, p. 5.

RIBEIRO, Gladys Sabina: A liberdade em construção: identidade nacional e conflitos antilusitanos no Primeiro Reinado, Ed. Relume Dumará, Rio de Janeiro, 2002.

RIVERA GARCÍA, Antonio: El concepto de libertad en la época de las Cortes de Cádiz en CHUST M. y FRASQUET, I. (eds.): La transcendencia del liberalismo doceañista en 
España y en América, Biblioteca Valenciana, Colección História/Estudios, Generalitat Valenciana, Valencia, 2004.

ROBLEDO, Ricardo: Tradición e Ilustración en la Universidad de Salamanca: sobre los orígenes intelectuales de los primeros liberales en ROBLEDO, R.: Orígenes del Liberalismo..., op. cit.

ROCHA PEREIRA, Maria Helena: Ecos da Reforma Pombalina na Poesia Setecentista in Bracara Augusta, vol. XXVIII, Braga, 1974.

RODRIGUES, Honório José: A Assembleia Constituinte de 1823, Editora Vozes, Petrópolis, 1974.

RODRIGUES, José Honório: Independência, revolução e contra-revolução. A política internacional, F. Alves, Rio de Janeiro, 1975.

RODRIGUES, José Honório: Independência: Revolução e contrarrevolução, Vol. 5, Ed. Francisco Alves, Rio de Janeiro, 1975-1976.

RODRIGUES, Manuel Augusto: D. Francisco de Lemos Faria Pereira Coutinho, bispo de Coimbra e reformador-reitor da Universidade in A Universidade de Coimbra. Figuras e factos da sua história, vol. I,

RODRIGUES, Manuel Augusto: Inventário da Livraria de D. Francisco de Lemos in Boletim do Arquivo da Universidade de Coimbra, vol. XIII e XIV, Coimbra, 1993/1994.

ROSAS, Roberto: Jurisprudência. Uniformização. Súmula. in Direito Processual (inovações e perspectivas): estudos em homenagem ao Ministro Sálvio de Figueiredo Teixeira, Editora Saraiva, São Paulo, 2003.

RUIZ JIMÉNEZ, Marta: El liberalismo exaltado. La confederación de comuneros españoles durante el Trienio Liberal, Madrid, Editorial Fundamentos, 2007.

RUOCCO, Giovanni: "La rivoluzione nelle parole: dalla régénération del regno di francia al processo costituente dell'Ottantanove", in Giornale di storia constituzionale, 1 (2001).

RUSSOMANO, Rosah: Facetas da Constituição de 1824 in Revista de Informação Legislativa, Janeiro-Março, 1974.

SAID, Edward W.: Cultura e Imperialismo, Companhia das Letras, São Paulo, 1995.

SALAS, Ramon: Lições de Direito Público Constitucional para as Escolas de Hespanha. Por Ramon Salas, Doutor de Salamanca; Traduzidas e Dedicadas por D. G. L de D`Andrade: Com o mesmo objeto à Regenerada Nação Portugueza, e offerecidas aos seus dignos representantes, Na Typographia Rollandiana, Lisboa, 1822

SALLES OLIVEIRA, Cecília Helena L. de: A astucia liberal. Relaçoes de Mercado e Projetos Políticos no Rio de Janeiro (1820-1824), Ícone Editora, Rio de Janeiro, 1999.

SÁNCHEZ AGESTA, Luis: Los principios cristianos del orden político, Madrid, Instituto de Estudios Politicos, 1962.

SÁNCHEZ GÓMEZ, Julio: “El otro año 8”, en F. J. MARRONI DE ABREU (ed.), Las invasiones napoleónicas y el mundo iberoamericano, Salamanca, Fundación Cultural Hispano-brasileña, 2008.

SÁNCHEZ HITA, Beatriz: José Joaquín de Clararrosa y su Diario Gaditano (1820-1822). Ilustración, Periodismo y Revolución en el Trienio Liberal, Centro de Estudios Constitucionales, Cádiz, 2009,

SÁNCHEZ HITA, Beatriz: La prensa y la imprenta en el Cádiz de la Guerra de la Independencia (1808-1814) en MORTARI FERNÁNDEZ, Manuel \& MARTÍN 
MORENO, Ana (coord.): Prensa y Libertad de Imprenta. Los periódicos en el Cádiz de las Cortes, Cádiz, Galería GH40, 2010.

SANTOS, Antonio Ribeiro: De sacerdotio, et império selectae dissertationes..., Typographia Regia, Olisipone, 1770.

SANTOS, Catarina Madeira: Um governo "polido" para Angola, reconfigurar dispositivos de domínio (1750-c. 1800), Dissertação de doutoramento apresentada à Universidade Nova de Lisboa (Faculdade de Ciências Sociais e Humanas), Lisboa, 2005.

SANTOS, Clemente José dos: Documentos para a história das Cortes Geraes da Nação Portugueza (1820-1828), Imprensa Nacional, Lisboa, 1883-1888.

SARRAILH, Jean: La España ilustrada en la segunda mitad del siglo XVIII, Fondo de Cultura Económica, México D.F., 1981.

SCHIAVINATTO, Iara Lis: "Cultura política do primeiro liberalismo constitucional. A adesão das Câmaras no processo de autonomização do Brasil", Araucaria. Revista Iberoamericana de Filosofia, Políticas y Humanidades, Nº 18. Segundo Semestre de 2007.

SCHULTZ, Kirsten: Tropical Versailles. Empire, Monarchy, and de Portuguese Royal Court in Rio de Janeiro, 1808-1821, Routledge, New York/London, 2001.

SENA, Nelson Coelho de: "Participação dos deputados brasileiros nas cortes portuguesas de 1821" en Livro do Centenário das Câmaras dos Deputados (1826-1926), Emp. Brasileira Editora, 1926.

SEOANE CRUZ, María: El primer lenguaje constitucional español (Las Cortes de Cádiz), Madrid, Editorial Moneda y Crédito, 1968.

SERRANO, José Antonio: Liberalismo y contribuciones directas en México, 1810-1835 en CHUST, Manuel y FRASQUET, Ivana: La transcendencia del Liberalismo Doceañista en España y en América, Imprenta Romeu, S.L -Generalitat Valenciana - Biblioteca Valenciana, Colección Historia/Estudios, Valencia, 2004.

SERRAO, Joaquim Verissimo: História de Portugal, Lisboa, Verbo, 1984.

SEWELL, William H.: "Le citoyen/la cotoyenne: Activity, Passivity, and the Revolutionary Concept of Citizenship.” In BAKER, Keith Michael (ed): The French Revolution and the Creation of Modern Political Culture, vol. 1, The Political Culture of the Old Regime, Oxford: Pergamon Press, 1987.

SIÉYES, Emmanuel Joseph : Déclaration des Droits de L`Homme en Société, Chez Baudouin Imprimeur de L`ASSEMBLÉE NATIONALE, A Versailles, 1789;

SIÉYES,Emmanuel Joseph :Opinion sur la Jurie Constitucionnaire, Suivie d Observations sur l’ouvrage de Siéyes 1795;

SIÉYES, Emmanuel Joseph :Déclaration des Droits du Citoyen François, Détachée du Préliminaire de la Constitution, 1789 ;

SIÉYES, Emmanuel Joseph :Préliminaires de la Constitution, Reconnaissance et Exposition Raisonnée (Des Droits de l'Homme et du Citoyen. Lu les 20 et 21 Juillet 1789, au Comité de Constitution), Chez Baudouin - Imprimeur de L`ASSEMBLÉE NATIONALE, A Paris, 1789 ;

SIÉYES, Emmanuel Joseph :Projet de Déclaration des Droits, Par un Membre de l'Assemblée Nationale, 1789 ; 
SIÉYES, Emmanuel Joseph :Qu`est-ce que le Tiers-État?, Pamphlet Publié en 1789, Par Siéyes, précédé d'une étude sur l’Auteur, par M. Chapuys-Montlaville, député, et orné d'un portrait de Siéyes, Pagnerre Editeur, Paris, 1839.

SIÈYÈS, Emmanuel Joseph: Déclaration des Droits de L`Homme en Sociètè, Chez Baudouin Imprimeur de L`Assemblée Nationale, Versailles, 1789, pp. 3-14.

SIÈYÈS, Emmanuel Joseph: Opinion sur la Jurie Constitutionnaire (Suivie d Observations sur louvrange de Sièyès), Eschasseriaux l`ainé, dans la discussion sur le jury constitutionnaire dans la Séance de la Convention nationale du 24 thermidor, 1795.

SIÈYÈS, Emmanuel Joseph: Préliminaire de la Constitution. Reconnoissance et Exposition Raisonnée Des Droits de l'Homme et du Citoyen. Lu les 20 et 21 Julliet 1789, au Comité de Constitution, Chez Baudouin - Imprimeur de L`Assemblée Nationale, Paris, 1789, pp. 3-32.

SIÈYÈS, Emmanuel Joseph: Quest-ce que le Tiers-État?, Pamphlet Publié en 1789 (Precede d’une Etude sur l'Auteur par M. Chapuys-Montlaville, deputé et orné d’un portrait de Sièyès), Pagnerre Editeur, Paris, 1839, pp. 1-192.

SILVA, Ana Rosa Cloclet da: "Entre Cádiz, Lisboa e Minas Gerais. Repercursoes do Constitucionalismo à luz do contexto social mineiro (1820-1822)", Hib. Revista de Historia Iberoamericana, ISSN: 1989-2616, Semestral, Año 2012, Vol. 5, Núm. 1, pp. 34-55.

SILVA, Antônio de Morais e: Dicionário da Língua Portugueza composto por Antônio de Morais e Silva, natural do Rio de Janeiro. Quarta Edição, reformada, emendada, e muito acrescida pelo mesmo autor: posta em ordem, correcta, enriquecida de grande numero de artigos novos e dos synonymos por Theotônio José de Oliveira Velho. Tomo II F-Z, Na Impressão Régia, Com Licença, Lisboa, 1831.

SILVA, Antônio de Morais e: Dicionário da Língua Portugueza, recompilado dos vocabulários impressos até agora, e nesta segunda edição novamente emendada, e muito acrescentado, Tomo II F-Z, Typographia Lacerdina, Lisboa, 1813.

SILVA, Cristina Nogueira da: “Representação Política e Cidadania no Império" in CATROGA, Fernando y ALMEIDA, Pedro Tavares de (cords.): "Res Pública": Cidadania e Representação Política em Portugal 1820-1926, Biblioteca Nacional de Portugal/Assembleia da República, Lisboa, 2010.

SILVA, Cristina Nogueira da: A cidadania nos Trópicos. O Ultramar no constitucionalismo monárquico português (c. 1820-1880), Dissertação de doutoramento apresentada à Universidade Nova de Lisboa (Faculdade de Direito), Lisboa, 2004.

SILVA, Cristina Nogueira da: Da "Carta de Alforria" ao "Alvará de Assimilação": a cidadania dos "Originários de África” na América e na África portuguesa, séculos XIX e $X X$ in BERBEL, Márcia e OLIVEIRA, Cecília H. de Salles (orgs.): A experiência constitucional de Cádiz. Espanha, Portugal e Brasil, Alameda Casa Editorial, São Paulo, 2012.

SILVA, Cristina Nogueira da: Liberdade e tolerância religiosa: "portugueses não católicos" no ultramar do século XIX, Historia Constitucional (revista electrónica), n. 8, 2007. http://hc.rediris.es/08/index.html ACCEDIDO EN 03/04/2013.

SILVA, Jairdilson da Paz: "Bipolaridad de una ciudadanía confesional: la definición dada por la Constitución Imperial de Brasil”" in AGUIRREGABIRIA, Alejandra Ibarra (coord. Ed.): Actas del Tercer Encuentro de Jóvenes Investigadores de la AHC (Religiosidad y Laicismo), Instituto Universitario de Historia Social Valentín de Foronda, ISBN: 978-849860-636-2, LG/D.L.: BI-540-2012, Vitoria-Gasteiz, 2012. 
SILVA, Jairdilson da Paz: "El flujo y reflujo revolucionario en la prensa española del trienio liberal: Nápoles, Oporto y Turín”, Hib - Revista de Historia Iberoamericana, DOI: 10.3232/RHI.2012.V.5..N1.03, ISNN: 1989-2616, Semestral, Año 2012, Vol. 5, Núm. 1. pp. 56-93. http://revistahistoria.universia.net/pdfs_revistas/articulo_170_1340980145796. pdf ISSN 1989-2616. Accedido en 07.05.2012.

SILVA, Jairdilson da Paz: La stampa e la rivoluzione. Il movimenti liberali del 1820 (Napoli, Porto e Torino) e il riferimento a questi movimenti sui giornali spagnoli, Iscritto presso la Biblioteca della Facoltà di Scienze Politiche, Università degli Studi di Messina e Università degli Studi de Milano, Coll.: SD.EMD. XI.1 (Collezione), INV.: TSI 352 (Inventario), Anno: 2012 - Messina/Italia, pp. 20 y ss.

SILVA, Jairdilson da Paz: Procesos constitucionales en Iberoamérica. Las exclusiones en Cádiz (1812), Portugal (1822) y Brasil (1824), Revista Ecléctica, Editor Associació d'Estudis Culturals. Universitat de València, ISSN-e 2254-0113, $\mathrm{N}^{\circ}$ 1, 2012, pp. 92-101. (In línea) http://revistaeclectica.org/ Accedido en 02.07.2012.

SILVA, José Afonso da: Curso de Direito Constitucional Positivo, $15^{\circ}$ Edição Revisada, Editora Malheiros, São Paulo, 1998.

SILVA, Luiz Geraldo: "Pernambucanos, sois portugueses", Almanack Braziliense, n¹ (maio de 2005).

SILVA, M ${ }^{\mathrm{a}}$ Beatriz Nizza da: "Liberalismo e separatismo no Brasil" en Cultura, História e Filosofia, Vol. IV, Instituto Nacional de Investigaçao Científica, Lisboa, 1996.

SILVA, Ma Beatriz Nizza da: A cultura luso-brasileira: da Reforma da Universidade à Independência do Brasil, Editorial Estampa, Lisboa, 1999.

SILVA, Ma Beatriz Nizza da: A repercussao da Revoluçao de 1820 no Brasil. Eventos e Ideologias en Revista de História das Idéias, Vol. II, Instituto de História e Teoria das Ideias, Universidade de Coimbra, 1978-79.

SILVA, Maria Beatriz Nizza da (coord.): Dicionário da História da Colonização Portuguesa no Brasil, Editora Verbo, Lisboa, 1994.

SILVA, Nuno E. Gomes da: História do Direito Portugues, Vol. I, Fundaçao Calouste Gulbenkian, Lisboa, 2006.

SLEMIAN, Andréa y PIMENTA, Joao Paulo G.: A corte e o mundo: Uma história em que a família real portuguesa chegou ao Brasil, Ed. Alameda, São Paulo, 2008.

SLEMIAN, Andréa: "Sob o império das leis: Constituição e unidade nacional na formação do Brasil (1822-1834)", Tese de doutoramento, Universidade de São Paulo - Faculdade de Letras e Ciências Humanas, São Paulo, 2006.

SLEMIAN, Andréa: "Um pacto constitucional para um novo Império: Brasil, 1822-1824” en CUARTERO, Izaskun Álvarez y GÓMEZ, Julio Sánchez (Eds.): Visiones y Revisiones de la Independencia Americana. La Independencia de América: la Constitución de Cádiz y las Constituciones Iberoamericanas, Editoras Universidad de Salamanca, Salamanca, 2007

SLEMIAN, Andréa: O Supremo Tribunal de Justiça nos primórdios do Brasil (1828-1841) en LOPES, José Reinaldo de Lima (org.): O Supremo Tribunal de Justiça do Império 18281889, Ed. Saraiva/Fundaçao Getúlio Vargas - Série Produçoes Cientificas (Direito Desenvolvimento Justiça), São Paulo, 2010.

SOARES, Márcio de Sousa: A remissao do cativeiro. A dádiva da alforria e o governo dos escravos nos Campos dos Goitacases, c. 1750-c.1850, Apicuri, Rio de Janeiro, 2009. 
SOBRAL, José Manuel: "O Norte, o Sul, a raça, a nação - representações da identidade nacional portuguesa (séculos XIX-XX)", in Análise Social, Vol. XXXIX, n 171, 2004.

SOLÉ TURA, Jordi \& AJA, Eliseo: Constituciones y períodos constituyentes en España (18081936), Madrid, Siglo Veintiuno de España Editores, $18^{a}$ Edición, 2000.

SOUSA E SAMPAIO, F. C.: Prelecções do Direito Pátrio Público e Particular, (Oferecido a D. Joao - Príncipe do Brasil), $1^{\mathrm{a}}$ e $2^{\mathrm{a}}$ Parte, Real Imprensa da Universidade - Com licença da Real Mesa da Comissão Geral sobre o Exame e Censura dos Livros, Coimbra, 1793

SOUSA, Joaquim Rodrigues de: Analyse e Commentario da Constituiçao Política do Império do Brazil ou Theoria e Pratica do Governo Constitucional Brazileiro, Volume II, São Luiz do Maranhao, 1870.

SOUSA, Joaquim Rodrigues de: Analyse e Commentario da Constituição Política do Império do Brazil ou Theoria e Pratica do Governo Constitucional Brazileiro, Volume I, São Luiz do Maranhão, 1867.

SOUSA, Joaquim Rodrigues: Analyse e Comentário da Constituição Política do Império do Brazil, Volume I, Typographia B. de Mattos, São Luiz, 1867.

SOUSA, Maria Aparecida Silva de: "Independência e soberania nacional na América Lusoespanhola" en COSTA, Wilma Peres y OLIVEIRA, Cecília Helena de Salles (org.): De um Império a outro. Formação do Brasil, séculos XVIII e XIX, Editora Hucitec/Fapesp, São Paulo, 2007,

SOUSA, Otávio Tarquínio de: Bernardo Pereira de Vasconcelos, Ed. Itatiaia, Belo Horizonte, 1988.

SOUZA, Bras Florentino Henrique de: Do Poder Moderador, Recife, 1864.

SOUZA, Francisco Belisário Soares de: O Sistema Eleitoral no Império, Senado Federal, Brasília, 1979.

SOUZA, Iara Lis C.: Pátria coroada: o Brasil como corpo autônomo (1780/1831), Unesp, São Paulo, 1999.

SUANZES-CARPEGNA, Joaquim Varela: "El constitucionalismo español y português durante la primera mitad del siglo XIX in SÁNCHEZ GÓMEZ, J. y ALVAREZ CUARTERO, I. (Eds.): Visiones y Revisiones de la Independencia Americana. La independencia de América: La Constitución de Cádiz y las constituciones iberoamericanas, Actas del Congreso, Ediciones Universidad de Salamanca, 2007.

SUANZES-CARPEGNA, Joaquim Varela: O constitucionalismo espanhol e português durante a primeira metade do século XIX (um estudo comparado), Historia Constitucional, n. 11, 2010. http://www.historiaconstitucional.com

SUBTIL, José: La vida de los desembargadores durante la crisis, las reformas y la Revolución Liberal en Portugal (1750-1820) in: NARANJO, Esteban Conde (Ed.): Vidas por el Derecho, Ediciones Universidad Carlos III, Madrid, 2012, p. 169 y ss.

T.ONGÁS, Pedro:La representación aragonesa en la Junta Central SupremaapudJIMÉNEZ GREGORIO, Fernando: Murcia y los Decretos de 22 de mayo y 08 de junio de 1809: aportación a la historia política de la Guerra por nuestra Independencia de 1808, Publicación de la Universidad de Murcia, Murcia capital, 1946.

TASSO, Luis Otávio Pagano: Considerações Politicas e Econômicas Sobre Portugal 18081812, Universidade de São Paulo, 2010.

TODESCAN, Franco: Le redici teologiche del iusnaturalismo laico, vol. I - Il problema della secolarizzazione nel pensiero giuridico di Ugo Grocio, Milano, 1983, Vol. II - Il problema 
della secolarizzazione nel pensiero di Jean Domat, Milano, 1987, Vol. III - Il problema della secolarizzazione nel pensiero de Samuel Pufendorf, Milano, 2001.

TOMÁS Y VALIENTE, Francisco: Constitución: Escritos de introducción histórica, Madrid, Marcial Pons Ediciones Jurídicas y Sociales, 1996.

TORGAL, Luis Reis y VARGUES, Isabel Nobre: A Revolução de 1820 e a instrução pública, Paisagem Editora, Porto, 1984.

TORRENO, Conde de: Historia del levantamiento, guerra y revolución de España, Imprenta de J. Martín Alegría, Callejón de San Marcos, n. 6, Madrid, 1848.

TORRES DEL MORAL, Antonio: Constitucionalismo histórico español, Madrid, Atomo Ediciones, 1986.

TORRES, Joao Camilo de Oliveira: “A Igreja e o Estado" en A Democracia Coroada: Teoria Política do Império do Brasil, Editora Vozes, Petrópolis, 1964.

TORRES, Joao Camilo de Oliveira: História das Idéias Religiosas no Brasil (A Igreja e a Sociedade Brasileira), Editora Grijalbo, São Paulo, 1968.

TOUCHARD, Jean: Historia de las Ideas Políticas, Ed. Tecnos, Madrid, 1996.

UDINA, Manlio: "Il Diritto Internazionale Tributario" en FEDOZZI, Prospero e ROMANO, Santi (per cura di - in collaborazione di vari autori): Trattato di Diritto Internazionale, Vol. Decimo, CEDAM - Casa Editrice Dott. Antonio Milani, Padova, 1949.

VAINFAS, Ronaldo (dir.): Dicionário do Brasil Colonial (1500-1808), Editora Objetiva, Rio de Janeiro, 2000.

VALDÉS, Portillo:Representación del Licenciado Primo de Verdad y Ramos, dirigida al virrey José de Iturrigaray sobre la legitimidad, utilidad y necesidad de la convocatoria para el establecimiento de una Junta de Gobierno Nacional del Reino de Nueva España. Septiembre 12, 1808, en Ernesto Lemoine, Carlos María de Bustamante y su "apologética historia" de la revolución de 1810, México DF, UNAM, 1984, pp. 9 y ss.

VALDES, Roberto: “El 'problema americano' en las primeras Cortes Liberales españolas (1810-1814)" in AAVV: Los Orígenes del Constitucionalismo Liberal en España e Iberoamérica: un estúdio comparado, Junta de Andalucía, Sevilla, 1993.

VARELA SUANZES-CAPEGNA, Joaquin: La teoría del Estado en los orígenes del constitucionalismo hispanico (Las Cortes de Cádiz), C.E.C, Madrid, 1983.

VARELA SUANZES-CARPEGNA, Joaquin: Constituciones y Leyes Fundamentales, Tomo I (Colección Leyes Políticas Españolas. 1808-1978, dirigida por el mismo autor), Iustel, Madrid, 2012.

VARELA SUANZES-CARPEGNA, Joaquin: El constitucionalismo español y portugués durante la primera mitad del siglo XIX (un estudio comparado) en ÁLVAREZ CUARTERO, I. y SÁNCHEZ GÓMEZ, J. (Eds.): Visiones y revisiones de la independencia americana. La independencia de América: la Constitución de Cádiz y las constituciones iberoamericanas, Salamanca, Ediciones Universidad de Salamanca, 2007.

VARELA SUANZES-CARPEGNA, Joaquin: La Constitución de Cádiz y el liberalismo español del siglo XIX, Revista de las Cortes Generales, núm. 10, enero-abril de 1987.

VARELA SUANZES-CARPEGNA, Joaquin: La teoría del Estado en los orígenes del constitucionalismo hispanico (Las Cortes de Cádiz), Madrid, C.E.C., 1983. 
VARELA SUANZES-CARPEGNA, Joaquin: La teoría del Estado en los orígenes del constitucionalismo hispánico (las Cortes de Cádiz), Centro de Estudios Constitucionales, Madrid, 1983.

VARELA SUAZES-CARPEGNA, Joaquín: La teoría del Estado en los orígenes del constitucionalismo hispano (las Cortes de Cádiz), Madrid, CEPC, 2008.

VARGUES, Isabel Nobre: "Liberalismo e Independencia. Os exiliados Italianos em Portugal (1820-1850)", Revista Portuguesa de História/Universidade de Coimbra, Tomo XXXI, Vol. 2 (1996).

VARNHAGEN, Frederico Adolfo de: História da Independência do Brasil, Ed. Melhoramentos,

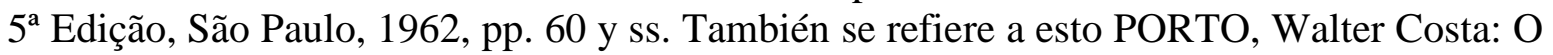
voto no Brasil, Ed. Topbooks, 2a Edição, Rio de Janeiro, 2002.

VARNHAGEN, Frederico Adolfo de: Historia Geral do Brazil, (dedicada a Sua Magestade Imperial o Senhor D. Pedro II), Tomo II, Casa de E. e H. Laemmert - Rua da Quitanda, Rio de Janeiro, 1857

VASCONCELOS, Zacarias de Goes: Da natureza e limites do poder moderador, Rio de Janeiro, 1862.

VATTEL, Emer de: El Derecho de Gentes o Principios de la Ley Natural, aplicados a la conducta y a los negocios de las naciones y de los soberanos (Traducidos en Castellano por D. Lucas Miguel Otarena de la última edición francesa publicada en Paris en 1820, corregida y aumentada con notas del autor y de los editores), Tomo I, Por Ibarra - Impresor de Cámara de S. M., Madrid, 1820.

VATTEL, Emmerich: El derecho de gentes, o principios de la ley natural, aplicadas a la conducta, y a los negocios de las naciones y de los soberanos (Traducida por Manuel Maria Pascual Hernández), Tomo I, Imprenta de D. Leon Amarita, Madrid, 1834.

VATTEL, Emmerich: El derecho de gentes, o principios de la ley natural, (Tomos I y II), Imprenta de D. Leon Amarita, Madrid, 1834.

VATTEL, Emmerich: Le droit de la guerre ou príncipes de la loir naturell..., Aux depens de la Compagnie, Amsterdam et Leide, 1758.

VATTEL, Emmerich: Le droit des gens, ou principes de la loi naturell appliqués a la conduite et aux affaires des Nations et des souverains, Chez Janet et Cotell, Libraires, Paris, 1820.

VEIGA ALONSO, Xosé Ramón: As familias políticas no liberalismo decimonónico español, 1808-1868 en BARREIRO FERNÁNDEZ, Xosé Ramón: O liberalismo nos seus contextos. Um estado da cuestión, Publicacións da Cátedra Juana de Vega, Santiago de Compostela, 2008.

VELOSO, Mariza y MADEIRA, Angélica: Leituras Brasileiras, Itinerários no Pensamento Social e na Literatura, Ed. Paz e Terra, Sao Paulo, 1999.

VERDELHO, Telmo dos Santos: As Palavras e as Idéias na Revoluçao Liberal de 1820, Instituto Nacional de Investigaçao Cientifica, Coimbra, 1981.

VERDELHO, Telmo: “As palavras e as ideias na revolução liberal de 1820”, Coimbra, INIC, 1981.

VERLINDEN, Jacques: Code et codification dans pensé de Jeremy Bentham in: Révue d’Histoire du Droit (Tijdschrift vor Rechtsgeschiedenis), Tomo XXXII, La Haye, 1964.

VERNEY, Luis Antonio: Verdadero Método de Estudiar para ser útil a la República, y a la Iglesia, proporcionado al estilo, y necesidades de Portugal, (Traducido al Castellano por 
Don Joseph Maymó y Ribes, abogado de los Reales Consejos), Tomo I y II, Imprenta de Joachin Ibarra, Madrid, 1760.

VICENTE, António Pedro: "El príncipe regente en Brasil, causas y consecuencias de una decisión estratégica", en F. J. MARRONI DE ABREU (ed.), op. cit.

VIEIRA CURA, A. A.: Transmissão da propriedade e aquisição de outros direitos reais (algumas consideraçoes sobre a história do sistema do título e do modo), in Estudos em homenagem ao Prof. Dr. Raúl Ventura, vol. I, cit.

VILLACAÑAS BERLANGA, José Luis: Una propuesta federal para la Constitución de Cádiz: el proyecto de Flórez Estrada en CHUST Manuel y FRASQUET, Ivana (eds.): op. cit.

VILLALTA, Luís Carlos: 1789-1808. O Império luso-brasileiro e os Brasis, (Coordenação: Laura de Mello e Souza e Lilian Moritz Schwarcz), Companhia das Letras - Virando Século, São Paulo, 2000.

VILLAVA, Victoriá: Cuadernos Aragoneses de Economía (Jaime Rubio, abogado de los Reales Consejos, edición de 1822), Año 1997, Vol. 7, Numero 1, ISSN 0211-0865, pp. 171-186.

WEFFORT, Francisco: Formação do Pensamento Político do Brasil. Idea e Personagens, Editora Ática, São Paulo, 2006.

WIEACKER, Franz: Historia do Direito Privado Moderno, cit., pp. 238 y ss, 340 y ss. También em COING, H.: Bartolus und der usus modernus Pandectarum in Deutschland, in Bartolo da Sassoferrato - Studi e documenti per il IV centenario, cit. Vol. I.

WOLFF, Christina von: Logic, or rational thoughts on the powers of the human understanding, Nachdruk der Ausgabe, London, 1770.

WOLKMER, Antônio Carlos: História do direito no Brasil, Ed. Forense, Rio de Janeiro, 1998.

ZAVALA, Iris María: Románticos y Socialistas. Prensa española del XIX, Madrid, Siglo XXI de España Editores S.A, 1972.

\section{a) DEBATES PARLAMENTARES}

DIARIO DE LAS DISCUSIONES Y ACTAS DE LAS CORTES, Tomo VIII, Imprenta Real, Cádiz, 1811.

ACTAS DE LA COMISIÓN DE CONSTITUCIÓN, 1811.

DIARIOS DAS CORTES GERAES E EXTRAORDINARIAS DA NAÇAO PORTUGUEZA, Sessao n. ${ }^{\circ}$ 2, Imprensa Nacional, Lisboa, 1821-1822, pp. 5 y 6.

DIARIOS DAS CORTES GERAES E EXTRAORDINARIAS DA NAÇAO PORTUGUEZA. Diário, n. ${ }^{\circ}$ 134, p. 1624.

DIARIOS DAS CORTES GERAES E EXTRAORDINARIAS DA NAÇAO PORTUGUEZA, Diário de Sessão, n. ${ }^{\circ} 66$.

ASSEMBLÉA GERAL CONSTITUINTE E LEGISLATIVA DO IMPERIO DO BRAZIL

DIARIO DAS CORTES GERAIS, EXTRAORDINARIAS, E CONSTITUYENTES DA NAÇAO PORTUGUEZA, Segundo Anno da Legislatura, Tomo VII, Na Imprensa Nacional, Lisboa, 1822. 
Correio Extraordinário do Rio de Janeiro. $\mathrm{n}^{\circ}$ 3, 21 setembro 1822.Publicada también en elDiário do Rio de Janeiro. 24 setembro 18In: NEVES, Lúcia Ma Bastos P. das: Corcundas e Constitucionais..., op. cit., p. 375.

ANNAES DO PARLAMENTO BRAZILEIRO - ASSEMBLEIA CONSTITUINTE, 1823, Tomo V, Typographia H. J. Pinto, Rua Nova do Ouvidor n. 31, Rio de Janeiro, 1880.

ANNAES DO SENADO DO IMPÉRIO DO BRAZIL. Regimento Interno da Assembleia Geral, Rio de Janeiro, 1910.

ANAIS DA CÂMARA DOS DEPUTADOS, 1827, v. 3.

COMISSAO DE CONSTITUIÇAO - Pedro de Araujo Lima, Manuoel Antonio Galvao, Lucio Soares Teixeira de Gouvea, Bernardo Pereira de VAsconcellos. Anais da Câmara dos Deputados, Sesión de 12 de julio de 1827, p. 123. http://imagem.camara.gov.br/dc 20b.asp? largura=\&altura $=\&$ selCodColecaoCsv=A\&Datain=12\%2F07\%2F1827\&txPagina $=123 \&$ txSuplemento=0\&enviar=Pes quisar Accedido en 17/08/2013.

COMISSAO ECLESIÁSTICA - Miguel José Reinaut, Antonio da Rocha Franco, José Bento Leite Ferreira de Mello, Diogo Antônio Feijó. ACD, Sesión de 12 de julio de 1827.

(Archivo John Carter Brown Library) Constituição Política do Império do Brasil, Na Typographia de Plancher, Impressor Livreiro de Sua Magestade Imperial, Rio de Janeiro, 1824.

Diario da Câmara dos Deputados, Sesión de 16 de julio de 1828, Sr. diputado Obispo de Maranhão, p. 128. http://imagem.camara.gov.br/dc 20b.asp?largura=\&altura=\&selCod ColecaoCsv=A\& Datain=16\%2F07\%2F1828\&txPagina $=\&$ txSuplemento=0\&enviar=Pesquisar Accedido en 30/09/2013

Anais do Senado do Império do Brasil. Assemblei Geral Legislativa. Sessão Legislativa Ordinária - $9^{a}$ Legislatura. Sessões de maio e junho de 1855, Senado Federal Subsecretaria dos Anais, Brasília, 1978. Sessão de 28 de maio de 1855, pp. 147 y ss. Senador Sr. Manuel da Fonseca.

Anais do Senado do Império do Brasil. Assemblei Geral Legislativa. Sessão Legislativa Ordinária - $9^{a}$ Legislatura. Sessões de maio e junho de 1855, Senado Federal Subsecretaria dos Anais, Brasília, 1978. Sessão de 9 de junio de 1855, p. 213. - Barão de Muritiba

O Parlamento e a evoluçao nacional - 1871-1888, $3^{\text {a }}$ Serie, Vol. 6, Sendado Federal, Brasilia, 1979.

DIARIOS DAS CORTES GERAES E EXTRAORDINARIAS DA NAÇAO PORTUGUEZA, Sessão de 13 de fevereiro de 1821. Diário, n. ${ }^{\circ}$ 14, de 14 de fevereiro de 1821.

DIARIO DAS CORTES GERAIS, EXTRAORDINARIAS, E CONSTITUINTES DA NAÇAO PORTUGUEZA, (Segundo Anno da Legislatura), Imprensa Nacional, Lisboa, 1822.

\section{b) ARCHIVOS DE BIBLIOTECAS CONSULTADOS}

Biblioteca Nacional, Lisboa - Virtual.

Biblioteca Nacional de España - Emeroteca - Virtual.

Archivo Secreto de Vaticano.

Biblioteca de la Universidad de Salamanca. 
Biblioteca Central de la Universidad de Coimbra.

Archivo de la John Carter Brown University - Virtural y Fisico.

Archivo Virtual del Senado Federal de Brasil.

Archivo Virtual de la Cámara de los Diputados Federales de Brasil

Archivo del Congreso en Madrid.

Biblioteca de la Università degli Studi di Messina.

\section{c) DOCUMENTOS}

(Archivo Secreto del Vaticano) BULA PRAECLARA PORTUGALIAE de 15 de mayo de 1827

- Bullarii Romani Continuatio Summorum Pontificum Clementis XIII. Clementis XIV. Pii VI. Pii VII. Leonis XII. Pii VIII. Et Gregorii XVI. Constitutionis, Literas in Forma Brevis Epistolas as Principes Viros, et Alios Atque Alloquutionis Complectens Quas Collegit Usque ad Pontificatum Pii VII. Andreas Advocatus Barbéri Curiae Capitolii Collateralis Additis Summariis, Adnotationibus, Indicibus Opera, et Studio Rainaldi Segreti I. C., Tomus Decimus Septimus Continens Potificatus Leonis XII. Annum Quartum ad Sextum, Romae, 1855 , pp. 56-60.

"Confederação do Equador - Manifesta dos Deputados à Assembleia Constituinte pelas Províncias de Pernambuco, Paraíba e Ceará (13 de dezembro de 1823)" In: BONAVIDES, Paulo y AMARAL, Roberto: Textos Políticos..., op. cit., p. 769 y 770.

Auto de Aclamação da Câmara da vila de Vitória. In: Arquivo Nacional. As Câmaras Municipais e a independência. Rio de Janeiro, Arquivo Nacional/ Conselho Federal de Cultura,1973, (v. 1), pp. 193-9. Termo de Vereação da Câmara da vila de Santa Maria do Baependi.Termo de Vereação da Câmara de vila Nova da Rainha do Caeté. Termo de Vereação da cidade de Mariana. In: Arquivo Nacional. Ibidem. (v. 2), pp. 12-18, 59-61 e 157-9, respectivamente. In: Ídem, p. 380.

Providências sobre a Assembleia Geral Constituinte e Legislativa do Brasil - 5 de janeiro de 1823 - José Bonifácio de Andrada e Silva In: BONAVIDES, Paulo e AMARAL, Roberto: Textos Políticos..., op. cit., p. 716.

Diccionario Histórico o Biografia Universal Compendiada, Tomo IX, Librería de los Editores (Antonio y Francisco Oliva), Barcelona, 1833, p. 280.

Fala que a Sua Majestade Imperial e Defensor Perpétuo do Brasil dirigiu o Prezidente do Senado da Câmara do Rio de Janeiro no Fausto Dia 12 de outubro de 1822, Rio de Janeiro: Off. Silva Porto \& Ca., 1822, pp. 5 e 6.

(Archivo John Carter Brown Library) - Cerimonial para o Juramento Solemne que há de prestar o Imperador Constitucional Defensor Perpétuo do Brasil Pedro I à Constituição Política da Nação Brasileira, Na Impressão Nacional, Rio de Janeiro, 25 de março de 1824.

(Archivo John Carter Brown Library) - Constituição Politica do Império do Brasil (Independência ou Morte), Na Typographia de Plancher, Impressor-Livreiro de Sua Magestade Imperial, Rio de Janeiro, 1824.

(Archivo John Carter Brown Library) - Constituição Politica do Império do Brasil (Independência ou Morte), Na Typographia de Plancher, Impressor-Livreiro de Sua Magestade Imperial, Rio de Janeiro, 1824. 
(Archivo John Carter Brown Library) - Projecto de Constitución para o Império do Brasil, organizado no Conselho de Estado sobre as Bases apresentadas por Sua Magestade Imperial o Senhor D. Pedro I. Imperador Constitucional, e Defensor Constitucional, e Defensor Perpetuo do Brasil, Na Typorgraphia Nacional, Rio de Janeiro, 1823.

(Archivo Secreto del Vaticano) BULA SOLLICITA CATHOLICIS de 15 de julio de 1826 Bullarii Romani Continuatio Summorum Pontificum Clementis XIII. Clementis XIV. Pii VI. Pii VII. Leonis XII. Pii VIII. Et Gregorii XVI. Constitutionis, Literas in Forma Brevis Epistolas as Principes Viros, et Alios Atque Alloquutionis Complectens Quas Collegit Usque ad Pontificatum Pii VII. Andreas Advocatus Barbéri Curiae Capitolii Collateralis Additis Summariis, Adnotationibus, Indicibus Opera, et Studio Rainaldi Segreti I. C., Tomus Decimus Sextus Continens Potificatus Leonis XII. Annum Primum ad Tertium, Romae, 1854, pp. 462-464.

"José da Silva Lisboa (Visconde de Cairú)" In: Revista do Instituto Histórico e Geografico Brazileiro, 1904, p. 187.

Agradecimento pela convocação da Assembleia Constituinte e Legislativa - Representação do Senado da Câmara do Rio de Janeiro em 10 de junho de 1822 in: BONAVIDES, Paulo e AMARAL, Roberto: Textos Políticos da História do Brasil, Vol. I, $3^{\text {a }}$ Edição, Senado Federal, Brasília, 2002, pp. 595-597.

As Câmaras e a Independência, Tomo III, Conselho Federal de Cultura, Rio de Janeiro, 1973, p. 38. (Arquivo Nacional). Formação Constitucional do Brasil, Tipografia do Jornal do Comercio, Rio de Janeiro, 1914, p. 78.

Astro da Lusitânia. 5 novembro 1822. Londres. Correio Braziliense. v. 29, novembro In: NEVES, Lúcia Ma Bastos P. das: Corcundas e Constitucionais..., op. cit., p. 376.

Ata da Câmara Municipal de Campo Maior (Quixeramobim, CE) Destituindo o Imperador D. Pedro I e Proclamando a República (Termo da Sessão Extraordinária que mandaram fazer o presidente e mais oficiais da Câmara, com assistência do Clero, Nobreza e Povo) - 9 de janeiro de 1824 In: BONAVIDES, Paulo y AMARAL, Roberto: Textos Políticos..., op. cit., p. 771 y 772.

Atuação da Maçonaria na Independência - Certidão das Atas das Sessões de Agosto a Outubro de 1822 da Loja Maçônica Grande Oriente do Brasil de 29 de Agosto de 1861 in: BONAVIDES, Paulo e AMARAL, Roberto: Textos Políticos..., op. cit., pp. 695-702.

Atuação da Maçonaria na Independência - Certidão das Atas das Sessões de Agosto a Outubro de 1822 da Loja Maçônica Grande Oriente do Brasil de 29 de Agosto de 1861 in: BONAVIDES, Paulo e AMARAL, Roberto: Textos Políticos..., op. cit., p. 696.

Atuação da Maçonaria na Independência - Certidão das Atas das Sessões de Agosto a Outubro de 1822 da Loja Maçônica Grande Oriente do Brasil de 29 de Agosto de 1861 in: BONAVIDES, Paulo e AMARAL, Roberto: Textos Políticos..., op. cit., pp. 701-702.

Carta II, enviada a D. Joao VI por el Príncipe Regente D. Pedro en 4 de agosto de 1822 y decreto anexo de $1^{\mathrm{o}}$ de agosto de 1822. (John Carter Brown Library)

Cartas e Documentos dirigidos a Sua Magestade o Senhor D. Joao VI pelo Príncipe Real o Senhor D. Pedro de Alcântara: e que forao presentes as Cortes em Sessao de 28 de Setembro de 1822, Na Imprensa Nacional, Lisboa, 1822, p. 5.

Cerimonial da sagração e coroação do Imperador Pedro I, na Capella Imperial de Nossa Senhora do Monte Carmo do Rio de Janeiro, pelo Bispo Capelão-Mór, no dia 1 de dezembro de 1822, Typographia Nacional, Rio de Janeiro, 1822. 
Cerimonial da sagração e coroação do Imperador Pedro I, na Capella Imperial de Nossa Senhora do Monte Carmo do Rio de Janeiro, pelo Bispo Capelão-Mór, no dia 1 de dezembro de 1822, Typographia Nacional, Rio de Janeiro, 1822.

Collecçao das Leis e Decretos do Império do Brasil, desde a feliz época da sua Independência, obra dedicada a Assembleia Legislativa; precedida de um discurso preliminar, e terminada por huma taboa alfabética, e arrosoada, por M.M., Na Imperial Typographia de P. Plancher-Seignot, Rua do olvidor, $\mathrm{n}^{\circ}$. 95, Rio de Janeiro, 1827, pp. V-VI.

CONSELHO DOS PROCURADORES GERAIS DAS PROVINCIAS DO BRASIL (1822-1823) In: Archivo Digital do Senado Federal. RODRIGUES, José Honório: O Parlamento e a Evolução Nacional, Introdução Histórica 1826-1840, Senado Federal, Brasília, 1972.

Convocação da Assembleias Constituinte e Legislativa - Representação do Povo do Rio de Janeiro ao Príncipe Regente em prol da convocação de uma Assembleia Geral Representação que à $S$. A. $R$. o príncipe regente constitucional e defensor perpetuo do Reino Unido do Brasil, dirige o povo do Rio de Janeiro pela Câmara desta Corte in: BONAVIDES, Paulo e AMARAL, Roberto: Textos Políticos da História do Brasil, Vol. I,

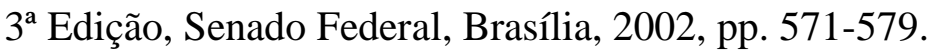

Criaçao de Comissao Militar para Processar os Chefes do Movimento - Decreto do Imperador (26 de julho de 1824) In: BONAVIDES, Paulo y AMARAL, Roberto: Textos Políticos..., op. cit., p. 795.

Decreto do Imperador de 26 de julho de 1824. Sentença de Morte de Joao Guilherme Racticlife e outros - Acordão de 12 de marzo de 1825 In: BONAVIDES, Paulo y AMARAL, Roberto: Textos Políticos..., op. cit., pp. 796 y 801.

Diccionario da Lingua Portugueza recompilado dos vocabularios impressos até agora, e nesta segunda edição novamente emendado, e muito accrescentado, por Antonio de Morais Silva natural do Rio de Janeiro, offerecido ao muito alto, e muito poderoso Principe Regente Nosso Senhor, Tomo I - A-E, Na Typographia Lacerdina, Com Licença da Meza do Desembargo do Paço, Lisboa, 1813, p. 395.

- Diccionario de la Lengua Castellana, en que se explica el verdadero sentido de las voces, su naturaleza y calidad con las frases y modos de hablar, los proverbios y refranes, y otras cosas convenientes al uso de la lengua. Dedicado al Rey Nuestro Señor Don Felipe V (que Dios guarde), a cuyas reales expensas se hace esta obra. Compuesto por la Real Academia Española. Tomo II - que contiene la letra C, En la Imprenta de Francisco del Hierro, Impresor de la Real Academia Española, Madrid, 1729, p. 364.

En sus ensayos políticos, Frei Caneca va a escribir las "Bases para a Formação do Pacto Social” In: BONAVIDES, Paulo y AMARAL, Roberto: Textos Políticos..., op. cit., p. 773 y 775 .

Fala do Senado da Câmara dirigida ao Príncipe D. Pedro a Propósito da Convocação de uma Assembleia Geral solicitada pelo povo em 23 de maio de 1822 in: BONAVIDES, Paulo e AMARAL, Roberto: Textos Políticos da História do Brasil, Vol. I, $3^{\text {a }}$ Edição, Senado Federal, Brasília, 2002, pp. 582-588.

Falla que Sua Magestade o Imperador pronuncia na Câmara dos Senadores no dia 6 de Maio de 1826 na Abertura da Assembléa Nacional - Collecção das Leis e Decretos do Império do Brasil..., op. cit., pp. 263-264.

Falla, que a S. A. R. o Príncipe Regente Constitucional, e Defensor-Perpetuo do Reino do Brazil, dirigia o Senado da Câmara desta Cidade pela voz do seu Presidente, no acto de apresentar ao mesmo Senhor a Representação do Povo desta Cidade sobre a Convocação de uma Assembléa Geral nesta Corte. (Archivo de la John Carter Brown Library) Cartas e 
mais Documentos dirigidos a Sua Magestade o Senhor D. Joao VI pelo Príncipe Real o Senhor D. Pedro de Alcântara com as datas de 19 e 22 de junho deste anno: e que forão presentes às Cortes Gerais Extraordinárias e Constituintes da Nação Portugueza. Em a Sessão de 26 de Agosto do mesmo anno, Na Imprensa Nacional, 1822, p. 23.

Manifesto aos Brazileiros - De S. A. R. o Príncipe Regente Constitucional, Defensor Perpetuo do Reino do Brazil aos Povos deste Reino. Ídem, p. 11.

Manifesto da Proclamação da Confederação do Equador (2 de julho de 1824) In: BONAVIDES, Paulo y AMARAL, Roberto: Textos Políticos..., op. cit., p. 786 y 788.

Manifesto de Falmouth lançado por los constituintes brasileiros que abandonaram as Cortes de Lisboa em 22 de outubro de 1822 in: BONAVIDES, Paulo e AMARAL, Roberto: Textos Políticos..., op. cit., pp. 669-670.

Manifesto do Frei Caneca (1824) In: BONAVIDES, Paulo y AMARAL, Roberto: Textos Políticos..., op. cit., p. 776 y 784.

Manifesto dos Deputados Pernambucanos - 7 de junho de 1823 In: BONAVIDES, Paulo y AMARAL, Roberto: Textos Políticos..., op. cit., p. 766 y 768. Firman dicho manifiesto: "O vigário Joao Evangelista Leal Periquito (pelo Clero); Basílio Quaresma Torreão (pelo Militar); Joao Francisco Bastos Junior (pelo Civil)".

Participação ao Presidente de Pernambuco sobre a Providencia para a Defesa da ProvínciaPortaria da Secretaria dos Negócios do Império (11 de junho de 1824) In: BONAVIDES, Paulo y AMARAL, Roberto: Textos Políticos..., op. cit., p. 785.

Pedido para que seja Jurado como Constituição o Projeto Apresentado pelo Imperador Representação do Senado da Câmara do Rio de Janeiro - 6 de janeiro de 1824 in: BONAVIDES, Paulo y AMARAL, Roberto: Textos Políticos..., op. cit., p. 749 y 753.

Proclamações do Presidente da Confederação do Equador (2 de julho de 1824) In: BONAVIDES, Paulo y AMARAL, Roberto: Textos Políticos..., op. cit., p. 789 y 794.

Projecto de Constitución para o Império do Brasil, organizado no Conselho de Estado sobre as Bases apresentadas por Sua Magestade Imperial o Senhor D. Pedro I. Imperador Constitucional, e Defensor Constitucional, e Defensor Perpetuo do Brasil, Na Typorgraphia Nacional, Rio de Janeiro, 1823.

Projet de Déclaration des Droits, Par un Membre de l'Assamblée Nationale (Abade Sièyes), 1789.

Projeto de Constituição para o Império do Brasil (Antônio Carlos de Andrada) in: MIRANDA, Jorge: $\mathrm{O}$ constitucionalismo liberal luso-brasileiro, Comissão Nacional para as Comemorações dos Descobrimentos Portugueses, Lisboa, 2001, p. 210.

Projeto de Constituição para o Império do Brasil, Organizado no Conselho de Estado sobre as Bases Apresentadas por Sua Magestade Imperial o Senhor D. Pedro I. Imperador Constitucional, e Defensor Perpetuo do Brasil, Na Typographia Nacional, Rio de Janeiro, 1823, pp. 3-5.

Reflexões dirigidas ao Imperador sobre o Projeto da Constituição (Oficio da Câmara de Itu de $1^{\circ}$ de fevereiro de 1824) in: BONAVIDES, Paulo y AMARAL, Roberto: Textos Políticos..., op. cit., p. 754 y 761. Firmará dichas Reflexiones: Joao Paulo Xavier, José Galvão de Barros França, Diogo Antônio Feijó, José Rodrigues do Amaral e Melo, Candido José da Mota, Fernando Dias Paes Leme, Manoel Ferraz de Camargo, Francisco Pacheco da Fonseca y Joao de Almeida Prado.

Representação da Vila Real da Praia Grande (Niteroi) pedindo a convocação de uma Assembleia Legislativa para o Brasil em 26 de maio de 1822 in: BONAVIDES, Paulo e 
AMARAL, Roberto: Textos Políticos da História do Brasil, Vol. I, $3^{\text {a }}$ Edição, Senado Federal, Brasília, 2002, pp. 589-591.

Representação que à $S$. A. R. príncipe regente levaram os procuradores e o ministério, corroborando a suplica do povo dirigida pelo Senado da Câmara no dia 23 de maio Súplica de convocatória de Assembleia Geral do dia 3 de junho de 1822 in: BONAVIDES, Paulo e AMARAL, Roberto: Textos Políticos da História do Brasil, Vol. I, $3^{\text {a }}$ Edição, Senado Federal, Brasília, 2002, pp. 592-594.

Se Pernambuco não jurar a Constituição já, também esta Província não jura - Carta de José Martiniano de Alencar a Manuel de Carvalho Paes de Andrade - 5 de maio de 1824 In: BONAVIDES, Paulo y AMARAL, Roberto: Textos Políticos..., op. cit., p. 764 y 765.

Sesión de las Cortes Gerais Extraordinárias e Constituintes da Nação Portuguesa de 30 de septiembre de 1822 ,

Termo de Juramento dos Deputados das Cortes Gerais Extraordinárias e Constituintes da Nação Portuguesa - assinada pelos Deputados Brasileiros em 30 de setembro de 1822 in: BONAVIDES, Paulo y AMARAL, Roberto: Textos Políticos..., op. cit., p. 668.

Vereação Extraordinária do Senado da Câmara destas Cortes (Rio de Janeiro) em 23 de maio de 1822 - Solicitação de Convocatória de uma Assembleia Geral in: BONAVIDES, Paulo e AMARAL, Roberto: Textos Políticos da História do Brasil, Vol. I, $3^{\text {a }}$ Edição, Senado Federal, Brasília, 2002,, pp. 580-581.

(Archivo John Carter Brown Library) - Analise do Projeto de Governo para as Províncias Confederadas, e que se deve reger em Nome da Soberania das Mesmas Províncias, Offerecido a todos os Brasileiros em Geral, e em particular aos das Províncias do Norte, especialmente aos Pernambucanos, por Manuel de Carvalho Paes de Andrade, Presidente do Governo de Pernambuco, Na Typographia Nacional, Rio de Janeiro, 1824, pp. 1-8.

"Lembranças e apontamentos do Governo Provisório da Província de São Paulo para os seus deputados" aprovadas no Palácio do Governo de São Paulo, 10 de outubro de 1821 en CALDEIRA, Jorge (org.): José Bonifácio de Andrada e Silva, Editora 34 - Coleção Formadores do Brasil, São Paulo, 2002, pp. 125-133.

"Reflexões sobre o Pacto Social e acerca da Constituição de Portugal", autor: Hum Cidadão Portuguêz, outubro de 1820. Primeiro mês da liberdade lusa, Imprensa Nacional, Lisboa, 1821.

ARCHIVO DEL CONGRESO DE LOS DIPUTADOS EN MADRID Signatura topográfica P01000029-0001-0001 (Sig. Topográfica antigua ACD, S General, Leg. 29 n ${ }^{\circ}$ 1, Título: Juramentos de la Constitución de 1812: Ecuador, Perú, Brasil, Callao, Uruguay, Bolivia, Panamá, Colombia, Venezuela, Argentina, Fechas extremas/Sin mes/1812-/sin mes/1812).

ARCHIVO DEL CONGRESO DE LOS DIPUTADOS EN MADRID Signatura topográfica P01000029-0001-0001 (Sig. Topográfica antigua ACD, S General, Leg. 29 n ${ }^{\circ}$ 1, Título: Juramentos de la Constitución de 1812: Ecuador, Perú, Brasil, Callao, Uruguay, Bolivia, Panamá, Colombia, Venezuela, Argentina, Fechas extremas/Sin mes/1812-/sin mes/1812).

Carta de Lei do Príncipe D. Joao de 18 de dezembro de 1815 in: BONAVIDES, Paulo e AMARAL, Roberto: Textos Políticos da História do Brasil, Vol. I, $3^{\text {a }}$ Ediçao, Senado Federal, Brasília, 2002, pp. 454-456.

Cartas dirigidas a Sua Magestade o Senhor D. Joao VI, pelo príncipe real o Senhor D. Pedro de Alcantara, Imprensa Nacional, Lisboa, 1822.

Compêndio Histórico da Universidade de Coimbra de 1771 
Compêndio Histórico da Universidade de Coimbra, (Na Regia Officina Typografica - Por ordem de Sua Majestade), Lisboa, 1771, p. 1.

Diccionario Aristocratico Contendo os Alvarás dos Foros de Fidalgos da Casa Real (Que se achao registrados nos livros das Merces, hoje pertencentes aos Arquivos da Torre do Tombo desde os mais antigos que neles há até os atuais), Tomo I (A-E), Imprensa Nacional, Lisboa, 1840, p. 455.

Manifesto da Naçao Portuguesa aos Soberanos e Povos da Europa" de 15 de diciembre de 1820, disponible en: http://www.arqnet.pt/portal/portugal/documentos/manifesto_nacao. $\underline{\mathrm{html}}$ Accedido en 25.03.2013.

\section{d) LEGISLACIÓN}

(Archivo John Carter Brown Library) - CONSTITUIÇAO POLÍTICA DO IMPERIO DO BRASIL (Independência ou Morte), Na Typographia de Plancher, Impressor Livreiro de Sua Magestade Imperial, Rio de Janeiro, 1824, p. 3.

(Archivo John Carter Brown Library) - CONSTITUIÇAO POLÍTICA DO IMPERIO DO BRASIL (Independência ou Morte), Na Typographia de Plancher, Impressor Livreiro de Sua Magestade Imperial, Rio de Janeiro, 1824, p. 48.

(Archivo John Carter Brown Library) - CONSTITUIÇAO POLÍTICA DO IMPERIO DO BRASIL (Independência ou Morte), Na Typographia de Plancher, Impressor Livreiro de Sua Magestade Imperial, Rio de Janeiro, 1824, p. 24.

(Archivo John Carter Brown Library) Constituição Política do Império do Brasil, Na Typographia de Plancher, Impressor Livreiro de Sua Magestade Imperial, Rio de Janeiro, 1824, p. 1.

(Archivo John Carter Brown Library) - CONSTITUIÇAO POLÍTICA DO IMPERIO DO BRASIL (Independência ou Morte), Na Typographia de Plancher, Impressor Livreiro de Sua Magestade Imperial, Rio de Janeiro, 1824, pp. 3 y 4.

(Archivo John Carter Brown Library) - CONSTITUIÇAO POLÍTICA DO IMPERIO DO BRASIL (Independência ou Morte), Na Typographia de Plancher, Impressor Livreiro de Sua Magestade Imperial, Rio de Janeiro, 1824, p. 26.

(Archivo John Carter Brown Library) - CONSTITUIÇAO POLÍTICA DO IMPERIO DO BRASIL (Independência ou Morte), Na Typographia de Plancher, Impressor Livreiro de Sua Magestade Imperial, Rio de Janeiro, 1824, p. 24. Decreto de 26 de marzo de 1824

(Archivo John Carter Brown Library) - CONSTITUIÇAO POLÍTICA DO IMPERIO DO BRASIL (Independência ou Morte), Na Typographia de Plancher, Impressor Livreiro de Sua Magestade Imperial, Rio de Janeiro, 1824, p. 26.

(Archivo John Carter Brown Library) - CONSTITUIÇAO POLÍTICA DO IMPERIO DO BRASIL (Independência ou Morte), Na Typographia de Plancher, Impressor Livreiro de Sua Magestade Imperial, Rio de Janeiro, 1824, pp. 1, 26, 36 y 38.

(Archivo John Carter Brown Library) - Constituição Politica do Império do Brasil (Independência ou Morte), $\mathrm{Na}$ Typographia de Plancher, Impressor-Livreiro de Sua Magestade Imperial, Rio de Janeiro, 1824, p. 1.

(Archivo John Carter Brown Library) - Constituição Politica do Império do Brasil (Independência ou Morte), Na Typographia de Plancher, Impressor-Livreiro de Sua Magestade Imperial, Rio de Janeiro, 1824, p. 5-8. Artículos 102, inciso III y XIV. 
(Archivo John Carter Brown Library) Constituição Política do Império do Brasil, Na Typographia de Plancher, Impressor Livreiro de Sua Magestade Imperial, Rio de Janeiro, 1824.

Ata de Deportação de Ex-Deputados à Assembleia Constituinte - Sessão do Conselho de Estado em 15 de novembro de 1823 In: BONAVIDES, Paulo y AMARAL, Roberto: Textos Políticos..., op. cit., p. 743 y 744.

Colecção das Leis do Império, 1842, Tomo $5^{\circ}$, Parte $2^{\mathrm{a}}$, Secçao $39^{\mathrm{a}}$ - Decreto n. 157 de 4 de mayo de 1842 , pp. 255 y ss.

Colecção das Leis do Império, 1846, Tomo $8^{\circ}$, Parte $1^{\mathrm{a}}$, Secçao $13^{\mathrm{a}}$ - Lei n. 387 de 19 de agosto de 1846.

Collecção das Leis do Império do Brasil de 1881, Parte I, Tomo XXVIII, Parte II, Tomo XLIV, Volume I, Typographia Nacional, Rio de Janeiro, 1882. Actos do Poder Legislativo Decreto n. 3.029 de 9 de janeiro de 1881, pp. 1-28.

Collecção das Leis do Império do Brasil de 1881, Parte I, Tomo XXVIII, Parte II, Tomo XLIV, Volume I, Typographia Nacional, Rio de Janeiro, 1882. Actos do Poder Legislativo Decreto n. 3.029 de 9 de janeiro de 1881, pp. 1-28.

Collecçao das Leis do Imperio do Brasil, 1828 - Parte Primeira, Typographia Nacional, Rio de Janeiro, 1878, pp. 47 y ss. Ley de 22 de septiembre de 1828. Extingue os Tribunais das Mesas do Desembargo do Paço e da Consciência e Ordens e regula a expedição dos negócios que lhes pertenciam e ficam subsistindo.

Collecçao das Leis do Imperio do Brasil, Tomo 16, Parte 1a, Secçao $18^{\text {a }}$ - Decreto n. 842 de 19 de setembro de 1855, pp. 49 y ss.

Collecção das Leis do Império do Brasil, Volume I, Typographia Nacional, Rio de Janeiro, 1882, p. 30. Decreto de 7 de marzo de 1821.

Collecção das Leis do Império do Brasil, Volume I, Typographia Nacional, Rio de Janeiro, 1882, p. 32. Decreto de 7 de marzo de 1821.

Constitución Política de la Monarquía Española, Promulgada en Cádiz a 19 de marzo de 1812, Reimpresa en la Imprenta Nacional, Madrid, 1820, pp. 12 y ss.

Constituição Política da Monarchia Portugueza, Imprensa Nacional, Lisboa, 1822, pp. 16 y ss.

CONVENÇAO ADDICIONAL AO TRATADO de 29 de agosto de 1825 - Collecção de Tratados, Convenções, Contractos e Actos Públicos celebrados entre a Coroa de Portugal e as mais potencias desde 1640, pp. 527-530.

Decisão no 57 de 19 de junio de 1822 - Idem, pp. 178 y ss.

Decreto de 10 de abril de 1826 - Collecção de Tratados, Convenções, Contractos e Actos Públicos celebrados entre a Coroa de Portugal e as mais potencias desde 1640 até ao presente, compilados, coordenados e anotados por José Ferreira Borges De Castro (Visconde de Borges de Castro); continuada por Júlio Firmino Júdice Biker, t. V, Lisboa, Imprensa Nacional, 1887, pp. 523-527.

DECRETO DE 11 DE MARZO DE 1824 - Collecção das Leis e Decretos do Império do Brasil, desde a feliz época da sua Independência, obra dedicada a Assembleia Legislativa; precedida de um discurso preliminar, e terminada por huma taboa alfabética, e arrosoada, por M.M., Na Imperial Typographia de P. Plancher-Seignot, Rua do olvidor, $\mathrm{n}^{\circ} .95$, Rio de Janeiro, 1827.

DECRETO DE 12 DE NOVIEMBRE DE 1823 - Collecção das Leis e Decretos do Império do Brasil, desde a feliz época da sua Independência, obra dedicada a Assembleia Legislativa; 
precedida de um discurso preliminar, e terminada por huma taboa alfabética, e arrosoada, por M.M., Na Imperial Typographia de P. Plancher-Seignot, Rua do olvidor, nº 95, Rio de Janeiro, 1827, p. 138.

DECRETO DE 13 DE NOVIEMBRE DE 1823 - Ídem, p. 139.

DECRETO DE 13 DE OCTUBRE DE 1822 - Collecção das Leis e Decretos do Império do Brasil, desde a feliz época da sua Independência, obra dedicada a Assembleia Legislativa; precedida de um discurso preliminar, e terminada por huma taboa alfabética, e arrosoada, por M.M., Na Imperial Typographia de P. Plancher-Seignot, Rua do olvidor, $\mathrm{n}^{\circ}$. 95, Rio de Janeiro, 1827, p. 12.

DECRETO DE 17 DE NOVIEMBRE DE 1823 - Ídem, p. 43.

DECRETO DE 20 DE NOVIEMBRE DE 1823 - Ídem, pp. 143-144.

DECRETO DE 25 DE MARZO DE 1824 - CONSTITUIÇAO POLÍTICA DO IMPERIO DO BRASIL - Collecção das Leis e Decretos do Império do Brasil, desde a feliz época da sua Independência, obra dedicada a Assembleia Legislativa; precedida de um discurso preliminar, e terminada por huma taboa alfabética, e arrosoada, por M.M., Na Imperial Typographia de P. Plancher-Seignot, Rua do olvidor, $n^{\circ}$. 95, Rio de Janeiro, 1827.

DECRETO DE 26 DE MARZO DE 1824 - Collecção das Leis e Decretos do Império do Brasil, desde a feliz época da sua Independência, obra dedicada a Assembleia Legislativa; precedida de um discurso preliminar, e terminada por huma taboa alfabética, e arrosoada, por M.M., Na Imperial Typographia de P. Plancher-Seignot, Rua do olvidor, $\mathrm{n}^{\circ}$. 95, Rio de Janeiro, 1827.

Decreto de 3 de junio de 1822 - SOUZA, Francisco Belisário Soares de: O Sistema Eleitoral..., op. cit., pp. 177 y ss.

Decreto do Imperador em 30 de outubro de 1822. Este y otros decretos se encuentran respectivamente en BONAVIDES, Paulo e AMARAL, Roberto: Textos Políticos..., op. cit., pp. 703, 704 y 706 .

Decreto n. 1.082 de 18 de agosto de 1860. También reforma la legislación electoral el Decreto n. 2675 de 20 de octubre de 1875.

Instrucción Eleitoral do Decreto de 26 de marzo de 1824.

LEI de 3 de novembro de 1823. Collecção das Leis e Decretos do Império do Brasil, desde a feliz época da sua Independência, obra dedicada a Assembléa Legislativa; precedida de hum discurso preliminar, e terminada por huma boa alfabética, e arrasoada, por MM., Na Imperial Typographia de P. Plancher-Seignot, Rio de Janeiro, 1827, p. 82.

Manifesto de S. M. o Imperador aos Brasileiros de 16 de noviembre de 1823 - Ídem, pp. 140143.

Proclamação de 13 de novembro de 1823 - Ídem, p. 140.

PROJECTO DE CONSTITUIÇAO PARA O IMPERIO DO BRASIL - A Assembleia Geral, Constituinte e Legislativa do Império do Brasil, depois de ter religiosamente implorado os auxílios da Sabedoria Divina, conformando-se aos princípios de justiça, e da utilidade geral, Decreta a seguinte Constituição, no Rio de Janeiro, 30 de Agosto de 1823 In: MIRANDA, Jorge: O constitucionalismo liberal..., op. cit., pp. 205-236. El proyecto fue leído en el pleno de la Asamblea en la Sesión de 1 septiembre de 1823. Diário da Assembleia Geral, Constituinte e Legislativa do Império do Brasil, Sessão de $1^{\circ}$ de setembro de $1823, \mathrm{n}^{\circ} 65$, pp. 689 y ss. 
PROJECTO DE CONSTITUIÇAO PARA O IMPERIO DO BRASIL - A Assembleia Geral, Constituinte e Legislativa do Império do Brasil, depois de ter religiosamente implorado os auxílios da Sabedoria Divina, conformando-se aos princípios de justiça, e da utilidade geral, Decreta a seguinte Constituição, no Rio de Janeiro, 30 de Agosto de 1823 In: MIRANDA, Jorge: O constitucionalismo liberal..., op. cit., pp. 205-236. Estas y otras consideraciones hace el mismo autor en las páginas 24-26.

PROJECTO DE CONSTITUIÇAO PARA O IMPÉRIO DO BRASIL (Asamblea Constituyente de 1823) In: MIRANDA, Jorge: O constitucionalismo..., op. cit., p. 206.

PROJECTO DE CONSTITUIÇAO PARA O IMPÉRIO DO BRASIL (Asamblea Constituyente de 1823) In: MIRANDA, Jorge: O constitucionalismo..., op. cit., p. 206.

PROJECTO DE CONSTITUIÇAO PARA O IMPÉRIO DO BRASIL (Asamblea Constituyente de 1823) In: MIRANDA, Jorge: O constitucionalismo..., op. cit., p. 206.

PROJECTO DE CONSTITUIÇAO PARA O IMPÉRIO DO BRASIL (Asamblea Constituyente de 1823) In: MIRANDA, Jorge: O constitucionalismo..., op. cit., p. 206.

PROJECTO DE CONSTITUIÇAO PARA O IMPÉRIO DO BRASIL (Asamblea Constituyente de 1823) In: MIRANDA, Jorge: O constitucionalismo..., op. cit., p. 206.

PROJECTO DE CONSTITUIÇAO PARA O IMPÉRIO DO BRASIL (Asamblea Constituyente de 1823) In: MIRANDA, Jorge: O constitucionalismo..., op. cit., p. 206.

PROJECTO DE CONSTITUIÇAO PARA O IMPÉRIO DO BRASIL (Asamblea Constituyente de 1823) In: MIRANDA, Jorge: O constitucionalismo..., op. cit., p. 206.

PROJECTO DE CONSTITUIÇAO PARA O IMPÉRIO DO BRASIL (Asamblea Constituyente de 1823) In: MIRANDA, Jorge: O constitucionalismo..., op. cit., p. 206.

Projeto de Constituição para o Império do Brasil, Organizado no Conselho de Estado sobre as Bases Appresentadas por Sua Magestade Imperial o Senhor D. Pedro I. Imperador Constitucional, e Defensor Perpetuo do Brasil, Typographia Nacional, Rio de Janeiro, 1823.

TRATADO DE PAZ E ALIANÇA de 29 de agosto de 1825 - Collecção das Leis e Decretos do Império do Brasil..., op. cit., p. 257.

TRATADO DE PAZ E ALIANÇA de 29 de agosto de 1825 - Collecção das Leis e Decretos do Império do Brasil..., op. cit., p. 257.

TRATADO DE PAZ E ALIANÇA de 29 de agosto de 1825 - Collecção das Leis e Decretos do Império do Brasil..., op. cit., p. 257. Artículo $1^{\circ}$.

Un Código eleitoral pasa a ser utilizado a partir de 1845 en el Imperio - Código de Eleiçoes para o Imperio do Brasil, Typographia Cearense de José Pio Machado, Ceará, 1845.

"Lei da Boa Razao" fue promulgada en 18 de agosto de 1769. Estas informaciones están disponibles en un texto del Prof. Antonio Carlos, pero se encuentran en el Archivo Virtual de la Facultad de Derecho de la Universidad Nueva de Lisboa: http://www.fd.unl.pt/ConteudosAreasDetalhe.asp?ID=40\&Titulo=Biblioteca Accedido en el $25 / 02 / 2012$.

Alvará de 28 de Junho de 1759, Collecção de Legislação Portuguesa pelo desembargador Antônio Delgado da Silva, 1750-1762, Lisboa, 1830, pp. 673-678.

Alvará de 4 de Junho de 1771, Colecção de Legislação, op. cit., 1763-1774, Lisboa 1829, pp. $540-541$.

Aviso Regio de 7 de mayo de 1805 
Bases da Constituição da Monarquia Portuguesa, apresentadas pelo Sr. Moura, em nome da Comissão de Constituição na sessão de 8 de fevereiro de 1821, Tipografia de J. F. M. de Campos, Com licença da Comissão de Censura, Lisboa, 1821.

Bill of Rights inglesa de 1688.

CARTA DE LEI DE 26 DE FEVEREIRO DE 1810.

Carta de Ley de 23 de diciembre de 1770 contenida en los Estatutos da Universidade de Coimbra, Livro II - Cursos Jurídicos das Faculdades de Cânones e Leis, Lisboa (Na Regia Officina Typografica - Por ordem de Sua Magestade), Anno de 1773.

CARTA LEI DE 26 DE FEVEREIRO DE 1810.

Collecção das Leis do Império do Brasil, Volume I, Typographia Nacional, Rio de Janeiro, 1882.

Collecção de Decretos, Editais, etc., Typografia Rollandiana, Lisboa, 1808, p. 143. Proclama de $1^{\circ}$ de fevereiro de 1808.

Collecção de Decretos, Editais, etc., Typografia Rollandiana, Lisboa, 1808, p. 151. Decreto de $1^{\text {o }}$ de Fevereiro de 1808.

CONSTITUCIÓN DE LA NACIÓN PORTUGUESA DE 1822

CONSTITUCIÓN DEL ESTADO DE MASSACHUSETTS, 1780.

CONSTITUCIÓN ESPAÑOLA DE 1812, Artículos 4 y 13.

CONSTITUCIÓN ESPAÑOLA DE 1812, Artículo 375.

Constitución Francesa (por D. Miguel de Burgos), Decretada por la Asamblea Constituyente en los años de 1789, 1790 y 1791; Aceptada por el rey en 14 de setiembre de 1791, Madrid, 1814, pp. 21 y 22.

CONSTITUIÇAO POLITICA DA MONARQUIA PORTUGUEZA, Imprensa Nacional, Lisboa, 1822, p. 12.

CONSTITUIÇAO POLITICA DA NAÇAO PORTUGUEZA, Imprensa Nacional, Lisboa, 1822.

DECLARACIÓN DE DERECHOS DE VIRGINIA, 1776.

DECLARACIÓN DE DERECHOS DEL HOMBRE Y EL CIUDADANO, 1789.

DECLARATION DE DROITS DE L'HOMME ET DU CITOYEN (1789

DECRETO DE $04 \quad D E$ MAYO DE 1814Se puede acceder al texto en: http://usuarios.multimania.es/historiahispana/txix.htm\# DECRETO DE FERNANDO VII ( MAYO1814) Acceso en: 20/09/2011.

DECRETO DE 10 DE NOVIEMBRE DE 1810 - Colección de los decretos..., op. cit., p. 13 y 14.

Decreto de 24 de Fevereiro de 1821. http://www2.camara.gov.br/atividade-legislativa/ legislacao/ publicacoes/doimperio Acceso en 23/09/11.

DECRETO DE 24 DE SEPTIEMBRE DE 1810 - Colección de los decretos..., op. cit., p. 1.

DECRETO de 25 de marzo de 1815

DECRETO DE 25 DE SETIEMBRE DE 1810 - Colección de los decretos y órdenes que han expedido las Cortes generales y extraordinarias desde su instalación en 24 de septiembre de 1810 hasta igual fecha de 1811, Imprenta Nacional, Madrid, 1813, Tomo I, pp. 3 y 4. 
Decreto de 26 de marzo de 1824, Capítulo I, párrafo 6º Francisco Belisário Soares de: O Sistema Eleitoral..., op. cit., p. 188.

Decreto de 26 de marzo de 1824. SOUZA, Francisco Belisário Soares de: O Sistema Eleitoral..., op. cit., p. 187.

Decreto de 4 de mayo de 1842.

El DECRETO de 3 de noviembre de 1827,

El Decreto de 31 de Marzo de 1778 - Collecção da Legislação Portugueza (desde a última recopilação das Ordenações, redigida pelo desembargador Antonio Delgado da Silva Legislação de 1775-1790), Typografia Maigrense - Com a licença da Mesa do Desembargo do Paço, Lisboa, 1828, p. 168.

En DECRETO de 18 de febrero de 1821,

Estatutos da Universidade de Coimbra, Livro II, (Titulo III, Cap. I, paragrafo 20), op. cit., pp. 304 y 305.

Estatutos da Universidade de Coimbra, op. cit., (Liv. II, Tít. II, Cap. 23 y 24), p. 306.

Estatutos Novos da Universidade de Coimbra, 1772, op. cit., pp. 253 y ss.

La Ley de 26 de agosto de 1826 - Collecção das Leis e Decretos do Império do Brasil, desde a feliz época da sua Independência: Obra dedicada à Assembleia Legislativa; precedida de hum discurso preliminar, e terminada por huma taboa alfabética, e arrosoada por MM., Imperial Typographia de P. Plancher-Seignot, Rio de Janeiro, 1827, pp. 281 y ss.

Lei de 6 de Novembro de 1772, Colecção de Legislação op. cit., 1763-1774, pp. 612-615".

Lei de 6 de Novembro de 1772, Colecção de Legislação, op. cit., 1763-1774, p. 613.

Projeto da Constituição Política para a Naçao Portugueza, offerecido às Cortes que se vão congregar em janeiro de 1821, Typographia Rollandiana, Com licença da Comissão de Censura, Lisboa, 1820, pp. 29 y ss.

REGULAMENTO ELEITORAL DE 22 DE NOVEMBRO DE 1820 (Documentos para a História das Cortes Gerais, vol. 1º pág. 108)

STATUT CONSTITUTIONNEL DU DUCHÉ DE VARSOVIE (Le Moniteur, Paris, 1 août)

TRATADO DE PAZ E ALIANÇA de 29 de agosto de 1825 - Collecção das Leis e Decretos do Império do Brasil, desde a Época da sua Independência. Obra dedicada à Assembleia Legislativa; Precedida de hum Discurso Preliminar, e Terminada por huma Taboa Alfabética, e Arrosoada, Por M M., Na Imperial Typographia de P. Plancher-Seignot, Rio de Janeiro, 1827.

\section{e) PERIÓDICOS}

Almanack Braziliense $\mathrm{n}^{\mathrm{o}}$ 7, maio de 2008, pp. 80-101.

O Espelho. $\mathrm{n}^{\circ}$ 109, 3 dezembro 1822.

“O PORTUGUÉS”, 6 de fevereiro de 1818.

ASTRO DA LUSITÂNIA (Periódico constitucional publicado en Lisboa entre 30 de octubre de 1820 a 15 de abril de 1823), n 265-266 de 12 y 13 de octubre de 1821 , el no 268 de 16 de octubre y el no 356 de 4 de febrero de 1822.

BORBOLETA CONSTITUCIONAL, Edición n ${ }^{\circ}$ 210, de 19 de septiembre de 1822Mnemosine Constitucional, edição de 12 de maio. 
BORBOLETA CONSTITUCIONAL, n 119 de 24 de mayo de 1822.

Carta III del Pobrecito Holgazán en Ídem, p. 121.

CORREIO BRAZILIENSE OU ARMAZÉM LITERÁRIO, v. 16, nº 93, febrero de 1816, p. 186.

Edinburgh Review, número 46, del volumen XXIII, de septiembre de 1814, en la página 363.

Edinburgh Review, tuvo su primer número impreso en 1755.

Edinburgh Review, vol. XXIII, n. ${ }^{\circ}$ 46, septiembre 1814, p. 362-363.

Edinburgh Review, vol. XXIII, n. ${ }^{\circ}$ 46, septiembre 1814, p..

Edinburgh Review, vol. XXXVII, n. ${ }^{\circ}$ 75, febrero de 1823, p. 242.

EL CENSOR, $\mathrm{n}^{\circ} .1,16$ de septiembre de 1820, pp. 34-45.

El CONSTITUCIONAL: CRÓNICA CIENTÍFICA, LITERARIA Y POLÍTICA, n. 486, Madrid, miércoles, 6 de septiembre de 1820, pp. 3 y 4.

El CONSTITUCIONAL: CRÓNICA CIENTÍFICA, LITERARIA Y POLÍTICA, n. 486, Madrid, miércoles, 4 de octubre de 1820, portada.

El CONSTITUCIONAL: CRÓNICA CIENTÍFICA, LITERARIA Y POLÍTICA, n. 515, Madrid, jueves, 5 de octubre de 1820, portada.

El CONSTITUCIONAL: CRÓNICA CIENTÍFICA, LITERARIA Y POLÍTICA, n. 528, Madrid, miércoles, 18 de octubre de 1820 , p. portada.

El CONSTITUCIONAL: CRÓNICA CIENTÍFICA, LITERARIA Y POLÍTICA, n. 545, Madrid, sábado, 04 de noviembre de 1820, p. 04.

El CONSTITUCIONAL: CRÓNICA CIENTÍFICA, LITERARIA Y POLÍTICA, n. 548, Madrid, martes, 07 de noviembre de 1820 , p. 1 y 2.

El CONSTITUCIONAL: CRÓNICA CIENTÍFICA, LITERARIA Y POLÍTICA, n. 578, Madrid, jueves, 07 de diciembre de 1820, p. 1-4.

El CONSTITUCIONAL: CRÓNICA CIENTÍFICA, LITERARIA Y POLÍTICA, n. 579, Madrid, viernes, 08 de diciembre de 1820, p. 2 y 3.

El CONSTITUCIONAL: CRÓNICA CIENTÍFICA, LITERARIA Y POLÍTICA, n. 548, Madrid, sábado, 23 de diciembre de 1820, p. 2 y 3.

Gazeta de Oviedo del 02 de julio de 1808,

GAZETA DO RIO DE JANEIRO, 9 de novembro de 1820.

GAZETA DO RIO DE JANEIRO, n. 9, de 12 de octubre de 1808.

Gazeta do Rio de Janeiro. $\mathrm{n}^{\circ} 124,15$ outubro 18.

Gazeta do Rio de Janeiro. ${ }^{\circ}$ 124, 15 outubro 1822.

La Colmena de 17 de mayo en Ídem, p. 121.

La GAZETA DE LISBOA de 13 de mayo de 1808

MERCURIO DE ESPAÑA, noviembre, página 225.

MISCELÁNEA DE COMERCIO, POLÍTICA Y LITERATURA, $\mathrm{n}^{\circ} 185$, viernes $1^{\circ}$ de septiembre de $1820,2^{\text {a }}$ página.

MISCELÁNEA DE COMERCIO, POLÍTICA Y LITERATURA, $\mathrm{n}^{\circ} 186$, viernes 02 de septiembre de $1820,1^{\text {a }}$ página. 
MISCELÁNEA DE COMERCIO, POLÍTICA Y LITERATURA, $\mathrm{n}^{\circ}$ 186, viernes 22 de septiembre de 1820 , página 4.

MISCELÁNEA DE COMERCIO, POLÍTICA Y LITERATURA, n 213, viernes 29 de septiembre de 1820 , portada.

MISCELÁNEA DE COMERCIO, POLÍTICA Y LITERATURA, n 221, sábado, 07 de octubre de $1820,2^{\mathrm{a}}$ página.

MISCELÁNEA DE COMERCIO, POLÍTICA Y LITERATURA, nº 228, sábado, 14 de octubre de 1820 , portada.

MISCELÁNEA DE COMERCIO, POLÍTICA Y LITERATURA, n ${ }^{\circ}$ 263, sábado 18 de noviembre de 1820 , portada y $2^{\mathrm{a}}$ página.

MISCELÁNEA DE COMERCIO, POLÍTICA Y LITERATURA, no 264, domingo 19 de septiembre de 1820 , portada y $2^{\mathrm{a}}$ página.

MISCELÁNEA DE COMERCIO, POLÍTICA Y LITERATURA, $\mathrm{n}^{\circ}$ 267, miércoles, 22 de noviembre de 1820 , portada.

MISCELÁNEA DE COMERCIO, POLÍTICA Y LITERATURA, $\mathrm{n}^{\circ} 271$, domingo, 26 de noviembre de 1820 , portada y $2^{\mathrm{a}}$ página.

MISCELÁNEA DE COMERCIO, POLÍTICA Y LITERATURA, $\mathrm{n}^{\circ}$ 288, miércoles, 13 de diciembre de 1820 , portada y $2^{\mathrm{a}}$ página.

MISCELÁNEA DE COMERCIO, POLÍTICA Y LITERATURA, $\mathrm{n}^{\circ}$ 295, viernes 20 de diciembre de 1820 , final de la página 2 y página 3.

MISCELÁNEA DE COMERCIO, POLÍTICA Y LITERATURA, $\mathrm{n}^{\circ}$ 299, domingo, 24 de diciembre de $1820,2^{a}$ página.

MISCELÁNEA DE COMERCIO, POLÍTICA Y LITERATURA, n $\mathrm{n}^{\circ}$ 302, miércoles, 27 de diciembre de $1820,2^{a}$ página.

MNEMOSINE CONSTITUCIONAL (Periódico salido en Lisboa de 25 de septiembre de 1820 a 30 de junio de 1821), no 112 de 12 de mayo de 1821 y no .113 de 13 de mayo de 1821.

O Espelho. $\mathrm{n}^{\circ}$ 109, 3 dezembro 182.

O Regulador Brasileiro. $\mathrm{n}^{\circ}$ 21, 11 dezembro 1822.

O Reverbero Constitucional Fluminense, Escrito por Dous Brasileiros Amigos da Nação e da Pátria, Tomo II, Typographia Nacional, Rio de Janeiro, 1822, p. 24.

Quarterly Review era un periódico oficial del partido ingles tories fundado en 1809 por John Murray.

Quarterly Review, vol. XXVIII, octubre-enero 1822-1823

REVÉRBERO CONSTITUCIONAL FLUMINENSE (1821-1822), nº 7, de 15 de diciembre de 1821.

SEMANARIO PATRIÓTICO, 22 de junio de 1809, pp. 124, 125, 127 y 128.

SEMANARIO PATRIÓTICO, n.III, 15 de septiembre de 1808, p. 47.

Suplemento del $\mathrm{n}^{\circ}$. 16, del día 22 de abril de 1808. GAZETA DE LISBOA, Suplemento do N.16, Sexta-Feira, 22 de abril de 1808, portada. 
LA “SANTA CIUDADANÍA” DEL IMPERIO: CONFESIONALIDAD COMO FUENTE RESTRICTIVA DE DERECHOS EN BRASIL $(1823-1831)$ 